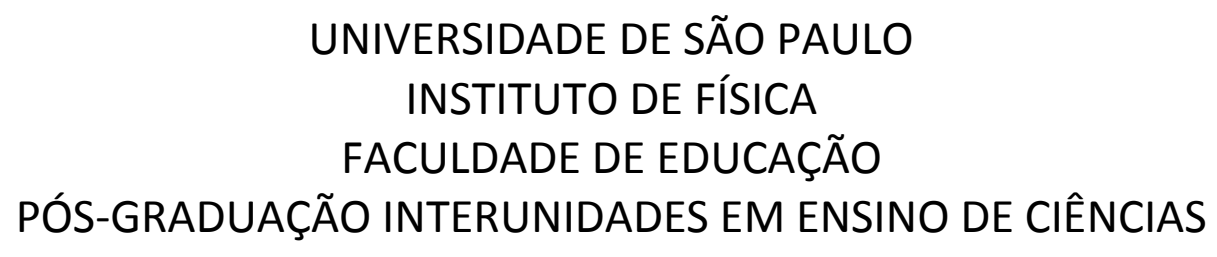

CARLA ALVES DE SOUZA

\title{
A Identidade de Licenciandos em Física: em busca de uma caracterização
}




\section{CARLA ALVES DE SOUZA}

\section{A Identidade de Licenciandos em Física: em busca de uma caracterização}

Dissertação apresentada aos Institutos de Física, Química, Biociências e à Faculdade de Educação da Universidade de São Paulo para obtenção do título de Mestre em Ensino de Ciências.

Área de Concentração: Ensino de Física.

Orientadora:

Profa Dra. Maria Regina Dubeux Kawamura.

São Paulo

2012 
Autorizo a reprodução e divulgação total ou parcial deste trabalho, por qualquer meio convencional ou eletrônico, para fins de estudo e pesquisa, desde que citada a fonte.

\section{FICHA CATALOGRÁFICA}

Preparada pelo Serviço de Biblioteca e Informação do Instituto de Física da Universidade de São Paulo

Souza, Carla Alves de

A identidade de licenciados em física: em busca de uma caracterização. São Paulo, 2012

Dissertação (Mestrado) - Universidade de São Paulo.

Faculdade de Educação, Instituto de Física, Instituto de Quimica e Instituto de Biociências

Orientador: Profa. Dra. Maria Regina Dubeux Kawamura

Área de Concentração: Ensino de Física

Unitermos: 1.Formação de Professores; 2.Física; 3.Ensino superior; 4. Identidade. 
Nome: SOUZA, Carla Alves de

Título: A Identidade de Licenciandos em Física: em busca de uma caracterização

Dissertação apresentada aos Institutos de

Física, Química, Biociências e à Faculdade

de Educação da Universidade de São

Paulo para obtenção do título de Mestre em Ensino de Ciências.

Aprovado em: 26 de Janeiro de 2012

\section{Banca Examinadora}

Profa. Dra. Maria Regina Dubeux Kawamura Julgamento:

Profa. Dra. Rebeca Villas Boas C. de Oliveira Julgamento:

Profa. Dra. Ivanilda Higa

Julgamento:
Instituição: IFUSP

Assinatura:

Instituição: IFECTSP

Assinatura:

Instituição: UFPR

Assinatura: 



\section{AGRADECIMENTOS}

À minha Família - meus pais, Joaquim e Celina, minhas irmãs Glória e Suzi - pela orientação, amparo e compreensão de toda ordem; e à minha tia Vita, por todas as conversas sobre ensino e aprendizagem e por seu exemplo de profissional da educação.

À minha primeira professora - Maria do Carmo - da pré-escola e demais professoras do primário que me inspiravam nas brincadeiras de 'escolinha'; e a todos os meus professores do ginásio, em especial ao professor de Ciências, Sebastião, pelas inesquecíveis excursões a centros de ciências, museus e planetário.

Aos professores do CEFAM, fundamentais em minha formação e à Sandra, companheira de estudos do magistério, da graduação em matemática e grande amiga para sempre.

Aos professores da FSA, onde cursei a Licenciatura em Matemática, especialmente ao professor Anastassios pela confiança nos anos em que fui sua monitora, ao professor Roberto (in memoria) por suas discussões sobre a formação de professores e ao professor Alécio que nos aconselhava a cursar a pós-graduação na Universidade de São Paulo.

Às professores do IME-USP, Elza Gomide pelo carinho como me recebeu e encaminhou para cursar as disciplinas da Especialização e à professora lole pelo compromisso com a formação de professores.

Aos professores do IF-USP, Nora, Vera, Menezes, Mazé e Zanetic que no decorrer da Licenciatura em Física - cada um a seu jeito - contribuíram para que eu acreditasse que poderia concluir o curso e para o despertar de meu interesse em aprender física. E, em especial ao professor Cristiano por crer e por fazer a diferença.

Aos meus amigos da graduação Vanessa (que evitou que eu desistisse ainda no primeiro ano), Marcos, Mônica, Lu, Roger, Wilson, Donald e Hamilton pela companhia, pelas conversas, pelas horas de estudos e, sobretudo, pelo apoio e carinho em todos os momentos. 
A todos os meus colegas de trabalho e alunos da EE Reverendo Omar Daibert, por inspirar as reflexões sobre minha própria prática.

À Angélica, Ana e Silmara pela amizade.

À professora Regina, da qual tive o privilégio e a honra de receber orientação já desde o final da graduação durante o desenvolvimento de projeto em iniciação científica. Que com muita paciência e sabedoria me guiou nestes primeiros passos na pesquisa em ensino e formação de professores e que será sempre a minha importante referência.

Às professoras Cristina, Rebeca e Ivanilda por toda a contribuição que deram ao meu trabalho, com suas leituras cuidadosas e discussões construtivas.

Aos professores das disciplinas da pós-graduação, Menezes, J. Pedro da Ponte, Osvaldo, Kimi, Paula e Daniela, por tudo que em mim puderam despertar em relação à prática educativa e de pesquisa.

À Soninha e à Renata que me auxiliaram e orientaram desde a época do Projeto Ensinar com Pesquisa. E aos demais do grupo da Regina: Bruna, Paula, Graci, Ivã, Giselle, Lígia, Marcília, Fred, Ana e Rose pelas discussões e pelos momentos de confraternização.

À Kátia da seção de alunos, pela disposição em fornecer informações que foram fundamentais para minha investigação; ao Thomas e Rosana da CPGI por todas as orientações e esclarecimentos e ao Ailton por toda a ajuda.

Aos professores Cristiano Oliveira, Suzana Salém, Vilma Vuolo, Daniel Cornejo, Elio Ricardo e às suas respectivas turmas, pela colaboração na aplicação e preenchimento dos questionários de investigação.

Aos colegas do corredor de ensino Lu, Leandro, Juliano, André, Esdras, Vanessa, Fernanda, Osvaldo e Glauco, pelas dicas e conversas e pela companhia em congressos e outros eventos. Em especial à Leika pela delicadeza, meiguice, pelo carinho e pelos maravilhosos chás; e à Yara pelo imprescindível apoio, pela confiança e grande amizade.

Amo vocês! 
Não entendo. Isso é tão vasto que ultrapassa qualquer entender. Entender é sempre limitado. Mas não entender pode não ter fronteiras. Sinto que sou mais completa quando não entendo. Não entender, do modo como falo, é um dom. Não entender, mas não como um simples de espírito. O bom é ser inteligente e não entender. É uma benção estranha, como ter loucura sem ser doida. É um desinteresse manso, é uma doçura de burrice. Só que de vez em quando vem a inquietação: quero entender um pouco. Não demais: mas pelo menos entender que não entendo. 



\section{RESUMO}

SOUZA, C. A. A Identidade de Licenciandos em Física: em busca de uma caracterização. 2012. 285p. Dissertação (Mestrado) apresentada aos Institutos de Física, Química, Biociências e à Faculdade de Educação da Universidade de São Paulo, São Paulo, 2012.

Um aspecto promissor das pesquisas mais recentes sobre formação docente é a atenção que vem sendo dirigida ao professor. Dentro desse quadro, o presente trabalho tem como especificidade o interesse em investigar a identidade de futuros professores, em um curso de formação inicial. Reconhecemos a caracterização do perfil do licenciando como importante na problemática que envolve o próprio curso, sobretudo pela intenção de contemplar, também, a dimensão sócio-cultural destes alunos. Nesse sentido, buscamos apoio e fundamentação teórica nos estudos de P. Bourdieu e nas pesquisas sobre representações sociais. Partimos da hipótese de que as representações de ciência/física/educação/perfil profissional do professor evoluem, se modificam e se articulam, no espaço de alguns anos, como parte do processo de formação inicial, resultado das interações e ações que o aluno da licenciatura vivencia. Investigar alguns elementos desse processo é o objetivo central do presente trabalho. Trata-se de um estudo de caso, envolvendo alunos do Curso de Licenciatura em Física do IFUSP, privilegiando representações do ser professor e da visão de ciência. Foram analisados, através de diferentes estratégias, três momentos do curso - o ingresso, o percurso e as condições de conclusão/evasão. Nossos resultados indicam que os ingressantes, em comparação com outras carreiras da USP, apresentam alta mobilidade educacional intergeracional e capital cultural mais limitado. Quanto às suas expectativas em relação à futura profissão, muitos não desejam exercê-la, sendo que essa fração aumenta ao longo do curso. Por outro lado, o curso tem um impacto positivo sobre os alunos, promovendo transformações de suas concepções de ciência e de suas representações sobre ser professor. Esses resultados apontam para a necessidade de promover um contínuo processo de discussão sobre a construção da identidade profissional do professor, ao longo do curso, para além do trabalho desenvolvido localmente nas disciplinas.

Palavras-chave: Formação de Professores, Ensino de Física, Representações Sociais, Identidade Docente. 


\section{ABSTRACT}

SOUZA, C. A. The identity of undergraduates in physics: in search of a characterization. 2012. 285p. Dissertação (Mestrado) apresentada ao Instituto de Física, ao Instituto de Química, ao Instituto de Biociências e à Faculdade de Educação da Universidade de São Paulo, São Paulo, 2012.

In recent years, more attention is being directed to teacher professional identity. In this context, we intend to investigate the identities of students during a physics teacher education university course. We consider that aspects like these must be inherent to the planning and developing of own undergraduate courses, especially considering social and culture context. With this purpose, we search for support on Bourdieu ideas and on social representation theories. To accomplish this intention, we developed a case study, taking as an object the Physics Teaching Course of the University of São Paulo. Special attention was directed to student representations about teacher profiles and their science conceptions, as well as to their expectation towards future profession practices. Three moments of the students formation were analyzed, through different approaches, including admission, trajectories and graduation (or not), searching for possible evolutions of their ideas about being teacher and studying Physics. Our results indicate that these students present very peculiar social characteristics and cultural capital baggage, as compare to other students in graduate courses at the same university. Most of them don't want to be teachers and their expectations toward future professional are restricted, decreasing along the advancing of the course. On the other hand, it seems clear that the course actions and design impact positively on their comprehensions about being teacher, withdrawing from technical professional profiles towards a more reflexive one. The same thing happens with science conceptions, the course promoting a more critical approach. It could be said that student identity shows a dual perspective, bounding through difficulties and successes. From these results, it came out that it must be very important that teacher identity should be explicit discussed in different times through their formation, aiming its clear and conscious course of construction along the time.

Keywords: Teacher Education, Physics Teacher, Social Representations, Teacher Identity. 


\section{LISTA DE TABELAS}

Tabela 1 - Escolaridade do pai, por carreiras e total geral, 2002, com o correspondente percentual de mobilidade intergeracional em educação.

Tabela 2 - Escolaridade da mãe, por carreiras e total geral, 2002, com o correspondente percentual de mobilidade intergeracional em educação.

Tabela 3 - Comparação entre as médias de índice de mobilidade tal como obtidas a partir da escolaridade do pai ou da mãe, por bloco de carreira (2002).

Tabela 4 - Percentual de mobilidade média, por ano, por bloco de carreiras na comparação da escolaridade de pai e mãe, nos anos 2000, 2002, 2005, 2007 e 2009

Tabela 5 - Percentual de mobilidade média, por ano, por bloco de carreiras.

Tabela 6 - Percentual da renda mensal familiar (em reais) de ingressantes 2002, por bloco de carreiras.

Tabela 7 - Percentual médio (aproximado) de ingressantes cuja renda familiar mensal é superior a 3 mil reais, por bloco de carreiras e nos anos de 2002, 2005, 2007 e 2009.

Tabela 8 - Percentual dos ingressantes, segundo a cor de pele, por Carreiras e Total Geral USP, 2002.

Tabela 9 - Percentual médio (aproximado) de brancos e negros (preto e pardo), por bloco de carreiras, para os anos de 2000, 2002, 2005, 2007 e 2009.

Tabela 10 - Percentual (aproximado) por tipo de estudos em nível médio, por bloco de carreiras para o ano de 2002

Tabela 11 - Percentual médio para o tipo de estudos em nível médio, por bloco de carreiras, para os anos de 2000, 2002, 2005, 2007 e 2009.

Tabela 12 - Percentual de ingressantes negros nos anos de 2007 e 2009, por bloco de carreiras. .... 95

Tabela 13 - Grau de persistência intergeracional em Educação (PNAD,1996).

Tabela 14 - Intenção primeira na escolha do curso - Percentual dos ingressantes 2002, por Categoria.

Tabela 15 - Intenção primeira na escolha do curso - Percentual dos ingressantes 2006, por Categoria.

Tabela 16 - Intenção primeira na escolha do curso - Percentual Médio Aproximado de ingressantes 2002 e 2006, por Categoria.

Tabela 17 - Percentual dos licenciandos que pretendem Ser Professor, segundo aspectos mais evidentes.

Tabela 18 - Visão de Física - Ingressante 2002 (valores absolutos).

Tabela 19 - Visão de Física - Ingressante 2002 (valores percentuais).

Tabela 20 - Número de estudantes por Tipos de Encerramento - 1997 a 2010. 136

Tabela 21 - Evolução anual dos encerramentos com e sem conclusão (de 1997 a 2010) .................. 139

Tabela 22 - Concluintes e evasão em fluxo (de 1997 a 2010)

Tabela 23 - Tipos de Encerramento.

Tabela 24 - Encerramentos por Tipo (de 1997 a 2010).

Tabela 25 - Distribuição nos diferentes Tipos de Encerramento de alunos com acúmulo de zero créditos cursados. 
Tabela 26 - Encerramentos por agrupamento de tipos (de 1997 a 2010).

Tabela 27 - Número de encerramentos classificados em dois grupos principais (sem concluintes). 151

Tabela 28 - Número de encerramentos classificados em dois grupos tipos principais (com

concluintes)

Tabela 29 - Percentual por Tipo de Encerramento dos ingressantes 2002 ..................................... 159

Tabela 30 - Intenções no ingresso e Tipo de Encerramento - Ingressantes 2002............................ 160

Tabela 31 - Distribuição dos alunos em Percurso por Turno, Disciplina e Grupo.............................. 168

Tabela 32 - Motivação principal para o ingresso na Licenciatura - Alunos em Percurso ................... 173

Tabela 33 - Pretensões para quando concluir o curso - Alunos em Percurso. .................................. 174

Tabela 34 - Intenção de Ser Professor no ingresso e no egresso - Alunos em Percurso.................... 175

Tabela 35 - Mudança na Visão de Física de Licenciandos em Percurso................................................ 182

Tabela 36 - Mudança na Visão de Física de Licenciandos em Percurso............................................ 182

Tabela 37 - Percentual referente à Visão da Física de Licenciandos em Percurso.............................. 183

Tabela 38 - Principais Categorias - Visão de Professor (Alunos em Percurso) ................................... 189

Tabela 39 - Visão de Professor -Alunos em percurso (valores absolutos) ......................................... 190

Tabela 40 - Visão de Professor -Alunos em percurso (percentuais) .................................................. 191 


\section{LISTA DE GRÁFICOS}

Gráfico 1 -Variação do percentual de filhos que igualam ou ultrapassam a escolaridade de seus pais no ingresso ao curso superior, ao longo dos anos.

Gráfico 2 - Variação do percentual de filhos que igualam ou ultrapassam a escolaridade de suas mães no ingresso ao curso superior, ao longo dos anos.

Gráfico 3 - Percentual médio (aproximado) de brancos e negros (preto/pardo), por bloco de carreiras, para os anos de 2000, 2002, 2005, 2007 e 2009 (não inclui o índice para cor de pele amarela e indígena).

Gráfico 4 - Percentual de ingressantes por tipo de estudo em nível médio, por carreira e para o ano de 2002.

Gráfico 5 - Percentual de ingressantes, por carreira, oriundos de escola pública, dos anos 2000, 2002, 2005, 2007 e 2009.

Gráfico 6 - Percentual de ingressantes, por carreira, oriundos de escola particular, dos anos 2000, 2002, 2005, 2007 e 2009.

Gráfico 7 - Percentual de ingressantes, por carreira, por origem de estudos em nível médio, nos anos 2000, 2002, 2005, 2007 e 2009.

Gráfico 8 - Percentual de ingressantes, por origem de estudos em nível médio, nos anos 2000, 2002, 2005, 2007 e 2009.

Gráfico 9 - Percentual dos ingressantes 2002 segundo as ideias/concepções que o levaram a estudar

Física.

Gráfico 10 - Número de conclusões e outros encerramentos de 1997 a 2010................................ 138

Gráfico 11 - Número de concluintes por ano, de 1997 a 2010 (valores absolutos)........................... 139

Gráfico 12 - Número de concluintes por ano, de 1997 a 2010 (valores percentuais). ..................... 140

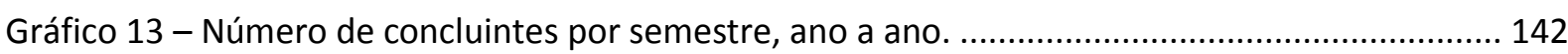

Gráfico 14 - Número de concluintes por turno ao longo dos anos. ............................................... 142

Gráfico 15 - Número médio, em semestres, conclusão do curso, por turno (ingressantes por vestibular)

Gráfico 16 - Número médio de semestres além/aquém do tempo ideal (8 diurno;10 noturno) para a

conclusão do curso.

Gráfico 17 - Porcentagem do excedente em semestres com relação ao tempo ideal para a conclusão do curso, por turno.

Gráfico 18 - Alunos por tipo de encerramento, segundo classificação da Tabela 22 (absoluto)....... 148

Gráfico 19 - Alunos por tipo de encerramento, segundo classificação da Tabela 22 (percentual). .. 148

Gráfico 20 - Percentual de Concluintes e Não-concluintes segundo os grupos de expectativa

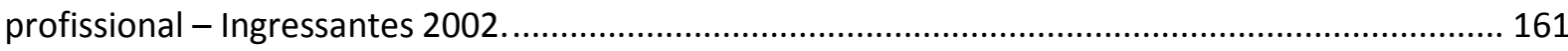

Gráfico 21 - Percentual de Conclusão e Evasão - Ingressantes 2002 .............................................. 162

Gráfico 22 - Percentual das Expectativas profissionais por Tipo de Encerramento........................... 163

Gráfico 23 - Créditos acumulados por não-concluintes (Ingressantes 2002). .................................... 164

Gráfico 24 - Expectativas profissionais de não-concluintes e o número de créditos acumulados

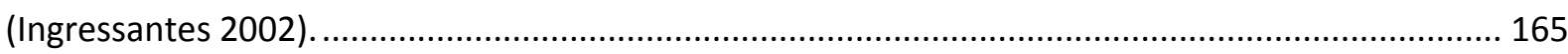

Gráfico 25 - Amostra de alunos em Percurso, por Grupo e turno (valores absolutos)...................... 168

Gráfico 26 - Amostra de alunos em Percurso, por Grupo e turno (percentual). ................................ 168 
Gráfico 27 - Escolaridade do pai, segundo os Grupos 1 e 2 de alunos em percurso (percentual).... 169

Gráfico 28 - Tipo de Escola em Nível Médio dos alunos em Percurso............................................. 170

Gráfico 29 - Tipo de ingresso dos alunos em Percurso, segundo os Grupos 1 e 2........................... 170

Gráfico 30 - Atividade Profissional dos alunos em Percurso, segundo os Grupos 1 e 2. ................... 171

Gráfico 31 - Alunos em Percurso que Lecionam, segundo os Grupos 1 e 2..................................... 172

Gráfico 32 - Intenção de Ser Professor no ingresso e no egresso do curso. ..................................... 175

Gráfico 33 - Mudança na Visão de Física dos alunos em Percurso. ................................................. 176

Gráfico 34 - Visão do que é Física dos alunos em Percurso. ............................................................. 183

Gráfico 35 - Visão de Professor do aluno em Percurso, segundo os Grupos 1 e 2. ........................... 190

Gráfico 36 - Visão de Professor do aluno em Percurso, em subcategorias....................................... 192 


\section{SUMÁRIO}

APRESENTAÇÃO.

CAPÍTULO 1 - ALGUMAS PERSPECTIVAS SOBRE FORMAÇÃO DE PROFESSORES. 19

CAPÍTULO 2 - CIRCUITOS DA PESQUISA E ESTRATÉGIAS METODOLÓGICAS ….................................. 25

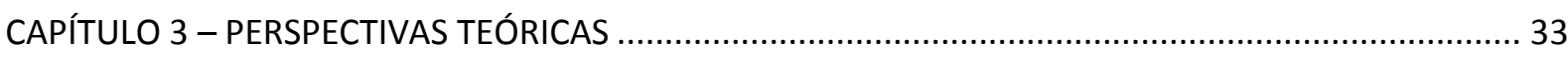

3. 1 Representações (Sociais) da Profissão Professor .................................................................. 33

3.1.1 Um pouco da história das Representações Sociais ............................................................ 34

3.1.2 Algumas pesquisas sobre Representações Sociais e a Educação......................................... 38

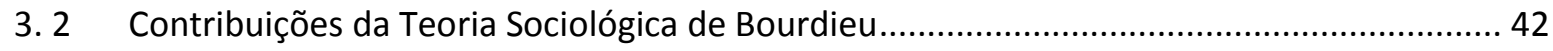

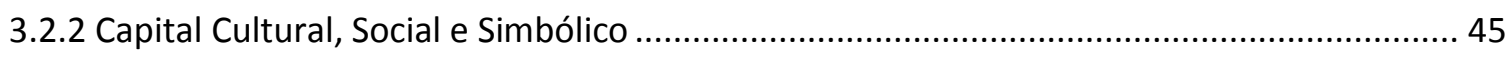

3.2.3 Argumentos da Sociologia da Educação de Bourdieu........................................................... 50

3.2.4 Algumas considerações acerca do conceito bourdieusiano de capital cultural e o sistema

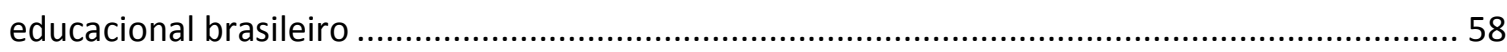

CAPÍTULO 4 - PERFIL DO INGRESSANTE - ASPECTOS SÓCIO-ECONÔMICOS........................................ 63

4.1 Aspectos sócio-econômicos e a Mobilidade Intergeracional em Educação - Comparação dos

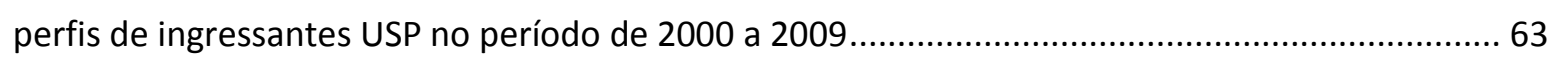

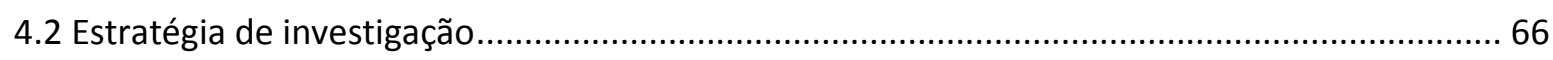

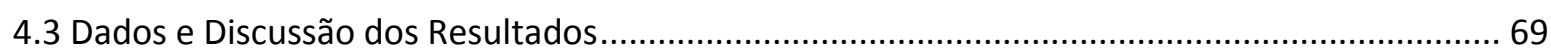

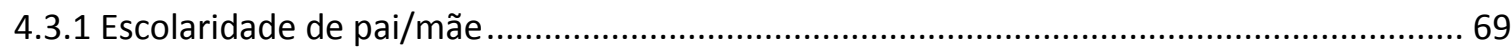

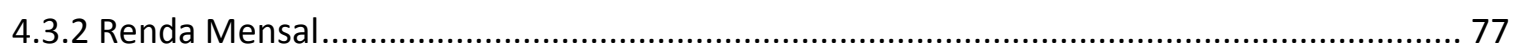

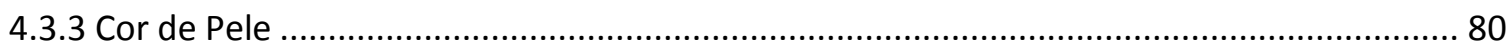

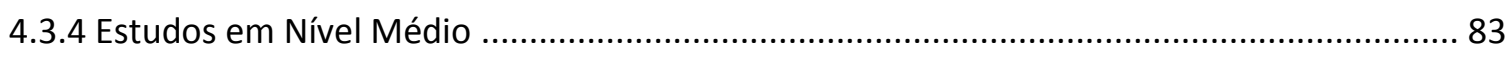

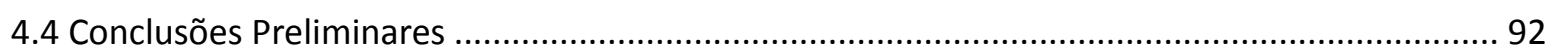

CAPÍTULO 5 - REPRESENTAÇÕES SOCIAIS DA PROFISSÃO PROFESSOR E PERSPECTIVAS PROFISSIONAIS

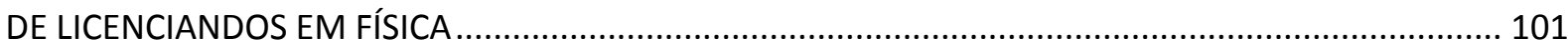

5.1 As Representações da Profissão Professor de Licenciandos em Física da USP........................ 102

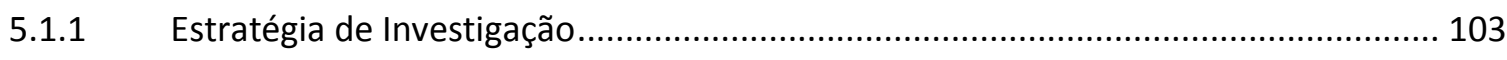

5.1.2 Principais Representações - Ingressantes 2002 e 2006........................................... 106

5.1.3 Uma análise quantitativa dos grupos de representações ............................................. 113 
5.1.4 Profissão Professor - Ingressantes que buscam a formação para atuar como docentes 115

5.2 Representações sobre a Física de ingressantes do Curso de Licenciatura em Física da USP.... 120

5.3 Conclusões Preliminares

CAPÍTULO 6 - UM PANORAMA DA EVASÃO E DOS CONCLUINTES DA LICENCIATURA EM FÍSICA DO

IFUSP: $1997-2010$

6.1 Considerações sobre a implementação da "nova" proposta curricular do IFUSP

6.2 Estratégia de Investigação

6.2.1 Evolução do número de concluintes

6.2.2 Caracterização dos diversos tipos de encerramento ..................................................... 146

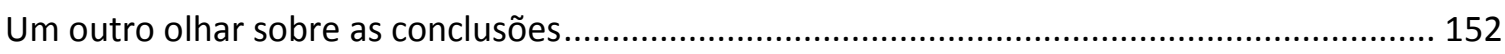

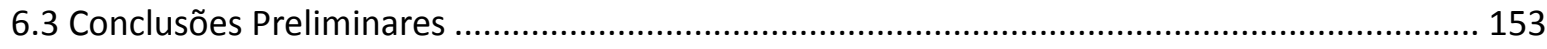

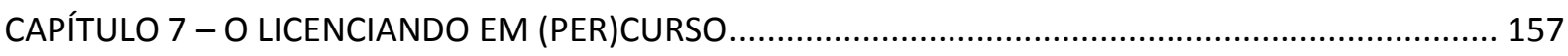

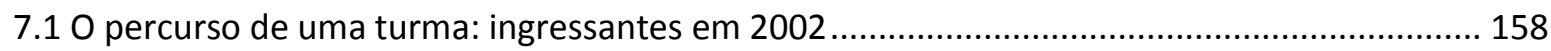

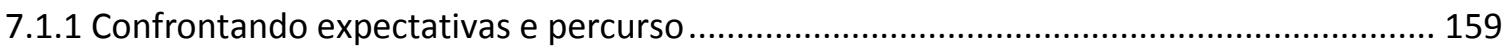

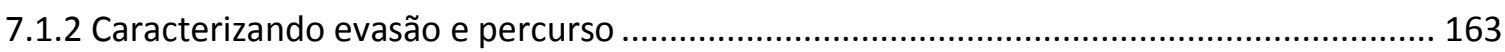

7.2 Alunos hoje em percurso - transformações em curso ............................................................ 166

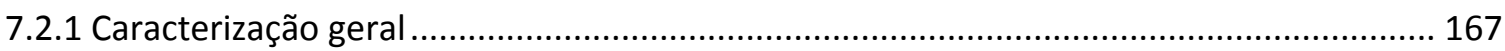

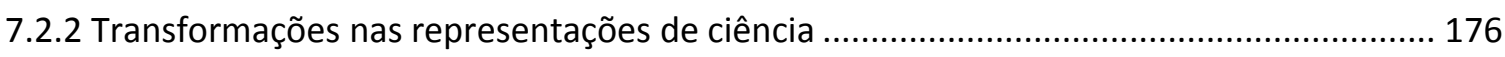

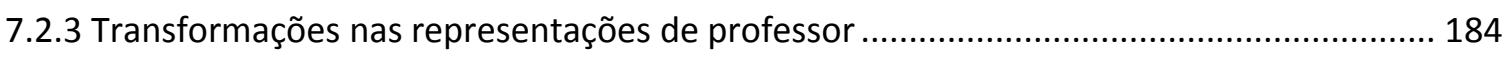

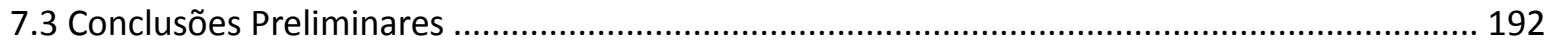

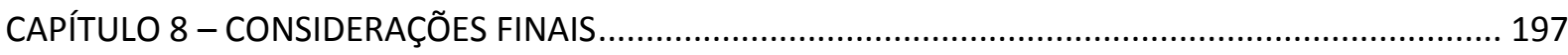

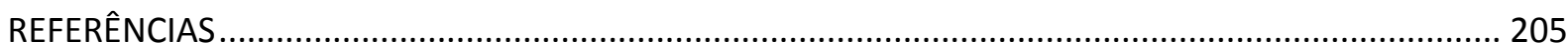

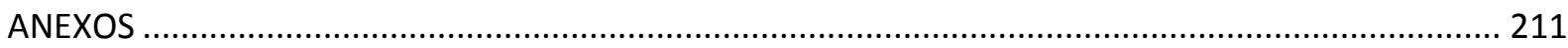

ANEXO A - Dados sobre Mobilidade Intergeracional de Ingressantes USP ................................. 211

ANEXO B - Dados dos Questionários de Ingressantes 2002 e 2006 .......................................... 219

ANEXO C - Questionário do Licenciando IFUSP em (Per)curso .................................................. 253

ANEXO D - Dados referentes ao Questionário do Licenciando em (Per)curso ........................... 257

ANEXO E - Considerações sobre o número de concluintes em função da forma e ano de ingresso 


\section{APRESENTAÇÃO}

A identidade de licenciandos em Física: em busca de uma caracterização. De algum modo, parece estranho falar de uma busca, da busca por uma caracterização, da caracterização de alunos de um curso de formação inicial, de um curso do qual também fui aluna. O estranhamento me ocorre porque tenho a impressão, quase a certeza, de que esta busca - lá no fundo - não tem muito sentido. Calma! Quero dizer que sinto, passados estes quase três anos de investigação, que nosso trabalho trata apenas de uma percepção pontual, de um olhar específico, que evidencia, com toda limitação que lhe é natural, aspectos relevantes do perfil de licenciandos em física.

Emociono-me ao tentar lembrar exatamente o que motivou a fazer esta pesquisa. Emociono-me porque, certamente a razão para eu ter iniciado este trabalho de mestrado em ensino de ciências, na área de formação de professores de física, não está somente nos tempos recentes. Não está na participação, ao final da graduação em física, de um projeto de iniciação científica de investigação sobre o curso de licenciatura, que me revelou inúmeros dados. Nem está na época em que fiz o curso de licenciatura em matemática e nos mais de quinze anos de profissão como professora desta disciplina. Também não está no período em que cursei o CEFAM, curso já extinto e específico de formação para o magistério. Não está nos anos em que cursava as primeiras séries do ensino fundamental e admirava minha tia que dava aulas particulares na casa da minha avó, usando uma lousinha e giz colorido. Não está nos dias em que brincava de 'escolinha', passando lição e dando broncas em meus alunos invisíveis. Não está em um lugar, em um tempo, em um momento. Está em todo lugar, em todo o tempo - o meu tempo - em cada momento, neste instante. Porque é assim que vejo, hoje.

Iniciei este trabalho de pesquisa porque gosto, porque me identifico, porque me preocupo, porque me emociono com o assunto formação de professores. As razões pelas quais segui fazendo a pesquisa, estas sim, foram sendo, a cada dia, influenciadas muito mais especificamente pelos caminhos percorridos durante a pós-graduação. Por exemplo, pelas 
discussões feitas em uma das primeiras disciplinas cursadas sobre o impacto que as histórias de vida de professoras recém formadas têm sobre a sua identidade profissional. Também, pelas discussões sobre a história da formação docente no Brasil, as imagens e as representações do ser professor, discussões sobre transmissão intergeracional, educação e trabalho, bem como o caráter social e cultural a elas associadas.

Obviamente era necessário que as questões de pesquisa fossem estabelecidas, ainda que temporariamente, com toda a chance de serem alteradas. Então, as primeiras foram: 0 que leva alguém a querer tornar-se professor? (e/ou professor de física?) O que faz com que alguém se torne um bom professor? (e/ou um bom professor de física?) O curso de formação inicial? Apenas ele?

E, ao poucos, pude evidenciar a complexidade de tais perguntas. Que a problemática envolvia questões muito amplas e nada sutis, incluindo o entrelaçamento de razões pessoais, escolhas, experiências de vida e aspectos mais institucionais, relacionados à instituição escola nos seus diversos níveis.

O trabalho desenvolvido na época da graduação em física, voltado a alguns aspectos do curso de licenciatura e da evasão nesse curso, embora quantitativo, trouxe a indagação sobre como serão esses hoje alunos quando passarem a ser professores. Daí então, o interesse em tentar, inicialmente, buscar - olhar e - compreender melhor quem são esses licenciandos, por que escolheram fazer o curso, o quanto de suas histórias pessoais influenciam suas atividades/escolhas/ações presentes e futuras.

Evidentemente isso é muitíssimo complicado, porque seria preciso acompanhar esses alunos durante todo o período de sua graduação e até depois de sua formação, por algum tempo.

Assim, inevitavelmente foi necessário que fizéssemos escolhas, tomássemos uma atitude e, como um primeiro passo, entendemos que uma investigação possível era tentar caracterizar o aluno que opta por fazer licenciatura (em física), procurando compreender qual sua relação com a identidade da profissão que escolheu, ou de que forma sua relação com a identidade de ser professor influencia em sua trajetória. 
Por isso, o presente trabalho objetiva caracterizar a identidade dos licenciandos em Física não do ponto de vista institucional, em termos de grade curricular, por exemplo, mas por meio da investigação e estruturação de aspectos relevantes do perfil destes alunos. Caracterizar aspectos que possam evidenciar as expectativas profissionais com relação ao curso por eles escolhido. Buscamos uma caracterização dos alunos do Curso de Licenciatura em Física que revele sua(s) identidade(s) em termos de ideias e concepções sobre o Ser Professor e sobre Ser Professor de Física.

Neste sentido, a pesquisa se direciona para a análise da trajetória destes licenciandos durante a formação, levando em conta, por um lado, suas expectativas e de como elas evoluem ao longo do curso. Trata-se de uma situação muito específica, na medida em que a maior parte deles tem pouca vivência pessoal da profissão.Assim, ao invés de buscar narrativas e histórias de vida, parece mais apropriado buscar, identificar algumas representações sociais que permeiam suas intenções e ações, desde a escolha e ingresso no curso até as possíveis e prováveis transformações que venham ocorrer durante a graduação no que diz respeito a seu futuro desenvolvimento e atuação profissional.

Além disso, e por outro lado, parece também indispensável considerar as condições sócio-culturais destes sujeitos como fator importante na caracterização de seu perfil, haja vista que todo processo identitário se dá no âmbito das relações, sejam elas mais ou menos abrangentes e/ou estruturadas.

A questão de investigação deste trabalho é, portanto, a busca pela compreensão e caracterização de alunos de um curso de formação inicial com o propósito de, a partir do conhecimento das particularidades daquilo que compõem a(s) identidade(s) do grupo de licenciandos, contribuir para uma reflexão, fundamentada na realidade, com vistas a transformações e melhorias nas estruturas de um curso dessa natureza.

Embora a própria noção de identidade seja objeto de diferentes compreensões e teorias, no campo da sociologia, pretende-se considerá-la, no âmbito dessa investigação, como uma instância ela mesma a ser caracterizada. Mais correto seria, então, referir-se ao intuito de investigar alguns aspectos e características dos alunos de um curso de 
licenciatura, procurando identificar que elementos podem ser reveladores de suas identidades.

Sobre identidades, Dubar observa:

O que existe são modos de identificação, variáveis no decorrer da história coletiva e da vida pessoal, destinações a categorias diversas que dependem do contexto. Essas maneiras de identificar são de dois tipos: as identificações atribuídas pelos outros (o que chamo "identidade para outrem") e as identificações reinvindicadas por si mesmo ("identidades para si") (Dubar, 2009, p. 14).

Além disso, para muitos pesquisadores em sociologia, a identidade social é sinônimo de categoria de pertencimento. Para outros, a identidade social é uma noção mais ambígua na medida em que os pertencimentos são múltiplos e nenhum deles pode impor-se, a priori, "objetivamente", como principal.

Mas outros pertencimentos pesam também sobre os comportamentos e as opiniões: a origem cultural, por exemplo, ou o lugar de habitação, a geração ou as crenças religiosas (Dubar, 2009, p. 17-18).

Assim, não se parte do princípio de que exista uma identidade única, mas que o pertencimento de cada indivíduo a um conjunto coletivo, com atividades comuns, dentro de uma mesma grade e proposta curricular, possa trazer elementos de compreensão mais aprofundada sobre o percurso de formação que desenvolvem, do ponto de vista de como eles mesmo se representam, ou das identidades que vão construindo para si. Ao mesmo tempo, assume-se que essa identidade não pode ser dissociada do contexto social em que esses indivíduos estão inseridos.

O desenvolvimento desta investigação em um estudo de caso se estrutura sobre a questão: quem é o licenciando em física? Que concepções e expectativas estão por traz de sua escolha pelo curso e como elas se modificam ao longo dos anos de graduação? Qual o impacto do curso na construção de sua identidade profissional?

A investigação que irá olhar a trajetória destes licenciandos no curso de formação inicial, em lugar do uso de análise de narrativas - comum nos estudos sobre identidade do professor em exercício - se dará a partir do olhar sobre o perfil sócio-cultural e sobre as 
representações sociais destes alunos presentes em três momentos - o ingresso, o percurso e o egresso.

Consideramos a hipótese de que as representações de ciência/física/educação/perfil profissional do professor evoluem, se modificam e se articulam como parte do processo de formação inicial, resultado das interações e ações que o aluno da licenciatura vivencia, o que justifica a relevância de escolhas e de representações sociais, histórias de vida e influências locais, bem como considerar sua opção pelo curso/carreira como relacionada ao seu espaço social e capital cultural.

O Capítulo 1 apresenta algumas perspectivas mais gerais a cerca de diversos trabalhos desenvolvidos na área sobre Formação de Professores, e em especificidades como formação inicial, licenciaturas em ciências, identidade profissional docente entre outros, para em seguida, neste contexto, situar a proposta do presente trabalho de pesquisa em termos da formação inicial de professores de física, perfil identitário e expectativas profissionais através da caracterização do perfil do licenciando, contemplando a dimensão sócio-cultural destes alunos.

Já o Capítulo 2, que trata dos circuitos da pesquisa e das estratégias metodológicas, destaca inicialmente alguns trabalhos cujas propostas se aproximam de modo mais específico de nosso projeto de investigação, buscando, finalmente enfatizar e detalhar o direcionamento dos estudos aqui pretendidos.

No Capítulo 3, como apoio para a fundamentação teórica, apresentamos pontos importantes dos estudos sobre habitus, ethos de classe e capital cultural de Pierre Bourdieu e das pesquisas sobre representações sociais da profissão professor desenvolvidas por Leanete Dotta, embasadas na teoria desenvolvida por Sèrge Moscovici. Esses autores destacam e definem processos particularmente dinâmicos e que proporcionam análises e discussões que contemplam as dimensões/condições individuais e coletivas do objeto de estudo desta investigação.

A partir do Capítulo 4 começa o trabalho de caracterização do nosso principal objeto de estudo: o licenciando em física. Este capítulo, que trata do perfil sócio-econômico-cultural 
do ingressante USP, coloca o licenciando em física como elemento de um conjunto maior daqueles que optaram pela Carreira da qual o Curso de Licenciatura em Física faz parte - e por isso analisa o perfil de modo comparativo a outras carreiras com diferentes status, procurando contemplar as dimensões sociais e culturais das expectativas destes estudantes, no sentido de compreender aspectos relevantes da decisão de suas escolhas por um curso superior e carreira profissional.

O Capítulo 5 segue caracterizando o licenciando em física, agora a partir das expectativas e perspectivas profissionais que esse aluno revela ter quando de sua matrícula no curso. $\mathrm{O}$ olhar sobre esses recém-matriculados busca revelar as representações sociais que têm acerca da profissão Professor, da ideia de Ciência/Física, de pesquisa e ensino, que permeiam suas escolhas pelo curso, pela área e/ou carreira docente.

O Capítulo 6, buscando fornecer subsídios para uma análise mais ampla sobre o perfil e a identidade do licenciando em física do IFUSP, apresenta um panorama que discute os aspectos relacionados à evasão, os motivos de abandono e tempo previsto/efetivo para o término da graduação.

No Capítulo 7 pretende-se uma caracterização deste licenciando em (per)curso, de sua evolução considerando as especificidades da trajetória traçada e as transformações por que passam(ram) suas expectativas com relação a carreira escolhida, procurando entender de que modo as representações de ciência, educação e perfil profissional evoluem(íram).

Por fim, o Capítulo 8 traz apontamentos sobre os aspectos relevantes do estudo desenvolvido e em que medida o mesmo pode contribuir para responder às questões de pesquisa. Além disso, destaca os resultados revelados pelo aprofundamento da investigação e indica algumas propostas de encaminhamentos para futuras análises. 


\section{CAPÍTULO 1 - ALGUMAS PERSPECTIVAS SOBRE FORMAÇÃO DE PROFESSORES}

A questão da formação de professores vem, nas últimas décadas, representando um grande desafio, sendo objeto de diversos estudos, sob diferentes perspectivas. Assim, o intuito desse capítulo inicial é fazer uma breve incursão sobre algumas investigações que vem sendo desenvolvidas nesses estudos. Não se trata, certamente, de buscar uma cobertura completa da temática, mas de apresentar alguns trabalhos que possam contribuir para nos situar no campo.

Segundo André (2009), a temática identidade e profissionalização docente se consolida no final dos anos 1990 e domina o campo de investigação sobre formação docente no início dos anos 2000. Também a esse período, correspondem significativo número de dissertações e teses sobre estudos e representações de alunos - futuros professores. Investigações sobre as políticas de formação aparecem de forma tímida nos anos 1990 e crescem um pouco nos anos 2000, principalmente a partir de 2001. Um aspecto muito promissor das pesquisas mais recentes é a atenção dada ao professor, com estudos sobre suas representações, processos de constituição de identidade, dos saberes e práticas docentes. Essa mesma autora também alerta que, ao mesmo tempo em que cresce o número de pesquisas voltadas para o professor, diminui o número de investigações sobre a formação inicial (André, 2009).

Recente investigação sobre a pesquisa em formação de professores de ciências identifica, no contexto mundial, a complexidade deste campo e revela que, entre os anos de 2006 e 2007, houve grande produção de trabalhos sobre práticas docentes. Sugere, também, uma tendência na concentração de estudos voltados para o Ensino por Investigação e de Natureza da Ciência, uma vez que é expressiva a presença desses assuntos em estudos que tratam principalmente de crenças docentes (Silva, 2009).

De modo geral, os trabalhos sobre concepções, crenças e conflitos de alunos de curso de formação inicial e/ou professores em início de carreira, se apresentam na forma de 
estudos de caso. Coimbra \& Lindino (2007), por exemplo, desenvolveram uma pesquisa com o objetivo de avaliar o pensamento de estudantes de um programa de formação inicial a partir de quatro tipos fundamentais de conflitos: fator coletivo, currículo, autoconceito e expectativas com o programa da universidade. Para isso, compôs sua amostra tanto com licenciandos que já atuavam como professores, como com estudantes regulares da disciplina de Prática de Ensino. A autora defende que os programas de formação, em sua maioria, carecem de superar a desarticulação entre a teoria e a prática, tanto em relação aos conceitos físicos basilares, quanto em relação às reflexões sobre o estágio curricular obrigatório, em prol da superação da concepção de professor como especialista técnico.

Há estudos sobre a problemática da atualização do currículo de física na escola de nível médio, na perspectiva de experiência de sala de aula e da formação inicial de professores. Nestes casos, os pesquisadores escolhem algum tópico e/ou tema para desenvolverem sua investigação. É o caso, por exemplo, de Ostermann \& Moreira (2001) em que a pesquisa de três anos descreve experiência de ensino-aprendizagem de Tópicos de Física Contemporânea em escolas médias, a partir da preparação de professores em formação inicial. Os autores discutem a importância do ensino destes tópicos na escola média e as implicações e necessidades acerca de mudanças $\mathrm{n} /$ do currículo e formação inicial (e continuada) de professores para uma efetiva implementação do tema.

Bejarano \& Carvalho (2003), em outro estudo de caso, acompanharam o trabalho de uma professora de física ainda em formação e utilizaram o conceito de desenvolvimento profissional de professores iniciantes, que envolve a deteç̧ão, a evolução e formas de solução de conflitos. Também aqui, os autores utilizaram como pano de fundo a disciplina de Práticas de Ensino. Apontam que a maneira como os professores lidam com seus conflitos e preocupações profissionais deriva, em grande parte, de suas crenças preexistentes e sua disposição para mudá-las, com destaque importante para variáveis como dados biográficos, forma de opção pela carreira e contextos escolares nos quais trabalham.

Ainda nesta linha, de estudo de caso, Castro \& Barbosa-Lima (2006), desenvolveram um trabalho com o objetivo de analisar e identificar as contribuições da formação inicial que foram cruciais para a formação do modelo epistemológico de um licenciando em física, 
tendo como documento de pesquisa as aulas, entrevistas e dados de campo. Esses autores ressaltam que - apesar da insuficiência do material de que dispõem para se fazer uma análise integral e profunda da prática de um professor - foi possível perceber quais fatores estão presentes no recém-licenciado e trazer subsídios para eventuais modificações no currículo vigente, por exemplo, quanto à análise na disciplina relacionada à linguagem. Os autores acreditam ser possível perceber claramente a interveniência de disciplinas como História e Filosofia da Física, História Geral e das Instrumentações e Práticas para o Ensino, cursadas na graduação.

Análises de trabalhos anteriores sobre a temática formação de professores indicam como pouco investigada a questão da avaliação do impacto dos cursos de formação inicial e continuada na melhoria da qualidade do ensino (Brzezinski \& Garrido, 2001). No final dos anos 90, é marcante a recorrência à temática da profissionalização docente com vistas para a construção da identidade profissional do professor, porém calam-se as fontes em relação à carreira docente e aos movimentos de valorização profissional. Brzezinski \& Garrido (2001) ainda advertem que, apesar dos contínuos aportes visando à melhoria dos cursos de formação inicial de professores, esses cursos têm sido continuamente questionados. Indagavam - há pelo menos dez anos - até que ponto os cursos de formação de professores estariam respondendo às necessidades da sociedade pós-industrial, da revolução tecnológica, marcada pela produção científica, pelo desenvolvimento dos meios de comunicação e informação, por desigualdades e tensões sociais alarmantes e por novas formas de exercício da cidadania. Indagavam, também, quais os novos papéis do professor, e que formação dar ao educador para que ele possa ser um efetivo agente social transformador inserido nos contextos culturais contemporâneos.

Muitos dos trabalhos relacionados à formação inicial investigam as primeiras impressões dos estudantes - futuros professores - com respeito à prática docente a partir das experiências de estágio. Baccon \& Arruda (2007), num ensaio em que colocam o licenciando diante do professor atuante em sala de aula, com o intuito de criar um paralelo análogo ao do analista e o analisando, acreditam contribuir para que haja a construção - por parte do estagiário - de seu estilo de professor. Segundo os autores, "ao contemplar o outro (professor) no exercício de seu estilo próprio, que um sujeito, o estagiário, pode construir e 
se construir em seu estilo." E ainda consideram que o estagiário tem a possibilidade de poder despertar "inconscientemente seu desejo em ser professor", ao comparar e analisar as atitudes dos professores regentes (Baccon \& Arruda, 2007).

Castro \& Queiroz (2007) creem que a prática de projetos no ensino básico através da parceria entre formadores, licenciandos e professores (universidade-escola) seja uma estratégia de inovação pedagógica adequada e facilitadora para a atuação do professor no processo de construção de seu próprio conhecimento profissional. O sucesso da relação estabelecida, no estágio, entre a instituição de ensino superior e a escola contribui tanto para a formação dos licenciandos, como também para os professores e alunos da educação básica (Castro \& Queiroz, 2007).

Em um trabalho que também propõe a parceria universidade-escola, Alves; Carvalho \& Mion (2010) analisam "o processo de construção de uma identidade - de professor e pesquisador em ensino de Física - a partir de uma proposta educacional construída, desenvolvida e estudada na formação inicial de professores de Física de uma Universidade pública" há algum tempo. Constataram que a vivência de uma praxis no desenvolvimento de uma proposta educacional na formação inicial de professores é condição imprescindível para a construção dessa referida identidade. Os autores concluem que "a mudança no curso da ação na formação do aprendiz de professor e pesquisador denota que uma identidade só pode ser construída pelo reconhecimento de que existem demandas, mas também existem situações-limite" e que "essa identidade necessidade advir do tecido de relações internas do grupo, fundamentadas por comprometimento e reconhecimento" (Alves; Carvalho \& Mion, 2010).

Terrazzan et al (2007) tomam por base os cursos de Licenciatura em Ciências Biológicas, em Física e em Química da UFSM para analisar as possibilidades de suas configurações curriculares favorecerem a formação identitária do professor. A partir de atos normativos, identificaram alguns componentes curriculares definidos como essenciais para a caracterização de Cursos de Licenciatura: Prática como Componente Curricular (PCC), Estágio Curricular (EC) e disciplinas de formação pedagógica. Relatam que "aparentemente, os cursos de licenciatura em Ciências Biológicas e em Física dão menor ênfase à formação 
pedagógica de seus licenciandos do que a licenciatura em Química". E, "de modo geral, os perfis profissionais expressos nos Projetos Político-Pedagógicos desses cursos contêm elementos favoráveis à estruturação de processos formativos que contribuam para a formação da identidade profissional de um professor. No entanto, as formas como os componentes curriculares analisados estão organizados nos três cursos parecem dificultar a concretização de boa parte das características constantes nesses perfis e, consequentemente, de uma formação identitária adequada" (Terrazzan et al., 2007).

Poderíamos destacar ainda, outras inúmeras perspectivas e abordagens sob as quais se dão os diversos estudos entorno do grande tema Formação de Professores, ou dos seus igualmente amplos sub-temas como formação inicial, licenciaturas em ciências, identidade profissional docente etc. No entanto, acreditamos serem suficientes as breves referências aqui apresentadas para atestar a complexidade dos problemas envolvidos e permitir. Situar, neste contexto, o que pretendemos privilegiar em nosso trabalho de pesquisa - formação inicial de professores de física, perfil identitário e expectativas profissionais.

Conforme descrito acima, é interesse de muitos autores a investigação sobre o estado da arte da formação de professores (André, 2009; Silva, 2009; Brzezinski e Garrido), sobre as concepções, crenças e conflitos de alunos em formação inicial (Coimbra e Lindino, 2007), sobre currículo de física do ensino médio (Ostermann e Moreira, 2001), sobre currículo de física da graduação (Terrazzan et al, 2007), sobre concepções de professores em exercício (Bejarano e Carvalho, 2003), sobre as contribuições da formação inicial para o modelo epistemológico do licenciando (Castro e Barbosa-Lima, 2006), sobre práticas e estágios (Baccon e Arruda, 2007) e também projetos de parceria universidade-escola (Castro e Queiroz, 2007; Carvalho e Mion, 2010).

Em sua maioria, os trabalhos que tratam mais especificamente da formação inicial direcionam seu olhar sobre o curso, e não tanto sobre o aluno no curso. Como podemos observar, alguns desses trabalhos também tratam da identidade e representações do professor. No entanto, a maioria deles o faz, quando tratam da formação inicial, do ponto de vista das disciplinas de Práticas de Ensino ou dos Estágios, atribuindo a esses espaços a função de articular teoria e prática ou à superação de determinadas concepções e crenças 
sobre a identidade do professor. Nesse sentido, busca-se, na verdade, identificar a representação de professor desses alunos em sua prática de estágio.

Acreditamos ser um diferencial em nosso trabalho o interesse por pensar o curso de licenciatura de forma mais ampla, a partir do perfil dos licenciandos; perfil este estabelecido não a partir de narrativas especificamente direcionadas, mas por meio de uma análise mais ampla e geral de informações que revelem as representações destes alunos acerca de seu curso como um todo, bem como considere os aspectos sociais e culturais destes indivíduos, fatores importantes na construção de sua identidade profissional. Nesse sentido, não se dará atenção nem à estrutura curricular nem às especificidades das disciplinas que envolvem práticas, ainda que esses aspectos façam parte da questão e permaneçam implícitos. Ao mesmo tempo, acreditamos que nossos resultados terão a dialogar com muitos dos trabalhos aqui referenciados.

Evidentemente os cursos de formação inicial de professores de física apresentam inúmeros problemas - sejam de ordem geral ou específica. Pretendemos muito mais chamar a atenção para aspectos que possam dar indicativos do que está por trás de tais problemas, do que propor soluções propriamente ditas. Neste sentido, destacamos a caracterização do perfil do licenciando como ponto importante da problemática que envolve o curso, sobretudo pela intenção de contemplar a dimensão sócio-cultural destes alunos.

Assim, adotamos uma perspectiva que analisa o conjunto de alunos de um curso de formação inicial em seu percurso, de seu ingresso até seu desligamento - tendo ou não concluído a graduação - com vistas a compreender a identidade desses licenciandos a partir de uma perspectiva que considera as representações que traz ao ingressar, bem como suas construções e transformações ao longo da graduação, buscando elementos que possam vir a subsidiar os formadores, em suas reflexões sobre a realidade e da necessidade de mudanças e melhoria desses cursos. 


\section{CAPÍTULO 2 - CIRCUITOS DA PESQUISA E ESTRATÉGIAS METODOLÓGICAS}

Nesse capítulo, procuramos trazer algumas considerações que inspiraram as definições sobre as estratégias a serem adotadas para a realização desse trabalho. Muitos dos elementos foram sendo percebidos a partir da leitura de diferentes investigações já realizadas ou da leitura de autores contemporâneos, desenvolvidas nas disciplinas cursadas.

Parte do interesse em aprofundar a questão da formação de professores de física partiu de um trabalho desenvolvido em iniciação científica, no qual se construiu um panorama da evasão e dos concluintes do curso de Licenciatura do IFUSP e que revelou uma preocupante realidade: alta taxa de desistência e considerável excedente no tempo para o término do curso (Souza et al., 2009).

Como conseqüência, a primeira delimitação metodológica consistiu em optar por realizar um estudo de caso, considerando o Curso de Licenciatura em Física da USP. Um aspecto importante é que, nesse curso, a opção pela licenciatura é feita já na inscrição do vestibular, em uma instituição que oferece, paralelamente, tanto o bacharelado como a licenciatura em carreiras e ingressos separados. Ainda que correspondendo a uma situação relativamente específica, acreditamos que muitas das características a serem analisadas têm abrangência maior, podendo ser estendidas a outras instituições.

A formação inicial apresentou grande impulso como temática em trabalhos de pesquisas em ensino de ciências no início dos anos 2000. Segundo Slongo, Delizoicov \& Rosset (2009), houve um grande e importante aumento do número de artigos sobre este tema em Encontros Nacionais de Pesquisa de 1999 para 2001, mantendo-se em ascensão ao longo de todo o período. "Este aspecto parece ter sido motivado, também, conforme destacam e argumentam Salém e Kawamura (2005), pelas reformas curriculares propostas, especialmente aos cursos de licenciatura, no início de 2000 , levando a uma revitalização das pesquisas nessa temática" (Delizoicov; Slongo; Lorenzetti, 2007). 
No Brasil, recentes pesquisas vêm mostrando que a escolha pela docência tem sido feita, em grande parte, por estudantes com mais dificuldades escolares e sócio-econômicas, quando comparados aos que não escolhem a docência, podendo indicar que a carreira tem sido vista, para a maioria dos que optam por esta profissão, como "trampolim social" (Leme, 2008). Em um estudo sobre como o conhecimento do perfil e expectativa de ingressantes do curso de pedagogia da USP contribuem para o entendimento da atratividade da carreira docente, Leme (2008) verificou que as características dos participantes aproximam-se em muitos aspectos aos encontrados nos estudos de outros países: a maioria é mulher, supera a escolaridade dos pais e boa parte ingressa após anos de conclusão do ensino médio. $\mathrm{Na}$ comparação a outros ingressantes USP, os de pedagogia estavam entre os que tiveram maiores dificuldades no vestibular e este curso apresenta a mesma problemática da atratividade docente, isto é, ao menos no ingresso, tornar-se professor parece não ser a intenção dos estudantes. A autora adverte que "em perspectiva diversa às críticas feitas aos professores de educação básica, conhecer o perfil e expectativa de candidatos à carreira docente, verificando a atratividade da mesma, pode colaborar para a elaboração e avaliação de políticas de atração do magistério. E alerta para o fato de "que não parece justo que esta carreira, ou a escolha de um curso superior, seja unicamente tomada como modo de ascensão social" (Leme, 2008).

Gobara \& Garcia (2007), considerando "o quadro complexo da formação de professores, em particular, o déficit de professores de física para atuar nas escolas de ensino médio", realizaram um levantamento sobre os cursos de Licenciatura do Brasil e discutem sugestões de organização institucional e possíveis percursos de formação desses profissionais. De acordo com os autores, "verifica-se um crescimento significativo do número de egressos de 2001 a 2005 e sugere-se como medida urgente que se invista nos cursos presenciais atuais para que possam aumentar a sua capacidade de formar professores" (Gobara \& Garcia, 2007). Apontam que, segundo censo realizado em 2003 pelo INEP/MEC, "grande parte dos estudantes dos cursos formação de professores são estudantes de classe média e oriundos de escolas públicas; têm uma base muito precária dos conhecimentos gerais e da língua portuguesa e a maioria abandona no primeiro e/ou segundo ano do curso porque não conseguem acompanhá-lo e também precisam trabalhar" 
(Gobara \& Garcia, 2007). Os autores salientam que a dificuldade de os estudantes se autosustentarem durante o curso, a baixa expectativa de renda em relação à futura profissão, a falta de expectativa de melhoria salarial, somados ao declínio do status social da profissão, fazem com que os cursos de licenciatura, tanto em instituições públicas como privadas, vivam em constante crise.

Essas considerações reforçaram a necessidade de considerar o perfil social ou econômico dos licenciandos, como parte da caracterização de sua identidade. Ao mesmo tempo, o contato com as idéias de Pierre Bourdieu, (por exemplo, em Nogueira e Nogueira (2009)), mostrou existir uma grande ressonância com as questões que vinham sendo analisadas em trabalhos dessa natureza, embora a partir de outros pontos de vista.

Martins; Martins \& Abdalla (2008) buscaram identificar elementos para compreender as representações sociais sobre o trabalho docente de estudantes de licenciatura e em que medida tal compreensão pode contribuir para possíveis direcionamentos em cursos de formação inicial para a docência. Utilizam de elementos-chave - como formação inicial, expectativas em relação a dificuldades de aprendizagem dos futuros alunos e à superação das mesmas, proposições para um curso de formação, motivação para ser um professor, escolha profissional e profissão professor - para desvendar as representações dos estudantes (de pedagogia e de licenciaturas), que foram categorizadas em três dimensões: necessidades/expectativas quanto ao percurso de formação; das motivações à escolha profissional e da atitude, da informação e do campo de representação. As autoras concluem que "os estudantes apostam na profissão, mas sentem necessidade de uma formação inicial que possibilite desenvolver práticas docentes mais adequadas às condições de trabalho existentes, bem como mais voltadas às características do alunado".

A ênfase às representações sociais como estratégia de trabalho para uma maior delimitação da identidade foi sugerida por trabalhos dessa natureza, mas, sobretudo, pela investigação realizada por Dotta (2006).

Dessa forma, tomamos como nossas principais referências as idéias de Bourdieu e as perspectivas abertas pela identificação de representações sociais. Esses dois marco teóricos serão melhor aprofundados no próximo capítulo. 
Dentre as características a serem privilegiadas na análise das representações sociais, diversos trabalhos nos indicaram a importância de uma maior ênfase nas questões relativas, por um lado, às diversas compreensões do ser professor, e, por outro, às compreensões sobre a natureza da ciência/Física.

Oliveira (2006), ao analisar a articulação entre a formação acadêmica e a prática docente, em entrevistas com professores de Física, ressalta a necessidade de uma compreensão do ser professor que lhes permita conquistar a autonomia de um professor reflexivo. Ao mesmo tempo, aponta a importância, em suas práticas, do sentido atribuído à disciplina Física e de seu papel educacional na formação dos alunos.

Segundo Dalri \& Mattos (2007), “a motivação para ensinar-aprender Física está relacionada com a valorização dada pelo indivíduo a esse objeto de estudo" e "o valor e o sentido que professores e estudantes dão à Física e à Educação é que motivaram/motivam suas escolhas profissionais e sua relação com o saber e seu desenvolvimento nas atividades de ensino-aprendizagem" (Dalri \& Mattos, 2007). Os autores entendem "perfis conceituais" como dimensões epistemológicas, ontológicas e axiológicas que integram aspectos cognitivo-afetivos do processo de significação da realidade; e se constituem na interação sujeito-mundo, num processo de atribuição de sentidos/significados. Neste sentido, desenvolveram um estudo em que procuraram estabelecer relações entre motivação, valor e perfil conceitual partindo do pressuposto de que se um objeto tem sentido/valor para o indivíduo dentro da sua rede de significações/representações, este sentido/valor se manifestará na sua interação com o mundo. E concluem que "entender a relação dos professores em formação com a Física e a Educação pode ser um caminho para identificar os valores, sentidos e fatores que os motivam ou desmotivam a cursar a Licenciatura em Física e pode ajudar a entender qual impacto que essa formação tem na sua atuação em sala de aula e na influência que exercem na construção que seus estudantes têm com o saber científico" (Dalri \& Mattos, 2007).

Da mesma forma, diversos trabalhos vêm sinalizando a importância da visão de ciência e da compreensão da Física na formação inicial. 
Higa (2005) investiga as visões de ciência de alunos de um curso de Licenciatura e de sua evolução (ou não) ao longo da formação inicial. A partir de entrevistas e levantamentos de concepções, evidencia a importância da construção de uma visão crítica da ciência, por parte dos alunos. Mais do que isso, aponta como tal visão tem ressonância na própria atividade docente, em suas relações com o aprendizado dos alunos.

Há, ainda, vários outros trabalhos que buscam identificar as diferentes visões de ciências e concepções prévias de licenciandos. Erthal \& Linhares (2010) em um estudo de caso - região norte fluminense - investigaram as predominâncias e as mudanças de visão de ciências em alunos de licenciatura em física em distintos períodos do curso, a partir da aplicação de atividades experimentais em laboratórios de Mecânica e Ondulatória. Segundo os autores, as intervenções feitas durante a pesquisa - como introdução e discussão de tópicos da história das ciências - visaram auxiliar no processo de reestruturação das concepções dos estudantes em sua formação inicial, com a preocupação de fornecer elementos que auxiliassem os licenciandos "a quebrarem com as visões empírica indutivista, aproblemática e ateória da ciência" e fortalecendo "a fundamentação de ciência como prática social e empreendimento humano" (Erthal \& Linhares, 2010).

Gatti; Silva \& Nardi (2007) também analisaram a evolução de concepções de futuros docentes em física em um curso de formação inicial a partir da inserção da História da Ciência em disciplinas de Prática de Ensino de Física. Os resultados revelaram indicadores que confirmam os resultados de pesquisas anteriores, mostrando a existência de concepções alternativas sobre os conceitos físicos, as noções de senso comum sobre a Ciência e os processos de ensino e aprendizagem e sua influência sobre a prática como professores. Além disso, os atores evidenciam as dificuldades para a mudança de postura na ação docente e propõem uma alternativa de formação que favoreça a adoção de metodologias de ensino voltadas para a construção de conhecimento.

Assim, diante da abrangência dos trabalhos sobre formação de professor, e conscientes da impossibilidade de uma pesquisa que contemple tão vasto conhecimento, situamos nossa questão de investigação como sendo a busca pela compreensão e caracterização da formação inicial a partir de seus principais protagonistas - os alunos. 
Nosso propósito é, a partir do conhecimento das particularidades daquilo que compõem a(s) identidade(s) do grupo de licenciandos, contribuir para uma reflexão, fundamentada na realidade, com vistas a transformações e melhorias nas estruturas de um curso dessa natureza.

Para isso, utilizaremos como referência as relações identificadas por Bourdieu entre o processo de escolarização/formação e as características sócio-culturais dos indivíduos. Isso implica em procurar levantar e analisar tais características nos alunos do curso de licenciatura em Física que constitui nosso estudo de caso. Ao mesmo tempo, utilizaremos o levantamento das representações desses alunos para complementar essa investigação, privilegiando tanto suas representações sobre ser professor como suas concepções acerca da ciência que estudam e vão lecionar.

No sentido de responder a essas propostas, os contornos da pesquisa irão perpassar por abordagens ora direcionadas a um olhar ao perfil econômico, ora às representações (de ciência/física e da profissão professor), ora das expectativas com relação à carreira (escolhida para o curso e/ou escolhida para o ingresso no mercado de trabalho).

Além disso, o estudo se dará com o intuito de compreender essa identidade no processo e, por isso deverá considerar diferentes momentos doa alunos no curso. Pretendemos investigar o ingresso, a permanência no curso e o egresso e/ou evasão, sempre com vistas a caracterizar os alunos como fazendo parte de um coletivo maior - dos licenciandos - e assim depreender como se modificam suas concepções e crenças ao longo do percurso.

Portanto, partimos da hipótese de que as representações de ciência/física/educação/perfil profissional do professor evoluem, se modificam e se articulam, no espaço de alguns anos, como parte do processo de formação inicial, resultado das interações e ações que o aluno da licenciatura vivencia. Tais transformações devem considerar a formação inicial como fruto de escolhas e de representações sociais, histórias de vida e influências locais, e também a opção pelo curso/carreira como relacionada ao espaço social e capital cultural destes licenciandos. 
Em suma, o trabalho apresenta duas abordagens - do perfil sócio-cultural e das representações sociais - que pretendem olhar três momentos do curso - o ingresso, o percurso e o egresso.

Para cada uma das etapas desse trabalho, as estratégias de investigação específicas são descritas quando da apresentação dos dados. São o resultado de uma articulação entre abordagem qualitativa e semi-quantitativa. No caso das análises de representações, utilizamos como metodologia de análise a análise de conteúdo, proposta por Bardin (2009), optando por categorias de síntese.

No capítulo que segue, Capítulo 3, buscamos apoio e fundamentação teórica nos estudos sobre habitus e capital cultural de Pierre Bourdieu e nas pesquisas sobre representações sociais da profissão professor desenvolvidas por Leanete Dotta, baseada na teoria desenvolvida por Sèrge Moscovic. Tais autores destacam e definem processos particularmente dinâmicos e que proporcionam análises e discussões que contemplam as dimensões/condições individuais e coletivas do objeto de estudo.

O Capítulo 4 inicia o trabalho de caracterização do licenciando em física, tratando do perfil sócio-econômico-cultural do ingressante USP, colocando-o como elemento de um conjunto maior - daqueles que optaram pela Carreira da qual o Curso de Licenciatura em Física faz parte. Traz uma análise do perfil de modo comparativo a outras carreiras, com diferentes status, procurando contemplar as dimensões sociais e culturais das expectativas destes estudantes, no sentido de compreender aspectos relevantes da decisão de suas escolhas por um curso superior e carreira profissional.

O Capítulo 5 procura caracterizar o licenciando em física a partir da análise das representações sociais que esses alunos, recém-matriculados, têm acerca da profissão Professor, da idéia de Ciência/Física, de pesquisa e ensino, que permeiam suas escolhas pelo curso, pela área e/ou carreira docente.

O Capítulo 6 apresenta um panorama que discute os aspectos relacionados à evasão, os motivos de abandono e tempo previsto/efetivo para o término da graduação, 
buscando fornecer subsídios para uma análise mais ampla sobre o perfil e a identidade do licenciando em física do IFUSP.

O Capítulo 7 pretende caracterizar o licenciando em (per)curso, olhando a evolução e considerando as especificidades de sua trajetória, buscando compreender as transformações por que passam(ram) suas expectativas com relação a carreira escolhida e como evoluem(íram) suas representações de ciência, educação e perfil profissional.

Finalmente, o Capítulo 8 apresenta as considerações finais acerca dos resultados revelados pela investigação, destacando os aspectos mais relevantes que respondem em alguma medida, às questões da pesquisa e apontando propostas de encaminhamentos para futuras análises. 


\section{CAPÍTULO 3 - PERSPECTIVAS TEÓRICAS}

Nesse capítulo, apresentamos dois conjuntos de reflexões que entendemos ser fundamentais para uma compreensão mais global de nosso trabalho: (1) O âmbito das investigações sobre representações sociais e (2) A noção de capital cultural e suas implicações. Esses aspectos nos parecem relevantes uma vez que pretendemos caracterizar o perfil do aluno da licenciatura e para tal desejamos compreender como se dá a construção de processos identitários em cursos de formação inicial de professores segundo uma perspectiva que considere a dimensão social destes alunos e, por isso mesmo deva discutir pontos relacionados às representações sociais e um contexto sócio-cultural mais amplo a elas associado.

\section{1 Representações (Sociais) da Profissão Professor}

As representações sociais dos professores (Dotta, 2006) são construídas a partir da apropriação que os mesmo fazem da prática das suas relações e dos saberes históricos e sociais. O estudo dessas representações possibilita a organização e ampliação dos conhecimentos da Educação, em especial no que diz respeito ao desvelamento da identidade profissional dos professores, e produz subsídios para atender necessidades profissionais destes, especialmente no que se refere à sua formação inicial ou continuada.

No Brasil, estudos que se fundamentam na Teoria das Representações Sociais apresentam um grau de importância relevante, podendo-se encontrar na área de Educação grande diversidade de trabalhos. Teóricos e pesquisadores como Pedra (1980), Souza (1996), Mello (1998), Souto (1995), Rangel (1999), Eizirik (1999), Madeira (2000), Costa e Almeida (2000) entre outros, apresentam estudos usando a noção de representação social em questões que envolvem a imagem do professor, as relações pedagógicas, os processos que constituem a realidade escolar da Educação Básica e Universitária (Dotta, 2006). 


\subsubsection{Um pouco da história das Representações Sociais}

O termo representação social foi postulado por Sérge Moscovici (1961), por ocasião de seus estudos sobre a Psicanálise, para designar o tipo de fenômeno ao qual a sua interpretação teórica se aplicava. Hoje o termo é usado de forma mais ampla, nem necessariamente estar vinculado ao conceito proposto por Moscovici (Dotta, 2006, p. 24).

Sá (1998 apud Dotta, 2006) define como grande teoria das representações sociais as proposições originais básicas de Moscovici, e fala de um desdobramento da teoria em três correntes teóricas complementares: Uma mais fiel à teoria original, liderada por Denise Jodelet, em Paris; uma que procura articulá-la com uma perspectiva mais sociológica, liderada por Willen Doise, em Genebra; uma que enfatiza a dimensão cognitiva-estrutural das representações, liderada por Jean-Claude Abric, em Aix-em-Provence.

Assim, a história da construção da Teoria das Representações Sociais teve início com o surgimento da Psicanálise que, segundo Moscovici (1978), a partir de sua apresentação, passou a ocupar lugar de destaque em nossa cultura. Esse autor constata que a linguagem está repleta de palavras, expressões originadas na Psicanálise que todos compreendem. Baseado nessas comprovações semi-empíricas, o precursor da Teoria das Representações Sociais julga-se autorizado a concluir que a psicanálise configura-se em um modelo que, assimilado, ensinado, comunicado, repartido, dá forma à nossa realidade (Moscovici, 1978, p. 20), e esse modelo regularmente retorna à superfície apoderando-se da consciência coletiva. A influência desse modelo confere à ciência de que se origina, status de importante fato social, implantando-se na vida cotidiana da sociedade. É isso que Moscovici se propõe a estudar e que é o ponto de partida para a sistematização de sua teoria (Dotta, 2006, p. 15).

Moscovici deteve suas considerações em duas ideias, na constatação de que a Psicanálise se constituía em um evento cultural que ultrapassa o domínio restrito das ciências, da literatura ou da filosofia, afetando a sociedade como um todo e, na observação do nascimento de um novo senso comum que não deveria ser compreendido em termos de vulgarização ou distorção da ciência. A análise do processo de disseminação da Psicanálise 
na sociedade Ihe foi possível por meio da Teoria das Representações Sociais, que pôde captar seus elementos essenciais, fazendo-o por meio do estudo das representações sociais e das comunicações. Este autor postula que toda representação é composta de figuras e de expressões socializadas. De forma conjunta, uma representação social é a organização de imagens e linguagem, porque ela realça e simboliza atos e situações que se tornam comuns. Devendo ser encaradas de modo ativo, as representações possuem papel de modelar o que é dado do exterior, mediante a relação entre indivíduos e grupos com objetos, sendo os atos e situações constituídos por interações sociais (Dotta, 2006, p. 16-17).

As representações sociais funcionam como reprodutoras, mas essa reprodução envolve um remanejamento de estruturas, remodelação de elementos, reconstrução dos dados considerando o contexto de valores, de regras e noções. Finalmente, ela produz e determina comportamentos, definindo simultaneamente a natureza dos estímulos que cercam e provocam os indivíduos, e o significado das respostas a serem dadas. Além disso, a representação social é uma modalidade de conhecimento particular que tem por função a elaboração de comportamentos e a comunicação entre indivíduos. É um corpus organizado de conhecimentos e uma das atividades psíquicas graças às quais os homens tornam inteligível a realidade física e social, inserem-se num grupo ou numa ligação cotidiana de trocas e liberam os poderes de sua imaginação (Moscovici, 1978, p. 26-28).

Abordar as representações sociais significa considerar algumas premissas. É necessário considerar que não existe uma ruptura entre o universo exterior e o universo do indivíduo ou do grupo, que o sujeito e o objeto não são absolutamente heterogêneos em seu campo comum. O objeto está inserido em um contexto ativo, dinâmico, considerado parcialmente pela pessoa ou coletividade, como prolongamento de seu comportamento, existindo somente para eles enquanto função dos meios e métodos que permitem conhecêlo. A origem da construção de uma representação social pelos indivíduos, segundo Moscovici (1978), está situada na necessidade de que eles possuem de estar ao corrente, não ser ignorante nem ficar fora do circuito coletivo. Desta forma, cada pessoa, enquanto homem comum - fora de sua profissão - comporta-se de forma idêntica diante de fatos do cotidiano, como um acidente na rua, uma notícia de jornal, um filme assistido etc. Esses 
fatos são resumidos, recortados, classificados e fundidos em um mesmo universo (Dotta, 2006, p.18-19).

A aproximação do conceito de representação social é possível de duas formas. Primeiro quando fica precisa sua natureza de processo psíquico, capaz de tornar familiar, situar e tornar presente em nosso universo interior o que se encontra, de certa forma, distanciado de nós, o que está, de certo modo, ausente. Em segundo lugar, a noção de representação social fica clara a partir da constatação de que, a fim de penetrar no universo de um indivíduo ou de um grupo, o objeto entra numa série de relacionamentos, de articulações e movimentações com outros objetos que já se encontram nesse universo, dos quais toma as propriedades e aos quais acrescenta as dele. A estrutura de cada representação aparece desdobrada, tem duas faces: a face figurativa e a face simbólica. Moscovici quer com isso dizer que a representação faz compreender a toda figura um sentido, e a todo sentido, uma figura. Duplicar um sentido por uma figura abstrata, materializar um objeto abstrato, foi chamado de objetivação. Duplicar uma figura por sentido, proporcionar um contexto inteligível ao objeto, interpretá-lo, foi denominado de ancoragem (Dotta, 2006, p. 19-20).

Nas considerações de Jodelet (1984), a ancoragem dá-se pela integração cognitiva do objeto representando ideias, acontecimentos, pessoas, relações etc; a um sistema de pensamento social preexistente e as transformações implicadas. As representações já disponíveis podem servir também como sistemas de acolhimento de novas representações. De forma geral, o processo é responsabilizado pelo enraizamento social da representação e de seu objeto. Para Moscovici (1985) a ancoragem diz respeito à classificação e denominação, e o que não é classificado nem denominado é estranho, não existe e, ao mesmo tempo, é ameaçador. Nesse processo, a neutralidade é proibida pela própria lógica do sistema em que cada objeto ou sujeito deve ter um valor positivo ou negativo e assumir um determinado lugar numa hierarquia claramente graduada. Segundo Pedra (2000), as funções básicas das representações articulam-se com o processo de ancoragem, as quais se constituem da integração da novidade por meio de processo cognitivo, da interpretação da realidade e da orientação das condutas e das relações sociais (Dotta, 2006). 
O outro processo da formação das representações sociais constitui-se na objetivação. Esse processo é responsável pela transformação de um esquema conceitual em real, é a atribuição de uma contrapartida material a uma imagem (Dotta, 2006, p. 22).

Objetivar é reabsorver um excesso de significações materializando-as. (...) É também transplantar para o nível de observação o que era apenas inferência ou símbolo (Moscovici, 1978, p. 111).

Moscovici (1978, p. 174-176) refere-se, de forma sintetizada, aos dois processos da seguinte forma: a objetivação transfere a ciência para o domínio do ser e a ancoragem a delimita ao domínio do fazer, a fim de contornar o interdito da comunicação. Se a objetivação mostra como os elementos representados de uma ciência se integram a uma realidade social, a ancoragem permite compreender o modo como eles contribuem para modelar as relações e como as exprimem.

Jodelet (2001) afirma que, no nível das dimensões das representações, relacionadas à edificação da conduta, estão à atitude, a informação e o campo de representações ou imagem. A dimensão da informação está relacionada à organização dos conhecimentos que um grupo possui sobre um dado objeto social; a dimensão do campo de representação, que remete a ideia de imagem, refere-se ao conteúdo concreto limitado das proposições atinentes a um aspecto preciso do objeto da representação; a dimensão da atitude é aquela que destaca a orientação global em relação ao objeto da representação social. Essas três dimensões foram postuladas por Moscovici (1978) diante da hipótese da existência de diferentes universos de opinião referentes a diferentes grupos, classes ou culturas, hipótese confirmada pelo seu estudo da psicanálise, no qual encontrou formatos diferentes das dimensões criadas segundo cada grupo que pesquisou.

O estudo das representações contribui para uma abordagem da vida mental individual e coletiva, uma vez que estas envolvem a pertença social dos indivíduos com as implicações afetivas e normativas, com as interiorizações de experiências, práticas, modelos de condutas e pensamentos, que são socialmente transmitidos pela comunicação social, que a ela estão ligadas. Sendo assim, as representações sociais são ao mesmo tempo produto e processo de uma atividade de apropriação da realidade exterior ao pensamento e de elaboração psicológica e social dessa realidade (Dotta, 2006, p. 25). 


\subsubsection{Algumas pesquisas sobre Representações Sociais e a Educação}

O campo da Educação tem privilegiado o uso da noção de representação social. Em seu estudo sobre Representações Sociais do Ser Professor, Dotta (2006), fez um minucioso levantamento de trabalhos no campo da Educação que fizeram uso da teoria das representações sociais. A autora encontrou em biblioteca de Portugal na literatura brasileira, importantes estudos que serviram de subsídios para sua pesquisa na qual faz um aprofundamento na apresentação de pesquisas semelhantes a sua na comparação entres autores brasileiros e portugueses.

Por exemplo, Gilly (2001), teórico francês, faz referência, considerando o contexto europeu, ao número significativo de trabalhos em que as representações são estudadas em apenas alguns de seus aspectos ou manifestações e, por outro lado, ao número relativamente reduzido de trabalhos que colocam as representações em lugar central ou que façam uso de todas as possibilidades que a Teoria permite. Este autor agrupa os estudos cujos objetos de investigação envolvem Educação e Representação Social realizados na França da seguinte forma: o discurso da escola sobre si mesma; o discurso de agentes da instituição; a escola e seu funcionamento do ponto de vista dos professores e pais; apreensão do aluno pelo professor; significação das situações escolares e construção dos saberes.

Martínez (2003), teórico argentino, faz considerações acerca das representações sociais no sentido de que elas seriam características de nossa época, principalmente em virtude da grande quantidade de informações que circulam, pela relativa brevidade de sua vigência e pela impossibilidade de estruturação de tantas ideias em um esquema teórico permanente. Considerando que nada é definitivo, que a renovação dos saberes é necessária e, de acordo com a elaboração desses saberes, que determinam e são determinados por práticas sociais, é que a escola é concebida. 
Sousa (2000) com o objetivo de confrontar o professor com as próprias representações bem como as dos colegas, alunos-formandos e alunos-crianças, fez um levantamento para identificar representações sociais negativas e positivas sobre o professor real e sobre o professor ideal.

Estudando a docência como uma ocupação ética, Silva (1997) buscou caracterizar as representações de um grupo de docentes (de escolas secundárias de Lisboa) no que diz respeito à docência enquanto ocupação ética, obtendo como resultado a representação da docência pelos professores com função de educar, de formar os alunos, de contribuir para o desenvolvimento pessoal e social das crianças e jovens. Outro autor português, Ruivo (1990), em um estudo de caso, investigou as características de bons e maus professores, a partir das representações de alunos e professores, em formação em uma Escola de Ensino Superior Politécnico.

Carrolo (1997) aponta em seus estudos as representações de três funções do professor, sendo a primeira a de mediador, a segunda a de tomada de decisões e por último a função de captar auditórios adversos. É próprio do contexto educador-educando que o professor se depare, simultaneamente, com essas diferentes funções. Segundo o autor, o ato de educar pode ser considerado um ato violento pelo que implica de confrontação entre duas consciências, e onde o professor é induzido a tomar decisões envolvidas de reflexão.

Loureiro (2001) apresenta representações da atividade docente como o relacionamento com os jovens e a atualização contínua dos saberes. A representação da docência como vocação também é apontada pelo autor, bem como a representação de uma atividade por meio da qual se pode melhorar a sociedade, uma atividade que envolve todo o tempo e que tem interesse intelectual.

Oliveira (2000), investigando as características positivas e negativas presentes nas representações dos professores acerca de si mesmos no ensino básico e secundário em Portugal, encontra na afetividade e na inteligência - ligadas, respectivamente, à pessoa e à profissão - as representações predominantes. O autor questiona os professores essencialmente a respeito das qualidades e defeitos de professores que tiveram e marcaram 
suas vidas escolares, bem como sobre as características mais importantes desse profissional do futuro. Diante dos resultados, Oliveira alerta para a necessidade de maiores investimentos na formação, quer inicial, quer contínua, em variáveis que envolvam motivação, simpatia, compreensão, sentido de humor, amizade, entre outras; não investir apenas na profissionalização, mas também na personalização dos docentes.

Rangel (1999) investigou como se dimensiona, em representações, o bom desempenho docente no processo ensino-aprendizagem, destacando-se as representações que envolvem habilidades de relações humanas e habilidades de ensino, seguidas em menor proporção das habilidades artísticas.

Procurando analisar as representações sociais de professores do Curso de Ciências Biológicas da Universidade Federal de Minas Gerais sobre aspectos do ensino, Pereira (2000) apresenta diferentes representações que surgiram, organizando-as em cinco grupos: no primeiro a atividade docente é representada como transmissão de conhecimentos; o segundo traz a ideia de que ensinar é transmitir conhecimentos associados com outras noções sobre a atividade docente, como "desenvolver senso crítico", "ensinar o aluno a aprender sozinho"; no terceiro o ensino é visto como mudança de comportamento; o quarto refere-se a ideia de que ensinar é um fenômeno que ocorre da interação professor-aluno; e no quinto, tem-se a representação do ensino como um fenômeno social contribuinte para a ampla formação do aluno. O autor conclui sobre a necessidade da reconstrução dessas representações, o que poderá levar à maior valorização da docência, da atividade de ensino e da formação profissional nas universidades brasileiras.

Souto (1995) analisa as representações sociais do professor e seu papel social, apresentados por funcionários, alunos e professores de uma universidade pública do Rio de Janeiro. Os resultados apontaram para uma representação do professor como aquele que passa conhecimento, sem outros tipos de exigências e, também uma tendência de representação dicotomizada: ora o professor é batalhador, dedicado, com sentimento de amor pela profissão, ora ele é desmotivado, desinteressado e pouco valorizado profissionalmente. 
Souza (1996), na tentativa de apreender as representações que os professores constroem acerca do trabalho docente, detecta representações sobre o ser professor associadas ao controle da sala de aula, uma imagem de professor que agrada aos alunos, a questão da qualificação docente, ao ter conhecimento e saber transmiti-lo, o conflito entre qualificação e as condições de trabalho, sendo o professor qualificado como aquele que domina o conteúdo, é criativo, politizado, tem empatia com os alunos, lê, estuda e pesquisa, não falta ao trabalho e cumpre os compromissos burocráticos.

Mello (1998) aponta a compreensão do conteúdo das representações que o professor constrói sobre sua prática profissional como estudo capaz de intervir na realidade da escola.

Paredes et al., (2003), realizaram uma pesquisa na Universidade Federal do Mato Grosso buscando investigar as possíveis representações sociais de professores acerca de suas atividades acadêmicas. Fundamentaram-se pela Teoria das Representações Sociais de Moscovic utilizaram recursos eletrônicos como o software EVOC $^{1}$ e ALCESTE $^{2}$. O estudo revelou que no núcleo central das representações sociais dos professores está o ensino. Nos sistema periférico, encontram-se atributos relacionados ao mal-estar, tais como baixos salários, dificuldades e sacrifícios; mas, em contrapartida, estão presentes atributos relacionados ao bem-estar, como prazer, realização, satisfação e respeito.

Em estudo sobre as representações sociais de professores do Ensino Fundamental, Ciclo I, acerca de sua própria profissão, Madeira (2003) define o objeto apoiada nas considerações de que a ação cotidiana não é neutra. Acredita que o estudo das representações sociais possibilita ao pesquisador aproximar-se do objeto definido, considerando-o no dinamismo que o gera.

\footnotetext{
${ }^{1}$ EVOC: programa que efetua a análise de vocábulos. Sua tela de abertura apresenta um conjunto de programas a que ele submete as palavras para realizar as análises fatorial e de tipificação ou de agrupamento. Foi construído na França por Pierre Verges e seus colaboradores (Dotta, 2006).

${ }^{2}$ ALCESTE: programa para análise textual desenvolvido na França por Max Reinert (Dotta, 2006).
} 
Costa e Almeida (2000) realizaram estudo objetivando conhecer o conteúdo, a organização e estrutura das representações sociais do bom professor, entre professores das séries iniciais do Ensino Fundamental, da rede pública de Rondonópolis, Mato Grosso. Procuraram responder a questões como a existência ou não de coerência entre essas representações e as valorizadas pela ciência, qual o vínculo dessas representações com questões de ordem cognitiva, profissional, socioafetivas ou políticas. A representação social do bom professor construída pelo grupo é mais coerente com princípios morais, éticos e profissionais do grupo social de pertença desses sujeitos, do que com os preceitos científicos.

Dotta (2006, p. 39) acredita que as investigações sobre as representações sociais do ser professor permitem apreender a profissão docente nessa dinâmica que envolve o pessoal e o profissional, o individual e o coletivo. Ampara-se na fala de Nóvoa (1997) quanto à urgência em se encontrar espaços de interação entre dimensões pessoais e profissionais, a fim de permitir aos professores a apropriação dos seus processos de formação, dando-lhes um sentido no quadro das suas histórias de vida. E destaca a importância da realização de diagnósticos das necessidades do professorado a fim de que ocorra uma oferta de formação que seja ampla, flexível e planejada, correspondendo às necessidades dos professores em termos de conhecimentos, destrezas ou atitudes.

\section{2 Contribuições da Teoria Sociológica de Bourdieu}

\subsubsection{Breve discussão para a compreensão das práticas sociais - o conceito de habitus}

A teoria criada/desenvolvida e alterada por Bourdieu ao longo do tempo - em função dos resultados de investigação e mudanças no campo intelectual e contexto social mais amplo - esteve sempre baseada numa crítica e afastamento das perspectivas subjetivista e objetivista, com uma proposta alternativa de uma teoria da prática centrada no conceito de habitus (Nogueira e Nogueira, 2009). 
Bourdieu se mostra interessado em compreender a ordem social de uma maneira inovadora, que escape tanto ao subjetivismo (tendência a ver essa ordem como produto consciente e intencional da ação individual) quanto ao objetivismo (tendência a reificar a ordem social, tomando-a como uma realidade externa, transcendente em relação aos indivíduos, e de concebê-la como algo que determina de fora para dentro, de maneira inflexível, as ações individuais) (Nogueira e Nogueira, 2009, p. 19)

Segundo Bourdieu (1983a) é possível conhecer o mundo social de três formas: fenomenológica, objetivista e praxiológica. O conhecimento fenomenológico, segundo o autor, restringe-se a captar a experiência primeira do mundo social, tal como vivida cotidianamente pelos membros da sociedade, sem a preocupação, contudo, do questionamento a respeito das condições objetivas que explicariam o curso dessas interações. O problema dessa forma de conhecimento está, sobretudo, no fato de ela contribuir para uma concepção ilusória do mundo social que confere aos sujeitos excessiva autonomia e consciência na condução de suas ações e interações. O conhecimento objetivista, contrariamente, caracteriza-se pela ruptura que promove em relação à experiência subjetiva imediata. Embora considere legítima e necessária essa ruptura, Bourdieu acredita que o objetivismo implicaria certos riscos pela dificuldade de construir uma teoria da prática (de explicar como se dá a articulação entre os planos da estrutura e da ação). O conhecimento objetivista tenderia a descrever as regularidades que estruturam um espaço social e a supor que os sujeitos obedecem às regras dessa estruturação, sem demonstrar como essas regras, de fato, operam na prática como princípios estruturantes das ações e representações dos sujeitos e são produzidas nesse processo. O terceiro tipo de conhecimento, o praxiológico, é defendido por Bourdieu como uma alternativa capaz de solucionar os problemas do subjetivismo e do objetivismo. Essa forma de conhecimento buscaria apreender a própria articulação entre o plano da ação ou das práticas subjetivas e o plano das estruturas.

[o conhecimento praxiológico] tem como objeto não somente o sistema das relações objetivas que o modo de conhecimento objetivista constrói, mas as relações dialéticas entre essas estruturas $e$ as disposições estruturadas, nas quais elas se atualizam e que tendem a reproduzi-las (Bourdieu, 1983a, p.47).

A questão fundamental para Bourdieu é entender o caráter estruturado ou ordenado das práticas sociais sem, por um lado, considerar essas práticas como organizadas 
autônoma, consciente e deliberadamente pelos sujeitos sociais (concepção subjetivista) e, nem por outro, reduzi-las à execução mecânica de estruturas externas e reificadas (perspectiva objetiva). Assim, Bourdieu (1983a, p. 60), afirma que seria "necessário e suficiente ir do opus operatum ao modus operandi, da regularidade estatística ou da estrutura algébrica ao princípio de produção dessa ordem observada". Bourdieu denomina por "habitus" esse princípio de produção, incorporado nos próprios sujeitos e entendido como sistema de disposições duráveis estruturadas de acordo com o meio social dos sujeitos e que seriam "predispostas a funcionar como estruturas estruturantes, isto é, como princípio gerador e estruturador das práticas e das representações" (1983a, p. 61).

[Para Bourdieu] as práticas sociais apresentariam propriedades típicas da posição social de quem às produz, porque a própria subjetividade dos indivíduos, sua forma de perceber e apreciar o mundo, suas preferências, seus gostos, suas aspirações, estariam previamente estruturadas em relação ao momento da ação (Nogueira e Nogueira, 2009, p. 25).

Bourdieu argumenta que cada sujeito vivenciaria uma série de características de experiências que estruturariam internamente sua subjetividade, construindo uma espécie de "matriz de percepções e apreciações" que orientaria suas ações subseqüentes. Essa matriz o habitus - seria formada por um sistema de disposições gerais que precisariam ser adaptadas pelo sujeito a cada conjuntura específica de ação. O habitus seria fruto da incorporação da estrutura social e da posição social de origem no interior do próprio sujeito; passaria a estruturar as ações e representações dos sujeitos, em situações que diferem, em alguma medida, das situações nas quais o habitus foi formado. Tal conceito desempenha, na obra de Bourdieu, o papel de elo articulador entre três dimensões fundamentais de análise: a estrutura das disposições objetivas, a subjetividade dos indivíduos e as situações concretas de ação. A posição de cada sujeito na estrutura das relações objetivas propiciaria um conjunto de vivências típicas que tenderiam a se consolidar na forma de um habitus adequado à sua posição social (Nogueira e Nogueira, 2009).

Esse habitus faria com que o sujeito agisse nas mais diversas situações sociais, não como um indivíduo qualquer, mas como um membro típico de um grupo ou classe social que ocupa uma posição determinada nas estruturas sociais (...), colaborando assim, sem saber, para reproduzir as propriedades do seu grupo social de origem e a própria estrutura das posições sociais na qual foi formado (Nogueira e Nogueira, 2009, p. 26). 
A convicção de Bourdieu (Nogueira e Nogueira, 2009) é a de que as ações dos sujeitos têm um sentido objetivo que lhes escapa, eles agem como membros de uma classe mesmo quando não possuem consciência clara disso; as marcas de sua posição social, os símbolos que as distinguem e que a situam na hierarquia das posições sociais, as estratégias de ação e de reprodução que Ihe são típicas, as crenças, os gostos, as preferências que a caracterizam são incorporadas pelos sujeitos tornando-se parte da sua própria natureza. Os sujeitos simplesmente agiriam de acordo com o que aprenderam ao longo de sua socialização no interior de uma posição social específica e, dessa forma, confeririam às suas ações um sentido objetivo que ultrapassa o sentido subjetivo diretamente percebido e intencionado.

Pois bem, para Bourdieu os indivíduos agem orientados por uma estrutura incorporada, um habitus, que reflete as características da realidade social na qual eles foram anteriormente socializados. O habitus de profissional de antemão ajustados às exigências do campo vai funcionar como instrumento de tradução. A transformação sistemática dos problemas e dos temas não é o produto de uma busca consciente, mas um efeito automático da pertença ao campo e do domínio da história específica do campo que essa pertença implica. O princípio das estratégias no interior de um campo "não é o cálculo cínico, a busca consciente da maximização do ganho específico, mas uma relação inconsciente entre um habitus e um campo" (Bourdieu, 1983, p. 125).

As estratégias são ações objetivamente orientadas por referência a fins que podem não ser os fins subjetivamente buscados. E a teoria do habitus visa fundar a possibilidade de uma ciência das práticas escapando à alternativa do finalismo e do mecanicismo (Bourdieu, 1983, p. 125).

\subsubsection{Capital Cultural, Social e Simbólico}

Para discutir/compreender o modo como Bourdieu concebe e analisa a realidade social é preciso considerar o papel de destaque atribuído pelo autor à dimensão de simbólica ou cultural na produção e reprodução da vida social. 
Bourdieu procura, com base nas tradições sociológicas de Durkheim, Sausurre e LéviStrauss e também Marx estabelecer uma síntese e como resultado de suas análises afirma que os sistemas simbólicos funcionam como estruturas estruturantes porque são estruturados, isto é,

as produções simbólicas seriam capazes de organizar (estruturar) a percepção dos indivíduos e de propiciar a comunicação entre eles exatamente porque seriam internamente estruturadas, apresentariam uma organização ou lógica interna, passível de identificada pela investigação científica (Nogueira e Nogueira, 2009, p.30).

Seguindo suas articulações, Bourdieu argumenta que a estrutura presente nos sistemas simbólicos e que orienta (estrutura) as ações dos agentes sociais reproduz as principais diferenciações e hierarquias sociais, ou seja, as estruturas de poder e dominação social. Segundo Bourdieu, as produções simbólicas participam da reprodução das estruturas de dominação social de uma forma indireta. Os sistemas simbólicos podem ser produzidos e apropriados pelo conjunto do grupo ou por um corpo de especialistas e por um campo de produção e circulação relativamente autônomo. Bourdieu utiliza o conceito de campo para se referir a certos espaços sociais nos quais determinado tipo de bem é produzido, consumido e classificado; no interior desses campos os indivíduos envolvidos passam a lutar pelo controle da produção e pelo direito de classificarem e hierarquizarem os bens de consumo (Nogueira e Nogueira, 2009, p. 30-31).

A estrutura do campo é um estado da relação de força entre os agentes ou as instituições envolvidas na luta ou, se se preferir, da distribuição do capital específico que, acumulado no decorrer das lutas anteriores, orienta as estratégias posteriores (Bourdieu, 1983, p. 120).

Cada campo de produção simbólica seria palco de disputas relativas aos critérios de classificação e hierarquização dos bens simbólicos produzidos e, indiretamente, das pessoas e instituições que os produzem; e no conjunto da sociedade, os agentes travam uma luta em torno dos critérios de classificação cultural. Certos critérios culturais são considerados superiores e outros inferiores e, no conjunto da sociedade, tenderia a prevalecer à imposição de um determinado arbitrário cultural como a única cultura legítima. Seja em relação a um campo específico, seja no âmbito da sociedade em geral (Nogueira e Nogueira, 2009), é preciso notar que os produtos simbólicos seriam classificados e hierarquizados; 
essas classificações incidiriam não apenas sobre os bens culturais num sentido mais estrito, mas sobre todas as representações e práticas cotidianas. As hierarquias culturais reforçariam as divisões sociais na medida em que são utilizadas para classificar os indivíduos segundo o tipo de bem cultural que eles produzem, apreciam e consomem. Para se referir a esse poder advindo da produção, da posse, da apreciação ou do consumo de bens culturais socialmente dominantes, Bourdieu utiliza, por analogia ao capital econômico, o termo capital cultural. O domínio da língua, por exemplo, funciona como uma moeda (um capital) que propicia a quem o possui uma série de recompensas (Nogueira e Nogueira, 2009).

As hierarquias entre bens simbólicos seriam uma base importante para a hierarquização dos indivíduos e grupos sociais. Indivíduos capazes de produzir, reconhecer, apreciar e consumir bens culturais tidos como superiores teriam melhores condições de ser bem-sucedidos no sistema escolar e no mercado de trabalho, por exemplo. Tais hierarquias reforçam as estruturas de dominação social na medida em que restringem a mobilidade social dos indivíduos; não basta ao indivíduo um conhecimento técnico específico para ter acesso às posições sociais dominantes; é exigido que tenha um certo capital cultural. Assim, por outro lado, segundo Bourdieu, essas mesmas hierarquias reproduzem, de forma eufemizada, a estrutura de dominação da sociedade.

A tese central de Bourdieu é a de que os indivíduos normalmente não percebem que a cultura dominante é a cultura das classes dominantes e, mais do que isso, que ela ocupa uma posição de destaque justamente por representar os grupos dominantes; [...] os indivíduos perceberiam como hierarquias apenas simbólicas o que seriam, principalmente, hierarquias sociais entre grupos e classes (Nogueira e Nogueira, 2009, p. 39).

Bourdieu desenvolve então, três argumentos básicos relativos ao papel dos sistemas simbólicos ou culturais na produção e reprodução das estruturas sociais. Primeiramente eles seriam formas de percepção e representação da realidade - os indivíduos criariam, sustentariam e defenderiam seus sistemas simbólicos no âmbito da sociedade em geral ou o interior de um campo específico. Segundo, os sistemas simbólicos seriam um meio capaz de traduzir e, portanto, escamotear, dissimular eufemizar as hierarquias sociais - a correspondência entre as formas culturais e classes sociais não seriam facilmente percebida pelos agentes sociais. E terceiro, os sistemas culturais contribuiriam para legitimar (justificar) 
essas hierarquias - as diferenças de poder passam a ser percebidas apenas como diferenças de conhecimento, de inteligência, de competência, de estilo, ou simplesmente, de cultura (Nogueira e Nogueira, 2009).

Nas modernas sociedades capitalistas, os dois tipos mais importantes de capital seriam o cultural e o econômico; os indivíduos ocupariam posições diferenciadas e mais ou menos privilegiadas na estrutura social em função do volume e da natureza de seus recursos. Além desses, há também, segundo Bourdieu, a influência do capital social e do capital simbólico. O primeiro se refere ao conjunto das relações sociais (amizades, laços de parentesco, contatos profissionais, etc); o segundo diz respeito ao prestígio ou à boa reputação que um indivíduo possui num campo específico ou na sociedade em geral.

O volume de capital social de um indivíduo seria definido em função da amplitude de seus contatos sociais e, principalmente, da qualidade desses contatos, ou seja, da posição social (volume de capital econômico, cultural, social e simbólico) das pessoas com quem se relaciona. [O conceito de capital simbólico] se refere ao modo como um indivíduo é percebido pelos outros. Geralmente, essa percepção está diretamente associada à posse dos outros três tipos de capital, mas não necessariamente (Nogueira e Nogueira, 2009, p. 43).

De acordo com Bourdieu, as diferentes esferas da vida social funcionariam como uma dinâmica análoga à econômica; o universo escolar, por exemplo, poderia ser considerado como um mercado no qual os indivíduos investem um volume maior ou menor de recursos sobretudo capital cultural - e obtém, em função disso, retorno mais ou menos elevado, na forma de sucesso escolar e de diplomas (capital cultural institucionalizado), que pode, por sua vez, ser reinvestido, por exemplo, nos mercados de trabalho. As decisões de investimento, no entanto, não seriam fruto de um cálculo racional plenamente consciente; na perspectiva de Bourdieu, ao longo do tempo, as melhores estratégias acabariam por ser adotadas pelos grupos e seriam incorporadas pelos agentes como parte de seu habitus. De toda forma, esse ajustamento entre as ações e as condições objetivas de existência, realizado por intermédio do habitus, não seria necessariamente perfeito. Aliás, há casos, por exemplo - que Bourdieu chama de "histeresis" - nos quais existe uma tendência do habitus a permanecer no indivíduo ao longo do tempo, mesmo que as condições objetivas que o produziram e que estão nele refletidas tenham se alterado. Existem outros casos de 
descompasso entre o que sugere o habitus incorporado e a realidade social. $E$ tais desajustamentos mostram que o espaço social, na perspectiva de Bourdieu, seria algo dinâmico (Nogueira e Nogueira, 2009, p. 44-47).

É relevante perceber a importância da dimensão política da noção de capital cultural formulada por Bourdieu, uma vez que a mesma está ligada a uma problematização da dominação - e por isso, "não se reduz a verificar os efeitos das diferenças de desempenho escolar sobre, por exemplo, a renda econômica dos indivíduos" (Almeida, 2007, p. 45).

O conceito de capital cultural não funciona apenas como uma ferramenta para explicar por que crianças dos meios desfavorecidos apresentam um pior desempenho na escola. Mais do que isto, o conceito aparece no interior de um quadro analítico voltado para explicar de que maneira o pior desempenho escolar desses grupos serve à estrutura de dominação vigente numa sociedade específica (Almeida, 2007, p. 45).

Sobre a importância do simbólico no espaço social pensado por Bourdieu, Almeida (2007) afirma que esta dimensão (simbólica) tem força suficiente para complicar a ordenação social dada pelo pólo material. E explica que, num primeiro movimento, Bourdieu apropria-se da herança de Kant e Durkheim e conceitua a cultura - ou os "sistemas simbólicos" - como instrumento de construção do mundo, dando inteligibilidade aos objetos; num segundo movimento, Bourdieu introduz a política no raciocínio, apoiando-se em Marx para notar que, nas sociedades estratificadas, os diferentes grupos sociais produzem sistemas simbólicos diversos que oferecem possibilidades conflitantes de percepção desse mundo.

O embate entre sistemas simbólicos (cultura) é o resultado de transformações em diferentes esferas sociais que fazem aumentar a interdependência entre os diferentes grupos e criam as condições para a unificação do mercado de bens simbólicos (Almeida, 2007, p. 46).

Para Almeida (2007), cultura dominante contribui, ao mesmo tempo para: (i) "a integração real da classe dominante (assegurando uma comunicação imediata entre todos os seus membros e distinguindo-os das outras classes)"; (ii) "a integração fictícia da sociedade no seu conjunto, portanto, à desmobilização (falsa consciência) das classes dominadas"; (iii) "para a legitimação da ordem estabelecida por meio dessas distinções" (Bourdieu, 1989, p. 10). 
O conceito de capital cultural é (Almeida, 2007) uma ferramenta para se apreender a dimensão simbólica da luta entre os diferentes grupos sociais e por isso tem por referência os diferenciais de poder imputados a diferenças simbólicas (cultura dominante ou legítima). Tal conceito também permite supor a sua transmissão entre gerações. Assim, a socialização é percebida como o processo de inculcação, pelas gerações mais velhas, da cultura própria ao grupo a que se destina o indivíduo. Os processos de transmissão da cultura às gerações mais novas implicam, assim, a transmissão dos esquemas de percepção e construção do mundo que são, ao mesmo tempo, princípios de ordenamento e classificação do mundo. $E$, nas sociedades industrializadas altamente estratificadas, a invenção da escola única e obrigatória, complexificou tanto os processos de socialização quanto a própria luta simbólica (Canedo, 1994).

Por um lado, a escola tornou-se uma agência de socialização com a qual a família é obrigada a partilhar a educação de seus filhos, perdendo o poder de definir o conteúdo e a forma dessa transmissão. Por outro lado, percebida como a transmissora do "patrimônio cultural", mas transmitindo de fato a cultura dominante, a escola dá a sua contribuição específica para a luta simbólica, impondo, ao conjunto dos grupos sociais, a cultura de um grupo social específico como cultura legítima e transmitidos para as novas gerações (Almeida, 2007, p. 49).

\subsubsection{Argumentos da Sociologia da Educação de Bourdieu}

A questão educacional está presente em toda a obra de Bourdieu, indo da atenção inicialmente concentrada nos mecanismos escolares de reprodução cultural e social, até a preocupação com as "estratégias" de utilização do sistema escolar postas em prática pelos diferentes agentes e grupos sociais.

Na Sociologia da Educação de Bourdieu cada indivíduo é caracterizado em termos de uma bagagem socialmente herdada (patrimônio transmitido pela família), que inclui, por um lado, certos componentes objetivos, externos ao indivíduo e que podem ser postos a serviço do sucesso escolar (capital econômico, capital social e capital cultural) e, por outro lado, certos componentes que passam a fazer parte da própria subjetividade do indivíduo (capital 
cultural "incorporado", no qual se destaca a "cultura geral", o domínio da língua culta, o gosto e o "bom gosto" e as informações sobre o mundo escolar).

Do ponto de vista de Bourdieu, o capital cultural constitui (sobretudo, na sua forma incorporada) o elemento da herança familiar que teria o maior impacto na definição do destino escolar. A Sociologia da Educação de Bourdieu se notabiliza, justamente, pela diminuição que promove do peso do fator econômico, comparativamente ao cultural, na explicação das desigualdades escolares (Nogueira e Nogueira, 2009, p. 52).

A posse de capital cultural favoreceria o desempenho escolar, em primeiro lugar, na medida em que facilitaria a aprendizagem dos conteúdos e dos códigos que a escola veicula e sanciona; e em segundo, porque propiciaria melhor desempenho nos processos formais e informais de avaliação.

Por meio de um processo denominado "causalidade do provável" (cf. Bourdieu, 1998b), os indivíduos iriam internalizando suas chances de acesso a esse ou àquele bem (material ou simbólico), numa dinâmica de transformação das condições objetivas em esperanças subjetivas. De acordo com o volume e os tipos de capital detidos (econômico, social, cultural e simbólico), certas estratégias se apresentariam como mais seguras e mais rentáveis; e as estratégias mais adequadas seriam adotadas pelos grupos e incorporadas pelos sujeitos como parte do seu habitus - num processo não deliberado de ajustamento entre investimentos e condições objetivas de ação. Aplicados à educação, isso significa que os membros de cada grupo social tenderão a fazer projetos, mais ou menos ambiciosos, na carreira escolar dos seus filhos conforme percebam serem maiores ou menores as probabilidades de êxito (Nogueira e Nogueira, 2009).

O "interesse" que um agente tem pelos "estudos" depende não somente de seu êxito escolar atual ou pressentido (i.e., de suas chances de sucesso dado seu capital cultural), mas também do grau em que seu êxito social depende de seu êxito escolar (Bourdieu, 1989, p. 393).

Um terceiro ponto observado por Bourdieu (1998c) é que o grau de investimento na carreira escolar está relacionado ao retorno provável que se pode obter com o certificado escolar, não apenas no mercado de trabalho, mas também nos diferentes mercados simbólicos. O retorno dependeria também do estado das relações entre o campo escolar e o campo econômico, o qual determina o grau de correspondência entre o diploma e os postos 
profissionais. Neste sentido, o valor de um título escolar estaria relacionado, em parte, a capacidade diferenciada que cada grupo social possui de tirar proveito desse título (Nogueira e Nogueira, 2009).

As estratégias escolares dos diferentes grupos sociais constituiriam um ponto central no conjunto das diversas estratégias de reprodução social e somente em relação a elas podem ser entendidas; elas não constituem senão um "aspecto particular" das estratégias educativas que recobrem um campo bem mais vasto destinado a "produzir agentes sociais capazes e dignos de receberem a herança do grupo, isto é, de serem herdados pelo grupo" (Bourdieu, 1998b, p. 116). Dentre as estratégias educativas, “a mais importante é a transmissão doméstica do capital cultural que depende de um investimento em tempo e em transmissão cultural, e que assegura o mais alto rendimento em termos de resultados escolar" (Nogueira e Nogueira, 2009, p.59).

A parte mais importante e mais ativa da herança cultural transmite-se de maneira osmótica, o que contribui para reforçar a convicção dos membros da classe culta de que eles só devem aos seus dons esses conhecimentos, essas aptidões e essas atitudes, que desse modo, não Ihes parecem resultar de uma aprendizagem (Bourdieu, 1966, p. 46).

As mesmas condições objetivas que definem as atitudes dos pais e dominam as escolhas importantes da carreira escolar regem também a atitude dos estudantes diante dessas mesmas escolhas e, consequentemente, toda a sua atitude com relação à escola. De maneira geral, as crianças e sua família se orientam sempre em referência às forças que as determinam. Até mesmo quando suas escolhas lhes parecem obedecer à inspiração irredutível do gosto ou da vocação, elas traem a ação transfigurada das condições objetivas (Bourdieu, 1966, p. 46-49).

A estrutura das oportunidades objetivas de ascensão social e, mais precisamente, das oportunidades de ascensão pela escola condicionam as atitudes frente à escola e à ascensão pela escola e isso por intermédio de esperanças subjetivas, que não são senão as oportunidades objetivas intuitivamente apreendidas e progressivamente interiorizadas (Bourdieu, 1966, p. 49). 
O habitus, entendido por Bourdieu (1983, p. 125) como "sistema de disposições adquiridas pela aprendizagem implícita ou explícita que funciona como sistema de esquemas geradores", é também gerador de estratégias que podem estar em conformidade (objetiva) com os interesses objetivos dos seus autores sem terem sido expressamente concebidas para esse fim.

Quando as pessoas só têm de deixar correr o seu habitus para obedecerem à necessidade imanente do campo e satisfazer as exigências que nele se encontram inscritas, não têm consciência de estar sacrificando um dever e menos ainda de estar buscando a maximização do ganho (específico) (Bourdieu, 1983, p. 126).

O capital social associado ao pertencimento à classe dominante, que permite maximizar o rendimento econômico e simbólico dos certificados escolares no mercado de trabalho, permite também minimizar as perdas em caso de fracasso. Os ramos de ensino e as carreiras de maior risco têm sempre uma espécie de par menos glorioso, relegado àqueles que não possuem suficiente capital (econômico, cultural e social) para assumirem os riscos da perda total ao pretenderem ganhar tudo; tais riscos nunca são assumidos a não ser quando se tem a certeza de nunca perder tudo ao tentar ganhar tudo (Bourdieu, 1998, p.9495).

O ethos de classe - enquanto necessidade feita virtude - é, para Bourdieu (1998), a propensão ao provável pela qual se realiza a causalidade do futuro objetivo em todos os casos de correspondência entre disposições e chances. Os efeitos do habitus "jamais se encontram tão bem escondidos a não ser quando aparecem como efeito direto das estruturas porque são produzidos por agentes que são a estrutura 'feita homem'"(Bourdieu, 1998, p. 98).

O custo relativo do filho, baixo para as famílias com renda mais baixa e baixo também para as famílias dotadas de renda elevada, passa por um máximo que corresponde às rendas médias, isto é, as classes médias forçadas, pela ambição da ascensão social, a fazerem investimentos educativos relativamente desproporcionados aos seus recursos. Assim se explica a forma da relação que se observa entre as estratégias de fecundidade das diferentes classes ou frações de classe e as chances de ascensão social objetivamente oferecidas a seus membros (Bourdieu, 1998, p. 98-99). 
As estratégias objetivamente orientadas para a manutenção ou melhora da posição ocupada na estrutura social constituem um sistema que só pode ser apreendido e entendido enquanto tal pelo retorno ao seu princípio gerador e unificado - o ethos de classe. É através de seu intermédio que toda a visão do mundo econômico e social, toda a relação com o outro e com o próprio corpo afirma-se em cada uma de suas práticas, "quer seja a mais natural em aparência, a menos controlada pela consciência, pela razão ou até pela moral." (Bourdieu, 1998, p 104)

O capital cultural e o ethos, ao se combinarem, concorrem para definir as condutas escolares e as atitudes diante da escola, que constituem o princípio de eliminação diferencial das crianças das diferentes classes sociais. Ainda que o êxito escolar, diretamente ligado ao capital cultural legado pelo meio familiar, desempenhe um papel na escolha da orientação, parece que o determinante principal do prosseguimento dos estudos seja a atitude da família a respeito da escola, como função das esperanças objetivas de êxito escolar encontradas em cada categoria social (Bourdieu, 1966, p. 50).

Segundo Bourdieu (1966) a questão do funcionamento da escola e sua função de conservação social é raramente colocada, "porque a ideologia jacobina que inspira a maior parte das críticas dirigidas ao sistema universitário evita levar em conta realmente as desigualdades frente ao sistema escolar, em virtude do apego a uma definição social de equidade nas oportunidades de escolarização" (Bourdieu, 1966, p. 53).

Ora, se considerarmos seriamente as desigualdades socialmente condicionadas diante da escola e da cultura, somos obrigados a concluir que a equidade formal à qual obedece todo o sistema escolar é injusta de fato, $e$ que, em toda sociedade onde se proclamam ideais democráticos, ela protege melhor os privilégios do que a transmissão aberta dos privilégios (Bourdieu, 1966, p. 53).

Ao atribuir aos indivíduos esperanças de vida escolar estritamente dimensionadas pela sua posição na hierarquia social, e operando uma seleção que sanciona e consagra as desigualdades reais, a escola contribui para perpetuar as desigualdades, ao mesmo tempo em que as legitima. 
... ela [a escola] transforma as desigualdades de fato em desigualdades de direito, as diferenças econômicas e sociais em "distinção de qualidade", e legitima a transmissão da herança cultural (Bourdieu, 1966, p. 58).

Bourdieu (1966) adverte que o sucesso excepcional de alguns indivíduos que escapam ao destino coletivo dá uma aparência de legitimidade à seleção escolar, e dá crédito ao mito da escola libertadora junto àqueles próprios indivíduos que ela eliminou, fazendo crer que o sucesso é uma simples questão de trabalho e de dons.

Aqueles que a escola "liberou", mestres ou professores, colocam sua fé na escola libertadora a serviço da escola conservadora, que deve ao mito da escola libertadora uma parte de seu poder de conservação (Bourdieu, 1966, p. 59).

A partir da perspectiva teórica de que é preciso conhecer as leis segundo as quais as estruturas tendem a se reproduzir produzindo agentes dotados do sistema de disposições em condições de reproduzir as estruturas, a sociologia das instituições de ensino - em particular, das instituições de ensino superior - pode trazer uma contribuição decisiva à ciência da dinâmica da estrutura das relações de classe. Dentre as soluções historicamente conhecidas quanto ao problema da transmissão hereditária do poder e dos privilégios, a mais dissimulada é aquela veiculada pelo sistema de ensino ao contribuir para a reprodução da estrutura das relações de classe dissimulando, sob as aparências da neutralidade, o cumprimento desta função (Bourdieu, 2009, p. 296).

Nas reflexões de Bourdieu, a escola não seria uma instância neutra que transmitiria uma forma de conhecimento intrinsecamente superior às outras formas de conhecimento, e que avaliaria os alunos com base em critérios universalistas; mas, ao contrário, é concebida como uma instituição a serviço da reprodução e da legitimação da dominação exercida pelas classes dominantes. A cultura consagrada e transmitida pela instituição escolar não seria objetivamente superior a nenhuma outra; seu valor seria arbitrário, muito embora a cultura escolar seja socialmente reconhecida como cultura legítima, como a única universalmente válida. Nas sociedades de classes, a capacidade de imposição e legitimação de um arbitrário cultural (convertendo-o em cultura legítima) corresponderia à força da classe social que o sustenta. Uma vez reconhecida como legítima, a escola passa a poder exercer suas funções 
de reprodução e legitimação das desigualdades sociais, paradoxalmente, por meio da equidade formal estabelecida pela escola entre todos os alunos (Nogueira e Nogueira, 2009).

[...] para que sejam favorecidos os mais favorecidos e desfavorecidos os mais desfavorecidos, é necessário e suficiente que a escola ignore, no âmbito dos conteúdos de ensino que transmite, dos métodos e técnicas de transmissão e dos critérios de avaliação, as desigualdades culturais entre as crianças das diferentes classes sociais (Bourdieu, 1998d, p. 53).

Nogueira e Nogueira (2009) reiteram a fórmula de Bourdieu ao afirmarem que "tratando, formalmente, de modo igual, em direitos e deveres, quem é diferente, a escola privilegiaria, dissimuladamente, quem, por sua bagagem familiar, já é privilegiado" (p. 73).

Ao dissimular que sua cultura é a cultura das classes dominantes, a escola dissimula igualmente os efeitos que isso tem para o sucesso escolar das classes dominantes. Assim, a escola, simultaneamente, reproduziria e legitimaria as desigualdades sociais:

A reprodução seria garantida pelo simples fato de que os alunos que dominam, por sua origem, os códigos necessários à decodificação $e$ assimilação da cultura escolar e que, em função disso, tenderiam a alcançar o êxito escolar, seriam aqueles pertencentes às classes dominantes. A legitimação das desigualdades sociais ocorreria, por sua vez, indiretamente, pela negação do privilégio cultural oferecido - camufladamente - aos filhos das classes dominantes (Nogueira e Nogueira, 2009, p. 75).

Para Bourdieu, a legitimação manifesta-se tanto sobre os filhos das camadas dominantes - que teriam dificuldade de se reconhecer como "herdeiros" - quanto sobre os das camadas dominadas - incapazes de perceber o caráter arbitrário e impositivo da cultura escolar. E, quanto ao modo como os indivíduos se relacionam com o mundo da cultura, o autor acredita que o fator determinante é "o modo pelo qual a cultura foi adquirida: por familiarização insensível (e mais precocemente), no caso dos agentes socialmente privilegiados, ou, por inculcação escolar (e mais tardiamente), no caso dos agentes sociais desfavorecidos" (Nogueira e Nogueira, 2009, p. 76).

Segundo Bourdieu, o sistema escolar leva em conta, tanto quanto a cultura, a relação que os alunos têm com ela - o modo de aquisição e de uso da cultura legítima. A escola reproduziria a distinção entre os dois modos básicos de se relacionar com a cultura: um primeiro, desvalorizado, se expressaria na figura do aluno esforçado, estudioso, aplicado que busca compensar sua distância em relação à cultura legítima através de uma dedicação 
tenaz às atividades escolares; e um segundo, valorizado, representado pelo aluno tido como brilhante, original, talentoso, desenvolto, que tende às exigências da escola sem exibir traços de um esforço tenso. Esta segunda postura seria a consagrada e cobrada pelo sistema de ensino - sobretudo nos seus ramos mais elevados. Mas essa desenvoltura seria encarada pela escola como manifestação de uma facilidade inata, de uma vocação natural para as atividades intelectuais. Por um lado, a escola valorizaria uma desenvoltura intelectual, uma familiaridade com a língua e com a cultura legítima que não poderiam ser adquiridos completamente pela aprendizagem escolar e, por outro negaria que essas habilidades sejam fruto da socialização familiar diferenciada vivida pelos alunos, supondo-as produto de um talento "natural". E isso configuraria "uma contradição implícita no próprio funcionamento do sistema escolar" (Nogueira e Nogueira, 2009, p. 78).

[...] as reflexões de Bourdieu sobre a escola partem da constatação de uma correlação entre as desigualdades sociais e escolares. As posições mais elevadas e prestigiosas dentro do sistema de ensino tendem a ser ocupadas pelos indivíduos pertencentes aos grupos socialmente dominantes. Essa correlação só pode ser explicada quando se considera que a escola dissimuladamente valoriza e exige dos alunos determinadas qualidades que são desigualdades distribuídas entre as classes sociais, notadamente, 0 capital cultural e uma certa naturalidade no trato com a cultura e o saber que apenas aqueles que foram desde a infância socializados na cultura legítima podem ter (Nogueira e Nogueira, 2009, p. 79).

Bourdieu ressalta, para a compreensão sociológica da escola, que essa instituição não é neutra. Alguns estariam em condições mais favoráveis do que outros para atender às exigências da escola; portanto, as chances (que formalmente seriam iguais) são, na verdade, desiguais. Como solução para a lógica (perversa) da acumulação do privilégio cultural por meio da escola, Bourdieu propôs a ideia de uma "pedagogia racional", que mais tarde se viu frustada:

Bourdieu anteviu uma saída que pudesse servir aos interesses dos alunos socialmente desfavorecidos. Essa saída estaria no processo mediante o qual a ação pedagógica com os alunos se daria por uma aprendizagem "metódica" visando tornar explícito tudo aquilo que funciona de modo implícito no curso do processo pedagógico. Bourdieu e Passeron (1964) se referiam a essa ação como uma "pedagogia racional que tudo fizesse para neutralizar metodicamente e continuamente, do maternal à universidade, a ação dos fatores sociais de desigualdade cultural". [...] Poucos anos mais tarde, porém, Bourdieu (1970) já se mostra convencido do caráter utópico de um trabalho 
pedagógico de tipo racional e de sua capacidade de levar a uma equitativa distribuição do saber (Nogueira e Nogueira, 2009, p. 85).

\subsubsection{Algumas considerações acerca do conceito bourdieusiano de capital cultural e o sistema educacional brasileiro}

Com a proposta de discutir até que ponto a noção de capital cultural se mostra útil para se pensar o Brasil - mais exatamente o sistema de ensino brasileiro - Almeida (2007), analisa alguns elementos da organização e funcionamento desse sistema buscando melhor compreender a questão.

A autora começa lembrando que as reformas administrativas permitiram a consolidação de um sistema de ensino unificado e segmentado; segmentação esta, resultado do controle do Estado sobre os aspectos mais simbólicos da organização do sistema escolar (por exemplo, definição de conteúdos, formação de professores, autorizações para criação de novos estabelecimentos). No entanto, adverte que qualquer análise dos efeitos desta unificação deve levar em consideração que a universalização da escolarização nunca foi alcançada de forma ampla no Brasil.

Se essa situação manteve os grupos menos privilegiados afastados da escola, e os mantém, ainda hoje, afastados das trajetórias de escolarização de longa duração, ela não impediu que os diplomas se tornassem cruciais nas estratégias reprodutivas das camadas sociais médias e superiores do Brasil, já que esses nunca deixaram de estar associados às possibilidades de acesso às posições dirigentes (Almeida, 2007, p. 50).

A cisão (Almeida 2007) que se efetuou progressivamente no interior do sistema é um fenômeno antigo responsável pela diferença do destino escolar reservado às crianças e jovens pertencentes a esses grupos. Com isso, as dimensões econômicas da origem social do aluno passam a ter um peso especial na determinação da sua exposição aos conteúdos escolares, se comparado com outros países onde a universalização e extensão da escolarização basearam-se mais significativamente na provisão da educação pública.

Outro fato importante é que, no Brasil, a seleção dos alunos chamados a ocupar as posições dirigentes - destinados às trajetórias escolares/sociais bem-sucedidas - trata-se de 
um processo que não utiliza diretamente as dimensões econômicas ou pessoais para a exclusão ou inclusão dos alunos, visto que "mesmo famílias melhor aquinhoadas em termos econômicos não conseguem evitar o fracasso escolar de seus filhos" (2007, p. 51).

A posição social futura passa a depender menos do diploma e mais da herança dos bens familiares, um processo que pode ser tanto mais bemsucedido quanto menos controles a sociedade apresentar à transmissão intergeneracional da riqueza. Essa, aliás, é uma das questões implícitas nas lutas em torno da criação de impostos sobre a herança (Almeida, 2007, p. 51).

Bourdieu construiu um programa analítico que, para compreender as hierarquias em vigor no espaço social de uma sociedade e sua duração no tempo, exige que o pesquisador invista em identificar - entre os sistemas simbólicos próprios a cada grupo - aquele que se encontra em posição dominante, descrevendo seus sistemas de validação. Geralmente, na tentativa de operacionalizar o conceito de capital cultural, os autores acabam utilizando os dados mais disponíveis, renunciando a criar um conjunto próprio, específico.

Num primeiro conjunto de casos, o que está disponível é a escolarização dos pais e a análise limita-se a correlacionar a escolarização dos pais (em geral do pai) com o desempenho escolar ou com alguma tomada de posição, sem indagar precisamente de que maneira e por meio de que medições esses elementos estão associados (Almeida, 2007, p. 53).

A forte segregação de base financeira que exclui as crianças e jovens oriundos dos grupos sociais economicamente desfavorecidos da distribuição de diplomas mais valorizados - particularmente os universitários - é operada primordialmente a partir da imposição de um mesmo conjunto de critérios que garantem a competência daqueles agraciados com um diploma escolar. Tais condições permitem à ideia de igualdade de oportunidades funcionar como um fundamento da diferenciação escolar. Portanto, a operação de capital cultural pede por mais estudos sobre os critérios de julgamento escolar em vigor no Brasil (indicadores da cultura legítima), para que possamos "sair do impasse entre o reconhecimento da inadequação para o caso brasileiro dos indicadores usados por Bourdieu e a utilização vazia de sentido da expressão "capital cultural" sem significado empírico algum" (Almeida, 2007, p. 53). 
Então, quando não se fixa na escolaridade do pai, o argumento geral baseia-se em informações obtidas pela manipulação de bases de dados que informam sobre graus de proximidade com formas e práticas culturais específicas (a alta cultura), bases estas "montadas com outras finalidades, mas que operam uma discussão sobre estratificação das práticas culturais" (Almeida, 2007, p. 54). A proximidade com a alta cultura não é objeto de uma investigação substantiva sobre o lugar que ocupam na sociedade em questão. Tanto que os primeiros resultados dessas apropriações do capital cultural não confirmaram pontos importantes das análises realizadas por Bourdieu para a França. Esses indícios (seja de uma certa imprecisão do modelo proposto por Bourdieu, seja da especificidade da sociedade francesa) só passaram a ser vistos como um possível efeito da maneira como os indicadores foram construídos a partir de meados da década de 1990. A partir de então, torna-se mais claro que as práticas definidas como cultura legítima são assim classificadas como efeito de uma situação própria do estado de organização das relações sociais.

(...) para se fazer de forma apropriada a transposição da análise, seria necessário encontrar um meio de se captar o estado de organização específico de cada sociedade num momento dado para evitar cair na armadilha de tomar as atividades identificadas, naquela conjuntura especificamente francesa, como trazendo em si uma natureza superior ou mais capaz de produzir posicionamentos privilegiados no espaço social (Almeida, 2007, p. 54).

Nos Estados Unidos e na Europa, parte da dificuldade de apropriação do conceito de capital cultural decorre do fato de que se fazia à época uma análise da estratificação das práticas culturais em moldes muito parecidos com a França, no Brasil as dificuldades derivam da carência de estudos desse tipo. Além de mais estudos sobre as práticas culturais dos grupos dominantes, é preciso interrogar o sistema de ensino - para precisar os elementos definidores da cultura que ele contribui para legitimar - através de estudos sobre os exames escolares. Essa é uma ideia particularmente produtiva (Almeida, 2007) quando aplicada ao estudo do vestibular brasileiro, um dos principais instrumentos de estruturação do sistema de ensino, em função de sua importância nas estratégias reprodutivas dos grupos médios e das elites.

A discussão do conteúdo do privilégio cultural por meio de uma sociologia do exame (...) permite reunir alguns elementos de resposta para a complicada 
questão de se identificar de forma substantiva o que está em jogo na associação entre escolarização do pai e da mãe e desempenho escolar (Almeida, 2007, p. 55).

Entre as principais competências buscadas nos estudantes está a capacidade de manipular a língua materna de forma reflexiva e inventiva, associado a uma capacidade de reflexão sobre o mundo e sobre si mesmo. Tais critérios "revelam uma estruturação da correção em torno de formas particulares de se apropriar do estoque cultural comum e que se explicita na oposição criar x executar" (Almeida, 2007).

O estudo das características valorizadas nas redações do vestibular de uma universidade pública ${ }^{3}$ que ocupa o pólo dominante do espaço da educação superior mostra, em primeiro lugar, a inequívoca valorização de uma das formas da língua (o padrão culto) como língua legítima. Em segundo lugar, explicita que a competência no manejo da língua culta é avaliada de forma muito particular no sistema em vigor. Não se poderia visualizar com maior clareza o privilégio que consiste, na sociedade brasileira, em estar imerso na cultura valorizada pela escola (Almeida, 2007).

\footnotetext{
${ }^{3}$ Trata-se de uma discussão que utilizou dados da Unicamp relativos ao vestibular 2006 (Almeida, 2007, p. 55).
} 


\section{CAPÍTULO 4 - PERFIL DO INGRESSANTE - ASPECTOS SÓCIO-ECONÔMICOS}

Entendemos que a investigação das características de ingressantes do curso de Licenciatura em Física da USP deva ser contemplada em sua dimensão social. A preocupação com indicadores sócio-econômicos e culturais expressa a intenção de situar as expectativas desses ingressantes em um contexto social mais amplo, reconhecendo que esse é um campo importante das escolhas profissionais dos jovens, nessa fase de suas trajetórias.

Neste primeiro momento, buscamos considerar este ingressante como elemento de um conjunto maior, daqueles que optaram pela Carreira da qual o Curso de Licenciatura em Física faz parte. Nesse sentido, procuramos analisar o perfil sócio-econômico dos alunos ingressantes na Licenciatura da USP, não em termos absolutos, mas apresentando um comparativo segundo carreiras com diferentes status, de modo a compreender a relevância de alguns aspectos sociais na decisão pela escolha de um curso superior.

Com essa intenção, optamos por analisar a mobilidade intergeracional educacional dos ingressantes USP, além de outros parâmetros com potencial para indicar aspectos sócioeconômicos, tais como renda média, cor de pele e natureza dos estudos no nível médio.

\subsection{Aspectos sócio-econômicos e a Mobilidade Intergeracional em Educação - Comparação dos perfis de ingressantes USP no período de 2000 a 2009}

Há muitos estudos sobre a desigualdade na educação brasileira, porém a questão da mobilidade intergeracional - tópico melhor compreendido no contexto da desigualdade não tem recebido a merecida atenção, uma vez que pouco se encontra a esse respeito. 
Trabalhos como os de Barros e Lam (1993), Barros et al (2001), Pastore (1979) e Pastore e Silva (1999) mostraram que a educação dos pais desempenha um importante papel na determinação do grau de escolaridade dos filhos.

Em um estudo de 2001 sobre mobilidade intergeracional de educação na América Latina, Behrman, Gaviria e Székely revelaram que o grau de mobilidade é consideravelmente menor em países latinos-americanos do que em países desenvolvidos e indicaram um aumento da mobilidade para coortes ${ }^{4}$ mais jovens no Brasil (Ferreira e Veloso, 2003).

Com base no suplemento de mobilidade da PNAD de 1996, Ferreira e Veloso (2003) apresentam evidências detalhadas sobre mobilidade intergeracional no Brasil utilizando diferentes métodos para caracterizar padrões não-lineares no grau de mobilidade e explorando as não-linearidades para analisar a dinâmica da mobilidade intergeracional de educação para coortes. Tal estudo revelou que o grau de mobilidade no Brasil é menor do que em países desenvolvidos e em desenvolvimento e que também varia entre regiões e raças (cor de pele) $)^{5}$. Além disso, a mobilidade é menor para filhos de pais com pouca escolaridade do que para filhos de pais com escolaridade mais elevada, com exceção de pais no topo da distribuição educacional. Com relação à evolução da mobilidade entre coortes, os resultados sugerem que isso ocorreu devido à elevação significativa do nível educacional dos filhos de pais com baixa escolaridade em relação á média educacional ${ }^{6}$.

O conceito de mobilidade empregado nos estudos pode variar segundo os autores. Para Pastore e co-autores, uma sociedade apresenta maior mobilidade que outra se os filhos na primeira têm uma probabilidade maior de pertencer a uma classe social diferente da de seus pais (literatura sociológica). De acordo com o conceito empregado por Ferreira e Veloso (2003), uma sociedade apresenta maior mobilidade do que outra se a classe social dos pais na primeira tem uma importância menor na determinação da classe social dos filhos (literatura econômica). Assim, é possível se obter alta mobilidade na primeira definição e baixa na segunda.

\footnotetext{
4. Estudos de coortes são aqueles nos quais os indivíduos são classificados segundo o status de exposição.

5 . Em particular, a mobilidade é menor no Nordeste que no Sudeste, e é mais baixa entre negros do que entre brancos.

${ }^{6}$. Ver também Lam e Levison (1992).
} 
O grau de mobilidade intergeracional de educação - no modelo econométrico ${ }^{7}$ mede o grau de persistência intergeracional, de modo que, quanto maior a persistência, menor será a mobilidade.

A análise de matrizes de transição é outro método comumente usado nos estudos de mobilidade, que fornecem a probabilidade de o filho pertencer a uma determinada categoria educacional dada a categoria de educação do pai ${ }^{8}$.

Um estudo recente sobre a evolução e desigualdade na educação brasileira, mostra que ocorreram avanços importantes na ampliação do acesso a todos os níveis e modalidades educacionais (com a universalização do ensino fundamental), mas que, no entanto, a baixa escolaridade média da população e a desigualdade permanente ainda é um grave problema - o que alerta para a necessidade da universalização da educação básica e a melhoria da qualidade da educação (Castro, 2009). Em tal estudo, apresenta-se um indicador denominado de hiato educacional, que mede a quantidade de anos de estudos que, em média, faltam aos brasileiros que estão abaixo da meta da educação. $E$, tendo em vista que a mobilidade intergeracional está diretamente relacionada aos anos de escolaridade de pais e filhos, indicadores como este são de grande importância para o entendimento da atual situação de mobilidade em educação no Brasil.

A dimensão social pretendida nesta investigação permite que associemos ao estudo da Mobilidade Intergeracional em Educação, uma análise dos resultados sob o ponto de vista do perfil econômico e da escolaridade em nível médio dos ingressantes USP.

Ao direcionar um olhar à mobilidade intergeracional em educação de ingressantes USP na comparação entre algumas carreiras e em cinco momentos distintos (considerando o período de 2000 a 2009), este trabalho pretende verificar, primeiro, se há mobilidade (e quanto) para essa amostra e, segundo, apresentar indicativos que possam ajudar no entendimento dos resultados obtidos. Isto é, além de responder à questão sobre qual o percentual de alunos que iguala ou supera a escolaridade de seu pai no ingresso a

\footnotetext{
7. Utilizado nos estudos de Ferreira e Veloso (2003).

${ }^{8}$. Ferreira e Veloso (2003) ressaltam que há outras medidas de mobilidade e sugerem ver Behrman (2000) e Bowles e Gintis (2002).
} 
universidade - o que equivale a olhar o complemento percentual de alunos cujos pais tenham curso superior incompleto, superior completo e/ou pós-graduação - buscamos compreender de que modo carreiras com diferentes status podem apresentar particularidades em termos de perfis dos alunos e ao longo de alguns anos. Assim, analisar em que medida esse fator é importante, ao se comparar, por exemplo, os ingressantes em um Curso de Medicina e aqueles ingressantes em um Curso de Licenciatura em Física de uma mesma universidade.

A análise inclui - além do comparativo entre escolaridade do ingressante e a escolaridade do pai, também a comparação com a escolaridade da mãe. Na maioria dos trabalhos dessa área, tem sido recorrente considerar a escolaridade do pai como indicativo principal. Nesse sentido, essa pode ser uma oportunidade conveniente para avaliar em que medida esses dois parâmetros são ou não equivalentes. Além disso, pretendemos incluir em nossa análise uma abordagem acerca do tópico "cor de pele", visto que em trabalhos anteriores informações a esse respeito são co-relacionadas à mobilidade intergeracional em educação.

Muito embora, os estudos sobre mobilidade intergeracional em educação sejam, em sua maioria, objeto de estudo da literatura econômica, nos apoiaremos na literatura sociológica, especificamente o conceito de capital cultural - como entendido por Bourdieu na interpretação dos resultados encontrados.

\subsection{Estratégia de investigação}

Os dados sobre os ingressantes USP dos anos 2000, 2002, 2005, 2007 e 2009 foram obtidos através de consulta ao site Fuvest $^{9}$, disponível atualmente, na seção Vestibular/Estatísticas/Questionário de Avaliação Sócio-Econômica. Nesse item são disponibilizadas informações estatísticas sobre cada uma das perguntas que compõe o questionário sócio-econômico, que deve ser respondido por todos os alunos no ato da

\footnotetext{
9. www.fuvest.br.
} 
inscrição. Pode-se optar por verificar as estatísticas por Carreira/Região e por Grupo (inscritos/convocados 1a matrícula/convocados segunda fase), uma vez selecionada a questão.

Inicialmente, foram selecionados os dados de ingressantes referentes às questões 7, 11, 12, 16 e 17 (reproduzidas a seguir) para o Grupo "Chamados para a primeira matrícula" e para diferentes opções de "Carreira". Nesse item, foram verificados os dados para o Total Geral USP (sem treineiros) e para mais seis Carreiras adiante discriminadas.

\section{Onde você realizou seus estudos de ensino médio?}

\section{Qual o grau de instrução mais alto que seu pai obteve?}

12. Qual o grau de instrução mais alto que sua mãe obteve?

16. Entre as alternativas abaixo, qual é a sua cor?

\section{Qual é a renda familiar mensal (em reais) de sua casa?}

Cerca de 30 questões compõem o Questionário de Avaliação SócioEconômica/FUVEST ${ }^{10}$. As primeiras quatro tratam do vestibular FUVEST; as seis seguintes do curso do ensino fundamental e médio, cursinho pré-vestibular e outros cursos superiores; pergunta-se também a profissão dos pais, estado civil, o número de pessoas que contribuem com a renda familiar e são sustentadas por ela; se o vestibulando trabalha e como pretende manter-se durante os estudos; quantidade de bens e acesso à internet; origem profissional, sexo e idade; e algumas perguntas específicas como: se a escolha é pela carreira de música ou artes plásticas e se há opção pela participação no INCLUSP ${ }^{11}$. Assim, a escolha pelas cinco questões selecionadas se justifica por entendermos que o conjunto de tais perguntas

\footnotetext{
10. O número de questões sofreu variações ao longo dos anos: 32 (2000); 27 (2002); 28 (2005); 29 (2007 e 2009).

11 . Programa de Inclusão Social da USP, lançado em 2007, que engloba ações antes, durante e após o vestibular.
} 
apresenta um quadro satisfatório das características sócio-econômicas e culturais relacionadas à investigação pretendida.

Os dados obtidos a partir das alternativas apresentadas no Questionário, foram reorganizados segundo categorias de interesse, substituindo aquelas da Fuvest por outras, de forma a facilitar a análise a que se propõe o presente trabalho. Os resultados foram organizados em tabelas, de forma independente para os cinco anos selecionados.

No caso da escolaridade do pai (e mãe), as categorias adotadas foram divididas em (I), (II), (III) e (IV), tal que as porcentagens aí descritas representam aqueles que têm:

(I) até Ensino Médio incompleto
(II) Ensino Médio completo
(III) Ensino Superior incompleto
(IV) Ensino Superior completo ou mais

Já as Carreiras foram sub-divididas em três blocos, procurando caracterizar conjuntos diferentes de carreiras que gozam de status sociais específicos. Assim, no primeiro bloco, reunimos carreiras de alta demanda e relação candidato/vaga, reconhecidas como de grande apelo e prestígio social pelos ingressantes. No segundo bloco, reunimos carreiras relacionadas à formação de professores, Pedagogia e Licenciaturas em Ciências, Física e Matemática. Além disso, e para estabelecer uma referência mais ampla, incluímos, também, os resultados para o conjunto de todos os ingressantes na primeira matrícula. Com esses critérios, os blocos de carreiras ficaram assim constituídos:

Bloco 1 - Direito, Engenharia e Medicina

Bloco 2 - Licenciatura em Ciências Exatas - São Carlos, Licenciatura em Matemática/Física e Pedagogia

Bloco 3 - Total Geral USP 


\subsection{Dados e Discussão dos Resultados}

Os resultados, obtidos a partir dos procedimentos descritos anteriormente, estão organizados em tabelas e gráficos, separadamente por questão abordada e para cada um dos cinco anos. Devido ao grande volume de dados, optamos, em um primeiro momento, por discutir e dar destaque aos resultados de um único ano (2002) e, em seguida, fazer as comparações com os demais dados, procurando estabelecer algumas conclusões a partir do panorama ao longo dos anos. No Anexo A podem ser encontradas todas as tabelas e gráficos. A escolha pelo ano de 2002 se deu pelo fato de que, uma vez iniciada esta pesquisa em 2009, teríamos, de lá para cá, um período suficiente para o qual grande parte dos ingressantes daquele ano pudessem já ter concluído seu curso. Assim, a investigação que envolve não somente o ingressante, mas também, no decorrer da investigação, o aluno em curso e o egresso, poderia ser consideravelmente assegurada.

\subsubsection{Escolaridade de pai/mãe}

A partir do banco de dados da Fuvest, e considerando a escolaridade dos pais, pode ser construída a Tabela 1, a seguir. O percentual de escolaridade indicado como (I) corresponde a pais com ensino médio incompleto, reunindo nesse grupo as diferentes possibilidades para que isso ocorra. Os percentuais de escolaridade II, III e IV correspondem, respectivamente, a pais com ensino médio completo, pais com ensino superior incompleto e pais com ensino superior completo e/ou pós-graduação. 
Tabela 1 - Escolaridade do pai, por carreiras e total geral, 2002, com o correspondente percentual de mobilidade intergeracional em educação.

\begin{tabular}{|c|c|c|c|c|c|c|}
\hline \multicolumn{7}{|c|}{2002} \\
\hline & \multirow{2}{*}{ Carreiras } & \multicolumn{4}{|c|}{ Escolaridade do pai (\%) } & \multirow{2}{*}{$\begin{array}{l}\text { Mobilidade média } \\
\text { (aprox.) }\end{array}$} \\
\hline & & (I) & (II) & (III) & (IV) & \\
\hline \multirow{3}{*}{$\begin{array}{c}\text { Bloco } \\
1\end{array}$} & Direito & 10,3 & 8,3 & 9,0 & 72,5 & \multirow{3}{*}{$16 \%$} \\
\hline & Engenharia & 3,5 & 10,5 & 10,4 & 69,3 & \\
\hline & Medicina & 6,9 & 9,4 & 3,7 & 79,9 & \\
\hline \multirow{3}{*}{$\begin{array}{c}\text { Bloco } \\
2\end{array}$} & $\begin{array}{l}\text { Lic. Ciências Exatas - } \\
\text { SC }\end{array}$ & 51,0 & 28,6 & 6,1 & 14,3 & \multirow{3}{*}{$63 \%$} \\
\hline & Lic. Matem/Física & 43,1 & 19,2 & 11,0 & 26,7 & \\
\hline & Pedagogia & 33,5 & 12,8 & 11,2 & 42,5 & \\
\hline $\begin{array}{c}\text { Bloco } \\
3\end{array}$ & Total Geral USP & 20,5 & 14,1 & 9,6 & 55,7 & $35 \%$ \\
\hline
\end{tabular}

(I) - até Ensino Médio incompleto; (II) - Ensino Médio completo; (III) - Ensino Superior incompleto; (IV) - Ensino Superior completo ou mais

Uma vez que, ao matricular-se, o estudante ingressante passa a integrar o grupo daqueles que possuem "ensino superior incompleto", e que nos interessa qual a porcentagem dos filhos que têm escolaridade maior ou igual a dos pais, a partir desses dados é possível obter a mobilidade. Tal informação nos é fornecida pela porcentagem complementar dos valores correspondentes aos itens (III) e (IV) da Tabela 1, já que neles temos o percentual dos pais com "ensino superior incompleto ou mais". Ou ainda, podemos entender que isso seria o equivalente à soma dos valores percentuais correspondentes a (I) e (II). E, desse modo, quanto maior for esse número [(III) + (IV) ou $100-$ (I) - (II)], menor será a mobilidade indicada, e vice-versa.

A partir da Tabela 1, podemos verificar que, em 2002, para as carreiras do Bloco 1, em média, apenas $16 \%$ dos filhos igualam ou superaram a escolaridade de seus pais ao ingressarem no curso superior. Isso significa que mais de $80 \%$ desses alunos pertencem a famílias onde há um alto grau de escolaridade. No Bloco 2, das Carreiras de Licenciatura e Pedagogia, esse percentual se diferencia grandemente, onde pouco mais de $60 \%$ dos alunos superaram ou igualaram-se à escolaridade de seus pais no ingresso ao curso superior. Destaque para o percentual de mobilidade da Carreira Lic. Matemática/Física que é de $62,3 \%$, índice muito próximo da média do bloco; diferente do que ocorre com Lic. Ciências 
Exatas/SC ( 80\%) e Pedagogia (46\%), que apresentam índices um pouco diversos da média do bloco. Observando o valor correspondente ao "Total Geral USP" (Bloco 3) vemos que 35\% dos estudantes igualou ou ultrapassou a escolaridade de seus pais ao ingressarem na USP em 2002; ou seja, cerca de $65 \%$ (ou $2 / 3$ ) dos chamados para $1^{\text {a }}$ matrícula na USP tem pais com, pelo menos, curso superior incompleto.

Esses dados nos indicam, por um lado, que o índice de mobilidade intergeracional em educação para a amostra geral estudada é pequeno - o que se justifica pelo fato de o curso superior estar no topo da distribuição educacional e, de acordo com a literatura, neste caso a mobilidade ser sempre baixa. Por outro, percebe-se diferenças relevantes entre os índices para os Blocos 1 e 2, o que evidencia importante caracterização do perfil do ingressante segundo o status da carreira escolhida.

Repetindo esses procedimentos, de forma equivalente, mas utilizando como parâmetro a escolaridade da mãe, foram obtidos os valores da Tabela 2 a seguir.

Tabela 2 - Escolaridade da mãe, por carreiras e total geral, 2002, com o correspondente percentual de mobilidade intergeracional em educação.

\begin{tabular}{|c|c|c|c|c|c|c|}
\hline \multicolumn{7}{|c|}{2002} \\
\hline \multirow{2}{*}{\multicolumn{2}{|c|}{ Carreiras }} & \multicolumn{4}{|c|}{ Escolaridade da mãe (\%) } & \multirow{2}{*}{$\begin{array}{l}\text { Mobilidade média } \\
\text { (aprox.) }\end{array}$} \\
\hline & & (I) & (II) & (III) & (IV) & \\
\hline \multirow{3}{*}{ Bloco 1} & Direito & 8,9 & 15,5 & 6,8 & 68,8 & \multirow{3}{*}{$24 \%$} \\
\hline & Engenharia & 12,6 & 17,8 & 10,0 & 59,5 & \\
\hline & Medicina & 4,8 & 13,7 & 11,0 & 70,5 & \\
\hline \multirow{3}{*}{ Bloco 2} & Lic. Ciências Exatas - SC & 67,3 & 16,3 & 41,1 & 12,2 & \multirow{3}{*}{$69 \%$} \\
\hline & Lic. Matemática/Física & 46,1 & 25,4 & 9,4 & 19,1 & \\
\hline & Pedagogia & 31,6 & 20,0 & 10,6 & 37,8 & \\
\hline Bloco 3 & Total Geral USP & 22,3 & 18,7 & 9,6 & 49,4 & $41 \%$ \\
\hline
\end{tabular}

(I) - até Ensino Médio incompleto; (II) - Ensino Médio completo; (III) - Ensino Superior incompleto; (IV) - Ensino Superior completo ou mais

Assim como no caso em que foi considerada a escolaridade do pai, os índices de mobilidade intergeracional levando em conta a escolaridade da mãe, mostram, novamente, 
que para o bloco 3 - Total Geral USP - mais da metade dos chamados para primeira matrícula tem pais com alto grau de escolaridade (superior completo e/ou pós-graduação (IV)) e que os blocos 1 (Direito/Engenharia/Medicina) e 2 (Licenciaturas em Ciências, Matemática, Física e Pedagogia) apresentam índices bastante distantes da média geral. Considerando a mobilidade com sendo o índice de alunos que igualam ou superam a escolaridade de sua mãe (soma dos percentuais (I) e (II)), notamos que a taxa é de $\sim 40 \%$ para o total USP, $\sim 70 \%$ para o bloco 2 e de $\sim 25 \%$ para o bloco 1 . O que, assim como no caso da escolaridade do pai, evidencia grande diferença no perfil dos alunos dos Blocos 1 e 2.

A Tabela 3, a seguir, apresenta os valores comparativos, por bloco de carreira, para a mobilidade baseada na escolaridade do pai e da mãe. Os resultados parecem dar um indicativo de que - conforme consta na literatura - há equivalência entre escolaridade de pai e mãe, para todos os Blocos. Maior evidência disso será observada na comparação dos dados para os demais anos.

Tabela 3 - Comparação entre as médias de índice de mobilidade tal como obtidas a partir da escolaridade do pai ou da mãe, por bloco de carreira (2002).

\begin{tabular}{|c|c|c|c|}
\hline \multicolumn{4}{|c|}{2002} \\
\hline & Carreiras & Mobilidade (escolaridade pai) & $\begin{array}{l}\text { Mobilidade (escolaridade } \\
\text { mãe) }\end{array}$ \\
\hline Bloco 1 & $\begin{array}{l}\text { Direito } \\
\text { Engenharia } \\
\text { Medicina }\end{array}$ & $16 \%$ & $24 \%$ \\
\hline Bloco 2 & $\begin{array}{l}\text { Lic. Ciências Exatas - SC } \\
\text { Lic. Matemática/Física } \\
\text { Pedagogia }\end{array}$ & $63 \%$ & $69 \%$ \\
\hline Bloco 3 & Total Geral & $35 \%$ & $41 \%$ \\
\hline
\end{tabular}




\section{Comparando os dados de Mobilidade Intergeracional em Educação de 2000 a 2009}

Para uma melhor análise comparativa entre os resultados apresentados nas tabelas acima (referente ao ano de 2002) e os dados de 2000, 2005, 2007 e $2009^{12}$, segue a Tabela 4:

Tabela 4 - Percentual de mobilidade média, por ano, por bloco de carreiras na comparação da escolaridade de pai e mãe, nos anos 2000, 2002, 2005, 2007 e 2009.

\begin{tabular}{|c|c|c|c|c|c|c|c|c|c|c|c|}
\hline & \multirow{3}{*}{ Carreiras } & \multicolumn{10}{|c|}{$\begin{array}{l}\text { Mobilidade Média (aprox.) - percentual de alunos que igualam ou } \\
\text { superam a escolaridade de seus pais e mães no ingresso à universidade }\end{array}$} \\
\hline & & \multicolumn{2}{|c|}{2000} & \multicolumn{2}{|c|}{2002} & \multicolumn{2}{|c|}{2005} & \multicolumn{2}{|c|}{2007} & \multicolumn{2}{|c|}{2009} \\
\hline & & pai & mãe & Pai & mãe & pai & mãe & Pai & Mãe & pai & Mãe \\
\hline Bloco 1 & $\begin{array}{l}\text { Direito } \\
\text { Engenharia } \\
\text { Medicina }\end{array}$ & $19 \%$ & $27 \%$ & $16 \%$ & $24 \%$ & $41 \%$ & $45 \%$ & $38 \%$ & $41 \%$ & $31 \%$ & $24 \%$ \\
\hline Bloco 2 & $\begin{array}{l}\text { Lic. Ciênc. Exatas } \\
\text { Lic. Matem/Física } \\
\text { Pedagogia }\end{array}$ & $60 \%$ & $70 \%$ & $63 \%$ & $69 \%$ & $84 \%$ & $87 \%$ & $81 \%$ & $84 \%$ & $55 \%$ & $60 \%$ \\
\hline Bloco 3 & Total Geral USP & $33 \%$ & $41 \%$ & $35 \%$ & $41 \%$ & $56 \%$ & $59 \%$ & $52 \%$ & $55 \%$ & $37 \%$ & $39 \%$ \\
\hline
\end{tabular}

Nota-se que nos anos 2000 e 2002, para os Blocos 1 e 3, a mobilidade com relação ao pai é razoavelmente maior do que a mobilidade em relação à mãe, cerca de 7-8 pontos percentuais. Porém, para os anos seguintes (2005, 2007 e 2009), essa diferença diminui, concordando com a literatura e evidenciando a equivalência entre escolaridade de pais e mães.

O Bloco 2, das Licenciaturas e Pedagogia, igualmente apresenta queda na diferença entre os percentuais para pais e mães - evidenciando a equivalência entre os mesmos - e também se destaca como o bloco em que a mobilidade intergeracional em educação é maior no comparativo com outras carreiras.

Os gráficos 1 e 2 ilustram a variação percentual ao longo dos cinco anos considerados para a mobilidade intergeracional em educação de ingressantes USP, respectivamente na

\footnotetext{
12. Em anexo, tabelas com os dados de 2000, 2005, 2007 e 2009.
} 
comparação com a escolaridade dos pais e das mães, como mais uma forma de evidenciar a equivalência já citada.

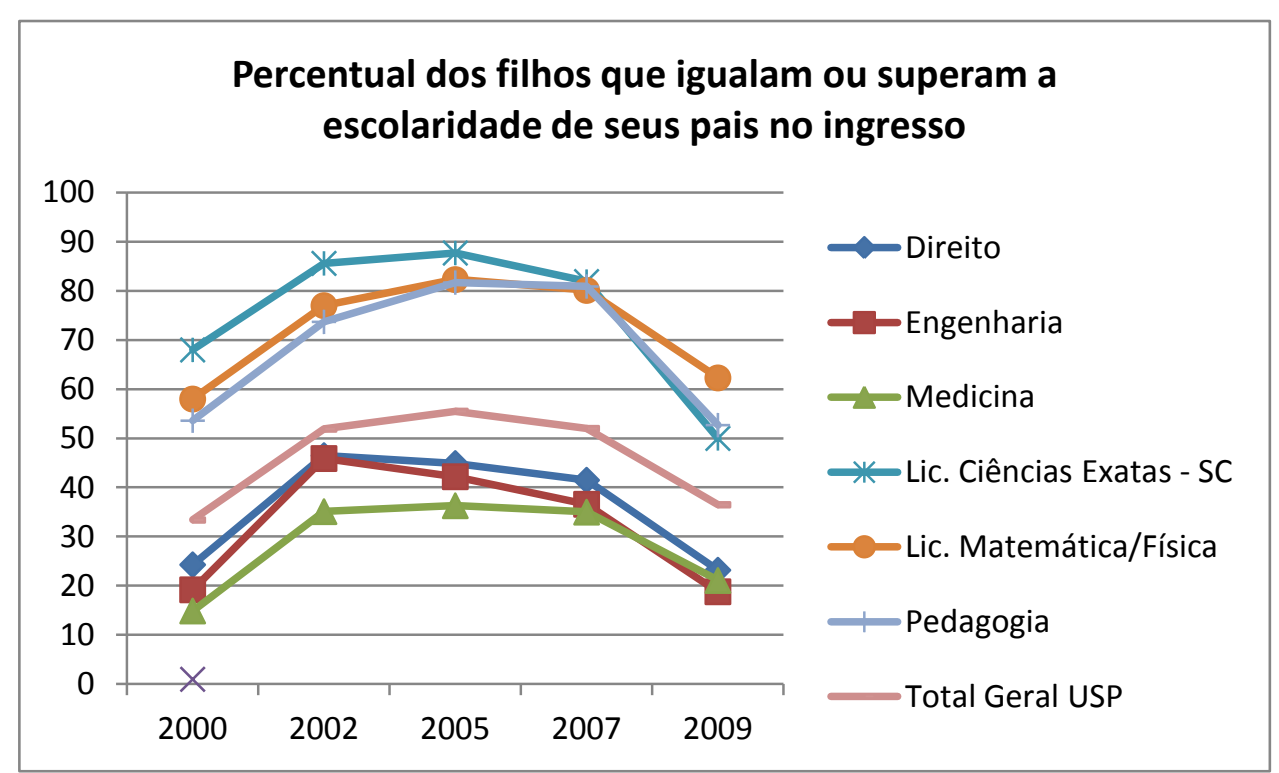

Gráfico 1 -Variação do percentual de filhos que igualam ou ultrapassam a escolaridade de seus pais no ingresso ao curso superior, ao longo dos anos.

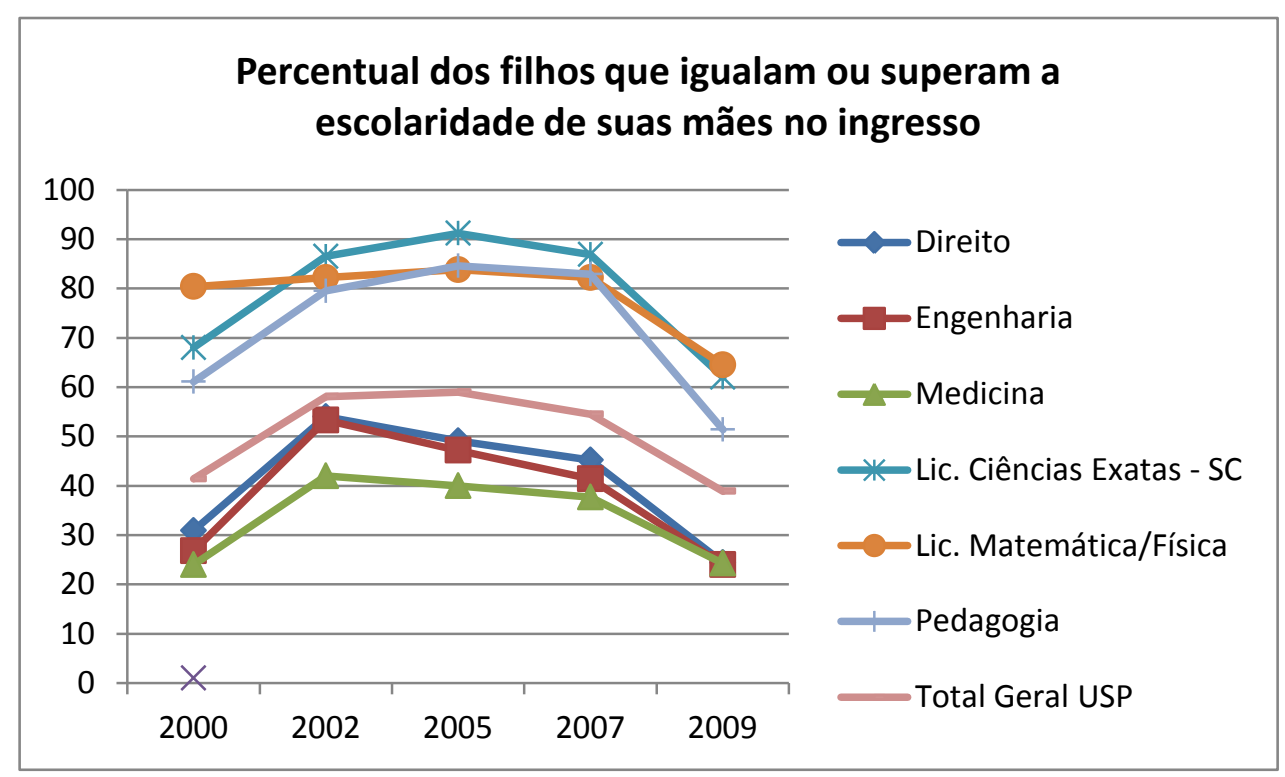

Gráfico 2 - Variação do percentual de filhos que igualam ou ultrapassam a escolaridade de suas mães no ingresso ao curso superior, ao longo dos anos. 
A linha correspondente ao Total Geral USP (Bloco 3) em ambos os gráficos, localizada na proximidade dos 50\%, separa as linhas referentes às carreiras do Blocos 1 (que estão abaixo) e Bloco 2 (que estão acima) o que facilita a visualização de que a mobilidade intergeracional para o segundo bloco é, de fato, bem maior que no primeiro.

A comparação entre os gráficos 1 e 2, também nos permite perceber grande semelhança na distribuição das curvas ao longo dos anos, levando a conclusão de que existe equivalência entre a escolaridade do pai e da mãe em termos de mobilidade intergeracional em educação para ingressantes USP para as carreiras aqui consideradas.

Uma vez assegurados da equivalência no uso da escolaridade de pai ou mãe no estudo da Mobilidade Intergeracional em Educação, podemos discutir a partir da Tabela 5, na qual usaremos somente os dados referentes ao pai, o que é mais frequentemente encontrado na literatura:

Tabela 5 - Percentual de mobilidade média, por ano, por bloco de carreiras.

\begin{tabular}{|c|c|c|c|c|c|c|}
\hline & \multirow{2}{*}{ Carreiras } & \multicolumn{5}{|c|}{$\begin{array}{l}\text { Mobilidade Média (aprox.) - percentual de alunos que } \\
\text { igualam ou superam a escolaridade de seus pais no } \\
\text { ingresso à universidade }\end{array}$} \\
\hline & & 2000 & 2002 & 2005 & 2007 & 2009 \\
\hline $\begin{array}{c}\text { Bloco } \\
1\end{array}$ & $\begin{array}{l}\text { Direito } \\
\text { Engenharia } \\
\text { Medicina }\end{array}$ & $19 \%$ & $16 \%$ & $41 \%$ & $38 \%$ & $31 \%$ \\
\hline $\begin{array}{c}\text { Bloco } \\
2\end{array}$ & $\begin{array}{l}\text { Lic. Ciências Exatas - SC } \\
\text { Lic. Matemática/Física } \\
\text { Pedagogia }\end{array}$ & $60 \%$ & $63 \%$ & $84 \%$ & $81 \%$ & $50 \%$ \\
\hline $\begin{array}{c}\text { Bloco } \\
3\end{array}$ & Total Geral USP & $33 \%$ & $35 \%$ & $56 \%$ & $52 \%$ & $37 \%$ \\
\hline
\end{tabular}

Podemos perceber - e agora ao longo de dez anos - que de fato como mostram pesquisas sobre o assunto, a mobilidade média dos ingressantes USP é baixa, uma vez que os "Chamados para a 1aㅡ Matrícula" fazem parte de um grupo privilegiado de alunos cujos pais estão no topo da distribuição educacional. O índice para o Total Geral USP que em 2000 
era de 33\%, sofreu certo aumento nos anos de 2002 e 2005, voltando a diminuir em 2007 e chegando a 37\% em 2009. Já os Blocos 1 e 2 apresentam índices mais baixos nos anos 2000 e 2002, um relevante aumento em 2005, seguida de pequena queda em 2007 e outra significativa diminuição em 2009. Porém, os índices da Bloco 1 ficaram (em média) em torno de $30 \%$ e os do Bloco 2 em torno de $70 \%$.

As particularidades das carreiras que constituem os Blocos 1 e 2 são responsáveis pelas diferenças nos valores encontrados. Ou seja, os resultados deixam claro a significativa diferença entre as carreiras que constituem os Blocos 1 e 2, confirmando a hipótese de que o status diferenciado implica em uma caracterização de perfis distintos de ingressantes.

$\mathrm{Na}$ tentativa de melhor entender esses resultados podemos nos apoiar em estudos da literatura sociológica e, por exemplo, considerarmos essas diferenças como expressão de forte influência do capital cultural, segundo Bourdieu.

Ora, vê-se nas oportunidades de acesso ao ensino superior o resultado de uma seleção direta ou indireta que, ao longo da escolaridade, pesa com rigor desigual sobre os sujeitos das diferentes classes sociais. (...) A ação do privilégio cultural só é percebida, na maior parte das vezes, sob suas formas grosseiras, isto é, como recomendações ou relações, ajuda no trabalho escolar ou ensino suplementar, informação sobre sistema de ensino e as perspectivas profissionais. Na realidade, cada família transmite a seus filhos, mais por vias indiretas que diretas, um certo capital cultural e um certo ethos, sistemas de valores implícitos e profundamente interiorizados, que contribui para definir, entre coisas, as atitudes face ao capital cultural e à instituição escolar (Bourdieu, 1966).

Assim como sugere a literatura econômica, nos estudos sobre mobilidade educacional, também Pierre Bourdieu acredita que a escolarização dos pais influencia de algum modo a do filho. Porém, suas afirmações não tratam do tipo de escolaridade em si, mas do nível cultural global da família.

As atitudes dos membros das diferentes classes sociais, pais ou filhos e, particularmente, as atitudes a respeito da escola, da cultura escolar e do futuro oferecido pelos estudos são, em grande parte, a expressão do sistema de valores implícitos ou explícitos que eles devem à sua posição social. (...) De maneira geral, as crianças e sua família se orientam sempre em referência às forças que as determinam. Até mesmo quando suas escolhas thes parecem obedecer à inspiração irredutível do gosto ou da vocação, elas traem a ação transfigurada das condições objetivas. Em outros termos, a estrutura das 
oportunidades objetivas de ascensão social e, mais precisamente, das oportunidades e ascensão pela escola condicionam as atitudes frente à escola e à ascensão pela escola e isso por intermédio de esperanças subjetivas, que não são senão as oportunidades objetivas intuitivamente apreendidas $e$ progressivamente interiorizadas (Bourdieu,1966).

Os resultados mostram, portanto, que pouca alteração ocorreu em termos de mobilidade intergeracional de ingressantes na USP, nesse período. Isto é, a baixa mobilidade - justificada, sobretudo, pelo fato de tal amostra pertencer ao topo da distribuição educacional - se manteve praticamente inalterada nesta evolução temporal aqui discutida. De certa forma, esses dados permitem generalizar os resultados, pelo menos para o período de, aproximadamente, dez anos.

\subsubsection{Renda Mensal}

Apesar de não ser o objetivo deste trabalho aprofundar discussões acerca das condições econômicas da amostra analisada, informações a esse respeito nos podem ser úteis para um entendimento mais global dos resultados encontrados. O Questionário de Avaliação Sócio-econômico da Fuvest apresenta sete alternativas, que foram aqui, reagrupadas em quatro categorias para facilitar a análise dos dados. A tabela 6, abaixo, apresenta os resultados referentes à renda mensal familiar, em reais, indicada pelos ingressantes do ano de 2002.

Tabela 6 - Percentual da renda mensal familiar (em reais) de ingressantes 2002, por bloco de carreiras.

\begin{tabular}{|c|c|c|c|c|c|c|}
\hline \multicolumn{7}{|c|}{2002} \\
\hline & \multirow[b]{2}{*}{ Carreiras } & \multicolumn{5}{|c|}{ Renda Mensal (em reais) } \\
\hline & & $\begin{array}{c}\text { Inferior } \\
\text { a } 500\end{array}$ & $\begin{array}{l}\text { Entre } \\
500 \mathrm{e} \\
1500 \\
\end{array}$ & $\begin{array}{c}\text { Entre } \\
1500 \mathrm{e} \\
3000 \\
\end{array}$ & $\begin{array}{c}\text { Superior } \\
\text { a } 3000\end{array}$ & $\begin{array}{l}\text { Percentual médio } \\
\text { (aproximado) para } \\
\text { renda superior a R\$ }\end{array}$ \\
\hline \multirow{3}{*}{ Bloco 1} & \multirow{3}{*}{$\begin{array}{l}\text { Direito } \\
\text { Engenharia } \\
\text { Medicina } \\
\end{array}$} & $1,1 \%$ & $6,4 \%$ & $16,3 \%$ & $76,3 \%$ & \multirow{3}{*}{$70 \%$} \\
\hline & & $1,3 \%$ & $10,0 \%$ & $25,9 \%$ & $62,8 \%$ & \\
\hline & & $0,5 \%$ & $6,5 \%$ & $21,6 \%$ & $71,4 \%$ & \\
\hline \multirow{3}{*}{ Bloco 2} & \multirow{3}{*}{$\begin{array}{l}\text { Lic. Ciências Exatas - SC } \\
\text { Lic. Matemática/Física } \\
\text { Pedagogia }\end{array}$} & $8,3 \%$ & $66,7 \%$ & $14,6 \%$ & $10,4 \%$ & \multirow{3}{*}{$24 \%$} \\
\hline & & $5,1 \%$ & $38,9 \%$ & $31,5 \%$ & $24,5 \%$ & \\
\hline & & $2,8 \%$ & $27,4 \%$ & $34,1 \%$ & $35,8 \%$ & \\
\hline Bloco 3 & Total Geral USP & $2,5 \%$ & $19,2 \%$ & $27,8 \%$ & $50,5 \%$ & $51 \%$ \\
\hline
\end{tabular}


É possível verificar que, em média, cerca de $50 \%$ dos ingressantes que compõem o Total Geral USP têm famílias cuja renda é superior a 3 mil reais. Porém, ao olharmos os Blocos de Carreiras 1 e 2 separadamente, percebemos significativa distinção nos valores de renda correspondente às famílias dos convocados para matrícula em 1aㅡ chamada destes dois grupos: em média, 70\% das famílias dos ingressantes do Bloco 1 têm renda mensal acima de 3 mil reais, enquanto que, para o Bloco 2, este índice é, em média, cerca de $24 \%$. Isto é, a renda familiar dos ingressantes aos cursos de Pedagogia e Licenciaturas em Ciências, Matemática e Física é notadamente inferior aos das famílias dos ingressantes das carreiras de Direito, Engenharia e Medicina.

\section{Comparando a Renda Familiar Mensal de Ingressantes 2002 a 2009}

O Questionário de Avaliação Sócio-econômico da FUVEST/2000 não traz a pergunta sobre a faixa de renda do vestibulando, por isso a comparação será apenas para os demais quatro anos. Nos anos de 2002, 2005, 2007 a questão sobre renda, traz no enunciado e nas alternativas, os valores em reais (R\$) e, em 2009 em salários mínimos. Por isso, optamos por agrupar os índices apresentados em $2009^{13}$ de forma a poder compará-los com as mesmas quatro categorias já estabelecidas para os anos de 2002, 2005 e 2007. A tabela 7 apresenta somente os percentuais médios para renda superior a 3 mil reais, para cada um dos Blocos de Carreira ${ }^{14}$ :

\footnotetext{
13. Valor utilizado: Salário Mínimo ${ }_{\text {março/2008 }}=\mathrm{R} \$ 415,00$ (http://www.guiatrabalhista.com.br/guia/salario minimo.htm)

14. Ver em anexo tabelas completas para cada um dos anos (2005, 2007 e 2009)
} 
Tabela 7 - Percentual médio (aproximado) de ingressantes cuja renda familiar mensal é superior a 3 mil reais, por bloco de carreiras e nos anos de 2002, 2005, 2007 e 2009.

\begin{tabular}{|c|l|c|c|c|c|}
\hline \multicolumn{2}{|c|}{ Carreiras } & \multicolumn{3}{c|}{$\begin{array}{c}\text { Percentual Médio (aproximado) de } \\
\text { ingressantes cuja Renda Familiar Mensal é } \\
\text { superior a R\$ 3.000,00 }\end{array}$} \\
\cline { 3 - 6 } & 2002 & 2005 & 2007 & 2009 \\
\hline $\begin{array}{c}\text { Bloco } \\
1\end{array}$ & Direito/Engenharia/Medicina & $70 \%$ & $75 \%$ & $77 \%$ & $74 \%$ \\
\hline $\begin{array}{c}\text { Bloco } \\
2\end{array}$ & $\begin{array}{l}\text { Lic. Ciências Exatas - SC/ } \\
\text { Lic. Matemática/Física e Pedagogia }\end{array}$ & $24 \%$ & $26 \%$ & $33 \%$ & $35 \%$ \\
\hline $\begin{array}{c}\text { Bloco } \\
3\end{array}$ & Total Geral USP & $51 \%$ & $52 \%$ & $56 \%$ & $55 \%$ \\
\hline
\end{tabular}

Os dados indicam, novamente, que o índice correspondente ao bloco 3 se difere em muitos pontos daqueles apresentados nos outros dois blocos de carreiras. Isto é, enquanto cerca de 55\% dos ingressantes do chamado Total Geral USP têm famílias cuja renda mensal é superior a 3 mil reais, para os ingressantes das Carreiras de Direito, Engenharia e Medicina este percentual gira em torno de $75 \%$ e, para os das Carreiras de Licenciatura em Ciências, Matemática, Física e Pedagogia, o índice é cerca de 30\%. Isto indica que, de alguma forma, o padrão econômico está relacionado à escolha da carreira.

Ainda que não tenha sido observada nenhuma alteração significativa ao longo dos anos, quando comparamos os resultados para os blocos, é possível observar um aumento da renda familiar média para todos os ingressantes USP. No entanto, para considerações sobre esse aumento seria necessária uma análise mais ampla, que foge aos nossos objetivos, no presente.

Segundo Bourdieu (2005, p.323), uma vez que o sistema de ensino ajusta o êxito ao capital cultural, compreende-se a razão pela qual os produtos do trabalho pedagógico das diferentes frações da classe dirigente ${ }^{15}$ recebem no mercado escolar valores organizados conforme uma hierarquia que reproduz a hierarquia das frações distribuídas segundo a importância de seu capital cultural, sabendo-se qual a estrutura das relações entre a

\footnotetext{
15. O conjunto das classes dirigentes: Empresários industriais; Grandes comerciantes; Profissionais liberais; Engenheiros; Técnicos e dirigentes do setor público e Professores, nesta ordem hierárquica.
} 
estrutura de distribuição do capital cultural e a estrutura de distribuição do capital econômico entre as diversas frações da referida classe.

Tal processo se concretiza de modo tanto mais seguro em virtude da tendência que as diferentes frações apresentam no sentido de investir o capital que estão em condições de transmitir no mercado capaz de the assegurar o melhor rendimento. Logo, deverão investir tanto mais na educação de seus filhos quanto mais disso depender seu êxito social, quer dizer, o mínimo necessário para sua manutenção nas classes dominantes (Bourdieu, 2005, p. 324).

\subsubsection{Cor de Pele}

A literatura sobre o assunto indica que o grau de mobilidade educacional varia segundo a cor de pele. No entanto, neste trabalho não pretendemos (tampouco sabemos) fazer discussões aprofundadas com relação a essa questão. Os valores obtidos junto ao banco de dados da Fuvest, no questionário de Avaliação Sócio-Econômica que a seguir são apresentados, têm por finalidade dar um indicativo da representatividade de brancos e negros no quadro de ingressantes USP, mais do que correlacionar, de forma conclusiva, tais valores à mobilidade intergeracional da amostra.

A tabela 8, abaixo, apresenta as porcentagens de ingressantes segundo sua cor de pele, por carreiras - Blocos 1 e 2 - e Total Geral USP, referentes ao ano de 2002.

Tabela 8 - Percentual dos ingressantes, segundo a cor de pele, por Carreiras e Total Geral USP, 2002.

\begin{tabular}{|c|l|c|c|c|}
\hline \multirow{2}{*}{ Carreiras } & \multicolumn{3}{c|}{ Cor de Pele } \\
\cline { 3 - 5 } & & Branca & Preta/parda & Amarela $^{\mathbf{1 6}}$ \\
\hline Bloco & Direito & $85,1 \%$ & $6,1 \%$ & $8,8 \%$ \\
\cline { 3 - 5 } $\mathbf{1}$ & Engenharia & $72,8 \%$ & $6,3 \%$ & $20,9 \%$ \\
\cline { 3 - 5 } & Medicina & $76,7 \%$ & $8,5 \%$ & $14,7 \%$ \\
\hline \multirow{2}{*}{ Bloco } & Lic. Ciências Exatas - SC & $87,8 \%$ & $12,2 \%$ & $0,0 \%$ \\
\cline { 3 - 5 } $\mathbf{2}$ & Lic. Matemática/Física & $74,3 \%$ & $16,7 \%$ & $9,0 \%$ \\
\cline { 3 - 5 } & Pedagogia & $80,6 \%$ & $12,7 \%$ & $6,7 \%$ \\
\hline Bloco & Total Geral USP & $80,3 \%$ & $8,5 \%$ & $11,3 \%$ \\
\hline
\end{tabular}

\footnotetext{
${ }^{16}$. Nas carreiras de Engenharia, Medicina, Lic. Matemática/Física e Total Geral o valor foi acrescido de 0,$2 ; 0,3 ; 1,6$ e 0,4 , respectivamente, referentes à cor de pele indígena.
} 
Os valores do Bloco 3 nos mostram que cerca de $80 \%$ dos ingressantes USP, em 2002, se dizem brancos e aproximadamente 9\% se consideram negros (cor de pele preta ou parda).

Uma análise por bloco de carreiras revela pouca, porém importante, alteração deste resultado. Vemos que, em média, as carreiras do Bloco 1 (Direito, Engenharia e Medicina) são compostas por $78 \%$ de brancos e cerca de $7 \%$ de negros. Para as carreiras do Bloco 2 (Licenciaturas e Pedagogia), temos - em média - $81 \%$ de brancos e $14 \%$ de negros. Vale a pena destacar que somente a carreira de Licenciatura Matemática/Física traz percentual de brancos abaixo de $80 \%$ e de negros acima de $15 \%$.

Segundo a literatura a mobilidade é menor entre negros (cor de pele preta e parda) do que entre brancos ${ }^{17}$. Mas também há estudos que revelam que a mobilidade é menor para filhos de pais com pouca escolaridade do que para filhos de pais com escolaridade mais elevada, com exceção de pais no topo da distribuição educacional. Isso justifica o fato de, no caso dos ingressantes USP que pertencem às carreiras do bloco 1 e cujos pais, em sua maioria, tem alta escolaridade, termos um percentual elevado de brancos e menor percentual de mobilidade educacional. E, no caso dos estudantes USP das carreiras do bloco 2, embora cerca de $70 \%$ (em média nos últimos dez anos) supere (ou pelo menos iguale) a escolaridade de seus pais no ingresso à universidade - ou seja, uma alta mobilidade - temos que considerar que trata-se, de toda forma, de pais com escolaridade elevada (mais de $40 \%$ tem, pelo menos o ensino médio completo), concordando assim com a literatura, sobretudo porque o índice de brancos (81\%) é também aí bastante maior que o de negros (14\%). Não é possível que tiremos maiores conclusões a esse respeito com os dados aqui disponíveis.

\section{Comparando os dados de cor de pele no período de 2000 a 2009}

Para uma comparação entre os anos 2000, 2002, 2005, 2007 e 2009, quanto à porcentagem de ingressantes brancos e negros, segundo os Blocos 1, 2 e 3, temos os dados da tabela 9 a seguir:

17. Ferreira e Veloso, 2003. 
Tabela 9 - Percentual médio (aproximado) de brancos e negros (preto e pardo), por bloco de carreiras, para os anos de 2000, 2002, 2005, 2007 e 2009.

\begin{tabular}{|c|c|c|c|c|c|c|c|c|c|c|c|}
\hline & \multirow{3}{*}{ Carreiras } & \multicolumn{10}{|c|}{ Cor de Pele - percentual médio por bloco de carreira ${ }^{18}$} \\
\hline & & \multicolumn{2}{|c|}{2000} & \multicolumn{2}{|c|}{2002} & \multicolumn{2}{|c|}{2005} & \multicolumn{2}{|c|}{2007} & \multicolumn{2}{|c|}{2009} \\
\hline & & Brancos & Negros & Brancos & Negros & Brancos & Negros & Brancos & Negros & Brancos & Negros \\
\hline Bloco 1 & $\begin{array}{l}\text { Direito/Engenharia } \\
\text { Medicina }\end{array}$ & $80 \%$ & $4 \%$ & $78 \%$ & $7 \%$ & $77 \%$ & $8 \%$ & $77 \%$ & $9 \%$ & $77 \%$ & $10 \%$ \\
\hline Bloco 2 & $\begin{array}{l}\text { Lic. Ciênc. Exatas } \\
\text { Lic. Mat/Física e Pedagogia }\end{array}$ & $79 \%$ & $12 \%$ & $81 \%$ & $14 \%$ & $76 \%$ & $17 \%$ & $72 \%$ & $23 \%$ & $72 \%$ & $21 \%$ \\
\hline Bloco 3 & Total Geral USP & $81 \%$ & $7 \%$ & $80 \%$ & $9 \%$ & $77 \%$ & $12 \%$ & $78 \%$ & $13 \%$ & $78 \%$ & $14 \%$ \\
\hline
\end{tabular}

Os dados acima revelam que houve um aumento significativo de ingressantes negros de 2000 para 2009 em todos os blocos, ao longo dos cinco anos considerados, com exceção de uma queda de 2 pontos percentuais (p.p.) de 2007 para 2009 no bloco das carreiras de Licenciaturas e Pedagogia.

O gráfico 3 abaixo ilustra os dados da tabela 9:

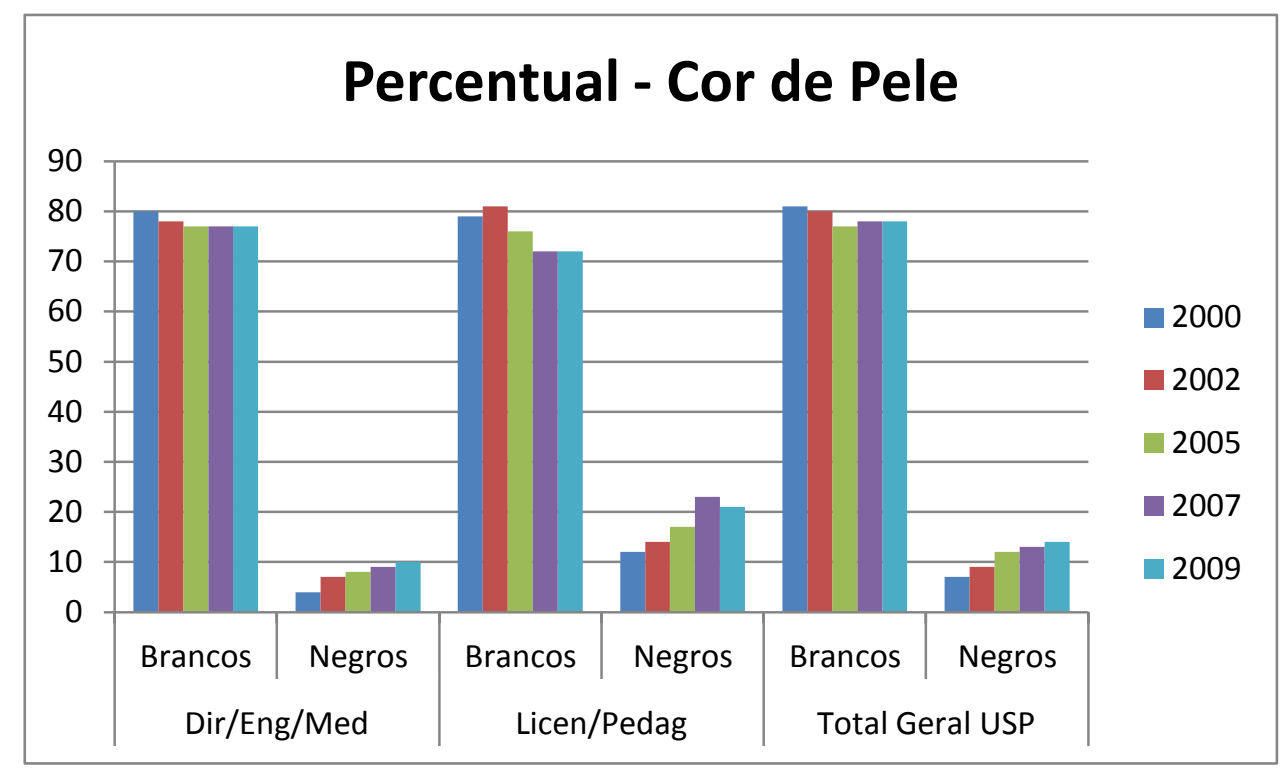

Gráfico 3 - Percentual médio (aproximado) de brancos e negros (preto/pardo), por bloco de carreiras, para os anos de 2000, 2002, 2005, 2007 e 2009 (não inclui o índice para cor de pele amarela e indígena).

\footnotetext{
18. O índice que completa $100 \%$ representa a fração referente a cor de pele amarela e indígena.
} 
O Bloco 1, composto pelas carreiras de Direito, Engenharia e Medicina apresentou um acréscimo de 6 p.p no ingresso de negros. O Bloco 2 - das carreiras de Licenciatura em Ciências Exatas de São Carlos, Licenciatura em Matemática/Física e Pedagogia - apresenta um acréscimo de 9 p.p. E, o terceiro bloco - do Total Geral de ingressantes sem Treineiros mostra que ocorreu um aumento de 7 p.p de 2000 para 2009.

Até poderíamos levantar a hipótese de que as políticas de inclusão, como o programa INCLUSP tenham contribuído de alguma forma para essa alteração, haja vista que desde sua implementação houve um aumento do percentual de participação de alunos de escolas públicas no vestibular da Fuvest e ingressantes USP e que, segundo Pimenta (2009) a maioria dos candidatos negros inscritos no vestibular são oriundos de escolas públicas. Ou seja, o grupo dos ingressantes provenientes de escolas públicas e os que se declaram negros apresentam semelhanças. No Relatório de Gestão - 2006-2009, na parte que trata do impacto do INCLUSP no ingresso de estudantes da escola pública na USP, no trecho em que faz referências aos estudantes negros, Pimenta (2009) destaca que "o percentual de candidatos negros inscritos no vestibular da USP tem diminuído no período de 2006 a 2009", mas que "em oposição à tendência observada no conjunto dos inscritos, o percentual de candidatos negros ingressantes na USP vem aumentando neste período". Ainda assim, preferimos nos atermos somente à descrição dos resultados encontrados e não arriscarmos uma análise dos mesmos evitando que a ausência de fundamentação leve a interpretações equivocadas. Pimenta (2009) faz uma discussão mais abalizada do assunto, inclusive relacionando a distribuição dos candidatos negros em carreiras USP e segundo uma análise do nível sócio-econômico, além da referência à origem da escola de Ensino Médio, além de dados sobre sua preparação em cursinhos pré-vestibulares; sobre qual o período em que ingressou na universidade; sobre a área do conhecimento relacionada ao curso escolhido e comparação entre algumas carreiras mais concorridas.

\subsubsection{Estudos em Nível Médio}

A despeito da superficialidade da discussão quanto ao tipo de estudos feitos em nível médio, os dados que dispomos são importantes indicativos para nossa análise. A tabela 10 
apresenta os percentuais correspondentes ao tipo de estudos feitos em nível médio pelos ingressantes convocados para matrícula em $1^{1}$ chamada do ano de 2002. O Questionário de Avaliação Sócio-econômico da FUVEST traz um total de oito alternativas para a questão 7 (Onde você realizou seus estudos de ensino médio?) as quais reagrupamos em apenas três categorias com o objetivo de facilitar a análise e discussão dos dados ${ }^{19}$. Vejamos:

Tabela 10 - Percentual (aproximado) por tipo de estudos em nível médio, por bloco de carreiras para o ano de 2002.

\begin{tabular}{|c|c|c|c|c|c|c|}
\hline \multicolumn{7}{|c|}{2002} \\
\hline \multirow{2}{*}{\multicolumn{2}{|c|}{ Carreiras }} & \multicolumn{5}{|c|}{ Estudos de ensino médio } \\
\hline & & \multicolumn{2}{|c|}{ Escola Pública } & \multicolumn{2}{|c|}{ Escola } & Outros \\
\hline \multirow{3}{*}{ Bloco 1} & \multirow{3}{*}{$\begin{array}{l}\text { Direito } \\
\text { Engenharia } \\
\text { Medicina } \\
\end{array}$} & $11,5 \%$ & \multirow{3}{*}{$14 \%$} & $87,6 \%$ & \multirow{3}{*}{$86 \%$} & $0,8 \%$ \\
\hline & & $22,6 \%$ & & $76,8 \%$ & & $0,7 \%$ \\
\hline & & $6,7 \%$ & & $93,0 \%$ & & $0,3 \%$ \\
\hline \multirow{3}{*}{ Bloco 2} & \multirow{3}{*}{$\begin{array}{l}\text { Lic. Ciências Exatas - SC } \\
\text { Lic. Matemática/Física } \\
\text { Pedagogia }\end{array}$} & $63,3 \%$ & \multirow{3}{*}{$52 \%$} & $36,7 \%$ & \multirow{3}{*}{$47 \%$} & $0,0 \%$ \\
\hline & & $55,4 \%$ & & $42,2 \%$ & & $2,3 \%$ \\
\hline & & $38,6 \%$ & & $60,9 \%$ & & $0,6 \%$ \\
\hline Bloco 3 & & & $27 \%$ & & $72 \%$ & \\
\hline
\end{tabular}

Em 2002 pouco menos de 30\% do Total Geral de ingressantes USP cursaram o ensino médio em escolas públicas e mais de 70\%, em escolas particulares. Numa análise por blocos, os dados mostram que os ingressantes oriundos de escolas particulares, correspondem a $86 \%$ no Bloco 1 e $47 \%$, no Bloco 2. Já os ingressantes vindos de escolas públicas são 14\% (Bloco 1) e 52\% (Bloco 2). Os dados evidenciam que o tipo de escolarização em nível médio pode ser considerado um fator característico do perfil de ingressantes USP em Carreiras com status diferenciados, indicando particularidades entre os blocos.

\footnotetext{
19. Eventualmente a soma dos percentuais difere de $100 \%$, devido o fato de os índices apresentados no site da FUVEST serem calculados sobre o total de alunos que efetivamente responderam a questão, o que na maioria das vezes não corresponde ao total de ingressantes chamados para a primeira matrícula. Além disso, foram feitas aproximações nas somas dos índices agrupados para a composição das três categorias aqui consideradas.
} 


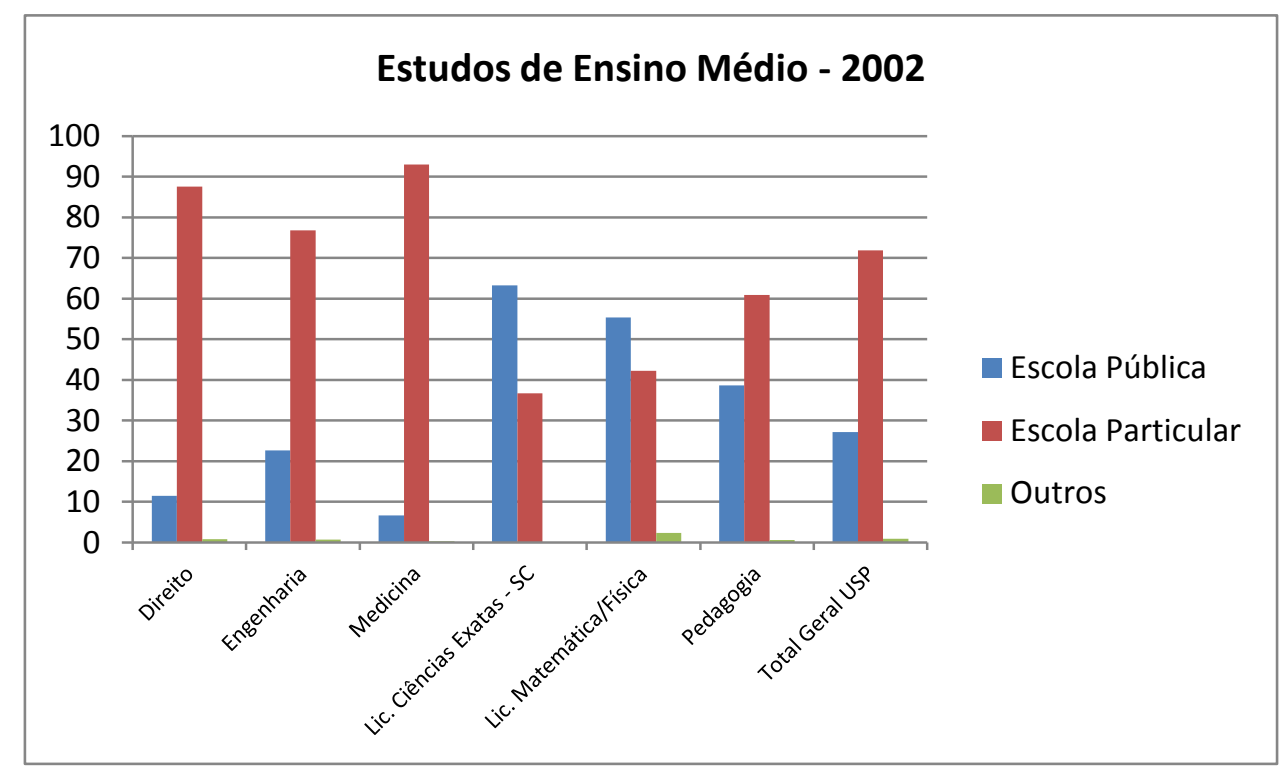

Gráfico 4 - Percentual de ingressantes por tipo de estudo em nível médio, por carreira e para o ano de 2002.

O gráfico 4 ilustra os dados da tabela 10, facilitando a visualização de que os ingressantes das Carreiras de Direito, Engenharia e Medicina são, em sua maioria, oriundos de escolas particulares, assim como aqueles do bloco Geral USP e, que - por outro lado - os ingressantes das Carreiras de Licenciatura em Ciências e Matemática/Física são, grande parte, oriundos de escolas públicas; o que os diferencia dos ingressantes da Carreira de Pedagogia (que embora faça parte do mesmo bloco) apresenta um perfil mais próximo do Total Geral USP, ou seja, onde a maioria é proveniente de escolas particulares.

Comparando os dados de estudos de ensino médio no período de 2000 a 2009

A tabela 11 apresenta os dados comparativos para os anos 2000, 2002, 2005, 2007 e 2009 referentes ao tipo de ensino médio cursado pelos convocados para matrícula em $1^{\text {a }}$ chamada, nos quais temos os percentuais para escola pública e escola particular. 
Tabela 11 - Percentual médio para o tipo de estudos em nível médio, por bloco de carreiras, para os anos de 2000, 2002, 2005, 2007 e 2009.

\begin{tabular}{|c|l|c|c|c|c|c|c|c|c|c|c|}
\hline \multirow{2}{*}{\multicolumn{2}{|c|}{ Carreiras }} & \multicolumn{6}{c|}{ Estudos de Ensino Médio - percentual médio por bloco de carreira } \\
\cline { 3 - 12 } & \multicolumn{2}{|c|}{2000} & \multicolumn{2}{c|}{2002} & \multicolumn{2}{c|}{2005} & \multicolumn{2}{c|}{2007} & \multicolumn{2}{c|}{2009} \\
\hline $\begin{array}{c}\text { Bloco } \\
\mathbf{1}\end{array}$ & $\begin{array}{l}\text { Direito/Engl. } \\
\text { Medicina }\end{array}$ & $11 \%$ & $88 \%$ & $14 \%$ & $86 \%$ & $12 \%$ & $87 \%$ & $16 \%$ & $84 \%$ & $24 \%$ & $75 \%$ \\
\hline $\begin{array}{c}\text { Bloco } \\
\mathbf{2}\end{array}$ & $\begin{array}{l}\text { Lic. Ciên. Exatas } \\
\text { Lic. Matem/Fisica } \\
\text { Pedagogia }\end{array}$ & $52 \%$ & $46 \%$ & $52 \%$ & $47 \%$ & $53 \%$ & $43 \%$ & $53 \%$ & $46 \%$ & $51 \%$ & $49 \%$ \\
\hline $\begin{array}{c}\text { Bloco } \\
\mathbf{3}\end{array}$ & Total Geral USP & $25 \%$ & $73 \%$ & $27 \%$ & $72 \%$ & $28 \%$ & $71 \%$ & $28 \%$ & $71 \%$ & $30 \%$ & $68 \%$ \\
\hline
\end{tabular}

A tabela 11 nos revela que - ao longo destes dez anos - embora o índice de ingressantes do bloco Geral USP oriundos de escola particular tenha ficado em torno de $70 \%$ (e de escolas públicas próximo aos $30 \%$ ), podemos perceber que numa análise por Carreira com status diferenciados, como as dos blocos 1 e 2, há grande variação do percentual correspondente a cada uma delas. Os índices de egressos de escolas públicas e particulares para as Carreiras do bloco 1 sofreram algumas alterações no decorrer do tempo considerado: em 2000 quase 90\% eram provenientes de escolas particulares e esse percentual vem diminuindo desde lá, chegando a 75\% em 2009. E, o percentual de egressos de escolas públicas mais do que dobrou de 2000 a 2009 (passando de 11\% para 24\%). Esse aumento pode estar associado ao surgimento do INCLUSP, Programa de Inclusão Social da USP.

Aprovado no CO de maio de 2006 e elaborado por professores e alunos, de Unidades e grupos de pesquisa da USP e colaboradores externos, o INCLUSP (Programa de Inclusão Social da USP) foi implementado a partir do ano de 2007 e, seu objetivo principal é ampliar progressivamente o percentual de ingressantes que cursaram o Ensino Médio na rede pública de ensino, sem comprometer o critério de mérito acadêmico como legitimador desse processo (PIMENTA, S. G. e outros, 2008).

Os índices correspondentes às Carreiras de Licenciaturas e Pedagogia, pouco oscilaram nestes dez anos e indicam que pouco mais de $45 \%$ desses ingressantes são provenientes de escolas particulares e um pouco mais de $50 \%$ de escolas públicas.

Os gráficos 5 e 6 trazem, separadamente, os dados referentes aos ingressantes egressos de escola pública e particular, respectivamente. A linha correspondente ao Total 
Geral USP aparece, em ambos os gráficos, numa posição intermediária separando as carreiras dos blocos 1 e 2, mas com uma maior tendência de aproximação com o bloco das carreiras de Direito, Engenharia e Medicina. Estas três carreiras parecem se comportar bem mais de modo assemelhado entre si e ao longo dos anos, do que as carreiras de Licenciaturas e Pedagogia. Especialmente a carreira de Licenciatura em Matemática/Física mostra uma diminuição do número de ingressantes vindos de escola pública de 2000 a 2007, seguida de um considerável crescimento em 2009 (cerca de 10 pontos percentuais).

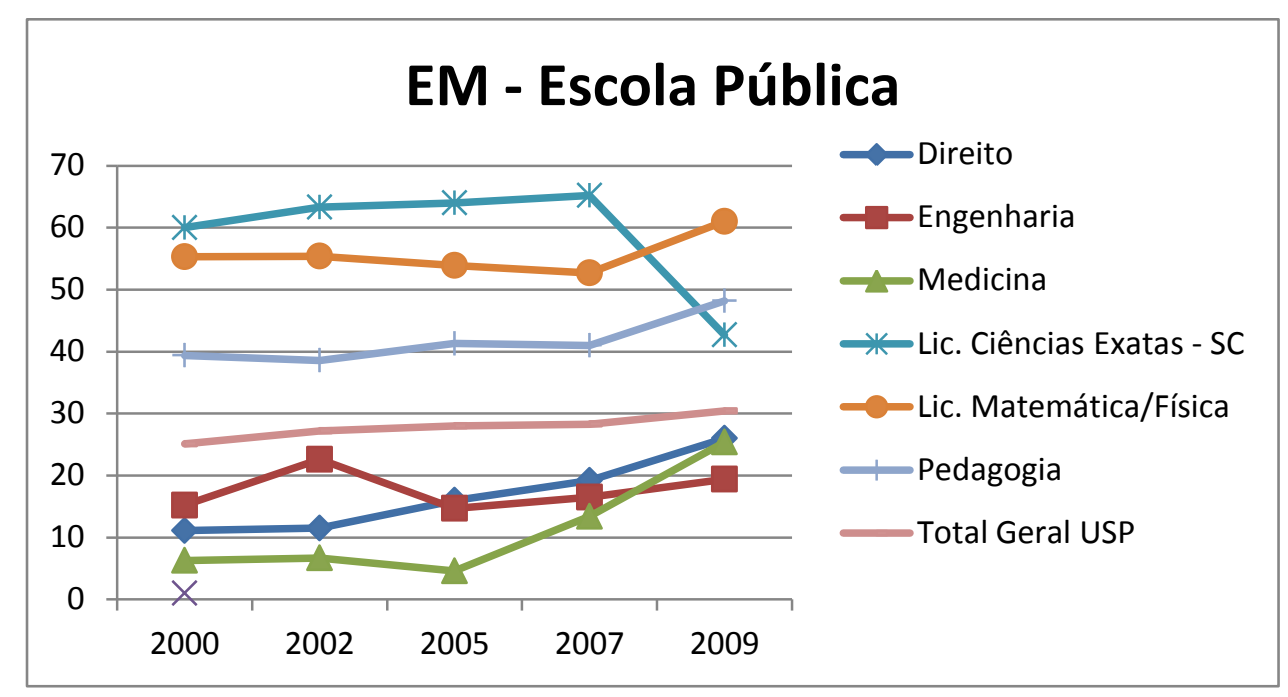

Gráfico 5 - Percentual de ingressantes, por carreira, oriundos de escola pública, dos anos 2000, 2002, 2005, 2007 e 2009.

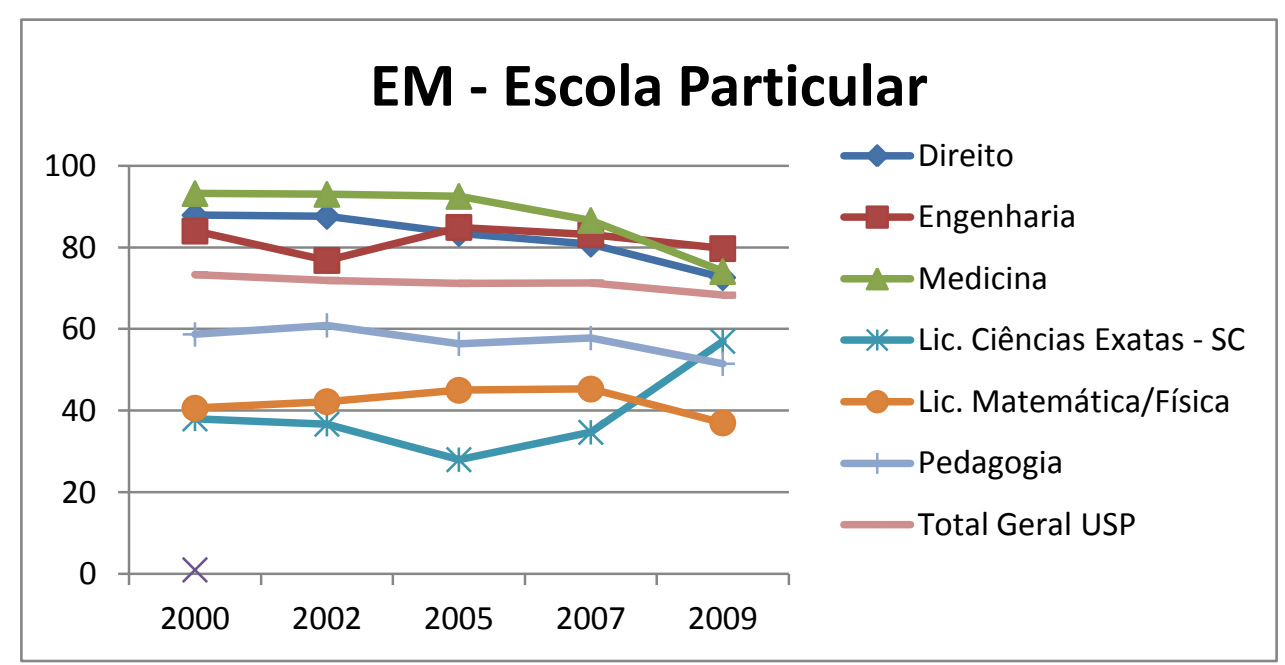

Gráfico 6 - Percentual de ingressantes, por carreira, oriundos de escola particular, dos anos 2000, 2002, 2005, 2007 e 2009. 
O gráfico 7 agrupa os dados por bloco de carreira, para os tipos de estudo médio (escola pública ou particular) nos cinco anos considerados:

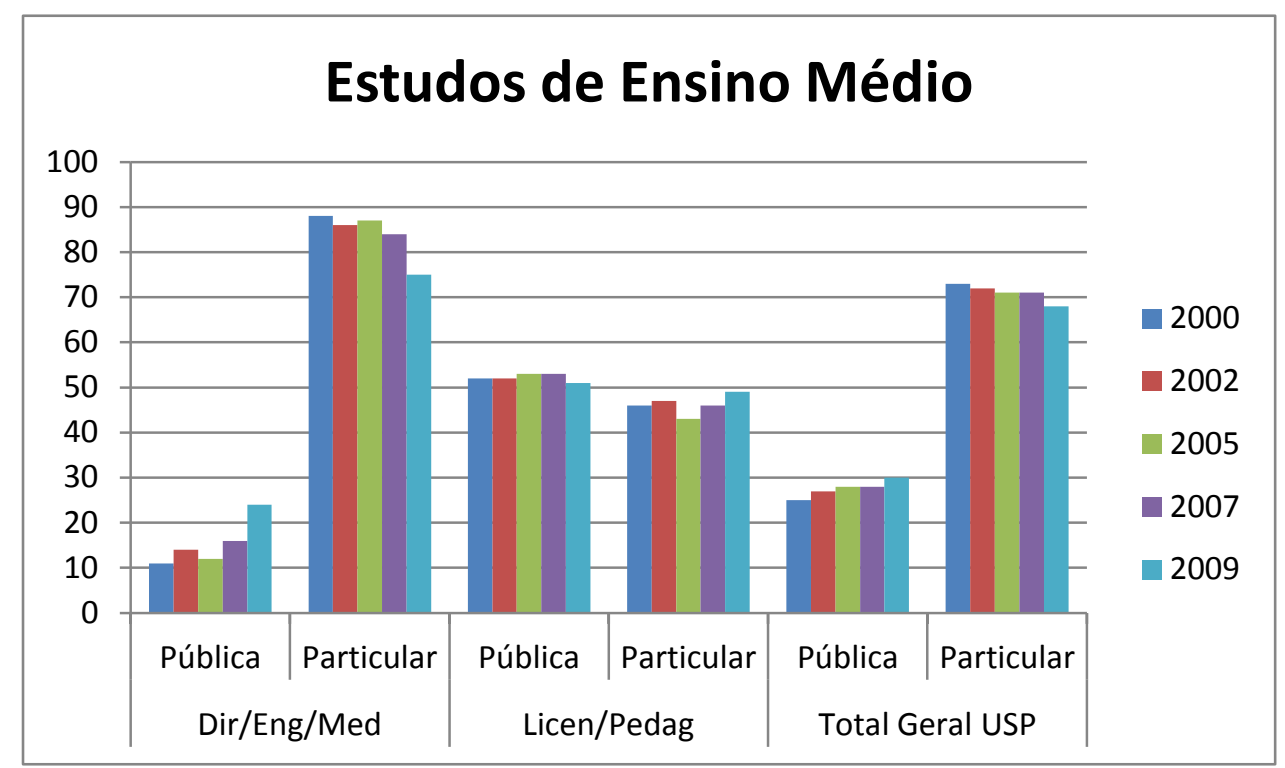

Gráfico 7 - Percentual de ingressantes, por carreira, por origem de estudos em nível médio, nos anos 2000, 2002, 2005, 2007 e 2009.

Nota-se aqui certas diferenças de comportamento dos dados referentes a cada um dos três blocos apresentados. As carreiras de Direito, Engenharia e Medicina aproximam-se mais do Total Geral USP, uma vez que o maior percentual é de egressos de escolas particulares. Já as carreiras de Licenciatura em Ciências, Matemática, Física e Pedagogia têm seus ingressantes distribuídos de forma quase equivalente em cada um dos segmentos, com pequena diferença para mais, dos egressos de escola pública.

Numa análise dos dados do bloco 3 (Total Geral USP), podemos - talvez - atribuir o perceptível aumento do número de ingressantes vindos de escola pública, ao Programa de Inclusão da USP (INCLUSP), implementado em 2007. A comparação dos resultados dos anos 2000, 2002, 2005, 2007 e 2009 pode permitir uma análise de forma a sinalizar se houve ou não (e com que intensidade) alterações significativas influenciadas por esse Programa. 
Segundo o Relatório de Gestão - 2006-200920 , “o egresso da escola pública tende a se sentir desestimulado a prestar o vestibular em razão de suas poucas chances de aprovação, o que denota que as condições sócio-econômicas dos candidatos têm influência preponderante nas possibilidades de acesso à universidade".

O relatório afirma que de 2006 a 2009, a ampliação de vagas na USP privilegiou a expansão contínua de cursos oferecidos em período integral e no noturno, sem expansão de vagas em cursos vespertinos. Até 2006, a ampliação de vagas era acompanhada por um aumento do número de inscrições no vestibular, mas a partir de então, teve início uma trajetória de queda nas inscrições dos vestibulares das universidades públicas no país. Essa tendência de diminuição do número total de inscritos coincide com a diminuição da proporção de estudantes oriundos de escolas públicas em relação ao conjunto total de inscritos (Pimenta, 2009).

Dos inscritos em 2009, os estudantes de escolas públicas representaram pouco mais de 30\%, a menor proporção dos últimos anos. Segundo Pimenta (2009) este resultado evidencia a tendência de diminuição da presença de estudantes com esse percurso escolar nas inscrições para o vestibular da USP, a despeito de aproximadamente $85 \%$ dos estudantes cursarem o Ensino Médio em escolas públicas em todo o Estado de São Paulo.

Pimenta (2009) aponta que dentre as possíveis hipóteses para explicar esta diminuição, estão a criação de novos campi da Universidade Federal de São Paulo (Unifesp), em Guarulhos e Diadema, a criação da Universidade Federal do ABC (UFABC) e, principalmente, a corrida dos alunos de Ensino Médio público ao programa de bolsas para o Ensino Superior privado concedidas pelo governo federal (PROUNI). A essas explicações soma-se a cultura de autoexclusão dos estudantes do Ensino Médio público em relação aos vestibulares das mais concorridas universidades públicas e o desconhecimento por parte desses jovens do sistema de Ensino Superior gratuito, ao qual têm direito.

\footnotetext{
${ }^{20}$ Pimenta, S. G. Relatório de Gestão - 2006-2009. Pró-Reitoria de Graduação. Universidade de São Paulo, nov 2009.
} 
Por outro lado, o relatório sinaliza que em oposição à tendência de queda observada nas inscrições no período de 2006 a 2009, a proporção de estudantes oriundos de escola pública no conjunto de alunos que ingressam na USP tem aumentado.

De fato, podemos notar pelo gráfico 8 , que houve uma pequena queda no número de ingressantes provenientes de escola particular e um pequeno aumento do número daqueles vindos de escola pública. A figura $1^{21}$, apresentada no Relatório de Gestão - 2006-2009 mostra o percentual de estudantes de escolas públicas que ingressaram na USP no período de 2001 a 2009 em relação ao número de vagas realmente preenchidas em cada um dos anos.

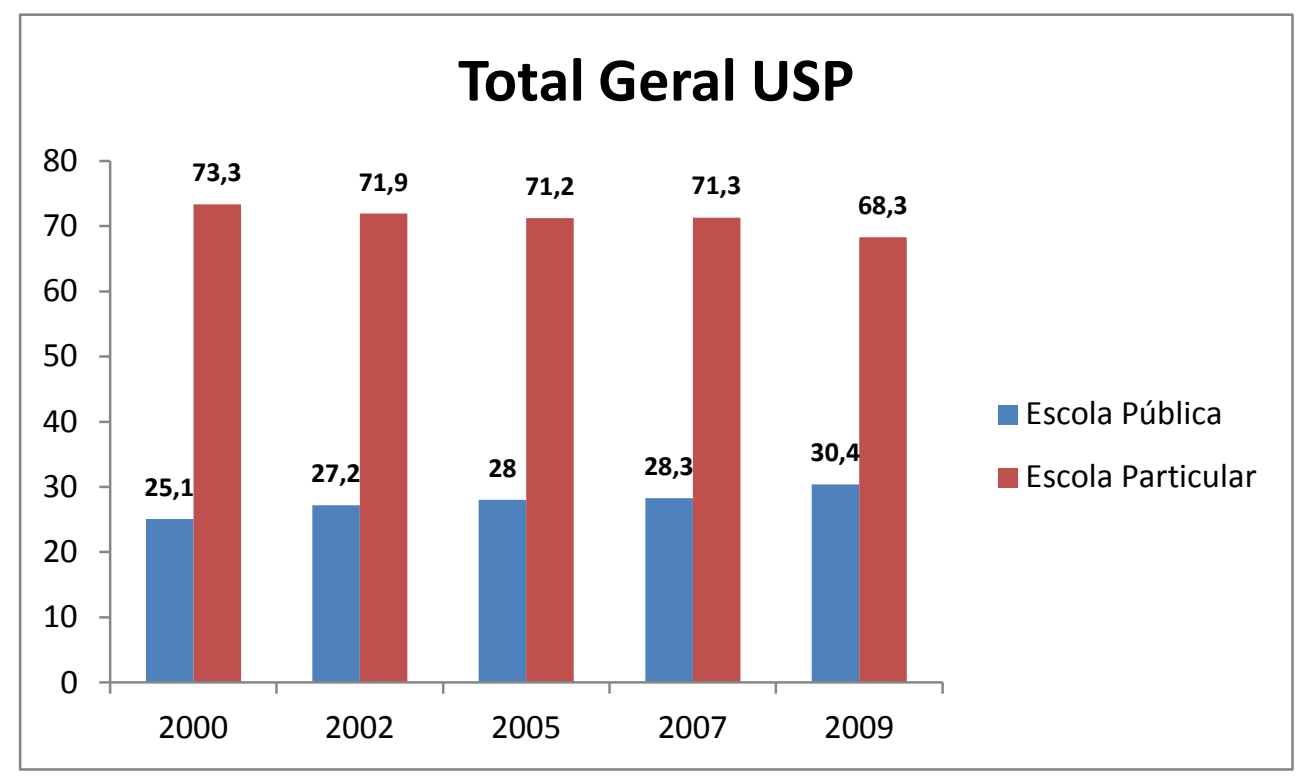

Gráfico 8 - Percentual de ingressantes, por origem de estudos em nível médio, nos anos 2000, 2002, 2005, 2007 e 2009.

21. Pimenta, S. G. Relatório de Gestão - 2006-2009. Pró-Reitoria de Graduação. Universidade de São Paulo, p. 112, nov 2009. 


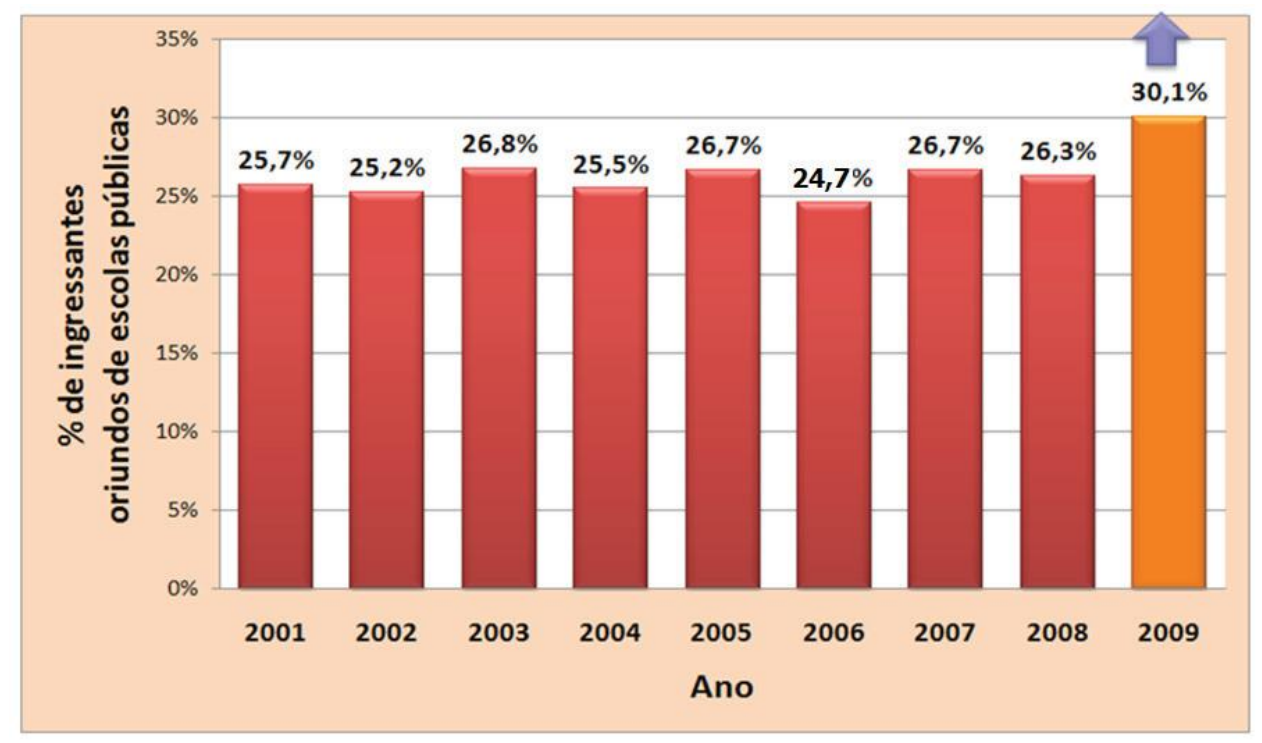

Figura 1 - Percentual de estudantes de escolas públicas que ingressaram na USP no período de 2001 a 2009 em relação ao número de vagas realmente preenchidas em cada um dos anos.

Embora os valores não coincidam devido à natureza de obtenção dos mesmos, há concordância entre os dados no sentido de que revelam um pequeno aumento dos índices de 2002 para 2005, de 2005 para 2007 e de 2007 para 2009.

Para Pimenta (2009), nos três anos de implementação do INCLUSP, o bônus teve papel determinante para a aprovação, em primeira chamada para matrícula. E ainda, que "sem o INCLUSP, a tendência de queda observada nas inscrições no período de 2007 a 2009 teria refletido em decréscimo ainda mais acentuado no número de ingressantes oriundos de escolas públicas"(Pimenta, p.113, 2009).

Os dados referentes ao tipo de ensino cursado em nível médio e à renda familiar de ingressantes USP evidenciam a forte influência do capital cultural, social e econômico da amostra como um todo e, sobretudo destaca as diferenças entre os blocos 1 e 2 , reiterando as particularidades das carreiras que os compõem.

O capital cultural e o ethos, ao se combinarem, concorrem para definir as condutas escolares e as atitudes diante da escola, que constituem o princípio de eliminação diferencial das crianças das diferentes classes sociais. Ainda que o êxito escolar, diretamente ligado ao capital cultural legado pelo meio familiar, desempenhe um papel na escolha da orientação, parece que o 
determinante principal do prosseguimento dos estudos seja a atitude da familia a respeito da escola, ela mesma função das esperanças objetivas de êxito escolar encontradas em cada categoria social (Bourdieu, 1966).

Com relação às estratégias de investimento escolar, Bourdieu (1974) afirma que "os agentes são tanto mais inclinados à audácia da especulação (por oposição à busca da segurança) quanto maior é a sua riqueza em capital e, particularmente, em capital cultural". E que "a segurança proporcionada pela certeza íntima de poder contar com uma série de 'redes de proteção' está na origem de todas as audácias, inclusive intelectuais, vetadas aos pequeno-burgueses em decorrência de sua insegurança ansiosa por segurança". Para Bourdieu (1974), a probabilidade de um superinvestimento, simultaneamente, econômico e psicológico, e da frustração correlativa, cresce na medida em que:

1) os lucros prometidos pelo ramo de ensino ou carreira considerada são mais dispersos e, sendo mais difícil a antecipação exata dos lucros escolares do investimento de capital cultural e dos lucros econômicos e simbólicos dos diplomas, tem todas as chances de ser ainda maior a defasagem entre aspirações que tendem a ser reguladas pelo lucro máximo e os resultados reais; 2) a raridade dos certificados escolares no mercado de trabalho diminui mais em relação à representação que os investidores tinham da raridade dos diplomas esperados e dos lucros correlativos em função das disposições inculcadas por um estado anterior do mercado; 3) os investidores são menos ricos em qualquer espécie de capital que não o cultural, portanto, obrigados a esperar tudo dos investimentos escolares e pouco preparados para extrair o melhor rendimento econômico e simbólico de seus certificados escolares (Bourdieu, 1966).

\subsection{Conclusões Preliminares}

Procuramos discutir aqui características do perfil de ingressantes do curso de Licenciatura em Física da USP, considerando indicadores sócio-educacionais e suas perspectivas profissionais. Essas características, possivelmente, não devem diferir muito daquelas encontradas em alunos de outras instituições, sobretudo no caso em que o curso de Licenciatura pertença a uma carreira distinta do Bacharelado, como já ocorre em várias instituições. Além disso, entendemos que as análises aqui apresentadas podem contribuir para uma reflexão e repensar de cursos de formação de professores. 
Nesse sentido, é preciso considerar como relevante a opção feita pelo ingressante dispensando atenção especial aos indicadores sócio-culturais que situam suas expectativas em um contexto social mais amplo, bem com suas perspectivas e encaminhamentos de ordem profissional.

A busca por caracterizar o licenciando do ponto de vista sócio-econômico, através de um olhar sobre a mobilidade intergeracional em educação de ingressantes USP, nos revelou - considerando carreiras que correspondem a status diferenciados - que os cursos de formação de professores apresentam status social menos privilegiado em relação a carreiras de medicina ou engenharia, por exemplo. Isso se expressa por um índice consideravelmente alto de mobilidade intergeracional em educação, associado a percentuais mais baixos de renda familiar e escolarização em nível médio majoritariamente de escola pública.

A literatura, sobretudo econômica, traz inúmeros métodos e medidas de mobilidade em educação. Procuramos mensurar de algum modo a mobilidade intergeracional de ingressantes USP, ao olharmos o índice de filhos que superam a escolaridade de seus pais quando de sua entrada na universidade. A mobilidade, aqui considerada, será menor quanto maior for este índice e, vice-versa.

Os resultados evidenciam que a amostra geral estudada - os "Chamados para a 1a Matrícula" - por fazerem parte de um grupo privilegiado de alunos cujos pais estão no topo da distribuição educacional apresenta baixa mobilidade intergeracional, concordando com as demais pesquisas sobre o assunto. No entanto, uma abordagem mais específica na qual se analisam certas carreiras que correspondem a status diferenciados, nos revela particularidades no fator de mobilidade intergeracional em educação. Isto é, as carreiras de alta demanda, reconhecidas como de grande apelo pelos ingressantes e prestígio social (Direito, Engenharia, Medicina e Odontologia) apresentam um fator ainda mais baixo que o referente ao Total Geral, ao contrário das carreiras relacionadas à formação de professores (Pedagogias e Licenciaturas em Ciências e Matemática) que apresentam um índice consideravelmente alto de mobilidade intergeracional em educação. Enquanto que para o 
primeiro grupo em torno de $30 \%$ dos ingressantes superam a escolaridade de seus pais na entrada à universidade, para o segundo, isso ocorre para cerca de $70 \%$ dos ingressantes.

Tais índices podem ser entendidos como resultado de forte influência do chamado capital cultural, social e simbólico, de que trata P. Bourdieu. Para este autor, o ponto central para o entendimento do comportamento - de toda ordem - dos indivíduos, está exatamente nas práticas dos agentes. Diferente de Durkheim, que discute a desigualdade fundada no mérito, Bourdieu, mostra em seus estudos a influência do social:

Ora, vê-se nas oportunidades de acesso ao ensino superior o resultado de uma seleção direta ou indireta que, ao longo da escolaridade, pesa com rigor desigual sobre os sujeitos das diferentes classes sociais. (...) Na realidade, cada família transmite a seus filhos, mais por vias indiretas que diretas, um certo capital cultural e um certo ethos, sistemas de valores implícitos $e$ profundamente interiorizados, que contribui para definir, entre coisas, as atitudes face ao capital cultural e à instituição escolar (Bourdieu, 1966).

Para tanto, utiliza-se, por exemplo, do conceito de habitus, como uma espécie de "mapa" quase consciente, o qual orienta as micros e macros escolhas e serve como ponte entre as dimensões objetiva e subjetiva, tendo caráter móvel de acordo com as experiências. Neste sentido, Bourdieu refere-se ao habitus como "estruturas estruturadas e estruturantes" - estruturadas no social e estruturantes na mente.

Deste modo, a influência da escolarização dos pais na dos filhos ocorre como expressão de um sistema de valores no qual, entre outras coisas, podemos entender as condições objetivas em acordo ou desacordo com as disposições subjetivas, o que implica considerar o nível cultural global da família.

O conceito de ethos de classe - também utilizado por Bourdieu - que indica os traços característicos de um grupo, do ponto de vista social e cultural, que o diferencia dos outros, igualmente nos ajuda a interpretar os resultados encontrados.

A despeito da superficialidade da discussão quanto ao tipo de estudos feitos em nível médio e acerca das condições econômicas da amostra analisada, os dados de que dispomos e aqui apresentados serviram como importantes indicativos para sustentar a análise segundo as referências já citadas. 
Com relação ao fato de que a literatura comumente se utiliza dos dados sobre filhos e pais - e não filhos e mães - os resultados mostraram que, de fato, há equivalência entre a escolaridade de pai e de mãe no trato da mobilidade intergeracional de ingressantes USP.

Embora os estudos sobre mobilidade também abordem os aspectos relacionados à cor de pele e regiões, aqui procuramos apenas expor os dados disponíveis (no questionário sócio-econômico) a título de complementação já que não nos sentimos seguros de, a partir dos mesmos, fazer análises mais conclusivas. De toda forma, é evidente a pouca participação e ingressantes que se consideram negros (14\%) na comparação com a parcela de brancos (78\%) do Total Geral de ingressantes em 2009. O que talvez seja importante destacar é que esses índices, em 2000, eram - respectivamente - 7\% e 81\%. Embora, passados dez anos, o percentual de ingressantes negros tenha dobrado, não podemos inferir - pelo menos para a amostra considerada nesta pesquisa - que tal ocorrência esteja relacionada diretamente a programas como o INCLUSP. Isto porque, sua implementação se deu em 2007 e os percentuais de ingressantes negros neste ano e em 2009, em cada um dos blocos aqui analisados, foram (Tabela 12):

Tabela 12 - Percentual de ingressantes negros nos anos de 2007 e 2009, por bloco de carreiras.

\begin{tabular}{|c|l|c|c|}
\hline \multicolumn{3}{|c|}{ Percentual de ingressantes negros } \\
\hline \multicolumn{1}{|c|}{ Carreiras } & 2007 & 2009 \\
\hline Bloco 1 & $\begin{array}{l}\text { Direito } \\
\text { Engenharia } \\
\text { Medicina }\end{array}$ & $9 \%$ & $10 \%$ \\
\hline Bloco 2 & $\begin{array}{l}\text { Lic. Ciências Exatas - SC } \\
\text { Lic. Matemática/Física } \\
\text { Pedagogia }\end{array}$ & $23 \%$ & $21 \%$ \\
\hline Bloco 3 & Total Geral USP & $13 \%$ & $14 \%$ \\
\hline
\end{tabular}

Ou seja, o aumento foi mínimo para as carreiras de Direito, Engenharia, Medicina e Total Geral USP (1p.p.) e houve, inclusive, uma redução no índice de ingressantes negros para as carreiras do bloco 2 ( -2 p.p). Neste bloco, analisando em separado os dados para cada uma das carreiras ${ }^{22}$, vemos que, por exemplo, para Lic. Matemática/Física, o índice de

${ }^{22}$. Ver tabela completa em anexo. 
$24 \%$ sobe para $26 \%$, demonstrando que esta se difere das carreiras de Lic. em Ciências Exatas/SC e Pedagogia, nas quais ocorreu diminuição destes índices (4 p.p. em cada uma).

Seguindo uma análise comparativa na evolução temporal de dez anos, concluímos que houve pouca alteração em termos de mobilidade intergeracional de ingressantes USP. E esta baixa mobilidade se justifica, sobretudo, pelo fato de tal amostra pertencer ao topo da distribuição educacional.

É preciso reiterar que neste estudo o termo "mobilidade intergeracional" foi utilizado de maneira um tanto distinta daquele comumente presente na literatura. Primeiro pela natureza da obtenção dos dados analisados: aqui temos os a escolaridade do pai de cada um dos ingressantes considerados - seja nos blocos de carreiras, seja no Total Geral USP; já os índices de mobilidade em níveis nacional e mundial são calculados a partir de pequena amostra da população e por isso, envolvem uma série de variáveis de controle para um ajuste mais acertado do valor obtido. Segundo, porque estamos tratando de uma amostra muito específica, com características bastante peculiares que se distingue de um retrato mais geral da população do país. Porém, para a análise que propomos, a comparação entre os índices - por nós encontrado e o fornecido pela literatura - é plausível.

Interessa-nos perceber que, a amostra dos ingressantes USP (das carreiras selecionadas e Total Geral) apresenta uma Mobilidade Intergeracional em Educação que se assemelha aos índices de mobilidade de países desenvolvidos. A mobilidade é - segundo a literatura - inversa à persistência: quanto maior a persistência, menor a mobilidade. Isto porque o grau de persistência revela a maior tendência de o filho permanecer com a mesma escolaridade de seu pai. Abaixo, temos os dados baseados no suplemento de mobilidade da PNAD $^{23}$ de 1996, que indicam o grau de persistência intergeracional em educação para alguns países (Tabela 13):

\footnotetext{
23. Pesquisa Nacional por Amostra de Domicílios.
} 
Tabela 13 - Grau de persistência intergeracional em Educação (PNAD,1996).

\begin{tabular}{|l|l|}
\hline \multicolumn{2}{|c|}{$\begin{array}{c}\text { Grau de Persistência Intergeracional em } \\
\text { Educação (PNAD,1996) }\end{array}$} \\
\hline EUA & 0,25 a 0,35 \\
\hline Alemanha & 0,20 \\
\hline Brasil/Colômbia & $\mathbf{0 , 7 0}$ \\
\hline México/ Peru & 0,50 \\
\hline
\end{tabular}

O índice 0,70 referente a Brasil revela, primeiro que a mobilidade é de 0,30. A interpretação da literatura para esse índice envolve dentre outras coisas, a média de escolaridade dos pais de tal modo que, por exemplo, se a persistência é de 0,5 , então o filho de um pai cuja educação exceda em dois anos a média terá uma educação cujo valor esperado será um ano acima da média (da educação dos filhos). Ou seja, para o Brasil o grau de persistência de 0,70 significa que, se o pai tem 1 ano de estudo acima da média, seu filho tem um valor esperado de $\mathbf{0 , 7 0}$ ano de estudo acima da média. Esse índice varia segundo o estudo e método utilizado, podendo ser 0,68 ou 0,56, por exemplo. (Ferreira e Veloso, p.488, 2003).

De toda forma, fica evidente que em países desenvolvidos como Estados Unidos e Alemanha, o grau de persistência é bastante menor e, portanto, a mobilidade é maior.

Segundo o uso que fizemos do termo mobilidade, esperamos indicar com o índice apresentado, o percentual de filhos que igualam ou superam a escolaridade de seus pais ao ingressarem no curso superior. Desse modo, nossa comparação é direta, não passando pelos índices médios e/ou produtos destes.

A literatura afirma que a mobilidade é menor para filhos de pais com pouca escolaridade do que para filhos de pais com escolaridade mais elevada, com exceção de pais no topo da distribuição educacional, que apresentam mobilidade relativamente baixa. E este é - exatamente - o caso da amostra aqui considerada: os pais dos ingressantes USP têm alta escolaridade (grande parte com pelo menos ensino médio completo, o que está acima da 
média nacional), assim como seus filhos, que estão ao se matricularem fazendo parte do grupo daqueles com curso superior incompleto.

Por isso, considerando o período aqui analisado, na comparação entre os índices de mobilidade intergeracional em educação encontrados para cada um dos blocos de carreira (1 e 2) e total geral USP, podemos afirmar que, por um lado, o percentual de $\sim 40 \%$ (Total USP) é um valor que indica razoável mobilidade, já que menos da metade dos convocados para a 1ạ. matrícula supera ou iguala a escolaridade de seus pais no ingresso ao curso superior e, por outro lado, que os percentuais em torno de 30\% e 70\% (respectivamente para Direito/Engenharia/Medicina e Lic. Ciências Exatas/Lic. Matemática e Física/Pedagogia) evidenciam a diferença de perfil dos ingressantes segundo a o status da carreira escolhida, de modo que a mobilidade para o primeiro bloco é ainda menor que a do Total Geral e a mobilidade do segundo bloco é muito maior que a do primeiro. Considerando que cerca de $70 \%$ dos pais de ingressantes do bloco 1 tenham curso superior completo ou pós-graduação é compreensível que se tenha baixíssima mobilidade neste caso.

Quanto aos ingressantes do bloco 2, cujos pais têm - em sua maioria - pelo menos o ensino médio completo (e, portanto, uma escolaridade acima da média do país, que é em torno de 8 anos) e somente cerca de $30 \%$ tem curso superior completo ou pós-graduação, é também compreensível que a mobilidade seja alta, concordando com a literatura.

Observando os resultados ao longo dos anos vemos na análise por blocos de Carreiras e Total Geral USP que naquelas de maior prestígio social houve um aumento de 10 p.p. do índice de mobilidade intergeracional de 2000 para 2009 e, no mesmo período uma diminuição de 10 p.p. para aquelas carreiras relacionadas à formação de professores. Para o Total Geral USP, a alteração foi de +4 p.p. No entanto, é notável que não podemos associar essas alterações (pelo menos, não de modo conclusivo) à influencia de políticas de inclusão, como o programa INCLUSP.

Entendemos que a busca por uma caracterização do perfil de ingressantes de um curso de Licenciatura em Física contribui de maneira expressiva com indicativo para ponderar os cursos de formação de professores. Evidencia a necessidade do reconhecimento 
dessas características na própria organização curricular, deixando de considerar o grupo de alunos idealmente, como equivalente aos que optaram por outras carreiras. Ao mesmo tempo, e sobretudo, aponta para a necessidade de promover um contínuo processo de discussão sobre a construção da identidade profissional do professor. Para muitos autores, essa identidade deve ser objeto ela mesma de atenção, o que nossos resultados vêm a reforçar. Levando em conta suas particularidades seja do ponto de vista social, seja do ponto de vista de suas perspectivas pessoais e profissionais, será necessário buscar formas de promover a construção de uma identidade profissional, para além do trabalho desenvolvido nas disciplinas, particularmente para aqueles cursos em que as disciplinas iniciais privilegiam principalmente conhecimentos de Física.

Dessa forma, consideramos fundamental que cada instituição procure buscar as formas apropriadas de contemplar esses aspectos nos projetos político-pedagógicos dos cursos que oferecem. 


\section{CAPÍTULO 5 - REPRESENTAÇÕES SOCIAIS DA PROFISSÃO PROFESSOR E PERSPECTIVAS PROFISSIONAIS DE LICENCIANDOS EM FÍSICA}

Seguindo a investigação das características de ingressantes USP, procuramos neste segundo momento, direcionar um olhar específico aos recém-matriculados no Curso de Licenciatura em Física do IFUSP, com o objetivo de compreender aspectos relevantes relacionados à opção desses jovens quando do ingresso no curso, suas expectativas e perspectivas profissionais.

Acreditamos que por trás de suas escolhas pelo curso, pela área e/ou carreira docente estão as Representações Sociais que têm a cerca da profissão Professor, da ideia de Ciência/Física, de pesquisa e ensino.

Como vimos, no capítulo 3, Dotta (2006) reconhece as representações do ser professor como dinâmicas, sendo construídas permanentemente na interação entre práticas e saberes de diversas naturezas. A autora acredita, também, que o estudo dessas representações pode contribuir significativamente para a compreensão da identidade profissional dos professores.

Ao buscar investigar as representações de alunos ingressantes em um Curso de Licenciatura estamos conscientes da especificidade do contexto em questão. Não se trata propriamente de representações construídas a partir de práticas profissionais, que só acontecerão ao final do curso, mas, sobretudo de imagens construídas por diferentes formas de interação com a escola e por suas próprias vivências na escola básica. Dessa forma, não é a expressão de um coletivo vivencial, mas de diferentes perspectivas e contextos escolares provavelmente muito heterogêneos.

Ainda assim, compartilhamos com Dotta (2006), o potencial de diagnóstico que o estudo dessas representações pode significar. 


\subsection{As Representações da Profissão Professor de Licenciandos em Física}

\section{da USP}

O ingresso no ensino superior no Brasil, sobretudo em universidades públicas é, sem dúvida, um privilégio de poucos. Ainda que seja um grupo restrito, pode - e deve - ser entendido como sendo formado por sub-grupos, cada qual com interesses, características e especificidades próprias, a começar pela escolha da carreira.

Entre as camadas médias (Foracchi, 1965, Salem, 1980, Romanelli, 1986) há um enorme empenho para que os filhos tenham acesso ao curso superior. Nas representações de pais e de filhos, a escolarização superior é avaliada como recurso que qualifica a força de trabalho, habilitando-a a disputar empregos bem remunerados, revestidos de alto valor simbólico, e a competir por posições hierárquicas elevadas nas empresas (Romanelli, 1995).

De fato, um acontecimento como o ingresso na universidade, carrega consigo inúmeras representações que refletem convicções, atitudes, expectativas, entre outros, tanto de ordens pessoais como sociais, passando, por determinantes econômicos e culturais.

As representações são modelos - ou padrões - elaborados no vivido de múltiplas experiências coletivas. Além disso, são modelos para a conduta, pois constituem ordenações simbólicas para a prática social (Durham, 1984).

Que representações estão por trás da escolha por um curso de licenciatura, especialmente, em física? Esta é uma questão a que este trabalho se propõe investigar e ainda que não a possa responder - encontrar explicações plausíveis para uma realidade que tem se mostrado um tanto ambígua, no sentido de que a decisão por ingressar em um curso de licenciatura não esteja necessariamente vinculada à perspectiva de carreira docente.

É recorrente a menção ao desprestígio do magistério, que não tem atraído o interesse das novas gerações, causando o decréscimo do número de inscritos nos processos de seleção para os cursos de licenciatura e a falta de professores de algumas disciplinas, tais como física e química (Vicentini e Lugli, 2009).

Identificar as imagens e representações que se faz e/ou se tem da profissão de professor, por aqueles que ingressam em um curso de licenciatura, bem como as suas 
impressões do que virá a caracterizá-lo em sua identidade profissional, pode ser significativo no entendimento destas questões.

Nesse sentido, procuraremos analisar as representações que ingressantes em um curso de Licenciatura em Física fazem de suas escolhas, na fase da opção de carreiras. Para esse conjunto de indivíduos, é possível esperar que nem todos de fato tenham interesse em ser professor. Mesmo nesses casos, a falta de interesse deveria corresponder também a representações negativas que tenham da profissão. Com esse objetivo, analisaremos algumas respostas dadas por ingressantes no ato de matrícula a um questionário, com foco nas expectativas sobre a opção profissional. Um aspecto limitante da pesquisa é a natureza do instrumento, já que o questionário não foi construído especificamente para isso.

A análise que propomos não tem a pretensão de ser completa ou categórica - e nem poderia, haja vista a restrição do material de que dispomos e as particularidades das circunstâncias de sua obtenção. Buscamos, contudo, entender até que ponto as representações acerca da profissão professor contribuem para a decisão de escolha em um curso de licenciatura em física associadas às suas expectativas. No futuro, pretendemos investigar possíveis correlações entre essas representações e a permanência dos alunos no curso.

\subsubsection{Estratégia de Investigação}

Com o intuito de identificar as representações em uma abrangência significativa, de ingressantes do curso de Licenciatura em Física da USP acerca da profissão professor, foram analisados questionários preenchidos pelos mesmos no ato de matrícula. Esses questionários pela foram aplicados a todos os alunos ingressantes pelo vestibular, no período de 1994 a 2007.

Não há aqui a pretensão de se fazer uma análise estatística e tão pouco completa sobre essas primeiras perspectivas profissionais dos ingressantes. Primeiro, pelas circunstâncias através das quais são obtidas as informações - os questionários são respondidos, quase que na totalidade, por alunos que ainda estão sob o efeito de muita 
empolgação, pelo ingresso na universidade, numa mescla de sentimentos e sensações de toda ordem. E, segundo, porque, ainda que fosse considerado todo o conjunto de respostas, não teríamos como argumentar de forma conclusiva sobre as reais impressões dos recémmatriculados - a leitura das respostas revela, por exemplo, as inúmeras interpretações para uma mesma questão; além de algumas inconsistências e ambigüidades.

Os questionários apresentam de início, uma justificativa para sua aplicação reiterando o pedido de colaboração dos alunos em seu preenchimento - seguida de cinco seções (dados pessoais, vestibular, opção profissional, conhecimentos de física e outros comentários). Nosso trabalho se restringe à análise das cinco questões presentes na terceira seção - opção profissional - e uma questão da quarta seção - conhecimentos de física, que será analisada no item 5.2.

A amostra selecionada para análise compreende um total de 212 questionários, 103 aplicados aos ingressantes do ano de 2002 - 48 do diurno e 55 do noturno; e 109 aplicados aos ingressantes do ano de 2006 - 50 do diurno e 59 do noturno. Corresponde, portanto, a dois conjuntos de alunos ingressantes, separados por alguns anos, com o intuito de verificar a especificidade ou abrangência temporal dos resultados obtidos.

A escolha pela turma de 2002 se justifica pelo fato de ser um ano cujos os alunos em sua totalidade apresentam-se nas listas de encerramento do sistema de matrícula, seja por conclusão, seja por abandono do curso. E, a turma de 2006 foi escolhida para permitir uma comparação entre turmas espaçadas por quatro anos no ingresso.

As perguntas e suas respectivas respostas foram agrupadas em tabelas de modo a facilitar o estudo pretendido ${ }^{24}$.

Acreditamos que as respostas dadas às questões:

\footnotetext{
${ }^{24}$ Ver tabelas no Anexo B.
} 


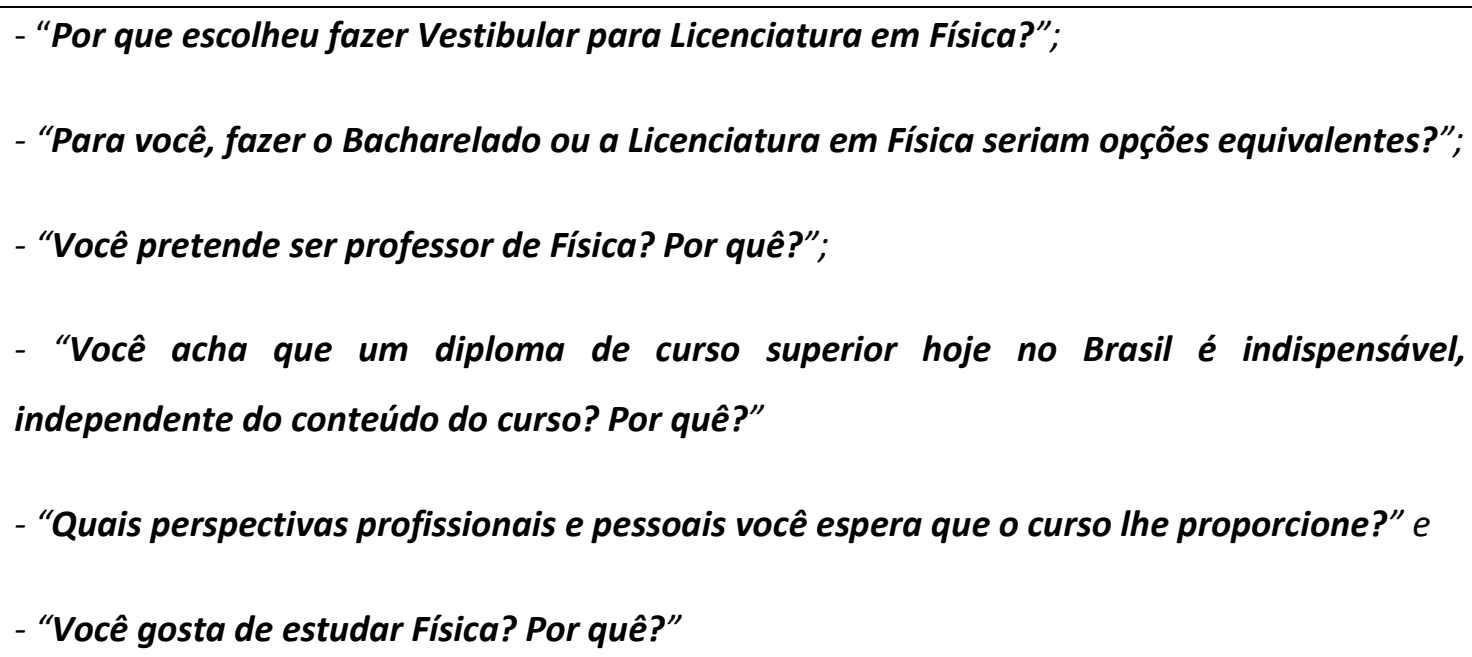

possam nos fornecer um importante indicativo das impressões e/ou representações da profissão Professor dos ingressantes em Licenciatura em Física, uma vez que a escolha por ele feita envolve, entre outros aspectos - as imagens que tem do curso (na área específica de física) e da profissão (docente). A leitura do conjunto de respostas dadas por cada aluno permitiu a identificação aparente de alguns grupos, por tipo de expectativa em relação ao Curso de Licenciatura em Física. Portanto, a análise das repostas não foi feita de forma individualizada para cada pergunta, mas para o conjunto das mesmas, o que também é justificado pelo fato de serem perguntas que permitem diferentes sentidos e cujas respostas envolvem sobreposições.

Assim, a análise permitiu identificar três categorias principais de representações, sendo que apenas uma das quais diz respeito efetivamente ao ser professor. Apresentaremos essas categorias, exemplificando-as, para em seguida, analisar mais detidamente o conjunto cujas representações são positivas.

Para cada categoria, são apresentados exemplos das citações de ingressantes diurno e noturno, do Curso de Licenciatura em Física do IFUSP - do ano de 2002 e em seguida de 2006, de forma a permitir uma comparação e análise das representações mais evidentes que caracterizam cada um dos grupos e em cada um dos anos considerados; A análise em separado dos dois grupos expressa uma tentativa de compreender o quanto as características encontradas para essa amostra poderiam ser consideradas como representativas para um conjunto maior de licenciandos em física. Assim, pudemos, num 
interstício de quatro anos, verificar semelhanças e diferenças em relação às representações sociais da profissão professor que trazem esses grupos de recém-matriculados no curso com a intenção maior de estabelecer os pontos comuns e relevantes que pudessem compor o quadro de características gerais - extrapolando o ano considerado - de ingressantes de um Curso de Licenciatura em Física, em termos de representação e perspectivas profissionais docentes.

\subsubsection{Principais Representações - Ingressantes 2002 e 2006}

Numa primeira tentativa de classificação dos ingressantes com respeito à opção profissional, poderíamos diferenciar os que pretendem dos que não pretendem ser professores de física (além de alguns casos de "talvez").

No entanto, uma análise mais abrangente, que leva em conta não somente a pretensão (ou não) de seguir a carreira docente como professor de física, mas, sobretudo, compreender - apesar das adversidades circunstanciais - as perspectivas dos ingressantes tanto em termos profissionais quanto pessoais na escolha pelo curso, revela a necessidade de um re-agrupamento destes perfis, com destaque característico para três grupos.

Assim, os dados nos indicam que a escolha pelo curso se justifica, aparentemente:

1) Pelo desejo de tornar-se professor de Física, ou

2) Pela necessidade de aprimoramento nos conhecimentos da área de Física, ou ainda

3) Pela possibilidade e/ou facilidade de obtenção de emprego e ascensão profissional, com a obtenção de um diploma de ensino superior.

É importante destacar, que a distribuição dos ingressantes da amostra nestes três grupos não se deu de maneira objetiva, tampouco inquestionável. Como já dito, foi preciso considerar o conjunto das seis respostas para uma inferência mais plausível e, em alguns casos, o uso de suposições, para deduzir as intenções do aluno e encaixá-lo em um dos grupos. Na medida do possível, foi despendido o cuidado necessário para se garantir a 
coerência e veracidade da análise. Apesar dessas limitações, os resultados obtidos podem ser. de certa forma, validados pelo grande número de respostas conclusivas.

O grupo 1, no qual a escolha pelo curso de licenciatura em física se deu pela intenção primeira de se tornar professor desta disciplina, é composto por alguns que já estão atuando na carreira e gostam, ou já atuaram em alguma época e gostaram; por aqueles que dizem querer (ou ser importante) transmitir ou socializar conhecimento; pelos que tem interesse específico em ensino (teoria e prática) e ainda, pelos que buscam aí realização pessoal. Alguns mostram-se interessados em um possível aperfeiçoamento na área de ensino com vistas em cursos de pós-graduação. Seguem abaixo, exemplos de expressões extraídas do conjunto de respostas dadas pelos ingressantes no questionário de recepção e ato de matrícula ${ }^{25}$ :

"Sim, pelo prazer de ensinar" (2N-2002) $)^{26}$

"Sim, porque eu gosto dessa área e sempre quis dar aula" (10D-2002)

"Além de gostar, tive boas experiências como professor." (39N-2002)

"Quero ter a possibilidade de lecionar, além da realização pessoal de fazer o curso de física. Depois quero fazer mestrado e doutorado." (27D-2002)

"Espero que o curso satisfaça minhas ambições e espero ser um bom profissional." (17D-2002)

"Porque já trabalho na área, e acho que será um curso muito interessante." (2N2006)

"Sim, para poder passar pra outras pessoas o conhecimento que eu irei receber." (42D-2006)

"Muito me agrada a oportunidade de desmitificar o estudo da Física, de modo a transmitir um pouco do meu fascínio por fenômenos naturais." (12N-2006)

\footnotetext{
${ }^{25}$ Ver detalhes nas tabelas em anexo.

${ }^{26}$ Referência a posição do aluno na lista, turno (Diurno/Noturno) e ano de ingresso para identificação nas tabelas.
} 
"Me proporcione conhecimento teórico e prático em física e principalmente, como passar esse conhecimento."(29N-2006)

"Ter oportunidade de realizar um mestrado e, após isso, um doutorado. Ter uma visão mais ampla das oportunidades e melhoria da educação do país." (10D-2006)

Certamente, as representações aqui identificáveis carregam imagens positivas, confiantes e até entusiasmadas da profissão docente. Vemos que a escolha pelo curso de licenciatura com a intenção principal de tornar-se professor de física ocorre, neste grupo, por diversos motivos. Tais motivações serão tratadas mais adiante com o intuito de identificar/destacar as prováveis representações da profissão professor que explicam estas diversidades.

No grupo 2, estão aqueles que, de forma mais categórica, dizem ter optado por este curso pela "afinidade", "facilidade" ou por gostarem muito da matéria (do conteúdo estudado em Física); aqueles que cogitam a possibilidade de mudar de curso (bacharelado em física ou outro em área afim); aqueles que pretendem aprofundar seus conhecimentos nesta área, inclusive com pretensões de seguir os estudos em nível de pós-graduação e trabalhar com pesquisas (não em ensino). Neste grupo, considerando diurno e noturno, a maioria declara não ter intenção de lecionar para o nível médio. Ou seja, para esse grupo, a área de conhecimento em Física seria preponderante ao ser professor de física. Vejamos algumas intenções e expectativas destes ingressantes:

“Não, apenas quero aprender, e não mestrar." (3D-2002)

"Não. Porque não tenho paciência." (10N-2002)

"Sim no caso de não conseguir entrar na área de pesquisa." (44N-2002)

"Desejo ter contato com cientistas de renome e participar dos avanços científicos de vanguarda." (46N-2002)

"Que seja um bom profissional e tenha uma condição de concorrer com qualquer profissional, da área de física." (35D-2002)

"Não, eu quero ser pesquisador." (1*D-2002) 
“...é a realização do maior objetivo de minha vida, o título de físico." (23N-2002)

"Estou fazendo por satisfação pessoal, e ter um maior conhecimento em uma área tão maravilhosa." (29D-2006)

"Por que interesso pelos assuntos abordados no curso de Física, e pretendo trabalhar nessa área, seja como professor ou como pesquisador (no caso de uma eventual transferência para o Bacharelado em Física)." (58N-2006)

"Sobretudo um maior contato, um aprofundamento na Física em geral, que é o que mais quero. Espero conseguir ainda com o curso capacidades e habilidades para seguir na vida acadêmica, trabalhar com pesquisas." (8D-2006)

"Para poder obter meus objetivos no futuro que é seguir a área de geofísica." (27D2006)

"Um conhecimento mais amplo e aprofundado e muitas áreas que a física atua." (44D-2006)

"Eu pretendo ter um grande desenvolvimento no conhecimento na área de exatas para uma maior especialização no futuro." (26N-2006)

"Espero que o curso de Física me proporcione um bom conhecimento na área das ciências exatas e possibilidades de trabalhar em centros de pesquisa." (58N-2006)

É notável que para os ingressantes deste grupo a escolha pelo curso de licenciatura em física ocorreu muito mais pela área (exatas) e matéria estudada (física) do que pela carreira profissional em si (docência).

O que os atrai é particularmente o conteúdo da ciência, possivelmente relacionado à imagem que têm da física e das ciências como área do conhecimento, suas várias dimensões de aplicação e status - seja em nível cultural ou social e econômico.

Aqueles que declaram a possibilidade de virem a lecionar, deixam transparecer que esta será uma opção alternativa, "no caso de não conseguir entrar na área de pesquisa", por exemplo. 
De alguma forma podemos inferir que o fato de optarem por um curso de formação de professores sem, no entanto, terem a intenção primeira de seguir em tal carreira, indica que as representações e imagens da profissão professor para este grupo de ingressantes são, no mínimo, nada atraentes.

De todo modo, o mais evidente neste grupo é que as imagens ou representações da profissão professor, em termos de exigência para o ofício, tendem mais a afastar os ingressantes do interesse pela carreira e aproximá-los do interesse pela área de estudo.

Aqueles que compõem o grupo 3, deixam mais evidente a ideia de que a escolha pelo curso se deu prioritariamente pela facilidade na obtenção de vagas e competitividade no mercado de trabalho; para mudar de carreira (ou ascender no emprego). Neste grupo há os que pretendem e os que não pretendem lecionar Física para o ensino médio, todos com justificativas mais relacionadas a razões financeiras do que interesse pela área de ensino. 0 que pode ser notado nos exemplos a seguir:

"Não, porque apesar de gostar da área de ensino pretendo usar o curso para obter promoção em atual emprego." (26D-2002)

"Não sei. Depende das oportunidades." (39D-2002)

"Sim! o mercado de trabalho exige que se tenha um curso superior p/ qualquer qualificação!" (49N-2002)

"Desenvolvimento de raciocínio lógico, desenvolvimento cultural e boas oportunidades no mercado de trabalho." (1N-2006)

"Espero que consiga encontrar um bom emprego para que eu possa possibilitar uma melhoria de vida para a minha família." (10N-2006)

"Sim por razões financeiras." (11N-2006)

"Ascensão de cargo no trabalho e maiores oportunidades em conseguir trabalho em outras empresas." (49N-2006)

"Não. Porque não teria paciência para ser professora. Porém ser professora em universidade, já sim." (39D-2006) 
"Não, porque o salário de professor hoje em dia é desestimulante." (29D-2006)

Ao justificarem a não pretensão em serem professores com "não é uma opção rentável" e "o salário é desestimulante" os ingressantes sugerem uma imagem da profissão como aquela que exige certo desprendimento em termos de valorização do trabalho - o qual eles não cogitam compartilhar.

Observa-se, no último exemplo dado acima, que a referência ao "hoje em dia" pode estar associada à ideia de que em algum tempo os professores foram/eram bem remunerados. Impressão esta, que faz parte de um senso comum - incluindo professores atuantes e ex-professores - que procura de forma imediata justificar as atuais circunstâncias de trabalho e atuação associadas às precárias condições de valorização salarial.

O exemplo correspondente a (39D-2006), revela que a ingressante distingue consideravelmente a imagem do professor do ensino médio daquele que leciona no curso superior, dando destaque para a questão da "paciência" - que parece ser uma exigência para o primeiro, mas não para o segundo.

Apesar de a maioria dos ingressantes deste grupo indicar "talvez" como resposta à pretensão de serem professores de física, podemos - na análise do conjunto de suas respostas - perceber que em muitos casos esta escolha não está associada ao exercício da profissão em si, com interesses em ensino e educação, mas motivada por uma ascensão (d)na carreira.

Possivelmente a obtenção do diploma de nível superior na área de ciências exatas seja o atrativo maior para o alcance de tais objetivos, ficando a possibilidade de lecionar em segundo plano ou como conseqüência de facilidade no mercado de trabalho.

Portanto, as representações da profissão professor parecem estar aqui associadas às perspectivas de estabilidade financeira proporcionada, de certa forma, devido a abrangência da carreira em termos de oferecimento de vagas. Essa referência fica clara em citações como: 
"Espero conquistar conhecimentos necessários para ingressar em uma carreira vitoriosa. Tenho certeza que muitas portas se abrirão com esse curso." (14D-2002)

"Talvez. Uma outra renda." (45D-2002)

"Profissionalmente a carreira traz grande número de caminhos a seguir, lecionar, fazer pesquisas, ou atuar na área industrial." (18N-2002)

"Porque gosto de Física, mas a preocupação em conseguir emprego, logo no início do curso limita a possibilidade do bacharelado." (20N-2002)

"Sim. Porque é uma matéria temida por muitos e que sempre está precisando de novos professores nas escolas." (9D-2006)

"Sim, devido à afeição pela matéria e pela aceitação e/ou deficiência do setor no mercado." (31D-2006)

"Na verdade, despertei grande interesse no campo da Física em meu ano de cursinho. Gostaria de aprender mais sobre essa área. Optei por Licenciatura para ter mais chances de conseguir trabalho, já que acredito que haja muitas vagas para ser professor de Física." (49D-2006)

"Acredito estar entrando num campo bastante carente e com várias opções $e$ pessoalmente que traga-me realização e satisfação de ser um profissional da área." $(53 N-2006)$

"Sim, é uma área muito interessante e o mercado de trabalho, ao que me consta, está necessitando de profissionais na área." (57N-2006)

Ou seja, não somente existem grandes chances de se conseguir emprego para "dar aulas", como maiores facilidades há, quando se trata de aulas de física. Assim, a imagem da carreira docente que por um lado sofre com a desvalorização e por outro, ambiguamente, oferece vários meios de acesso - e por isso passa a ser atrativa - acaba sendo ainda mais reforçada pela especificidade da área de exatas, no caso da disciplina de física. 


\subsubsection{Uma análise quantitativa dos grupos de representações}

Em termos numéricos e numa análise global, incluindo os alunos do diurno e noturno do ano de 2002, verificamos que quase $70 \%$ dos ingressantes pertencem ao Grupo 1, ou seja, escolheram o curso de Licenciatura em Física com a intenção na formação e atuação profissional como professores de Física do Ensino Médio.

Quase um quarto dos ingressantes 2002 compõem o Grupo 2, dos que buscam no curso mais conhecimento de Física e que trazem um histórico de grande interesse e habilidade com a disciplina.

Por fim, cerca de $8 \%$ dos matriculados em 2002 no curso de licenciatura, formam o Grupo 3, que esperam que o curso thes proporcione oportunidades e sucesso profissional em termos financeiros, seja atuando como professores ou não.

Considerando os conjuntos correspondentes aos turnos (diurno e noturno) em separado, os resultados mostram significativa diferença nos índices dos Grupos 1 e 2, visto que diurno apresenta 6 p.p. a mais que o noturno daqueles matriculados que buscam formar-se professores; e por lado, o noturno apresenta 7 p.p. a mais para o grupo dos que buscam aperfeiçoamento na área, o que pode ser verificado pela tabela 14, abaixo:

Tabela 14 - Intenção primeira na escolha do curso - Percentual dos ingressantes 2002, por Categoria.

\begin{tabular}{|l|c|c|c|}
\hline \multicolumn{4}{|c|}{ Percentual dos ingressantes 2002 por Categoria } \\
\multicolumn{4}{|c|}{ Intenção Primeira na busca pelo Curso de Licenciatura em Física } \\
\hline Categorias & Diurno & Noturno & Total de Ingressantes \\
\hline Grupo 1: Formação de Professores & $\mathbf{7 1 \%}$ & $\mathbf{6 5 \%}$ & $\mathbf{6 8 \%}$ \\
\hline Grupo 2: Aperfeiçoamento na Área & $\mathbf{2 1 \%}$ & $\mathbf{2 8 \%}$ & $\mathbf{2 4 , 5 \%}$ \\
\hline Grupo 3: Ascenção Profissional & $\mathbf{8 \%}$ & $\mathbf{7 \%}$ & $\mathbf{7 , 5 \%}$ \\
\hline
\end{tabular}

A análise dos questionários dos ingressantes do ano de 2006 - diurno e noturno - do Curso de Licenciatura em Física da USP, revela índices bastante semelhantes ao de 2002, especialmente quanto aos interessados pela Formação de Professores como primeira intenção na busca pelo curso. Veja Tabela 15 a seguir: 
Tabela 15 - Intenção primeira na escolha do curso - Percentual dos ingressantes 2006, por Categoria.

\begin{tabular}{|l|c|c|c|}
\hline \multicolumn{4}{|c|}{ Percentual dos ingressantes 2006 por Categoria } \\
\multicolumn{2}{|c|}{ Intenção Primeira na busca pelo Curso de Licenciatura em Física } \\
\hline Categorias & Diurno & Noturno & Total de Ingressantes \\
\hline Grupo 1: Formação de Professores & $70 \%$ & $64 \%$ & $67 \%$ \\
\hline Grupo 2: Aperfeiçoamento na Área & $14 \%$ & $17 \%$ & $15,5 \%$ \\
\hline Grupo 3: Ascenção Profissional & $16 \%$ & $19 \%$ & $17,5 \%$ \\
\hline
\end{tabular}

Novamente, quase $70 \%$ dos matriculados na Licenciatura em Física desejam seguir a carreira docente, e o restante busca aprimoramento na área ou ascenção profissional. Vistos em separado, os turnos - em 2006 - apresentam significativa diferença de índices, sobretudo para o Grupo 1, no qual tem-se 6 p.p. a mais no diurno; e 3 p.p. a mais no noturno para aos Grupos 2 e 3.

Numa comparação entre os anos, é notável certa diferença nos índices para os grupos 2 e 3: em 2002 é maior o percentual daqueles que pretendem aperfeiçoar-se na área de física, aproximadamente 25\%, enquanto em 2006 este índice é cerca de 16\%. Por outro lado, a porcentagem dos matriculados que buscam no curso a facilidade para o ingresso no mercado de trabalho (não docente) sofreu um aumento de 10 pontos percentuais de 2002 para 2006 (Tabela 16).

Tabela 16 - Intenção primeira na escolha do curso - Percentual Médio Aproximado de ingressantes 2002 e 2006, por Categoria.

\begin{tabular}{|l|c|c|}
\hline \multicolumn{3}{|c|}{ Percentual Médio Aproximado de ingressantes 2002 e 2006 por Categoria } \\
\hline \multicolumn{3}{|c|}{ Intenção Primeira na busca pelo Curso de Licenciatura em Física } \\
\hline Categorias & 2002 & 2006 \\
\hline Grupo 1: Formação de Professores & $68 \%$ & $67 \%$ \\
\hline Grupo 2: Aperfeiçoamento na Área & $25 \%$ & $16 \%$ \\
\hline Grupo 3: Ascenção Profissional & $7 \%$ & $17 \%$ \\
\hline
\end{tabular}

Vemos, portanto, que cerca de dois terços dos ingressantes da Licenciatura em Física da USP, têm a intenção primeira de Tornar-se Professor ao fazer a escolha por este Curso. Este percentual pode até ser considerado razoável, inclusive pela possibilidade de aumento - ao considerar-se mais alguns ingressantes classificados em outra categoria que declaram interesse em lecionar. No entanto, numa comparação com cursos como Medicina ou 
Engenharia - nos quais praticamente a totalidade de ingressantes pretende seguir a carreira escolhida - podemos entender este índice como inferior ao esperado ou, no mínimo significativo para suscitar a pergunta: o que faz os cursos de licenciatura, como o de física, ser alvo de interesses tão diversos da intenção de seguir a carreira docente. É plausível, neste caso, fazermos referências às representações da profissão professor que têm esses ingressantes.

\subsubsection{Profissão Professor - Ingressantes que buscam a formação para atuar como docentes}

Cabe aqui um destaque para a análise das respostas referentes ao Grupo 1, uma vez que o interesse de tais ingressantes pelo curso de licenciatura se dá especialmente pela intenção de seguir a carreira docente, ou seja, Tornar-se Professor.

São, sem dúvida, muito diversas as representações e imagens que podemos associar - de forma talvez arriscada, porém aceitável - a sub-grupos desta unidade maior que compõem os interessados pela formação e atuação docente como professores de física.

Por isso mesmo, as inferências que seguem são de nossa inteira responsabilidade e procuram apenas indicar/destacar algumas características das diversas impressões/imagens de professor aparentemente presentes nas respostas dadas pelos ingressantes no questionário de recepção e matrícula do curso.

Podemos começar citando que, enquanto cerca de 15\% dos ingressantes/2006 deste Grupo 1 fazem referência à "vocação" e "aptidão" como justificativa para suas escolhas, em 2002 isso aparece nos questionário de apenas 5\% dos matriculados. Dentre elas, temos, por exemplo:

"Sim, tenho aptidão". (37D-2002)

"Sim. Vocação." (47N-2002)

"Por causa de minha aptidão com a carreira." (2D-2006) 
"Vocação. É um prazer estudar Física, compreender o Universo em que vivo e comunicar aos outros o que aprendi." (5D-2006)

"Pela aptidão pessoal para lecionar." (18D-2006)

"Sim. Aptidões pessoais e interesse." (30N-2006)

"Por achar que tenho vocação e afinidade com a carreira." (51N-2006)

As representações, portanto, trazem a ideia de que seja importante ao profissional possuir disposições naturais para o ofício, talvez no sentido de que isso facilite tanto o processo de formação quanto a prática no exercício da profissão.

Seguindo mais ou menos nesta mesma direção, observamos (em 2002 e 2006) um alto índice de citações acerca do "gosto", "interesse", "afinidade", pela matéria (física) e pela área (que tanto pode ser interpretada como sendo a área de exatas, como área de ensino). $\mathrm{E}$ também a "vontade", "desejo" ou "sonho" de "ensinar".

Todos esses aspectos de caráter positivo com relação a imagens e representações da profissão professor podem ser destacados em separado na evidenciação de particularidades como:

a) Interesse pela formação e em como ensinar (técnicas e práticas), com uma representação de professor como aquele que deve aprender a ensinar bem, seja numa perspectiva mais de transmissão do conhecimento, seja com vistas às novas metodologias.

"Espero sair apto a lecionar física de maneira invejável, acreditando estar pronto para os desafios que a atual sociedade impõe aos novos universitários." (21D-2002)

"A possibilidade do desenvolvimento de novas técnicas pedagógicas para exatas são meus maiores anseios!" (27N-2002)

"Espero que o curso me proporcione relacionar a Física teórica (na sala de aula) com o que vemos na nossa vida (Física diária) para passar isso aos meus alunos, criando-Ihes interesse pela matéria." (14D-2006)

"Aprendizado técnico e aprendizado didático. Na área técnica ter um bom conteúdo, e na didática técnicas de como motivar, organizar aulas." (35D-2006) 
"Me proporcione conhecimento teórico e prático em física e principalmente, como passar esse conhecimento." (29N-2006)

"Espero receber conhecimento suficiente para lidar com alunos e parâmetros suficientes para poder ensinar da melhor forma possivel." (37N-2006)

"Boa formação em Física; técnicas em educação e nova forma de passar o conteúdo de Física, menos tradicional, que motivem mais os alunos." (51N-2006)

b) Expectativas de mudança de sua visão de mundo (e da matéria) e também dos seus futuros alunos. As representações parecem remeter a um professor mais transformador e crítico do ponto de vista de sua formação e atuação.

"Espero que o curso me proporcione novas maneiras de ver o mundo, várias opções para o trabalho e como tratar os futuros alunos." (7D-2002)

"Para trabalhar na área Didática, com o intuito de melhorar e lutar por reformas no ensino." (18D-2002)

"Sim. Acredito ser fundamental que o conhecimento da física seja distribuído para toda população brasileira se quisermos que o Brasil tenha alguma importância neste mundo globalizado." (30N-2002)

"Anseio aprender bem a física, porém dentro de um contexto sócio-cultural, não acredito que a física seja puramente exata. E com este conhecimento, desejo poder ser professora." $(31 N-2002)$

"Pretendo ser um bom profissional e mudar minha forma de ver o mundo." (3D-2006)

“Ampliar visão da realidade e da natureza (...)" (24D-2006)

"Quero ser professor de física e ajudar a mudar o país com a educação." (25N-2006)

c) Perspectivas favoráveis de atuação no mercado de trabalho, com representações que refletem uma preocupação em ser "bom professor" para então ser valorizado no mercado de trabalho e obter estabilidade financeira. 
"Um bom emprego, que me forneça estabilidade financeira que venha a aprender muito relacionado a Física."(4D-2002)

"Pretendo sair daqui e conseguir um bom emprego em uma boa escola e pretendo ganhar muito conhecimento." (10D-2002)

"Um conhecimento maior sobre a física, uma inclusão no mercado de trabalho na área de ensino." $(3 * N-2002)$

"Espero que o curso enriqueça os meus conhecimentos teóricos e práticos da física e me proporcione vantagens referentes ao mercado de trabalho." (33N-2002)

"Aprofundamento dos meus conhecimentos, lapidação, e com isso o ingresso em ótimas escolas." (42N-2002)

"Acredito que o curso poderá me proporcionar uma ótima formação a fim de concretizar uma experiência, em especial no que diz respeito ao ato de ensino, necessária essencial para o sucesso na execução de meus futuros trabalhos." (19N-2006)

"Espero concluir meu curso, me tornar uma excelente profissional e trabalhar com isso." (23D-2006)

d) Pretensão de aperfeiçoar-se em ensino, numa representação de professor satisfeito em estar em uma carreira que permite um desenvolvimento pessoal permanente. 0 que aponta para oportunidades de ascensão na carreira mantendo-se o foco nas questões de ensino.

"Capacitação para lecionar no ensino médio ou superior e pesquisas." (1D-2002)

"Espero conseguir fazer uma pós-graduação. Em termos pessoais, espero ajudar muita gente a chegar nas Universidades Públicas." (5D-2002)

"Espero que seja capaz de sair daqui conseguindo explicar o fundamental da física e que o curso me dê condições de tentar o mestrado." (24N-2002)

"Permita que eu esteja preparada para dar aulas; e consiga desenvolver uma tese p/ mestrado e doutorado futuramente." (28N-2006) 
"Espero exercer a profissão de professor, principalmente como pós-graduado. Na vida pessoal ter mais auto-estima." (23N-2006)

"Capacitação para lecionar até no ensino médio, e o início de uma carreira como pesquisadora (depois da pós) e posteriormente lecionar em curso superior." (5D-2006)

"Que eu esteja apto para poder dar aula numa escola, poder seguir estudos posteriores e ser um grande profissional." (9D-2006)

"Ter oportunidade de realizar um mestrado e, após isso, um doutorado. Ter uma visão mais ampla das oportunidades e melhoria da educação do país." (10D-2006)

"Espero que o curso me proporcione todas as perspectivas necessárias para ingressar na carreira como professor e como pesquisador." (50N-2006)

"Trabalhar como professor e se possivel fazer um mestrado na área de ensino." (55N-2006)

Os quatro aspectos descritos e exemplificados acima, poderiam ser entendidos como sub-categorias daquela que chamamos Ser Professor. Isto é, dos ingressantes do curso que têm a intenção primeira de seguir a profissão docente, podemos destacar como aspecto mais evidente:
A) Interesse pela formação e em como ensinar
B) Expectativas de mudanças de sua visão de mundo e de seus futuros alunos
C) Perspectivas favoráveis de atuação no mercado de trabalho
D) Pretensão de aperfeiçoar-se em ensino e ascender na carreira

Compõem a categoria Ser Professor um total de 142 alunos. A tabela 17 mostra como se dá distribuição percentual nas quatro sub-categorias:

Tabela 17 - Percentual dos licenciandos que pretendem Ser Professor, segundo aspectos mais evidentes.

\begin{tabular}{|l|c|}
\hline \multicolumn{1}{|c|}{ Percentual Médio aproximado dos Licenciandos que pretendem Ser Professor, segundo aspectos mais } \\
\hline \multicolumn{1}{|c|}{ Sub-Categorias } & Percentual \\
\hline A. Interesse pela formação e em como ensinar & $\mathbf{2 0 \%}$ \\
\hline B. Expectativas de mudança de sua visão de mundo e de seus futuros & $\mathbf{7 \%}$ \\
\hline C. Perspectivas favoráveis de atuação no mercado de trabalho & $\mathbf{6 0 \%}$ \\
\hline D. Pretensão de aperfeiçoar-se em ensino e ascender na carreira & $\mathbf{1 1 \%}$ \\
\hline
\end{tabular}


Vemos que mais da metade (60\%) se enquadra na sub-categoria (C), isto é, são ingressantes da licenciatura que têm com o curso a perspectiva primeira de ingresso no mercado de trabalho, pretendem ser bons professores e almejam estabilidade financeira como docentes.

Cerca de $20 \%$ dos ingressantes que pretendem atuar como professores de física, têm interesse em técnicas e práticas, para "ensinar bem" aquilo que aprenderam e compõem a sub-categoria (A). Em suas declarações, estes alunos fazem referência aos seus futuros alunos, diferente daqueles classificados na sub-categoria (C), que mais dão ênfase ao emprego de professor e nem tanto à atuação como docente.

Já os 7\% da sub-categoria (B), assim como os da (A) fazem citações a respeito de seus futuros alunos, porém com um caráter que remete à uma intenção de atuar de forma transformadora e crítica, ou que de alguma forma apresente mudanças na comparação com aquilo que vivenciou até então como aluno.

Por fim, pouco mais de $10 \%$ dos que pretendem seguir a carreira docente, também esperam ter oportunidade para aperfeiçoarem-se na área de ensino e com isso buscar ascensão profissional, inclusive como professores universitários.

Outras imagens ou representações da profissão professor certamente estão presentes nos inúmeros questionários que compõem a amostra analisada. No entanto, entendemos que as observações acima são suficientes para dar uma ideia significativa daquilo que seria uma possível explicação para a escolha destes ingressantes pelo curso de licenciatura em física associada à intenção de se tornarem professores. A evidência maior, neste caso, nos parece ser as impressões positivas que os recém-matriculados têm da carreira pretendida, a despeito de todas as adversidades conhecidas e que permeiam a profissão docente.

\subsection{Representações sobre a Física de ingressantes do Curso de Licenciatura em Física da USP}


Neste tópico, pretendemos desenvolver uma análise específica da questão: "Você gosta de estudar Física? Por quê?" - constante do questionário de matrícula (no item referente a Conhecimentos de Física), com a intenção de identificar as concepções sobre as Ciências/Física que trazem os alunos quando do ingresso no curso.

Nas tabelas em anexo com as transcrições das respostas dos ingressantes, esta questão aparece como sexta e última.

Considerando que a Carreira via vestibular a qual pertence o Curso de Licenciatura em Física, também oferece a opção para a Licenciatura em Matemática, acreditamos ser interessante/importante, compreender - ainda que de modo indireto - as ideias sobre a Física que têm esses alunos ao efetivarem sua matrícula no IFUSP.

Para melhor estabelecer as categorias, bem como classificar cada um dos alunos nas mesmas, optamos por analisar conjuntamente as respostas dadas às seguintes perguntas do questionário de matrícula: "Por que escolheu fazer vestibular para licenciatura em Física?" e "Você gosta de estudar Física? Por quê?". A partir daí construímos quatro categorias que, de certa forma, revelam as ideias e concepções destes ingressantes acerca desta ciência Física ao mesmo tempo que respondem: por que você escolheu estudar Física?

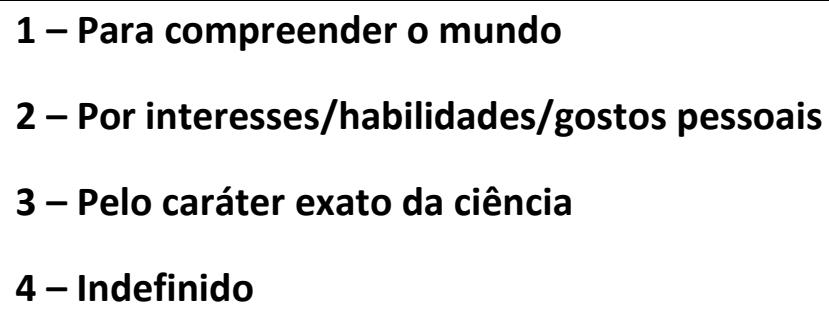

A análise do conjunto de respostas revelou os seguintes dados (Tabela 18):

Tabela 18 - Visão de Física - Ingressante 2002 (valores absolutos).

\begin{tabular}{|c|c|c|}
\hline \multicolumn{3}{|c|}{ POR QUE ESCOLHEU ESTUDAR FÍSICA? } \\
\hline Categorias & Diurno & Noturno \\
\hline 1 - Para compreender o mundo & 22 & 30 \\
\hline 2 - Por interesses ou habilidades pessoais & 16 & 10 \\
\hline 3 - Pelo caráter exato da ciência & 4 & 4 \\
\hline 4 - Indefinido & 6 & 11 \\
\hline Total & 48 & 55 \\
\hline
\end{tabular}


Em termos percntuais as categoriais mostram o seguinte (Tabela 19):

Tabela 19 - Visão de Física - Ingressante 2002 (valores percentuais).

\begin{tabular}{|c|c|c|c|}
\hline \multicolumn{4}{|c|}{ POR QUE ESCOLHEU ESTUDAR FÍSICA? } \\
\hline Categorias & Diurno & Noturno & Geral \\
\hline Para compreender o mundo & $46 \%$ & $55 \%$ & $50 \%$ \\
\hline Por interesses ou habilidades pessoais & $33 \%$ & $18 \%$ & $26 \%$ \\
\hline Pelo caráter exato da ciência & $8 \%$ & $7 \%$ & $8 \%$ \\
\hline Indefinido & $13 \%$ & $20 \%$ & $16 \%$ \\
\hline Total & $100 \%$ & $100 \%$ & $100 \%$ \\
\hline
\end{tabular}

Foram agrupados à primeira categoria os ingressantes que apresentaram em seu discurso a ideia de que a Física serve para explicar os fenômenos da natureza, o funcionamento da vida e do universo, proporcionando uma compreensão do mundo por meio de seus fundamentos. A seguir, algumas citações que ilustram tais aspectos:

"Sim, pois ela explica, através da lógica, vários efeitos naturais e artificiais." [D1]

"Para poder entender os mais diversos fenômenos, suas causas e utilizá-los." [D14]

"Sim, por ser uma ciência que nos possibilita entender os fenômenos físicos que ocorrem." [D16]

"Sim, porque a física faz parte de nosso cotidiano. Ela também explica como o mundo funciona." [D26]

"Sim, porque torna possivel o entendimento da natureza e das interações entre ambiente $e$ elementos." [D32]

"Sim, gosto de observar a natureza e entender os seus mecanismos, logo gosto de física." [D34]

"Sim, me interesso pela visão do universo com máquina." [D40]

"Sim pois ao estudar física eu tento compreender os mistérios do "gigantesco" universo e o "minúsculo" átomo." [D44]

"Sim, é o estudo do universo e da vida." [D1*] 
"Sim. Porque mostra a essência de tudo ou quase tudo." [N7]

"Sim. Porque tudo em volta é física, sua vida é baseada na física." [N8]

"Sim. Porque em busca dos porquês da vida foi na física que encontrei muitas respostas." [N9]

"Sim. Porque numa linha de raciocínio geral da ciência ela tenta desvendar o funcionamento do universo, o que é fascinante." [N20]

"Sim, pois explica muitos fenômenos que ocorrem no nosso cotidiano (como tudo funcionava e os porquês)." [N28]

"Sim, pois estudamos os assuntos mais simples que ocorrem na natureza, no dia a dia. $\grave{E}$ interessante saber como podemos explicar e aprofundar sobre algum fenômeno." [N39] "Sim, porque acredito que o conhecimento da física amplie a percepção e o conhecimento do mundo que nos cerca." [N41]

"Sim, pois ela rege próprio começo do universo, revela seu interior e nos permite entender o que chamamos de realidade." [N44]

"Adoro. A física consegue explicar o mundo, seus fenômenos. Nada que vemos ou sentimos passa em branco na física, ela tem uma explicação para cada coisa. É impressionante com ela é precisa em suas definições." [N53]

"Sim, pois, a Física trata sobre o universo, o macro e o micro." [N3*]

Os ingressantes classificados na segunda categoria parecem ter escolhido estudar Física por motivos relacionados às suas habilidades ou interesses pessoais, como facilidade e admiração pela matéria, interesse ou gosto por desafios. Vejamos algumas de suas declarações:

"Sim. Porque trata de assuntos de meu interesse." [D4]

"Sim, tenho facilidade." [D6]

"Sim. Gosto de desafios." [D9] 
"Sim, porque me interesso pelo estudo dos movimentos e forças de interação dos elementos da natureza." [D12]

"Sim, porque é uma matéria a qual sempre tive alguma facilidade para estudar." [D25]

"Sim, tenho afinidade com a matéria." [D30]

"Sim, gosto de coisas que poucas pessoas podem ou conseguem compreender." [D36]

"Sim. Facilidade de entendimento e prazer." [D45]

"Sim. Sempre tive interesse por ciências em geral, como gosto mais de astronomia e ele tem ligação muito forte com física (astrofísica), passei a gostar de física." [N34]

"Sim, pois tenho grande interesse e facilidade nesta área." [N36]

"Sim. Me agrada o fato da descoberta e o querer saber sempre mais." [N37]

"Gosto porque a física sempre me mostrou muitos desafios." [N38]

"Muito, gosto de dificuldades." [N43]

Já aqueles que compõem a terceira categoria evidenciam o interesse pelo estudo da Física por seu caráter enquanto ciência exata, sua relação com a lógica e a matemática. Como mostram os trechos a seguir:

"Sim. Sempre gostei de cálculos, mas a física vai além e mostra coisas do nosso cotidiano que acho muito interessante." [D15]

"Sim, porque é uma matéria que embora exija bastante estudo, esta não é algo decorado, mas sim uma coisa lógica, que vai desenvolvendo." [D31]

"Gosto, pois eu gosto de trabalhar com a matemática, e na física a matemática se alheia [alia] aos conhecimentos da natureza." [D43]

"Sim. Gosto de exatas." [N11] 
"Sim, especialmente a parte teórica, pois o pensamento debruçado sobre as ciências exatas levam-me a contínua superação de mim mesmo e estabelece uma lógica que permeia a vida cotidiana." [N46]

"Gosto de poder associar a matemática a tudo que está ocorrendo agora ao nosso redor." [N52]

Alguns ingressantes não deixam claro em suas respostas o que, essencialmente, os levaram a escolher um curso de Física. Pelo menos, não pudemos agrupá-los de modo consistente nas categorias anteriores e, então preferimos classificá-los como "Indefinidos". Também foram agrupadas aí as respostas em branco. Abaixo, alguns exemplos do que chamamos de indefinido:

"Sim, aprendi no colegial" [D37]

"Sim." [D41]

"Porque é bem dinâmico, e é um curso muito legal." [D47]

"Sim, não faço idéia do porque." [N19]

"Sim. Tive grandes incentivo de excelentes professores..." [N33]

"Sim. Não sei" [N47]

O gráfico 9 abaixo ilustra a distribuição percentual dos ingressantes 2002 nas categorias acima descritas. 


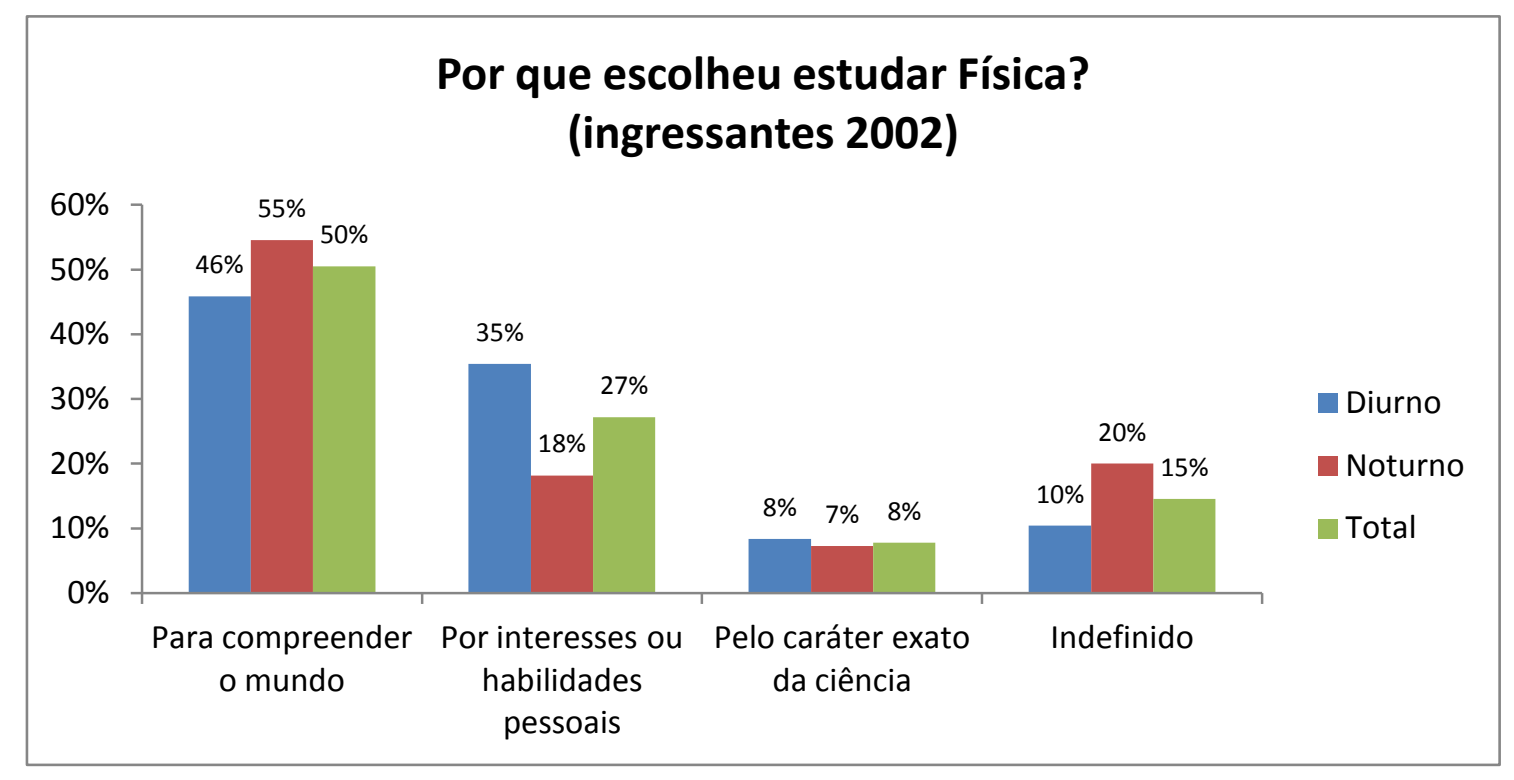

Gráfico 9 - Percentual dos ingressantes 2002 segundo as ideias/concepções que o levaram a estudar Física.

O gráfico nos mostra que para $\mathbf{5 0 \%}$ dos ingressantes 2002 a escolha por estudar Física está mais diretamente relacionada à ideia de compreensão de mundo. Pouco mais de $\mathbf{2 5 \%}$ do total de alunos revelou em suas respostas que a escolha pela Física se deu por gosto, interesse e/ou habilidades pessoais. Um percentual pequeno, menos de $10 \%$, destaca o caráter exato da ciência como sendo a principal razão pela escolha do curso. E ainda temos uma taxa considerável, $15 \%$, de alunos que não responderam à questão ou não deixaram evidente a concepção por traz de sua escolha em estudar Física.

É importante destacar que $10 \%$ dos ingressantes de 2002 que responderam ao questionário de matrícula apresentam em suas declarações uma grande admiração, fascínio e/ou encantamento pela Física e tal aspecto parece ser próprio desta fase primeira de expectativa e empolgação do momento de matrícula no curso.

"Sim, porque admiro as teorias da mesma." [D8]

"Sim, me fascina." [D21]

"Sim. Além de facilidade para a matéria, a física me fascina." [N1]

"Sim. Porque numa linha de raciocínio geral da ciência ela tenta desvendar o funcionamento do universo, o que é fascinante." [N20] 
"Por minha atração em relação as ciências físicas..." [N32]

"Adoro. A física consegue explicar o mundo, seus fenômenos. Nada que vemos ou sentimos passa em branco na física, ela tem uma explicação para cada coisa. É impressionante como ela é precisa em suas definições." [N53]

\subsection{Conclusões Preliminares}

Procuramos aqui, investigar e identificar as representações que estão por trás da escolha por um curso de licenciatura, especialmente em física. Enfrentamos a dificuldade em entender uma realidade um tanto controversa, que mostra a decisão por ingressar em um curso de licenciatura desvinculada - em grande parte - da perspectiva em seguir a carreira docente.

O material de investigação é composto pelos questionários preenchidos no ato de matrícula pelos ingressantes 2002 e 2006, diurno e noturno, do curso de Licenciatura em Física da Universidade de São Paulo. Sendo assim, dispomos apenas das expectativas que Ihes serviram como motivação para a escolha feita, uma vez que ainda não tiveram contato com as disciplinas curriculares.

A decisão pela análise de dois anos distintos, espaçados do período de quatro anos, se deu pela intenção de evidenciar - se há e quais - semelhanças e diferenças em relação às representações que trazem esses grupos de recém-matriculados, podendo estabelecer os pontos comuns e relevantes que podem compor o quadro de características gerais extrapolando os anos considerados - de ingressantes de um Curso de Licenciatura em Física, em termos de representação e perspectivas profissionais docentes. Em relação a esse aspecto, nossos resultados indicaram que não há variações expressivas entre as expectativas dos ingressantes nesses dois anos, o que permite inferir uma certa generalidade para os resultados.

Entendemos que as perspectivas dos ingressantes - que pretendem ou não ser professores - refletem as representações e imagens que têm a cerca da profissão professor 
e que, de alguma forma, são indicativos do que poderá caracterizá-lo em sua identidade profissional.

Os resultados mostram que cerca de dois terços dos que ingressam no curso de Licenciatura em Física têm a pretensão de serem professores desta disciplina, o que nos permite inferir que são positivas as representações que têm da profissão. Interessa-nos, também, compreender as razões que levam um terço dos que se matriculam neste curso de formação de professores, a não terem a intenção primeira de seguir carreira docente.

A atração pelo curso associada a não atração pela carreira pode estar relacionadas às ambigüidades que marcam boa parte da história da profissão docente. As transformações da escola e da profissão; os interesses políticos, econômicos e sociais que permeiam e moldam a(s) identidade(s) desta categoria são percebidas não somente pelos agentes mais diretos como professores e Estado - mas por toda a sociedade.

As representações que cada um desses segmentos faz da profissão professor são múltiplas e muda(ra)m ao longo do tempo, como reflexo - entre outros - das mudanças comportamentais, disputas internas e externas de toda ordem, aspectos propriamente simbólicos e determinantes sócio-culturais.

É possível que o desprestígio por que passa - há tempos - a carreira do magistério seja um ponto forte na justificativa da não atratividade para os cursos de licenciatura. Segundo Pereira (2001), o magistério pode ser representado, numa topografia axiológica, sob duas adequações: o ethos ${ }^{27}$ missionário e o ethos do trabalho. 0 primeiro refere-se a um conjunto de disposições mais inclinadas a ressaltar a dimensão simbólica das posições ocupadas; percepção de si: carisma da missão espiritual de educar; "espírito de doação". O segundo a um conjunto de disposições contestatórias mais inclinadas a ressaltar as competências propriamente pedagógicas e as virtudes laboriosas do trabalhador; racionalização cotidiana do trabalho; "espírito de equivalência" baseada na venda da força de trabalho.

\footnotetext{
${ }^{27}$ Como entendido por P. Bourdieu.
} 
Estas duas adequações se mesclam em inúmeras e distintas proporções na formação de imagens e representações que cada indivíduo ou grupo de indivíduos têm ou fazem da profissão professor.

Muito embora exista a limitação desta pesquisa, em termos da natureza do instrumento, a análise permitiu a identificação de três categorias (ou grupos) principais de representações, nas quais a escolha pelo curso se justifica predominante e aparentemente: 1) pelo desejo de tornar-se professor de Física, ou 2) pela necessidade de aprimoramento nos conhecimentos da área de Física, ou ainda 3) pela possibilidade e/ou facilidade de obtenção de emprego e ascensão profissional.

Numericamente, numa análise global, temos que cerca de $70 \%$ dos ingressantes, tanto em 2002 quanto em 2006, pertencem ao primeiro grupo - ou seja, buscam a formação para atuarem como Professores de Física. Em 2002, aproximadamente 25\% pertence ao segundo grupo, enquanto em 2006 o percentual correspondente aos que buscam maior aprimoramento na área é de $16 \%$. Daqueles que pretendem com o curso o ingresso no mercado de trabalho (prioritariamente não docente), em 2002 o índice é de 7\% e em 2006, $17 \%$.

Como já dito, nos surpreende o fato de que uma fração em torno de um terço represente aqueles que ingressam em um curso de licenciatura em física com a clara intenção de não se tornarem professores desta disciplina. Embora o percentual dos que pretendem ser professor seja razoável - inclusive podendo alterar-se para mais, se considerarmos parte dos ingressantes dos outros dois grupos/categorias - entendemos que este índice continua inferior ao esperado, sobretudo quando pensamos em outros cursos nos quais a escolha da maioria se dá pelo interesse no prosseguimento da carreira - por exemplo, escolhe-se cursar engenharia para ser engenheiro, medicina para ser médico, direito para se advogado. Diante disto, devemos nos perguntar o que faz os cursos de licenciatura, como o de física, ser alvo de interesses tão diversos da intenção de seguir a carreira docente. 
Dentre os compõem o grupo 2, notamos que as representações de professor por parte dos ingressantes tendem a afastá-los da intenção de seguir a carreira reforçando o interesse prioritariamente pelo aprofundamento dos estudos na área.

Os ingressantes do grupo 3 deixam transparecer, no conjunto das respostas, a ideia de que optaram pelo ingresso no Curso de Licenciatura em Física, muito mais pelas facilidades de entrada e permanência no mercado de trabalho, do que pelo interesse e compromisso específicos da carreira docente.

E finalmente, da análise das perspectivas profissionais daqueles que ingressam no curso com a intenção de serem professores de física, podemos destacar dentre as inúmeras representações, particularidades que remetem, por exemplo: a) ao interesse pela formação e em como ensinar, numa perspectiva (talvez) mais de transmissão do conhecimento; b) expectativas de mudança na visão de mundo, com indicativos de transformação e criticidade do ponto de vista da formação e atuação; c) preocupação com o mercado de trabalho em termos de oferecer bons serviços para um retorno de maior valorização na área; d) pretensão de aperfeiçoar-se em ensino e desenvolvimento pessoal associado à satisfação de pertencimento da carreira com oportunidades de ascensão profissional.

Nesse caso, é interessante observar que essas perspectivas profissionais, tal como foram expressas pelos ingressantes, nem sempre se referem diretamente ao conteúdo da profissão, ou à missão de ser professor. Nos casos daqueles que expressaram representações do tipo (c) e (d) acima, a justificativa manifestada diz mais respeito ao mercado de trabalho e carreira profissional. Ao contrário, para aqueles que expressaram representações do tipo (a) e (b), o ser professor foi a ênfase central. Em números médios, isso significa que cerca de $70 \%$ dos que querem ser professor o justificam pela carreira e mercado de trabalho. Por outro lado, pouco menos de $30 \%$, o justificam pela natureza da própria profissão.

Considerando que os que querem ser professores são apenas $70 \%$ do total, podemos inferir que, daqueles alunos ingressantes no curso, apenas cerca de $20 \%$ (ou um em cada cinco) explicitam suas opções em termos de como antecipam o perfil profissional desejado. 
Para esse grupo, é importante destacar que sobressaem citações como vocação, aptidão, gosto, interesse, afinidade, prazer, admiração, fascínio - pela área e pelo ensino - e que seria interessante um estudo que investigasse a origem destes sentimentos.

Dentre essas representações de ser professor, como vimos, prevalece o grupo (a), que poderíamos associar ao modelo da racionalidade técnica, ou ao que Contreras (2002) associa ao perfil do profissional técnico. Segundo esse autor, os perfis profissionais podem ser identificados como os de profissionais técnicos, professores reflexivos ou professores críticos. Na racionalidade técnica, também discutida por outros autores, o processo de ensino seria representado pela justaposição dos saberes técnicos docentes ao saberes do conteúdo específico. Nesse caso, para ensinar "bem" é preciso conhecer "bem" a Física e se apropriar de métodos de ensino adequados.

Essa, talvez, seja a representação social predominante em relação ao processo de ensino, mesmo do ponto de vista de docentes universitários. Assim, é compreensível que seja preponderante. Mas, ao contrário, surpreende positivamente identificar que existe uma parcela dos ingressantes, ainda que pouco expressiva numericamente, para os quais o ser professor está relacionado a promover uma ação transformadora ou uma compreensão crítica do mundo.

Do mesmo modo nos interessa aprofundar um estudo que correlaciona as expectativas e representações destes ingressantes no momento de sua matrícula com sua atual situação em relação ao curso (permanência, conclusão, desistência etc). Esse aspecto será tratado no próximo capítulo. 


\section{CAPÍTULO 6 - UM PANORAMA DA EVASÃO E DOS CONCLUINTES DA LICENCIATURA EM FÍSICA DO IFUSP:} 1997-2010

Neste capítulo buscamos apresentar um panorama da evasão e dos concluintes do curso de Licenciatura em Física da USP, no período que abrange os anos de 1997 a 2010, por acreditar ser importante - na caracterização do perfil do licenciando em física - uma discussão, ainda que preliminar, sobre os aspectos relacionados à evasão, os motivos de abandono e tempo previsto/efetivo para o término da graduação, no sentido de fornecer subsídios para uma análise mais ampla sobre o perfil e a identidade da licenciatura.

\subsection{Considerações sobre a implementação da "nova" proposta curricular do IFUSP}

O Instituto de Física da Universidade de São Paulo vem oferecendo, desde 1993, um Curso de Licenciatura em Física, com carreira independente do Curso de Bacharelado desde o ingresso no vestibular da FUVEST. Assim, os cursos de licenciatura e bacharelado em Física possuem tanto projetos pedagógicos como identidades próprias, buscando atender às especificidades dos dois perfis formativos desejados, ou seja, professor/educador e bacharel. Essa diferenciação resulta, também, em estruturas curriculares específicas, desde as disciplinas iniciais. A proposta de dois cursos, como opções paralelas e separadas desde o início, foi pioneira no país para a área de Física, sendo ambos os cursos oferecidos tanto no período diurno como no noturno. Atualmente, para a Licenciatura, são disponibilizadas, a cada ano, 50 vagas para o período diurno e 60 vagas para o período noturno, que se constituem em uma carreira própria, nas opções do vestibular de ingresso, juntamente com as vagas para o curso de Licenciatura em Matemática, oferecido pelo IME (Instituto de Matemática e Estatística). Para o curso de Bacharelado, o ingresso nas 160 vagas disponíveis 
é feito através de outra carreira, possibilitando aos ingressantes a opção por outros cursos de bacharelado.

O objetivo inicial da implantação da Licenciatura, nesses moldes, foi o de procurar resgatar a participação da Universidade na formação de professores, numa tentativa de reverter o quadro anterior, em que o número de alunos licenciados em Física representava uma fração bastante inexpressiva do total de vagas oferecidas pelo IF e, ainda, buscar melhor atender às urgentes demandas por professores do ensino médio.

Ao longo dos últimos dez anos, vem sendo realizado um processo contínuo de acompanhamento e avaliação do curso, através da caracterização do perfil dos ingressantes, do desempenho em disciplinas, analisadas em blocos, do acompanhamento individual de alunos de algumas turmas, além de avaliações formais e informais de diversas naturezas. Dentre os problemas identificados temos, como em muitos outros cursos, um alto índice de evasão, caracterizado pelo conjunto dos ingressantes que não concluem o curso.

Neste capítulo apresentamos alguns dados quantitativos sobre o número de concluintes e a evasão nos Cursos de Licenciatura, nos últimos catorze anos.

\subsection{Estratégia de Investigação}

Estudos sobre evasão em cursos superiores têm sido realizados em diferentes contextos e através de variadas metodologias, o que envolve, também, indicadores de evasão com significados diversos. Esse aspecto deve ser considerado atentamente quando se buscam comparações entre resultados de trabalhos na área. Particularmente, na USP, foi desenvolvido um amplo estudo sobre evasão, realizado pela Pró-Reitoria de Graduação em 2004, que descreve e analisa os resultados do Projeto "Acompanhamento da Trajetória Escolar dos Alunos da Universidade de São Paulo, Ingressantes de 1995 a 1998", que fornece um conjunto de dados e resultados importantes sobre a evasão e a permanência prolongada na USP nesse período. 
A estratégia de pesquisa, no caso da presente abordagem, consistiu em utilizar dados apenas quantitativos, a partir do acompanhamento, ano a ano, do número de alunos desligados do curso, seja por terem concluído, seja por abandono, ou outros motivos.

A delimitação do período a ser analisado é motivada pelo interesse em acompanhar a instauração da licenciatura como opção independente. Somente a partir de 1997 é possível já ter concluintes do curso, sendo esse o ano de conclusão da primeira turma ingressante em 1993, no período noturno. As grades curriculares dos cursos diurno e noturno são equivalentes, diferindo apenas no número de horas de aulas semanais, o que acarreta uma duração diferente para a integralização dos créditos, estando previstos, para o diurno, um total de 4 anos ( 8 semestres) e para o noturno, 5 anos (10 semestres).

Em um primeiro momento, foi realizado um levantamento de informações sobre encerramentos de históricos por parte de alunos da licenciatura no período 1997-2010, extraídas de listas geradas pelo sistema de dados da Graduação da USP (Sistema Júpiter).

Os dados obtidos foram sistematizados em planilhas contendo as seguintes informações para cada aluno: ano de ingresso; semestre de ingresso; tipo de ingresso; turno; créditos acumulados; ano de conclusão; semestre de conclusão, data de encerramento ${ }^{28}$; tipo de encerramento.

As planilhas com os encerramentos apresentam um importante indicativo de como se dá a trajetória dos alunos que ingressam no curso, via vestibular ou outras. Pode-se observar, além do tempo decorrido entre ingresso e conclusão, a incidência de cada um dos tipos de encerramento. Embora o conjunto desses dados permita análises muito diversificadas, apresentamos a seguir os resultados obtidos a partir apenas de dois pontos de vista diferentes. Primeiramente, acompanhamos o número de concluintes ao longo do período analisado. Em seguida, analisamos os índices de encerramento, procurando identificar suas principais razões.

\footnotetext{
28 As listas de encerramentos referentes aos anos de 2008, 2009 e 2010 não apresentam data de encerramento.
} 


\subsubsection{Evolução do número de concluintes}

A análise dos concluintes no período mencionado pode ser realizada de diversas formas: (i) em números globais, referentes a todo o período, (ii) em valores anuais, (iii) em função do semestre de conclusão (1ㅇo ou 2ํ), (iv) em função do turno (diurno ou noturno), ou, ainda, (v) em função do tempo médio de conclusão. Essas diferentes abordagens visam identificar possíveis características que favoreçam (ou não) a conclusão de um maior número de alunos.

\section{Conclusões totais do período}

Considerando os dados fornecidos pelo Sistema de Graduação da USP nas listas de Encerramentos dos anos de 1997 a 2010, obtemos o que segue apresentado na Tabela 20:

Tabela 20 - Número de estudantes por Tipos de Encerramento - 1997 a 2010.

\begin{tabular}{|c|c|}
\hline Tipo de Encerramento & No. de alunos \\
\hline Conclusões & 779 \\
\hline Encerramentos sem conclusão & 1190 \\
\hline Total & 1969 \\
\hline
\end{tabular}

Os tipos de encerramento nos quais são classificados os alunos totalizam $15 \mathrm{e}$ incluem, além das conclusões e transferências (interna e externa), doze outros motivos de desligamento do curso. Uma análise mais detalhada dessas várias formas de encerramento será discutida mais adiante.

O período em análise envolve um conjunto de catorze anos. Independente do ano de ingresso, podemos estimar, inicialmente, quantos alunos poderiam ter concluído o curso, nesse intervalo, incluindo tanto o diurno como o noturno. Essa estimativa seria simples se o número de ingressantes tivesse permanecido constante, em 100 vagas por ano, como nos primeiros anos. Nesse caso, teríamos contabilizado a possibilidade de 1400 conclusões. No entanto, a partir de 2000, o número de vagas do curso noturno passou de 50 para 60, fazendo com que para os anos entre 2004 e 2010 (sete anos), pudessem ser esperadas mais conclusões. Nessa nova perspectiva, foi possível contabilizar a possibilidade de que 1470 
alunos poderiam ter concluído o curso, no intervalo de anos considerado, desde que todas as vagas tivessem sido preenchidas e não houvesse nenhuma desistência, no período que pretendemos analisar.

Nossos resultados indicam, no entanto, para esse período, 779 conclusões, o que significa uma taxa de $53 \%$ de integralização do curso pelos alunos. Esse número, como já foi observado, tem um significado local e específico, uma vez que a conclusão/evasão está sendo estimada para um período longo. Assim, ainda que correto, contribui com uma informação limitada em relação aos objetivos desejados. Além disso, trata-se de uma média em um período com significativa evolução nos índices de conclusão, incluindo o período de implementação inicial do curso, o que também relativiza o resultado.

Um outro aspecto importante a ser considerado é o fato de que nem todos os alunos ingressam por vestibular, ou seja, o número de ingressantes por ano não corresponde ao número de vagas.

Essa informação também pode ser obtida a partir das listas geradas pelo Sistema Júpiter, como já citado, uma vez que se fornecem a informação tanto do tipo de ingresso quanto do tipo de encerramento. São, basicamente, quatro ${ }^{29}$ os tipos de ingresso: vestibular, graduado, transferência externa e transferência USP.

O ingresso via vestibular não indica necessariamente que este aluno seja recémformado no ensino médio e/ou que já não tenha iniciado um curso superior ou até mesmo concluído uma graduação. No total de encerramentos analisados, há inúmeros re-ingressos via vestibular de alunos vindo de outros cursos (concluídos ou não) e também há os que já cursaram créditos na própria licenciatura em física e que decidem prestar novamente o vestibular e pedir posterior aproveitamento de estudos.

O ingresso do tipo graduado indica que o aluno matriculou-se na Licenciatura em Física por já ter concluído algum curso afim, podendo ser, por exemplo, o Bacharelado em Física, Licenciatura em Matemática etc. Os casos de transferência externa são aqueles nos

\footnotetext{
${ }^{29}$ Há um caso, em 2005, de ingresso via Liminar, no qual o aluno obtém junto a justiça uma autorização para se matricular no curso.
} 
quais o aluno oriundo de outra instituição de ensino superior ingressa após ser aprovado em uma prova específica, diferente do vestibular. Já as transferências USP (ou interna) representam os casos de alunos vindos de outros cursos da Universidade de São Paulo que tenham alguma afinidade curricular com a licenciatura em física; a maior parte dos casos é de alunos oriundos do curso de Bacharelado em Física.

Há pouco dissemos que as 779 conclusões registradas nestes catorze anos, sobre um total de 1470 possíveis ingressos, 53\%, representa uma taxa que fornece pouca informação significativa por inúmeros motivos, dentre eles o fato de não estar sendo considerado (neste total de 1470) aqueles ingressos do tipo graduado e transferências (externa e interna).

Se calcularmos o percentual de concluintes sobre o total de encerramentos ao longo destes anos - 779/1969 - obtemos uma taxa de aproximadamente $40 \%$, que talvez esteja mais próxima de representar o percentual médio de conclusões a cada ano. 0 gráfico 10 ilustra os valores absolutos e percentuais do total de encerramentos divididos em dois blocos: conclusões e outros encerramentos.

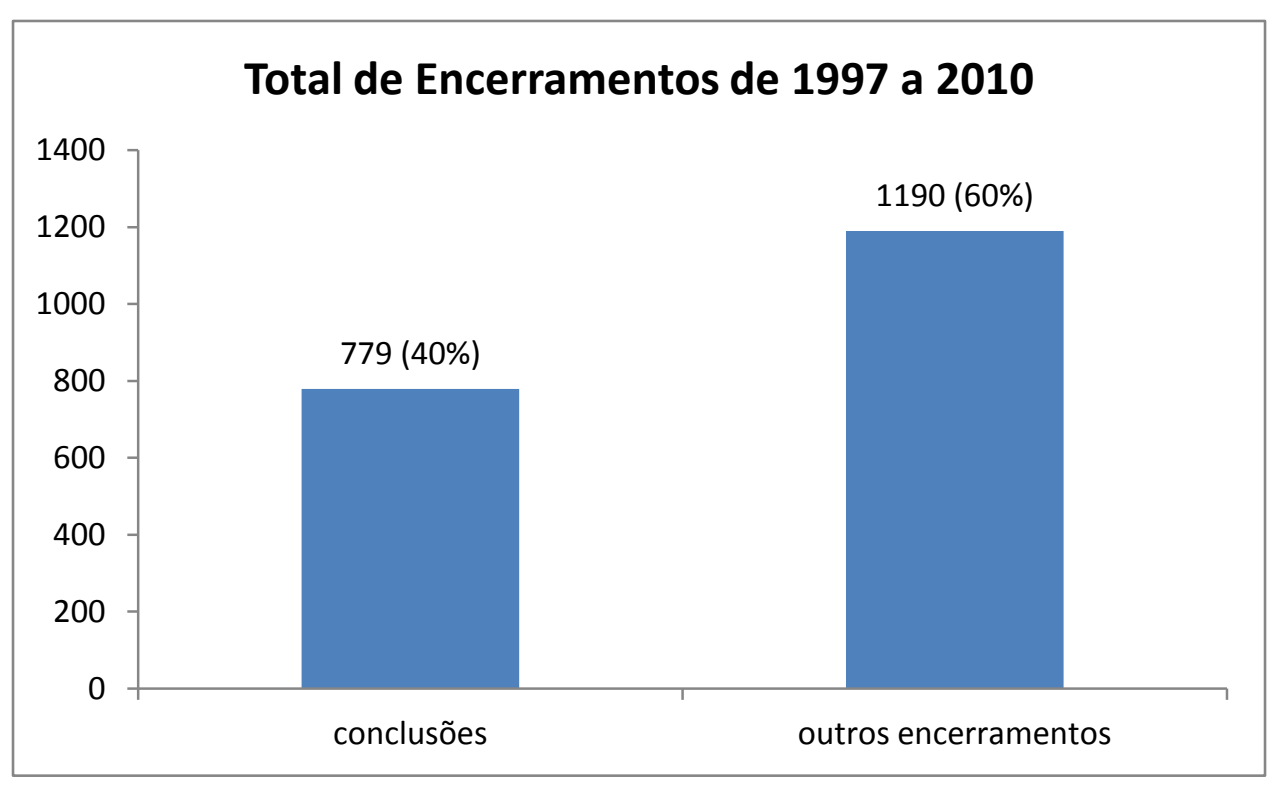

Gráfico 10 - Número de conclusões e outros encerramentos de 1997 a 2010. 


\section{Evolução anual dos concluintes}

Uma análise mais detalhada da evolução do número de concluintes pode ser observada a partir dos dados da tabela 21 abaixo, construída com os dados fornecidos pelo Sistema.

Tabela 21 - Evolução anual dos encerramentos com e sem conclusão (de 1997 a 2010)

\begin{tabular}{|c|c|c|c|c|c|c|c|c|c|c|c|c|c|c|c|}
\hline & 1997 & 1998 & 1999 & 2000 & 2001 & 2002 & 2003 & 2004 & 2005 & 2006 & 2007 & 2008 & 2009 & 2010 & \\
\hline Concluintes & 13 & 26 & 33 & 47 & 63 & 51 & 62 & 58 & 79 & 61 & 63 & 82 & 67 & 74 & 779 \\
\hline $\begin{array}{l}\text { Encerramentos } \\
\text { sem conclusão }\end{array}$ & 22 & 85 & 101 & 87 & 84 & 85 & 86 & 86 & 74 & 82 & 111 & 72 & 97 & 99 & 424 \\
\hline Totais & 35 & 111 & 134 & 134 & 147 & 136 & 148 & 144 & 153 & 143 & 174 & 154 & 164 & 173 & 1969 \\
\hline
\end{tabular}

Podemos, ao considerar o número de conclusões sobre o total de encerramentos em cada um dos anos, obter um panorama da evolução do número de concluintes nesses catorze anos (Gráficos 11 e 12):

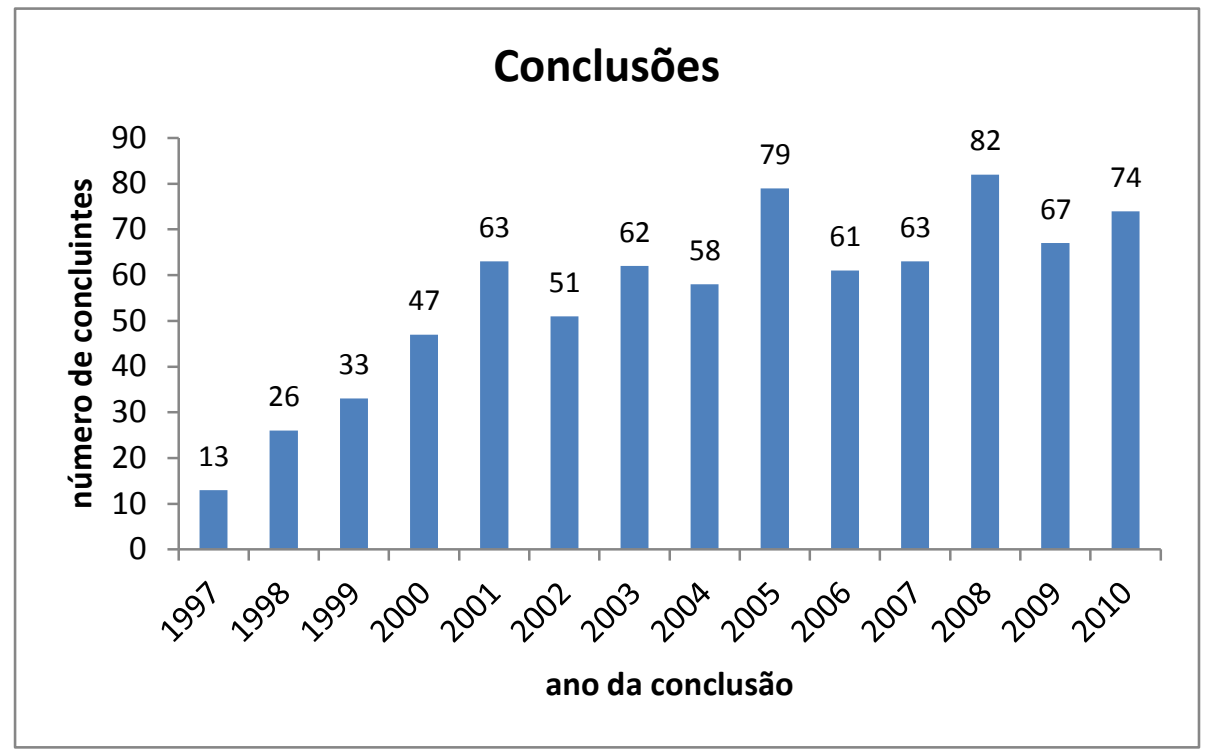

Gráfico 11 - Número de concluintes por ano, de 1997 a 2010 (valores absolutos). 


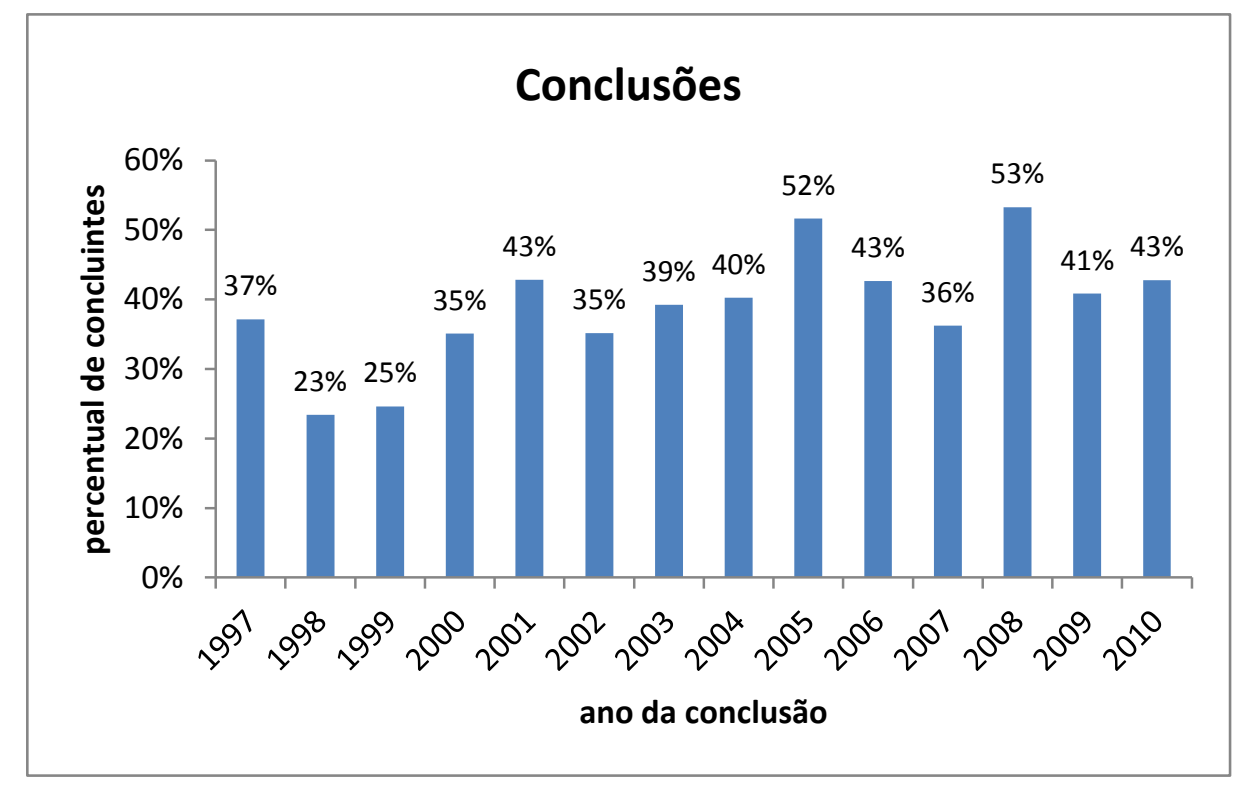

Gráfico 12 - Número de concluintes por ano, de 1997 a 2010 (valores percentuais).

Percebe-se que, nesse período, houve um expressivo crescimento do número anual de concluintes, passando, de pouco mais de uma dezena em 1997, para mais de sete dezenas, em 2010. No entanto, essa evolução não é homogênea. Ao crescimento gradual dos primeiros anos, até 2001, segue-se uma queda, em 2002; novo aumento em 2003 com suave queda em 2004; considerável elevação em 2005, seguida por outra diminuição em 2006; discreta elevação em 2007 e outra bastante significativa em 2008; novo decréscimo em 2009 e, finalmente elevação em 2010.

Em média, nos catorze anos, formaram-se 55-56 alunos por ano. De um modo geral, essas oscilações não apresentam, especialmente a partir de 2003, alguma tendência quer de crescimento, quer de redução, podendo possivelmente ser indicativas de certa estabilização. O crescimento observado nos primeiros anos pode ser atribuído ao fato de corresponderem aos primeiros anos de conclusão das turmas iniciantes no curso após a reforma curricular.

Os dois últimos anos apresentam valores muito próximos da média de concluintes dos últimos oito anos - 68 - o que talvez reforce a hipótese de tendência à estabilidade. Considerando apenas o período de 2003 a 2010, o valor médio de concluintes representa cerca de $45 \%$ do total de encerramentos. 
Como já observado anteriormente, uma forma usual de analisar a evasão é considerar as taxas de conclusão anual em função do número de vagas/ingressos (por vestibular) também anual. Isso corresponde ao que denominamos de evasão em fluxo, ainda que esse parâmetro apresente restrições já discutidas acima. A Tabela 22 abaixo apresenta a evolução da evasão para o período considerado.

Tabela 22 - Concluintes e evasão em fluxo (de 1997 a 2010)

\begin{tabular}{|l|r|r|r|r|r|r|r|r|r|r|r|r|r|r|r|}
\hline & $\mathbf{1 9 9 7}$ & $\mathbf{1 9 9 8}$ & $\mathbf{1 9 9 9}$ & $\mathbf{2 0 0 0}$ & $\mathbf{2 0 0 1}$ & $\mathbf{2 0 0 2}$ & $\mathbf{2 0 0 3}$ & $\mathbf{2 0 0 4}$ & $\mathbf{2 0 0 5}$ & $\mathbf{2 0 0 6}$ & $\mathbf{2 0 0 7}$ & $\mathbf{2 0 0 8}$ & $\mathbf{2 0 0 9}$ & $\mathbf{2 0 1 0}$ & \\
\hline Concl & 13 & 26 & 33 & 47 & 63 & 51 & 62 & 58 & 79 & 61 & 63 & 82 & 67 & 74 & 779 \\
\hline Ingressantes & 100 & 100 & 100 & 100 & 100 & 100 & 100 & 110 & 110 & 110 & 110 & 110 & 110 & 110 & \\
\hline Evasão & $87 \%$ & $74 \%$ & $67 \%$ & $53 \%$ & $37 \%$ & $49 \%$ & $38 \%$ & $47 \%$ & $28 \%$ & $44 \%$ & $43 \%$ & $25 \%$ & $39 \%$ & $33 \%$ & \\
\hline
\end{tabular}

De uma forma geral, observa-se uma evasão fortemente decrescente, nos primeiros anos, correspondentes a implementação da nova estrutura curricular, passando, em seguida, a oscilar, mas sempre em valores inferiores a 50\%. Nesses termos, e apenas considerando os últimos dez anos, é possível estimar uma evasão média de cerca 38\%.

De forma mais detalhada, podemos analisar o número de concluintes tanto por semestre de conclusão (primeiro/segundo de cada ano), como por período (diurno/noturno), ao longo desses catorze anos. Além disso, é possível analisarmos o tempo de duração do curso, ou seja, o número de semestres em que o curso foi integralizado para cada concluinte.

\section{Evolução dos concluintes em função do semestre de conclusão}

O Gráfico 13 apresenta, em valores absolutos, o número de concluintes por ano, distribuídos em 1 e 2 으 semestre. 


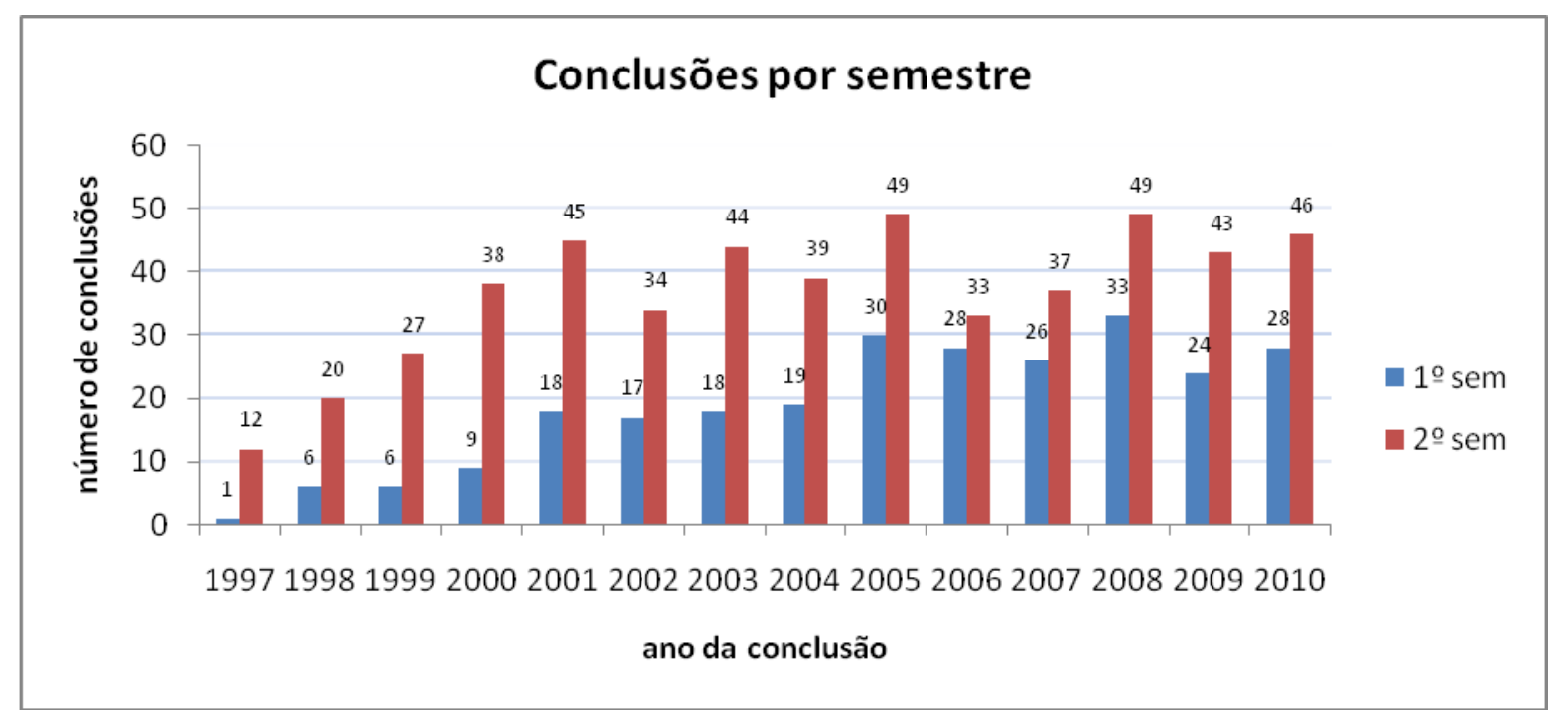

Gráfico 13 - Número de concluintes por semestre, ano a ano.

Nota-se que o número de concluintes de 2 o semestre excede em muito o de concluintes de 1 을 semestre. Esse é o resultado de fato a ser esperado, uma vez que os cursos - seja diurno ou noturno - têm duração ideal em número inteiro de anos e são organizados semestralmente, com ingresso por vestibular apenas no 1ㅇ semestre.

\section{Evolução do número de concluintes em função do turno}

Para uma análise em relação ao número de conclusões por turno - diurno ou noturno - os dados foram sistematizados na forma apresentada no Gráfico 14:

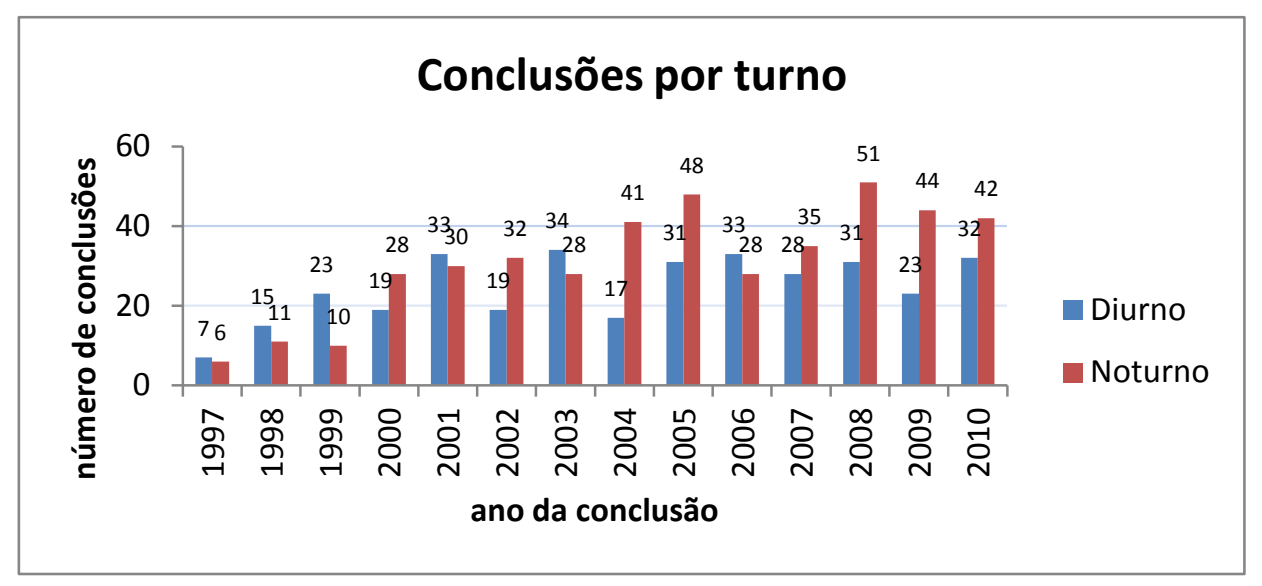

Gráfico 14 - Número de concluintes por turno ao longo dos anos. 
Comparando o número de formandos dos períodos diurno e noturno (Gráfico 14), percebemos uma oscilação dos valores, no decorrer dos anos, em ambos os turnos. De 1997 a 2003 há uma maior incidência de conclusões no período diurno; já de 2004 a 2010 a maior incidência de conclusões é do noturno. É preciso considerar o fato de ser comum os alunos mudarem do diurno para noturno e vice-versa ao longo de seus percursos na instituição, o que demandaria uma análise mais detalhada quanto ao turno em que estavam ao final do curso e no ano de ingresso. Por outro lado, a oscilação dos dados obtidos não estimula nem justifica esse aprofundamento.

\section{Tempo médio para conclusão do curso}

As listas com os Encerramentos geradas pelo sistema Jupiter, apresentam - como já dito - o tipo de ingresso do aluno, que são quatro: vestibular, graduado, transferência USP e transferência Externa. Para uma análise do tempo médio gasto para a conclusão do curso, optamos por considerar somente os ingressantes via vestibular, muito embora, por si só isso não garante uma total homogeneidade dos resultados, visto que incluem alguns casos de discrepâncias ${ }^{30}$. Os gráficos 15, 16 e 17 nos ajudam na análise dos dados.

30As discrepâncias aqui referidas são os casos em que o aluno levou apenas 2, 3, 4 ou 5 semestres para conclusão do curso. Esses são alunos que, muito embora tenham ingressado pelo vestibular, possivelmente fizeram uso de aproveitamento de estudos anteriores, reduzindo assim, significativamente seu tempo para conclusão. Há ainda, um caso em que um aluno levou um total de 31 semestres para concluir seu curso. Este pode ser um caso em que o aluno ficou algum tempo com o curso trancado, devidamente justificado, pois de outro modo excederia, inclusive, o prazo para jubilamento. 


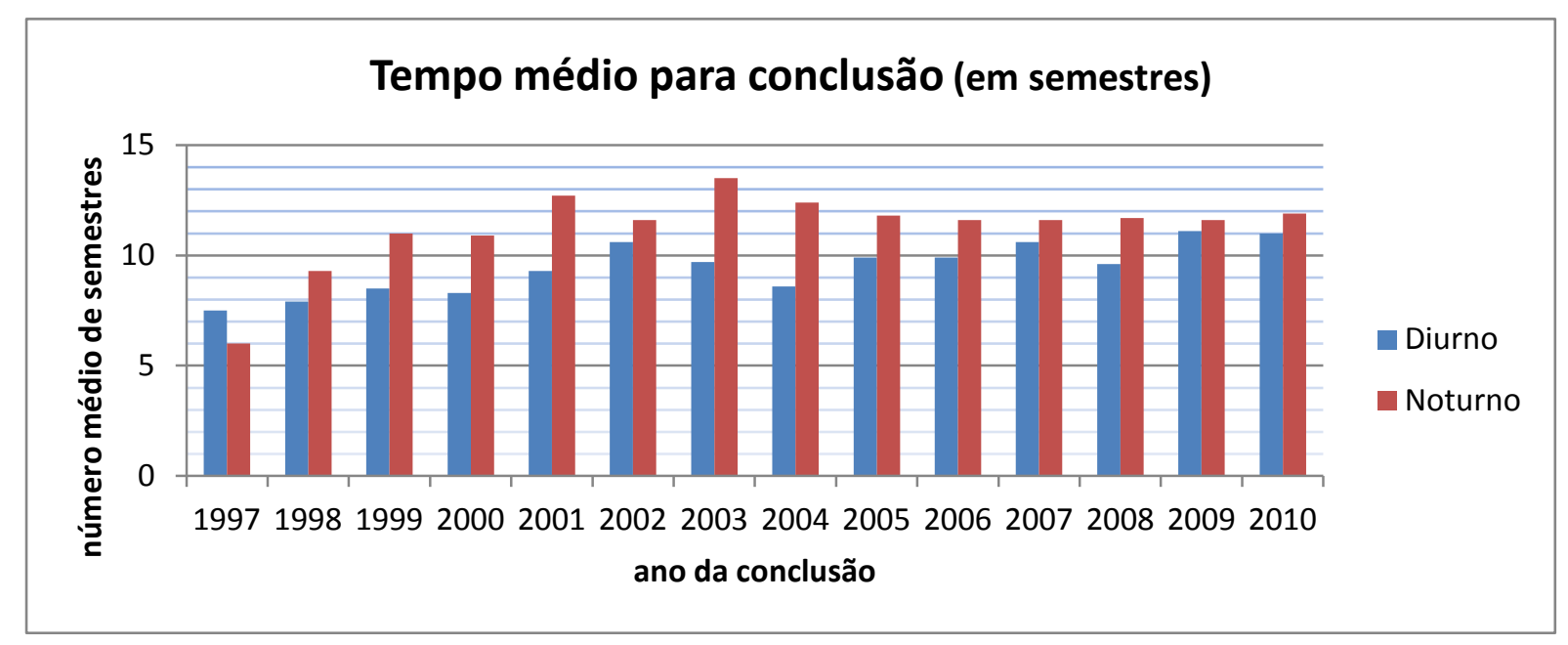

Gráfico 15 - Número médio, em semestres, conclusão do curso, por turno (ingressantes por vestibular).

Praticamente em todos os anos, ao longo desse período, percebe-se que os alunos vão além do tempo ideal para concluírem seus cursos. Os períodos diurno e noturno têm tempo ideal para conclusão diferentes -8 semestres, para o primeiro e 10 semestres para o segundo. O Gráfico 15 apresenta o valor médio absoluto de semestres além (ou aquém, como ocorre em 1997 e 1998) destes tempos ideais e o Gráfico 16 mostra os dados em valores percentuais:

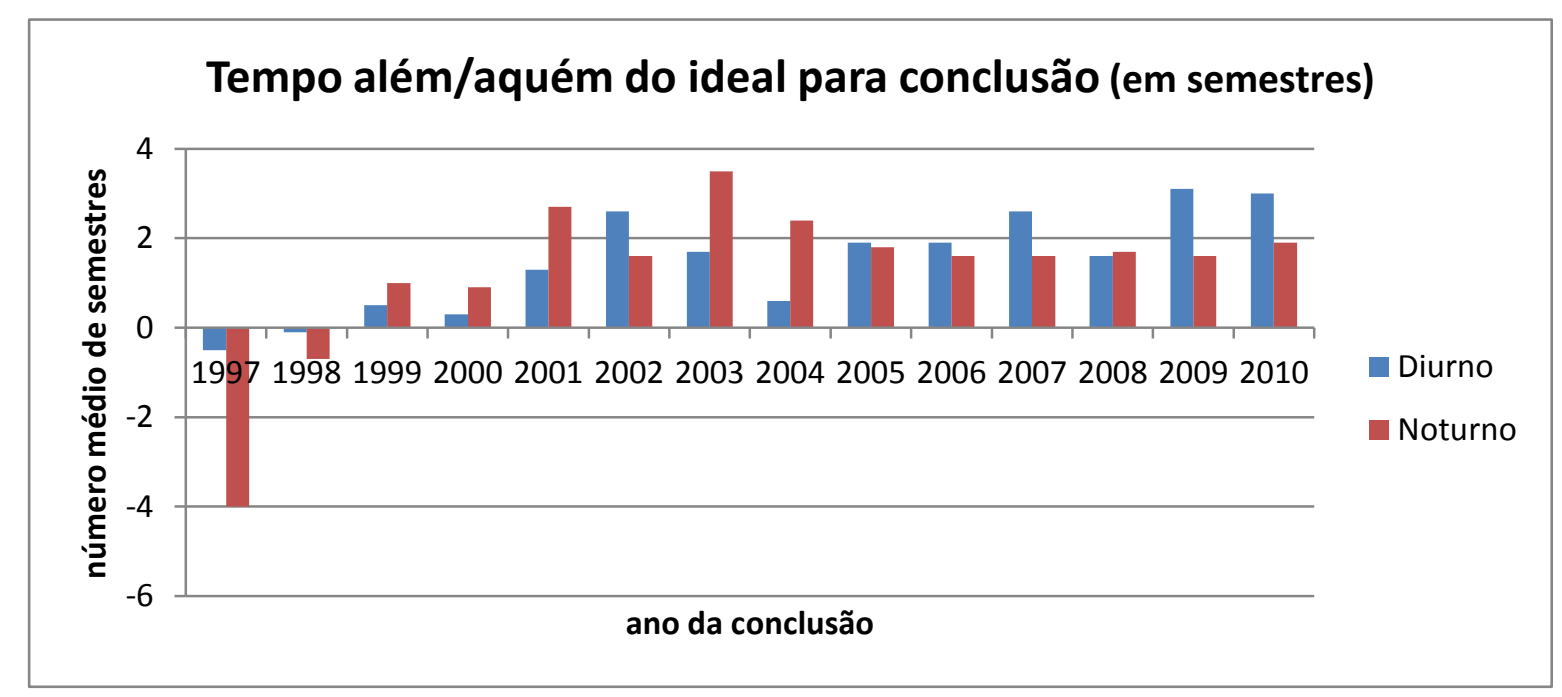

Gráfico 16 - Número médio de semestres além/aquém do tempo ideal ( 8 diurno;10 noturno) para a conclusão do curso. 


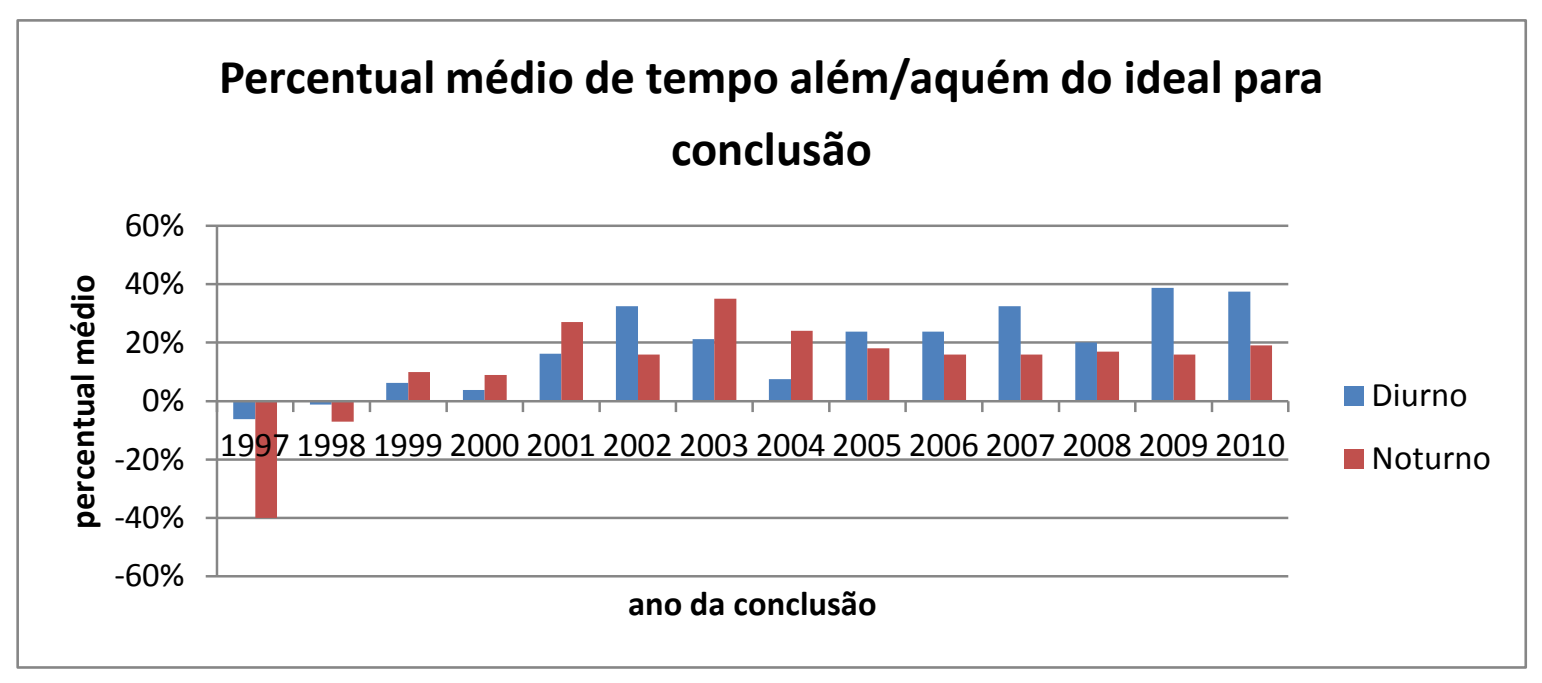

Gráfico 17 - Porcentagem do excedente em semestres com relação ao tempo ideal para a conclusão do curso, por turno.

Os Gráficos 16 e 17 mostram que não há um padrão de crescimento ou decrescimento dos valores de excedente em um turno ou outro ao longo destes catorze anos. Porém, é possível notar que no noturno, a partir de 2005 , há certa estabilização no tempo médio excedente para a conclusão do curso (em torno de 2 semestres, ou 1 ano); e no diurno, a partir de 2009, uma tendência de estabilização em torno de 3 semestres excedendo o tempo médio para conclusão do curso.

Percebe-se, por exemplo, que de 2000 a 2002, o excedente de semestres para a conclusão de curso dos alunos do diurno sofre um aumento a cada ano. Em 2003 e 2004 esses valores decrescem; voltando a subir em 2005 e permanecendo o mesmo em 2006; nova elevação em 2007 seguida de uma considerável queda em 2008. Por fim, significativa elevação em 2009 com suave diminuição em 2010. Com relação ao noturno, vemos que em 1997 e 1998 os formandos concluíram seu curso em um tempo médio inferior ao ideal. Em 1999 e 2000 já aparecem valores excedentes ao ideal em torno dos 10\%. Este percentual sobe em 2001; decresce em 2002, voltando a crescer em 2003. De 2004 para 2005 o índice sofre uma pequena queda, permanecendo praticamente o mesmo até 2009. Finalmente em 2010 há novo aumento. De modo geral, nos últimos seis anos, os alunos do diurno têm levado mais tempo para concluir seu curso se comparados aos do noturno. 
No entanto, apesar das flutuações observadas, e das considerações sobre as possibilidades de transição entre turnos, os dados explicitam um tempo de duração da formação muito acima da previsão contida na grade curricular. Há, certamente, razões de ordem pessoal. A quase totalidade dos alunos do período noturno trabalha, assim como um número expressivo de alunos do diurno. Isso faz com que tenham pouco tempo para dedicar ao curso, optando, muitas vezes, por cursar menos disciplinas por semestre do que o previsto na grade. De certa forma, essa tem sido uma postura até mesmo estimulada pela coordenação do curso, reconhecendo suas dificuldades. Outro aspecto importante é de ordem estrutural. A maior parte das disciplinas é oferecida apenas em um dos semestres e, portanto, uma vez ao ano. Isso faz com que, diante de uma reprovação em dada disciplina, o aluno tenha seu curso estendido de mais um ano, pois terá que esperar pelo novo oferecimento dessa disciplina no ano seguinte.

\subsubsection{Caracterização dos diversos tipos de encerramento}

A perspectiva complementar aos resultados acerca dos concluintes, já apresentados, nos leva a procurar analisar o universo de alunos que encerraram seus cursos, sem a conclusão, ao longo desse mesmo período. Essa não é uma análise simples, a partir da forma como as planilhas foram desenhadas, e faz-se necessário um conjunto de considerações.

Em primeiro lugar, dos 1969 casos analisados, 1190 encerraram o curso antes de seu término, já que tivemos, neste período de catorze anos, 779 conclusões. Como já alertado anteriormente, o número de alunos que passaram pelo curso não é só aquele decorrente dos ingressos pelo vestibular, o que por si só gera uma dificuldade para análises seguras em termos de taxas de conclusão e evasão no curso. É preciso contabilizar as transferências, tanto de alunos de outras unidades e cursos para a licenciatura, como no sentido inverso, além do ingresso de alunos da categoria graduados. Todos esses aspectos devem merecer uma atenção especial no futuro. Mas, ainda assim, para efeitos de análise, uma primeira aproximação à chamada evasão pode ser obtida passando a considerar o universo de desligamentos ao longo de todo o período, procurando caracterizá-lo. 
Outro problema é que, por ora, somente é possível a utilização dos tipos de desligamento tal como registrados pelo sistema de matrículas, que incluem denominações muito específicas, respondendo às normas e restrições do regimento da graduação. A Tabela 23 traz as nomenclaturas utilizadas pelo Sistema para os diversos tipos de encerramento, bem como as notações abreviadas das quais faremos uso no decorrer do texto:

Tabela 23 - Tipos de Encerramento.

\begin{tabular}{|l|l|}
\hline \multicolumn{1}{|c|}{ Denominação do Sistema de Graduação } & \multicolumn{1}{|c|}{ Abreviação } \\
\hline 1. Abandono, $\mathbf{3}$ semestres sem matrícula & $\mathrm{Ab} \mathrm{3} \mathrm{s/} \mathrm{m}$ \\
\hline 2. Cancelamento, menos de 20\% de créditos aprovados & $\mathrm{C}-\mathbf{2 0 \%}$ \\
\hline 3. Cancelamento, trancado por mais de $\mathbf{1 0}$ semestres & $\mathrm{C}$ t $10 \mathrm{sem}$ \\
\hline 4. Cancelamento, trancado por mais de 4 semestres & $\mathrm{C} \mathrm{t} 4$ sem \\
\hline 5. Cancelamento, ultrapassou prazo máximo & $\mathrm{C}$ ult prazo \\
\hline 6. Cancelamento, zero créditos & Canc 0 \\
\hline 7. Conclusão & Concl \\
\hline 8. Desistência a pedido & Desis a ped \\
\hline 9. Encerramento novo ingresso & Enc nv ing \\
\hline 10. Falecimento & Falec \\
\hline 11. Ingresso sem freqüência & Ing s/ freq \\
\hline 12. Transferência externa & T ext \\
\hline 13. Transferência USP & T usp \\
\hline 14. Unificação de programa & Unif de prog \\
\hline
\end{tabular}

Na Tabela 24 podemos observar a distribuição dos 1969 casos analisados por tipo e ano do encerramento:

Tabela 24 - Encerramentos por Tipo (de 1997 a 2010).

\begin{tabular}{|l|r|r|r|r|r|r|r|r|r|r|r|r|r|r|r|}
\hline & 1997 & $\mathbf{1 9 9 8}$ & $\mathbf{1 9 9 9}$ & $\mathbf{2 0 0 0}$ & $\mathbf{2 0 0 1}$ & $\mathbf{2 0 0 2}$ & $\mathbf{2 0 0 3}$ & $\mathbf{2 0 0 4}$ & $\mathbf{2 0 0 5}$ & $\mathbf{2 0 0 6}$ & $\mathbf{2 0 0 7}$ & $\mathbf{2 0 0 8}$ & $\mathbf{2 0 0 9}$ & $\mathbf{2 0 1 0}$ & \\
\hline 1. ab 3 s/ m & 0 & 23 & 38 & 28 & 35 & 17 & 22 & 22 & 8 & 11 & 16 & 11 & 16 & 10 & 257 \\
\hline 2. c t 10 sem & 0 & 0 & 1 & 1 & 5 & 9 & 18 & 6 & 11 & 2 & 1 & 1 & 0 & 1 & 56 \\
\hline 3. c t 4 sem & 0 & 0 & 0 & 0 & 0 & 0 & 10 & 9 & 7 & 6 & 5 & 7 & 8 & 9 & 61 \\
\hline 4. c ultr prazo & 0 & 0 & 0 & 0 & 0 & 1 & 0 & 1 & 0 & 0 & 0 & 0 & 0 & 5 & 7 \\
\hline 5. c-20\% & 9 & 16 & 16 & 15 & 7 & 19 & 0 & 4 & 3 & 4 & 0 & 0 & 0 & 0 & 93 \\
\hline 6. canc 0 & 4 & 15 & 3 & 11 & 10 & 7 & 14 & 20 & 17 & 27 & 26 & 15 & 25 & 29 & 223 \\
\hline 7. concl & 13 & 26 & 33 & 47 & 63 & 51 & 62 & 58 & 79 & 61 & 63 & 82 & 67 & 74 & 779 \\
\hline 8. desis a ped & 1 & 3 & 7 & 2 & 0 & 9 & 2 & 5 & 5 & 5 & 13 & 2 & 9 & 6 & 69 \\
\hline 9. enc nv ing & 3 & 7 & 4 & 3 & 4 & 6 & 3 & 2 & 4 & 3 & 7 & 3 & 6 & 6 & 61 \\
\hline 10. falecimento & 0 & 0 & 0 & 1 & 0 & 0 & 0 & 0 & 0 & 0 & 0 & 0 & 0 & 0 & 1 \\
\hline 11. ing s/ freq & 0 & 10 & 14 & 9 & 9 & 11 & 9 & 6 & 11 & 8 & 22 & 14 & 16 & 14 & 153 \\
\hline 12. t ext & 0 & 1 & 1 & 1 & 1 & 1 & 0 & 0 & 0 & 0 & 1 & 0 & 0 & 0 & 6 \\
\hline 13. t usp & 5 & 10 & 16 & 16 & 13 & 14 & 18 & 11 & 8 & 16 & 20 & 19 & 17 & 19 & 202 \\
\hline 14. unif de prog & 0 & 0 & 1 & 0 & 0 & 0 & 0 & 0 & 0 & 0 & 0 & 0 & 0 & 0 & 1 \\
\hline
\end{tabular}


Esses mesmos resultados podem ser visualizados nos Gráfico 18 e 19, onde são apresentados os casos de encerramento por tipo, em número absoluto e distribuição percentual.

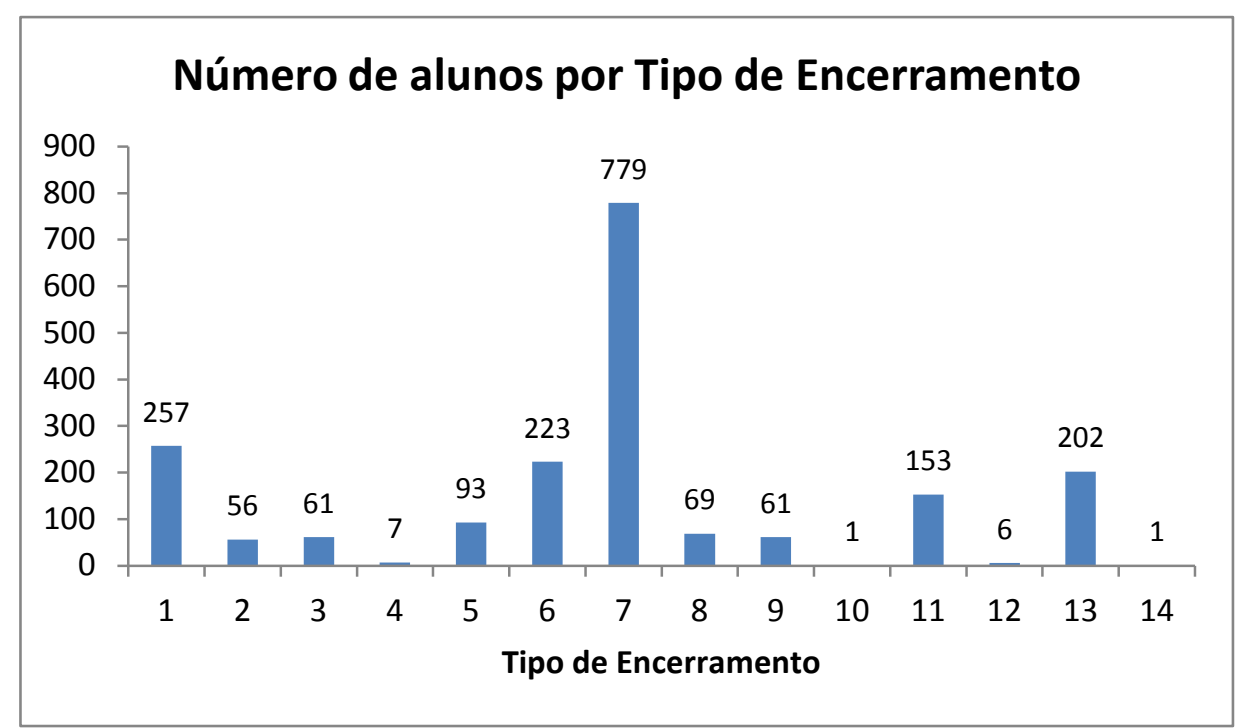

Gráfico 18 - Alunos por tipo de encerramento, segundo classificação da Tabela 22 (absoluto).

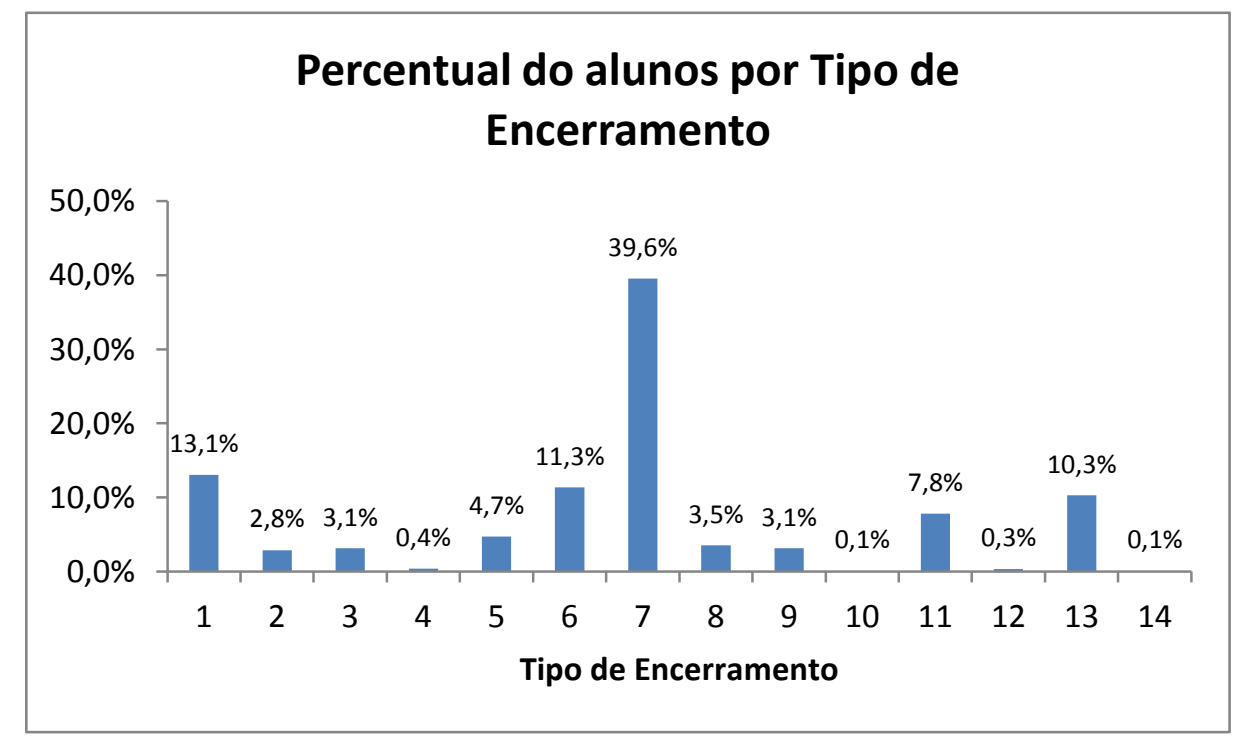

Gráfico 19 - Alunos por tipo de encerramento, segundo classificação da Tabela 22 (percentual). 
Apesar da predominância do número de concluintes, é preciso analisar que todos os demais tipos de encerramento somados superam esse valor, como mostrado no Gráfico 18, e equivalem quase que totalmente ao que poderíamos chamar de abandono do curso.

Assim, para desenhar um panorama mais direto com relação à "evasão", buscando verificar de que forma associá-la ao abandono, foi feito um reagrupamento dos tipos de encerramento (excluídos os concluintes) em dois grupos denominados e classificados como:

Abandono $=$ Abandono, 3 semestres sem matrícula + Cancelamento, menos de 20\% de créditos aprovados + Cancelamento, trancado por mais de 10 semestres + Cancelamento, trancado por mais de 4 semestres + Cancelamento, ultrapassou o prazo máximo + Desistência a pedido + Cancelamento, zero créditos Esses encerramentos correspondem às linhas 1 a 6 e 8, apresentadas na Tabela 24.

Interrupção = Transferência externa + Transferência USP. + Ingresso sem freqüência + Encerramento novo ingresso.+ Falecimento + Unificação de programa. Esses encerramentos corrrespondem às linhas 9 a 14, apresentadas na Tabela 24.

O primeiro grupo (Abandono), expressa o número de alunos que desistiu durante o percurso, em algum semestre, independente do número de créditos já cursados. As razões de encerramento possivelmente podem estar relacionadas às dificuldades com freqüência ao curso ou aprovação nas disciplinas, sendo que a maior parte dos mesmos (excluída o encerramento a pedidos) tem sua origem nas regras regimentais do sistema de graduação.

No segundo grupo (Interrupção), estão os alunos que optaram pela transferência para outros cursos, ou seja, não abandonaram a universidade propriamente, mas se recolocaram em outras perspectivas. Quase a totalidade destes casos (97\%) acumulou algum crédito na licenciatura antes de sua transferência, o que indica que apesar de não terem desistido da universidade, de certa forma, desistiram de prosseguir especialmente no curso de Licenciatura em Física. Inclui também os encerramentos sem freqüência, em que os alunos praticamente não cursaram a licenciatura, além de outros motivos independentes do desempenho dos alunos 
Cabe aqui, uma consideração importante a respeito de alunos que abandonaram o curso sem que tenha havia acúmulo de crédito. Embora o Sistema tenha uma classificação específica chamada "cancelamento, zero créditos", é possível verificar que apenas 11 do total de 223 casos assim classificados (5\%), de fato, têm zero créditos acumulados. Isso ocorre, geralmente, quando há reingressos por vestibular de alunos que solicitam aproveitamento de estudos, mas que, por um motivo ou por outro, deixam de acumular créditos por dois semestres seguidos, quando então o Sistema faz seu encerramento e o classifica como: "encerramento, zero crédito", mas apresenta seus créditos anteriormente acumulados. Na verdade, os 173 casos de alunos com zero créditos acumulados (9\% dos 1969 analisados) estão distribuídos em 9 dos tipos de encerramentos, sendo 96 (55\%) sob a classificação: "ingresso sem frequência". Aliás, cerca de $60 \%$ dos "ingresso sem frequência" são de alunos com zero créditos acumulados. Tais casos representam aqueles que não chegaram a começar o curso, o que, em outros trabalhos, tem sido denominado de evasão branca. Ou seja, são alunos que não obtiveram qualquer crédito em alguma disciplina, ou nem mesmo obtiveram freqüência nos dois primeiros semestres do curso, como é exigido. $A$ Tabela 25 traz os 173 casos aqui discutidos:

Tabela 25 - Distribuição nos diferentes Tipos de Encerramento de alunos com acúmulo de zero créditos cursados.

\begin{tabular}{|l|c|}
\hline \multicolumn{1}{|c|}{ Tipo de Encerramento } & $\begin{array}{c}\text { No de alunos com zero } \\
\text { créditos acumulados }\end{array}$ \\
\hline Abandono, 3 semestres sem matrícula & 32 \\
\hline Cancelamento, trancado por mais de 10 semestres & 2 \\
\hline Cancelamento, trancado por mais de 4 semestres & 1 \\
\hline Cancelamento, zero créditos & 11 \\
\hline Desistência a pedido & 13 \\
\hline Encerramento novo ingresso & 11 \\
\hline Ingresso sem freqüência & 96 \\
\hline Transferência USP & 6 \\
\hline Unificação de programa & 1 \\
\hline
\end{tabular}

Devido à dispersão na forma em que aparecem distribuídos esses alunos, resolvemos por bem, manter a classificação acima denominada Abandono, incluindo os tipos que, aparentemente, poderiam representar uma desistência inicial, mas que não se revelam 
como tal numa análise mais cuidadosa. São eles: "encerramento, novo ingresso", ingresso sem frequência" e "cancelamento, zero créditos".

Com essas especificações e considerações, é possível reformular a Tabela 25, de forma mais simplificada, tal como apresentado na Tabela 26.

Tabela 26 - Encerramentos por agrupamento de tipos (de 1997 a 2010).

\begin{tabular}{|l|r|r|r|r|r|r|r|r|r|r|r|r|r|r|r|}
\hline & $\mathbf{1 9 9 7}$ & $\mathbf{1 9 9 8}$ & $\mathbf{1 9 9 9}$ & $\mathbf{2 0 0 0}$ & $\mathbf{2 0 0 1}$ & $\mathbf{2 0 0 2}$ & $\mathbf{2 0 0 3}$ & $\mathbf{2 0 0 4}$ & $\mathbf{2 0 0 5}$ & $\mathbf{2 0 0 6}$ & $\mathbf{2 0 0 7}$ & $\mathbf{2 0 0 8}$ & $\mathbf{2 0 0 9}$ & $\mathbf{2 0 1 0}$ & \\
\hline Abandono & 14 & 57 & 65 & 57 & 57 & 53 & 56 & 67 & 51 & 55 & 61 & 36 & 58 & 60 & 766 \\
\hline Conclusão & 13 & 26 & 33 & 47 & 63 & 51 & 62 & 58 & 79 & 61 & 63 & 82 & 67 & 74 & 779 \\
\hline Interrupção & 8 & 28 & 36 & 30 & 27 & 32 & 30 & 19 & 23 & 27 & 50 & 36 & 39 & 39 & 424 \\
\hline
\end{tabular}

Da mesma forma, os valores cumulativos nesse período para os dois grupos podem ser expressos como na Tabela 27:

Tabela 27 - Número de encerramentos classificados em dois grupos principais (sem concluintes).

\begin{tabular}{|c|c|c|}
\hline TIPO DE ENCERRAMENTO & Número de alunos & Taxa \\
\hline Abandono & 766 & $64 \%$ \\
\hline Interrupções & 424 & $36 \%$ \\
\hline Total & 1190 & $100 \%$ \\
\hline
\end{tabular}

Esses mesmos dados podem ser também analisados incluindo-se os concluintes, ou seja, em função do total de encerramentos, tal como apresentado na Tabela 28:

Tabela 28 - Número de encerramentos classificados em dois grupos tipos principais (com concluintes).

\begin{tabular}{|c|c|c|}
\hline TIPO DE ENCERRAMENTO & Número de alunos & Taxa \\
\hline Abandono & 766 & $39 \%$ \\
\hline Interrupções & 424 & $21 \%$ \\
\hline Concluintes & 779 & $40 \%$ \\
\hline & 1969 & $100 \%$ \\
\hline
\end{tabular}

Esses últimos resultados deverão merecer, com certeza, uma análise mais detalhada. No entanto, na perspectiva em que foram aqui sistematizados, verifica-se que a evasão decorrente de não acompanhamento do curso, que denominamos de abandono, 
corresponde a $82 \%$ de todas as desistências ou razões de encerramento. Essas, talvez, devam ser consideradas como as evasões cujos motivos precisam ser investigados em função do momento ou semestre em que ocorreram e, talvez, possam ser atribuídas de fato às dificuldades com o curso. Em termos absolutos, considerando-se apenas os concluintes e os encerramentos por abandono, esses últimos representariam $56 \%$ do total, frente aos $44 \%$ de concluintes.

Por outro lado, foi possível constatar que uma parte expressiva dos desligamentos não pode ser considerada simplesmente como evasão - que são as transferências - pois, corresponde a alunos que optaram por outros percursos formativos. Excluídos os concluintes, tal taxa é de $17 \%$ e, na totalidade de encerramentos o percentual é de $10 \%$. As razões para esses desligamentos podem não depender das dificuldades ao longo das disciplinas, mas de opções individuais relacionadas à suas estórias pessoais. Isto de certa forma estaria independente da proposta e estrutura curricular. Esses mesmos aspectos foram identificados em diferentes cursos da universidade.

\section{Um outro olhar sobre as conclusões}

Como vimos, ainda que consideremos as estimativas para um regime de fluxo contínuo, podem ser inferidas diferentes taxas de evasão, especialmente considerando a questão no tipo de ingressso e do tempo de permanência no curso. Levando em conta alguns desses aspectos já mencionados (que por um lado facilitam as análises e por outro limitam as conclusões) teríamos, de modo geral, uma taxa de $40 \%$ de conclusões e $60 \%$ de evasão. De outro ponto de vista, considerando apenas o fluxo em função do número de vagas, a evasão média se situa em torno $40 \%$ de evasão.

Essa aparente diversidade de índices reflete diferentes perspectivas que requerem uma análise mais detalhada. Uma primeira tentativa nesse sentido pode ser obtida a partir dos dados fornecidos pelo Sistema de Graduação, considerando as taxas de conclusão, tal que sejam levados em conta o ano e o tipo de ingresso além da possibilidade efetiva, de que o curso possa ter sido integralizado. Um estudo/ensaio dessa natureza é apresentado no 
Anexo $\mathrm{E}$, (Considerações sobre o número de concluintes em função da forma e ano de ingresso), sendo que essas considerações não modificam, de forma geral, as conclusões aqui apresentadas.

\subsection{Conclusões Preliminares}

Os dados analisados apontam para a expressiva contribuição da implementação do Curso de Licenciatura, como carreira própria desde o ingresso, na formação de um significativo contingente de professores de Física. Esse resultado suplanta, em muito, aqueles que vinham sendo obtidos antes da reforma curricular, no início da década de 90, quando o número de licenciandos que concluíam o curso, por ano, era inferior a uma dezena.

O número de concluintes, atualmente, pode ser estimado como oscilando em torno de 70 licenciandos por ano, o que pode ser considerado bastante expressivo no cenário nacional.

A partir da análise realizada é possível concluir, também, que nem o semestre de conclusão nem o turno (diurno/noturno) são parâmetros significativos para as questões de evasão. Para ambos os turnos, entretanto, o curso é completado em um período muito acima do idealizado pela estrutura curricular, sendo esse um possível indicador de eventuais problemas enfrentados pelos alunos.

Esses dados demonstram, ao mesmo tempo, que a evasão ainda continua expressiva, requerendo uma atenção mais detalhada, buscando-se identificar as possíveis adequações da estrutura curricular e do projeto pedagógico do Curso de Licenciatura às demandas de seus alunos, no sentido de contribuir para superá-la.

No entanto, a evasão observada na licenciatura é inferior aos resultados que vêm sendo obtidos no Curso de Bacharelado do IFUSP, nesse mesmo período. Segundo estudos (Souza, Salem e Kawamura, 2009), no período entre 1997 e 2006, enquanto o percentual de 
concluintes e de abandono na licenciatura correspondiam, respectivamente a $37 \%$ e $30 \%$, no bacharelado correspondiam a 30\% e 35\%.

Como já foi observado, esses valores são difíceis de serem comparados com outros índices de outros trabalhos. No caso de estudo realizado pela Pró-Reitoria de Graduação da USP em 2004, os valores médios da evasão apresentados para a universidade de um modo geral caem de 32\% para 22\%, quando se compara ingressantes em 1995 e 1998, o que dificulta uma comparação por dois motivos: em primeiro lugar pela própria definição atribuída e correspondente cálculo de evasão, e em segundo lugar pelo período analisado. Tais resultados requerem, portanto, que se recoloque o problema da evasão na nossa licenciatura em uma perspectiva mais ampla.

Da mesma forma, foram também identificados problemas relacionados às dificuldades de análise dos vários tipos de encerramentos. Em uma primeira aproximação, procurou-se agrupá-los em dois grandes conjuntos, denominados de Abandono e Interrupção.

A distinção entre esses dois conjuntos pode vir a ser um indicativo importante, na medida em que procura distinguir razões mais estruturais daquelas conjunturais. Assim, ao primeiro grupo podem estar associadas razões de evasão mais diretamente relacionadas à estrutura curricular e às dificuldades de percurso dos alunos no curso, razões que poderiam ser classificadas como internas ao curso e estruturais.

Já no segundo grupo, estariam reunidas motivações para não conclusão que seriam de ordem mais diretamente relacionadas a aspectos individuais ou conjunturais, ou razões externas ao curso. Razões que provavelmente tem raízes fora do âmbito da estrutura curricular e não dependeriam tão fortemente de propostas e modificações do próprio curso. Isso inclui transferências (quando o aluno não se evade, mas escolhe outro curso, em função de opções muito pessoais), ingresso sem frequência (quando o aluno nem chega a cursar), falecimento, ou novo ingresso, o que também não pode ser considerado como evasão no estrito senso. 
Nesse quadro, do total de encerramentos sem conclusão, 64\% poderiam ser atribuídos às questões que envolvem mais diretamente a estrutura e proposta do curso. Os demais, incluindo desistências e transferências, que extrapolam o âmbito interno do curso, apontam para possíveis motivações e características igualmente mais gerais.

Assim, a questão da não conclusão do curso por um número grande de alunos passa a assumir duas dimensões diferentes, uma mais local e outra mais geral, cada uma das quais deverá exigir uma forma de abordagem e aprofundamento próprios no futuro.

Seja através de um olhar ou através de outro, fica evidente que a desistência ou a não conclusão são suficientemente expressivas para fazer parte da própria identidade do curso. Os alunos têm consciência desses aspectos, na medida em que envolvem diretamente seus colegas de curso.

Esses resultados reforçam o potencial e a necessidade de um contínuo acompanhamento do curso, mediante os mais diversos indicadores, com o objetivo de garantir seu aprimoramento e a realização dos objetivos para os quais foi planejado. No entanto, podem indicar também que as causas de evasão vão além do curso, envolvendo possíveis percepções das perspectivas profissionais futuras, eventualmente relacionadas à valorização social do professor e da carreira docente.

Como outro desdobramento da análise, entendemos que seja igualmente importante reunir e sistematizar diferentes investigações, metodologias de pesquisa, definições e interpretações atribuídas à evasão de cursos superiores, de modo a possibilitar estudos comparados, agregar resultados e reflexões sobre essa problemática, comum a inúmeras instituições e, particularmente, a cursos de formação inicial de professores. 


\section{CAPÍTULO 7-O LICENCIANDO EM (PER)CURSO}

Uma vez estruturados pontos relevantes que caracterizam o ingressante e o egresso da Licenciatura em Física, faz-se necessária, então, a análise de como se dá a evolução deste licenciando durante o curso, considerando as especificidades de sua trajetória e as transformações por que passam(ram) suas expectativas com relação à carreira escolhida, procurando entender em que medida as representações de ciência, educação e perfil profissional evoluem(íram) ou não.

Este capítulo pretende apresentar duas abordagens para a compreensão das características desse licenciando em percurso. A primeira, envolve a escolha de uma amostra limitada, correspondente aos alunos ingressantes em um ano específico - turma de 2002 ,confrontando a análise cuidadosa de informações obtidas nos questionários de ingresso com seus históricos escolares individuais, ao longo do curso. Com isso, pretendemos investigar, entre outros aspectos, de que forma suas expectativas no momento da matrícula repercutem sobre suas trajetórias no curso. A segunda abordagem envolve um instantâneo do curso hoje, analisando grupos de alunos em dois diferentes momentos curso. Para isso, foi realizada a aplicação de um questionário a alunos (independentemente do ano de ingresso), com vistas a verificar, sobretudo, as intenções desses licenciandos com relação ao seguimento (ou não) na carreira docente, considerando particularidades de seu percurso, assim como possíveis transformações de suas idéias.

Acreditamos que a partir de tais abordagens seja possível confrontar/comparar os dados aqui obtidos com aqueles já sistematizados no Capítulo 5, no qual temos as expectativas de ingresso, e no Capítulo 6 que apresenta o panorama da evasão e dos concluintes em um período de catorze anos (1997-2010). 


\subsection{O percurso de uma turma: ingressantes em 2002}

A escolha pela turma de 2002 se justifica por ser um ano cujos ingressantes já estão na sua totalidade (com poucas exceções) com o curso encerrado - seja por conclusão, abandono ou transferência.

O objetivo de acompanhar a trajetória desta turma específica é buscar possíveis correlações sobre as características manifestas no ingresso e as trajetórias no curso. Para isso, buscamos confrontar as respostas aos questionários de matrícula (particularmente suas ideias sobre a Física, sobre ser professor e sobre suas expectativas profissionais) e os dados fornecidos pela análise do histórico/currículo de cada um, peculiaridades desses alunos (como, por exemplo, tempo para conclusão e casos de abandono) de modo a poder traçar e/ou estabelecer parâmetros para um perfil característico dos licenciandos em física do IFUSP.

No ato da matrícula os alunos são convidados a preencher um questionário de quatro páginas, dividido em cinco seções: dados pessoais, vestibular, opção profissional, conhecimentos de física e outros comentários. O Capítulo 5 traz uma discussão baseada na análise de seis questões ( 5 da terceira seção e 1 da quarta seção) a partir da qual foram estabelecidas 3 categorias que procuraram - apesar das adversidades circunstanciais agrupar os alunos segundo suas aparentes intenções quando da escolha pelo curso. Isto é, a leitura do conjunto das respostas revelou aspectos importantes das representações sociais trazidas por esses ingressantes que possibilitam a evidência de três justificativas para a escolha feita: 1) Desejo de tornar-se professor de Física; 2) Necessidade de aprimoramento nos conhecimentos da área de Física; 3) Possibilidade e/ou facilidade de obtenção de emprego e ascensão profissional.

Dispomos de 100 questionários de alunos ingressantes em 2002, incluindo matriculados no diurno e noturno. A maior parte deles (78\%) retificou sua matrícula e, portanto, compõe a lista de Encerramentos gerada pelo Sistema de matrícula, como ingressantes via vestibular. 
Conforme apresentado no Capítulo 6 (tabela 6) as listas de Encerramentos geradas pelo Sistema Júpiter totalizam 138 alunos ingressantes em 2002 que encerraram o curso (por conclusão ou abandono) até o 2o semestre de 2010. Dentre estes há aqueles que ingressaram via vestibular, graduados ou por transferência.

Partimos da amostra inicial de 100 alunos, cujas aparentes expectativas de ingresso são conhecidas.

Como o preenchimento do questionário acima citado ocorre somente pelos ingressantes por vestibular, a amostra para esta análise específica sofreu uma redução. A saber, dos 100 alunos que preencheram o questionário de matrícula, 78 constam nas listas de encerramento do IFUSP (geradas pelo Sistema Júpiter), porém 1 deles entregou o questionário com as seções 3, 4 e 5 em branco. E, os 22 restantes não aparecem nas listas de encerramento IFUSP, mas, em alguns casos, foi possível acessar informações a partir de seu histórico escolar.

\subsubsection{Confrontando expectativas e percurso}

A intenção aqui é verificar se há (e qual é a) correlação entre as expectativas dos alunos na época da matrícula e as características de seu percurso e caráter de encerramento.

Assim, dos 99 alunos, conforme tabela 29, 37\% concluíram o curso; $48 \%$ não concluíram (por abandono ou transferência) e 15\% estão ativos no curso ou não se conhece informações sobre sua atual situação (Outros). Das conclusões, vale destacar que cerca de 10\% (4 alunos) cursou a Licenciatura em Matemática e, dentre os ativos, 10\% (1 caso) é aluno do IME-USP.

Tabela 29 - Percentual por Tipo de Encerramento dos ingressantes 2002.

\begin{tabular}{|c|c|}
\hline Tipo de encerramento & Percentual \\
\hline Conclusão & $\mathbf{3 7 \%}$ \\
\hline Evasão & $\mathbf{4 8 \%}$ \\
\hline Outros & $15 \%$ \\
\hline
\end{tabular}


Tais índices revelam para essa amostra específica - mas significativa - que a taxa de conclusão é menor que a encontrada e discutida no Capítulo 6 (cerca de 40\%). Porém, considerando que parte dos alunos desta amostra (6 casos), não fez a retificação de matrícula e, assim, não efetivou o vínculo ao curso, além daqueles que ainda permanecem ativos (9 alunos em curso), chegamos a uma taxa de conclusão de 37 em 84, o que resulta em aproximadamente $44 \%$.

Se desejarmos considerar apenas os alunos que preencheram o questionário de matrícula e que efetivaram seu vínculo ao curso de Licenciatura em Física, isto é, aqueles que constam nas listas de Encerramento geradas pelo Sistema Júpiter do IFUSP Licenciatura, obtemos o índice de $43 \%$ para conclusões e $67 \%$ para evasão (abandono, transferência e outros). Ou seja, neste caso, podemos dizer que os resultados para esta amostra (de um ano específico) concordam com aqueles obtidos para um número maior de alunos (em um período de catorze anos).

Conhecidos os índices correspondentes a concluintes e não concluintes, podemos partir para a tentativa de estabelecer uma (co)relação entre as expectativas de início de curso e as particularidades de sua trajetória na graduação.

A tabela 30 apresenta os dados referentes aos ingressantes 2002, segundo suas intenções no ingresso e sua situação de encerramento do curso.

Tabela 30 - Intenções no ingresso e Tipo de Encerramento - Ingressantes 2002.

\begin{tabular}{|c|c|c|c|c|}
\hline \multicolumn{5}{|c|}{ Ingressantes 2002 } \\
\hline Conclusões & Ser professor & Aperfeiçoamento & Mercado de & Total \\
\hline Evasão & 29 & 5 & 3 & 37 \\
\hline Outros & 29 & 15 & 3 & 47 \\
\hline Total & 9 & 4 & 2 & 15 \\
\hline
\end{tabular}

Por um lado, podemos considerar a expectativa do ingressante e analisar o percentual daqueles que concluíram e daqueles que não concluíram o curso. É o que nos permite fazer os dados apresentados no gráfico 20, abaixo: 


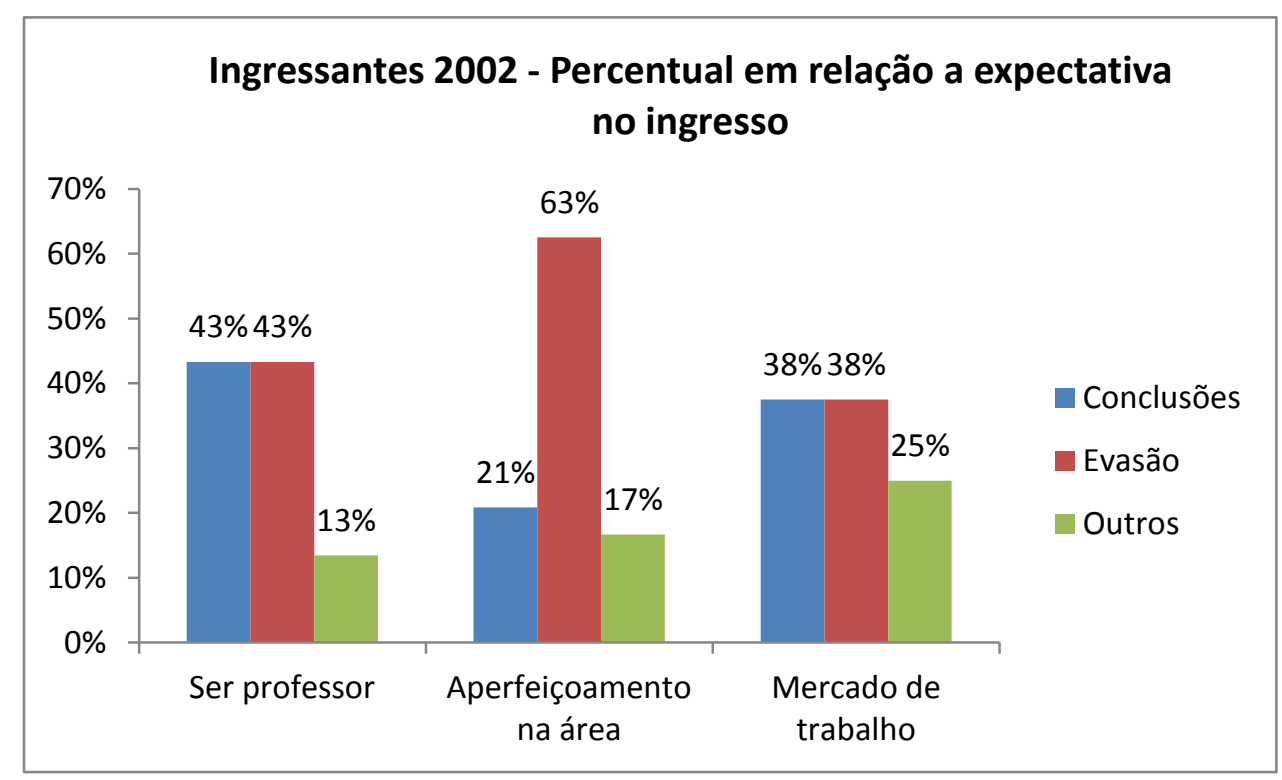

Gráfico 20 - Percentual de Concluintes e Não-concluintes segundo os grupos de expectativa profissional - Ingressantes 2002.

O gráfico 20 nos mostra o percentual de concluintes e de não-concluintes dentre o total de alunos classificados segundo os grupos de expectativas na carreira profissional. Ou seja, vemos que dentre aqueles que declararam (no ingresso) a pretensão primeira de tornar-se professor, $43 \%$ concluíram o curso e um percentual exatamente igual, $43 \%$, evadiu-se do curso. Isso mostra, portanto, que o fato de um ingressante de um curso de licenciatura em Física declarar que pretende formar-se professor não implica que terá maior sucesso no encaminhamento e conclusão do curso.

Algo semelhante ocorre quando consideramos os ingressantes que parecem ter escolhido o curso objetivando, prioritariamente, a entrada no mercado de trabalho. Isto é, $\mathbf{3 8 \%}$ concluíram e $\mathbf{3 8 \%}$ evadiram-se do curso, indicando novamente que sua intenção na escolha e ingresso não está, necessariamente, co-relacionada à sua trajetória na graduação.

Porém, há que se destacar que, dentre aqueles que tinham como objetivo principal de ingresso na licenciatura em Física, seu aperfeiçoamento na área, um percentual consideravelmente alto, quase $2 / 3$, evadiu-se do curso. Neste caso, a natureza do curso pode ter sido fator determinante, ou seja, o curso de licenciatura não atendeu às 
expectativas destes alunos que parecem ter um perfil mais próximo daqueles que buscam o curso de bacharelado.

Porém, calculado sobre o total de alunos - e não mais sobre o total por expectativa - os percentuais de concluintes e não concluintes ficam assim determinados (Gráfico 21):

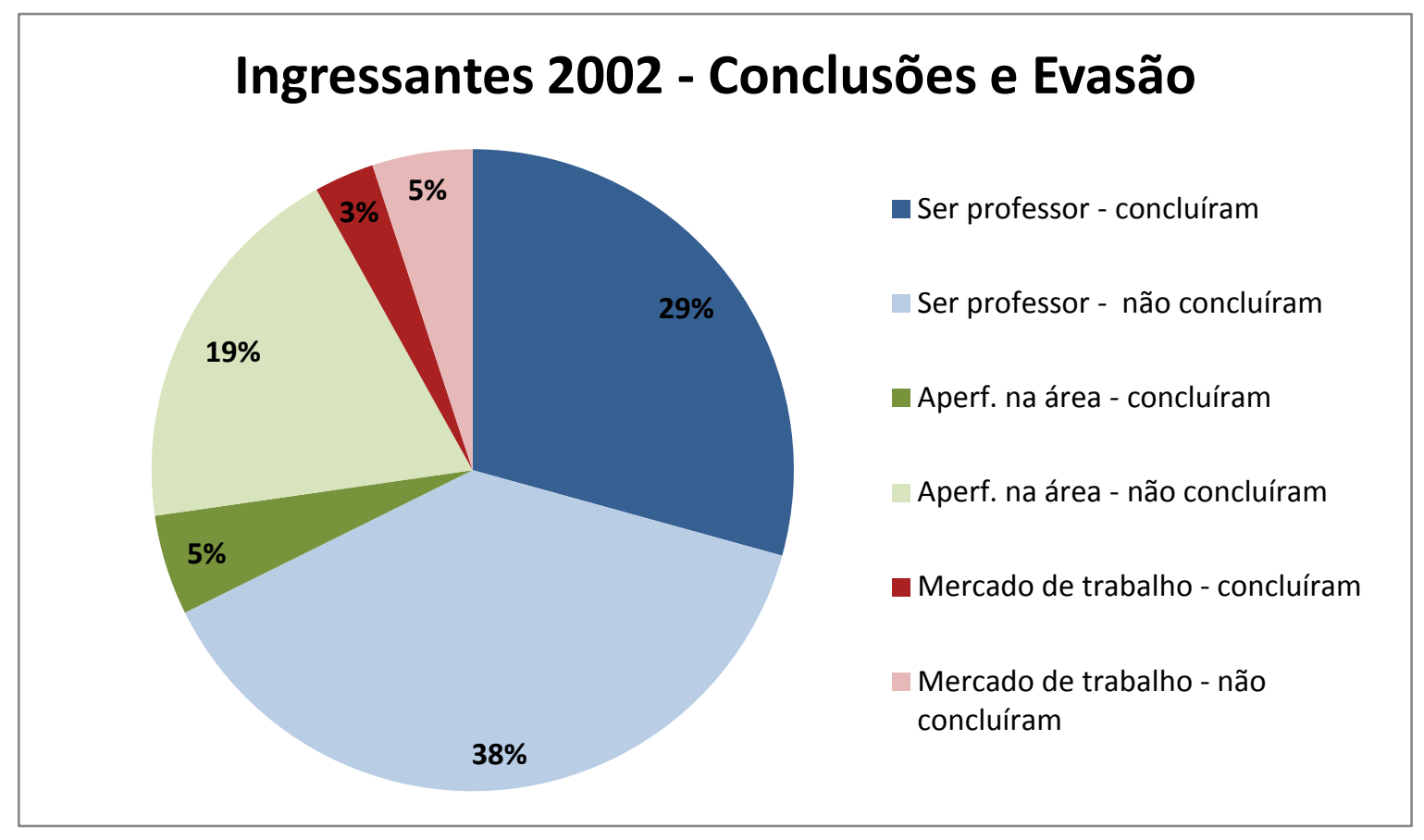

Gráfico 21 - Percentual de Conclusão e Evasão - Ingressantes 2002.

Deste modo, podemos notar que, embora o percentual daqueles que concluíram o curso seja sempre menor que o de não-concluintes em cada uma das categorias, é evidente que a taxa dos concluintes que desejavam ser professor - $\mathbf{2 9 \%}$ - é bastante superior às demais: aperfeiçoamento na área $(\mathbf{5 \%})$ e mercado de trabalho (3\%). Portanto, a intenção/objetivo/expectativa por trás da escolha e ingresso no curso ainda que não possa ser considerada fator determinante em termos da trajetória que este aluno virá a ter, pode ao menos indicar uma maior ou menor probabilidade em termos do tipo de encerramento. Ou melhor, os dados mostram que o percentual dos alunos que concluem o curso, tendo ingressado com a intenção de tornar-se professor é maior do que os percentuais correspondentes às outras intenções. 
Por outro lado, podemos considerar o tipo de encerramento (concluintes ou não concluintes) e analisar a expectativa que tais alunos tinham no ingresso. Vejamos o gráfico 22:

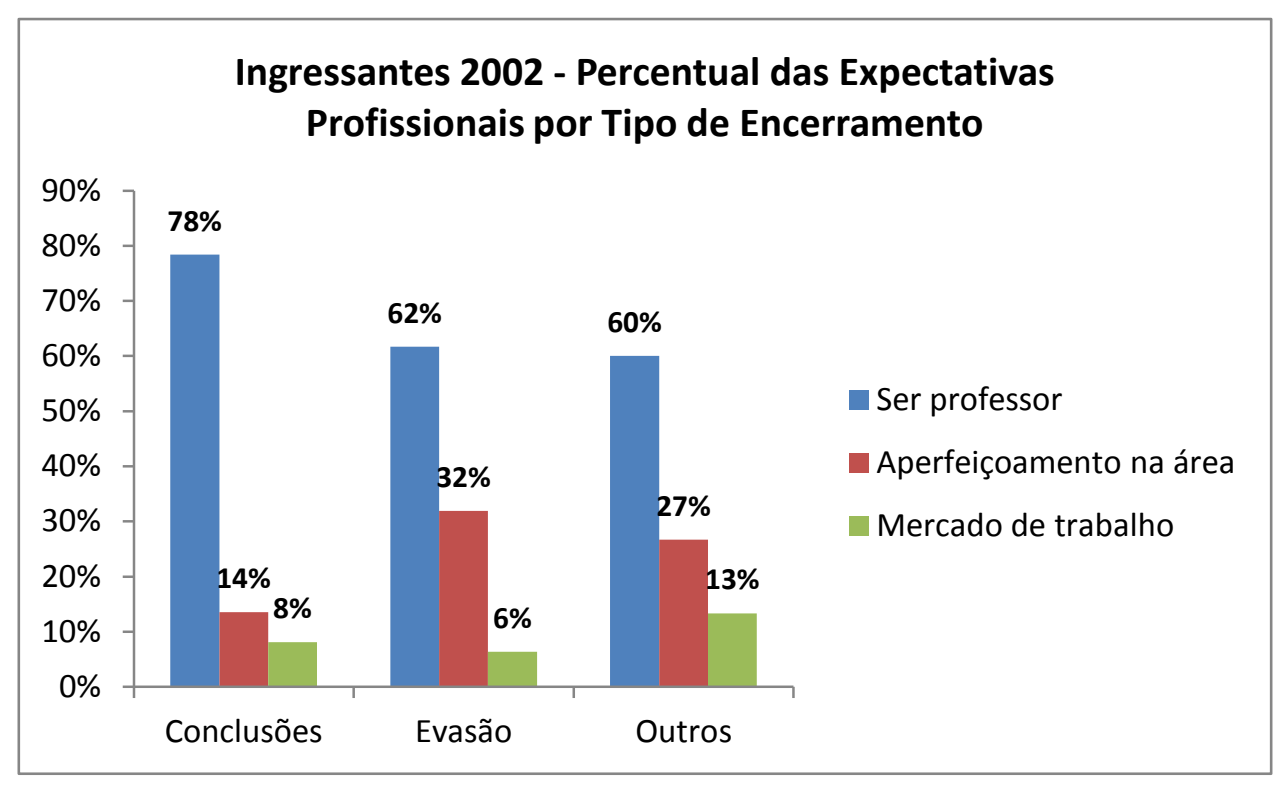

Gráfico 22 - Percentual das Expectativas profissionais por Tipo de Encerramento.

Olhando desta forma, vemos que, quase $80 \%$ dentre aqueles que tinham como expectativa de ingresso tornar-se professor chegaram a concluir o curso. Ainda assim, o percentual dentre os evadidos que também ingressaram com a intenção de formar-se professor é bastante alto, $60 \%$. Por isso, novamente, não podemos afirmar que a intenção por trás da escolha e ingresso no curso, por si só determina a provável trajetória deste aluno na graduação.

\subsubsection{Caracterizando evasão e percurso}

Também é possível verificar se há alguma (co)relação entre o número de créditos acumulados pelos alunos que não concluíram o curso e a sua aparente expectativa de ingresso no curso a respeito da carreira profissional. 
Com base no número máximo de créditos acumulados por alunos evadidos criamos três faixas para agrupar os elementos da amostra com a intenção de verificar alguma correlação entre os dados. O maior número de créditos acumulados por um não-concluinte foi 120 , o que equivale a quase $70 \%$ dos créditos necessários (172) para a conclusão do curso. Divididas igualmente, as faixas ficaram assim estabelecidas: $\mathbf{0}$ a $\mathbf{4 0}$ créditos; $\mathbf{4 1}$ a $\mathbf{8 0}$ créditos e 81 a 120 créditos.

O gráfico 23 abaixo mostra que 64\% dos não-concluintes encerraram o curso tendo acumulado de $\mathbf{0}$ a $\mathbf{4 0}$ créditos, ou seja, cursaram o equivalente a menos de dois semestres. Há um índice de $\mathbf{2 5 \%}$ de alunos que encerraram o curso sem concluí-lo acumulando de $\mathbf{4 1}$ a 80 créditos-aula, o que indica que 1 em cada 4 dos evadidos chegaram a cursar de $24 \%$ a 47\%. E ainda temos $11 \%$ de alunos que abandonaram o curso apesar de já terem cursado de 47\% a 70\% dos créditos necessários para a conclusão (de 81 a 120).

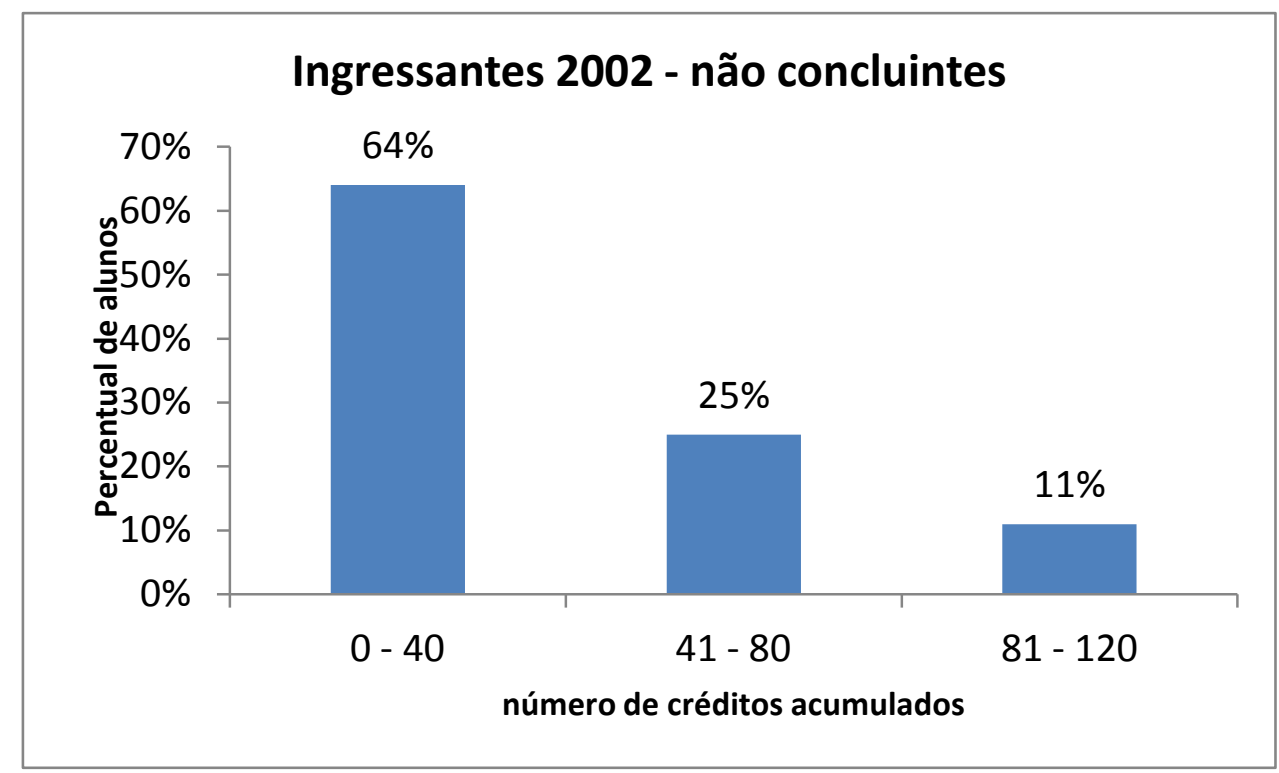

Gráfico 23 - Créditos acumulados por não-concluintes (Ingressantes 2002).

Analisando segundo as expectativas de ingresso, os percentuais relativos a créditos acumulados dos alunos que não concluíram o curso, apresentam-se como visto no Gráfico 24: 


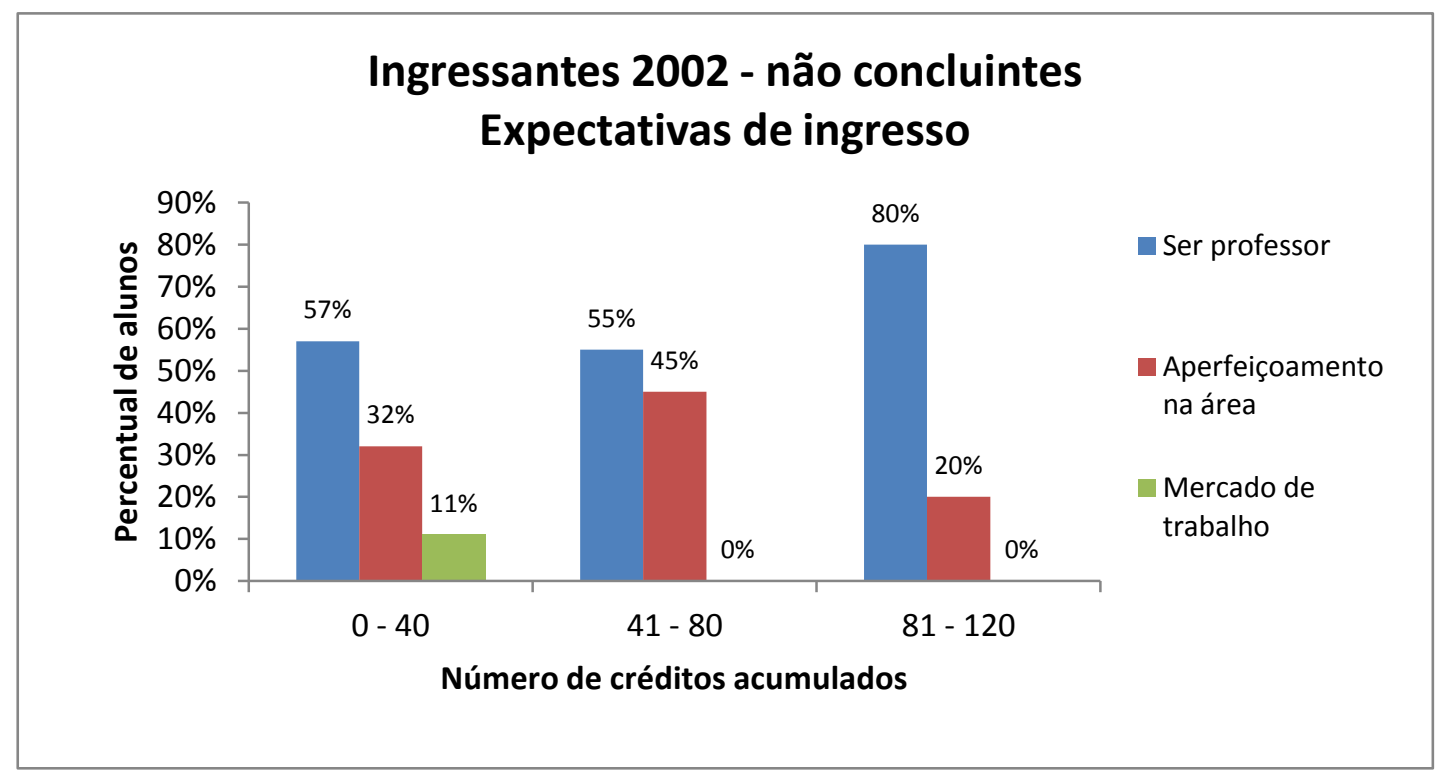

Gráfico 24 - Expectativas profissionais de não-concluintes e o número de créditos acumulados (Ingressantes 2002).

Para todas as faixas, o percentual daqueles que ingressaram com a intenção de Ser Professor, é sempre maior do que para as outras duas expectativas consideradas. Dentre os que cursaram até 80 créditos (cerca de $47 \%$ dos créditos necessários para conclusão) e se evadiram do curso, esse percentual é, em média, de $56 \%$. Já dentre os que desistiram do curso tendo acumulado em torno de $50 \%$ a $70 \%$ dos créditos necessários para aprovação, esse índice é bastante alto: $80 \%$.

Observando os percentuais referentes aos alunos desistentes que ingressaram com a intenção primeira de aperfeiçoamento na área, vemos que tal taxa é maior dentre aqueles que cursaram de $24 \%$ a $47 \%$ dos créditos necessários para a conclusão.

Talvez seja interessante perceber que, dentre os que acumularam mais créditos até o abandono, não há representação de alunos que tenham ingressado no curso com vistas a facilidade de entrada no mercado de trabalho. 


\subsection{Alunos hoje em percurso - transformações em curso}

Como já introduzido, para esta abordagem, optamos pelo uso de um mesmo questionário $^{31}$, aplicado a dois grupos diferentes de alunos: em turmas que estão na primeira metade do curso e turmas que estão no final do curso. Isso correspondeu a alunos das disciplinas de Eletricidade II (4o semestre) e Complementos de Mecânica (8이으ํ semestres). Trata-se de verificar a existência ou não de modificações nas respostas - que além de informações de caracterização, traz mais sete perguntas (de caráter objetivo e discursivo), especialmente relacionadas às expectativas iniciais, atuais e futuras deste licenciando.

O questionário aplicado é composto de questões objetivas e discursivas. A parte inicial traz um quadro que procura caracterizar o perfil do licenciando a partir de informações como o período em que estuda, ano e forma de ingresso, tipo de escola em que cursou o nível médio, escolaridade do pai e atividade profissional.

Em seguida são apresentadas seis questões, sendo a primeira e a última do tipo objetiva e as demais discursivas com o objetivo de investigar mais diretamente as ideias, concepções e expectativas dos licenciandos em relação ao curso escolhido.

A primeira, pergunta ao aluno sobre sua principal motivação quando do ingresso na Licenciatura em Física, como por exemplo: ser professor; fazer pesquisa em Física; facilitar a entrada no mercado de trabalho entre outras. Muito embora saibamos que a resposta a tal pergunta certamente carrega ideias, concepções e inúmeras influências que a distancia de alguma forma daquela que seria (ou foi) dada na época da matrícula, acreditamos ser uma significativa informação, sobretudo, para ser confrontada com as respostas dadas à última questão: sobre as pretensões e expectativas profissionais para quando concluir o curso, no sentido de seguir (ou não) a carreira docente, isto é, se irá ou não ministrar aulas (seja como atividade principal ou eventualmente).

\footnotetext{
${ }^{31}$ Em Anexo C.
} 
As perguntas 2 e 3, questionam se houve mudança (ou não) - bem como em que aspectos - da visão sobre o que é a ciência Física e o que é Ser Professor depois do ingresso e das disciplinas já cursadas.

Também foi solicitado ao licenciando que citasse características consideradas fundamentais para um bom professor (questão 4) e que indicasse aspectos do curso que estão (e não estão) correspondendo às suas expectativas (questão 5).

Por fim, existe ainda, um campo para comentários e/ou observações caso o aluno desejasse complementar suas respostas.

Os questionários foram aplicados para um total de 91 alunos, em 5 turmas distintas: Eletricidade II, diurno e noturno (ED e EN) ${ }^{32}$; Complementos de Mecânica Clássica, diurno e noturno (CD e CN) e Metodologia do Ensino de Física II (MN), noturno. Somente esta última disciplina é ministrada na Faculdade de Educação, sendo as demais cursadas no Instituto de Física.

Com a intenção de estabelecer comparações entre as ideias, concepções e expectativas de alunos em diferentes etapas do curso, optamos por nomear de Grupo1 os alunos das disciplinas de Eletricidade diurno e noturno e, Grupo 2 os alunos das disciplinas de Complementos e Metodologia do Ensino. Como já mencionado, o Grupo 1 é formado, majoritariamente, por alunos que encontram-se nos meados do curso e o Grupo 2, por aqueles que estão próximos da conclusão.

\subsubsection{Caracterização geral}

A partir dos dados fornecidos referentes à primeira parte e das questões objetivas 1 e 6 do questionário, foi possível fazermos uma caracterização mais geral destes licenciandos em aspectos como, por exemplo, escolaridade do pai, forma de ingresso, escola em que cursou o nível médio, atividade profissional e perspectivas de Ser Professor.

\footnotetext{
${ }^{32}$ Nomenclatura utilizada para identificação dos sujeitos da amostra.
} 


\section{Turno}

A tabela 31 apresenta a distribuição dos alunos respondentes, por turno, disciplina e grupo:

Tabela 31 - Distribuição dos alunos em Percurso por Turno, Disciplina e Grupo.

\begin{tabular}{|c|c|c|c|c|}
\hline \multicolumn{2}{|c|}{ Grupo/Disciplinas } & Diurno & Noturno & \\
\hline Grupo 1 & Eletricidade e Magnetismo & 18 & 34 & $\mathbf{5 2}$ \\
\hline \multirow{2}{*}{ Grupo 2 } & Complementos de Mecânica Clássica & 16 & 15 & $\mathbf{3 9}$ \\
\cline { 2 - 5 } & Metodologia do Ensino de Física II & - & 8 & $\mathbf{9 1}$ \\
\hline
\end{tabular}

Assim, teríamos 34 alunos do diurno e 57 do noturno, 52 pertencentes ao Grupo 1 e 39 ao Grupo 2. Porém, é permitido ao aluno ingressante de um certo turno, matricular-se em disciplinas do contra-turno, ou até mesmo - no caso de autorizado pelo professor assistir às aulas em qualquer um dos turnos. Deste modo, houve casos em que, por exemplo, alunos do noturno preencheram o questionário numa turma do diurno, e vice-versa. Por isso, optamos por agrupá-los segundo as informações declaradas e não apenas segundo o turno da disciplina cursada, ficando por fim com 33 alunos do diurno e 58 do noturno.

Os gráficos 25 e 26 abaixo apresentam os dados por turno segundo os Grupos 1 e 2, em valores absolutos e percentuais.

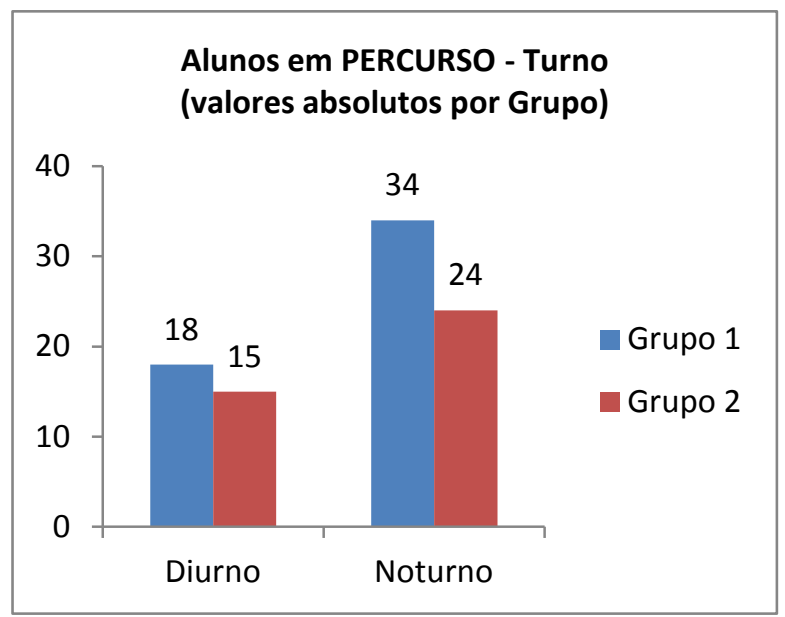

Gráfico 25 - Amostra de alunos em Percurso, por Grupo e turno (valores absolutos).

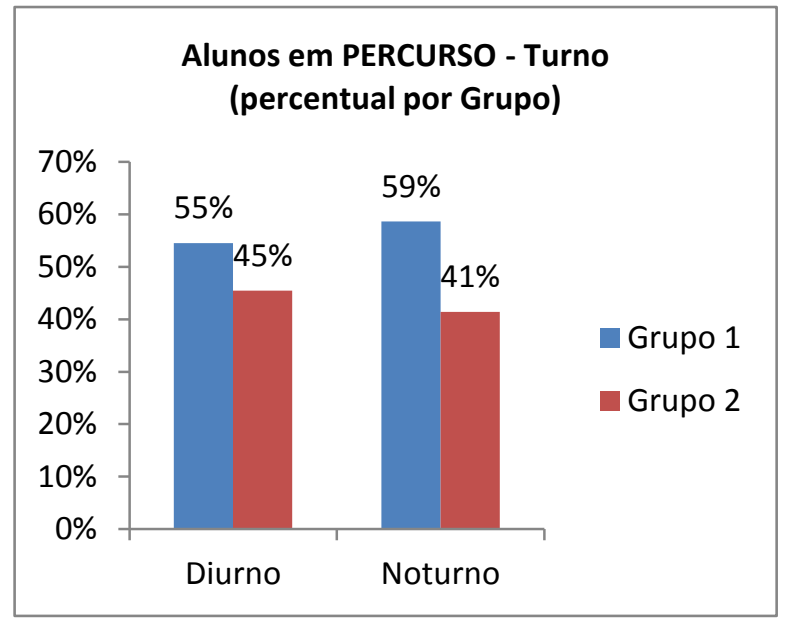

Gráfico 26 - Amostra de alunos em Percurso, por Grupo e turno (percentual). 


\section{Escolaridade do pai}

Com relação à escolaridade do pai, os dados revelaram que a mesma é maior para os alunos do Grupo 1, visto que o percentual de pais com ensino superior é de $\mathbf{3 8 \%}$ para o Grupo 1 e $\mathbf{2 8 \%}$ para o Grupo 2. Por isso, em média, quase 70 destes licenciandos ativos no curso, superam - no momento - a escolaridade de seus pais. Este valor está de acordo com aqueles encontrados no Capítulo 4 nas discussões sobre mobilidade intergeracional em educação de alunos USP, que revelaram que cerca de 70\% (em média entre 2000 e 2009) dos chamados para a 1ạ. matrícula da Carreira Licenciatura em Matemática e Física, igualavam ou superavam - já no ingresso - a escolaridade de seus pais.

O gráfico 27 ilustra esses dados em valores percentuais.

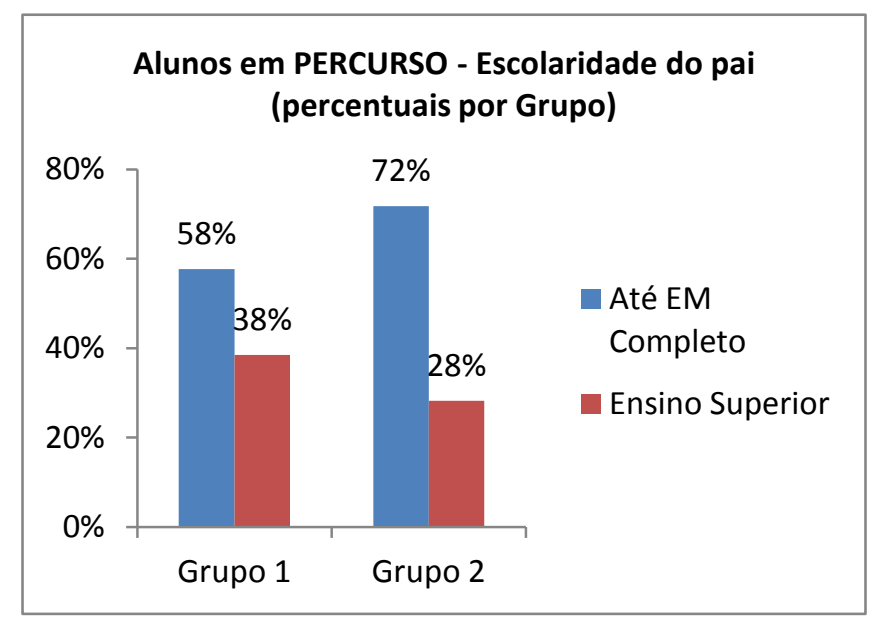

Gráfico 27 - Escolaridade do pai, segundo os Grupos 1 e 2 de alunos em percurso (percentual).

\section{Tipo de Escola e de curso de nível médio}

Com relação ao tipo de escola em que o licenciando cursou seu Ensino Médio, os dados mostram que o índice de alunos oriundos de escola pública é de $65 \%$ no Grupo 1, enquanto do Grupo 2 é de 59\%. O percentual de alunos que cursaram o ensino médio regular no Grupo 1 é de 87\%, ao passo que no Grupo 2 o índice é 77\%, 10pp menor.

O gráfico 28 apresenta tais dados em valores percentuais. 


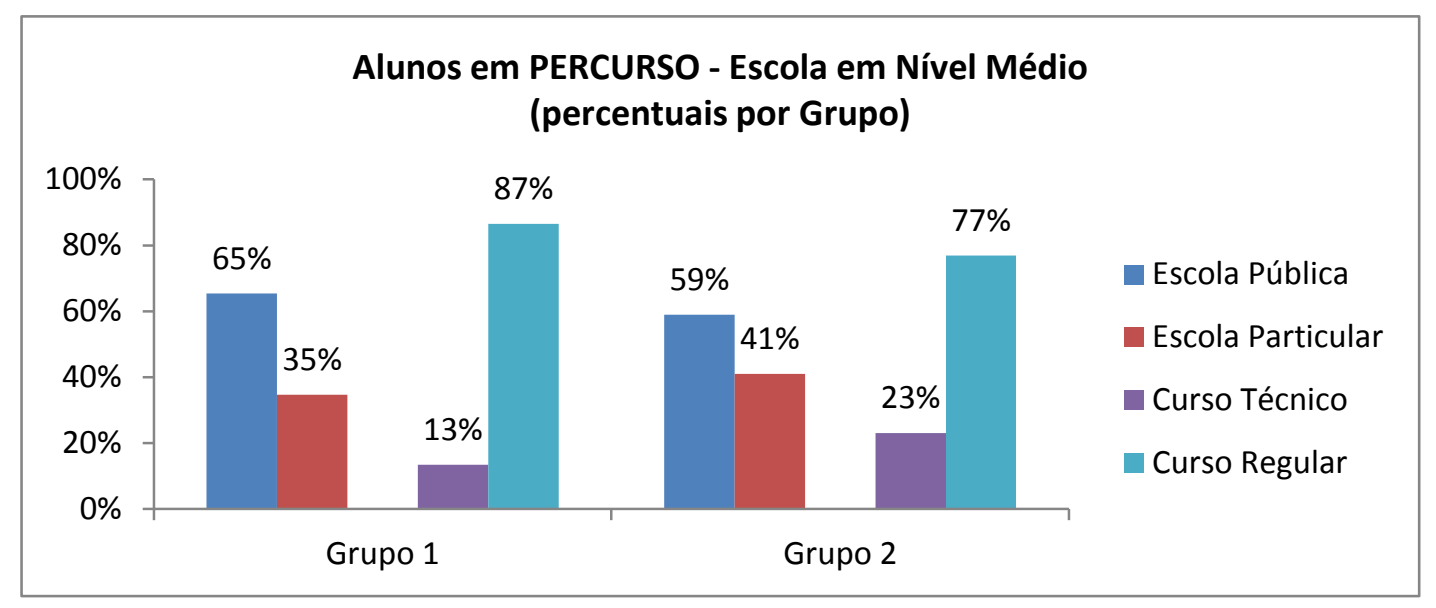

Gráfico 28 - Tipo de Escola em Nível Médio dos alunos em Percurso.

Portanto, em média, $60 \%$ dos licenciandos são oriundos de escola pública, percentual um pouco maior do que aquele encontrado nas discussões do Capítulo 4, nas quais verificamos que em torno de $50 \%$ dos chamados para a 1a. matrícula da Carreira Licenciatura em Matemática e Física, haviam cursado o ensino médio em escola pública.

\section{Tipo de ingresso}

As informações fornecidas pelos licenciandos nos permite verificar que para ambos os Grupos, pouco mais de $\mathbf{8 0 \%}$ dos alunos ingressaram via vestibular e em torno de $\mathbf{1 5 \%}$ são alunos transferidos do curso de Bacharelado (Ver gráfico 29).

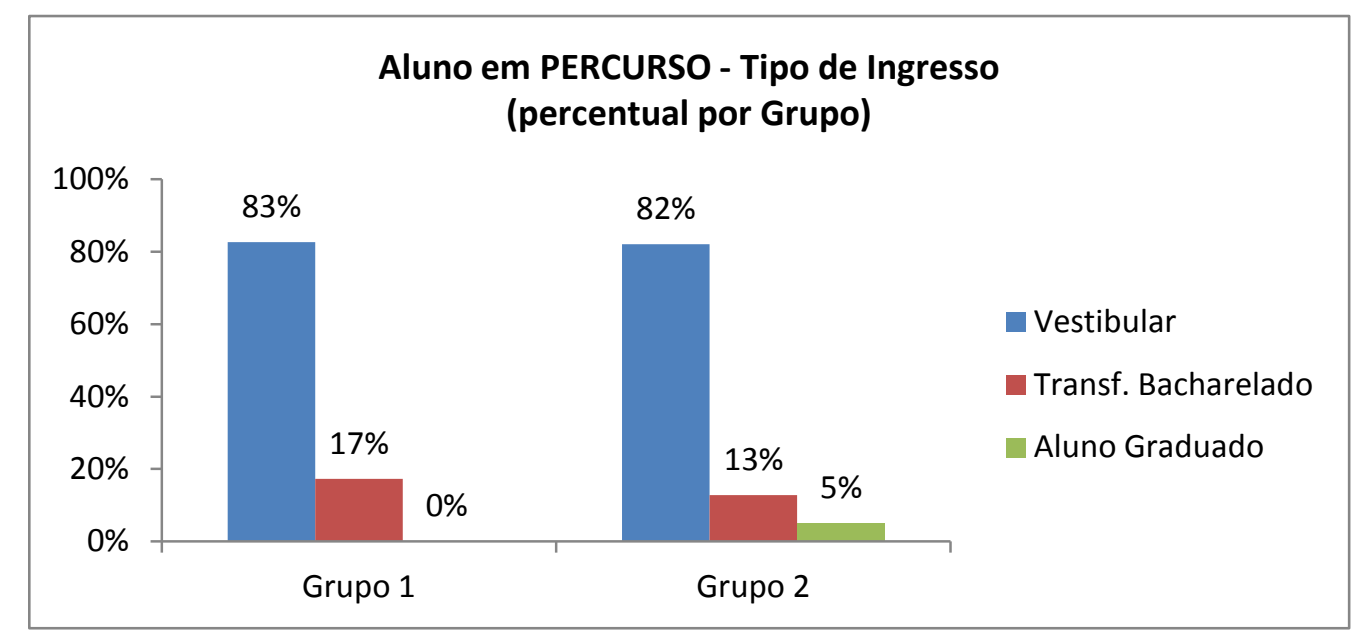

Gráfico 29 - Tipo de ingresso dos alunos em Percurso, segundo os Grupos 1 e 2. 
Certamente, dentre os ingressantes por vestibular, existem casos de reingresso, bem como ingresso de alunos já graduados. Isso pode ser notado, por exemplo, quando o aluno declara ter ingressado há um ano (em 2010) e está cursando a disciplina de Complementos de Mecânica, matéria do fim do curso que exige pré-requisitos. No entanto, na impossibilidade de verificação caso a caso optamos por considerar e computar os dados segundo as declarações dos alunos.

\section{Atividade Profissional}

Quanto à atividade profissional dos licenciandos em percurso, os dados dos questionários nos revelam que no Grupo $\mathbf{1}$, menos de $\mathbf{3 0}$ dos alunos lecionam, quase $\mathbf{5 0 \%}$ deles exercem outra atividade - que não a docência - e cerca de $\mathbf{2 0} \%$ não trabalha. Para o Grupo 2, o percentual daqueles que lecionam é maior que o do outro grupo, quase $\mathbf{4 0 \%}$ dos alunos; o índice dos que exercem outra atividade é praticamente o mesmo, pouco menos que $\mathbf{5 0 \%}$ e apenas $\mathbf{1 5 \%}$ não trabalha, $6 \mathrm{pp}$ a menos em relação ao outro grupo (Gráfico 30 ).

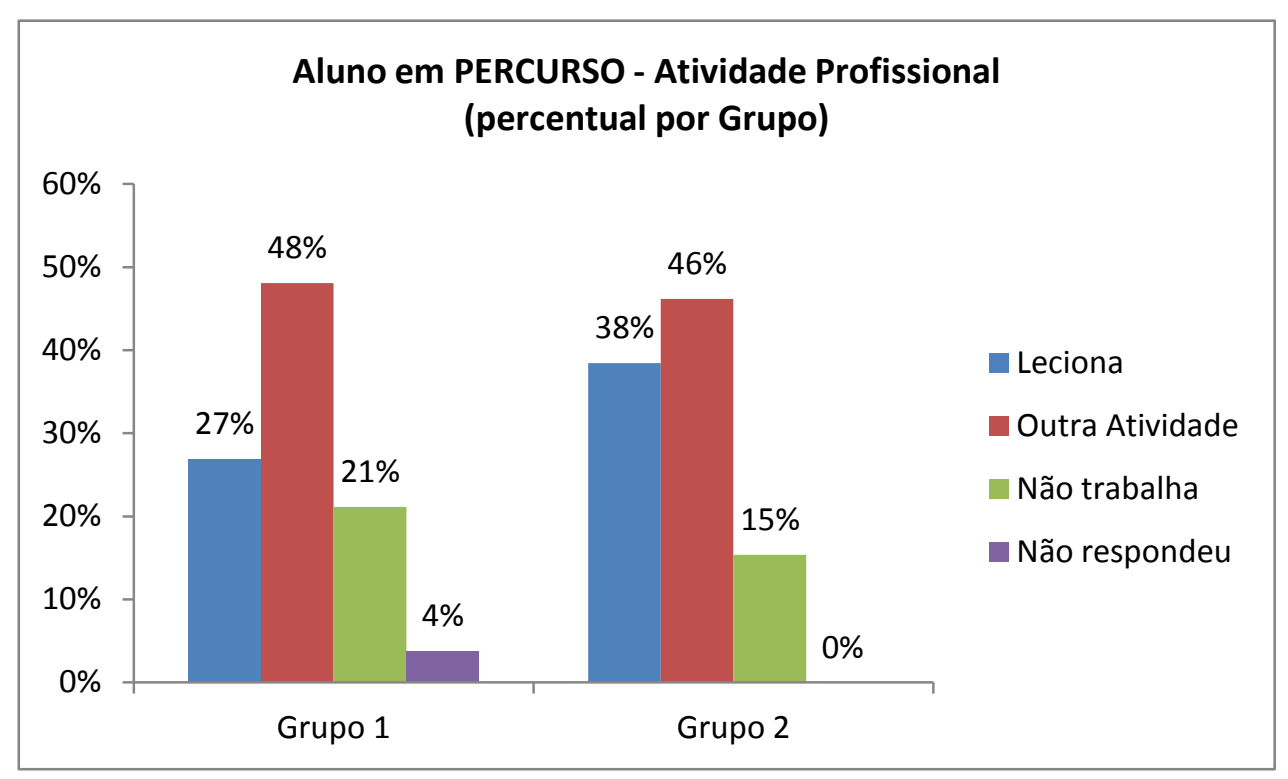

Gráfico 30 - Atividade Profissional dos alunos em Percurso, segundo os Grupos 1 e 2. 
Assim, em média, dos alunos respondentes, pouco mais de $\mathbf{3 0 \%}$ leciona, pouco menos $\mathbf{5 0 \%}$ exercem outra atividade remunerada e quase $\mathbf{2 0 \%}$ não trabalha.

Dentre os licenciandos que lecionam, podemos verificar (Gráfico 31) que o percentual de atuação em escolas públicas é menor do que o de escolas e/ou aulas particulares, sobretudo para o Grupo 1, no qual apenas 7\% são professores da rede pública; no Grupo 2 essa taxa sobe para $\mathbf{4 0 \%}$.

Em média, portanto, cerca de $80 \%$ dos licenciandos que lecionam trabalham com aulas e/ou escolas particulares.

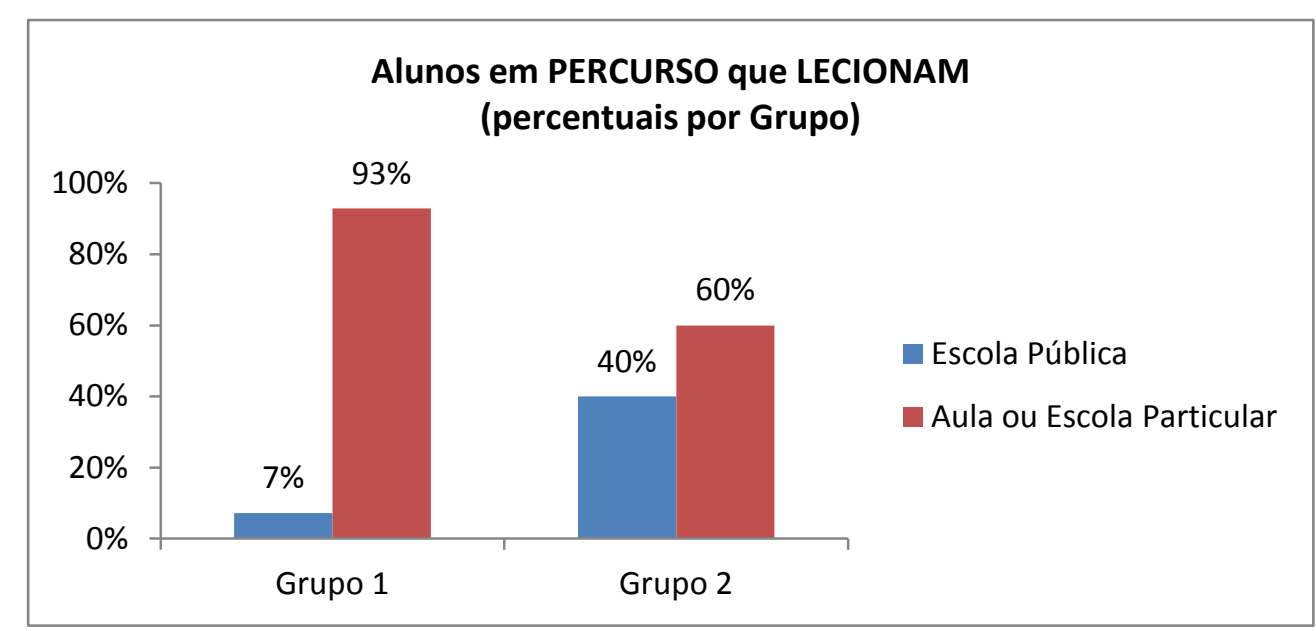

Gráfico 31 - Alunos em Percurso que Lecionam, segundo os Grupos 1 e 2.

\section{Perspectivas quanto a Ser Professor}

A questão objetiva 1 do questionário (“Ao ingressar no Curso de Licenciatura em Física, sua PRINCIPAL motivação era:") apresentava as seguintes alternativas: 


\section{Ser professor \\ Fazer pesquisa em Física \\ Facilitar a entrada no mercado de trabalho \\ Obter uma formação científica geral \\ Ingressar em uma universidade pública \\ Outra:}

De modo geral, os alunos assinalaram uma única alternativa - como de fato esperávamos que fosse - já que a questão pedia 'a principal' motivação. Porém, alguns indicaram mais de uma motivação, sobretudo marcando "Ser Professor" e uma outra qualquer. Então, para efeito de tabulação dos dados, optamos por criar uma 'alternativa' conforme aparece na Tabela 32, a seguir:

Tabela 32 - Motivação principal para o ingresso na Licenciatura - Alunos em Percurso

\begin{tabular}{|c|c|c|c|c|c|c|}
\hline \multicolumn{7}{|c|}{ Ao ingressar no Curso de Licenciatura em Física, sua PRINCIPAL motivação era: } \\
\hline & \multicolumn{3}{|c|}{ GRUPO 1} & \multicolumn{3}{|c|}{ GRUPO 2} \\
\hline & \multirow{2}{*}{$\begin{array}{c}\text { absoluto } \\
23\end{array}$} & \multicolumn{2}{|c|}{ percentual } & \multirow{2}{*}{$\begin{array}{c}\text { absoluto } \\
22\end{array}$} & \multicolumn{2}{|c|}{ Percentual } \\
\hline Ser professor & & $44 \%$ & \multirow{2}{*}{$63 \%$} & & $56 \%$ & \multirow{2}{*}{$64 \%$} \\
\hline Ser professor e mais alguma & 10 & $19 \%$ & & 3 & $8 \%$ & \\
\hline Fazer pesquisa em Física & 1 & \multicolumn{2}{|c|}{$2 \%$} & 4 & \multicolumn{2}{|c|}{$5 \%$} \\
\hline Facilitar a entrada no mercado & 4 & \multicolumn{2}{|c|}{$8 \%$} & 2 & \multicolumn{2}{|c|}{$15 \%$} \\
\hline Obter uma formação científica & 8 & \multicolumn{2}{|c|}{$15 \%$} & 6 & \multicolumn{2}{|c|}{$3 \%$} \\
\hline Ingressar um uma universidade & 3 & \multicolumn{2}{|c|}{$6 \%$} & 1 & \multicolumn{2}{|c|}{$3 \%$} \\
\hline Outra & 3 & \multicolumn{2}{|c|}{$6 \%$} & 1 & \multicolumn{2}{|c|}{$8 \%$} \\
\hline Total & 52 & \multicolumn{2}{|c|}{$100 \%$} & 39 & \multicolumn{2}{|c|}{$100 \%$} \\
\hline
\end{tabular}

De onde percebemos que, cerca de $63-64 \%$ dos alunos, em ambos os Grupos, parecem ter sido motivados pela vontade de Ser Professor. Tal índice é obtido se considerarmos aqueles que escolheram somente a alternativa 'Ser Professor' e também aqueles que marcaram esta e mais uma.

Caso, seja considerado apenas a marcação da alternativa 'Ser Professor', os percentuais são 44\% para o Grupo 1 e $56 \%$ para o Grupo 2. 
A questão objetiva 6 do questionário ("O que você pretende fazer quando concluir o curso?") apresentava as seguintes alternativas:

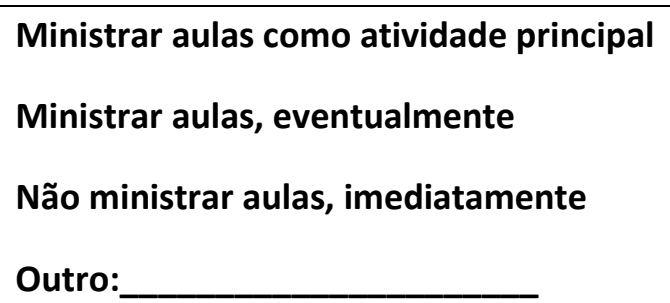

Nos poucos casos em que o licenciando indicou mais de uma alternativa - 'Ministrar aula como atividade principal' e uma outra qualquer - optamos aqui, por computar tal dado nesta 'outra qualquer', entendendo que ele, portanto, não pretende exercer a profissão docente como atividade principal.

O quadro geral de respostas está representado abaixo na Tabela 33:

Tabela 33 - Pretensões para quando concluir o curso - Alunos em Percurso.

\begin{tabular}{|c|c|c|c|c|}
\hline \multicolumn{5}{|c|}{ O que você pretende fazer quando concluir o curso? } \\
\hline & \multicolumn{2}{|c|}{ GRUPO 1} & \multicolumn{2}{|c|}{ GRUPO2 } \\
\hline & Absoluto & Percentual & Absoluto & Percentual \\
\hline Ministrar aulas como atividade principal & 21 & $40 \%$ & 15 & $38 \%$ \\
\hline Ministrar aulas, eventualmente & 11 & $21 \%$ & 9 & $23 \%$ \\
\hline Não ministrar aulas imediatamente & 2 & $4 \%$ & 2 & $5 \%$ \\
\hline Outro & 16 & $31 \%$ & 12 & $31 \%$ \\
\hline Não respondeu & 2 & $4 \%$ & 1 & $3 \%$ \\
\hline Total & 52 & $100 \%$ & 39 & $100 \%$ \\
\hline
\end{tabular}

É interessante perceber que praticamente os percentuais se igualam em ambos os Grupos. A taxa daqueles que pretendem exercer a profissão de professor, ou seja, ministrar aulas como atividade principal, é de $38 \%$ para o Grupo 2 e $40 \%$ para o Grupo 1.

Agora, se juntarmos as informações a cerca da intenção de Ser Professor no ingresso (ainda que declarada no momento presente e influenciada por inúmeros aspectos) e no egresso do curso, encontramos o que ilustra, abaixo, a Tabela 34: 
Tabela 34 - Intenção de Ser Professor no ingresso e no egresso - Alunos em Percurso.

\begin{tabular}{|c|c|c|c|}
\hline \multicolumn{4}{|c|}{ Ser Professor (única alternativa marcada) } \\
\hline \multicolumn{2}{|c|}{ Quando ingressou } & Quando concluir \\
\hline GRUPO 1 & GRUPO 2 & GRUPO 1 & GRUPO 2 \\
\hline $44 \%$ & $56 \%$ & $40 \%$ & $38 \%$ \\
\hline
\end{tabular}

Vemos, portanto, que para ambos os Grupos, ocorre uma diminuição da intenção em querer seguir a carreira docente.

O Gráfico 32, ilustra os dados da Tabela 34, e mostra que o percentual de diminuição da intenção de Ser Professor é maior para o Grupo 2 (-18 p.p), já que para o Grupo 1 esse índice é de $-\mathbf{4}$ p.p.

Gráfico 32 - Intenção de Ser Professor no ingresso e no egresso do curso.

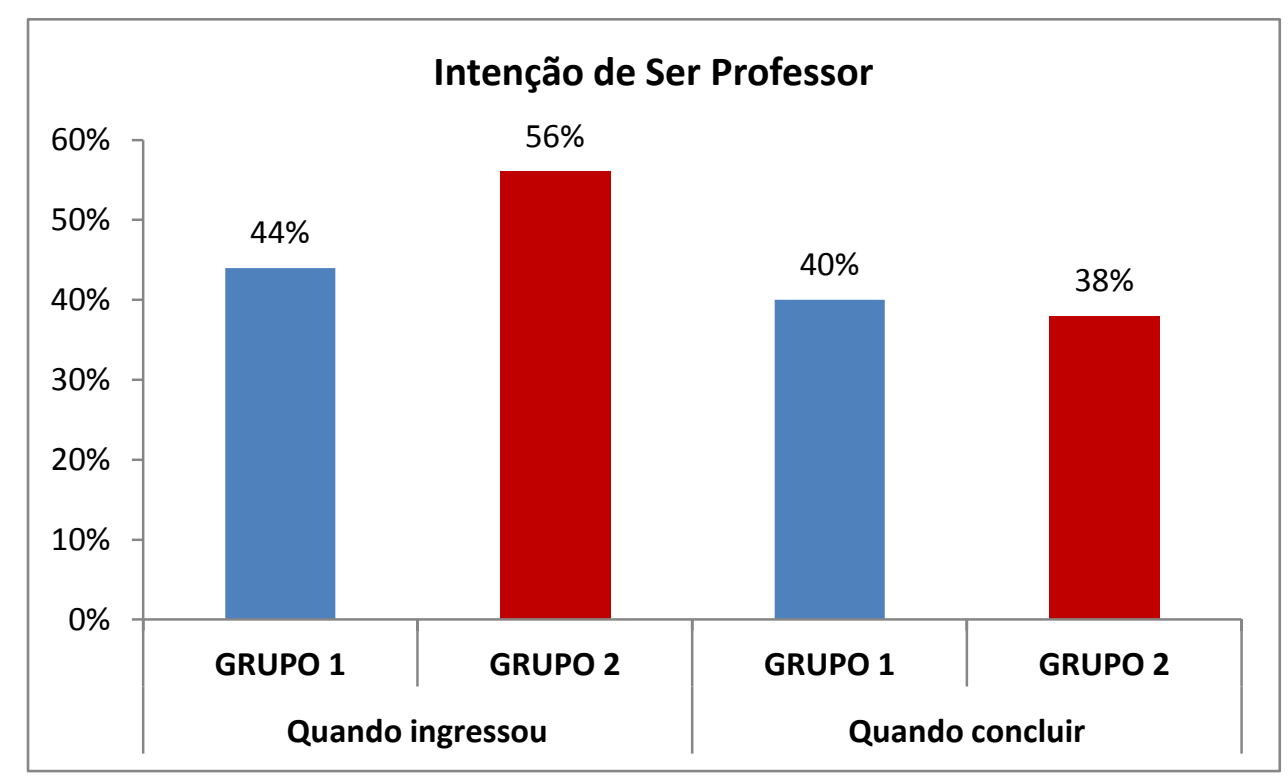

Portanto, em média, $\mathbf{5 0 \%}$ dos licenciandos ingressam na Licenciantura em Física com a intenção de Ser Professor e quase $\mathbf{4 0 \%}$ pretendem seguir a carreira docente quando concluir o curso.

Esses são, certamente, dados relevantes para a discussão final das conclusões em torno dos resultados gerais desta pesquisa. Assim como também o são, as análises que vêm 
a seguir, uma vez que partimos da hipótese de que as ideias, concepções e representações de ciência/física/educação/perfil profissional do professor evoluem, se modificam e se articulam como parte do processo de formação inicial, no período de alguns anos.

\subsubsection{Transformações nas representações de ciência}

Entendemos que evidenciação da mudança na visão de Física do licenciando em percurso está muito além do que simplesmente aparece explicitamente em suas respostas. Assim, ao perguntar: "Sua visão do que é a ciência FísICA mudou (ou não), a partir das disciplinas que já cursou? Em que sentido?" esperamos mais do que o percentual de "sim" e "não" declarado pelo aluno. Nosso interesse é o de perceber em suas declarações indícios de mudança e características relevantes que as configurem.

De todo modo, podemos iniciar a análise observando (Gráfico 33) que de acordo com as respostas dadas, a maior parte dos alunos - sejam os que estão na primeira metade do curso, sejam os que estão próximos da conclusão - acredita ter mudado sua visão sobre a Física. No Grupo 1 o índice é de $71 \%$ e no Grupo 2 de $85 \%$.

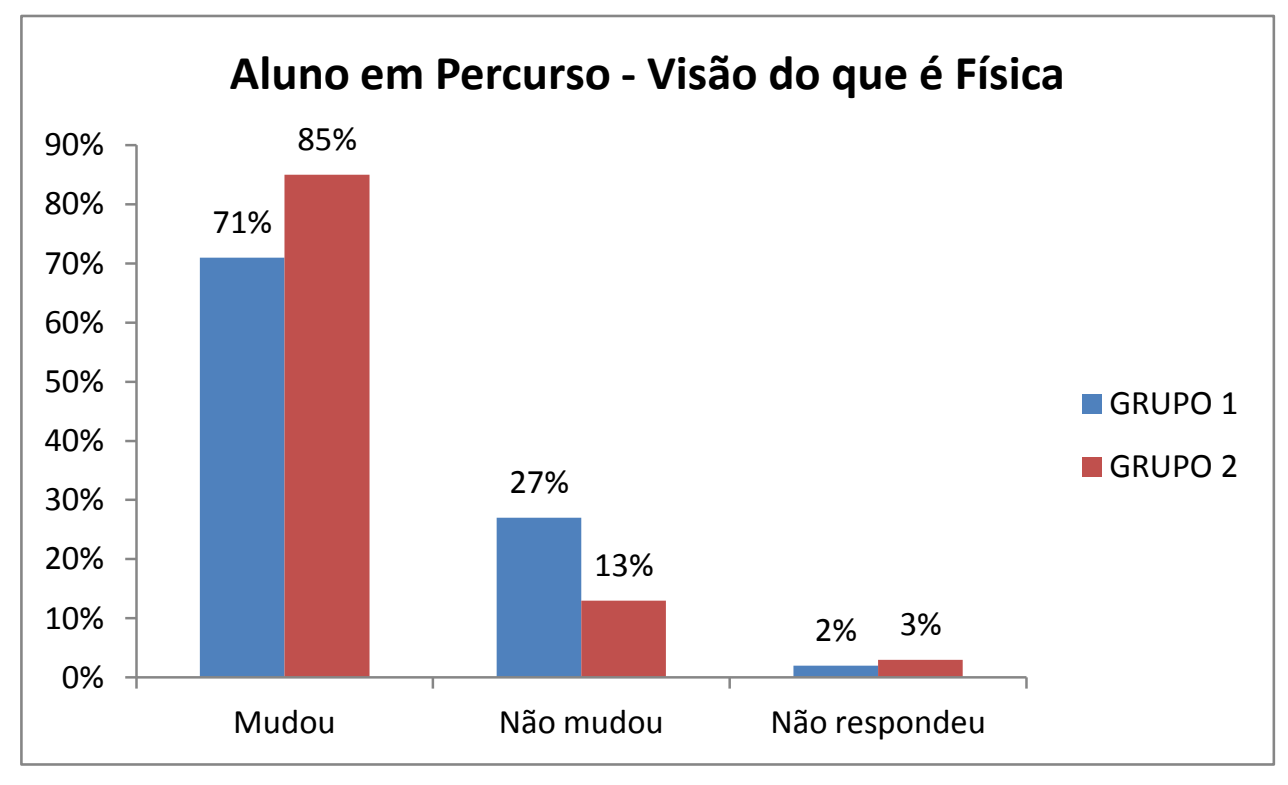

Gráfico 33 - Mudança na Visão de Física dos alunos em Percurso. 
É razoável que o Grupo 2 apresente uma maior probabilidade de percepção de mudança, visto que na comparação com o outro grupo, está mais avançado em sua trajetória no curso.

Uma vez identificado o aluno que declarou ter sofrido mudanças em sua visão do que é a Física, nos interessa agora, verificar em sua fala as ideias acerca desta ciência. Optamos por estabelecer, com base nas citações, quatro categorias que parecem refletir a maior parte das concepções dos licenciandos.

Alguns alunos parecem entender a Física como fundamental para a compreensão da natureza da ciência, aquela que permite entender as leis e fenômenos da natureza, estuda, descreve e cria modelos para explicá-los, algo além de fórmulas, com dimensão social e que tem suas limitações, visto que se trata de uma construção humana.

A seguir, algumas citações que ilustram esta categoria ${ }^{33}$ :

"Sim. Em muitas disciplinas no IFUSP os professores ensinaram a observar a natureza, e tentar entender as leis que nos faz existir." [ED4] $]^{34}$

"Mudou. Aqui nos foi apresentado por alguns professores (os bons) que a física estuda fenômenos e cria modelos para estudá-los e prevê-los." [ED5]

"Sim. Mudou no sentido de ver a física mais como uma descrição da natureza." [ED10]

Sim. Por mais que temos professores focado nos conteúdos, outros fizeram perceber a dimensão deste curso não somente no âmbito acadêmico como no social." [CN3]

"Sim, vejo que vai muito além do que se aprende na escola, é algo muito mais amplo e não necessariamente 'matemático'". [CN15]

\footnotetext{
${ }^{33}$ No Anexo D encontram-se todas as descrições e respectivas classificações.

34 Identificação do aluno, segundo a disciplina e turno no qual preencheu o questionário (Eletricidade, Complementos ou Metodologia, Diurno ou Noturno).
} 
"Sim mudou. A Física para mim era como uma verdade incontestável (quase uma religião) essa era a minha visão na época colegial, agora é só uma construção humana." [CD2]

“Sim, hoje tenho mais consciência das suas limitações." [CD10]

"Sim, mudou no sentido que hoje compreendo a estrutura das ciências e como seus discursos repercutem no dia a dia." [CD12]

"Mudou, percebi o quanto a física é uma criação do homem e necessariamente ñ representa realmente a natureza." [CD13]

"Sim. Muitas disciplinas ainda ensinam através do rigor matemático, porém algumas me fez enxergar o mundo de outra maneira." [MN3]

"Sim, a física deixou de ser algo neutro e racional, para ser uma empreitada humana, em busca da compreensão do Universo." [MN4]

“Não muito. Sempre tive a visão da Física como um processo contínuo e filosófico. Idéia que reforcei no curso." [MN5]

Grande parte dos licenciandos, apresenta em suas declarações uma ideia da Física como algo abrangente, complexa e interessante. A visão desta ciência, para estes alunos, parece ter mudado no sentido de ampliar/aprofundar alguns conceitos, sobretudo como um aprofundamento da física estudada em nível médio. Talvez suas concepções sejam até de outra natureza, porém, em um primeiro momento e em virtude das limitações do instrumento, optamos por classificar os alunos segundo as impressões mais evidentes em suas respostas. Abaixo, alguns exemplos de sujeitos que compõem tal categoria:

\footnotetext{
"Sim, hoje eu acho a física muito mais interessante e difícil." [ED7]

“Mudou, ela agora me parece muito mais complexa e interessante." [ED16]

"Sim, a Física é muito mais abrangente do que eu imaginei." [ED18]
} 
“Mudou em alguns aspectos, onde eu não tinha uma visão tão ampla do que é a física e o quanto ela é importante." [EN2]

"Sim. Através de um estudo mais formal, pode-se adquirir uma visão mais profunda e também maior ligação entre diversas partes da Física que antes pareciam isoladas." [EN5]

“Sim principalmente por ver as disciplinas 'profundamente' ou melhor por ver as disciplinas que cursei no colegial de outra maneira." [EN7]

"Sim, Física é muito mais do que se pensava no ensino médio." [EN9]

"Sim, hoje tenho uma noção maior do tamanho da física (abrangência) e entendo melhor que ela não é tão simples, mas apesar disto muito bela." [EN14]

"Sim, mudou bastante. A Física possui um campo extremamente vasto e multidisciplinar, em muitos momentos me surpreendi e gostei ainda mais de aprofundar assuntos que eram vistos superficialmente durante o E.M." [EN32]

"Sem dúvida mudou, a visão de física do ensino médio que tinha era totalmente clássica nunca tive contato com física moderna." [CN7]

"Creio que melhorei meu entendimento sobre as coisas em geral, em especial nos ramos da física." [CN11]

"Sim. Obtive um entendimento mais profundo de conhecimentos específicos e gerais da Física, que me proporciona maior prazer ao estudar." [CD1]

"Sim, mudou no sentido de me trazer maior fundamentação para explicação dos fenômenos." [CD3]

"A minha visão mudou: as disciplinas ampliaram o meu conhecimento." [CD16]

"Sim, eu tinha quase nenhuma idéia sobre o que é física, eu só achava legal alguns tópicos que lia em um livro sobre explicações de objetos e fenômenos. Mas a física é muito além disso." [MN2] 


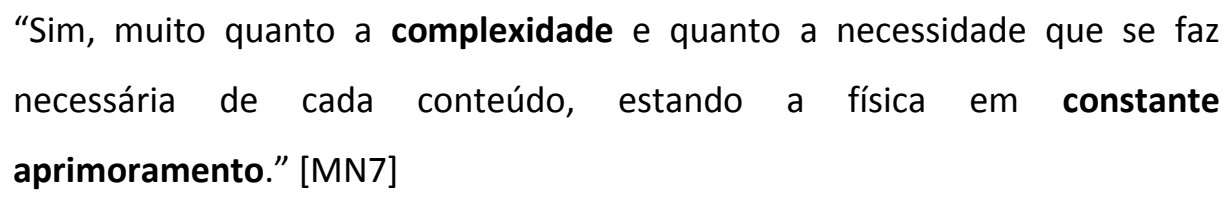

Foi possível identificar nas respostas de alguns alunos uma grande importância dada às aplicações da Física, o que permite enxergar, analisar, entender melhor o mundo à sua volta. Apesar de serem poucos os casos, acreditamos ser relevante destacar tal concepção e diferenciá-la das demais citadas. A seguir, algumas das respostas que configuram esta categoria:

\footnotetext{
"Sim, mostrou-me ser mais abrangente e aplicável do que imaginava inicialmente." [ED15]
}

"Sim. No sentido de enxergar o que existe por trás das coisas." [EN3]

"Ajudou eu analisar melhor os problemas que encontramos no dia a dia." [EN24]

"Obtive maiores conhecimentos sobre quais fatores físicos influenciam em nosso cotidiano, fazendo assim com que eu tenha maior possibilidade de entender o mundo ao meu redor." [EN25]

"Sim, mudou no sentido de conseguir enxergar a física no dia-a-dia." [EN26]

“Sim. No sentido de usar a matemática como ferramenta." [EN31]

"Sim! No sentido de ver as coisas que estão ao meu redor." [CN5]

E, finalmente, foi preciso agrupar em uma categoria de indefinidos os demais licenciandos que declararam ter mudado sua visão de Física, mas que, no entanto, não deixaram claro - no nosso entender - em que sentido isso ocorreu; ou pelo menos não puderam ser agrupados nas três categorias anteriores. São exemplos: 
“Não sei responder ao certo. Acredito que a visão esteja em constante transformação. Espero, daqui algum tempo, poder responder mais objetivamente à essa pergunta." [ED2]

"Sim, pois agora sei que tenho que estudar e me preparar mais em termos de conteúdos e práticas. Dependerá de mim." [EN12]

"Sim, em parte. Uso menos a intuição e mais o cálculo agora." [EN19]

"Sim, entrei na faculdade imaginando que teria aulas referentes aos assuntos vistos no cursinho, mais de maneira + aprofundada e discutida, e na maior parte das matérias que fiz tive que memorizar resolução de exercícios $p /$ ser aprovado." [EN27]

"Sim. Antes de entrar no curso de licenciatura eu pensava que descobriria muitos dos "porquês", e depois me parece que há apenas uma necessidade de querer passar nas matérias, mesmo sem entender nada." [CN9]

“Sim. As atividades de estágio mostraram uma realidade bastante distante do discurso que se tem por parte dos docentes da área de ensino, a ponto de me fazer desistir de ser professora." [CD5]

Portanto, se constituíram assim as quatro categorias que identificam as ideias e concepções destes licenciandos que declararam ter mudado sua visão da Física até o momento em que se encontra na trajetória de seu curso:

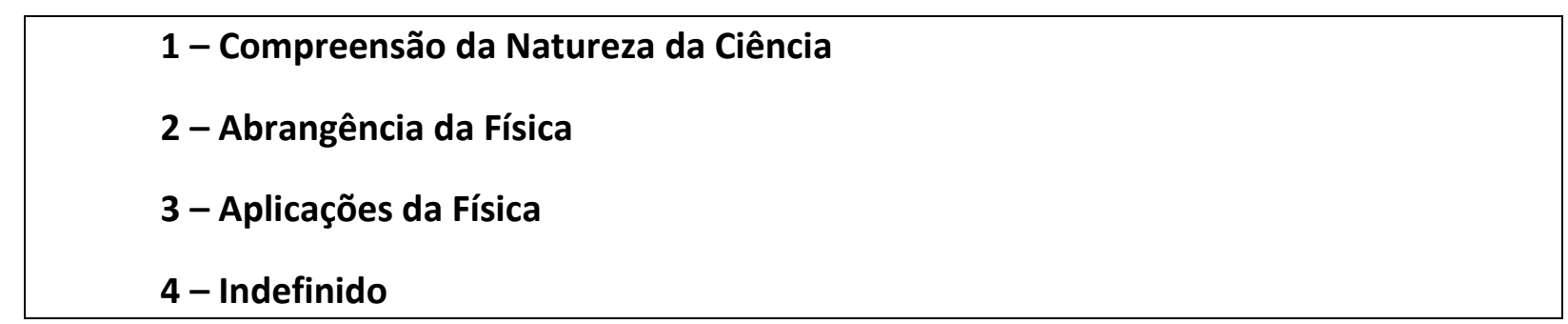

As tabelas 35, 36 e 37, trazem os dados referentes à distribuição dos alunos que declararam ter ou não mudado sua visão da Física, e as categorias que representam suas ideia acerca desta ciência, em valores absolutos e percentuais. 
Praticamente $80 \%$ dos respondentes afirmam ter mudado sua visão sobre a Física (Tabela 35).

Tabela 35 - Mudança na Visão de Física de Licenciandos em Percurso.

\begin{tabular}{|l|c|c|c|}
\hline \multicolumn{4}{|c|}{ VISÃO DE FíSICA - Alunos em Percurso } \\
\hline & GRUPO 1 & GRUPO 2 & Média \\
\hline Mudou & $\mathbf{7 1 \%}$ & $\mathbf{8 5 \%}$ & $\mathbf{8 0 \%}$ \\
\hline Não mudou & $27 \%$ & $13 \%$ & $20 \%$ \\
\hline Não respondeu & $2 \%$ & $3 \%$ & \\
\cline { 1 - 3 } Total & $100 \%$ & $100 \%$ & \\
\hline
\end{tabular}

Importa-nos agora, verificar na comparação entre os dois grupos, em que medida o período em que se encontra o aluno pode marcar/indicar diferenças quanto ao tipo de concepção, ideia/visão da física dos alunos da licenciatura.

A Tabela 36, apresenta o número de alunos por categoria, segundo descritas anteriormente.

Tabela 36 - Mudança na Visão de Física de Licenciandos em Percurso.

\begin{tabular}{|c|l|c|c|}
\hline \multicolumn{4}{|l|}{ VISÃO DE FíSICA - Alunos em Percurso } \\
\hline \multirow{3}{*}{ Categoria } & GRUPO 1 & GRUPO 2 \\
\hline \multirow{3}{*}{ Comprou } & Compreensão da Natureza & 4 & 16 \\
\cline { 2 - 4 } & Abrangência da Física & 22 & 13 \\
\cline { 2 - 4 } & Aplicações da Física & 7 & 1 \\
\cline { 2 - 4 } & Indefinido & 4 & 3 \\
\hline \multicolumn{2}{|r|}{ Tõal } & 14 & 5 \\
\hline & Não respondeu & 1 & 1 \\
\hline
\end{tabular}

Conforme mostra a Tabela 37, a Física é entendida/vista como relacionada à Natureza da Ciência por mais de $\mathbf{4 0 \%}$ dos licenciandos do Grupo 2, isto é, daqueles que estão mais próximos da finalização do curso. O percentual para o Grupo 1, segundo esta mesma concepção é de apenas $\mathbf{8 \%}$.

A categoria que agrupa os alunos que parecem ter uma visão da Física como uma área muito abrangente é a mais numerosa para ambos os grupos, representando $\mathbf{4 2} \%$ dos licenciandos do Grupo 1 e 33\% dos licenciandos do Grupo 2. 
A ideia de Física como aplicações aparece muito mais dentre os alunos do Grupo 1 (13\%) do que dentre os do Grupo 2 (3\%).

$E$, finalmente, notamos que pouco menos que $10 \%$ dos alunos respondentes em ambos os grupos não deixam claro a ideia que têm sobre a ciência/física, isto é, compõem a categoria dos Indefinidos.

Tabela 37 - Percentual referente à Visão da Física de Licenciandos em Percurso.
\begin{tabular}{|c|c|c|c|}
\hline \multirow{3}{*}{ MUDOU DE FísICA - Alunos em Percurso } \\
\hline \multirow{3}{*}{ VISÃO } & Natureza da Ciência & $8 \%$ & $41 \%$ \\
\cline { 2 - 4 } & Abrangência & $42 \%$ & $33 \%$ \\
\cline { 2 - 4 } & Aplicações & $13 \%$ & $3 \%$ \\
\cline { 2 - 4 } & Indefinido & $8 \%$ & $8 \%$ \\
\hline & NÃO MUDOU & $27 \%$ & $13 \%$ \\
\hline NÃO RESPONDEU & $2 \%$ & $3 \%$ \\
\hline
\end{tabular}

O Gráfico 34, abaixo, ilustra apresentando os dados da Tabela 37.

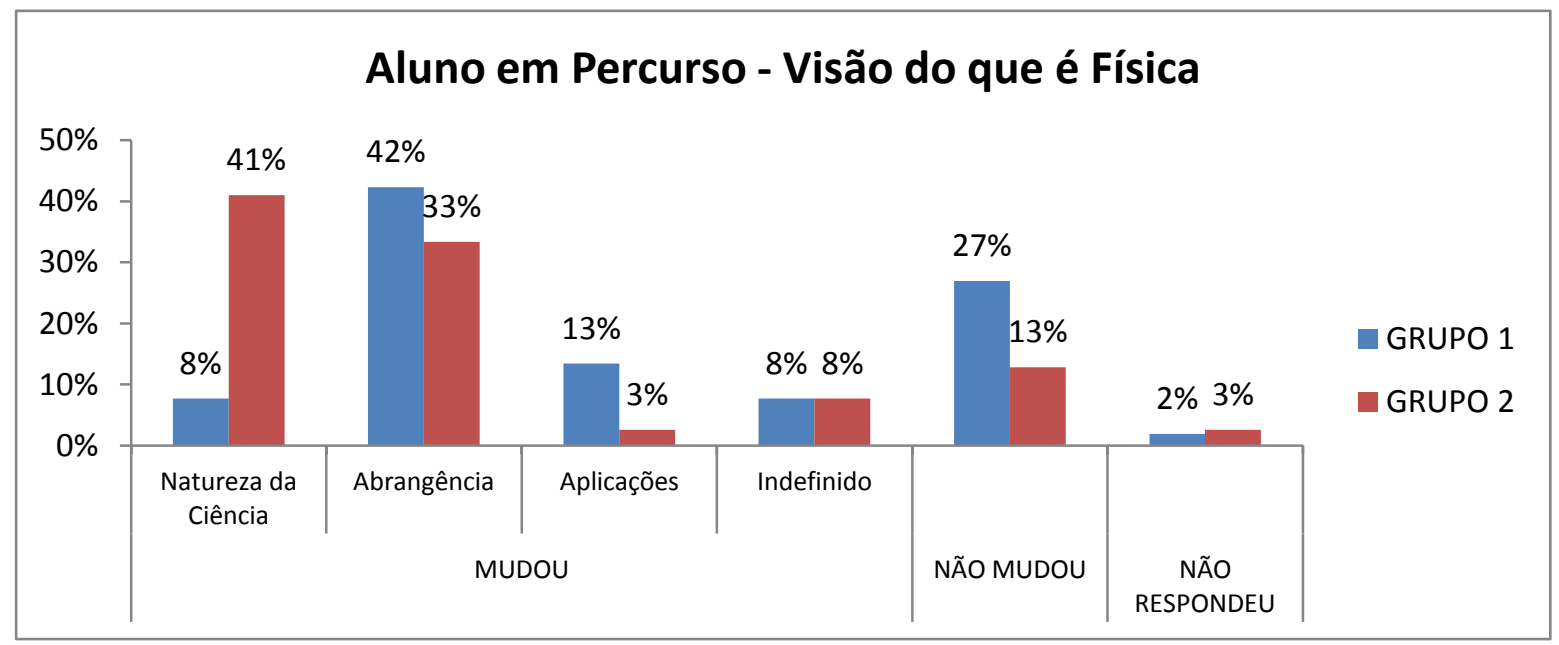

Gráfico 34 - Visão do que é Física dos alunos em Percurso. 


\subsubsection{Transformações nas representações de professor}

Do mesmo modo que nos interessa evidenciar as mudanças a respeito da ciência/Física, igualmente desejamos verificar em que medida o curso traz impactos na transformação e alterações das ideias e concepções dos licenciandos em relação à profissão docente. Novamente - e sobretudo neste caso - mais do que a resposta explícita à pergunta: "Sua visão do que é SER PROFESSOR mudou (ou não), depois que você entrou no curso? Em que sentido?", esperamos verificar no conjunto das respostas dadas também às questões: "Um bom professor, do seu ponto de vista, é aquele que, por exemplo, ..." e "Indique alguns aspectos positivos (e negativos) do curso que correspondam (ou não) as suas expectativas", indicativos das representações do Ser Professor e do Ser Professor de Física dos licenciandos.

Se considerarmos apenas a declaração dos licenciandos teríamos, em média ${ }^{35}, 65 \%$ referente aos licenciandos que afirmam ter mudado sua visão do que é Ser Professor, e 35\% que acreditam não ter mudado. Porém, em nosso entender a mudança ou não será melhor percebida/entendida na comparação entre as ideias e concepções apresentadas pelos Grupos 1 e 2, uma vez que eles são compostos por alunos em etapas distintas do curso.

Assim como no caso da análise sobre a visão de Física, também foi necessário aqui, estabelecermos categorias sobre a visão de Professor destes licenciandos que pudesse nos ajudar a visualizar e entender não somente se houve ou não mudança em suas ideias ao longo da graduação, mas, principalmente - e independentemente do 'sim' ou 'não' da resposta dada - identificar características de suas concepções do Ser Professor, de educação, de ensino e aprendizagem.

Parte dos alunos parece conceber o professor como aquele que mantém o foco no ensino, com preocupações acerca da transmissão do conhecimento. O bom professor, neste caso, é aquele que tem domínio dos conteúdos que leciona, boa didática na preparação das aulas e sabe motivar seus alunos. Isto é, existe aqui uma valorização maior da técnica para o ensino, o foco está na atuação do professor, em sua competência para transmitir o

\footnotetext{
${ }^{35}$ Ver, em Anexo D, tabela completa com esses dados.
} 
conhecimento e, ainda que no discurso o aluno seja citado, tal referência se dá mais fortemente no sentido de que este será/deverá ser motivado num processo que - de novo depende exclusivamente do professor. Vejamos alguns exemplos ${ }^{36}$ :

"Prepara aula, conhece profundamente a matéria, tem paciência para explicar a matéria de várias maneiras." [ED3]

“Possui uma boa didática, apresentando de forma simples e com exemplos do cotidiano, além do domínio do conteúdo exposto." [ED6]

"Consegue passar transmitir o seu conhecimento de maneira simples e clara, e faz com que o aluno fique interessado pelo conteúdo." [ED10]

"Tem prazer em ensinar e procure passar o conhecimento de maneira que todos entendem." [EN3]

"Procura manter-se atualizado, ser cuidadoso no preparo de aulas, buscar sempre estar disponível." [EN5]

"Sabe a matéria e permite o aprendizado dos alunos." [EN9]

"Sabe cativar o aluno $\mathrm{p} /$ que este fique apto a receber conhecimento a partir da sala de aula." [EN21]

"Consegue transmitir o conteúdo a ser ensinado, tem domínio de conteúdo, é responsável nos seus atos, e se importa com o ato de ensinar." [CN6]

"Sabe lidar com a falta de motivação dos alunos, conseguindo motivá-los e fazerem ter interesse em aprender." [CN15]

"Além de saber muito sobre o que leciona sabe transmiti-lo de forma com que a maior parte entenda." [CD11]

"Que tem conhecimento e preparação para ensinar." [MN8]

\footnotetext{
${ }^{36}$ Em Anexo D, planilha completa.
} 
Alguns licenciandos apresentam uma concepção de professor que de algum modo direcionam o foco na aprendizagem, na qual o aluno é parte do processo educativo. Neste caso, o processo educativo é visto como algo dinâmico com a participação ativa tanto do professor quanto do aluno, onde há interação e ambos se responsabilizam pelo ensino e pela aprendizagem. A seguir, algumas citações que ilustram tal concepção:

“Sim. O professor deve despertar a curiosidade do aluno, e levá-lo a pensar e a pesquisar. E não apenas adestrá-lo com conteúdos cristalizados." [ED4]

"Tem a capacidade de interessar o aluno ao que ele vai aprender, relacionar com o contexto do aluno, consegue construir o conhecimento com o aluno e tem interesse de tocar a mente do aluno em vários aspectos, não só ligados à física." [ED8]

"Motiva o aluno a buscar mais informações acerca do tema e a interagir mais com o professor pela vontade de aprender." [ED9]

"Sim, não vejo o professor como um mero "profeta", que cospe informação, mas alguém formador de opinião, que constrói perspectivas de vida." [ED13]

“Sim, pois tinha visão do professor de escola pública que apenas dá sua aula e em grande parte das vezes não se importa co o aluno e hoje vejo o quanto o papel do professor é importante na formação do aluno." [EN7]

“Leciona e deixa o aluno ser participativo." [EN31]

"Sim, antes achava que deveria ensinar aos alunos cálculos, acho que os alunos devem aprender a pensar." [EN33]

“A visão do que é ser professor mudou, percebi que não basta dominar a matéria que ministra, que há outros problemas e questões sociais tão ou até mais importante para resolver $\mathrm{p} /$ que os alunos aprendam física." [CN2]

"Sim. Passei a valorizar mais essa profissão da responsabilidade de ser professor, pois como alunos e futuros professores temos, pelo menos, modelos bons e não tão bons assim de professores." [CN3] 


\begin{abstract}
"Conhece as suas limitações, as limitações dos estudantes, ser flexível às diferentes circunstâncias, realidades/problemas sociais." [CD9]

"Que problematiza situações do cotidiano, evolvendo a física, levanta um debate e cria conciência social nas pessoas." [CD15]

"Consegue apresentar questões que fazem sentido para os alunos, que envolvam questões sociais e temas de física para que $\boldsymbol{o}$ aluno possa pensar $\mathbf{e}$ atuar ativamente na sociedade em que vive." [MN2]

"Mudou muito, a ideia que tinha de ser professor era de reprodutor de conteúdo e preparador para o vestibular. Hoje eu acredito numa formação científica para as pessoas leigas." [MN4]
\end{abstract}

E ainda é possível encontrar dentre as respostas dadas, aquelas que refletem uma ideia de professor com perspectiva educacional mais ampla, que considera aspectos sociais, que é reflexivo e se compromete com uma formação mais global do aluno.

\footnotetext{
“Minha visão mudou, pois o professor não transmitirá apenas conhecimento sobre Física; o educador também é responsável pela formação de caráter do aluno." [EN8]

“Sim, professor para mim, tinha apenas o papel de mostrar conteúdo hoje vejo que o intuito é formar cidadãos." [CN10]

"Tem responsabilidade e compromisso com a turma e com o seu trabalho, ao ponto de se preocupar quando muitos alunos vão mal em uma avaliação, questionando o seu próprio trabalho." [CD5]

"Mostra a educação como ferramenta libertadora." [MN5]
}

Por fim, ainda encontramos - assim como no caso da visão de Física - algumas citações nas quais não fica claro que concepção de professor tem o licenciando, ou pelo 
menos, não foi possível incluí-la nas três anteriores. Optamos por agrupar e denominar por Indefinidos tais alunos. Por exemplo:

"Se dedica muito a sua profissão, está sempre se atualizando e estudando." [ED7]

"Gosta de lecionar." [EN28]

“Prepara suas aulas, prepara outra visão do curso. Visão que não foi passada no curso de licenciatura." [CN4]

"Sim. Hoje compreendo que um professor precisa de muito mais que conhecimento científico. Também compreendi que boa vontade e amor não basta para ser um bom professor atualmente." [CN8]

"Dedica parte de sua vida aos alunos." [CD4]

“Sim, pensando hoje na atual grade, seja universitária ou mesmo em escola pública mudou drasticamente e juntamente com o conceito do que seria educar." [CD12]

“Mudou, o professor é um pastor, da disciplina que ministra." [CD13]

As quatro principais categorias, portanto, ficaram assim estabelecidas:

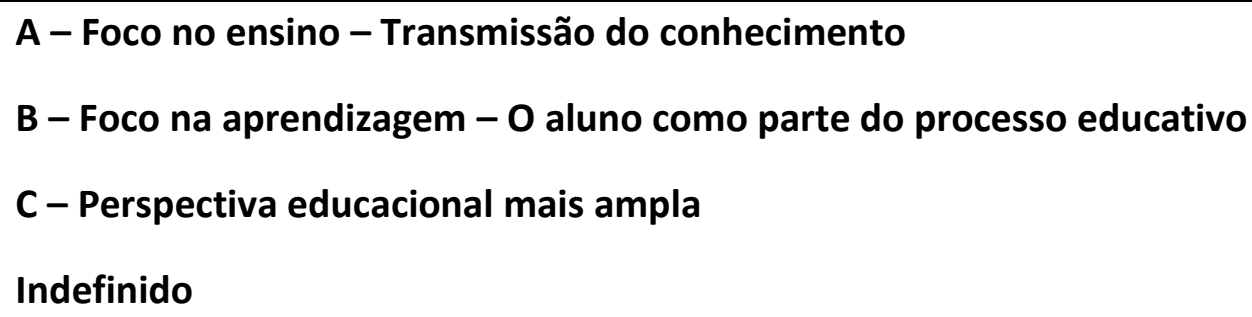

Pouco mais de $\mathbf{8 0 \%}$ dos alunos compõem as categorias A, B e C. A tabela 38 apresenta os percentuais referentes à distribuição dos alunos nestas três categorias, com relação ao total de licenciandos respondentes: 
Tabela 38 - Principais Categorias - Visão de Professor (Alunos em Percurso)

\begin{tabular}{|c|c|c|c|}
\hline \multicolumn{4}{|c|}{ VISÃO DE PROFESSOR - Alunos em Percurso } \\
\hline Categoria & GRUPO & GRUPO & Geral \\
\hline A - Foco no Ensino - Transmissão do conhecimento & $61 \%$ & $41 \%$ & $51 \%$ \\
\hline B - Foco na aprendizagem - Aluno como parte do processo educativo & $31 \%$ & $23 \%$ & $27 \%$ \\
\hline C - Perspectiva educacional mais ampla & $\mathbf{2 \%}$ & $\mathbf{8} \%$ & $5 \%$ \\
\hline Total & $\mathbf{9 4 \%}$ & $\mathbf{7 2 \%}$ & $\mathbf{8 3 \%}$ \\
\hline
\end{tabular}

Aqui vemos que, em média, $\mathbf{5 0 \%}$ dos licenciandos têm uma visão de professor como transmissor do conhecimento, pouco menos de $30 \%$ já entende o aluno como parte do processo educativo e apenas $\mathbf{5 \%}$ do total de licenciandos, apresenta uma perspectiva educacional mais ampla.

As categorias $\mathbf{A}$ e $\mathbf{B}$, foram posteriormente subdividas em A1, A2, B1 e B2, pois entendemos que havia certa gradação no interior das mesmas. Ou melhor, dentre os que compõem a categoria A (com foco no ensino - transmissão do conhecimento), aqueles em o 'aluno' não aparecia citado classificamos como A1; aqueles em que o 'aluno' era citado embora ainda sem que a ele estava sendo dado um papel ativo no processo educativo classificamos como A2. Com relação aos que compõem a categoria B (com foco na aprendizagem - o aluno como parte do processo educativo), aqueles que além de colocarem o aluno como importante no processo ensino-aprendizagem também destacava aspectos sociais como relevantes, foram classificados como B2; os que apenas faziam referência à atuação e interação do aluno, foram classificados como B1.

O Gráfico 35 traz os percentuais da distribuição dos licenciandos nas três principais categorias, segundo o Grupo 1 (alunos que estão na 1a. metade do curso) e Grupo 2 (alunos que estão próximos da conclusão do curso). 


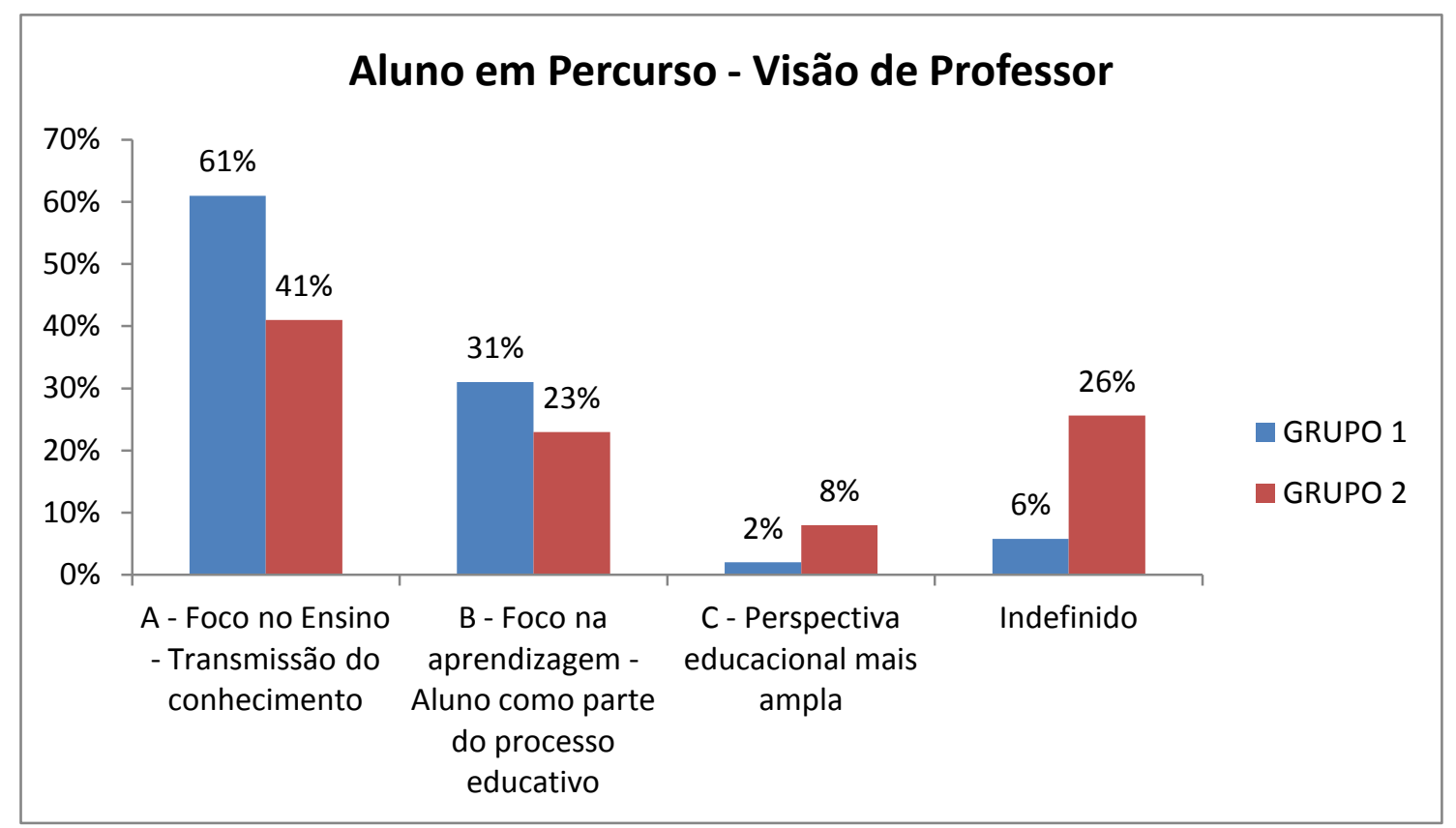

Gráfico 35 - Visão de Professor do aluno em Percurso, segundo os Grupos 1 e 2.

Podemos verificar que com relação às Categorias A e B, o maior percentual é representado por alunos 'mais novos', ou seja, pertencentes ao Grupo 1. Já a Categoria C aparece mais representada por alunos 'mais adiantados' no curso, isto é, pertencentes ao Grupo 2.

As tabelas 39 e 40 apresentam o total de alunos distribuídos nas quatro principais categorias (e suas subdivisões), além daqueles que não responderam.

Tabela 39 - Visão de Professor -Alunos em percurso (valores absolutos)

\begin{tabular}{|c|c|c|c|c|}
\hline \multicolumn{5}{|c|}{ VISÃO DE PROFESSOR - Alunos em Percurso } \\
\hline Categoria & GRUPO 1 & GRUPO 2 & Geral \\
\hline A - Foco no Ensino - Transmissão do conhecimento & $\mathrm{A} 1$ & 7 & 7 & 14 \\
\cline { 2 - 5 } & $\mathrm{A} 2$ & 25 & 9 & 34 \\
\hline $\begin{array}{c}\text { B - Foco na aprendizagem - Aluno como parte do } \\
\text { processo educativo }\end{array}$ & $\mathrm{B} 1$ & 13 & 3 & 16 \\
\cline { 2 - 5 } & $\mathrm{B} 2$ & 3 & 6 & 9 \\
\hline C- Perspectiva educacional mais ampla & 1 & 3 & 4 \\
\hline $\begin{array}{c}\text { Indefinido } \\
\text { Não respondeu }\end{array}$ & 3 & 10 & 13 \\
\hline \multicolumn{2}{|c|}{ Total } & $\mathbf{5 2}$ & $\mathbf{3 9}$ & $\mathbf{9 1}$ \\
\hline
\end{tabular}


Tabela 40 - Visão de Professor -Alunos em percurso (percentuais)

\begin{tabular}{|c|c|c|c|c|c|}
\hline \multicolumn{6}{|c|}{ VISÃO DE PROFESSOR - Alunos em Percurso } \\
\hline \multirow{3}{*}{$\begin{array}{c}\text { Categoria } \\
\text { A - Foco no Ensino - Transmissão do } \\
\text { conhecimento }\end{array}$} & \multirow{3}{*}{$\begin{array}{ll}\mathrm{A} 1 \\
\mathrm{~A} 2\end{array}$} & \multirow{3}{*}{$\begin{array}{c}\text { GRUPO } 1 \\
13 \% \\
48 \%\end{array}$} & \multirow{3}{*}{$\begin{array}{c}\text { GRUPO } 2 \\
18 \% \\
23 \%\end{array}$} & \multicolumn{2}{|c|}{ Média (aprox.) } \\
\hline & & & & $15 \%$ & \\
\hline & & & & $38 \%$ & $50 \%$ \\
\hline \multirow{2}{*}{$\begin{array}{c}\text { B - Foco na aprendizagem - Aluno como parte } \\
\text { do processo educativo }\end{array}$} & B1 & $25 \%$ & $8 \%$ & $18 \%$ & \multirow{2}{*}{$30 \%$} \\
\hline & B2 & $6 \%$ & $15 \%$ & $10 \%$ & \\
\hline \multicolumn{2}{|l|}{ C - Perspectiva educacional mais ampla } & $2 \%$ & $8 \%$ & $4 \%$ & $5 \%$ \\
\hline \multicolumn{2}{|l|}{ Indefinido } & $6 \%$ & $26 \%$ & $14 \%$ & $15 \%$ \\
\hline \multicolumn{2}{|l|}{ Não respondeu } & $0 \%$ & $3 \%$ & $1 \%$ & \\
\hline & Total & $100 \%$ & $100 \%$ & $100 \%$ & \\
\hline
\end{tabular}

Das tabelas acima, em média, $\mathbf{1 5 \%}$ dos licenciandos pertencem à categoria que chamamos $\mathrm{A} 1$; quase $\mathbf{4 0 \%}$ à categoria $\mathrm{A2}$; pouco menos de $\mathbf{2 0 \%}$ à categoria $\mathrm{B} 1$ e $\mathbf{1 0 \%}$ à categoria B2.

Em valores aproximados, temos cerca de $50 \%$ do total de licenciandos com uma representação de professor na qual predomina a concepção de transmissão do conhecimento; 30\% já parecem mostrar alguma preocupação com a participação do aluno no processo educativo; apenas $5 \%$ deixa transparecer uma ideia de professor que considera perspectivas educacionais mais amplas. O percentual referente aos indefinidos, embora alto (15\%) indica, por um lado - sobretudo pela diminuição de 20 p.p do Grupo 1 para o Grupo 2 nesta categoria e aumento nas B e C - que os licenciandos podem não ter muito claro ou definida uma representação do ser professor, mas por outro lado, indica uma favorável mudança em termos de suas concepções no sentido de que não mais entendem o professor como técnico transmissor do conhecimento.

No Gráfico 36 podemos conferir a distribuição percentual dos licenciandos nas subcategorias A1, A2, B1 e B2, categorias C e Indefinidos e os que não responderam, segundo dados da Tabela 40: 


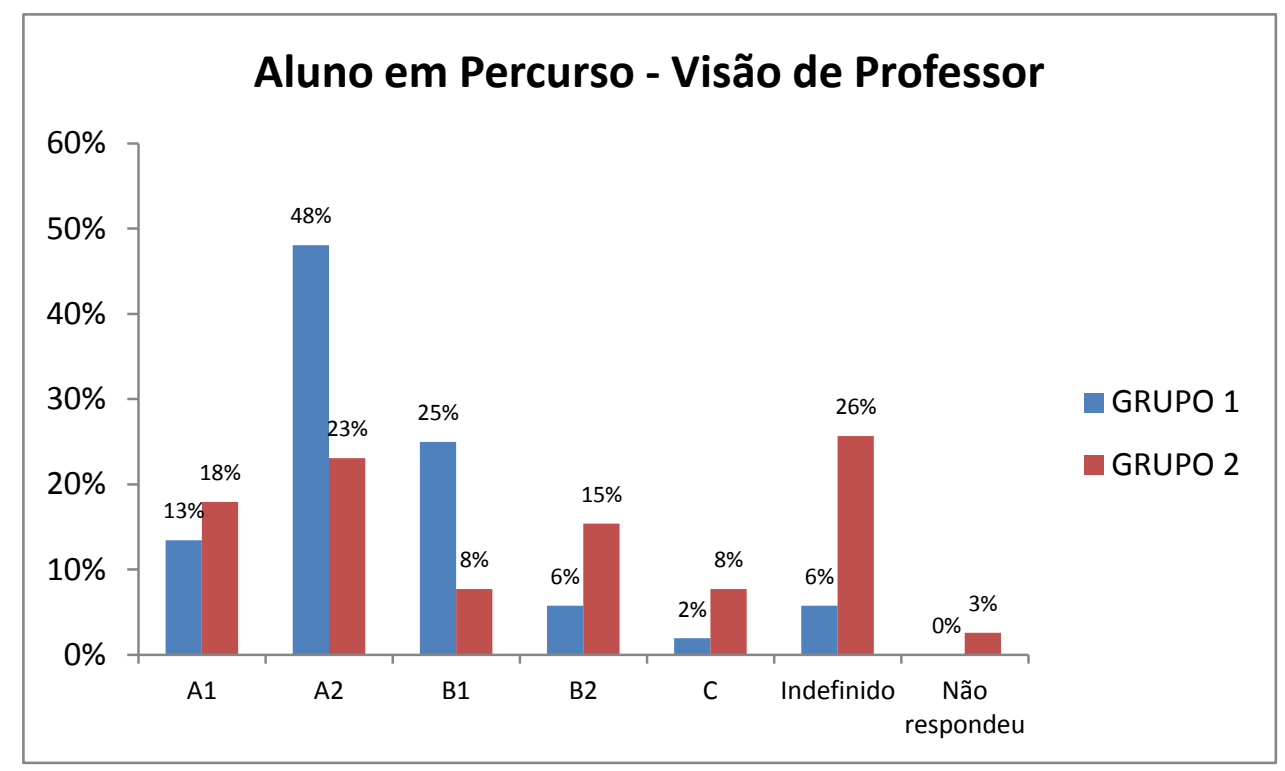

Gráfico 36 - Visão de Professor do aluno em Percurso, em subcategorias.

Se atentarmos para as categorias A2, B1, B2 e C, percebemos que as duas primeiras apresentam maior representatividade dentre os alunos 'mais novos' e as duas últimas dentre os 'mais velhos' no curso. Chama-nos atenção o percentual dos indefinidos dentre os licenciandos do Grupo 2, que equivale a praticamente $1 / 4$ dos alunos deste grupo.

\subsection{Conclusões Preliminares}

Neste capítulo procuramos direcionar um olhar sobre o aluno da Licenciatura em Física em situação de percurso. Em um primeiro momento, com foco em alunos que já completaram encerraram seu vínculo com a instituição - tento concluído ou não seu curso e, em um segundo momento com foco sobre alunos ainda em atividade no curso.

Para a primeira abordagem, foi escolhida uma turma com ingresso em um ano específico (2002), da qual pudéssemos ter garantido a totalidade (ou quase) dos encerramentos (seja por conclusão ou abandono do curso).

A partir daí, foi possível confrontarmos as expectativas profissionais declaradas por esses alunos no questionário de matrícula com o tipo de encerramento de toda a turma. Os 
dados revelaram que pouco menos de $40 \%$ dos alunos desta turma (ingressantes 2002) concluíram o curso, quase $50 \%$ evadiram-se (por abandono ou interrupção - conforme Capítulo 6) e os demais estão ativos ou em situação não conhecida.

O confronto entre as expectativas e o percurso mostra que se olharmos o percentual de concluintes e de evadidos em função das expectativas, concluímos que a expectativa declarada pelo aluno no ingresso parece não ter implicações no sucesso dos encaminhamentos e conclusão do curso. Ou seja, o fato de concluir ou não o curso não parece estar correlacionado com as intenções em ser ou não professor que tinha no momento do ingresso.

Também procuramos caracterizar a evasão associada ao percurso ao relacionar o número de créditos acumulados com o período de tempo cursado até o momento do abandono ou interrupção do curso. Notamos que, dentre os que não concluíram, a maior parte $(3 / 4)$ avançou pouco no curso - acumulando cerca de $1 / 4$ dos créditos que seriam necessários para a conclusão. Porém, é notável que daqueles que mais avançaram até a desistência (cerca de 10\% dos não-concluintes), $80 \%$ haviam declarado que o ingresso no curso foi devido à intenção de formar-se professor.

Para a segunda abordagem da análise, direcionamos um olhar sobre os licenciandos hoje no curso (em percurso), optando por encaminhar as discussões a partir de dois grupos de alunos, em períodos distintos de sua trajetória na graduação - um deles (Grupo 1) com alunos, em média, cursando a primeira metade do curso - e o outro (Grupo 2) com alunos, em média, cursando as disciplinas do final do curso.

Com os dados pudemos compor um quadro de caracterização geral dos licenciandos com relação a aspectos como escolaridade do pai, tipo de escola em nível médio, tipo de ingresso, atuação profissional, além de intenções e expectativas futuras na carreira docente.

Os resultados revelam que, em média, $2 / 3$ desses alunos igualam ou superam a escolaridade de seus pais no momento em que estão; se olharmos separadamente os percentuais nos Grupos, a mobilidade é maior no Grupo 2, ou seja, dos 'mais velhos' no curso. 
Cerca de $80 \%$ dos alunos respondentes ingressou via vestibular, em média e em ambos os grupos. Em média, $3 / 5$ cursou o nível médio em escola pública, sendo o percentual um pouco maior no Grupo 1 comparado com o Grupo 2.

Mais de 30\% desses licenciandos, em média, leciona (maior índice no Grupo 2); pouco menos de $50 \%$ exerce outra atividade (taxas iguais nos dois Grupos) e uns $20 \%$ não trabalha (maior percentual no Grupo 1). Dentre os que lecionam, em média, $80 \%$ o fazem junto à rede particular de ensino.

Desse quadro de características gerais, podemos inferir que o capital cultural não influi diretamente sobre a progressão no curso, ainda que os alunos vindos de escola particular apresentem uma pequena "vantagem". No entanto, essa é apenas uma hipótese consistente, podendo também haver outras explicações plausíveis. Nesse caso, seria mais prudente concluir que, depois do ingresso, a influência do capital cultural não é expressiva nem determinante.

Quanto à declaração, agora, das intenções que os levaram a escolher a Licenciatura em Física e das intenções para quando concluírem a graduação, em média, 50\% dos alunos afirma que no ingresso desejavam Ser Professor e 39\% pretendem seguir a carreira docente após o término do curso. Desse e de outro ponto de vista, fica claro que há uma diminuição da intenção em ser professor, ou uma desistência da opção pela carreira docente.

De modo geral, $80 \%$ dos licenciandos acredita que sua visão do que é a Física mudou a partir das disciplinas já cursadas, sendo um percentual maior para o Grupo 2. Dentre estes, a ideia de ciência/física como aquela relacionada a compreensão da Natureza da Ciência, é percebida nas declarações de cerca de $25 \%$ dos licenciandos e, pouco menos de $40 \%$ parecem ter uma visão que considera prioritariamente a abrangência da física.

Com relação à visão do que é ser professor, $2 / 3$ acreditam ter mudado sua ideia/concepção ao longo de sua trajetória no curso. A despeito destas declarações, procuramos verificar, na comparação entre os Grupos, a natureza desta mudança bem como estabelecer categorias que nos auxiliasse no entendimento das concepções/representações do Ser Professor destes licenciandos. Em média, 50\% deles (um pouco mais no Grupo 1) 
apresenta uma concepção de professor com foco no ensino, na qual dá-se ênfase à técnica e a transmissão do conhecimento. Cerca de 30\%, em média (índices praticamente iguais em ambos os Grupos), já esboçam uma ideia de professor que considera o aluno como parte do processo educativo, com foco na aprendizagem. E, um percentual pequeno, mas relevante, em média, 5\% (2\% no Grupo 1 e $8 \%$ no Grupo 2) apresenta uma concepção de professor com perspectivas educacionais mais amplas. Ainda temos um índice em torno de $15 \%$ ( $6 \%$ para o Grupo 1 e 26\% para o Grupo 2) de alunos que não deixam claro a ideia de professor que os acompanha neste momento porém indicam, de algum modo, que - sobretudo pela diferença entre os Grupos - aqueles que estão mais avançados no curso não mais permanecem com a ideia de professor técnico e transmissor de conhecimento.

Ou seja, esse último conjunto de resultados, tanto no que diz respeito à concepção de ciência/física como no que se refere às representações do professor, o curso de Licenciatura parece ter resultado em um impacto significativo sobre as idéias dos alunos. Esse seria o aspecto positivo, que é contrabalançado pelo maior número de desistências em ser professor, que seria um aspecto negativo. De qualquer forma, embora possam ser identificadas evoluções na forma de conceber ser professor de física, ainda assim, os resultados não são tão expressivos como se poderia desejar. 


\section{CAPÍTULO 8 - CONSIDERAÇÕES FINAIS}

Da proposta inicial deste trabalho - a busca pela caracterização do perfil e identidade profissional de alunos ao longo de um Curso de Licenciatura em Física - acreditamos ter concluído que tal busca se manifesta, se concretiza, de fato, por meio de discussões e olhares que revelam, segundo esta ou aquela perspectiva, aspectos relevantes que dão forma e significado aos resultados obtidos. Isso significa que essa diversidade é múltipla, e sua caracterização depende, em certa medida, da perspectiva adotada.

Esperamos, nestas considerações finais, buscar sistematizar um quadro geral com as conclusões mais importantes acerca da questão de pesquisa, isto é, responder a contento apesar da limitação dos instrumentos utilizados - sobre quem é o aluno do curso de Licenciatura em Física, considerando as condições sócio-culturais destes sujeitos e procurando compreender de que forma sua relação com a identidade de ser professor, bem como as ideias e concepções sobre a física, influenciam em sua trajetória no curso e nas perspectivas profissionais para além dele.

A investigação desenvolveu basicamente um olhar sobre três momentos por que passa o licenciando durante a graduação: o ingresso, o percurso e o egresso. Do ingressante, procuramos caracterizar o perfil sócio-cultural, direcionando o olhar sobre a mobilidade intergeracional em educação e seus aspectos mais relevantes e, também, sobre as expectativas por trás de suas escolhas, assim como das representações de ciência e de professor desses alunos. No percurso, novamente as análises ocorreram em relação às expectativas profissionais dos licenciandos e suas concepções e ideias sobre a física e sobre o professor, além das perspectivas profissionais futuras.

Essas análises ocorreram, em um primeiro momento, considerando uma turma específica, confrontando as expectativas, o tipo de encerramento e a (co)relação entre evasão e número de créditos. Em um segundo momento, considerando os alunos hoje no curso e obtendo - a partir da comparação entre dois grupos em períodos distintos indicativos de evolução, sobretudo das representações dos licenciandos. Com respeito aos 
egressos, foram analisados dados referentes ao panorama de evasão e dos concluintes em um período de 14 anos.

Nossa investigação mostrou que existe certo contraste e/ou diferenças significativas entre esses momentos, manifestando a existência de uma dinâmica subjacente ao próprio curso.

Assim, os circuitos da pesquisa seguiram com o intuito de compreender que aspectos sócio-culturais e representações sociais estão por trás da escolha que faz ao se matricular no curso e que são decisivos (ou não) para sua permanência e trajetória na graduação situando suas perspectivas e encaminhamentos de ordem profissional.

As abordagens que contemplaram o estudo do perfil sócio-cultural nos mostraram considerando carreiras que correspondem a status diferenciados - que os cursos de formação de professores apresentam status sociais menos privilegiados em relação a carreiras de medicina ou engenharia, por exemplo. Isso se expressa por um índice consideravelmente alto de mobilidade intergeracional em educação, associado a percentuais mais baixos de renda familiar e escolarização em nível médio majoritariamente de escola pública.

A amostra estudada apresenta um perfil sócio-cultural bem definido que, por um lado, parece atraído pelo curso com vistas a uma ascensão cultural e, por outro, apresenta uma desmotivação em optar pela carreira docente durante seu percurso, talvez influenciado - sobretudo - pela desvalorização profissional por que passa tal segmento.

Assim, identificamos aspectos que revelaram uma realidade parcialmente controversa, ao mostrar que a decisão por ingressar em um curso de formação de professores pode estar desvinculada - em cerca de um terço dos casos - da perspectiva em seguir a carreira docente. Analisando com mais atenção, mesmo dentre aqueles que de algum modo afirmam a pretensão em tornar-se professor, no momento do ingresso, uma fração considerável se mostra - no fundo - mais interessada nas facilidades para a entrada no mercado de trabalho e estabilidade profissional. Isso indica, de certa forma, que a 
intenção deste aluno pode ser apenas a de obter capital cultural institucionalizado, como afirma Bourdieu, contemplando a importância de um diploma de nível universitário.

Bourdieu (1998a) observa que o capital cultural pode se apresentar em três modalidades: objetivado, incorporado ou institucionalizado. O primeiro diz respeito à propriedade de objetos culturais valorizados (livros e obras de arte). O segundo se refere à cultura legítima internalizada pelo indivíduo (habilidades linguísticas, postura corporal, crenças, conhecimentos, preferências, hábitos e comportamentos relacionados à cultura dominante adquiridos e assumidos pelo sujeito). O terceiro se refere à posse de certificados escolares, que tendem a ser socialmente utilizados como atestados de certa formação cultural (Nogueira e Nogueira, 2009, p. 35).

Além disso, embora as características socioculturais sejam um fator preponderante no ingresso ao curso, nossos resultados indicam que esses mesmos aspectos perdem peso no decorrer dos anos, no sentido de não mais serem determinantes para o sucesso (ou não) de sua trajetória, em termos de conclusão ou tempo de permanência, nem como na decisão de permanência no curso e opção pela carreira docente. Ou seja, nos limites desse trabalho, não foi possível estabelecer nenhuma correlação específica envolvendo essas influências, ao longo do curso.

Das expectativas dos licenciandos quanto à opção em seguir a carreira docente, os resultados mostram que, se já no ingresso cerca de um terço explicita não querer ser professor, mais preocupante, conforme visto, é o fato de que o percentual de alunos que pretendem exercer a profissão de professor de física diminui com o passar dos anos, durante a graduação.

Outra evidência importante está relacionada ao confronto entre expectativas profissionais de ingresso e as taxas de evasão e conclusão da licenciatura em física. Os dados nos mostram que as expectativas dos licenciandos quando de seu ingresso não são determinantes para seu sucesso em termos de conclusão do curso e em tempo ideal. Ou seja, por exemplo, o fato de o aluno declarar na ocasião da matrícula que sua pretensão é tornar-se professor, não fará com que tenha maiores ou menores chances de conclusão da licenciatura.

De todo modo, a alta taxa de evasão indica que as expectativas da maior parte daqueles que ingressam na licenciatura não são alcançadas. E, conforme indicam os dados, o 
expressivo percentual de desistência e/ou interrupção corresponde aos alunos que avançam pouco no curso.

Assim, grande parte dos licenciandos vivencia, durante seu curso, em maior ou menor grau, a dúvida em terminar ou não o curso. As dificuldades e a perspectiva limitada em termos do mercado de trabalho concorrem com a possibilidade de um diploma de nível superior, que Ihes poderia proporcionar um melhor status. Seu desempenho nas disciplinas e nas atividades pode estar sinalizando, em alguns momentos, esse embate.

Segundo Bourdieu, a competência exigida pela "escolha" das melhores estratégias objetivas (por exemplo, a escolha de uma carreira profissional) é repartida de modo muito desigual, uma vez que varia quase exatamente como o poder do qual depende o êxito dessas estratégias. As aspirações efetivas, capazes de orientar realmente as práticas, não têm nada em comum com as aspirações sonhadas, ou com os simples projetos, projeções conscientes e explícitas possíveis que venham a acontecer ou não e expressamente constituídas como fins da ação destinada a fazê-los advir. A vocação efetiva inclui, enquanto disposição adquirida dentro de certas condições sociais, a referência às suas condições de realização de modo que tende a ajustar-se às potencialidades objetivas (Bourdieu, 1998, p. 88-89).

A propensão a abandonar os estudos é tanto mais forte - permanecendo iguais todos os outros fatores (e, em particular, o êxito escolar) - quanto mais fracas forem, para a classe de origem, as chances objetivas de acesso aos níveis mais elevados do sistema de ensino; e os efeitos dessa causalidade do provável são observados para além das práticas e até nas representações subjetivas do futuro e na expressão declarada das esperanças (Bourdieu, 1998, p. 89).

As abordagens que procuraram contemplar o estudo das representações dos licenciandos, sobre a física e sobre o ser professor, revelaram resultados importantes para a caracterização da identidade desses alunos. Para Dotta (2006):

as representações sociais enquanto sistemas de interpretação que regem as relações das pessoas com o mundo e com os outros, orientam e organizam as condutas e comunicações sociais, interferindo em processos variados como a difusão e assimilação dos conhecimentos, o desenvolvimento individual $e$ coletivo, a definição das identidades pessoais e sociais, a expressão dos grupos e as transformações sociais (Dotta, 2006, p. 22-23). 
Com relação às ideias e concepções dos licenciandos acerca da física, os dados indicam que a fração mais representativa a entendem, no momento do ingresso, como associada à compreensão da natureza, do mundo, de forma genérica. Considerando, principalmente, as informações fornecidas pelos licenciandos em percurso, na comparação entre grupos em períodos distintos na trajetória, fica evidente a mudança de sua concepção com o avanço no curso.

Nesse caso, o impacto do curso pode ser inferido de duas formas. Uma delas, a partir da comparação entre o que revelam os questionários de ingressantes e aqueles respondidos por alunos ainda em percurso. Outra, por meio do confronto entre as ideias e concepções reveladas pelos dois grupos de licenciandos em percurso, que se encontram em momentos distintos da trajetória do curso. Com base na primeira, podemos afirmar que o ingressante traz uma ideia da física associada à compreensão de mundo com destaque para aspectos relacionados a entusiasmo e deslumbramento pela ciência e que tal empolgação diminui com o passar de alguns anos, dando lugar às preocupações de ordem técnica e relacionada aos problemas com as disciplinas da graduação. A segunda forma nos permite concluir que, embora transcorrida metade do curso, a ideia da física como compreensão ampla de mundo não aparece com evidência e para aqueles que estão cursando as últimas disciplinas, concepções mais críticas em relação à natureza da ciência passam a ter destaque na visão dos licenciandos.

Da análise das perspectivas profissionais daqueles que ingressam no curso com a intenção de serem professores de física, podemos destacar dentre as inúmeras representações, características que remetem tanto a concepções e imagens mais tradicionais, relacionadas ao profissional técnico - responsável pela transmissão do conhecimento - como representações em que abrem espaço para a ação do professor na perspectiva de mudança na visão de mundo dos alunos, com indicativos de transformação e criticidade do ponto de vista da formação e atuação. Embora a primeira citada seja a concepção majoritária, foi possível evidenciar que ao longo do curso tal quadro se modifica de modo satisfatório, visto que há certa tendência na diminuição de ideias e concepções 
relacionadas à racionalidade técnica do professor, e aumento daquelas com perspectivas educacionais mais amplas.

Os indicativos nos levam a crer que o curso de formação inicial tem um impacto significativo - embora menor do que o desejado - sobre as ideias e representações de ciência, educação e perfil profissional dos licenciandos, uma vez que estas se modificam e se articulam, no espaço de alguns anos, como resultado das interações e ações que os alunos vivenciam.

Entendemos que a busca por uma caracterização do licenciando em física contribui de maneira expressiva com indicativos para ponderar os cursos de formação de professores nessa área.

Considerando as limitações de um trabalho dessa natureza frente à complexidade dos dados, talvez a contribuição mais significativa que possamos ter demonstrado é a necessidade de considerar as características dos alunos e suas expectativas, como elementos fundamentais no planejamento e nas ações ao longo da graduação. Mais do que um perfil idealmente concebido, nos projetos pedagógicos de curso, a realidade e expectativas concretas dos alunos deveriam receber maior atenção.

Nosso estudo evidencia a necessidade do reconhecimento dessas características na própria organização curricular, deixando de considerar o grupo de alunos idealmente, como equivalente aos que optaram por outras carreiras.

Ao mesmo tempo, e sobretudo, aponta para a necessidade de promover um contínuo processo de discussão sobre a construção da identidade profissional do professor, ao longo do curso. A própria tomada de consciência acerca dessas questões e tensões, por parte dos alunos, poderia contribuir para um melhor encaminhamento das decisões que eles venham a tomar durante a graduação.

Assim, nossos resultados vêm reforçar a premissa de que essa identidade deve ser objeto, ela mesma, de atenção. Levando em conta suas particularidades, seja do ponto de vista social, seja do ponto de vista de suas perspectivas pessoais e profissionais, será necessário buscar formas de promover a construção de uma identidade profissional, para 
além do trabalho desenvolvido nas disciplinas, particularmente para aqueles cursos em que as disciplinas iniciais privilegiam principalmente conhecimentos de Física. Isso poderia significar, por exemplo, promover espaços de discussão, ao longo do curso e para além das disciplinas individuais, reconhecendo que um currículo é mais do que apenas a justaposição de disciplinas.

Dessa forma, consideramos fundamental que cada instituição procure buscar as formas apropriadas de contemplar esses aspectos nos projetos político-pedagógicos dos cursos que oferecem. Ao mesmo tempo, reconhecemos que a aproximação à identidade dos licenciandos, desenvolvida em nosso trabalho, é ainda muito limitada e que novos e mais abrangentes estudos precisam ser desenvolvidos, de forma a que se possa instaurar uma cultura de identidade nos diversos cursos de formação. 


\section{REFERÊNCIAS}

ALMEIDA, A. M. F. A noção de Capital Cultural é útil para se pensar o Brasil? In: PAIXÃO, L.P; ZAGO, N. (orgs) Sociologia da Educação - Pesquisa e realidade brasileira. Petrópolis: Editora Vozes, 2007.

ALVES, J. A. P.; CARVALHO, W. L. P; MION, R. A. A formação inicial de professores de física e a construção da identidade de professor e pesquisador. In: XII Encontro de Pesquisa em Ensino de Física, 2010. Águas de Lindóia/ SP. Anais do XI EPEF, p. 1-11, 2010. Disponível em: http://www.sbf1.sbfisica.org.br/eventos/epef/xii/sys/resumos/T0178-1.pdf. Acesso em: 03/02/2011.

ANDRÉ, M. A produção acadêmica sobre formação de professores: um estudo comparativo das dissertações e teses defendidas nos anos 1990 e 2000. Revista Brasileira de Pesquisa sobre Formação de Professores, v. 1, n. 1, ago-dez 2009.

ANDRÉ, M.; SIMÕES, R. H. S.; CARVALHO, J. M.; BRZEZINSKI, I. Estado da Arte da Formação de Professores no Brasil. Educação \& Sociedade, ano XX, n. 68, p. 301-309, dezembro 1999. Disponível em: http://www.scielo.br/pdf/es/v20n68/a15v2068.pdf. Acesso em: 03/02/2011.

AOKI, Suely; KAWAMURA, Maria Regina D. Acompanhamento da progressão dos alunos em um curso de licenciatura. Trabalho apresentado no XIV Simpósio Nacional de Ensino de Física, Natal, 2001.

BACCON, A. L. P.; ARRUDA, S. M. A formação inicial de professores de física: uma questão de estilo? In: VI Encontro Nacional de Pesquisa em Educação em Ciências, 2007. Florianólpolis/SC. Anais do VI ENPEC, p. 1-12. 2007. Disponível em: http://www.fae.ufmg.br/abrapec/viempec/viempec/CR2/p699.pdf. Acesso em: 03/02/2011.

BARDIN, L., Análise de Conteúdo. Portugal, Edições 70-Brasil, 2009.

BARROSO, Marta F.; FALCÃO, Eliane B.M. Evasão universitária: o caso do Instituto de Física da UFRJ. IX Encontro Nacional de Pesquisa em Ensino de Física. Jaboticatubas, 2004 (Atas).

BEJARANO, N. R.R.; CARVALHO, A. M. P. Tornando-se professor de ciências: crenças e conflitos. Revista Ciência \& Educação, v. 9, n. 1, p. 1-15, 2003.

BOURDIEU, P. A Escola conservadora: as desigualdade frente à escola e à cultura. In: NOGUEIRA, MA.; CATANI, A.M. (orgs) Escritos de Educação. Petrópolis: Editora Vozes, 2003.

BOURDIEU, P. A força da representação. In: A Economia das trocas lingüísticas: o que falar quer dizer. São Paulo: EDUSP, 1996.

BOURDIEU, P. Algumas propriedades dos Campos. In: Questões de Sociologia. Editora Marco Zero. Rio de Janeiro, p.119-126, 1983. 
BOURDIEU, P. Futuro de classe e causalidade do provável. In: NOGUEIRA, MA.; CATANI, A.M. (orgs) Escritos de Educação. Petrópolis: Editora Vozes, 1998.

BOURDIEU, P. O Poder simbólico. Rio de Janeiro/Lisboa: DIFEL/Bertrand Brasil, 1989.

BRZEZINSKI, I.; GARRIDO, E. Análise dos trabalhos do GT Formação de Professores: o que revelam as pesquisas do período 1992-1998. Revista Brasileira de Educação,n. 18, p. 82-100, set/out/nov/dez 2001.

CASTRO, G. F.; BARBOSA-LIMA, M. C. Formação inicial de um professor de física: estudo de caso. In: X Encontro de Pesquisa em Ensino de Física, 2006. Londrina/SP. Anais do X EPEF, p. 1-11, 2006. Disponível em: http://www.sbf1.sbfisica.org.br/eventos/epef/x/sys/resumos/T01641.pdf. Acesso em: 03/02/2011.

CASTRO, G. F.; QUEIROZ, G. A formação inicial de professores de física a partir da prática de projetos. In: VI Encontro Nacional de Pesquisa em Educação em Ciências, 2007. Florianólpolis/SC. Anais do VI ENPEC, p. 1-12. 2007. Disponível em: http://www.fae.ufmg.br/abrapec/viempec/viempec/CR2/p400.pdf. Acesso em: 03/02/2011.

CASTRO, J. A. Evolução e desigualdade na educação brasileira. Educação \& Sociedade. Vol.30, n.108. Campinas, out/2009.

CHARTIER, R. O Mundo como Representação. Estudos Avançados, 11(5), p.173-191, janabr/1991. Disponível em: http://www.scielo.br/scielo.pid php? =\$010340141991000100010\&script=sci arttext. Acesso em: 02/03/2011.

COIMBRA, D.; LINDINO, T. C. Concepções e crenças de professores em início do exercício de docência: um estudo de caso. In: XVII Simpósio Nacional de Ensino de Física, 2007. São Luís/MA. Anais do XVII SNEF, p. 1-10, 2007. Disponível em: http://www.sbf1.sbfisica.org.br/eventos/snef/xvii/sys/resumos/t0139-1.pdf. Acesso em: 03/02/2011.

CONTRERAS, J. A autonomia de professores. São Paulo, Cortez Editora, 2002.

CORRÊA, Ana Carolina Costa; NORONHA, Adriana Backx. Avaliação da evasão e permanência prolongada em um curso de graduação em administração de uma universidade pública. VII SEMEAD, Faculdade de Economia e Administração-USP. São Paulo, 2003.

DALRI, J.; MATTOS, C. R. Relações entre motivação, valor e perfil conceitual: um exemplo. In: VI Encontro Nacional de Pesquisa em Educação em Ciências, 2007. Florianólpolis/SC. Anais do VI ENPEC, p. 1-12. 2007. Disponível em: http://www.fae.ufmg.br/abrapec/viempec/viempec/CR2/p764.pdf. Acesso em: 03/02/2011.

DOTTA, L. T. Representações Sociais do Ser Professor. Campinas, SP: Editora Alínea, 2006.

ERTHAL, J. P. C; LINHARES, M. P. Identificação de visões de ciências de licenciandos em física da região norte fluminense. In: XII Encontro de Pesquisa em Ensino de Física, 2010. 
Águas de Lindóia/ SP. Anais do XI EPEF, p. 1-11, 2010. Disponível em: http://www.sbf1.sbfisica.org.br/eventos/epef/xii/sys/resumos/T0023-1.pdf. Acesso em: 03/02/2011.

FERREIRA, S. G.; VELOSO, F. A. Mobilidade Intergeracional em Educação no Brasil. Pesquisa e planejamento econômico (PPE). Vol. 33, n. 3, dez/2003.

FUSINATO, Polonia Altoé; ZERMIANI, Aldolino. FREGONEIS, Jucelia G. P. Panorama do Curso de Física da Universidade Estadual de Maringá. VI Encontro Nacional de Pesquisa em Ensino de Física, Florianópolis, Outubro de 1998 (Atas).

FUVEST. Questionário de Avaliação Sócio-Econômica. 2000 e 2009. www.fuvest.br

GATTI, S. R. T.; SILVA, D.; NARDI, R. Um estudo sobre a evolução de concepções de futuros docentes de física em um curso de formação inicial. In: XVII Simpósio Nacional de Ensino de Física, 2007. São Luís/MA. Anais do XVII SNEF, p. 1-10, 2007.

GOBARA, S. T.; GARCIA, J. R. B. As licenciaturas em física das universidades brasileiras: um diagnóstico da formação inicial de professores de física. Revista Brasileira de Ensino de Física, v. 29, n. 4, p. 519-525, 2007.

HIGA, I., Visão de professores sobre ciência: elementos para repensar os cursos de licenciatura em Física. Tese de Doutorado, Faculdade de Educação da USP, 2005.

Impacto do INCLUSP e do Programa de Avaliação Seriada da USP no vestibular FUVEST 2009. Disponível em: http://www.usp.br/prg/site/images/stories/arquivos/impactolnclusp 16abril2009.pdf

LAWN, Martin. Os professores e a fabricação de identidades. NÓVOA, A. \& SCHRIEWER, J. A difusão mundial da escola. Lisboa: EDUCA, 2000, p. 69-84. Disponível em: http://www.oei.es/docentes/articulos/profesores fabricacion identidades lawn.pdf

LEME, Luciana França. Contribuições de um Estudo Sobre Perfil e Expectativa de Ingressantes do Curso de Pedagogia da USP à Atratividade da Carreira Docente. Projeto de Pesquisa. Faculdade de Educação - USP, 2008.

MARTINS, M. A. R; MARTINS, A. M.; ABDALLA, M. F. B. Representações Sociais sobre o Trabalho Docente de Estudantes de Licenciaturas. In: 31a Reunião Anual da Anped. Caxambú, 2008.

MENIN, M. S. S.; SHIMIZU, A. M.; LIMA, C. M. A Teoria das Representações Sociais nos Estudos sobre Representação de Professores. Cadernos de Pesquisa, v. 39, n. 137, p. 549576, maio/ago 2009.

NOGUEIRA, M. A; NOGUEIRA, C. M. M. Bourdieu \& a Educação. 3 ed. - Belo Horizonte: Autêntica, 2009.

OLIVEIRA, R.V.B.C., O professor de física e sua prática: perspectivas de uma reelaboração crítica. Tese de Doutorado, Faculdade de Educação da USP, 2006. 
OSTERMANN, F.; MOREIRA, M. A. Atualização do currículo de física na escola de nível médio: um estudo dessa problemática na perspectiva de uma experiência em sala de aula e da formação inicial de professores. Caderno Catarinense de Ensino de Física, v. 18, n. 2: p. 135-150, ago. 2001.

PEREIRA, G. R. M. Servidão Ambígua: valores e condições do magistério. São Paulo: Escrituras Editora, 2001.

PIMENTA, S. G. e OUTROS. O impacto do INCLUSP no ingresso de estudantes da escola pública na USP - análises iniciais. FEUSP. São Paulo, 2008.

PRÓ-REITORIA DE GRADUAÇÃO - Universidade de São Paulo. Acompanhamento da trajetória escolar dos alunos da Universidade de São Paulo; ingressantes de 1995 a 1998. Relatório Final. São Paulo. 2004.

ROMANELLI, G. O Significado da Educação Superior para Duas Gerações de Famílias de Camadas Médias. Revista Brasileira de Estudos Pedagógicos. Vol. 76, n.184, set/dez, 1995. Disponível em: http://www.rbep.inep.gov.br/index.php/RBEP/article/viewFile/268/269

SALEM, S.; KAWAMURA, M. R. D. Estado da Arte dos Estados da Arte da Pesquisa em Ensino de Física. In: VII Encontro Nacional de Pesquisa em Educação em Ciências, 2009. Florianópolis/SC. Anais do VII ENPEC, p. 1-9, 2009. Disponível em: http://www.fae.ufmg.br/abrapec/viempec/7enpec/pdfs/novo 06.pdf. Acesso em: 03/02/2011.

SHIMIZU, A. M.; GOMES, A. A.; ZECHI, J. A. M.; MENIN, M. S. S.; LEITE, Y. U. F. Representações Sociais sobre Identidade e Trabalho Docente: A Formação Inicial em Foco. In: 31a Reunião Anual da Anped. Caxambú, 2008. Disponível em: http://www.anped.org.br/reunioes/31ra/1trabalho/GT08-4278--Res.pdf. Acesso em: 03/02/2011.

SILVA, A. P. S.; CARVALHO, C. M.; MUNFORD, D. Formação de professores de ciências: revisão de periódicos (2006-2007). In: VII Encontro Nacional de Pesquisa em Educação em Ciências, 2009. Florianópolis/SC. Anais do VII ENPEC, p. 1-9, 2009. Disponível em: http://www.fae.ufmg.br/abrapec/viempec/7enpec/pdfs/892.pdf. Acesso em: 03/02/2011.

SLONGO, I. I. P.; DELIZOICOV, N. C.; ROSSET, J. M. A formação de professores nas atas do ENPEC: uma análise preliminar. In: VII Encontro Nacional de Pesquisa em Educação em Ciências, 2009. Florianópolis/SC. Anais do VII ENPEC, p. 1-9, 2009. Disponível em: http://www.fae.ufmg.br/abrapec/viempec/7enpec/pdfs/1396.pdf. Acesso em: 03/02/2011.

SOUZA, C. A., SALEM, S. e KAWAMURA, M.R., Um panorama da evasão e dos concluintes no Curso de Licenciatura em Física na USP: 1997-2007. XVIII Simpósio Nacional de Ensino de Física, SBF, UFES, Vitória, ES, Janeiro de 2009.

TARDIF, M. Saberes Docentes e Formação Profissional. 10 ed. Petrópolis, RJ: Vozes, 2010.

TERRAZAN, E. A; DUTRA, Edna Falcão; WINCH, Paula Gaida; SILVA, A. A. Configurações Curriculares de Cursos de Licenciatura e Formação identitária de Professores. In: VI 
Encontro Nacional de Pesquisa em Educação em Ciências, 2007. Florianólpolis/SC. Anais do VI ENPEC, p. 1-12. 2007.

VICENTINI, Paula P.; LUGLI, Rosário G. História da profissão docente no Brasil: representações em disputa. Biblioteca básica da história da educação brasileira; v.4. São Paulo: Cortez, 2009. 


\section{ANEXOS}

ANEXO A - Dados sobre Mobilidade Intergeracional de Ingressantes USP 


\begin{tabular}{|c|c|c|c|c|c|c|c|c|c|}
\hline \multicolumn{10}{|c|}{2009} \\
\hline \multicolumn{2}{|r|}{ Carreiras } & \multicolumn{4}{|c|}{ Escolaridade do pai (\%) } & \multicolumn{4}{|c|}{ Escolaridade da mãe (\%) } \\
\hline & & (I) & (II) & (III) & (IV) & (I) & (II) & (III) & (IV) \\
\hline \multirow[t]{3}{*}{ Bloco 1} & Direito & 10,9 & 12,3 & 7,6 & 68,6 & 9,9 & 14,5 & 8,4 & 66,8 \\
\hline & Engenharia & 7,6 & 11,2 & 9,9 & 70,9 & 8,2 & 15,8 & 8,1 & 67,4 \\
\hline & Medicina & 9,7 & 11,4 & 8,5 & 69,9 & 10,2 & 14,1 & 8,5 & 66,8 \\
\hline \multirow[t]{3}{*}{ Bloco 2} & Lic. Ciências Exatas - SC & 26 & 24 & 12 & 38 & 28 & 34 & 6 & 32 \\
\hline & Lic. Matemática/Física & 40,5 & 21,8 & 7,4 & 28,4 & 40,1 & 24,4 & 8,1 & 27,1 \\
\hline & Pedagogia & 36 & 16,7 & 11,7 & 35,1 & 33 & 18,4 & 7,8 & 38,4 \\
\hline Bloco 3 & Total Geral USP & 18,3 & 18,2 & 9,8 & 53,2 & 17,2 & 21,7 & 8,8 & 51,9 \\
\hline
\end{tabular}

\begin{tabular}{|c|c|c|c|c|c|c|c|c|c|}
\hline \multicolumn{10}{|c|}{2007} \\
\hline \multirow{2}{*}{\multicolumn{2}{|c|}{ Carreiras }} & \multicolumn{4}{|c|}{ Escolaridade do pai (\%) } & \multicolumn{4}{|c|}{ Escolaridade da mãe (\%) } \\
\hline & & (I) & (II) & (III) & (IV) & (I) & (II) & (III) & (IV) \\
\hline \multirow[t]{3}{*}{ Bloco 1} & Direito & 25,8 & 15,7 & 8,1 & 50,3 & 26,1 & 19,1 & 8,1 & 46,7 \\
\hline & Engenharia & 18,7 & 17,9 & 10,7 & 52,7 & 18,2 & 23,2 & 10,0 & 48,6 \\
\hline & Medicina & 18,6 & 16,4 & 9,2 & 55,7 & 17,1 & 20,6 & 8,3 & 54,0 \\
\hline \multirow[t]{3}{*}{ Bloco 2} & Lic. Ciências Exatas - SC & 63,3 & 18,6 & 5,3 & 12,8 & 60,2 & 26,7 & 4,2 & 8,9 \\
\hline & Lic. Matemática/Física & 60,5 & 19,6 & 6,3 & 13,5 & 60,7 & 21,5 & 5,9 & 11,8 \\
\hline & Pedagogia & 66,0 & 14,9 & 4,7 & 14,4 & 63,5 & 19,4 & 4,8 & 12,3 \\
\hline Bloco 3 & Total Geral USP & 31,9 & 20,1 & 9,0 & 39,0 & 30,9 & 23,6 & 8,0 & 37,6 \\
\hline
\end{tabular}

\begin{tabular}{|c|c|c|c|c|c|c|c|c|c|}
\hline \multicolumn{10}{|c|}{2005} \\
\hline \multirow{2}{*}{\multicolumn{2}{|c|}{ Carreiras }} & \multicolumn{4}{|c|}{ Escolaridade do pai (\%) } & \multicolumn{4}{|c|}{ Escolaridade da mãe (\%) } \\
\hline & & (I) & (II) & (III) & (IV) & (I) & (II) & (III) & (IV) \\
\hline \multirow[t]{3}{*}{ Bloco 1} & Direito & 29,4 & 15,5 & 8,3 & 46,8 & 29,8 & 19,3 & 7,9 & 43,1 \\
\hline & Engenharia & 23,7 & 18,5 & 10,0 & 47,9 & 24,2 & 23,0 & 10,1 & 42,7 \\
\hline & Medicina & 20,3 & 16,0 & 8,6 & 55,1 & 19,9 & 20,1 & 9,1 & 50,9 \\
\hline \multirow[t]{3}{*}{ Bloco 2} & Lic. Ciências Exatas - SC & 62,5 & 25,2 & 5,9 & 6,4 & 64,6 & 26,6 & 1,5 & 7,4 \\
\hline & Lic. Matemática/Física & 64,0 & 18,3 & 5,4 & 12,2 & 62,3 & 21,5 & 4,1 & 12,1 \\
\hline & Pedagogia & 66,6 & 15,1 & 4,6 & 13,8 & 67,1 & 17,5 & 4,2 & 11,1 \\
\hline Bloco 3 & Total Geral USP & 36,5 & 19,0 & 8,7 & 35,7 & 36,3 & 22,7 & 7,9 & 33,1 \\
\hline
\end{tabular}

\begin{tabular}{|l|l|c|c|c|c|c|c|c|c|}
\hline \multicolumn{9}{|c|}{ Carreiras } & \multicolumn{3}{c|}{ Escolaridade do pai (\%) } & \multicolumn{3}{c|}{ Escolaridade da mãe (\%) } \\
\cline { 3 - 11 } & & (I) & (II) & (III) & (IV) & (I) & (II) & (III) & (IV) \\
\hline \multirow{3}{*}{ Bloco 1 } & Direito & 32,6 & 13,9 & 8,4 & 45,1 & 34,5 & 19,5 & 8,0 & 37,9 \\
\cline { 2 - 11 } & Engenharia & 28,2 & 17,7 & 10,6 & 43,6 & 30,5 & 22,8 & 9,1 & 37,6 \\
\cline { 2 - 11 } & Medicina & 20,7 & 14,4 & 8,9 & 55,9 & 21,9 & 20,1 & 9,4 & 48,6 \\
\hline \multirow{3}{*}{ Bloco 2 } & Lic. Ciências Exatas - SC & 63,9 & 21,7 & 3,9 & 10,4 & 70,0 & 16,5 & 3,9 & 9,7 \\
\cline { 2 - 11 } & Lic. Matemática/Física & 59,7 & 17,3 & 6,5 & 16,1 & 63,2 & 19,0 & 5,6 & 11,8 \\
\cline { 2 - 11 } & Pedagogia & 58,6 & 15,1 & 6,2 & 20,0 & 61,2 & 18,3 & 5,1 & 15,4 \\
\hline Bloco 3 & Total Geral USP & 34,7 & 17,2 & 9,2 & 39,0 & 36,6 & 21,5 & 8,4 & 33,6 \\
\hline
\end{tabular}

\begin{tabular}{|l|l|c|c|c|c|c|c|c|c|}
\hline \multicolumn{9}{|c|}{ Carreiras } & \multicolumn{3}{c|}{ Escolaridade do pai (\%) } & \multicolumn{3}{c|}{ Escolaridade da mãe (\%) } \\
\cline { 3 - 11 } & & (I) & (II) & (III) & (IV) & (I) & (II) & (III) & (IV) \\
\hline \multirow{3}{*}{ Bloco 1 } & Direito & 12 & 12,3 & 7,4 & 67,9 & 11,9 & 19 & 4,8 & 63,7 \\
\cline { 2 - 11 } & Engenharia & 8,9 & 10,3 & 7,4 & 73 & 12,5 & 14,3 & 10,3 & 62,5 \\
\cline { 2 - 11 } & Medicina & 7,3 & 7,6 & 6,6 & 78,1 & 8,5 & 15,5 & 7,4 & 68,2 \\
\hline \multirow{3}{*}{ Bloco 2 } & Lic. Ciências Exatas - SC & 44 & 24 & 6 & 26 & 54 & 14 & 4 & 28 \\
\cline { 2 - 10 } & Lic. Matemática/Física & 39,3 & 18,7 & 10,5 & 31,1 & 58,6 & 21,8 & 3,9 & 25,3 \\
\cline { 2 - 10 } & Pedagogia & 35,2 & 18,4 & 9,2 & 36,9 & 41,8 & 19,3 & 6,7 & 31,8 \\
\hline Bloco 3 & Total Geral USP & 19,7 & 13,7 & 9,3 & 56,9 & 22,9 & 18,5 & 8,4 & 49,2 \\
\hline
\end{tabular}



(I) - até Ensino Médio incompleto
(II) - Ensino Médio completo

(III) - Ensino Superior incompleto

(IV) - Ensino Superior completo ou mais

\begin{tabular}{|c|c|c|c|c|c|c|c|c|}
\hline \multicolumn{9}{|c|}{2009} \\
\hline \multirow{2}{*}{\multicolumn{2}{|c|}{ Carreiras }} & \multicolumn{3}{|c|}{ Cor de pele } & \multicolumn{4}{|c|}{ Renda Mensal (salários mínimos) } \\
\hline & & $\begin{array}{c}\text { Branca } \\
\text { (\%) }\end{array}$ & $\begin{array}{c}\text { Preta/parda } \\
\text { (\%) }\end{array}$ & $\begin{array}{c}\text { Amarela* } \\
\text { (\%) }\end{array}$ & $\begin{array}{c}\text { Até } 3 \\
\text { (\%) }\end{array}$ & 3 a $5(\%)$ & $\begin{array}{c}5 \text { a } 10 \\
(\%)\end{array}$ & $\begin{array}{c}\text { Mais que } \\
10(\%)\end{array}$ \\
\hline \multirow[t]{3}{*}{ Bloco 1} & Direito & 76,5 & 14,4 & 8,9 & 5,3 & 8,9 & 25,6 & 59,7 \\
\hline & Engenharia & 76,6 & 7,5 & 15,8 & 5,3 & 8,7 & 24,2 & 61,4 \\
\hline & Medicina & 76,6 & 8 & 15,2 & 5,8 & 10,7 & 26,8 & 56,3 \\
\hline \multirow[t]{3}{*}{ Bloco 2} & Lic. Ciências Exatas - SC & 78 & 16 & 6 & 36 & 20 & 28 & 16 \\
\hline & Lic. Matemática/Física & 66,6 & 25,9 & 7,2 & 26,7 & 24,1 & 29,9 & 18,9 \\
\hline & Pedagogia & 72,3 & 19,6 & 7,9 & 24,1 & 16,2 & 31,9 & 27,4 \\
\hline Bloco 3 & Total Geral USP & 77,6 & 13,5 & 8,7 & 12,9 & 16,8 & 31 & 38,9 \\
\hline
\end{tabular}

$\left({ }^{*}\right)$ Nas carreiras Medicina, Lic. Matemática/Física e Total Geral sem treineiros acrescido de 0,1;0,2 e 0,3, respectivamente, referente à indígena.

\begin{tabular}{|c|c|c|c|c|c|c|c|c|}
\hline \multicolumn{9}{|c|}{2007} \\
\hline \multirow{2}{*}{\multicolumn{2}{|c|}{ Carreiras }} & \multicolumn{3}{|c|}{ Cor de pele } & \multicolumn{4}{|c|}{ Renda Mensal" (salários mínimos) } \\
\hline & & $\begin{array}{c}\text { Branca } \\
(\%)\end{array}$ & $\begin{array}{c}\text { Preta/parda } \\
\text { (\%) }\end{array}$ & $\begin{array}{c}\text { Amarela* } \\
\text { (\%) }\end{array}$ & $\begin{array}{c}\text { Até 1,5 } \\
\text { (\%) }\end{array}$ & $\begin{array}{c}1,5 \text { a } 4,5 \\
(\%)\end{array}$ & $\begin{array}{c}4,5 \text { a } 8,5 \\
(\%)\end{array}$ & $\begin{array}{c}\text { Mais que } \\
8,5(\%)\end{array}$ \\
\hline \multirow[t]{3}{*}{ Bloco 1} & Direito & 74,8 & 19,7 & 5,5 & 5,7 & 21,8 & 20,1 & 52,4 \\
\hline & Engenharia & 72,2 & 14,7 & 13,1 & 3,1 & 19,1 & 24,0 & 53,9 \\
\hline & Medicina & 78,6 & 13,5 & 7,7 & 3,0 & 16,8 & 21,8 & 58,4 \\
\hline \multirow[t]{3}{*}{ Bloco 2} & Lic. Ciências Exatas - SC & 68,4 & 29,0 & 2,6 & 14,2 & 58,4 & 19,5 & 8,0 \\
\hline & Lic. Matemática/Física & 58,0 & 37,2 & 4,8 & 12,4 & 49,7 & 22,6 & 15,1 \\
\hline & Pedagogia & 55,7 & 39,8 & 4,5 & 20,1 & 50,3 & 15,0 & 14,5 \\
\hline Bloco 3 & Total Geral USP & 72,2 & 21,1 & 6,7 & 6,2 & 29,9 & 23,8 & 40,0 \\
\hline
\end{tabular}

* no site FUVEST, as estatísticas são dadas em R\$; para a conversão utilizou-se Salário Mínimo ${ }_{\text {abril/2006 }}=$ R\$ 350,00 (www.tecnocop.kit.net )

\begin{tabular}{|c|c|c|c|c|c|c|c|c|}
\hline \multicolumn{9}{|c|}{2005} \\
\hline \multirow{2}{*}{\multicolumn{2}{|c|}{ Carreiras }} & \multicolumn{3}{|c|}{ Cor de pele } & \multicolumn{4}{|c|}{ Renda Mensal (salários mínimos) } \\
\hline & & $\begin{array}{c}\text { Branca } \\
(\%)\end{array}$ & $\begin{array}{c}\text { Preta/parda } \\
\text { (\%) }\end{array}$ & $\begin{array}{c}\text { Amarela* } \\
(\%)\end{array}$ & $\begin{array}{c}\text { Até } 2 \\
(\%)\end{array}$ & $\begin{array}{c}2 \text { a } 5,5 \\
(\%)\end{array}$ & $\begin{array}{c}5,5 \text { a } \\
11,5(\%)\end{array}$ & $\begin{array}{c}\text { Mais que } \\
11,5(\%)\end{array}$ \\
\hline \multirow[t]{3}{*}{ Bloco 1} & Direito & 74,1 & 20,3 & 5,6 & 7,4 & 23,6 & 20,2 & 48,9 \\
\hline & Engenharia & 69,5 & 17,0 & 13,6 & 4,1 & 24,6 & 25,1 & 46,2 \\
\hline & Medicina & 77,8 & 14,3 & 7,9 & 3,7 & 18,1 & 22,5 & 55,6 \\
\hline \multirow[t]{3}{*}{ Bloco 2} & Lic. Ciências Exatas - SC & 72,4 & 23,2 & 4,4 & 16,3 & 61,1 & 15,8 & 6,9 \\
\hline & Lic. Matemática/Física & 56,0 & 38,6 & 5,3 & 16,7 & 52,3 & 19,3 & 11,7 \\
\hline & Pedagogia & 56,5 & 39,4 & 4,1 & 23,4 & 50,1 & 14,6 & 12,0 \\
\hline Bloco 3 & Total Geral USP & 70,3 & 22,9 & 6,8 & 9,0 & 33,2 & 23,1 & 34,8 \\
\hline
\end{tabular}

* no site FUVEST, as estatísticas são dadas em R\$; para a conversão utilizou-se Salário Mínimo maio/2004 $=$ R\$ 260,00 (www.tecnocop.kit.net )

\begin{tabular}{|c|c|c|c|c|c|c|c|c|}
\hline \multicolumn{9}{|c|}{2002} \\
\hline \multicolumn{2}{|r|}{ Carreiras } & \multicolumn{3}{|c|}{ Cor de pele } & \multicolumn{4}{|c|}{ Renda Mensal (salários mínimos)* } \\
\hline \multirow{2}{*}{ Bloco 1} & Engenharia & 73,0 & 12,9 & 14,1 & 4,6 & 28,0 & 28,6 & 38,9 \\
\hline & Medicina & 83,2 & 8,7 & 8,0 & 3,2 & 18,3 & 23,3 & 65,3 \\
\hline Bloco 2 & Lic. Ciências Exatas - SC & 80,5 & 16,6 & 2,9 & 17,2 & 61,3 & 13,2 & 8,4 \\
\hline Bloco 3 & Total Geral USP & 77,8 & 14,3 & 7,8 & 6,2 & 31,2 & 26,6 & 36,1 \\
\hline
\end{tabular}

* no site FUVEST, as estatísticas são dadas em R\$; para a conversão utilizou-se Salário Mínimo abril/2002 $_{2}$ R\$ 200,00 (www.tecnocop.kit.net ) 


\begin{tabular}{|l|l|c|c|c|}
\hline \multicolumn{2}{|c|}{ Carreiras } & \multicolumn{3}{c|}{ Cor de pele } \\
\cline { 3 - 5 } & & $\begin{array}{c}\text { Branca } \\
(\%)\end{array}$ & $\begin{array}{c}\text { Preta/parda } \\
(\%)\end{array}$ & $\begin{array}{c}\text { Amarela* } \\
\text { (\%) }\end{array}$ \\
\hline \multirow{2}{*}{ Bloco 1 } & Direito & 87 & 3,8 & 8,9 \\
\cline { 2 - 5 } & Engenharia & 76,7 & 4,1 & 19 \\
\cline { 2 - 5 } & Medicina & 75,6 & 3,3 & 21 \\
\cline { 2 - 5 } & Odontologia & 63,6 & 8,2 & 28 \\
\hline \multirow{3}{*}{ Bloco 2 } & Lic. Ciências Exatas - SC & 79,5 & 12,2 & 8,1 \\
\cline { 2 - 5 } & Lic. Matemática/Física & 77,8 & 10 & 11,9 \\
\cline { 2 - 5 } & Pedagogia & 79,6 & 13,5 & 6,7 \\
\hline Bloco 3 & Total Geral sem Treineiros & 80,5 & 6,6 & 12,6 \\
\hline
\end{tabular}

(*) Nas carreiras Engenharia, Medicina, Lic. Matemática/Física, Pedagogia e Total Geral sem treineiros acrescido de 0,2; 0,2; 0,7; 0,8 e 0,4, respectivamente, referente à indígena.

\begin{tabular}{|l|l|c|c|c|}
\hline \multicolumn{2}{|c|}{ Carreiras } & \multicolumn{2}{|c|}{2009} \\
\hline \multirow{2}{*}{} & & \multicolumn{2}{|c|}{ Estudos de ensino médio } \\
\cline { 3 - 5 } & Escola Pública (\%) & $\begin{array}{c}\text { Escola Particular } \\
\text { (\%) }\end{array}$ & Outros (\%) \\
\hline \multirow{3}{*}{ Bloco 1 } & Direito & 26 & 72,6 & 1 \\
\cline { 2 - 5 } & Engenharia & 19,4 & 79,7 & 0,6 \\
\cline { 2 - 5 } & Medicina & 25,4 & 74,1 & 0,2 \\
\hline \multirow{3}{*}{ Bloco 2 } & Lic. Ciências Exatas - SC & 42,7 & 57 & 0 \\
\cline { 2 - 5 } & Lic. Matemática/Física & 61 & 37 & 0 \\
\cline { 2 - 5 } & Pedagogia & 48,2 & 51,5 & 0,7 \\
\hline Bloco 3 & Total Geral USP & 30,4 & 68,3 & 0 \\
\hline
\end{tabular}

\begin{tabular}{|c|c|c|c|c|}
\hline \multicolumn{5}{|c|}{2007} \\
\hline \multicolumn{2}{|r|}{ Carreiras } & \multicolumn{3}{|c|}{ Estudos de ensino médio } \\
\hline & & Escola Pública (\%) & $\begin{array}{c}\text { Escola Particular } \\
(\%)\end{array}$ & Outros (\%) \\
\hline \multirow[t]{3}{*}{ Bloco 1} & Direito & 32,9 & 65,1 & 2,0 \\
\hline & Engenharia & 30,0 & 69,2 & 0,7 \\
\hline & Medicina & 24,0 & 77,7 & 0,6 \\
\hline \multirow[t]{3}{*}{ Bloco 2} & Lic. Ciências Exatas - SC & 77,0 & 20,4 & 2,6 \\
\hline & Lic. Matemática/Física & 72,5 & 24,5 & 3,1 \\
\hline & Pedagogia & 73,6 & 21,6 & 4,7 \\
\hline Bloco 3 & Total Geral USP & 41,5 & 57,1 & 1,3 \\
\hline
\end{tabular}

\begin{tabular}{|l|l|c|c|c|}
\hline \multicolumn{2}{|c|}{ Carreiras } & \multicolumn{2}{|c|}{2005} \\
\hline \multirow{2}{*}{} & & \multicolumn{2}{|c|}{ Estudos de ensino médio } \\
\cline { 3 - 5 } & Escola Pública (\%) & $\begin{array}{c}\text { Escola Particular } \\
\text { (\%) }\end{array}$ & Outros (\%) \\
\hline \multirow{3}{*}{ Bloco 1 } & Direito & 35,3 & 62,3 & 2,3 \\
\cline { 2 - 5 } & Engenharia & 36,0 & 63,2 & 0,9 \\
\cline { 2 - 5 } & Medicina & 23,4 & 75,8 & 0,9 \\
\hline \multirow{3}{*}{ Bloco 2 } & Lic. Ciências Exatas - SC & 80,3 & 15,9 & 4,0 \\
\cline { 2 - 5 } & Lic. Matemática/Física & 75,4 & 22,0 & 2,6 \\
\cline { 2 - 5 } & Pedagogia & 75,6 & 21,1 & 3,3 \\
\hline Bloco 3 & Total Geral USP & 45,9 & 52,4 & 1,5 \\
\hline
\end{tabular}




\begin{tabular}{|l|l|c|c|c|}
\hline \multicolumn{2}{|c|}{ Carreiras } & \multicolumn{2}{|c|}{2002} \\
\cline { 3 - 5 } & & Escola Pública (\%) & $\begin{array}{c}\text { Escola Particular } \\
\text { (\%) }\end{array}$ & \multicolumn{2}{c|}{ Outros (\%) } \\
\hline \multirow{2}{*}{ Bloco 1 } & Direito & 38,0 & 59,8 & 2,2 \\
\cline { 2 - 5 } & Engenharia & 41,4 & 57,7 & 1,0 \\
\cline { 2 - 5 } & Medicina & 23,6 & 75,7 & 0,8 \\
\hline \multirow{3}{*}{ Bloco 2 } & Lic. Ciências Exatas - SC & 74,2 & 23,8 & 1,9 \\
\cline { 2 - 5 } & Lic. Matemática/Física & 69,1 & 27,7 & 2,7 \\
\cline { 2 - 5 } & Pedagogia & 66,2 & 30,9 & 2,9 \\
\hline \multirow{2}{*}{ Bloco 3 } & Total Geral USP & 43,2 & 55,4 & 1,5 \\
\hline
\end{tabular}

\begin{tabular}{|l|l|c|c|c|}
\hline \multicolumn{2}{|c|}{ Carreiras } & \multicolumn{2}{c|}{$\mathbf{2 0 0 0}$} \\
\hline \multirow{4}{*}{} & & \begin{tabular}{c} 
Estudos de ensino médio \\
\cline { 3 - 5 }
\end{tabular} & $\begin{array}{c}\text { Escola Pública (\%) } \\
\text { Escola Particular } \\
\text { (\%) }\end{array}$ & Outros (\%) \\
\hline \multirow{3}{*}{ Bloco 1 } & Direito & 11,1 & 87,9 & 0,6 \\
\cline { 2 - 5 } & Engenharia & 15,2 & 84 & 0,3 \\
\cline { 2 - 5 } & Medicina & 6,3 & 93,2 & 0 \\
\hline \multirow{3}{*}{ Bloco 2 } & Lic. Ciências Exatas - SC & 60 & 38 & 2 \\
\cline { 2 - 5 } & Lic. Matemática/Física & 55,3 & 40,6 & 3,7 \\
\cline { 2 - 5 } & Pedagogia & 39,4 & 58,7 & 0 \\
\hline Bloco 3 & Total Geral USP & 25,1 & 73,3 & 1,2 \\
\hline
\end{tabular}

GRÁFICOS - Dados FUVEST - Questionário de Avaliação Sócio-Econômica
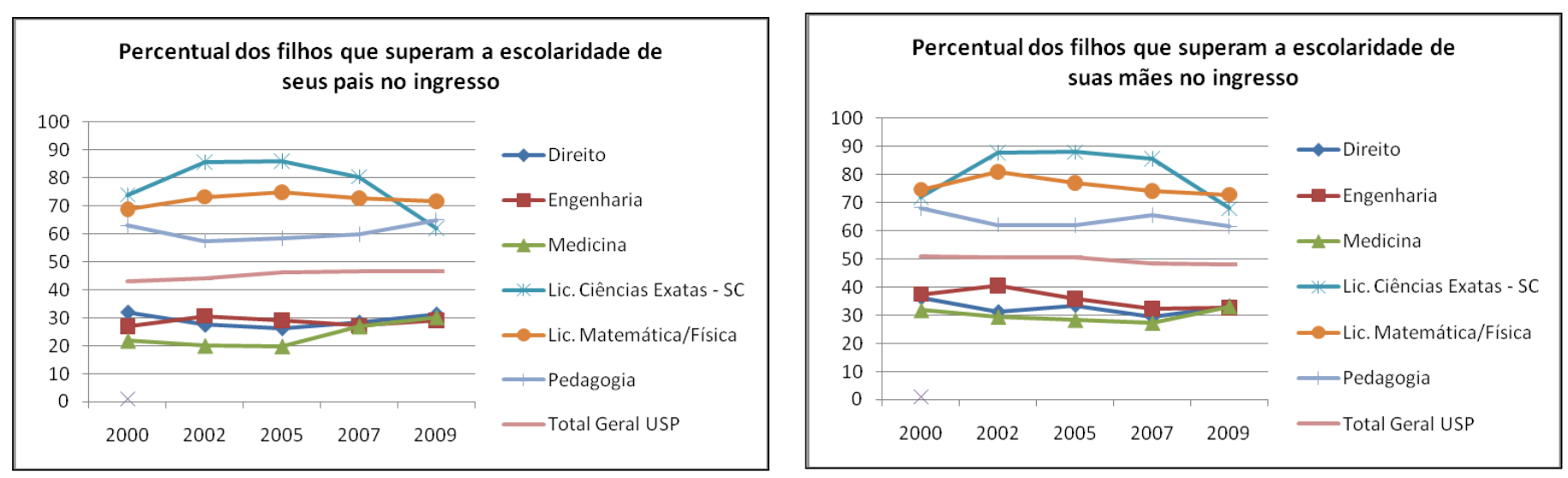

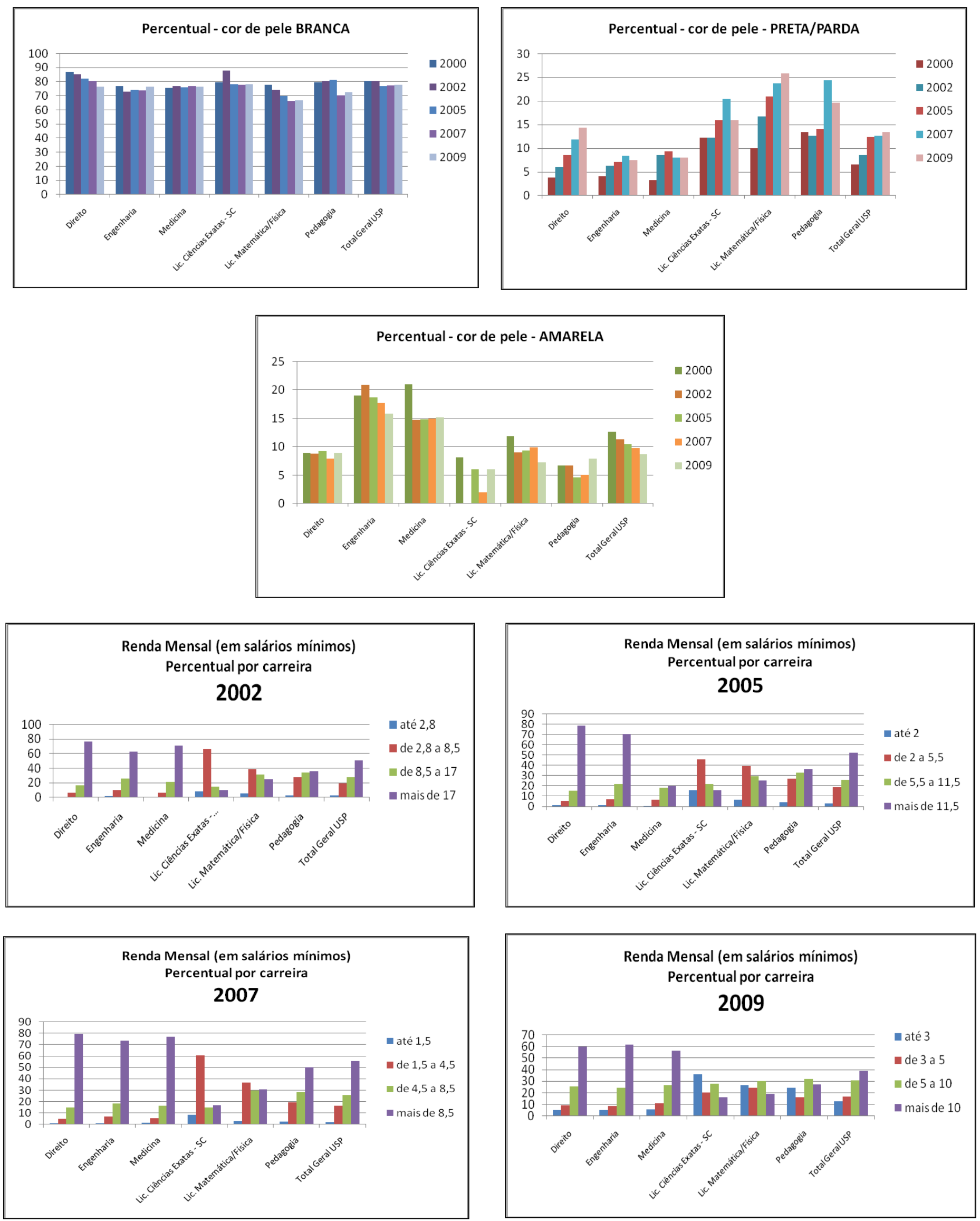

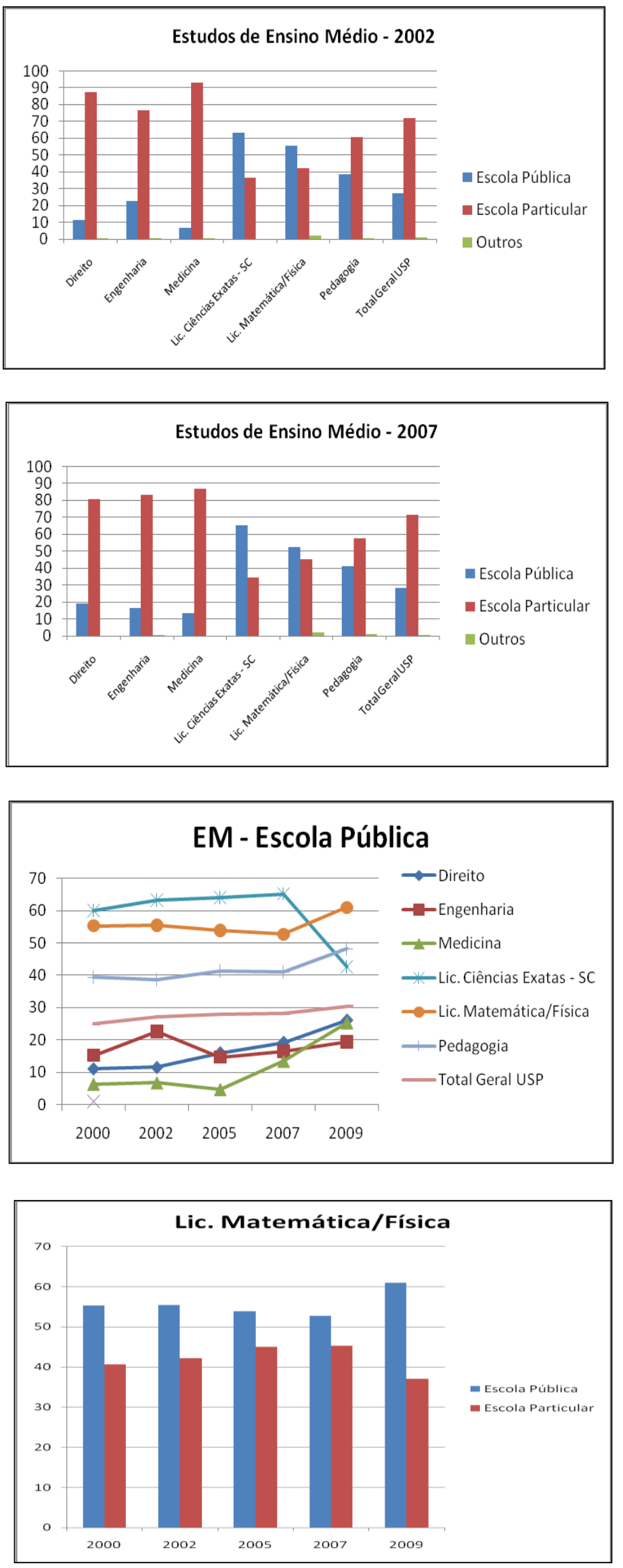

Estudos de Ensino Médio - 2005
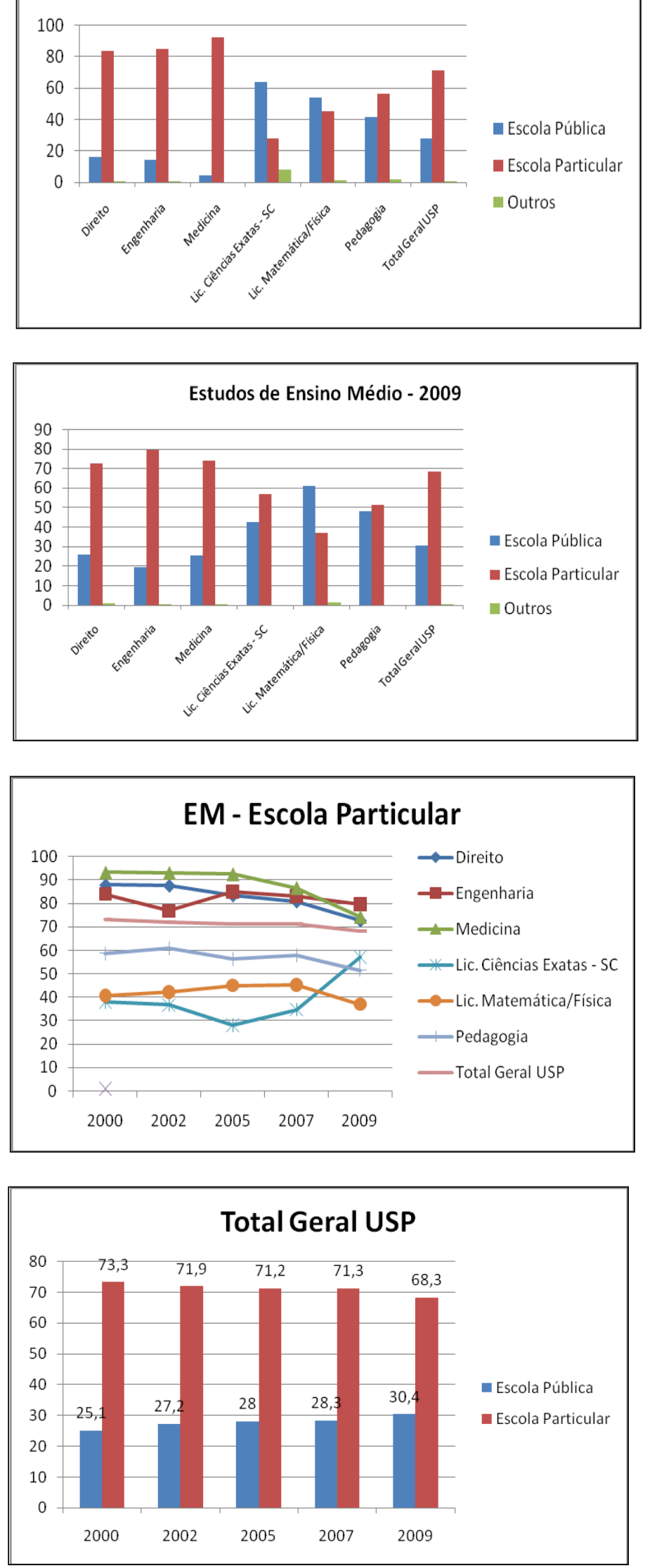
ANEXO B - Dados dos Questionários de Ingressantes 2002 e 2006 (diurno e noturno) 


\section{Questionário de Ingressantes do Curso de Licenciatura - USP - DIURNO/2002}

\begin{tabular}{|c|c|c|c|c|c|c|}
\hline № & $\begin{array}{l}\text { Por que escolheu fazer } \\
\text { Vestibular para Licenciatura } \\
\text { em Física? }\end{array}$ & $\begin{array}{c}\text { Para você, fazer o } \\
\text { Bacharelado ou a } \\
\text { Licenciatura em Física seriam } \\
\text { opções equivalentes? }\end{array}$ & $\begin{array}{l}\text { Você pretende ser professor } \\
\text { de Física? Por quê? }\end{array}$ & $\begin{array}{l}\text { Você acha que um diploma } \\
\text { de curso superior hoje no } \\
\text { Brasil é indispensável, } \\
\text { independente do conteúdo } \\
\text { do curso? Por quê? }\end{array}$ & $\begin{array}{l}\text { Quais perspectivas } \\
\text { profissionais e pessoais você } \\
\text { espera que o curso lhe } \\
\text { proporcione? }\end{array}$ & $\begin{array}{c}\text { Você gosta de estudar Física? } \\
\text { Por quê? }\end{array}$ \\
\hline D1 & Para lecionar. & & $\begin{array}{l}\text { Sim, porque gosto de ajudar } \\
\text { as pessoas no estudo. }\end{array}$ & $\begin{array}{l}\text { Sim, porque o mercado de } \\
\text { trabalho é muito competitivo. }\end{array}$ & $\begin{array}{l}\text { Capacitação para lecionar no } \\
\text { ensino médio ou superior e } \\
\text { pesquisas. }\end{array}$ & $\begin{array}{l}\text { Sim, pois ela explica, através } \\
\text { da lógica, vários efeitos } \\
\text { naturais e artificiais. }\end{array}$ \\
\hline D2 & $\begin{array}{l}\text { Eu gosto de Física e também } \\
\text { gosto de dar aulas. }\end{array}$ & Sim. & $\begin{array}{l}\text { Vou. Porque eu gosto de } \\
\text { ensinar, mas não pretendo } \\
\text { ficar a vida toda ensinando. }\end{array}$ & $\begin{array}{l}\text { Não. Fazer curso superior em } \\
\text { qualquer faculdade não vai } \\
\text { lhe render seu sacrifício. }\end{array}$ & $\begin{array}{l}\text { Espero sair do curso de } \\
\text { Licenciatura preparado para } \\
\text { oferecer as melhores aulas. } \\
\text { Pessoalmente, espero que o } \\
\text { curso me agrade. }\end{array}$ & $\begin{array}{l}\text { Gosto. Eu gosto de entender } \\
\text { o que ocorre ao meu redor. }\end{array}$ \\
\hline D3 & $\begin{array}{l}\text { Porque eu gosto muito desta } \\
\text { área. }\end{array}$ & Sim. & $\begin{array}{l}\text { Não, apenas quero aprender, } \\
\text { e não mestrar. }\end{array}$ & $\begin{array}{l}\text { Sim, porque ele abre muitas } \\
\text { portas. }\end{array}$ & $\begin{array}{l}\begin{array}{l}\text { Espero um } \\
\text { crescimento }\end{array} \text { prande } \\
\text { podendo me integrar com } \\
\text { diferentes } \\
\begin{array}{l}\text { Profissionalmente o curmas. } \\
\text { facilitará em muito o acesso }\end{array} \\
\begin{array}{l}\text { às profissões que estou } \\
\text { visando atualmente. }\end{array}\end{array}$ & $\begin{array}{l}\text { Sim. Porque acho que a física } \\
\text { é fundamental. }\end{array}$ \\
\hline D4 & $\begin{array}{l}\text { Por ser uma carreira } \\
\text { promissora. }\end{array}$ & Não. & $\begin{array}{l}\text { Sim. } \\
\text { retransmitir o que aprendo. }\end{array}$ & $\begin{array}{l}\text { Sim. O mercado só tem lugar } \\
\text { para os mais preparados. }\end{array}$ & $\begin{array}{l}\text { Um bom emprego, que me } \\
\text { forneça estabilidade } \\
\text { financeira que venha a } \\
\text { aprender muito relacionado a } \\
\text { Física. }\end{array}$ & $\begin{array}{l}\text { Sim. Porque trata de assuntos } \\
\text { de meu interesse. }\end{array}$ \\
\hline D5 & $\begin{array}{l}\text { Porque eu gosto de Física e } \\
\text { também porque gosto de } \\
\text { passar meus conhecimentos } \\
\text { aos outros. }\end{array}$ & $\begin{array}{l}\text { Não, para mim Bacharelado } \\
\text { envolve indústrias e } \\
\text { Licenciatura as escolas. }\end{array}$ & $\begin{array}{l}\text { Sim, porque há uma carência } \\
\text { de professores de física nas } \\
\text { escolas, e muitos alunos } \\
\text { estão sendo prejudicados por } \\
\text { isso. }\end{array}$ & $\begin{array}{l}\text { Sim, pois com o avanço das } \\
\text { tecnologias e da globalização, } \\
\text { as pessoas necessitam de } \\
\text { muitos conhecimentos e ter } \\
\text { um diploma é uma forma de } \\
\text { provar esses conhecimentos } \\
\text { - na maioria das vezes. }\end{array}$ & $\begin{array}{l}\text { Espero conseguir fazer uma } \\
\text { pós-graduação. Em termos } \\
\text { pessoais, espero ajudar muita } \\
\text { gente a chegar nas } \\
\text { Universidades Públicas. }\end{array}$ & $\begin{array}{l}\text { Sim, porque é uma disciplina } \\
\text { que estuda os } \\
\text { acontecimentos do dia-a-dia } \\
\text { e o Universo. }\end{array}$ \\
\hline D6 & Porque quero lecionar. & Não. & Sim. Gosto da área. & $\begin{array}{l}\text { Sim. Porque o mercado está } \\
\text { muito concorrido. }\end{array}$ & $\begin{array}{l}\text { Êxito pessoal, dar aulas em } \\
\text { cursinhos e universidades, }\end{array}$ & Sim, tenho facilidade. \\
\hline
\end{tabular}




\begin{tabular}{|c|c|c|c|c|c|c|}
\hline & & & & & $\begin{array}{l}\text { fazer mestrados e } \\
\text { doutorados. }\end{array}$ & \\
\hline D7 & $\begin{array}{l}\text { Porque gosto de física e gosto } \\
\text { de dar aulas e explicar para } \\
\text { os outros. }\end{array}$ & Sim. & $\begin{array}{l}\text { Pretendo ser de matemática, } \\
\text { mas se não conseguir serei de } \\
\text { física porque gosto de } \\
\text { explicar para os outros. }\end{array}$ & $\begin{array}{l}\text { Sim para entrar no mercado } \\
\text { de trabalho mais preparado. }\end{array}$ & $\begin{array}{l}\text { Espero que o curso me } \\
\text { proporcione novas maneiras } \\
\text { de ver o mundo, várias } \\
\text { opcõ̃es para o trabalho e } \\
\text { como tratar os futuros } \\
\text { alunos. }\end{array}$ & $\begin{array}{l}\text { Sim, porque a física está em } \\
\text { tudo no mundo. }\end{array}$ \\
\hline D8 & $\begin{array}{l}\text { Porque possuo facilidade em } \\
\text { cálculos e admiro o curso. }\end{array}$ & Não. & $\begin{array}{l}\text { Sim, pretendo transmitir meu } \\
\text { conhecimento. }\end{array}$ & $\begin{array}{l}\text { Sim, devido a concorrência } \\
\text { no mercado de trabalho. }\end{array}$ & $\begin{array}{l}\text { Conhecimento a nível de } \\
\text { pesquisas e técnicas, e que } \\
\text { me dê um fator de } \\
\text { competitividade. }\end{array}$ & $\begin{array}{l}\text { Sim, porque admiro as teorias } \\
\text { da mesma. }\end{array}$ \\
\hline D9 & $\begin{array}{l}\text { Porque é uma carreira que } \\
\text { me atrai e o ensino necessita } \\
\text { de bons profissionais atuando } \\
\text { na área. }\end{array}$ & $\begin{array}{l}\text { Não, o bacharelado é voltado } \\
\text { para pesquisa e a licenciatura } \\
\text { para a prática do ensino. }\end{array}$ & Sim. & $\begin{array}{l}\text { Sim. O mercado de trabalho } \\
\text { exige cada vez uma formação } \\
\text { mais específica. }\end{array}$ & $\begin{array}{l}\text { Espero que me proporcione a } \\
\text { abertura de portas para atuar } \\
\text { na área de ensino. }\end{array}$ & Sim. Gosto de desafios. \\
\hline D10 & $\begin{array}{l}\text { Porque eu pretendo ser } \\
\text { professora e/ou pesquisadora } \\
\text { e pretendo fazer matemática } \\
\text { quando terminar esse curso. }\end{array}$ & Não. & $\begin{array}{l}\text { Sim, porque eu gosto dessa } \\
\text { área e sempre quis dar aula. }\end{array}$ & $\begin{array}{l}\text { Sim, pois a cada dia está mais } \\
\text { difícil conseguir um emprego. }\end{array}$ & $\begin{array}{l}\text { Pretendo sair daqui e } \\
\text { conseguir um bom emprego } \\
\text { em uma boa escola e } \\
\text { pretendo ganhar muito } \\
\text { conhecimento. }\end{array}$ & $\begin{array}{l}\text { Sim, a matéria me interessa, } \\
\text { acho que tem muita coisa a } \\
\text { ver com o cotidiano. }\end{array}$ \\
\hline D11 & $\begin{array}{l}\text { Para conhecer a física de } \\
\text { perto e aperfeiçoar minha } \\
\text { capacidade em exatas. }\end{array}$ & Não. & Se precisar, serei professora. & $\begin{array}{l}\text { Sim, é preciso ir até o fim nos } \\
\text { estudos. }\end{array}$ & $\begin{array}{l}\text { Espero que eu consiga } \\
\text { aperfeiçoar meu raciocínio } \\
\text { para exatas e espero que } \\
\text { "incremente" meu currículo } \\
\text { caso siga outro caminho. }\end{array}$ & $\begin{array}{l}\text { Depende da parte da física } \\
\text { pois dentro da física existem } \\
\text { "pontos" diferentes. Me } \\
\text { identifico com } \\
\text { eletromagnetismo e gosto de } \\
\text { estudar essa parte. O que não } \\
\text { acontece com Mecânica. }\end{array}$ \\
\hline D12 & $\begin{array}{l}\text { Porque me interesso pelo } \\
\text { magistério e adoro física e } \\
\text { matemática. }\end{array}$ & $\begin{array}{l}\text { Sim, mas minha decisão foi } \\
\text { pelo magistério. }\end{array}$ & $\begin{array}{l}\text { Sim, porque gosto de ensinar } \\
\text { e gosto muito da disciplina. }\end{array}$ & $\begin{array}{l}\text { Sim, por causa da renda e da } \\
\text { possibilidade de escolha. }\end{array}$ & $\begin{array}{l}\text { Espero que consiga me tornar } \\
\text { professor da rede particular } \\
\text { de ensino e ensinar quando } \\
\text { puder. }\end{array}$ & $\begin{array}{l}\text { Sim, porque me interesso } \\
\text { pelo estudo dos movimentos } \\
\text { e forças de interação dos } \\
\text { elementos da natureza. }\end{array}$ \\
\hline D13 & $\begin{array}{l}\text { Opção pessoal (gosto muito } \\
\text { de física). }\end{array}$ & Não. & $\begin{array}{l}\text { Talvez. Pretendo seguir a } \\
\text { área que mais me agradar. }\end{array}$ & $\begin{array}{l}\text { Não. Acho o conteúdo do } \\
\text { curso essencial. }\end{array}$ & $\begin{array}{l}\text { A de trabalhar como } \\
\text { professor do ensino médio ou } \\
\text { superior ou seguir carreira. }\end{array}$ & $\begin{array}{l}\text { Sim. Pelos meus interesses } \\
\text { meticulosos pelos fenômenos } \\
\text { da natureza. }\end{array}$ \\
\hline D14 & $\begin{array}{ll}\begin{array}{l}\text { Porque é a área que me } \\
\text { interessa e para poder } \\
\text { posteriormente }\end{array} & \text { fazer } \\
\end{array}$ & $\begin{array}{l}\text { Não, Bacharelado é mais } \\
\text { abrangente, ao qual interesso } \\
\text { cursar. }\end{array}$ & 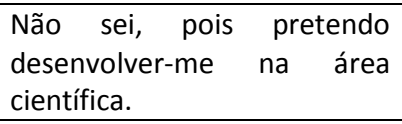 & $\begin{array}{l}\text { Sim, pois o mercado de } \\
\text { trabalho está exigindo cada } \\
\text { vez mais. }\end{array}$ & $\begin{array}{l}\text { Desenvolver-me na área } \\
\text { científica possibilitando-me } \\
\text { desenvolver projetos. }\end{array}$ & $\begin{array}{l}\text { Para poder entender os mais } \\
\text { diversos fenômenos, suas } \\
\text { causas e utilizá-los. }\end{array}$ \\
\hline
\end{tabular}




\begin{tabular}{|c|c|c|c|c|c|c|}
\hline & Engenharia. & & & & & \\
\hline D15 & $\begin{array}{l}\text { No cursinho achei física } \\
\text { muito interessante, corri } \\
\text { atrás para saber mais sobre o } \\
\text { curso e acabei desistindo de } \\
\text { prestar Matemática para } \\
\text { prestar física. }\end{array}$ & Não. & $\begin{array}{l}\text { Sim. Pois acho muito legal e } \\
\text { divertido passar o meu } \\
\text { conhecimento para outras } \\
\text { pessoas e física é muito legal. }\end{array}$ & $\begin{array}{l}\text { Não. Pois muitos cursos } \\
\text { superiores que o aluno } \\
\text { consegue o diploma mas não } \\
\text { tem conteúdo para entrar no } \\
\text { mercado de trabalho. }\end{array}$ & $\begin{array}{l}\text { No caso profissional espero } \\
\text { que o curso me ajude em } \\
\text { pesquisas além do que os } \\
\text { professores ensinam e } \\
\text { pessoais espero que seja } \\
\text { divertido como eu acho que } \\
\text { vai ser. }\end{array}$ & $\begin{array}{l}\text { Sim. Sempre gostei de } \\
\text { cálculos, mas a física vai além } \\
\text { e mostra coisas do nosso } \\
\text { cotidiano que acho muito } \\
\text { interessante. }\end{array}$ \\
\hline D16 & $\begin{array}{l}\text { Por gostar da carreira, e } \\
\text { também por ter uma baixa } \\
\text { nota de corte. }\end{array}$ & Sim. & $\begin{array}{l}\text { Sim, porque sinto prazer em } \\
\text { passar conhecimento aos } \\
\text { outros, e também se não } \\
\text { quisesse ser professor } \\
\text { escolheria outro curso. }\end{array}$ & $\begin{array}{l}\text { O diploma é indispensável } \\
\text { sim, mas o conteúdo do curso } \\
\text { é mais importante. }\end{array}$ & $\begin{array}{l}\text { Espero que o curso me } \\
\text { proporcione a possibilidade } \\
\text { de boas oportunidades no } \\
\text { mercado de trabalho. }\end{array}$ & $\begin{array}{l}\text { Sim, por ser uma ciência que } \\
\text { nos possibilita entender os } \\
\text { fenômenos físicos que } \\
\text { ocorrem. }\end{array}$ \\
\hline D17 & $\begin{array}{l}\text { Porque eu cursei até o } 30 \text { ano } \\
\text { de magistério e gostei muito } \\
\text { de ministrar aulas. }\end{array}$ & $\begin{array}{l}\text { Não, visto que o bacharelado } \\
\text { volta-se mais para a pesquisa. }\end{array}$ & $\begin{array}{l}\text { Sim. Porque gosto de dar } \\
\text { aulas e, principalmente, de } \\
\text { Física. }\end{array}$ & $\begin{array}{l}\text { Sim. Porque o mercado é } \\
\text { competitivo e exige } \\
\text { profissionais qualificados. }\end{array}$ & $\begin{array}{l}\text { Espero que o curso satisfaça } \\
\text { minhas ambições e espero } \\
\text { ser um bom profissional. }\end{array}$ & $\begin{array}{llr}\text { Sim, porque } & \text { é muito } \\
\text { gratificante } & \text { encontrar } \\
\text { explicações } & \text { para os } \\
\text { fenômenos que ocorrem ao } \\
\text { meu redor. }\end{array}$ \\
\hline D18 & $\begin{array}{l}\text { Para trabalhar na área } \\
\text { Didática, com o intuito de } \\
\text { melhorar e lutar por reformas } \\
\text { no ensino. }\end{array}$ & $\begin{array}{l}\text { Não, pois necessito trabalhar } \\
\text { com a educação apesar de } \\
\text { que posso mudar de idéia } \\
\text { posteriormente. }\end{array}$ & $\begin{array}{l}\text { Pretendo, porque gosto desta } \\
\text { área e acho que faltam } \\
\text { professores qualificados. }\end{array}$ & $\begin{array}{l}\text { Sim, porque a vida (custo) } \\
\text { está pesada, sendo } \\
\text { necessários alguns atalhos. }\end{array}$ & $\begin{array}{l}\text { Tenho a esperança de sair da } \\
\text { universidade para me tornar } \\
\text { um cidadão, lutando por } \\
\text { objetivos, agora com uma } \\
\text { boa formação e qualificação. }\end{array}$ & $\begin{array}{l}\text { Sim, gosto de analisar o } \\
\text { mundo, usar o raciocínio para } \\
\text { evoluir psicologicamente. }\end{array}$ \\
\hline D19 & $\begin{array}{l}\text { Porque eu gosto de ensinar } \\
\text { física. }\end{array}$ & Sim. & Sim. Porque gosto. & $\begin{array}{l}\text { Não, e preciso de um curso } \\
\text { de qualidade. }\end{array}$ & $\begin{array}{l}\text { Boa formação profissional, } \\
\text { um bom emprego e um } \\
\text { conhecimento muito maior } \\
\text { sobre o mundo. }\end{array}$ & $\begin{array}{l}\text { Por que me ajuda a entender } \\
\text { o mundo. }\end{array}$ \\
\hline D20 & $\begin{array}{l}\text { Por gostar muito da matéria, } \\
\text { e achar que serei um bom } \\
\text { profissional no ramo. }\end{array}$ & $\begin{array}{l}\text { Não, tenho preferência por } \\
\text { licenciatura. }\end{array}$ & $\begin{array}{l}\text { Sim, porque me enquadro } \\
\text { bem na profissão. }\end{array}$ & $\begin{array}{l}\text { Sim, pois a concorrência } \\
\text { aumenta a cada dia. }\end{array}$ & $\begin{array}{l}\text { Espero que o curso me } \\
\text { proporcione as condições } \\
\text { básicas para que eu possa me } \\
\text { tornar um bom professor e } \\
\text { assim me realizar } \\
\text { pessoalmente. }\end{array}$ & $\begin{array}{l}\text { Sim, pois é uma } \\
\text { lógica, } \\
\text { dificuldades. }\end{array}$ \\
\hline D21 & Para dar aulas de física. & $\begin{array}{l}\text { Não, no bacharelado a física é } \\
\text { mais complexa, por isso do } \\
\text { meu interesse. }\end{array}$ & Talvez, por gostar de ensinar. & $\begin{array}{l}\text { Sim, elevar um pouco a } \\
\text { instrução do povo. }\end{array}$ & $\begin{array}{l}\text { Espero sair apto a lecionar } \\
\text { física de maneira invejável, } \\
\text { acreditando estar pronto } \\
\text { para os desafios que a atual } \\
\text { sociedade impõe aos novos }\end{array}$ & Sim, me fascina. \\
\hline
\end{tabular}




\begin{tabular}{|c|c|c|c|c|c|c|}
\hline & & & & & universitários. & \\
\hline D22 & Porque quero lecionar Física. & Não. & $\begin{array}{l}\text { Porque quero arrumar um } \\
\text { emprego público. }\end{array}$ & Não. Depende da faculdade. & $\begin{array}{l}\text { Conseguir um emprego } \\
\text { público que me garanta } \\
\text { estabilidade apesar de mal } \\
\text { remunerado. }\end{array}$ & $\begin{array}{l}\text { Sim, porque é a ciência } \\
\text { natural. }\end{array}$ \\
\hline D23 & $\begin{array}{l}\text { Para combinar minhas duas } \\
\text { paixões: física e ensinar. Há } \\
\text { anos sonho em trabalhar } \\
\text { lecionando. }\end{array}$ & $\begin{array}{l}\text { Não, mas pretendo adquirir o } \\
\text { Bacharelado também. }\end{array}$ & $\begin{array}{l}\text { Sim. Porque esta é a razão } \\
\text { pela qual estou cursando. }\end{array}$ & $\begin{array}{l}\text { Sim, pois a aplicação e } \\
\text { conseqüente aprendizado } \\
\text { independem do conteúdo, } \\
\text { mas o mesmo deve ser } \\
\text { levado em conta. }\end{array}$ & $\begin{array}{l}\text { Espero que me prepare para } \\
\text { lecionar, mas também me } \\
\text { proporcione educação } \\
\text { suficiente para ingressar em } \\
\text { outros mercados de trabalho. }\end{array}$ & $\begin{array}{l}\text { Sim, porque é aplicável ao } \\
\text { dia-a-dia, ajuda-nos a explicar } \\
\text { fenômenos. }\end{array}$ \\
\hline D24 & $\begin{array}{l}\text { No ano de } 2000 \text { eu estava } \\
\text { tentando prestar para } \\
\text { administração com muita } \\
\text { dúvida, mas durante o ano } \\
\text { percebi que gostava de } \\
\text { ensinar, ainda mais, gostava } \\
\text { de ensinar Física, naquele } \\
\text { ano acabei prestando ADM, } \\
\text { mas no seguinte mudei para } \\
\text { Física. }\end{array}$ & $\begin{array}{lr}\text { Não, } & \text { pretendo } \\
\text { posteriormente } & \text { fazer } \\
\text { bacharelado, mas meu } \\
\text { interesse agora é ensinar } \\
\text { (Licenciatura). }\end{array}$ & $\begin{array}{l}\text { Sim. Percebi que eu gostava e } \\
\text { sabia fazer bem. }\end{array}$ & $\begin{array}{l}\text { Não, existem cursos técnicos } \\
\text { mais curtos e mais baratos. }\end{array}$ & $\begin{array}{l}\text { Que eu consiga ser um bom } \\
\text { professor e que ao final do } \\
\text { curso perceba o quanto } \\
\text { evolui nesses } 4 \text { anos. }\end{array}$ & $\begin{array}{l}\text { Sim, Não sei explicar } \quad \text { } \\
\text { porquê, gosto do desafio. }\end{array}$ \\
\hline D25 & $\begin{array}{l}\text { Devido ao grande campo de } \\
\text { trabalho. }\end{array}$ & Não. & $\begin{array}{l}\text { Sim, porque é uma profissão } \\
\text { na qual estarei trabalhando } \\
\text { com uma matéria que eu } \\
\text { gosto e que tem um grande } \\
\text { campo de trabalho. }\end{array}$ & $\begin{array}{l}\text { Não, porque as empresas não } \\
\text { conseguem absorver todas as } \\
\text { pessoas com curso superior. }\end{array}$ & $\begin{array}{l}\text { Espero que com este curso eu } \\
\text { possa me tornar um bom } \\
\text { profissional apto a dar aulas } \\
\text { em qualquer escola do } 20 \\
\text { grau. }\end{array}$ & $\begin{array}{l}\text { Sim, porque é uma matéria a } \\
\text { qual sempre tive alguma } \\
\text { facilidade para estudar. }\end{array}$ \\
\hline D26 & $\begin{array}{l}\text { Porque gosto de Física e } \\
\text { tenho uma admiração pela } \\
\text { classe dos professores. }\end{array}$ & Não. & $\begin{array}{l}\text { Não, porque apesar de gostar } \\
\text { da área de ensino pretendo } \\
\text { usar o curso para obter } \\
\text { promoção em meu atual } \\
\text { emprego. }\end{array}$ & $\begin{array}{l}\text { Sim, porque o Brasil é um } \\
\text { país em desenvolvimento e } \\
\text { ter um curso superior } \\
\text { aumenta as chances de } \\
\text { inserção no mercado de } \\
\text { trabalho. }\end{array}$ & $\begin{array}{l}\text { A chance de ser promovido } \\
\text { em meu atual trabalho e o } \\
\text { crescimento humano que a } \\
\text { universidade } \\
\text { proporcionará. }\end{array}$ & $\begin{array}{l}\text { Sim, porque a física faz parte } \\
\text { de nosso cotidiano. Ela } \\
\text { também explica como o } \\
\text { mundo funciona. }\end{array}$ \\
\hline D27 & $\begin{array}{lrr}\text { Quero lecionar, e } & \text { depois } \\
\text { fazer mestrado } & \text { ou } \\
\text { doutorado. } & & \end{array}$ & Não. & $\begin{array}{l}\text { Também. Sempre foi meu } \\
\text { objetivo lecionar na área de } \\
\text { exatas. }\end{array}$ & $\begin{array}{l}\text { Não. Acho que o conteúdo do } \\
\text { curso tem que ser de } \\
\text { qualidade. Não dá pra fazer } \\
\text { em qualquer escola. }\end{array}$ & $\begin{array}{l}\text { Quero ter a possibilidade de } \\
\text { lecionar, além da realização } \\
\text { pessoal de fazer o curso de } \\
\text { física. Depois quero fazer } \\
\text { mestrado ou doutorado. }\end{array}$ & $\begin{array}{l}\text { Sim. É a ciência que tenho } \\
\text { maior interesse. }\end{array}$ \\
\hline D28 & $\begin{array}{l}\text { Pois creio ser uma área que } \\
\text { tende a expandir cada vez }\end{array}$ & $\begin{array}{l}\text { Não, pois Bacharelado deve } \\
\text { ser mais abrangente. }\end{array}$ & $\begin{array}{l}\text { Sim, é importante que os } \\
\text { alunos aprendam a apreciar a }\end{array}$ & $\begin{array}{l}\text { Um diploma de curso } \\
\text { superior acaba } \\
\text { sendo }\end{array}$ & $\begin{array}{l}\text { Creio que este curso é uma } \\
\text { oportunidade para que eu }\end{array}$ & $\begin{array}{l}\text { Aprendi a gostar de física ao } \\
\text { descobrir sua importância e }\end{array}$ \\
\hline
\end{tabular}




\begin{tabular}{|c|c|c|c|c|c|c|}
\hline & $\begin{array}{l}\text { mais, e muito importante ao } \\
\text { desenvolvimento } \\
\text { tecnológico. }\end{array}$ & & $\begin{array}{l}\text { Física é entender sua } \\
\text { importância, seu valor. Creio } \\
\text { que devemos ajudá-los a } \\
\text { enxergar isso. }\end{array}$ & $\begin{array}{l}\text { indispensável para enfrentar } \\
\text { a concorrência do mercado } \\
\text { de trabalho. }\end{array}$ & $\begin{array}{l}\text { possa ampliar meus } \\
\text { argumentos, meu senso } \\
\text { crítico e visão de mundo. }\end{array}$ & aplicações. \\
\hline D29 & Trabalho na área. & Não. & $\begin{array}{l}\text { Sim. Me identifico com a } \\
\text { profissão de professor. }\end{array}$ & $\begin{array}{l}\text { Sim. Mercado de trabalho } \\
\text { cada vez mais exigente. }\end{array}$ & $\begin{array}{l}\text { Que me proporcione } \\
\text { "bagagem" suficiente para } \\
\text { dar continuidade ao meu } \\
\text { trabalho de professor. }\end{array}$ & $\begin{array}{l}\text { Sim. Sempre gostei de fazer } \\
\text { experiências relacionadas aos } \\
\text { fundamentos físicos. }\end{array}$ \\
\hline D30 & $\begin{array}{l}\text { Porque gosto da área e já } \\
\text { trabalhei nela. }\end{array}$ & Não. & $\begin{array}{l}\text { Sim, porque quero ser } \\
\text { professor de Física. }\end{array}$ & $\begin{array}{l}\text { Sim, a exigência do mercado } \\
\text { de trabalho está muito } \\
\text { grande. }\end{array}$ & $\begin{array}{l}\text { Espero que esse curso me } \\
\text { prepare para ser um bom } \\
\text { professor de Física. }\end{array}$ & $\begin{array}{l}\text { Sim, tenho afinidade com a } \\
\text { matéria. }\end{array}$ \\
\hline D31 & $\begin{array}{l}\text { Porque sempre gostei desta } \\
\text { matéria. }\end{array}$ & Sim. & $\begin{array}{l}\text { Não. Pretendo seguir carreira } \\
\text { acadêmica. }\end{array}$ & $\begin{array}{l}\text { Não, acho que o conteúdo é } \\
\text { indispensável. }\end{array}$ & $\begin{array}{l}\text { Espero bastante, pois é um } \\
\text { dos cursos de Física mais bem } \\
\text { conceituados. Acredito que } \\
\text { eu possa continuar } \\
\text { estudando (mestrado) aqui } \\
\text { mesmo. }\end{array}$ & $\begin{array}{l}\text { Sim, porque é uma matéria } \\
\text { que embora exija bastante } \\
\text { estudo, esta não é algo } \\
\text { decorado, mas sim uma coisa } \\
\text { lógica, que vai } \\
\text { desenvolvendo. }\end{array}$ \\
\hline D32 & $\begin{array}{lccr}\text { Por ser } & \text { um } & \text { curso } & \text { que } \\
\text { aproxima } & \circ & \text { aluno } & \text { da } \\
\text { realidade. } & & & \end{array}$ & $\begin{array}{l}\text { Não, o bacharelado acaba } \\
\text { sendo } \\
\text { demasiadamente. }\end{array}$ & $\begin{array}{l}\text { Sim, pois põe em prática o } \\
\text { que se aprende na teoria. }\end{array}$ & $\begin{array}{l}\text { Não, apenas a especialização } \\
\text { torna o } \begin{array}{l}\text { indivíduo } \\
\text { aproveitável } \\
\text { sociedade. }\end{array} \text { para a } \\
\text { sora }\end{array}$ & $\begin{array}{l}\text { Este curso além da clara } \\
\text { opção pelo ensino abre } \\
\text { opções múltiplas para } \\
\text { consultorias e atividades } \\
\text { afins. }\end{array}$ & $\begin{array}{l}\text { Sim, porque torna possível o } \\
\text { entendimento da natureza e } \\
\text { das interações entre } \\
\text { ambiente e elementos. }\end{array}$ \\
\hline D33 & Gosto de dar aulas de Física. & Não. & $\begin{array}{l}\text { Sim. Gosto da matéria (já } \\
\text { leciono em em caráter } \\
\text { excepcional). }\end{array}$ & $\begin{array}{l}\text { Sim, independente do curso, } \\
\text { mas a faculdade influencia } \\
\text { bastante, pois o mercado de } \\
\text { trabalho é muito exigente e } \\
\text { competitivo. }\end{array}$ & $\begin{array}{l}\text { Reconhecimento pelas } \\
\text { autoridades da Secretaria de } \\
\text { Estado da Educação para } \\
\text { exercer o magistério de física. }\end{array}$ & $\begin{array}{l}\text { Sim, porque é aplicada a } \\
\text { todos os campos da vida } \\
\text { moderna. }\end{array}$ \\
\hline D34 & $\begin{array}{l}\text { Gosto muito de estudar física } \\
\text { e matemática e pretendo } \\
\text { lecionar. }\end{array}$ & $\begin{array}{l}\text { Pretendo fazer os dois, quero } \\
\text { trabalhar com pesquisas e } \\
\text { dar aulas. }\end{array}$ & Sim, sinto prazer em ensinar. & $\begin{array}{l}\text { O diploma só é válido quando } \\
\text { se faz o curso que ama e que } \\
\text { pretende dedicar a vida na } \\
\text { determinada área. }\end{array}$ & $\begin{array}{l}\text { Profissionalmente espero que } \\
\text { o curso me proporcione uma } \\
\text { ótima didática, opções para } \\
\text { pesquisas e um profundo } \\
\text { conhecimento do assunto. } \\
\text { Pessoalmente, vou estar } \\
\text { realizado em estudar e } \\
\text { trabalhar no que gosto. }\end{array}$ & $\begin{array}{l}\text { Sim, gosto de observar a } \\
\text { natureza e entender os seus } \\
\text { mecanismos, logo gosto de } \\
\text { física. }\end{array}$ \\
\hline D35 & Pela carreira e amar a física. & Sim. & Sim. Pelo prazer de ensinar. & $\begin{array}{l}\text { É indispensável, porém } \\
\text { depende do conteúdo do } \\
\text { curso. }\end{array}$ & $\begin{array}{l}\text { Que seja um bom profissional } \\
\text { e tenha uma condição de } \\
\text { concorrer com qualquer }\end{array}$ & $\begin{array}{l}\text { Sim. A física é a base do } \\
\text { mundo e conhecem o mundo } \\
\text { e seus mistérios é minha }\end{array}$ \\
\hline
\end{tabular}




\begin{tabular}{|c|c|c|c|c|c|c|}
\hline & & & & & profissional, da área de física. & $\begin{array}{l}\begin{array}{l}\text { principal função } \\
\text { mundo. }\end{array} \\
\end{array}$ \\
\hline D36 & $\begin{array}{l}\text { Para dar aula já que gosto de } \\
\text { ensinar e de física } \\
\text { simultaneamente. }\end{array}$ & Não. & $\begin{array}{l}\text { Sim, porque eu gosto de dar } \\
\text { aula. }\end{array}$ & $\begin{array}{l}\text { Não, pois diploma não } \\
\text { significa conhecimento. }\end{array}$ & $\begin{array}{l}\text { Ser reconhecido pelo meu } \\
\text { esforço financeiramente e } \\
\text { pessoalmente, pela família e } \\
\text { pela sociedade. }\end{array}$ & $\begin{array}{l}\text { Sim, gosto de coisas que } \\
\text { poucas pessoas podem ou } \\
\text { conseguem compreender. }\end{array}$ \\
\hline D37 & $\begin{array}{l}\text { Gosto do curso e pretendo } \\
\text { formar pessoas conscientes. }\end{array}$ & $\begin{array}{l}\text { Não, são } \\
\text { diferentes. }\end{array}$ & Sim, tenho aptidão. & Sim. & Conscientizar da vida. & Sim, aprendi no colegial. \\
\hline D38 & Para dar aula. & Não. & Sim. Para ensinar. & Não. & & $\begin{array}{l}\text { Sim, porque aprendo sobre a } \\
\text { vida. }\end{array}$ \\
\hline D39 & $\begin{array}{l}\text { Já comecei e estou com } \\
\text { medo de ser jubilado. Estou } \\
\text { "reentrando" na física. }\end{array}$ & Não. & $\begin{array}{l}\text { Não sei. Depende das } \\
\text { oportunidades. }\end{array}$ & Sim. Ajuda, no geral. & $\begin{array}{l}\text { Não tenho expectativas. } \\
\text { Escolhi física porque gosto e } \\
\text { preciso. É necessário um } \\
\text { curso superior para você ser } \\
+ \text { valorizado socialmente. }\end{array}$ & $\begin{array}{l}\text { Sim. Mas o cálculo atrapalha. } \\
\text { É bom para entender a } \\
\text { natureza e enriquece a } \\
\text { cultura. }\end{array}$ \\
\hline D40 & $\begin{array}{l}\text { Porque pretendo ser } \\
\text { professor e tenho afinidade } \\
\text { com a Física. }\end{array}$ & $\begin{array}{l}\text { Não, pois o bacharel não tem } \\
\text { preparação para dar aulas. }\end{array}$ & Sim porque gosto de ensinar. & $\begin{array}{l}\text { Um diploma de curso } \\
\text { superior é indispensável, } \\
\text { porém o mais importante é o } \\
\text { conteúdo do curso. }\end{array}$ & $\begin{array}{l}\text { Espero que o curso me dê } \\
\text { estudos aprofundados sobre } \\
\text { Física e Matemática, e me } \\
\text { prepare para ser um bom } \\
\text { professor. }\end{array}$ & $\begin{array}{l}\text { Sim, me interesso pela visão } \\
\text { do universo com máquina. }\end{array}$ \\
\hline D41 & $\begin{array}{l}\text { Porque este curso é voltado } \\
\text { para o ensino. }\end{array}$ & Não. & Talvez. & $\begin{array}{l}\text { Sim. Pois abre muitas } \\
\text { oportunidades. }\end{array}$ & $\begin{array}{l}\text { Espero revisar muitos } \\
\text { conceitos esquecidos... e } \\
\text { tenho maior perspectiva p/ as } \\
\text { metodologias de ensino. }\end{array}$ & Sim. \\
\hline D42 & Por gostar da área de ensino. & $\begin{array}{l}\text { Não, para pesquisa o } \\
\text { bacharelado seria a melhor } \\
\text { opção. }\end{array}$ & $\begin{array}{ll}\text { Provavelmente, } & \text { porque } \\
\text { enriquecedor } & \text { para } \\
\text { profissional de física. }\end{array}$ & $\begin{array}{l}\text { Aparentemente sim, mas } \\
\text { deve haver uma preocupação } \\
\text { permanente com a qualidade } \\
\text { do ensino. }\end{array}$ & $\begin{array}{l}\text { Acredito que atualmente o } \\
\text { mundo precise de } \\
\text { multiplicadores do } \\
\text { conhecimento para tal fim. }\end{array}$ & $\begin{array}{l}\text { Sim pois é um mundo de } \\
\text { descobertas sobre a natureza } \\
\text { e a vida. }\end{array}$ \\
\hline D43 & $\begin{array}{l}\text { Porque sou fascinado em } \\
\text { física. É a área a qual eu mais } \\
\text { me identifico. }\end{array}$ & Não. & $\begin{array}{l}\text { Sim, pois eu gosto de } \\
\text { lecionar. }\end{array}$ & $\begin{array}{l}\text { Depende dos objetivos da } \\
\text { pessoa. Muitas pessoas } \\
\text { podem seguir carreiras } \\
\text { apenas com um curso } \\
\text { profissionalizante e prática. }\end{array}$ & $\begin{array}{l}\text { Maior conhecimento na área, } \\
\text { o que possa me permitir ser } \\
\text { um bom profissional. }\end{array}$ & $\begin{array}{l}\text { Gosto, pois eu gosto de } \\
\text { trabalhar com a matemática, } \\
\text { e na física a matemática se } \\
\text { alheia aos conhecimentos da } \\
\text { natureza. }\end{array}$ \\
\hline D44 & $\begin{array}{l}\text { Porque sempre me interessei } \\
\text { pelo assunto e vi no curso } \\
\text { uma oportunidade para } \\
\text { aprender mais a respeito dos }\end{array}$ & $\begin{array}{lrr}\text { Não, pois no } & \text { curso } & \text { de } \\
\text { bacharelado são dadas mais } \\
\text { oportunidades } & \text { para } & \text { o } \\
\text { desenvolvimento } & & \text { de } \\
\end{array}$ & $\begin{array}{l}\text { Sim, pois me interesso pela } \\
\text { área da educação e em fazer } \\
\text { com que o aluno goste do } \\
\text { assunto } \quad \text { através de }\end{array}$ & $\begin{array}{l}\text { Não. Além do diploma é } \\
\text { preciso gostar do que faz e se } \\
\text { o profissional não estiver em } \\
\text { um curso que gosta por }\end{array}$ & $\begin{array}{l}\text { Eu espero através do curso } \\
\text { de física exercer a profissão } \\
\text { que gosto: lecionar, além de } \\
\text { aprender coisas que }\end{array}$ & $\begin{array}{l}\text { Sim pois ao estudar física eu } \\
\text { tento compreender os } \\
\text { mistérios do "gigantesco" } \\
\text { universo e o "minúsculo" }\end{array}$ \\
\hline
\end{tabular}




\begin{tabular}{|c|c|c|c|c|c|c|}
\hline & $\begin{array}{l}\text { mistérios do universo e da } \\
\text { estrutura da matéria. }\end{array}$ & $\begin{array}{l}\text { pesquisas, enquanto a } \\
\text { licenciatura é mais voltada } \\
\text { para a área da educação. }\end{array}$ & metodologias inovadoras. & $\begin{array}{l}\text { melhor que seja sua } \\
\text { formação ele não será um } \\
\text { profissional completo. }\end{array}$ & $\begin{array}{l}\text { realmente são do meu } \\
\text { interesse. }\end{array}$ & átomo. \\
\hline D45 & Eu gosto muito de Física. & Sim. & Talvez. Uma outra renda. & Sim. O mercado exige. & $\begin{array}{l}\text { O meio acadêmico sempre } \\
\text { tem muito a acrescentar, o } \\
\text { contato com alunos e } \\
\text { professores enriquecem a } \\
\text { vida de qualquer profissional, } \\
\text { principalmente aquele que } \\
\text { esta atuando no mundo de } \\
\text { negócios. }\end{array}$ & $\begin{array}{l}\text { Sim. } \quad \text { Facilidade } \\
\text { entendimento e prazer. }\end{array}$ \\
\hline D46 & \begin{tabular}{lllr} 
Por poder & \multicolumn{2}{ll}{ passar } & o \\
conhecimento & a & novas \\
pessoas. & & & \\
\end{tabular} & Não, mas pretendo fazer os 2 . & $\begin{array}{l}\text { Para poder passar adiante o } \\
\text { conhecimento (o meu) para } \\
\text { novas pessoas. }\end{array}$ & $\begin{array}{l}\text { Sim, facilita na busca por um } \\
\text { emprego. }\end{array}$ & $\begin{array}{l}\text { Que eu seja um ótimo } \\
\text { profissional e que isso me } \\
\text { traga retorno material. }\end{array}$ & Sim, facilidade e gosto. \\
\hline D47 & $\begin{array}{l}\text { Porque me identifico com } \\
\text { este curso. }\end{array}$ & Sim. & $\begin{array}{l}\text { Provavelmente. } \\
\text { gosto. }\end{array}$ & $\begin{array}{l}\text { Sim. O mercado de trabalho } \\
\text { está bem disputado. }\end{array}$ & $\begin{array}{l}\text { As melhores possíveis, pois a } \\
\text { USP tem um nome bem } \\
\text { reconhecido, e gosto do que } \\
\text { vou fazer. }\end{array}$ & $\begin{array}{l}\text { Porque é bem dinâmico, e é } \\
\text { um curso muito legal. }\end{array}$ \\
\hline D1* & $\begin{array}{l}\text { Eu não escolhi eu preenchi } \\
\text { errada a ficha de inscrição eu } \\
\text { queria física bacharelado. }\end{array}$ & $\begin{array}{l}\text { Não, eu } \quad \text { quero } \\
\text { pesquisador. }\end{array}$ & Não, não levo jeito. & $\begin{array}{l}\text { Não, você pode ter um } \\
\text { técnico e viver bem. }\end{array}$ & $\begin{array}{l}\text { Eu desejo me tornar um físico } \\
\text { teórico e acredito estar no } \\
\text { caminho certo. }\end{array}$ & $\begin{array}{l}\text { Sim, é o estudo do universo e } \\
\text { da vida. }\end{array}$ \\
\hline
\end{tabular}




\section{QUESTIONÁRIO DE INGRESSANTES DO CURSO DE LICENCIATURA EM FÍSICA - USP - NOTURNO/2002}

\begin{tabular}{|c|c|c|c|c|c|c|}
\hline № & $\begin{array}{c}\text { Por que escolheu fazer } \\
\text { Vestibular para Licenciatura } \\
\text { em Física? }\end{array}$ & $\begin{array}{c}\text { Para você, fazer o } \\
\text { Bacharelado ou a } \\
\text { Licenciatura em Física seriam } \\
\text { opções equivalentes? }\end{array}$ & $\begin{array}{l}\text { Você pretende ser professor } \\
\text { de Física? Por quê? }\end{array}$ & $\begin{array}{l}\text { Você acha que um diploma } \\
\text { de curso superior hoje no } \\
\text { Brasil é indispensável, } \\
\text { independente do conteúdo } \\
\text { do curso? Por quê? }\end{array}$ & $\begin{array}{l}\text { Quais perspectivas } \\
\text { profissionais e pessoais você } \\
\text { espera que o curso lhe } \\
\text { proporcione? }\end{array}$ & $\begin{array}{l}\text { Você gosta de estudar Física? } \\
\text { Por quê? }\end{array}$ \\
\hline N1 & $\begin{array}{l}\text { Porque gosto de física e estou } \\
\text { acostumado a dar aulas. }\end{array}$ & Não. & $\begin{array}{l}\text { Sim. É interessante o contato } \\
\text { com jovens. }\end{array}$ & $\begin{array}{l}\text { Sim. Pelas exigências do } \\
\text { mercado de trabalho. }\end{array}$ & $\begin{array}{l}\text { Quero dar aulas em colégios } \\
\text { de nome, e para isso preciso } \\
\text { de um diploma conceituado. } \\
\text { Então escolhi a USP para me } \\
\text { fornecer tal documento. }\end{array}$ & $\begin{array}{l}\text { Sim. Além de facilidade para a } \\
\text { matéria, a física me fascina. }\end{array}$ \\
\hline N2 & Para se tornar professor. & $\begin{array}{l}\text { Não, o bacharelado está mais } \\
\text { ligado a pesquisa etc... }\end{array}$ & Sim, pelo prazer de ensinar. & $\begin{array}{l}\text { Sim, pois o mercado de } \\
\text { trabalho } \\
\text { competitivo. }\end{array}$ & $\begin{array}{l}\text { Muitos conhecimentos, e } \\
\text { após concluir o curso, um } \\
\text { emprego realmente bom. }\end{array}$ & $\begin{array}{l}\text { Sim, pois é muito } \\
\text { interessante. }\end{array}$ \\
\hline N3 & $\begin{array}{l}\text { Lecionar, prestar concurso } \\
\text { público. }\end{array}$ & Não. & Sim, por gostar da profissão. & 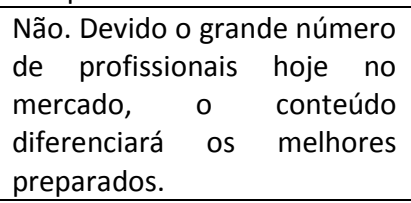 & $\begin{array}{l}\text { Proporcione conhecimentos } \\
\text { necessários para ser um bom } \\
\text { profissional, com profundo } \\
\text { conhecimento na área. }\end{array}$ & $\begin{array}{l}\text { Pela descoberta feita cada } \\
\text { passo, apresentando um } \\
\text { universo de conhecimentos. }\end{array}$ \\
\hline N4 & $\begin{array}{l}\text { Lecionar, possibilidade de } \\
\text { prestar concursos públicos }\end{array}$ & Não. & $\begin{array}{l}\text { Sim. Satisfação pessoal em } \\
\text { lecionar aquilo que gosto. }\end{array}$ & $\begin{array}{l}\text { Sim. Porque o mercado de } \\
\text { trabalho está cada vez mais } \\
\text { exigindo um profissional mais } \\
\text { qualificado. }\end{array}$ & $\begin{array}{l}\text { Profissionais: adquirir o } \\
\text { máximo de conhecimentos } \\
\text { para no futuro poder lecionar. } \\
\text { Pessoais: satisfação de estar } \\
\text { entre os melhores do Brasil } \\
\text { na parte de física. }\end{array}$ & $\begin{array}{l}\text { Sim. Porque é uma matéria } \\
\text { que proporciona vários } \\
\text { conhecimentos. }\end{array}$ \\
\hline N5 & $\begin{array}{l}\text { Porque vou fazer residência } \\
\text { médica de radiologia e dou } \\
\text { aula de física em um cursinho }\end{array}$ & Não. & Sim. Porque gosto. & Claro que não. & $\begin{array}{l}\text { Espero que melhore meus } \\
\text { conhecimentos de física e } \\
\text { permita conseguir um campo } \\
\text { na área médica, para } \\
\text { pesquisar. }\end{array}$ & Porque é legal. \\
\hline N6 & $\begin{array}{l}\text { Porque me identifico muito } \\
\text { com a matemática e a física e } \\
\text { com a carreira de professor. }\end{array}$ & $\begin{array}{l}\text { Não, pois pelo que sei, para } \\
\text { poder lecionar, é preciso fazer } \\
\text { licenciatura e, a princípio, é } \\
\text { isto que eu quero. }\end{array}$ & $\begin{array}{l}\text { Porque gosto desta carreira, } \\
\text { gosto de ensinar as pessoas. }\end{array}$ & $\begin{array}{l}\text { Muitas empresas, no } \\
\text { mercado de trabalho, exigem } \\
\text { curso superior não importa } \\
\text { qual, mas eu acho que para se } \\
\text { tornar um bom profissional, } \\
\text { deve-se tentar ao máximo }\end{array}$ & $\begin{array}{l}\text { Espero ser um excelente } \\
\text { conhecedor de matemática e } \\
\text { física, primeiramente, poder } \\
\text { lecionar, que é o que eu } \\
\text { quero ou trabalhar em outra } \\
\text { área de meu agrado ou }\end{array}$ & $\begin{array}{l}\text { Porque me interesso pelo que } \\
\text { está por trás dos fenômenos } \\
\text { que me cercam e pela } \\
\text { matemática. }\end{array}$ \\
\hline
\end{tabular}




\begin{tabular}{|c|c|c|c|c|c|c|}
\hline & & & & fazer aquilo que gosta. & $\begin{array}{l}\text { necessidade (bancos, } \\
\text { concursos públicos etc...) }\end{array}$ & \\
\hline N7 & $\begin{array}{l}\mathrm{Na} \text { verdade, eu pretendia } \\
\text { Licenciatura em Matemática. } \\
\text { Coloquei Física como outras } \\
\text { opções porque estava na } \\
\text { mesma Carreira. }\end{array}$ & Não. & Não sei ainda. & $\begin{array}{l}\text { Sim, devido a preferência por } \\
\text { profissionais qualificados no } \\
\text { mercado de trabalho. }\end{array}$ & $\begin{array}{l}\text { Eu espero que o curso me } \\
\text { proporcione muito } \\
\text { conhecimento em sua } \\
\text { didática para me tornar um } \\
\text { grande profissional para o } \\
\text { mercado de trabalho. }\end{array}$ & $\begin{array}{l}\text { Sim. Porque mostra a } \\
\text { essência de tudo ou quase } \\
\text { tudo. }\end{array}$ \\
\hline N8 & $\begin{array}{l}\text { Pretendo dar aulas de física } \\
\text { em colégios e cursinhos. }\end{array}$ & Sim. & $\begin{array}{l}\text { Sim. Porque é muito legal ser } \\
\text { professor. }\end{array}$ & $\begin{array}{l}\text { Sim. Pq se não tiver, não } \\
\text { arranja um bom emprego. }\end{array}$ & $\begin{array}{l}\text { O suficiente para ser um } \\
\text { ótimo profissional. }\end{array}$ & $\begin{array}{l}\text { Sim. Porque tudo em volta é } \\
\text { física, sua vida é baseada na } \\
\text { física. }\end{array}$ \\
\hline N9 & $\begin{array}{l}\text { Porque já leciono Física no } \\
\text { Ensino Médio. }\end{array}$ & $\begin{array}{l}\text { Não. Pois pretendo continuar } \\
\text { a lecionar. }\end{array}$ & Porque gosto de Física. & $\begin{array}{l}\text { Sim. Porque é um dos } \\
\text { requisitos para se admitir um } \\
\text { funcionário em determinadas } \\
\text { áreas. }\end{array}$ & $\begin{array}{lr}\text { Acredito que } & \text { vou } \\
\text { complementar } & \text { meus } \\
\text { conhecimentos em Física e } \\
\text { com isso melhorar minhas } \\
\text { aulas. }\end{array}$ & $\begin{array}{l}\text { Sim. Porque em busca dos } \\
\text { porquês da vida foi na física } \\
\text { que encontrei muitas } \\
\text { respostas. }\end{array}$ \\
\hline N10 & $\begin{array}{l}\text { Curiosidade em relação à } \\
\text { Física. }\end{array}$ & $\begin{array}{l}\text { Não. O curso de Bacharelado } \\
\text { está mais acima da } \\
\text { licenciatura. }\end{array}$ & $\begin{array}{l}\text { Não. Porque não tenho } \\
\text { paciência. }\end{array}$ & $\begin{array}{l}\text { Acho. Infelizmente o diploma } \\
\text { só tem valor se for de uma } \\
\text { grande universidade não } \\
\text { dependendo qual o curso. }\end{array}$ & $\begin{array}{l}\text { Profissionais nenhuma. Mas } \\
\text { pessoais, espero tentar gostar } \\
\text { da física, compreendê-la. }\end{array}$ & $\begin{array}{l}\text { Gosto, pois você pode aplicar } \\
\text { seus conceitos na vida real. } \\
\text { Na vida tudo tem um pouco } \\
\text { de física. }\end{array}$ \\
\hline N11 & $\begin{array}{l}\text { Porque gostaria muito de } \\
\text { trabalhar com pesquisas na } \\
\text { área de Exatas. }\end{array}$ & Sim. & $\begin{array}{l}\text { Talvez. Mas, minha opção } \\
\text { principal é a pesquisa. }\end{array}$ & $\begin{array}{l}\text { Sim. Porque para entrevistas } \\
\text { em emprego, é algo } \\
\text { indispensável hoje. }\end{array}$ & $\begin{array}{ll}\text { Acesso a equipamentos } & \text { e } \\
\text { professores para } & \text { o } \\
\text { desenvolvimento } & \text { de } \\
\text { pesquisas. } & \\
\end{array}$ & Sim. Gosto de exatas. \\
\hline N12 & $\begin{array}{l}\text { Para lecionar e aprofundar } \\
\text { em pesquisas. }\end{array}$ & Sim. & $\begin{array}{l}\text { Talvez. Pois pretendo investir } \\
\text { na área de pesquisa. }\end{array}$ & $\begin{array}{l}\text { Sim, pois a exigência por } \\
\text { profissionais qualificados } \\
\text { aumenta a cada dia. E o curso } \\
\text { superior oferece várias } \\
\text { possibilidades de emprego e } \\
\text { de promoção no emprego. }\end{array}$ & $\begin{array}{l}\text { Espero que me ajude a ficar } \\
\text { apto a entender e explicar os } \\
\text { fenômenos físicos e que me } \\
\text { ajude a ter um bom salário. }\end{array}$ & $\begin{array}{l}\text { Sim. Me interesso pelos } \\
\text { fenômenos que ocorrem } \\
\text { cotidianamente e porque a } \\
\text { física é um meio importante } \\
\text { para a tecnologia. }\end{array}$ \\
\hline \multicolumn{7}{|c|}{ 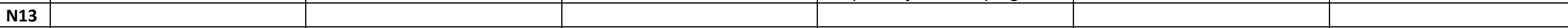 } \\
\hline N14 & $\begin{array}{l}\text { Pretendo lecionar na área de } \\
\text { Física futuramente. }\end{array}$ & $\begin{array}{lrr}\text { Não. Acredito } & \text { que } \\
\text { bacharelado visa } & \text { a } \\
\text { preparação de } & \text { um } \\
\text { pesquisador e o que pretendo } \\
\text { ser é professora, por isso } \\
\text { optei por Licenciatura. }\end{array}$ & $\begin{array}{l}\text { Sim. Gosto da área do ensino } \\
\text { de Física e pretendo dividir os } \\
\text { conhecimentos que vier a } \\
\text { adquirir com outras pessoas. }\end{array}$ & $\begin{array}{l}\text { Sim, mas é claro que deve ser } \\
\text { de uma boa universidade. } \\
\text { Como o mercado de trabalho } \\
\text { está muito seletivo acredito } \\
\text { que quanto mais tivermos p/ } \\
\text { provar nosso potencial é } \\
\text { necessário. }\end{array}$ & $\begin{array}{l}\text { Profissionais: Espero me } \\
\text { formar uma boa educadora } \\
\text { de Física. } \\
\text { Pessoais: Gosto da área e } \\
\text { acredito que tenho muito } \\
\text { para aprender. Aprender é a } \\
\text { minha maior satisfação. }\end{array}$ & $\begin{array}{l}\text { Sim. Pois é através dela que } \\
\text { podemos entender como } \\
\text { funciona o universo em que } \\
\text { vivemos. }\end{array}$ \\
\hline
\end{tabular}




\begin{tabular}{|c|c|c|c|c|c|c|}
\hline N15 & $\begin{array}{l}\text { Desejo de dar aula, ser } \\
\text { professor. }\end{array}$ & Não. & Sim. & $\begin{array}{l}\text { Ter o diploma talvez não, mas } \\
\text { o acesso ao conhecimento de } \\
\text { um curso superior sim. }\end{array}$ & $\begin{array}{l}\text { O prazer de dar aula, uma } \\
\text { grande possibilidade de } \\
\text { aprendizado. }\end{array}$ & $\begin{array}{l}\text { Observam fatos físicos e } \\
\text { podem explicá-los no papel, } \\
\text { entender porque ocorre me } \\
\text { fascina. }\end{array}$ \\
\hline N16 & $\begin{array}{l}\text { Porque pretendo seguir esta } \\
\text { carreira. }\end{array}$ & Não. & $\begin{array}{l}\text { Sim. Porque } \\
\text { interessante fazer da arte de } \\
\text { ensinar, } \\
\text { profissional. }\end{array}$ & $\begin{array}{l}\text { Sim. Porque até mesmo as } \\
\text { empresas de pequena } \\
\text { expressão exigem um } \\
\text { diploma de curso superior, } \\
\text { não levando em conta o } \\
\text { conteúdo do curso de } \\
\text { formação. }\end{array}$ & $\begin{array}{l}\text { Quanto a perspectiva pessoal, } \\
\text { espero que tenha prazer e } \\
\text { satisfação de cursar } \\
\text { Licenciatura. Já quanto à } \\
\text { profissional, além da } \\
\text { satisfação, retorno financeiro. }\end{array}$ & $\begin{array}{l}\text { Sim. Porque envolve ciência e } \\
\text { tecnologia. }\end{array}$ \\
\hline N17 & $\begin{array}{l}\text { Porque eu gosto de física e } \\
\text { tenho por objetivo entender } \\
\text { o mundo que me rodeia. }\end{array}$ & Não. & $\begin{array}{l}\text { Talvez, acho interessante } \\
\text { transmitir conhecimento. }\end{array}$ & $\begin{array}{l}\text { Independente não, mas que é } \\
\text { indispensável é! }\end{array}$ & $\begin{array}{l}\text { Além da satisfação em ter a } \\
\text { oportunidade de estudar o } \\
\text { mundo que me rodeia, eu } \\
\text { tenho a chance de passar este } \\
\text { conhecimento adiante. }\end{array}$ & Sim. Vide resposta 3 \\
\hline N18 & $\begin{array}{l}\text { Atende minhas pretensões } \\
\text { profissionais. }\end{array}$ & & $\begin{array}{l}\text { Sim, pois tenho } \\
\text { [não concluiu a frase] }\end{array}$ & $\begin{array}{l}\text { Não, pois o conteúdo do } \\
\text { curso é que pode e irá } \\
\text { diferenciar a formação do } \\
\text { profissional. }\end{array}$ & $\begin{array}{l}\text { Profissionalmente a carreira } \\
\text { traz um grande número de } \\
\text { caminhos a seguir, lecionar, } \\
\text { fazer pesquisas, ou atuar na } \\
\text { área industrial. }\end{array}$ & $\begin{array}{l}\text { Facilidade em entender a } \\
\text { matéria, já que cursei fica } \\
\text { bacharel durante } 1 \text { ano, e } \\
\text { este interesse já era vivo. }\end{array}$ \\
\hline N19 & Adequação pessoal ao curso. & Sim. & Pretendo, por gosto pessoal. & $\begin{array}{l}\text { Sim, devido ao preconceito } \\
\text { por parte de muitos } \\
\text { empregadores. }\end{array}$ & $\begin{array}{l}\text { Quanto às perspectivas } \\
\text { profissionais, desejo que o } \\
\text { curso me habilite a ministrar } \\
\text { aulas e a trabalhar em centro } \\
\text { de pesquisas e quanto ao } \\
\text { pessoal, pretendo adquirir um } \\
\text { profundo conhecimento em } \\
\text { física. }\end{array}$ & $\begin{array}{l}\text { Sim, não faço idéia do } \\
\text { porque. }\end{array}$ \\
\hline N2O & $\begin{array}{l}\text { Porque gosto de Física, mas a } \\
\text { preocupação em conseguir } \\
\text { emprego, logo no início do } \\
\text { curso limita a possibilidade do } \\
\text { bacharelado. }\end{array}$ & $\begin{array}{l}\text { Não, eu gostaria de fazer o } \\
\text { bacharelado, porém preciso } \\
\text { trabalhar. }\end{array}$ & $\begin{array}{l}\text { Sim. Porque eu acredito que o } \\
\text { professor tem um papel social } \\
\text { importante, alem de gostar } \\
\text { muito de física. }\end{array}$ & $\begin{array}{l}\text { Sim. Porque o mercado é } \\
\text { muito competitivo. }\end{array}$ & $\begin{array}{l}\text { Eu imagino que na física eu } \\
\text { consiga mais satisfações } \\
\text { pessoais do que profissionais, } \\
\text { porém não acredito que eu } \\
\text { estejaranarando } \\
\text { possibilidades de ganhar um } \\
\text { bom salário. }\end{array}$ & $\begin{array}{l}\text { Sim. Porque numa linha de } \\
\text { raciocínio geral da ciência ela } \\
\text { tenta desvendar o } \\
\text { funcionamento do universo, o } \\
\text { que é fascinante. }\end{array}$ \\
\hline N21 & Para poder dar aulas. & $\begin{array}{l}\text { Não, Bacharelado é específico } \\
\text { para pesquisa e Licenciatura é }\end{array}$ & Sim, porque gosto de ensinar. & $\begin{array}{l}\text { Sim, pois curso superior é } \\
\text { necessário para arrumar um }\end{array}$ & $\begin{array}{l}\text { Profissionalmente o curso vai } \\
\text { me ajudar bastante pois }\end{array}$ & $\begin{array}{l}\text { Sim, pois gosto de assuntos } \\
\text { relacionados a ciência. }\end{array}$ \\
\hline
\end{tabular}




\begin{tabular}{|c|c|c|c|c|c|c|}
\hline & & $\begin{array}{l}\text { próprio para quem quer dar } \\
\text { aulas. }\end{array}$ & & bom emprego. & $\begin{array}{l}\text { preciso estar cursando } \\
\text { faculdade para ser } \\
\text { promovido, porém pretendo } \\
\text { começar a lecionar. }\end{array}$ & \\
\hline N22 & Para ingressar na USP. & Não. & Talvez. & $\begin{array}{l}\text { Sim. Manter-se no mercado } \\
\text { de trabalho. }\end{array}$ & $\begin{array}{l}\text { Crescimento profissional, } \\
\text { realização pessoal. }\end{array}$ & Sim. Porque gosto. \\
\hline N23 & $\begin{array}{l}\text { Para melhor desenvolvimento } \\
\text { no ensino da física, fórmula } \\
\text { indispensável para um bom } \\
\text { professor. }\end{array}$ & $\begin{array}{l}\text { Não, porque o Bacharelado } \\
\text { permite um aprofundamento } \\
\text { mais específico voltado para a } \\
\text { pesquisa ou aplicação técnica } \\
\text { e a licenciatura possui } \\
\text { elementos táticos para } \\
\text { encaminhar pessoas a esse } \\
\text { aprofundamento. }\end{array}$ & $\begin{array}{l}\text { O meu maior objetivo é ser } \\
\text { um cientista e acredito que } \\
\text { como professor, terei muitas } \\
\text { chances de passar o que } \\
\text { aprendi e manter contato } \\
\text { permanente com pessoas que } \\
\text { tenham interesse de } \\
\text { desvendar esta ciência } \\
\text { incrível que é a física. }\end{array}$ & $\begin{array}{l}\text { Não, porque é muito comum } \\
\text { pessoas com nível superior e } \\
\text { desempregadas devido a falta } \\
\text { de capacidade profissional. }\end{array}$ & $\begin{array}{l}\text { As perspectivas profissionais } \\
\text { é a condição mínima de } \\
\text { sobrevivência. E pessoais, é a } \\
\text { realização do maior objetivo } \\
\text { de minha vida, o título de } \\
\text { físico. }\end{array}$ & 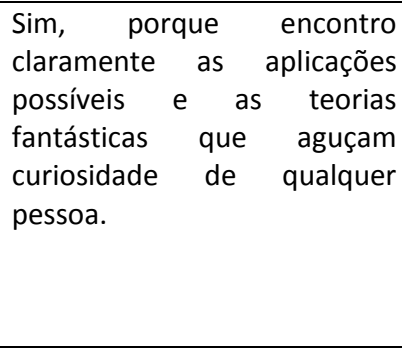 \\
\hline N24 & $\begin{array}{l}\text { Por pretender lecionar e } \\
\text { Física é uma matéria que eu } \\
\text { gosto e muitos odeiam. }\end{array}$ & Não. & $\begin{array}{l}\text { Porque a Física impressiona e } \\
\text { detém atenção quando bem } \\
\text { explicada. }\end{array}$ & $\begin{array}{l}\text { Não. Depende muito também } \\
\text { do profissional. }\end{array}$ & $\begin{array}{l}\text { Espero eu que seja capaz de } \\
\text { sair daqui conseguindo } \\
\text { explicar o fundamental da } \\
\text { física e que o curso me dê } \\
\text { condições de tentar o } \\
\text { mestrado. }\end{array}$ & $\begin{array}{l}\text { Sim, porque explica todos os } \\
\text { fenômenos da natureza e } \\
\text { principalmente do cotidiano. }\end{array}$ \\
\hline N25 & $\begin{array}{l}\text { Interesso-me por Física e } \\
\text { quero dar aulas de Física. }\end{array}$ & Não. & $\begin{array}{l}\text { Sim. Já dei aula particular, } \\
\text { acho que serei um bom } \\
\text { professor, pois sinto que a } \\
\text { profissão é recompensatória. }\end{array}$ & $\begin{array}{l}\text { Não. Pois o importante é o } \\
\text { que se aprende e em algumas } \\
\text { instituições não acontece isto. }\end{array}$ & $\begin{array}{l}\text { Espero ter uma formação } \\
\text { forte para ter uma boa base } \\
\text { de conhecimento e, portanto, } \\
\text { ser capacitado para dar boas } \\
\text { aulas. }\end{array}$ & $\begin{array}{l}\text { Sim. Pois acho que a física é } \\
\text { uma forma de ver o mundo. }\end{array}$ \\
\hline N26 & $\begin{array}{l}\text { Porque me identifico com a } \\
\text { área de exatas, } \\
\text { principalmente tecnologia e } \\
\text { ciências, tais como física. }\end{array}$ & $\begin{array}{l}\text { Sim, ambos Bacharelado e } \\
\text { licenciatura seriam opções } \\
\text { equivalentes. }\end{array}$ & $\begin{array}{l}\text { Sim, pretendo ter a } \\
\text { oportunidade de ensinar ou } \\
\text { fazer pesquisas nessa área. }\end{array}$ & 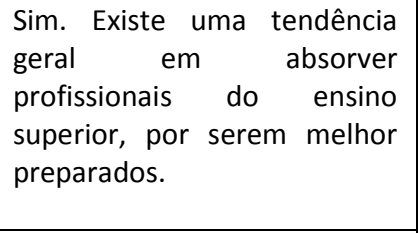 & $\begin{array}{l}\text { Espero que o curso me } \\
\text { direcione para tornar-me um } \\
\text { profissional que saiba lidar, } \\
\text { tanto com os aspectos } \\
\text { práticos e teóricos que essa } \\
\text { ciência proporciona. }\end{array}$ & $\begin{array}{l}\text { Si. Porque gosto de entender } \\
\text { os mecanismos práticos e } \\
\text { teóricos que regem nosso } \\
\text { mundo. }\end{array}$ \\
\hline N27 & $\begin{array}{l}\text { Acredito haver uma extrema } \\
\text { carência de bons profissionais } \\
\text { e métodos de ensino nas } \\
\text { áreas de exatas e, acredito } \\
\text { que uma reformulação desses } \\
\text { profissionais deve fortalecer o }\end{array}$ & $\begin{array}{lcc}\text { Não, } & \text { a licenciatura } & \text { tem } \\
\text { ênfase } & \text { pedagógica } & \text { não } \\
\text { alcançada no bacharelado. }\end{array}$ & $\begin{array}{l}\text { Sim, acredito na força do bom } \\
\text { ensino de exatas. }\end{array}$ & 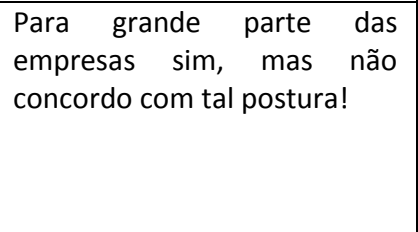 & $\begin{array}{l}\text { A possibilidade } \\
\text { desenvolvimento de novas } \\
\text { técnicas pedagógicas para } \\
\text { exatas são meus maiores } \\
\text { anseios! }\end{array}$ & $\begin{array}{l}\text { Sim, pois trata-se de uma } \\
\text { ciência próxima do cotidiano. }\end{array}$ \\
\hline
\end{tabular}




\begin{tabular}{|c|c|c|c|c|c|c|}
\hline & $\begin{array}{l}\text { interesse dos alunos pela } \\
\text { área. }\end{array}$ & & & & & \\
\hline N28 & $\begin{array}{l}\text { Porque já trabalhei como } \\
\text { professora de Física em um } \\
\text { cursinho preparatório para o } \\
\text { vestibular e esta experiência } \\
\text { foi muito gratificante. }\end{array}$ & Sim. & $\begin{array}{l}\text { Sim, porque é gratificante ver } \\
\text { que os alunos estão } \\
\text { aprendendo a matéria e estão } \\
\text { satisfeitos consigo mesmo por } \\
\text { conseguir. }\end{array}$ & $\begin{array}{llr}\text { Um curso } & \text { superior } & \text { é } \\
\text { indispensável, } & \text { mas } & \text { é } \\
\text { necessário que } & \text { este } \\
\text { realmente prepare o aluno } \\
\text { para o mercado de trabalho; } \\
\text { caso contrário o aluno não } \\
\text { terá um desenvolvimento } \\
\text { profissional satisfatório. }\end{array}$ & $\begin{array}{l}\text { Permita que eu esteja } \\
\text { preparada para dar aulas; e } \\
\text { consiga desenvolver uma tese } \\
\text { p/ mestrado e doutorado } \\
\text { futuramente. }\end{array}$ & $\begin{array}{l}\text { Sim, pois explica muitos } \\
\text { fenômenos que ocorrem no } \\
\text { nosso cotidiano (como tudo } \\
\text { funcionava e os porquês). }\end{array}$ \\
\hline N29 & $\begin{array}{l}\text { Já sou professor. Preciso do } \\
\text { diploma. }\end{array}$ & Não. & Já sou. & $\begin{array}{l}\text { Não. Existem várias outras } \\
\text { opções que não necessitam } \\
\text { de curso superior. }\end{array}$ & $\begin{array}{l}\text { Espero aprender algo útil p/ } \\
\text { minha profissão. }\end{array}$ & Sim. \\
\hline N30 & $\begin{array}{l}\text { Admiro a Física e tenho uma } \\
\text { pequena facilidade com a } \\
\text { matéria. }\end{array}$ & Sim. & $\begin{array}{lrr}\text { Sim. Acredito } & \text { ser } \\
\text { fundamental que o } & \text { o } \\
\text { conhecimento da física seja } \\
\text { distribuído para toda } \\
\text { população brasileira se } \\
\text { quisermos que o Brasil tenha } \\
\text { alguma importância neste } \\
\text { mundo globalizado. }\end{array}$ & $\begin{array}{l}\text { Sim. Porque estamos sendo } \\
\text { pressionados para assinarmos } \\
\text { o ALCA e quem não tiver um } \\
\text { bom curso superior terá suas } \\
\text { condições de sobrevivência } \\
\text { minimizadas. }\end{array}$ & $\begin{array}{l}\text { Espero encontrar professores } \\
\text { que se dediquem a ensinar } \\
\text { com paciência, vontade e que } \\
\text { eles façam com que as aulas } \\
\text { sejam muito prazerosas. Que } \\
\text { os professores estejam } \\
\text { realmente preocupados com } \\
\text { os alunos. }\end{array}$ & $\begin{array}{l}\text { Sim. Porque gosto de } \\
\text { compreender o que está em } \\
\text { minha volta. }\end{array}$ \\
\hline N31 & $\begin{array}{l}\text { Porque desejo ser professora } \\
\text { e vejo a física como um } \\
\text { desafio. Estou cansada de } \\
\text { Engenheiros dando aula de } \\
\text { física e de aulas que } \\
\text { desprezam a matéria graças a } \\
\text { professores sem metodologia } \\
\text { adequada. }\end{array}$ & Não, de maneira nenhuma. & $\begin{array}{l}\text { Porque amo a profissão de } \\
\text { Educadora. }\end{array}$ & $\begin{array}{l}\text { Não, o conteúdo é muito mais } \\
\text { importante que o diploma, } \\
\text { apesar de infelizmente, a } \\
\text { sociedade destacar } \\
\text { diploma. }\end{array}$ & $\begin{array}{l}\text { Anseio aprender bem a física, } \\
\text { porém dentro de um contexto } \\
\text { sócio-cultural, não acredito } \\
\text { que a física seja puramente } \\
\text { exata. E com este } \\
\text { conhecimento, desejo poder } \\
\text { ser professora. }\end{array}$ & $\begin{array}{l}\text { Gosto de estudar física, mas } \\
\text { amo d Saber o que seus } \\
\text { "inventores" queriam ou } \\
\text { almejavam ao "inventá-la". } \\
\text { Quais os "problemas" sociais } \\
\text { que os motivaram a buscar a } \\
\text { solução. }\end{array}$ \\
\hline N32 & $\begin{array}{l}\text { Por minha atração em relação } \\
\text { as ciências físicas e pela } \\
\text { disponibilidade de horário. }\end{array}$ & Não. & $\begin{array}{l}\text { Sim, por ser uma matéria de } \\
\text { certa forma evitada pelos } \\
\text { professores. }\end{array}$ & $\begin{array}{l}\text { Não, pois nem sempre o } \\
\text { curso superior ultrapassa a } \\
\text { experiência profissional. }\end{array}$ & $\begin{array}{l}\text { Conhecimentos máximos } \\
\text { quanto à Física e respeito aos } \\
\text { meus familiares e amigos. }\end{array}$ & $\begin{array}{l}\text { Sim, porque através dela } \\
\text { encontramos explicações de } \\
\text { fenômenos que antes fugiam } \\
\text { a exatidão. }\end{array}$ \\
\hline N33 & $\begin{array}{l}\text { Desejo futuramente ministrar } \\
\text { aulas em universidades e } \\
\text { escolas de } 20 \text { grau. }\end{array}$ & $\begin{array}{l}\text { Não. Na minha opinião cada } \\
\text { curso tem seu propósito. }\end{array}$ & $\begin{array}{l}\text { Sim. Considero que tenho } \\
\text { facilidade em transmitir meus } \\
\text { conhecimentos. }\end{array}$ & $\begin{array}{l}\text { Não. Algumas vezes um bom } \\
\text { curso técnico vale mais que } \\
\text { um curso superior mal feito. }\end{array}$ & $\begin{array}{l}\text { Espero que o curso enriqueça } \\
\text { os meus conhecimentos } \\
\text { teóricos e práticos da física e } \\
\text { me proporcione vantagens } \\
\text { referentes ao mercado de }\end{array}$ & $\begin{array}{l}\text { Sim. Tive grandes incentivo de } \\
\text { excelentes professores, tanto } \\
\text { dos professores do 2o grau } \\
\text { quanto aos de alguns cursos } \\
\text { técnicos que freqüentei. }\end{array}$ \\
\hline
\end{tabular}




\begin{tabular}{|c|c|c|c|c|c|c|}
\hline & & & & & trabalho. & \\
\hline N34 & $\begin{array}{l}\text { Tentei por três vezes } \\
\text { prestando bacharelado e não } \\
\text { consegui, tentei licenciatura } \\
\text { por ter menor nota, e é um } \\
\text { bom curso para iniciar em } \\
\text { física. }\end{array}$ & $\begin{array}{l}\text { Não, bacharelado é um curso } \\
\text { mais voltado para pesquisa, } \\
\text { enquanto o outro é mais } \\
\text { voltado para a didática. }\end{array}$ & $\begin{array}{l}\text { Não. Na verdade pretendo } \\
\text { fazer matérias de } \\
\text { bacharelado futuramente, } \\
\text { gostaria de trabalhar com } \\
\text { pesquisas. }\end{array}$ & $\begin{array}{l}\text { Sim. O curso superior é visto } \\
\text { como um comprovante de } \\
\text { que a pessoa corre atrás do } \\
\text { seu futuro, até concursos } \\
\text { públicos pedem nível superior } \\
\text { em qualquer área (alguns) } \\
\text { para realizar as provas. }\end{array}$ & $\begin{array}{l}\text { Espero que o curso permita } \\
\text { que eu ingresse no mundo da } \\
\text { pesquisa científica, pois eu } \\
\text { gosto muito, pessoalmente } \\
\text { ficaria muito contente com } \\
\text { isso. }\end{array}$ & $\begin{array}{l}\text { Sim. Sempre tive interesse } \\
\text { por ciências em geral, como } \\
\text { gosto mais de astronomia e } \\
\text { ele tem ligação muito forte } \\
\text { com física (astrofísica), passei } \\
\text { a gostar de física. }\end{array}$ \\
\hline N35 & Gostaria de lecionar física. & Não. & Pretendo. & $\begin{array}{l}\text { Não, mas ajuda a conseguir } \\
\text { um emprego depois. }\end{array}$ & Pesquisa e ensino de física. & Sim. \\
\hline N36 & $\begin{array}{l}\text { Pois pretendo adquirir o } \\
\text { máximo de conhecimentos } \\
\text { para lecionar Física e } \\
\text { Matemática após me formar. }\end{array}$ & Não. & $\begin{array}{l}\text { Sim, pois este é um sonho } \\
\text { antigo. }\end{array}$ & 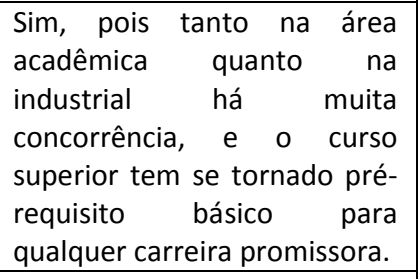 & \begin{tabular}{lrrr} 
Espero que & o & curso & me \\
proporcione & & os \\
conhecimentos & \multicolumn{2}{c}{ básicos } \\
necessários para que & me \\
torne um bom professor. &
\end{tabular} & $\begin{array}{l}\text { Sim, pois tenho } \text { grande } \\
\text { interesse e facilidade nesta } \\
\text { área. }\end{array}$ \\
\hline N37 & $\begin{array}{l}\text { Porque pretendo ser } \\
\text { professora de Física. Adoro a } \\
\text { matéria e tudo que a envolve. }\end{array}$ & Não. & $\begin{array}{l}\text { Sim. Pretendo mudar a visão } \\
\text { dos alunos sobre a física. } \\
\text { Mostrar a eles a física na } \\
\text { prática e perceberem a física } \\
\text { no dia-a-dia. }\end{array}$ & $\begin{array}{l}\text { Talvez. Depende do ramo em } \\
\text { que o profissional atua e } \\
\text { como atua o profissional. }\end{array}$ & $\begin{array}{l}\text { Pretendo que o curso me } \\
\text { abra as portas no campo } \\
\text { profissional e também será } \\
\text { uma realização pessoal. Para } \\
\text { mim, cursar a faculdade de } \\
\text { física e lecioná-la são meus } \\
\text { sonhos. }\end{array}$ & $\begin{array}{l}\text { Sim. Me agrada o fato da } \\
\text { descoberta e o querer saber } \\
\text { sempre mais. }\end{array}$ \\
\hline N38 & $\begin{array}{l}\text { Porque gosto de Física e } \\
\text { sempre levantei a bandeira da } \\
\text { educação. }\end{array}$ & Não. Meu objetivo é dar aula. & $\begin{array}{l}\text { Sim. Através da Física quero } \\
\text { ensinar arte, filosofia, história } \\
\text { e todas as matérias que farão } \\
\text { o meu aluno aprender a } \\
\text { pensar. }\end{array}$ & $\begin{array}{l}\text { Se você pensar no diploma } \\
\text { universitário para o mercado } \\
\text { de trabalho, eu respondo que } \\
\text { sim; mas se pensar no } \\
\text { diploma de um curso superior } \\
\text { como a porta de entrada para } \\
\text { uma formação acadêmica } \\
\text { completa, eu respondo que } \\
\text { não. }\end{array}$ & $\begin{array}{l}\text { Quero terminar esse curso } \\
\text { apta a ensinar física de uma } \\
\text { maneira diferente da qual eu } \\
\text { aprendi. Quero ter conteúdo } \\
\text { suficiente para romper com } \\
\text { todo método de ensino da } \\
\text { física aplicado nas escolas } \\
\text { hoje em dia. E por último, } \\
\text { quero dar aula onde estiver } \\
\text { precisando de um professor. }\end{array}$ & $\begin{array}{l}\text { Gosto porque a física sempre } \\
\text { me mostrou muitos desafios. }\end{array}$ \\
\hline N39 & $\begin{array}{l}\text { Além do interesse por Física, } \\
\text { tenho interesse em dar aulas } \\
\text { sobre o assunto, acredito ter } \\
\text { condições e jeito para }\end{array}$ & $\begin{array}{l}\text { Não, minha prioridade é } \\
\text { Licenciatura, embora, seria } \\
\text { uma boa opção Bacharelado } \\
\text { (infelizmente não podemos }\end{array}$ & $\begin{array}{l}\text { Além de gostar, tive boas } \\
\text { experiências como professor. }\end{array}$ & $\begin{array}{l}\text { Não. Hoje, o diploma já não é } \\
\text { mais um diferencial, } \\
\text { justamente porque todos (ou } \\
\text { a maioria), não oferecem }\end{array}$ & $\begin{array}{l}\text { Que eu tenha facilidade para } \\
\text { explanar os diversos assuntos } \\
\text { em física e entendê-los em } \\
\text { sua } \quad \text { profundidade, }\end{array}$ & $\begin{array}{l}\text { Sim, pois estudamos os } \\
\text { assuntos mais simples que } \\
\text { ocorrem na natureza, no dia a } \\
\text { dia. } \grave{E} \text { interessante saber }\end{array}$ \\
\hline
\end{tabular}




\begin{tabular}{|c|c|c|c|c|c|c|}
\hline & lecionar. & $\begin{array}{l}\text { escolher no vestibular esta } \\
\text { opção) }\end{array}$ & & grande conteúdo. & $\begin{array}{l}\text { desenvolvendo } 0 \text { assunto } \\
\text { através do raciocínio } \\
\text { adquirido no curso. }\end{array}$ & $\begin{array}{l}\text { como podemos explicar e } \\
\text { aprofundar sobre algum } \\
\text { fenômeno. }\end{array}$ \\
\hline N40 & Pretendo pesquisar na área. & Sim. & & $\begin{array}{l}\text { Sim, todos tem suas } \\
\text { especialidades. }\end{array}$ & $\begin{array}{l}\text { Realização de ter feito algo } \\
\text { novo ou que melhore meus } \\
\text { conhecimentos. }\end{array}$ & Tenho facilidade. \\
\hline N41 & Porque pretendo dar aulas. & $\begin{array}{l}\text { Não pois a ênfase do curso de } \\
\text { bacharelado é a pesquisa. }\end{array}$ & $\begin{array}{l}\text { Sim, não sei bem porquê, me } \\
\text { pego indagando sobre esta } \\
\text { opção com freqüência. }\end{array}$ & $\begin{array}{l}\text { Não, pois há carreiras fora da } \\
\text { área acadêmica que não } \\
\text { exigem curso superior que } \\
\text { podem ser bem rentáveis ou } \\
\text { tão gratificantes, depende de } \\
\text { opções pessoais. }\end{array}$ & $\begin{array}{l}\text { Possibilidade de dar aula p/ } \\
\text { 20 grau e cursos técnicos, já } \\
\text { que também tenho formação } \\
\text { nesta área. }\end{array}$ & $\begin{array}{l}\text { Sim, porque acredito que o } \\
\text { conhecimento da física } \\
\text { amplie a percepção e o } \\
\text { conhecimento do mundo que } \\
\text { nos cerca. }\end{array}$ \\
\hline N42 & $\begin{array}{lrr}\text { Já ministrei aulas } & \text { tanto na } \\
\text { escola pública } & \text { como } \\
\text { particular, e pretendo } \\
\text { continuar com maior } \\
\text { capacidade do que já possuo, } \\
\text { aprendendo não apenas } \\
\text { ensinar a matéria mas como } \\
\text { ensinar. }\end{array}$ & $\begin{array}{l}\text { Não, pois o bacharelado se } \\
\text { aprofunda sem o interesse } \\
\text { didático, já a licenciatura não } \\
\text { se aprofunda nas experiências } \\
\text { e se preocupa com a didática. }\end{array}$ & $\begin{array}{l}\text { Sim. Gosto de ensinar, lidar } \\
\text { com pessoas, passar } \\
\text { conhecimentos. }\end{array}$ & $\begin{array}{l}\text { Não. O que depende é a força } \\
\text { de vontade e persistência do } \\
\text { objetivo que se almeja. }\end{array}$ & $\begin{array}{l}\text { Aprofundamento dos meus } \\
\text { conhecimentos, lapidação, e } \\
\text { com isto o ingresso em } \\
\text { ótimas escolas. }\end{array}$ & $\begin{array}{l}\text { Para poder entender melhor } \\
\text { o mundo. } \\
\text { Saber resolver problemas } \\
\text { cotidianos e problemas } \\
\text { inesperados. }\end{array}$ \\
\hline N43 & Porque gosto da matéria. & Não & Sim, gosto de lecionar. & $\begin{array}{l}\text { Sim, mas o conteúdo é } \\
\text { fundamental. }\end{array}$ & $\begin{array}{l}\text { Boas condições de trabalho e } \\
\text { excelente satisfação pessoal; } \\
\text { se identificando com o que eu } \\
\text { lecionarei }\end{array}$ & Muito, gosto de dificuldades. \\
\hline N44 & $\begin{array}{l}\text { Por ter adquirido interesse } \\
\text { por esta ciência durante o } \\
\text { decorrer do colégio técnico. }\end{array}$ & Sim. & $\begin{array}{l}\text { Sim no caso de não conseguir } \\
\text { entrar na área de pesquisa. }\end{array}$ & $\begin{array}{l}\text { Sim pois não se pode parar de } \\
\text { estudar atualmente. }\end{array}$ & $\begin{array}{l}\text { Estabilidade profissional e } \\
\text { satisfação pessoal. }\end{array}$ & $\begin{array}{l}\text { Sim pois ela rege próprio } \\
\text { começo do universo, revela } \\
\text { seu interior e nos permite } \\
\text { entender o que chamamos de } \\
\text { realidade. }\end{array}$ \\
\hline N45 & $\begin{array}{l}\text { Vontade de ensinar, gosto } \\
\text { pela Física, realização pessoal, } \\
\text { econômica e profissional. }\end{array}$ & Não. & $\begin{array}{l}\text { Sim. Faltam profissionais } \\
\text { desse tipo e também me } \\
\text { ocorre o desejo de lecionar. }\end{array}$ & $\begin{array}{l}\text { O diploma é fundamental, } \\
\text { mas o curso e o conteúdo do } \\
\text { mesmo é um diferencial } \\
\text { importante. }\end{array}$ & $\begin{array}{l}\text { Lecionar ou trabalhar com } \\
\text { Física. }\end{array}$ & $\begin{array}{l}\text { Sim. É a ciência mais } \\
\text { fundamental e que explica o } \\
\text { mundo. }\end{array}$ \\
\hline N46 & $\begin{array}{l}\text { Pretendo atuar na área de } \\
\text { ensino escrevendo livros de } \\
\text { introdução à física básica e } \\
\text { realizar } \\
\text { interdisciplinares. }\end{array}$ & $\begin{array}{l}\text { Sim, pois posso enriquecer } \\
\text { meu currículo com atividades } \\
\text { extra-curriculares. }\end{array}$ & $\begin{array}{ll}\text { Prefiro atuar } & \text { no apoio } \\
\text { pedagógico } & \text { elaborando } \\
\text { material didático. } & \end{array}$ & $\begin{array}{l}\text { Sim, dependendo do renome } \\
\text { da universidade. }\end{array}$ & $\begin{array}{l}\text { Desejo ter contato com } \\
\text { cientistas de renome e } \\
\text { participar dos avanços } \\
\text { científicos de vanguarda. } \\
\text { Pretendo fazer do ensino e }\end{array}$ & $\begin{array}{l}\text { Sim, especialmente a parte } \\
\text { teórica, pois o pensamento } \\
\text { debruçado sobre as ciências } \\
\text { exatas levam-me a contínua } \\
\text { superação de mim mesmo e }\end{array}$ \\
\hline
\end{tabular}




\begin{tabular}{|c|c|c|c|c|c|c|}
\hline & & & & & $\begin{array}{l}\text { propagação do conhecimento } \\
\text { um sacerdócio. }\end{array}$ & $\begin{array}{l}\text { estabelece uma lógica que } \\
\text { permeia a vida cotidiana. }\end{array}$ \\
\hline N47 & $\begin{array}{l}\text { Para ser professor de Física } \\
\text { do ensino médio. }\end{array}$ & Não. & Sim. Vocação. & $\begin{array}{l}\text { Sim. O mercado de trabalho } \\
\text { não contrata ninguém sem } \\
\text { diploma. }\end{array}$ & $\begin{array}{l}\text { Ser professor de Física no } \\
\text { ensino público de segundo } \\
\text { grau, preferencialmente na } \\
\text { periferia. }\end{array}$ & Sim. Não sei. \\
\hline N48 & $\begin{array}{l}\text { Pois vai me preparar para } \\
\text { fazer o que eu quero que é } \\
\text { dar aulas. }\end{array}$ & Não. & $\begin{array}{l}\text { Sim, porque há falta de bons } \\
\text { profissionais atuando nessa } \\
\text { área, não quero ser só mais } \\
\text { um professor, mas sim um } \\
\text { excelente professor. }\end{array}$ & $\begin{array}{l}\text { Não. Acho importante cada } \\
\text { pessoa se especializar naquilo } \\
\text { que gosta, independente } \\
\text { disso ser algo que se estude } \\
\text { numa universidade. }\end{array}$ & $\begin{array}{l}\text { Espero que este curso me } \\
\text { mostre um panorama vasto } \\
\text { no campo da pesquisa e da } \\
\text { ciência, onde não se limite } \\
\text { apenas a decoreba de teorias, } \\
\text { acredito nisso. }\end{array}$ & $\begin{array}{l}\text { Sim, pois a física é capaz de } \\
\text { explicar diversos fenômenos } \\
\text { da natureza, além de } \\
\text { contribuir para o } \\
\text { melhoramento de diversos } \\
\text { produtos industriais. }\end{array}$ \\
\hline N49 & $\begin{array}{l}\text { Para complementar } \\
\text { conhecimentos na área de } \\
\text { física. }\end{array}$ & Sim! & $\begin{array}{l}\text { Talvez! } \begin{array}{c}\text { Se } \\
\text { necessidade, sim! }\end{array} \\
\text { houver }\end{array}$ & $\begin{array}{l}\text { Sim! o mercado de trabalho } \\
\text { exige que se tenha um curso } \\
\text { superior p/ qualquer } \\
\text { qualificação! }\end{array}$ & $\begin{array}{ll}\text { Aprimoramento pessoal na } \\
\text { área. Complemento } \\
\text { conhecimentos técnicos. }\end{array}$ & $\begin{array}{l}\text { Sim. Por se tratar de uma } \\
\text { matéria que explora o lado } \\
\text { científico. }\end{array}$ \\
\hline N50 & Aptidão, interesse. & 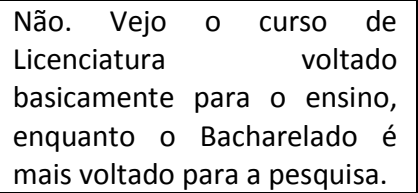 & $\begin{array}{l}\text { Sim. Interesse e gosto pelo } \\
\text { ensino de ciências/física. }\end{array}$ & $\begin{array}{l}\text { Não. A escola onde é feito o } \\
\text { curso, o corpo docente e as } \\
\text { aptidões pessoais devem ser } \\
\text { levados em consideração. }\end{array}$ & $\begin{array}{l}\text { Ingresso em carreiras } \\
\text { técnicas, correlatas ao curso. } \\
\text { Possibilidade de ingressar no } \\
\text { meio docente. }\end{array}$ & $\begin{array}{l}\text { Sim. Interesse pelas causas e } \\
\text { conhecê-las deste sua origem. }\end{array}$ \\
\hline N51 & $\begin{array}{l}\text { Acho uma carreira } \\
\text { interessante e tenho vontade } \\
\text { de ser professor. }\end{array}$ & Sim. & Sim, pois gosto de ensinar. & $\begin{array}{l}\text { Sim, pois abre muitas portas } \\
\text { para concurso. }\end{array}$ & $\begin{array}{l}\text { Aprender os conceitos e } \\
\text { aplicação para poder dar } \\
\text { aulas ou trabalhar em } \\
\text { pesquisas. }\end{array}$ & $\begin{array}{l}\text { Sim, para saber } \\
\text { funcionamento das coisas. }\end{array}$ \\
\hline N52 & $\begin{array}{l}\text { Escolhi a licenciatura pois } \\
\text { acredito poder transmitir } \\
\text { meus conhecimentos para as } \\
\text { pessoas e também escolhi a } \\
\text { área da física pois desde o } \\
\text { colégio técnico até hoje na } \\
\text { indústria estou plenamente } \\
\text { em contato. }\end{array}$ & $\begin{array}{l}\text { Não, a licenciatura tem toda a } \\
\text { estrutura pedagógica, que o } \\
\text { bacharelado não tem. }\end{array}$ & $\begin{array}{l}\text { Porque acredito } \\
\text { capacidade de } \\
\text { absorver toda a bago só } \\
\text { acadêmica, mas também } \\
\text { passar a despertar o interesse } \\
\text { pela física para os alunos. }\end{array}$ & $\begin{array}{l}\text { Acredito que um curso } \\
\text { superior deva } \text { fornecer } \\
\text { ferramentas } \\
\text { determinada área de atuação, } \\
\text { assim é muito importante seu } \\
\text { conteúdo, sem dúvida. }\end{array}$ & $\begin{array}{l}\text { Tenho consciência do leque e } \\
\text { recursos que serão fornecidos } \\
\text { ao decorrer do curso, } \\
\text { poderão e serão aplicados em } \\
\text { eventos reais do nosso dia a } \\
\text { dia, e também o poder } \\
\text { lecionar para pessoas irá } \\
\text { proporcionar um grande } \\
\text { crescimento pessoal como } \\
\text { forma de interação com } \\
\text { outras pessoas. }\end{array}$ & $\begin{array}{l}\text { Gosto de poder associar a } \\
\text { matemática a tudo que está } \\
\text { ocorrendo agora ao nosso } \\
\text { redor. }\end{array}$ \\
\hline N53 & $\begin{array}{l}\text { Pretendo seguir uma carreira } \\
\text { acadêmica, onde o curso de }\end{array}$ & $\begin{array}{l}\text { Não, pois inicialmente meu } \\
\text { objetivo é trabalhar na área }\end{array}$ & $\begin{array}{l}\text { Sim, faz parte do meu plano } \\
\text { de trilhar a carreira }\end{array}$ & $\begin{array}{l}\text { De certo modo sim, mas na } \\
\text { verdade não é o diploma, a }\end{array}$ & $\begin{array}{l}\text { O curso me proporcionará a } \\
\text { possibilidade de ser professor }\end{array}$ & $\begin{array}{l}\text { Adoro. A física consegue } \\
\text { explicar o mundo, seus }\end{array}$ \\
\hline
\end{tabular}




\begin{tabular}{|c|c|c|c|c|c|c|}
\hline & $\begin{array}{l}\text { Licenciatura em } \quad \text { Física } \\
\text { proporcionar-me-á } r \text { uma } \\
\text { estrutura de conhecimento } \\
\text { para que eu possa alcançar } \\
\text { meu objetivo. }\end{array}$ & $\begin{array}{l}\text { da educação e o título e } \\
\text { bacharelado criaria uma série } \\
\text { de barreiras para tal, já que } \\
\text { esta formação está centrada } \\
\text { em pesquisa científica. }\end{array}$ & $\begin{array}{l}\text { acadêmica. Tal passo será } \\
\text { importante como experiência } \\
\text { para dar continuação na } \\
\text { minha realização. }\end{array}$ & $\begin{array}{l}\text { importância versa sobre o } \\
\text { indivíduo desenvolver } \\
\text { raciocínio e percepção quanto } \\
\text { ao mercado de trabalho, } \\
\text { sendo estes quesitos } \\
\text { aprimorados durante o curso } \\
\text { do universitário. }\end{array}$ & $\begin{array}{l}\text { (sonho de criança) e também } \\
\text { o fato de poder contribuir no } \\
\text { desenvolvimento educacional } \\
\text { e científico brasileiro, o que } \\
\text { me deixa esperançoso. }\end{array}$ & $\begin{array}{l}\text { fenômenos. Nada que vemos } \\
\text { ou sentimos passa em branco } \\
\text { na física, ela tem uma } \\
\text { explicação para cada coisa. É } \\
\text { impressionante com ela é } \\
\text { precisa em suas definições. }\end{array}$ \\
\hline N2* & $\begin{array}{l}\text { Para obter a formação } \\
\text { necessária para ser professor. }\end{array}$ & & & & & \\
\hline N3* & $\begin{array}{l}\text { Porque é algo que gosto e } \\
\text { atuarei na área que pretendo. }\end{array}$ & $\begin{array}{l}\text { Não, o Bacharelado é voltado } \\
\text { para pesquisas e a Lic. em } \\
\text { Física para ser professor. }\end{array}$ & $\begin{array}{l}\text { Sim, porque gosto de passar a } \\
\text { física. }\end{array}$ & $\begin{array}{l}\text { Não, o diploma só tem valor } \\
\text { se tiver conteúdo. }\end{array}$ & $\begin{array}{l}\text { Um conhecimento maior } \\
\text { sobre a física, uma inclusão } \\
\text { no mercado de trabalho na } \\
\text { área de ensino. }\end{array}$ & $\begin{array}{l}\text { Sim, pois, a Física trata sobre } \\
\text { o universo, o macro e o } \\
\text { micro. }\end{array}$ \\
\hline \multicolumn{7}{|c|}{ QUESTIONÁRIO DE INGRESSANTES DO CURSO DE LICENCIATURA EM FÍSICA - USP - DIURNO/2006 } \\
\hline № & $\begin{array}{c}\text { Por que escolheu fazer } \\
\text { Vestibular para Licenciatura } \\
\text { em Física? }\end{array}$ & $\begin{array}{c}\text { Para você, fazer o } \\
\text { Bacharelado ou a } \\
\text { Licenciatura em Física seriam } \\
\text { opções equivalentes? }\end{array}$ & $\begin{array}{c}\text { Você pretende ser professor } \\
\text { de Física? Por quê? }\end{array}$ & $\begin{array}{l}\text { Você acha que um diploma } \\
\text { de curso superior hoje no } \\
\text { Brasil é indispensável, } \\
\text { independente do conteúdo } \\
\text { do curso? Por que? }\end{array}$ & $\begin{array}{c}\text { Quais perspectivas } \\
\text { profissionais e pessoais você } \\
\text { espera que o curso lhe } \\
\text { proporcione? }\end{array}$ & $\begin{array}{c}\text { Você gosta de estudar Física? } \\
\text { Por quê? }\end{array}$ \\
\hline D1 & Interesse pela área. & Não. & $\begin{array}{l}\text { Sim, pois há falta de } \\
\text { professores nessa área. }\end{array}$ & $\begin{array}{l}\text { Não. Porque sem conteúdo o } \\
\text { diploma não passa de um } \\
\text { papel. }\end{array}$ & $\begin{array}{l}\text { Espero que o curso me } \\
\text { proporcione qualidade de } \\
\text { ensino e que, com isso eu } \\
\text { possa me tornar um bom } \\
\text { professor e possa conseguir } \\
\text { um bom emprego. }\end{array}$ & $\begin{array}{l}\text { Sim. Porque ela ajuda a } \\
\text { entender o mundo de um } \\
\text { ponto de vista prático. }\end{array}$ \\
\hline D2 & $\begin{array}{l}\text { Por causa de minha aptidão } \\
\text { com a carreira. }\end{array}$ & Não. & $\begin{array}{l}\text { Sim para poder transmitir o } \\
\text { que aprendi. }\end{array}$ & $\begin{array}{l}\text { Sim, pois há } \quad \text { maiores } \\
\text { oportunidades no mercado de } \\
\text { trabalho. }\end{array}$ & $\begin{array}{l}\text { Continuar estudando } \\
\text { paralelamente ao trabalho. }\end{array}$ & Sim, porque é fascinate. \\
\hline D3 & $\begin{array}{l}\text { Gosto pela matéria e vontade } \\
\text { de ensinar. }\end{array}$ & Não. & $\begin{array}{l}\text { Sim, acredito ser um trabalho } \\
\text { gratificante. }\end{array}$ & $\begin{array}{l}\text { Não, o Brasil ainda está no } \\
\text { início desse processo e não } \\
\text { adianta formar profissionais } \\
\text { incapacitados de exercerem a } \\
\text { profissão. }\end{array}$ & $\begin{array}{l}\text { Pretendo ser um bom } \\
\text { profissional e mudar minha } \\
\text { forma de ver o mundo. }\end{array}$ & $\begin{array}{l}\text { Sim. É uma ciência muito } \\
\text { interessante e desafiadora. }\end{array}$ \\
\hline D4 & $\begin{array}{l}\text { Pois é uma matéria que eu } \\
\text { gosto e pretendo dar aulas } \\
\text { dessa matéria. }\end{array}$ & Não. & $\begin{array}{l}\text { Sim, acho importante essa } \\
\text { matéria para os alunos do } \\
\text { ensino médio e que na } \\
\text { maioria não tem professores }\end{array}$ & $\begin{array}{l}\text { É indispensável, pois a crise } \\
\text { nesse país já tendo um curso } \\
\text { superior já é difícil de se } \\
\text { encontrar trabalho quase }\end{array}$ & $\begin{array}{l}\text { As perspectivas profissionais } \\
\text { é que eu possa passar o meu } \\
\text { conhecimento para os alunos } \\
\text { e fazendo com que eles }\end{array}$ & $\begin{array}{l}\text { Sim, física para mim é a lógica } \\
\text { de como se vê o } \\
\text { funcionamento do universo } \\
\text { então se torna prazeroso }\end{array}$ \\
\hline
\end{tabular}




\begin{tabular}{|c|c|c|c|c|c|c|}
\hline & & & $\begin{array}{l}\text { bons que incentivem aos } \\
\text { alunos terem interesse dessa } \\
\text { matéria. }\end{array}$ & impossível sem ele. & gostem da matéria. & estudar. \\
\hline D5 & $\begin{array}{l}\text { Vocação. É um prazer estudar } \\
\text { Física, compreender o } \\
\text { Universo em que vivo e } \\
\text { comunicar aos outros o que } \\
\text { aprendi. }\end{array}$ & $\begin{array}{lcc}\text { Não, antes } & \text { de } & \text { ser } \\
\text { pesquisadora, } & \text { quero } & \text { ser } \\
\text { professora. } & & \\
\end{array}$ & Sim. Porque me dá prazer. & $\begin{array}{l}\text { Um curso superior é } \\
\text { indispensável para quem } \\
\text { sente a necessidade de } \\
\text { aprofundar reus } \\
\text { conhecimentos em qualquer } \\
\text { tempo e lugar. Mas é } \\
\text { necessário, não só o curso, e } \\
\text { sim empreendedorismo e } \\
\text { criatividade juntos. }\end{array}$ & $\begin{array}{l}\text { Capacitação para lecionar até } \\
\text { no ensino médio, e o início de } \\
\text { uma carreira como } \\
\text { pesquisadora (depois da pós) } \\
\text { e posteriormente lecionar em } \\
\text { curso superior. }\end{array}$ & $\begin{array}{l}\text { Sim. É envolvente, me ajuda a } \\
\text { ter uma visão mais completa } \\
\text { do Universo em que vivo. }\end{array}$ \\
\hline D6 & $\begin{array}{l}\text { Porque desde o } 1 \text { o ano do } \\
\text { Ensino Médio eu demonstro } \\
\text { certa habilidade na } \\
\text { disseminação dos conceitos } \\
\text { abordados Pela Física, além } \\
\text { de me achar muito afeiçoado } \\
\text { a essa matéria. }\end{array}$ & $\begin{array}{l}\text { Não, pois durante o Ensino } \\
\text { Médio pude me adequar, ou } \\
\text { melhor, estive em contato } \\
\text { com as eventuais deficiências } \\
\text { dos alunos. Portanto, a } \\
\text { Licenciatura seria, para mim, } \\
\text { uma opção mais viável. }\end{array}$ & $\begin{array}{l}\text { Sim, pois acho que é uma } \\
\text { atividade que eu } \\
\text { desenvolveria com grande } \\
\text { eficiência, além de ser algo } \\
\text { que muito me interessa. }\end{array}$ & $\begin{array}{l}\text { Sim. O diploma de curso } \\
\text { superior é essencial, pois } \\
\text { revela que você pode } \\
\text { desenvolver certo ofício de } \\
\text { maneira hábil. Mas, às vezes, } \\
\text { precisa ser acompanhado de } \\
\text { outros atributos, dada a } \\
\text { grande ocorrência existente } \\
\text { no mercado de trabalho. }\end{array}$ & $\begin{array}{l}\text { Espero que o curso me } \\
\text { proporcione conhecimentos } \\
\text { suficientes para garantir uma } \\
\text { boa saúde financeira e } \\
\text { progresso dentro do ramo } \\
\text { científico. }\end{array}$ & $\begin{array}{l}\text { Sim, pois ela é uma ciência } \\
\text { que me permite entender, } \\
\text { através do raciocínio lógico, } \\
\text { muito do que está a minha } \\
\text { volta. }\end{array}$ \\
\hline D7 & $\begin{array}{l}\text { Interesse na matéria durante } \\
\text { o ensino médio e após } \\
\text { pesquisas sobre o curso. }\end{array}$ & Não. & $\begin{array}{l}\text { Sim. Vontade e conhecer a } \\
\text { área e é o emprego para o } \\
\text { qual imagino estar melhor } \\
\text { preparado após o curso. }\end{array}$ & $\begin{array}{l}\text { Sim. Em muitos empregos, } \\
\text { necessita-se de diploma de } \\
\text { curso superior, independente } \\
\text { de ter ou não capacidade } \\
\text { para desenvolver o serviço. }\end{array}$ & $\begin{array}{l}\text { Inicialmente, ainda sem a } \\
\text { conclusão do curso, pretendo } \\
\text { trabalhar como plantonista e } \\
\text { futuramente como professor. }\end{array}$ & $\begin{array}{l}\text { Sim. Interesse pela } \\
\text { matemática. }\end{array}$ \\
\hline D8 & $\begin{array}{l}\text { Porque eu gosto de física e } \\
\text { achei que seria um primeiro } \\
\text { passo para depois continuar } \\
\text { me especializando. }\end{array}$ & $\begin{array}{l}\text { Não. Pretendo ainda fazer } \\
\text { bacharelado, depois de } \\
\text { licenciatura. }\end{array}$ & $\begin{array}{l}\text { Talvez sim, mas em última } \\
\text { instância. }\end{array}$ & & $\begin{array}{l}\text { Sobretudo um maior contato, } \\
\text { um aprofundamento na Física } \\
\text { em geral, que é o que mais } \\
\text { quero. Espero conseguir ainda } \\
\text { com o curso capacidades e } \\
\text { habilidades para seguir na } \\
\text { vida acadêmica, trabalhar } \\
\text { com pesquisas. }\end{array}$ & $\begin{array}{l}\text { Porque eu me sinto bem. } \\
\text { Sinto-me muito mais a } \\
\text { vontade trabalhando com } \\
\text { números e tudo mais que a } \\
\text { física implica. Particularmente } \\
\text { considero esta minha } \\
\text { vocação. }\end{array}$ \\
\hline D9 & $\begin{array}{l}\text { Por ter maior afinidade com a } \\
\text { Física, querer saber os } \\
\text { fenômenos da Física para um } \\
\text { dia poder dar aula. }\end{array}$ & $\begin{array}{l}\text { Não. O Bacharelado eu teria } \\
\text { de trabalhar com pesquisa e } \\
\text { não poderia dar aula. }\end{array}$ & $\begin{array}{l}\text { Sim. Porque é uma matéria } \\
\text { temida por muitos e que } \\
\text { sempre está precisando de } \\
\text { novos professores nas }\end{array}$ & $\begin{array}{l}\text { Sim, com a falta de empregos } \\
\text { que estamos vivendo, um } \\
\text { diploma superior é } \\
\text { fundamental e ajuda, e muito, }\end{array}$ & $\begin{array}{l}\text { Que eu esteja apto para } \\
\text { poder dar aula numa escola, } \\
\text { poder seguir estudos } \\
\text { posteriores e ser um grande }\end{array}$ & $\begin{array}{l}\text { Sim, por ser uma matéria que } \\
\text { aborda fenômenos, ciências, } \\
\text { experiências que vale se } \\
\text { dedicar ao estudo. }\end{array}$ \\
\hline
\end{tabular}




\begin{tabular}{|c|c|c|c|c|c|c|}
\hline & & & escolas. & numa seleção de empregos. & profissional. & \\
\hline D10 & $\begin{array}{l}\text { Interesse na Área da } \\
\text { educação e pesquisa. }\end{array}$ & $\begin{array}{l}\text { Não, há diferenças relevantes } \\
\text { entre um e outro. }\end{array}$ & Sim. Interesse na Educação. & $\begin{array}{l}\text { É importante, mas é claro que } \\
\text { instituição conta bastante. }\end{array}$ & $\begin{array}{l}\text { Ter oportunidade de realizar } \\
\text { um mestrado e, após isso, um } \\
\text { doutorado. Ter uma visão } \\
\text { mais ampla das } \\
\text { oportunidades e melhoria da } \\
\text { educação do país. }\end{array}$ & $\begin{array}{l}\text { Sim. É utilizável em várias } \\
\text { atividades. }\end{array}$ \\
\hline D11 & $\begin{array}{l}\text { Porque gosto da matéria e } \\
\text { pretendo dar continuidade } \\
\text { nos estudos. }\end{array}$ & $\begin{array}{l}\text { Sim, mas optei por } \\
\text { licenciatura para dar aula } \\
\text { mais facilmente. }\end{array}$ & $\begin{array}{l}\text { Sim, sofri influência de alguns } \\
\text { professores. }\end{array}$ & $\begin{array}{l}\text { Não. Eu acho que prevalece o } \\
\text { conteúdo e as características } \\
\text { do profissional. }\end{array}$ & $\begin{array}{l}\text { Pretendo dar aula em colégio } \\
\text { ou em cursinho e e } \\
\text { posteriormente trabalhar no } \\
\text { campo de pesquisa. }\end{array}$ & $\begin{array}{l}\text { Sim. Gosto muito da física } \\
\text { nuclear e magnetismo. }\end{array}$ \\
\hline D12 & $\begin{array}{l}\text { Pois pretendo ser professor } \\
\text { de física. }\end{array}$ & $\begin{array}{l}\text { Não, mas pretendo fazer os } \\
\text { dois. }\end{array}$ & $\begin{array}{l}\text { Sim, pois é a matéria que } \\
\text { gosto e quero trabalhar com } \\
\text { ela. }\end{array}$ & $\begin{array}{l}\text { Sim, pois o mercado de } \\
\text { trabalho está cada vez mais } \\
\text { concorrido. }\end{array}$ & $\begin{array}{l}\text { Eu espero que consiga me } \\
\text { formar em física e que } \\
\text { consiga trabalhar sendo } \\
\text { professora de física. }\end{array}$ & Sim, pois acho fascinante. \\
\hline D13 & $\begin{array}{l}\text { Escolhi licenciatura por julgar } \\
\text { ser fácil o acesso, embora } \\
\text { tenha pretensões futuras no } \\
\text { bacharelado. }\end{array}$ & Pretendo fazer as duas. & $\begin{array}{l}\text { Talvez, acho cedo para ter } \\
\text { essa certeza. }\end{array}$ & $\begin{array}{l}\text { Não, depende muito do } \\
\text { conteúdo, acho que o } \\
\text { conhecimento adquirido vale } \\
\text { muito mais que o diploma. }\end{array}$ & $\begin{array}{lr}\text { Espero } & \text { conquistar } \\
\text { conhecimentos necessários } \\
\text { para ingressar em uma } \\
\text { carreira vitoriosa. Tenho } \\
\text { certeza que muitas portas se } \\
\text { abrirão com esse curso. }\end{array}$ & $\begin{array}{l}\text { Sim, sempre me entendi } \\
\text { muito bem com ela e a } \\
\text { matemática. }\end{array}$ \\
\hline D14 & Ministrar aulas de Física. & $\begin{array}{l}\text { Não, pois é mais fácil } \\
\text { conseguir aulas. }\end{array}$ & $\begin{array}{l}\text { Sim, porque pretendo ajudar } \\
\text { a formar cidadãos críticos e } \\
\text { reflexivos. }\end{array}$ & $\begin{array}{lrr}\text { Sim, porque é } & \text { quase } \\
\text { indispensável para } & \text { um } \\
\text { emprego com } & \text { boa } \\
\text { remuneração, embora a } \\
\text { competência do profissional } \\
\text { conte muito na remuneração. }\end{array}$ & $\begin{array}{l}\text { Espero que o curso me } \\
\text { proporcione relacionar a } \\
\text { Física teórica (na sala de aula) } \\
\text { com o que vemos na nossa } \\
\text { vida (Física diária) para passar } \\
\text { isso aos meus alunos, } \\
\text { criando-lhes interesse pela } \\
\text { matéria. }\end{array}$ & $\begin{array}{l}\text { Sim, porque vejo a Física no } \\
\text { meu dia-a-dia. }\end{array}$ \\
\hline D15 & $\begin{array}{l}\text { Porque gosto da área de } \\
\text { exatas. }\end{array}$ & Não. & Sim. & $\begin{array}{l}\text { Sim, devido as exigências do } \\
\text { mercado de trabalho. }\end{array}$ & & \\
\hline D16 & $\begin{array}{l}\text { Por afinidade na área de } \\
\text { exatas. }\end{array}$ & $\begin{array}{l}\text { Não, pois o Bacharel seguiria } \\
\text { mais a área de pesquisas. }\end{array}$ & $\begin{array}{l}\text { Sim, porque gosto da área de } \\
\text { educação, mas também tenho } \\
\text { interesse em pesquisas. }\end{array}$ & $\begin{array}{l}\text { Sim, pois é necessário uma } \\
\text { boa qualificação no Brasil } \\
\text { atualmente. }\end{array}$ & $\begin{array}{l}\text { Espero uma boa qualificação } \\
\text { e que essa qualificação me } \\
\text { proporcioner boas } \\
\text { oportunidades profissionais. }\end{array}$ & $\begin{array}{l}\text { Sim, porque gosto da área de } \\
\text { exatas, e na física existe uma } \\
\text { aplicação. }\end{array}$ \\
\hline D17 & $\begin{array}{l}\text { Para ministrar aulas em } \\
\text { Escolas e/ou cursinhos. }\end{array}$ & Não. & Sim. Porque gosto de ensinar. & $\begin{array}{l}\text { Sim. Porque muitas empresas } \\
\text { pedem um curso superior } \\
\text { para qualquer tipo de função. }\end{array}$ & $\begin{array}{l}\text { No âmbito profissional espero } \\
\text { que me de opções de } \\
\text { trabalho e de como ministrar }\end{array}$ & $\begin{array}{l}\text { Sim. Porque gosto de saber o } \\
\text { "porque" que acontece. }\end{array}$ \\
\hline
\end{tabular}




\begin{tabular}{|c|c|c|c|c|c|c|}
\hline & & & & & $\begin{array}{l}\text { uma boa aula e pessoal que já } \\
\text { gosto de física, que realmente } \\
\text { seja aquilo que falam sobre o } \\
\text { curso. }\end{array}$ & \\
\hline D18 & $\begin{array}{l}\text { Pela aptidão pessoal para } \\
\text { lecionar. }\end{array}$ & Não. & $\begin{array}{l}\text { Sim, porque me comprazo da } \\
\text { matéria e do ofício. }\end{array}$ & $\begin{array}{l}\text { Não necessariamente, } \\
\text { depende do curso, escola, } \\
\text { etc. }\end{array}$ & $\begin{array}{l}\text { Possibilidade e habilitação } \\
\text { para lecionar tanto física } \\
\text { quanto } \quad \text { matemática; } \\
\text { realização pessoal ao exercer } \\
\text { o ofício. } \\
\end{array}$ & $\begin{array}{l}\text { Sim, sempre gostei da } \\
\text { matéria. }\end{array}$ \\
\hline D19 & $\begin{array}{l}\text { Unir o útil ao agradável: } \\
\text { voltar a estudar e fazer um } \\
\text { curso de licenciatura, que me } \\
\text { dará o direito de ser professor } \\
\text { no ensino médio, pois parece } \\
\text { que a única coisa que sei fazer } \\
\text { bem é ensinar. }\end{array}$ & $\begin{array}{l}\text { Não, pelo fato do curso de } \\
\text { Bacharelado não dar o direito } \\
\text { de dar aulas no ensino médio. } \\
\text { Para mim essa separação é } \\
\text { incômoda. Gostaria de fazer o } \\
\text { Bacharelado e estudar física } \\
\text { mais profundamente, mas } \\
\text { também quero ser professor. }\end{array}$ & $\begin{array}{l}\text { Sim. Ensinar para mim é uma } \\
\text { atividade agradável. }\end{array}$ & $\begin{array}{l}\text { Sim. Parece que o diploma } \\
\text { virou uma espécie de } \\
\text { "validade" de competências. } \\
\text { Não basta ser competente, é } \\
\text { necessário ter o "certificado" } \\
\text { de competência. }\end{array}$ & $\begin{array}{l}\text { Gostaria de poder dar aulas } \\
\text { no ensino médio. }\end{array}$ & $\begin{array}{l}\text { Sim. Porque é a ciência mais } \\
\text { atraente para mim pelos } \\
\text { assuntos que abrange. }\end{array}$ \\
\hline D20 & Quero ser professor. & Claro. & $\begin{array}{l}\text { Sim. Porque gosto de Física e } \\
\text { de compartilhar o meu } \\
\text { conhecimento, fazer outras } \\
\text { pessoas gostarem também. }\end{array}$ & $\begin{array}{l}\text { Sim, porque é um diferencial, } \\
\text { já que apenas alguns são } \\
\text { privilegiados com um diploma } \\
\text { de nível superior. }\end{array}$ & $\begin{array}{l}\text { Conseguir um emprego em } \\
\text { cursinho pré-vestibular para } \\
\text { ajudar os alunos na física. }\end{array}$ & $\begin{array}{l}\text { Sim. Porque é a ciência que } \\
\text { explica os fenômenos que nos } \\
\text { rodeam. }\end{array}$ \\
\hline D21 & $\begin{array}{l}\text { Gosto da Disciplina, e gosto } \\
\text { de exatas por isso optei por } \\
\text { licenciatura, o qual é um } \\
\text { pouco mais puxado. }\end{array}$ & $\begin{array}{l}\text { Bacharelado ou licenciatura } \\
\text { na matemática. }\end{array}$ & $\begin{array}{l}\text { Não, porque o professor não } \\
\text { é bem remunerado. }\end{array}$ & $\begin{array}{l}\text { Sim, porque o mercado busca } \\
\text { qualificação. }\end{array}$ & $\begin{array}{l}\text { O curso pode proporcionar } \\
\text { uma profissão que } \\
\text { juntamente com as } \\
\text { qualificações me dará um } \\
\text { bom futuro. }\end{array}$ & $\begin{array}{l}\text { Sim, porque me identifico } \\
\text { com fórmulas, cálculos e } \\
\text { teorias. }\end{array}$ \\
\hline D22 & $\begin{array}{l}\text { Devido a gostar de Física e ter } \\
\text { vontade de lecionar. }\end{array}$ & Não. & $\begin{array}{l}\text { Sim, pois lecionar é uma } \\
\text { forma de ter contato humano } \\
\text { com outras pessoas e ensinar } \\
\text { é uma forma de aprender. }\end{array}$ & $\begin{array}{l}\text { É fundamental ter o curso } \\
\text { superior devido ao mercado } \\
\text { de trabalho ser muito } \\
\text { concorrido. }\end{array}$ & $\begin{array}{l}\text { Poder lecionar em escolar, } \\
\text { tendo em vista crescimento } \\
\text { profissional onde estiver } \\
\text { atuando. }\end{array}$ & $\begin{array}{l}\text { Sim, pois entender todos os } \\
\text { fenômenos da Física é } \\
\text { maravilhoso. }\end{array}$ \\
\hline D23 & Para lecionar a matéria. & Não. & $\begin{array}{l}\text { Sim, porque gosto da matéria } \\
\text { e espero poder passar isso } \\
\text { aos meus futuros alunos. }\end{array}$ & $\begin{array}{l}\text { Sim, porque está cada vez } \\
\text { mais difícil conseguir um bom } \\
\text { emprego e o diploma ajuda } \\
\text { bastante. }\end{array}$ & $\begin{array}{l}\text { Espero concluir meu curso, } \\
\text { me tornar uma excelente } \\
\text { profissional e trabalhar com } \\
\text { isso. }\end{array}$ & $\begin{array}{l}\text { Sim. Porque acho desafiante, } \\
\text { gosto de tentar entender } \\
\text { como as coisas funcionam. }\end{array}$ \\
\hline D24 & $\begin{array}{l}\text { Para dar aulas no ensino } \\
\text { médio, e continuar estudando } \\
\text { na área. }\end{array}$ & Não. & $\begin{array}{l}\text { Sim. Gosto de dar aulas de } \\
\text { Física. }\end{array}$ & $\begin{array}{l}\text { Sim. É pre-requisito para o } \\
\text { trabalho, concursos, etc. }\end{array}$ & $\begin{array}{l}\text { Ampliar visão da realidade e } \\
\text { da natureza, seguir a carreira } \\
\text { acadêmica. }\end{array}$ & $\begin{array}{l}\text { Sim. Possibilita o } \\
\text { entendimento da natureza. }\end{array}$ \\
\hline D25 & Pretendo ser professor de & Não. Minha prioridade & Sim. Pois acredito que eu & Sim. Pois é importante ter & Profissionalmente, acredito & Sim. Pois é uma grande área \\
\hline
\end{tabular}




\begin{tabular}{|c|c|c|c|c|c|c|}
\hline & física. & Licenciatura. & $\begin{array}{l}\text { posso fazer isso também. } \\
\text { Passando esse conhecimento } \\
\text { com competência aos alunos. }\end{array}$ & $\begin{array}{l}\text { profissionais especializados } \\
\text { em todas as áreas de } \\
\text { trabalho. }\end{array}$ & $\begin{array}{lr}\text { que conseguirei passar com } & \text { com } \\
\text { competência } & \text { meu } \\
\text { conhecimento, a } & \text { meus } \\
\text { alunos. Além } & \text { de } \\
\text { independência financeira. }\end{array}$ & do conhecimento. \\
\hline D26 & Por gosto pessoal. & Não. & $\begin{array}{l}\text { Sim. Porque a profissão me } \\
\text { agrada. }\end{array}$ & $\begin{array}{l}\text { Não. O conteúdo do curso é } \\
\text { mais importante. }\end{array}$ & $\begin{array}{l}\text { Espero que o curso seja-me } \\
\text { agradável e que possa me dar } \\
\text { uma boa formação. }\end{array}$ & Sim. Gosto pessoal. \\
\hline D27 & $\begin{array}{l}\text { Para poder obter meus } \\
\text { objetivos no futuro que é } \\
\text { seguir a área de geofísica. }\end{array}$ & Não. & $\begin{array}{l}\text { Não. Porque procuro pesquisa } \\
\text { e na área de geofísica. }\end{array}$ & $\begin{array}{l}\text { Não, pois o mercado está } \\
\text { saturado. }\end{array}$ & $\begin{array}{l}\text { Abrindo meu campo de } \\
\text { entendimento seria a minha } \\
\text { perspectiva pessoal, e } \\
\text { juntamente me ajudando } \\
\text { para realização profissional. }\end{array}$ & $\begin{array}{l}\text { Muito. Pois é uma área que } \\
\text { posso explicar e provar } \\
\text { conceitos inéditos. }\end{array}$ \\
\hline D28 & $\begin{array}{l}\text { Pelo gosto da matéria em } \\
\text { questão e gosto pelo } \\
\text { magistério. }\end{array}$ & $\begin{array}{l}\text { Não. Existem diferenças } \\
\text { específicas, mas que podem } \\
\text { ser contornadas após o curso, } \\
\text { dependendo da opção de } \\
\text { carreira. }\end{array}$ & $\begin{array}{l}\text { Já leciono, pois cursei } 2 \text { anos } \\
\text { no Centro Federal (CEFET) e } \\
\text { pretendo continuar. }\end{array}$ & $\begin{array}{l}\text { Sim, cada vez mais o nível } \\
\text { mínimo de escolaridade, que } \\
\text { o mercado exige, está se } \\
\text { aproximando do nível } \\
\text { superior. }\end{array}$ & $\begin{array}{l}\text { Pretendo continuar dando } \\
\text { aula e me aprimorando para } \\
\text { estar cada vez em Instituições } \\
\text { melhores. }\end{array}$ & $\begin{array}{l}\text { A curiosidade leva o homem a } \\
\text { gostar de física, revelar os } \\
\text { segredos que esta curiosidade } \\
\text { busca é essencial. }\end{array}$ \\
\hline D29 & $\begin{array}{l}\text { Por ser a Carreira em que } \\
\text { mais me enquadro. }\end{array}$ & Não. & $\begin{array}{l}\text { Não, porque o salário de } \\
\text { professor hoje em dia é } \\
\text { desestimulante. }\end{array}$ & $\begin{array}{l}\text { Sim, a necessidade de um } \\
\text { curso superior existe, mas o } \\
\text { seu conteúdo e tão } \\
\text { importante quanto a sua } \\
\text { finalização. }\end{array}$ & $\begin{array}{l}\text { Estou fazendo por satisfação } \\
\text { pessoal, e ter um maior } \\
\text { conhecimento em uma área } \\
\text { tão maravilhosa. }\end{array}$ & $\begin{array}{l}\text { Sim, porque usa o raciocínio e } \\
\text { explica os fenômenos que } \\
\text { ocorrem no universo. }\end{array}$ \\
\hline D30 & $\begin{array}{l}\text { Sempre me identifiquei com a } \\
\text { matéria. }\end{array}$ & Sim. & $\begin{array}{lll}\text { Sim. Quero levar } & \text { o } \\
\text { conhecimento da ciência } & \text { a } \\
\text { outras pessoas. } & & \end{array}$ & $\begin{array}{l}\text { Sim, é fundamental que se } \\
\text { tenha um conhecimento } \\
\text { reconhecido por uma } \\
\text { faculdade. }\end{array}$ & & $\begin{array}{l}\text { Sim, saber um pouco mais } \\
\text { sobre os fenômenos físicos. }\end{array}$ \\
\hline D31 & $\begin{array}{l}\text { Interesse pela matéria e } \\
\text { vontade de lecionar esta } \\
\text { matéria. }\end{array}$ & Não. & $\begin{array}{l}\text { Sim, devido à afeição pela } \\
\text { matéria e pela aceitação e/ou } \\
\text { deficiência do setor no } \\
\text { mercado. }\end{array}$ & $\begin{array}{l}\text { Não, o diploma não faz nada } \\
\text { sozinho. É necessário que o } \\
\text { curso superior forme um } \\
\text { profissional qualificado, e não } \\
\text { só o dê o diploma. }\end{array}$ & $\begin{array}{l}\text { Uma boa aceitação no } \\
\text { mercado devido a falta de } \\
\text { profissionais qualificados no } \\
\text { setor e a satisfação do } \\
\text { conhecimento e cultura } \\
\text { adquiridos com o curso. }\end{array}$ & $\begin{array}{l}\text { Sim, é uma matéria que busca } \\
\text { explicações e nos faz saber os } \\
\text { porquês dos fenômenos e } \\
\text { como acontecem. }\end{array}$ \\
\hline D32 & $\begin{array}{l}\text { Porque pretendo lecionar } \\
\text { Física para nível superior. }\end{array}$ & Não. & Sim, porque gosto de ensinar. & $\begin{array}{l}\text { Sim é indispensável. Porque a } \\
\text { sociedade é } \\
\text { diplomática. }\end{array}$ & $\begin{array}{l}\text { Todas as técnicas para eu } \\
\text { poder ter conhecimento para } \\
\text { lecionar e até atuar em } \\
\text { equipes. }\end{array}$ & $\begin{array}{l}\text { Sim, sempre tive curiosidade } \\
\text { e paixão em desvendar e } \\
\text { provar a natureza. }\end{array}$ \\
\hline D33 & Porque acho o campo de & Não, Licenciatura é o curso & Sim, porque, gosto da área. & É indispensável, & Espero que o curso faça com & Sim, pois gosto de entender $\mathrm{o}$ \\
\hline
\end{tabular}




\begin{tabular}{|c|c|c|c|c|c|c|}
\hline & $\begin{array}{l}\text { trabalho amplo e me } \\
\text { identifico com o curso. }\end{array}$ & $\begin{array}{l}\text { voltado para ser professor do } \\
\text { Ensino Médio e Fundamental. }\end{array}$ & & $\begin{array}{l}\text { conhecimento é o único bem } \\
\text { que realmente você adquire. }\end{array}$ & $\begin{array}{l}\text { que eu "cresça", que eu } \\
\text { termine minha formação de } \\
\text { forma ampla. }\end{array}$ & fenômenos naturais. \\
\hline D34 & $\begin{array}{l}\text { Gosto de Física e não } \\
\text { enfrentaria } \\
\text { concorrência no vestibular. }\end{array}$ & Não. & Sim. Tenho boa didática. & $\begin{array}{l}\text { Não. Depende da } \\
\text { perspectiva profissional. }\end{array}$ & $\begin{array}{l}\text { Atuação nas redes pública e } \\
\text { privada de ensino; utilização } \\
\text { da Física em diversas outras } \\
\text { áreas do conhecimento. }\end{array}$ & $\begin{array}{l}\text { Sim. Ajuda a entender o } \\
\text { mundo. }\end{array}$ \\
\hline D35 & $\begin{array}{l}\text { Por ter afinidade com a } \\
\text { matéria, e gostar de dar } \\
\text { aulas. }\end{array}$ & Não. & $\begin{array}{l}\text { Por gostar de dar aula e ter } \\
\text { afinidade com a matéria. }\end{array}$ & $\begin{array}{l}\text { Claro que não. O conteúdo é } \\
\text { fundamental, o conteúdo } \\
\text { habilita diploma não. }\end{array}$ & $\begin{array}{l}\text { Aprendizado técnico e } \\
\text { aprendizado didático. Na área } \\
\text { técnica ter um bom conteúdo, } \\
\text { e na didática técnicas de } \\
\text { como motivar, organizar } \\
\text { aulas. }\end{array}$ & $\begin{array}{l}\text { Sou oriundo da área de } \\
\text { telecomunicações. }\end{array}$ \\
\hline D36 & Interesse pela área. & Sim. & Talvez. & $\begin{array}{l}\text { Sim, pelas exigências do } \\
\text { mercado de trabalho. }\end{array}$ & $\begin{array}{l}\text { Uma visão mais detalhada da } \\
\text { física, e um método de ensino } \\
\text { diferenciado para uma } \\
\text { matéria mais difícil, como } \\
\text { exatas. }\end{array}$ & $\begin{array}{l}\text { Sim, pois me interesso pela } \\
\text { ciência e sua evolução e } \\
\text { também de cálculos. }\end{array}$ \\
\hline D37 & $\begin{array}{l}\text { Eu gosto de exatas e pretendo } \\
\text { seguir uma carreira } \\
\text { acadêmica. }\end{array}$ & Não. & $\begin{array}{l}\text { Sim. Eu adoro Física e gostaria } \\
\text { muito de trabalhar em uma } \\
\text { instituição de ensino, } \\
\text { aprendendo e ensinando. }\end{array}$ & 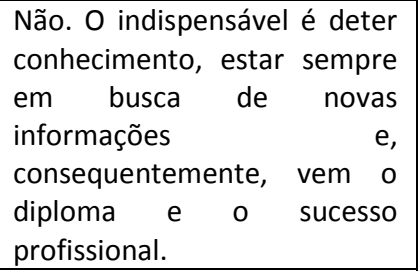 & $\begin{array}{l}\text { Quero aprender o máximo } \\
\text { possível, participar de } \\
\text { atividades extra-curriculares, } \\
\text { participar de pesquisas, } \\
\text { congressos e estar entre os } \\
\text { melhores neste ramo. }\end{array}$ & $\begin{array}{l}\text { Adoro. Tenho facilidade para } \\
\text { compreender os fenômenos } \\
\text { físicos e admiro muito os } \\
\text { profissionais dessa área. }\end{array}$ \\
\hline D38 & $\begin{array}{l}\text { Para lecionar em escolas, e } \\
\text { depois em universidades. }\end{array}$ & Não. & $\begin{array}{l}\text { Sim, para mostrar aos alunos } \\
\text { que física não é ruim para } \\
\text { estudar, e mostrá-los as } \\
\text { aplicações da física no } \\
\text { cotidiano de todos. }\end{array}$ & $\begin{array}{l}\text { Sim, pois o diploma pode } \\
\text { mostrar, que seu possuidor } \\
\text { tenha habilidades para } \\
\text { realização de algumas tarefas. }\end{array}$ & $\begin{array}{l}\text { Acredito que o curso possa } \\
\text { estar passando pra mim, além } \\
\text { do conteúdo, um pouco das } \\
\text { experiências que os } \\
\text { professores possuem, } \\
\text { ajudando-me assim, a ser um } \\
\text { melhor profissional. }\end{array}$ & $\begin{array}{l}\text { Sim, porque a física possui } \\
\text { uma maneira muito } \\
\text { interessante de procurar } \\
\text { saber o porquê de alguns } \\
\text { fenômenos ocorrerem, e as } \\
\text { explicações variam, dede } \\
\text { simples até complexos. }\end{array}$ \\
\hline D39 & $\begin{array}{l}\text { Porque me interesso por } \\
\text { física e se necessário serei } \\
\text { professora de física. }\end{array}$ & $\begin{array}{l}\text { Não. Estou na licenciatura } \\
\text { porém, gostaria de fazer os } \\
\text { dois. }\end{array}$ & $\begin{array}{l}\text { Não. Porque não teria } \\
\text { paciência para ser professora. } \\
\text { Porém ser professora em } \\
\text { universidade, já sim. Também } \\
\text { porque a maioria dos } \\
\text { professores que conheço não }\end{array}$ & $\begin{array}{l}\text { Sim. Devido ao mercado de } \\
\text { trabalho cada vez mais } \\
\text { competitivo. }\end{array}$ & $\begin{array}{l}\text { Gostaria de entrar nos } \\
\text { projetos de iniciação } \\
\text { científica, sair da faculdade } \\
\text { com algum emprego fixo na } \\
\text { área, etc. }\end{array}$ & $\begin{array}{l}\text { Sim. Porque gosto muito de } \\
\text { astronomia e de conhecer o } \\
\text { porquê das coisas. }\end{array}$ \\
\hline
\end{tabular}




\begin{tabular}{|c|c|c|c|c|c|c|}
\hline & & & tem um salário bom e digno. & & & \\
\hline D40 & $\begin{array}{l}\text { Dou aula desde os } 17 \text { anos de } \\
\text { Física, e adoro isso. }\end{array}$ & Não. & Sim. Gosto muito de lecionar. & $\begin{array}{l}\text { Não, conheço excelentes } \\
\text { proficionais (sic) que não } \\
\text { precisaram de diplomas, } \\
\text { porém tiveram mais } \\
\text { dificuldade para chegar a este } \\
\text { posto. }\end{array}$ & $\begin{array}{l}\text { Profissionalmente virá dar a } \\
\text { possibilidade de lecionar em } \\
\text { colégios e pessoalmente será } \\
\text { um salto no aprendizado e na } \\
\text { resolução de problemas. }\end{array}$ & $\begin{array}{l}\text { Sim. É algo que se pode } \\
\text { aprender apenas por observar } \\
\text { o que ocorre a nossa volta. }\end{array}$ \\
\hline D41 & $\begin{array}{l}\text { Tenho vontade de seguir a } \\
\text { carreira de professor de } \\
\text { ensino médio e com um } \\
\text { mestrado, atuar na área de } \\
\text { professor de faculdade. }\end{array}$ & $\begin{array}{l}\text { Não são equivalentes, são } \\
\text { complementares. Pretendo } \\
\text { junto com o curso de } \\
\text { licenciatura freqüentar aulas } \\
\text { do curso em bacharelado. }\end{array}$ & $\begin{array}{l}\text { Sim, pretendo. Creio que todo } \\
\text { aluno devia ter o privilégio de } \\
\text { ter aulas com um professor } \\
\text { que realmente quer dar aulas. }\end{array}$ & $\begin{array}{l}\text { Sim, em qualquer carreira } \\
\text { está muito difícil de exercer } \\
\text { sua função sem um diploma e } \\
\text { hoje no Brasil, é até difícil } \\
\text { com um único diploma. }\end{array}$ & $\begin{array}{l}\text { Acho que esse curso me } \\
\text { proporcionará recursos e } \\
\text { conhecimento o suficiente } \\
\text { para que eu possa passá-la } \\
\text { adiante aos futuros } \\
\text { universitários. }\end{array}$ & $\begin{array}{l}\text { Sim, acho a física uma ciência } \\
\text { fascinante, é a definição } \\
\text { científica dos fenômenos } \\
\text { naturais. }\end{array}$ \\
\hline D42 & $\begin{array}{lr}\text { Para poder dar aula, para } \\
\text { poder transmitir os } \\
\text { conhecimentos que irei } \\
\text { adquirir. }\end{array}$ & Não. & $\begin{array}{l}\text { Sim, para poder passar pra } \\
\text { outras pessoas o } \\
\text { conhecimento que eu irei } \\
\text { receber. }\end{array}$ & $\begin{array}{l}\text { Não, o conteúdo do curso é o } \\
\text { que conta, pois é o diferencial } \\
\text { com a concorrência na área } \\
\text { de trabalho. }\end{array}$ & $\begin{array}{l}\text { Espero que o curso me } \\
\text { proporcione conhecimento na } \\
\text { área de Física pra que eu } \\
\text { possa adquirir didática para } \\
\text { ser uma boa professora. }\end{array}$ & $\begin{array}{l}\text { Sim, porque pra mim é uma } \\
\text { matéria fascinante. }\end{array}$ \\
\hline D43 & $\begin{array}{l}\text { Porque gosto de Física, tenho } \\
\text { vontade de ser professor, } \\
\text { portanto Licenciatura em } \\
\text { Física. }\end{array}$ & $\begin{array}{l}\text { Não, apesar de gostar dos } \\
\text { dois. }\end{array}$ & $\begin{array}{l}\text { Porque gosto de ensinar, } \\
\text { queria poder fazer isso com a } \\
\text { Física. }\end{array}$ & $\begin{array}{l}\text { É indispensável para os que } \\
\text { podem cursar um curso } \\
\text { superior se o conteúdo } \\
\text { agrada o estudante. }\end{array}$ & $\begin{array}{l}\text { Eu espero que o curso abra } \\
\text { minha visão em relação à } \\
\text { Física, profissionalmente eu } \\
\text { espero que me ajude na } \\
\text { engenharia na qual eu estou } \\
\text { cursando. }\end{array}$ & $\begin{array}{l}\text { Sim, pois a matéria me atrai a } \\
\text { desafios. }\end{array}$ \\
\hline D44 & $\begin{array}{l}\text { É uma área que eu gosto } \\
\text { muito. }\end{array}$ & Sim. & $\begin{array}{l}\text { Talvez, porque tenho } \\
\text { paciência para poder explicar. }\end{array}$ & $\begin{array}{l}\text { Sim, porque a cada momento } \\
\text { se necessita de } \\
\text { conhecimentos específicos. }\end{array}$ & $\begin{array}{l}\text { Um conhecimento mais } \\
\text { amplo e aprofundado e } \\
\text { muitas áreas que a física atua. }\end{array}$ & $\begin{array}{l}\text { Sim, porquê onde estivermos } \\
\text { a física está lá atuando com } \\
\text { suas forças e leis. }\end{array}$ \\
\hline D45 & $\begin{array}{l}\text { Porque me interesso por } \\
\text { ciência e matemática e } \\
\text { pretendo lecionar. }\end{array}$ & $\begin{array}{l}\text { Não, a licenciatura tem toda } \\
\text { uma carga voltada pra } \\
\text { educação. }\end{array}$ & $\begin{array}{l}\text { Sim, a área de Física, nas } \\
\text { escolas, no ensino médio, } \\
\text { vem se mostrando pouco } \\
\text { aproveitada, e por isso, há } \\
\text { grande desinteresse na área } \\
\text { por parte dos alunos. }\end{array}$ & $\begin{array}{l}\text { É bastante importante ter o } \\
\text { diploma, mas conteúdo é } \\
\text { também importante, porque } \\
\text { um bom profissional, com } \\
\text { boa formação faz toda } \\
\text { diferença. }\end{array}$ & $\begin{array}{l}\text { Espero que o curso me dê } \\
\text { além de uma base em } \\
\text { educação, a base na Física. }\end{array}$ & $\begin{array}{l}\text { Sim, os fenômenos naturais } \\
\text { são bastante curiosos. }\end{array}$ \\
\hline D46 & $\begin{array}{l}\text { Porque gosto da matéria de } \\
\text { Física e pretendo lecionar } \\
\text { aulas. }\end{array}$ & Não. & $\begin{array}{l}\text { Sim, porque gosto de explicar } \\
\text { Física para as pessoas. }\end{array}$ & $\begin{array}{l}\text { Sim, porque no Brasil esta } \\
\text { muito difícil se manter } \\
\text { economicamente sem um } \\
\text { diploma de curso superior. }\end{array}$ & $\begin{array}{l}\text { Espero que o curso me dê } \\
\text { condições de conseguir um } \\
\text { bom emprego, seja como } \\
\text { professor ou em outras áreas } \\
\text { como a de consultoria. }\end{array}$ & $\begin{array}{l}\text { Sim, porque gosto da matéria, } \\
\text { é realista. }\end{array}$ \\
\hline
\end{tabular}




\begin{tabular}{|c|c|c|c|c|c|c|}
\hline D47 & $\begin{array}{l}\text { Porque me identifico e } \\
\text { também por falta de opção! }\end{array}$ & Não. & Sim, pois gosto. & $\begin{array}{l}\text { Sim, pelo desenvolvimento } \\
\text { social e prestígio. }\end{array}$ & Não tenho perspectivas. & Nem gosto nem desgosto. \\
\hline D48 & $\begin{array}{l}\text { Me interessei pela matéria, e } \\
\text { aspiro lecionar. }\end{array}$ & Não. & $\begin{array}{l}\text { Pretendo, pois me interessei } \\
\text { pela carreira. }\end{array}$ & $\begin{array}{l}\text { Acho ser indispensável, mas } \\
\text { também considero relevante } \\
\text { o conteúdo do curso. }\end{array}$ & & $\begin{array}{l}\text { Gosto, pois expressa } \\
\text { conceitos e explica } \\
\text { fenômenos com uma } \\
\text { abordagem científica. }\end{array}$ \\
\hline D49 & $\begin{array}{l}\text { Na verdade, despertei grande } \\
\text { interesse no campo da Física } \\
\text { em meu ano de cursinho. } \\
\text { Gostaria de aprender mais } \\
\text { sobre essa área. Optei por } \\
\text { Licenciatura para ter mais } \\
\text { chances de conseguir } \\
\text { trabalho, já que acredito que } \\
\text { haja muitas vagas para ser } \\
\text { professor de Física. }\end{array}$ & $\begin{array}{l}\text { Não. A Licenciatura, voltada } \\
\text { para aulas, garante mais } \\
\text { oportunidades de emprego } \\
\text { (na minha opinião). }\end{array}$ & $\begin{array}{l}\text { Sim. Após despertar interesse } \\
\text { por Física acredito que possa } \\
\text { passar esse interesse para as } \\
\text { outras pessoas, se tiver a } \\
\text { condições para isso. } \\
\text { Condições essas que a } \\
\text { universidade poderá me dar. }\end{array}$ & $\begin{array}{l}\text { Sim. Devido a exigência que o } \\
\text { mercado de trabalho tem, um } \\
\text { diploma de curso superior } \\
\text { seria indispensável para um } \\
\text { bom emprego. }\end{array}$ & $\begin{array}{l}\text { Espero que o curso me } \\
\text { proporcione condições de ser } \\
\text { um bom professor e passar } \\
\text { meu conhecimento aos } \\
\text { outros. }\end{array}$ & $\begin{array}{l}\text { Sim. A Física é uma matéria } \\
\text { extremamente interessante } \\
\text { por explicar as leis da } \\
\text { natureza. Praticamente tudo } \\
\text { pode ser explicado pela Física. } \\
\text { É uma disciplina realmente } \\
\text { interessante. }\end{array}$ \\
\hline D50 & $\begin{array}{l}\text { Porque a física é uma das } \\
\text { áreas do conhecimento que } \\
\text { auxiliam muito na } \\
\text { compreensão da natureza e } \\
\text { esta busca por respostas me } \\
\text { faz ter o interesse e a } \\
\text { curiosidade por essa área. }\end{array}$ & Não. & $\begin{array}{l}\text { Sim, porque gosto de ensinar, } \\
\text { acho uma das profissões mais } \\
\text { i (..... não terminou......) }\end{array}$ & $\begin{array}{l}\text { O diploma de um curso } \\
\text { superior na atual situação do } \\
\text { país, pois abre mais portas } \\
\text { para um bom emprego. }\end{array}$ & $\begin{array}{l}\text { Ascensão na carreira, } \\
\text { conhecimento na área e } \\
\text { quem sabe a ascensão até o } \\
\text { nível universitário. }\end{array}$ & $\begin{array}{l}\text { Sim, porque é a área do } \\
\text { conhecimento que mais me } \\
\text { chama a atenção e me } \\
\text { interessa. }\end{array}$ \\
\hline
\end{tabular}




\section{QUESTIONÁRIO DE INGRESSANTES DO CURSO DE LICENCIATURA EM FÍSICA - USP - NOTURNO/2006}

\begin{tabular}{|c|c|c|c|c|c|c|}
\hline № & $\begin{array}{c}\text { Por que escolheu fazer } \\
\text { Vestibular para Licenciatura } \\
\text { em Física? }\end{array}$ & $\begin{array}{c}\text { Para você, fazer o } \\
\text { Bacharelado ou a } \\
\text { Licenciatura em Física seriam } \\
\text { opções equivalentes? }\end{array}$ & $\begin{array}{l}\text { Você pretende ser professor } \\
\text { de Física? Por quê? }\end{array}$ & $\begin{array}{l}\text { Você acha que um diploma } \\
\text { de curso superior hoje no } \\
\text { Brasil é indispensável, } \\
\text { independente do conteúdo } \\
\text { do curso? Por quê? }\end{array}$ & $\begin{array}{l}\text { Quais perspectivas } \\
\text { profissionais e pessoais você } \\
\text { espera que o curso lhe } \\
\text { proporcione? }\end{array}$ & $\begin{array}{l}\text { Você gosta de estudar Física? } \\
\text { Por quê? }\end{array}$ \\
\hline N1 & $\begin{array}{l}\text { Por ser um curso que se } \\
\text { adéqua ao meu perfil. }\end{array}$ & Sim. & $\begin{array}{l}\text { É uma profissão que se } \\
\text { adéqua ao meu perfil, e que } \\
\text { acredito, me trará muita } \\
\text { gratificação. }\end{array}$ & $\begin{array}{l}\text { Não. É necessário que o } \\
\text { estudo, em todos os níveis, } \\
\text { promova desenvolvimento } \\
\text { pessoal, cidadania e ascensão } \\
\text { social e econômica. }\end{array}$ & $\begin{array}{l}\text { Desenvolvimento de } \\
\text { raciocínio lógico, } \\
\text { desenvolvimento cultural e } \\
\text { boas oportunidades no } \\
\text { mercado de trabalho. }\end{array}$ & $\begin{array}{l}\text { Possibilita a compreensão do } \\
\text { universo. }\end{array}$ \\
\hline N2 & $\begin{array}{l}\text { Porque já trabalho na área, e } \\
\text { acho que será um curso muito } \\
\text { interessante. }\end{array}$ & Não. & Sim. Porque adoro dar aula. & $\begin{array}{l}\text { Não. Há várias atividades } \\
\text { econômicas [que] não } \\
\text { dependem de um curso } \\
\text { superior. Por exemplo } \\
\text { vendas. }\end{array}$ & $\begin{array}{l}\text { Trabalhar efetivado como } \\
\text { professor de física em alguns } \\
\text { colégios. }\end{array}$ & $\begin{array}{l}\text { Sim. Pois a concidero (sic) } \\
\text { uma ciência muito } \\
\text { interessante. }\end{array}$ \\
\hline N3 & $\begin{array}{l}\text { Sempre li sobre ciência desde } \\
\text { pequeno, tendo fascínio por } \\
\text { física teórica e gostaria de dar } \\
\text { aulas como um trabalho } \\
\text { social. }\end{array}$ & $\begin{array}{l}\text { Sinceramente ainda tenho } \\
\text { dúvidas, mas sei que } \\
\text { realmente me interessa a } \\
\text { física de ponta. }\end{array}$ & $\begin{array}{l}\text { Sim mas não como carreira ou } \\
\text { prioridade apenas como } \\
\text { trabalho social. }\end{array}$ & $\begin{array}{l}\text { Sim pois um curso superior } \\
\text { independente de qual seja } \\
\text { pode trazer melhor } \\
\text { intendimento (sic) do mundo } \\
\text { e das pessoas ajudando seu } \\
\text { convívio e sua evolução } \\
\text { pessoal e em sociedade. }\end{array}$ & $\begin{array}{l}\text { Não tenho pretensões } \\
\text { financeiras, apesar de não ser } \\
\text { dispensável, mas gostaria de } \\
\text { contribuir com a ciência } \\
\text { aprender com ela, quem sabe } \\
\text { descobrir algo, isso sim me } \\
\text { encantaria. }\end{array}$ & $\begin{array}{lll}\text { Sim, pois posso } & \text { usar o } \\
\text { pensamento puro } & \text { abstrair, } \\
\text { filosofar } & \text { e } & \text { depois } \\
\text { metematiza-lo. } & \end{array}$ \\
\hline N4 & $\begin{array}{l}\text { Porque gosto muito da área } \\
\text { de exatas, principalmente } \\
\text { física. }\end{array}$ & Não. & $\begin{array}{l}\text { Não sei ainda, durante } 0 \\
\text { curso pretendo decidir. }\end{array}$ & $\begin{array}{l}\text { Não; fazer um curso superior } \\
\text { pode fazer a diferença, desde } \\
\text { que esse curso seja bem feito. }\end{array}$ & 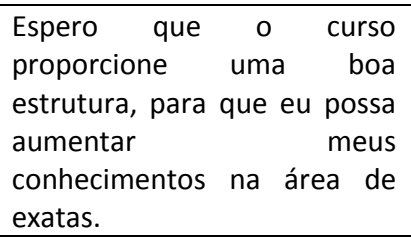 & $\begin{array}{l}\text { Sim, porque é uma área [não } \\
\text { terminou] }\end{array}$ \\
\hline N5 & Paixão pela matéria. & $\begin{array}{l}\text { Não. Optei por licenciatura } \\
\text { justamente para poder dar } \\
\text { aula. }\end{array}$ & $\begin{array}{l}\text { Sim, porque me gratifica a } \\
\text { socialização } \\
\text { conhecimento. }\end{array}$ & $\begin{array}{l}\text { Nãoindispensável, mas } \\
\text { importante. Nós não temos } \\
\text { um presidente sem } \\
\text { diploma...? }\end{array}$ & $\begin{array}{l}\text { Base teórica para a } \\
\text { continuidade dos estudos } \\
\text { nesta área além de } \\
\text { ferramentas importantes para } \\
\text { o aprimoramento no mercado } \\
\text { de trabalho. }\end{array}$ & $\begin{array}{l}\text { Sim, porque me satisfaz poder } \\
\text { entender o mundo. }\end{array}$ \\
\hline N6 & Porque eu quero dar aula de & Não. & Sim. Porque pelo fato de eu & Sim. Porque o diploma abre & É indiscutível que a pessoa & Sim. Sempre gostei de exatas. \\
\hline
\end{tabular}




\begin{tabular}{|c|c|c|c|c|c|c|}
\hline & Física. & & $\begin{array}{l}\text { ser militar, ser professor é a } \\
\text { única profissão que posso } \\
\text { exercer com } \quad \text { carteira } \\
\text { assinada. }\end{array}$ & muitas portas. & $\begin{array}{l}\text { que faz uma faculdade } \\
\text { pessoalmente é uma pessoa } \\
\text { melhor. E acho que com esse } \\
\text { curso vou conseguir emprego } \\
\text { com certa facilidade. }\end{array}$ & \\
\hline N7 & Afinidade com a carreira. & Não. & Sim, aptidão pessoal. & $\begin{array}{l}\text { Sim, pois o mercado exigi (sic) } \\
\text { um profissional mais } \\
\text { qualificado possível }\end{array}$ & $\begin{array}{l}\text { Um crescimento pessoal e } \\
\text { profissional por causa da } \\
\text { faculdade. }\end{array}$ & $\begin{array}{l}\text { Sim, para poder entender os } \\
\text { fenômenos que nos cercam. }\end{array}$ \\
\hline N8 & Pelo trabalho que exerço. & Não. & $\begin{array}{l}\text { Sim. O aprendizado é algo } \\
\text { que não se acaba. }\end{array}$ & $\begin{array}{l}\text { Independente pois a maioria } \\
\text { da população está } \\
\text { trabalhando fora de função e } \\
\text { sim onde lhe oferecem } \\
\text { emprego. }\end{array}$ & $\begin{array}{l}\text { O lado profissional será o } \\
\text { melhor pois a USP é uma } \\
\text { universidade de grande peso, } \\
\text { hoje no Brasil, com um corpo } \\
\text { docente muito bom. E } \\
\text { pessoalmenter estarei } \\
\text { cursando uma universidade } \\
\text { que sempre quis e sonhei. }\end{array}$ & $\begin{array}{l}\text { Sim. Pois todo o universo é } \\
\text { físico e no dia a dia estarem } \\
\text { sempre empregando física. }\end{array}$ \\
\hline N9 & $\begin{array}{l}\text { Trabalho na área de proteção } \\
\text { radiológica há } 10 \text { anos, nesse } \\
\text { caso o curso de física vai me } \\
\text { dar as condições necessárias } \\
\text { para continuar atuando na } \\
\text { profissão, de forma mais } \\
\text { competitiva. Pretendo depois } \\
\text { de algum tempo na } \\
\text { licenciatura mudar para o } \\
\text { bacharelado. }\end{array}$ & Não. & $\begin{array}{l}\text { Ainda não pensei sobre isso. } \\
\text { Talvez possa pensar em dar } \\
\text { aulas, como mais uma } \\
\text { experiência profissional } \\
\text { complemento de renda. }\end{array}$ & $\begin{array}{l}\text { O diploma de curso superior } \\
\text { realmente é indispensável. } \\
\text { Porém alguns fatores são } \\
\text { primordiais para que se tenha } \\
\text { sucesso: a faculdade, } \\
\text { tendências do mercado de } \\
\text { trabalho, adequação do curso } \\
\text { a essas tendências, } \\
\text { [não terminou] }\end{array}$ & $\begin{array}{l}\text { Como perspectivas } \\
\text { profissionais, espero que o } \\
\text { curso possa me trazer } \\
\text { conhecimento necessário } \\
\text { para atuar com conhecimento } \\
\text { técnico na proteção } \\
\text { radiológica. Como pessoais, } \\
\text { espero adquirir habilidades } \\
\text { para pesquisa em } \\
\text { laboratórios públicos ou } \\
\text { privados em alguns assuntos } \\
\text { que acho fascinante. }\end{array}$ & $\begin{array}{l}\text { Sim, adoro. Além de fazer } \\
\text { parte integrante da minha } \\
\text { profissão (proteção } \\
\text { radiológica), ela nos } \\
\text { proporciona uma visão maior } \\
\text { do mundo em nossa volta. }\end{array}$ \\
\hline N10 & $\begin{array}{l}\text { Porque gosto da disciplina e } \\
\text { me identifico com ela. }\end{array}$ & $\begin{array}{l}\text { Não, pois os cursos são } \\
\text { diferentes. }\end{array}$ & $\begin{array}{l}\text { Sim, porque quero } \\
\text { proporcionar a alguém a } \\
\text { mesma alegria que senti } \\
\text { quando passei no vestibular. }\end{array}$ & $\begin{array}{l}\text { Um diploma de curso superior } \\
\text { é indispensável, porque } \\
\text { realmente possibilita que } \\
\text { uma pessoa melhore de vida. }\end{array}$ & $\begin{array}{l}\text { Espero que consiga encontrar } \\
\text { um bom emprego para que } \\
\text { eu possa possibilitar uma } \\
\text { melhoria de vida para a } \\
\text { minha família. }\end{array}$ & $\begin{array}{l}\text { Sim, porque tenho facilidade } \\
\text { com a matéria, além de } \\
\text { gostar. }\end{array}$ \\
\hline N11 & Ascensão profissional. & Sim. & Sim por razões financeiras. & $\begin{array}{l}\text { Devido a saturação do } \\
\text { mercado, um diploma é } \\
\text { indispensável. }\end{array}$ & $\begin{array}{l}\text { A perspectiva profissional é a } \\
\text { de conseguir cargos melhores } \\
\text { na empresa em que trabalho } \\
\text { e as pessoais seriam a } \\
\text { satisfação pessoal de estar }\end{array}$ & $\begin{array}{l}\text { Sim, pois tenho facilidade } \\
\text { acho o conhecimento que ela } \\
\text { proporciona interessante. }\end{array}$ \\
\hline
\end{tabular}




\begin{tabular}{|c|c|c|c|c|c|c|}
\hline & & & & & estudando algo que eu goste. & \\
\hline N12 & $\begin{array}{l}\text { Interesse por fenômenos da } \\
\text { natureza, interesse que já } \\
\text { fora frustrado em curso } \\
\text { anterior (engenharia, na Esc. } \\
\text { Politécnica), o qual foi } \\
\text { determinado erroneamente, } \\
\text { por uma suposta melhor } \\
\text { colocação no mercado de } \\
\text { trabalho. }\end{array}$ & $\begin{array}{l}\text { Não. Tenho o interesse } \\
\text { específico na área de } \\
\text { educação, que não seria } \\
\text { atendido pelo Bacharelado. }\end{array}$ & $\begin{array}{l}\text { Sim. Muito me agrada a } \\
\text { oportunidade de desmitificar } \\
\text { o estudo da Física, de modo a } \\
\text { transmitir um pouco do meu } \\
\text { fascínio por fenômenos } \\
\text { naturais. }\end{array}$ & $\begin{array}{l}\text { Não, pelo menos da forma } \\
\text { como é procurado; o diploma, } \\
\text { em si, é vazio se almejado } \\
\text { apenas para fins financeiros. }\end{array}$ & $\begin{array}{l}\text { Não busco retorno financeiro } \\
\text { no curso, mas sim uma } \\
\text { capacitação profissional que } \\
\text { possa, de alguma forma, } \\
\text { realizar-me pessoalmente - } \\
\text { desta vez creio que tenha } \\
\text { orientado melhor minha } \\
\text { escolha. }\end{array}$ & $\begin{array}{l}\text { Sim; já mencionei em diversas } \\
\text { questões meu interesse por } \\
\text { fenômenos naturais. }\end{array}$ \\
\hline N13 & $\begin{array}{l}\text { Oportunidade de trabalhar } \\
\text { em pesquisas tecnológicas e } \\
\text { dar aula. }\end{array}$ & Não. & $\begin{array}{l}\text { Sim. Pois a maioria dos } \\
\text { professores de Física que eu } \\
\text { tive eram muito ruins. }\end{array}$ & $\begin{array}{l}\text { Indispensável sim, porém o } \\
\text { conteúdo do curso é muito } \\
\text { importante. }\end{array}$ & $\begin{array}{l}\text { Espero aumentar minha } \\
\text { capacidade de raciocínio } \\
\text { lógico e de resolução rápida } \\
\text { de problemas. }\end{array}$ & $\begin{array}{l}\text { Sim. Para ver a aplicação } \\
\text { prática da matemática. }\end{array}$ \\
\hline N14 & $\begin{array}{l}\text { Afinidade com ciências } \\
\text { exatas, e opção para mudar } \\
\text { de carreira. }\end{array}$ & $\begin{array}{lll}\text { Não, minha } & \text { opção é para } \\
\text { ingressar } & \text { na } & \text { carreira } \\
\text { acadêmica. } & & \end{array}$ & $\begin{array}{l}\text { Sim, para melhorar a } \\
\text { formação de novos alunos no } \\
\text { nosso país. }\end{array}$ & $\begin{array}{l}\text { Não, isto é colocado a todo } \\
\text { momento em qualquer } \\
\text { função que se exerce. }\end{array}$ & $\begin{array}{l}\text { Sou formado na área técnica, } \\
\text { já tenho afinidade com as } \\
\text { disciplinas exatas, o curso de } \\
\text { licenciatura irá prover o } \\
\text { acesso a carreira acadêmica, } \\
\text { criando artifícios para uma } \\
\text { mudança de carreira e ajudar } \\
\text { na formação de novos } \\
\text { profissionais de nosso país. }\end{array}$ & $\begin{array}{l}\text { Sim, por se tratar da área de } \\
\text { exatas e possibilitar entender } \\
\text { os fenômenos que cercam o } \\
\text { nosso dia-a-dia. }\end{array}$ \\
\hline N15 & $\begin{array}{l}\text { Tenho curiosidades em Física. } \\
\text { Sempre gostei de Física. }\end{array}$ & Não. Seriam parecidas. & Talvez. É uma boa carreira. & $\begin{array}{l}\text { Sim, pois o mercado de } \\
\text { trabalho está mais exigente. }\end{array}$ & $\begin{array}{l}\text { Melhores condições no } \\
\text { mercado de trabalho, muito } \\
\text { mais conhecimento aplicável. }\end{array}$ & $\begin{array}{l}\text { Sim. É uma área muito ampla } \\
\text { e interessante. }\end{array}$ \\
\hline N16 & Gosto de Física e de dar aulas. & Não. & Sim. Porque gosto. & $\begin{array}{l}\text { Sim. Sem diploma não se } \\
\text { consegue um bom emprego. }\end{array}$ & $\begin{array}{l}\text { Espero poder terminar desta } \\
\text { vez, fui jubilado e estou } \\
\text { reingressando. }\end{array}$ & $\begin{array}{l}\text { Sim. Gosto de Física pois ela } \\
\text { explica o mundo que vivemos. }\end{array}$ \\
\hline N17 & Para ser professor. & Não. & Admiro a profissão. & $\begin{array}{l}\text { É indispensável, porém o } \\
\text { conteúdo do curso é } \\
\text { importante. }\end{array}$ & $\begin{array}{l}\text { Espero que seja um curso } \\
\text { sério que proporcione muitas } \\
\text { chances no mercado de } \\
\text { trabalho. }\end{array}$ & Sim, é uma matéria de exatas. \\
\hline N18 & $\begin{array}{l}\text { Era um dos poucos cursos que } \\
\text { eu tinha chance de passar. }\end{array}$ & Não sei. & Sim, não faz nada mesmo. & Não sei. & $\begin{array}{ll}\begin{array}{l}\text { Aumentar } \\
\text { conhecimentos. }\end{array} & \text { meus } \\
\end{array}$ & $\begin{array}{l}\text { Não gosto de estudar, mas é } \\
\text { [o] jeito. }\end{array}$ \\
\hline N19 & $\begin{array}{l}\text { Meu interesse foi o de } \\
\text { procurar um curso voltado } \\
\text { para o lecionamento e que }\end{array}$ & $\begin{array}{l}\text { Não. Como pretendo atuar na } \\
\text { área de ensino, as opções de } \\
\text { Bacharelado e Licenciatura }\end{array}$ & $\begin{array}{l}\text { Sim, pois tenho muito } \\
\text { interesse em lecionar ciência } \\
\text { e, em especial, na área de }\end{array}$ & $\begin{array}{l}\text { Sim. Considerando o mercado } \\
\text { de trabalho em que nos } \\
\text { encontramos, um diploma de }\end{array}$ & $\begin{array}{l}\text { Acredito que o curso poderá } \\
\text { me proporcionar uma ótima } \\
\text { formação a fim de concretizar }\end{array}$ & $\begin{array}{l}\text { Sim. Gosto muito de } \\
\text { correlacionar as interações } \\
\text { entre todos os corpos }\end{array}$ \\
\hline
\end{tabular}




\begin{tabular}{|c|c|c|c|c|c|c|}
\hline & $\begin{array}{l}\text { tivesse maior conteúdo na } \\
\text { área de ciência acadêmica. }\end{array}$ & tornam-se muito distintas. & $\begin{array}{l}\text { Física, tanto para o Ensino } \\
\text { Médio quanto } \\
\text { Universitário. }\end{array}$ & $\begin{array}{l}\text { curso superior é um elemento } \\
\text { diferencial. Deve-se, no } \\
\text { entanto, se ater a uma boa } \\
\text { referência de Ensino e a um } \\
\text { conteúdo ponderável e } \\
\text { satisfatório para a profissão. }\end{array}$ & $\begin{array}{l}\text { uma experiência, em especial } \\
\text { no que diz respeito ao ato de } \\
\text { ensino, necessária essencial } \\
\text { para o sucesso na execução } \\
\text { de meus futuros trabalhos. }\end{array}$ & $\begin{array}{l}\text { constituintes do ambiente em } \\
\text { que vivemos, podendo assim } \\
\text { analisar através de uma } \\
\text { perspectiva científica os } \\
\text { fenômenos e as } \\
\text { transformações a que esses } \\
\text { corpos são submetidos. }\end{array}$ \\
\hline N20 & $\begin{array}{l}\text { Porque tenho facilidades e } \\
\text { curiosidades na área da Física. }\end{array}$ & Não. & $\begin{array}{l}\text { Talvez. Porque não tenho } \\
\text { muito conhecimento em ser } \\
\text { professor de Física. }\end{array}$ & $\begin{array}{l}\text { Sim. Porém o curso deve ser } \\
\text { equivalente ao desejo } \\
\text { pessoal. }\end{array}$ & $\begin{array}{l}\text { Profundos conhecimentos em } \\
\text { Física. }\end{array}$ & $\begin{array}{l}\text { Sim. Das matérias de exatas, é } \\
\text { a que tenho mais facilidade. }\end{array}$ \\
\hline N21 & $\begin{array}{l}\text { Devido à profissão de } \\
\text { professor ser uma profissão } \\
\text { que gosto e também gosto da } \\
\text { matéria Física. }\end{array}$ & $\begin{array}{l}\text { Não, bacharelado seria } \\
\text { voltado mais a pesquisa e } \\
\text { licenciatura a aula. }\end{array}$ & $\begin{array}{l}\text { Pretendo primeiro porque } \\
\text { gosto e também devido a } \\
\text { minha idade ser difícil uma } \\
\text { colocação em uma empresa. }\end{array}$ & $\begin{array}{l}\text { Sim o curso superior se } \\
\text { tornou indispensável devido a } \\
\text { concorrência que existe no } \\
\text { ramo profissional. }\end{array}$ & $\begin{array}{l}\text { As perspectivas pessoais seria } \\
\text { possuir uma profissão a qual } \\
\text { tem contato com nossa } \\
\text { juventude e também com } \\
\text { adultos ajudando na } \\
\text { aquisição de conhecimentos e } \\
\text { também retorno financeiro. }\end{array}$ & $\begin{array}{l}\text { Gosto porque Física estuda } \\
\text { fenômenos da natureza e } \\
\text { com a Física podemos } \\
\text { entender porque muita coisa } \\
\text { existe. }\end{array}$ \\
\hline N22 & $\begin{array}{l}\text { Gosto de ensinar, e gostaria } \\
\text { de mudar de profissão. }\end{array}$ & Não. & $\begin{array}{l}\text { Sim. Gosto de passar para os } \\
\text { outros meus conhecimentos. }\end{array}$ & $\begin{array}{l}\text { É indispensável, mas tem que } \\
\text { ter conteúdo. }\end{array}$ & $\begin{array}{l}\text { Satisfação em estar numa } \\
\text { área que eu gosto. }\end{array}$ & Sim. Acho interessante. \\
\hline N23 & Para atuar como professor. & $\begin{array}{l}\text { Sim, pois me apeguei a essa } \\
\text { disciplina. }\end{array}$ & $\begin{array}{l}\text { Sim. Pois admiro esses } \\
\text { profissionais e pretendo ser } \\
\text { um deles. }\end{array}$ & $\begin{array}{l}\text { Sim, porque aumenta as } \\
\text { opções de trabalho. }\end{array}$ & $\begin{array}{l}\text { Espero exercer a profissão de } \\
\text { professor, principalmente } \\
\text { como pós-graduado. Na vida } \\
\text { pessoal ter mais auto-estima. }\end{array}$ & $\begin{array}{l}\text { Compreenda bem o que e } \\
\text { apresentado pelo professor. }\end{array}$ \\
\hline N24 & $\begin{array}{l}\text { Porque quero seguir nesta } \\
\text { carreira com a qual me } \\
\text { identifico muito. }\end{array}$ & Não. & $\begin{array}{lrr}\text { Sim, porque } & \text { gosto } & \text { de } \\
\text { transmitir } & & \text { meus } \\
\text { conhecimentos. } & & \end{array}$ & $\begin{array}{l}\text { Não, porque algumas } \\
\text { carreiras não possuem } \\
\text { incentivo do governo para } \\
\text { crescerem. }\end{array}$ & $\begin{array}{l}\text { Eu espero que eu realmente } \\
\text { me identifique com o curso } \\
\text { para poder seguir de uma } \\
\text { forma com a qual eu consiga } \\
\text { dar andamento aos meus } \\
\text { planos de pesquisa. }\end{array}$ & $\begin{array}{l}\text { Sim, porque é a ciência mais } \\
\text { interessante, na minha } \\
\text { opinião. }\end{array}$ \\
\hline N25 & Pois quero ser professor. & Não. & Sim, pois gosto de lecionar. & $\begin{array}{l}\text { Sim, pois sem estudo nada é } \\
\text { no país. }\end{array}$ & $\begin{array}{l}\text { Quero ser professor de física } \\
\text { e ajudar a mudar o país com a } \\
\text { educação. }\end{array}$ & Sim, pois acho legal. \\
\hline N26 & $\begin{array}{l}\text { É uma matéria que eu sempre } \\
\text { gostei e no momento a única } \\
\text { possível por não ser de } \\
\text { período integral. }\end{array}$ & Sim. & $\begin{array}{l}\text { Não. Porque no momento } \\
\text { não é o que eu tenho em } \\
\text { vista. }\end{array}$ & $\begin{array}{l}\text { Sim. Porque muitas empresas } \\
\text { requerem curso superior não } \\
\text { importando que curso seja. }\end{array}$ & $\begin{array}{l}\text { Eu pretendo ter um grande } \\
\text { desenvolvimento no } \\
\text { conhecimento na área de } \\
\text { exatas para uma maior } \\
\text { especialização no futuro. }\end{array}$ & $\begin{array}{l}\text { Sim. porque a física está em } \\
\text { todo lugar sendo portanto } \\
\text { uma área vasta para } \\
\text { profundas pesquisas. }\end{array}$ \\
\hline N27 & Porque gosto da carreira & Não, na licenciatura tem-se a & Sim, porque & Sim o diploma universitário é & As perspectivas profissionais & Sim, porque gosto das coisas \\
\hline
\end{tabular}




\begin{tabular}{|c|c|c|c|c|c|c|}
\hline & acadêmica. & $\begin{array}{l}\text { finalidade de formar } \\
\text { profissionais aptos à carreira } \\
\text { acadêmica, já o Bacharelado } \\
\text { forma profissionais nas } \\
\text { atividades de uma escola ou } \\
\text { universidade. }\end{array}$ & $\begin{array}{l}\text { profissão e gosto do ambiente } \\
\text { escolar. }\end{array}$ & $\begin{array}{l}\text { indispensável porém depende } \\
\text { muito da escolha do curso. } \\
\text { Não basta ter o curso é } \\
\text { preciso ter interesse pela } \\
\text { matéria. }\end{array}$ & $\begin{array}{l}\text { são as melhores possíveis, já } \\
\text { que estou ingressando em } \\
\text { uma das melhores e mais } \\
\text { renomadas universidades do } \\
\text { país. Já as perspectivas } \\
\text { pessoais, espero ganhar mais } \\
\text { responsabilidade e romper a } \\
\text { dependência dos pais. }\end{array}$ & estudadas. \\
\hline N28 & $\begin{array}{l}\text { Porque sempre gostei das } \\
\text { exatas, especialmente da área } \\
\text { de física. }\end{array}$ & Não exatamente. & $\begin{array}{l}\text { Sim. Gosto da idéia de passar } \\
\text { meu conhecimento a diante. }\end{array}$ & $\begin{array}{l}\text { Não. O importante não é ter } \\
\text { um diploma, mas ser um bom } \\
\text { profissional, embora ter um } \\
\text { diploma conte bastante na } \\
\text { hora de conseguir uma } \\
\text { oportunidade. }\end{array}$ & $\begin{array}{l}\text { Espero que me proporcione o } \\
\text { conhecimento pelo qual } \\
\text { anseio ao ingressar, } \\
\text { tornando-me mais que um } \\
\text { bom profissional da } \\
\text { educação, mas, também, } \\
\text { confirmando meu fascínio } \\
\text { pelaárea. }\end{array}$ & $\begin{array}{l}\text { Sim, acho fascinante todas as } \\
\text { áreas da física: da elétrica à } \\
\text { astrofísica. }\end{array}$ \\
\hline N29 & Porque adoro Física. & Não. Pretendo lecionar. & $\begin{array}{l}\text { Sim. Porque acho uma } \\
\text { carreira muito legal. }\end{array}$ & $\begin{array}{l}\text { Não. Todo curso precisa de } \\
\text { conteúdo } \\
\text { indispensavelmente. }\end{array}$ & $\begin{array}{ll}\text { Me } & \text { proporcione } \\
\text { conhecimento teórico e } \\
\text { prático em física e e } \\
\text { principalmente, como passar } \\
\text { esse conhecimento. }\end{array}$ & $\begin{array}{l}\text { Sim. Porque é uma matéria } \\
\text { intrigante. }\end{array}$ \\
\hline N30 & Interesse. & Não. & $\begin{array}{l}\text { Sim. Aptidões pessoais e } \\
\text { interesse. }\end{array}$ & $\begin{array}{l}\text { Não. Acho importante mas } \\
\text { existem muitas carreiras no } \\
\text { nível médio que podem ser } \\
\text { gratificante profissional e } \\
\text { pessoalmente. }\end{array}$ & $\begin{array}{l}\text { Conhecimento teórico, } \\
\text { formação prática e satisfação } \\
\text { pessoal. }\end{array}$ & $\begin{array}{l}\text { Sim. Não existe um porque, } \\
\text { sempre me interessei pela } \\
\text { área. }\end{array}$ \\
\hline N31 & & $\begin{array}{l}\text { Não. A Licenciatura me } \\
\text { habilitará ao ofício desejado. }\end{array}$ & $\begin{array}{l}\text { Pretendo. Além de ser uma } \\
\text { matéria que admiro, sempre } \\
\text { desejei ser professor. Só } \\
\text { precisei saber de que seria. }\end{array}$ & $\begin{array}{l}\text { Sim. Muitos cargos públicos e } \\
\text { privados o exigem. }\end{array}$ & 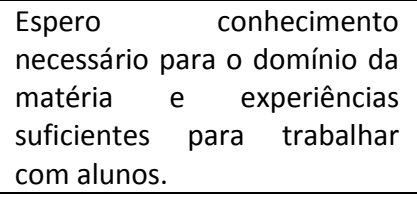 & $\begin{array}{l}\text { Sim. A Física me possibilita } \\
\text { compreender aquilo que me } \\
\text { cerca. }\end{array}$ \\
\hline N32 & $\begin{array}{l}\text { Para me aprimorar como } \\
\text { professor (sou professor de } \\
\text { matemática). }\end{array}$ & $\begin{array}{l}\text { Não. Quero fazer a } \\
\text { licenciatura porque meu } \\
\text { interesse é em educação. }\end{array}$ & $\begin{array}{l}\text { Não. Sou } \\
\text { matefessor de } \\
\text { matemática, e pretendo } \\
\text { seguir a área. }\end{array}$ & $\begin{array}{l}\text { Diploma e qualidade da } \\
\text { formação são igualmente } \\
\text { importantes. }\end{array}$ & $\begin{array}{l}\text { Como disse anteriormente, } \\
\text { pretendo aprimorar meus } \\
\text { conhecimentos em Física para } \\
\text { me tornar um professor de } \\
\text { matemática mais competente } \\
\text { (e interdisciplinar). }\end{array}$ & $\begin{array}{l}\text { Sim, apesar dessa não ter sido } \\
\text { minha área de interesse na } \\
\text { minha outra graduação } \\
\text { (matemática), atualmente } \\
\text { gostaria de me aprofundar na } \\
\text { área. }\end{array}$ \\
\hline N33 & Gosto & Não. & Sim, pois me identifico com a & Não, acho apenas & Profissionalmente espero que & Sim, gosto de descobrir a \\
\hline
\end{tabular}




\begin{tabular}{|c|c|c|c|c|c|c|}
\hline & $\begin{array}{l}\text { matemática e pretendo } \\
\text { lecionar. }\end{array}$ & & profissão e matéria. & $\begin{array}{l}\text { indispensável um diploma de } \\
\text { um bom curso aqueles que } \\
\text { visam grande futuro } \\
\text { profissional. }\end{array}$ & $\begin{array}{l}\text { o curso me habilite para } \\
\text { lecionar nas melhores escolas } \\
\text { do Brasil assim como } \\
\text { ingressar em pós-graduação. } \\
\text { Pessoalmente é o prazer de } \\
\text { saber física e estudar na } \\
\text { melhor universidade do país. }\end{array}$ & $\begin{array}{l}\text { forma como a física age na } \\
\text { sociedade e na história da } \\
\text { Terra. }\end{array}$ \\
\hline N34 & $\begin{array}{l}\text { Aptidão para áreas das exatas } \\
\text { e conceitos físicos e afinidade } \\
\text { com a matéria estudada na } \\
\text { Física. }\end{array}$ & Não. & $\begin{array}{l}\text { Sim, porque eu poderei } \\
\text { passar conhecimentos meus e } \\
\text { adquiridos. }\end{array}$ & $\begin{array}{l}\text { Sim, pois significa um melhor } \\
\text { emprego. }\end{array}$ & $\begin{array}{l}\text { Espero ser uma professora de } \\
\text { Física, } \\
\text { conhecimentos, } \\
\text { profissionalmente. }\end{array}$ & $\begin{array}{l}\text { Sim, porque eu aprendo os } \\
\text { fenômenos da natureza na } \\
\text { teoria, podendo analisa-los e } \\
\text { entende-los. }\end{array}$ \\
\hline N35 & $\begin{array}{l}\text { Porque sempre amei Física e } \\
\text { experiências como monitoria } \\
\text { me fez pensar em dar aulas. }\end{array}$ & Não, de jeito nenhum. & $\begin{array}{l}\text { Sim, porque já tive } \\
\text { experiências do gênero e } \\
\text { gostei muito. }\end{array}$ & $\begin{array}{l}\text { Sim, porque o mercado de } \\
\text { trabalho esta cada vez mais } \\
\text { difícil. }\end{array}$ & $\begin{array}{l}\text { A USP é uma universidade } \\
\text { que engrandece } \\
\text { profissionalmente, mas o fato } \\
\text { de cursar o que gosto nela é } \\
\text { ótimo para minhas } \\
\text { perspectivas pessoais. }\end{array}$ & $\begin{array}{l}\text { Sim, é super interessante } \\
\text { conseguir atravez (sic) dos } \\
\text { números, fórmulas e } \\
\text { conhecimentos calcular as } \\
\text { coisas do próprio dia-a-dia. }\end{array}$ \\
\hline N36 & $\begin{array}{l}\text { Pelo gosto pela matéria e } \\
\text { vontade de dar aulas. }\end{array}$ & Não. & Sim, por gosto. & Sim, pois sem ele é pior. & $\begin{array}{l}\text { Realização pessoal e também } \\
\text { profissional, pois tenho muita } \\
\text { vontade de dar aulas e } \\
\text { posteriormente talvez } \\
\text { trabalhar em pesquisas. }\end{array}$ & $\begin{array}{l}\text { Sim, pois tudo é muito lógico, } \\
\text { muito interessante. }\end{array}$ \\
\hline N37 & $\begin{array}{l}\text { Devido ao contato com } \\
\text { atividades profissionais em } \\
\text { cursinhos. }\end{array}$ & Não. & $\begin{array}{l}\text { Sim, devido a experiências } \\
\text { com alunos e materiais } \\
\text { envolvendo ensino. Nos } \\
\text { últimos anos tive bastante } \\
\text { contato com vestibulares e } \\
\text { provas. }\end{array}$ & $\begin{array}{l}\text { É indispensável, mas depende } \\
\text { do curso, pois apresenta um } \\
\text { mercado de trabalho } \\
\text { concorrido e exigente. }\end{array}$ & $\begin{array}{l}\text { Espero receber conhecimento } \\
\text { suficiente para lidar com } \\
\text { alunos e parâmetros } \\
\text { suficientes para poder ensinar } \\
\text { da melhor forma possível. }\end{array}$ & $\begin{array}{l}\text { Sim, por ter facilidade com a } \\
\text { matéria, entender melhor as } \\
\text { coisas que acontecem, suas } \\
\text { explicações. }\end{array}$ \\
\hline N38 & Por causa da profissão. & $\begin{array}{l}\text { Não. No momento preferi } \\
\text { fazer licenciatura. }\end{array}$ & Sim. Gosto da área. & $\begin{array}{l}\text { Sim, por uma questão de } \\
\text { "título". }\end{array}$ & $\begin{array}{l}\text { Espero que a conclusão do } \\
\text { curso me proporcione seguir } \\
\text { carreira como professor, sem } \\
\text { impedimentos. }\end{array}$ & $\begin{array}{l}\text { Sim, pois gosto das } \\
\text { explicações dos fenômenos } \\
\text { da natureza. }\end{array}$ \\
\hline N39 & $\begin{array}{l}\text { Porque durante o colégio } \\
\text { aprendi a gostar de física e } \\
\text { me identifico com a matéria. }\end{array}$ & Não. & $\begin{array}{l}\text { Sim, porque gosto dessa } \\
\text { profissão. }\end{array}$ & $\begin{array}{l}\text { Não porque muitos cursos } \\
\text { superior (sic) não tem } \\
\text { qualidade. }\end{array}$ & $\begin{array}{l}\text { Espero que o curso me } \\
\text { proporcione um ótimo } \\
\text { conhecimento em física. }\end{array}$ & $\begin{array}{l}\text { Sim porque admiro essa } \\
\text { ciência. }\end{array}$ \\
\hline N40 & Para ser professor de Física. & $\begin{array}{l}\text { Não, pois pretendo seguir } \\
\text { carreira educacional e não } \\
\text { científica. }\end{array}$ & $\begin{array}{l}\text { Sim. Pois gosto da área de } \\
\text { educação e minha matéria } \\
\text { preferida é Física. }\end{array}$ & $\begin{array}{l}\text { Não. Depende do quê quer } \\
\text { fazer da sua vida. Se alguém } \\
\text { optar por ser mestre de obras }\end{array}$ & $\begin{array}{l}\text { Espero adquirir } 0 \\
\text { conhecimento necessário } \\
\text { para passar para meus }\end{array}$ & $\begin{array}{l}\text { Sim. Porque na física nos } \\
\text { podemos imaginar coisas fora } \\
\text { do comum além de poder }\end{array}$ \\
\hline
\end{tabular}




\begin{tabular}{|c|c|c|c|c|c|c|}
\hline & & & & $\begin{array}{l}\text { ou mecânico ninguém pode } \\
\text { fazer nada a respeito. }\end{array}$ & futuros alunos. & prová-las matematicamente. \\
\hline N41 & Para ser professor de Física. & Não. & Porque gosto de lecionar. & $\begin{array}{l}\text { Não, depende muito da } \\
\text { pessoa e não do diploma. }\end{array}$ & $\begin{array}{l}\text { Maior conhecimento na área } \\
\text { de Física além de } \\
\text { oportunidade de emprego na } \\
\text { área. }\end{array}$ & Sim, porque tudo é física. \\
\hline N42 & Desejo lecionar Física. & Sim. & $\begin{array}{l}\text { Gosto pessoal e concorrência } \\
\text { no mercado de trabalho. }\end{array}$ & $\begin{array}{l}\text { Não. é possível ser } \\
\text { economicamente bem } \\
\text { sucedido, por outras vias } \\
\text { alternativas. }\end{array}$ & $\begin{array}{lr}\text { Pretendo em } 2007 \text { trabalhar } \\
\text { como professor } \\
\text { posteriormente } \\
\text { pesquisador. }\end{array}$ & $\begin{array}{l}\text { Sim. Porque me sinto } \\
\text { avontade (sic) e realizado ao } \\
\text { estudar física. }\end{array}$ \\
\hline N43 & $\begin{array}{l}\text { Tenho afinidade com a } \\
\text { matéria. }\end{array}$ & Não. & $\begin{array}{l}\text { Não. Não é uma opção } \\
\text { rentável. }\end{array}$ & $\begin{array}{l}\text { Sim. Pois as pessoas precisam } \\
\text { de uma garantia da } \\
\text { capacidade de outrem. }\end{array}$ & 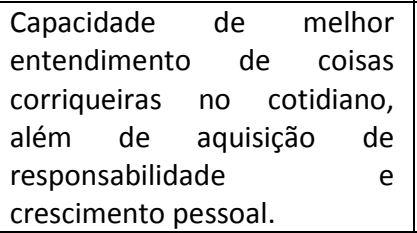 & $\begin{array}{l}\text { Sim. Pois me ajuda a entender } \\
\text { melhor o mundo. }\end{array}$ \\
\hline N44 & $\begin{array}{l}\text { Gosto de Física e quero passar } \\
\text { meus conhecimentos, aos } \\
\text { outros. }\end{array}$ & Sim! & Sim. Gosto de dar aula. & Sim. A pessoa faz seu curso. & $\begin{array}{l}\text { Que eu consiga subir na } \\
\text { minha carreira e consiga } \\
\text { ensinar os outros. }\end{array}$ & $\begin{array}{l}\text { Sim. Concidero (sic) um } \\
\text { desafio. }\end{array}$ \\
\hline N45 & $\begin{array}{l}\text { Porque me identifiquei com a } \\
\text { ciência da Física, logo } \\
\text { pretendo não apenas } \\
\text { assimilar conhecimento } \\
\text { didático mas, sobretudo, } \\
\text { científico. }\end{array}$ & Não, pretendo ser professor. & $\begin{array}{l}\text { Sim, porque terei a } \\
\text { disponibilidade intelectual } \\
\text { para mostrar o admirável } \\
\text { mundo da Física aquelas } \\
\text { pessoas que tenham interesse } \\
\text { por essa ciência. }\end{array}$ & $\begin{array}{l}\text { Sim, mas o aluno precisa ter } \\
\text { aptidão em que faz. }\end{array}$ & $\begin{array}{l}\text { Muito } \\
\text { científico. }\end{array}$ & $\begin{array}{l}\text { Sim, porque } \\
\text { aumentar minha consigo } \\
\text { de percepção. }\end{array}$ \\
\hline N46 & $\begin{array}{l}\text { Por já atuar como professor e } \\
\text { poder expandir minha } \\
\text { atuação profissional no } \\
\text { ensino médio. }\end{array}$ & Não. & $\begin{array}{l}\text { Sim. Por ter imenso prazer em } \\
\text { dar aula. }\end{array}$ & $\begin{array}{l}\text { Não. Atualmente o diploma } \\
\text { soa mais como mote } \\
\text { comercial à uma real } \\
\text { necessidade de mercado. }\end{array}$ & $\begin{array}{l}\text { Considerando a falta relativa } \\
\text { de licenciados em Física } \\
\text { atuando na área de ensino e } \\
\text { minha experiência atual na } \\
\text { área, ambos apontam para } \\
\text { uma perspectiva positiva em } \\
\text { termos profissionais. }\end{array}$ & $\begin{array}{l}\text { Sim. A compreensão dos } \\
\text { fenômenos é um assunto } \\
\text { muito sedutor. }\end{array}$ \\
\hline N47 & $\begin{array}{l}\text { Porque gosto de saber como } \\
\text { funciona o mundo e adoro } \\
\text { dar aulas. }\end{array}$ & $\begin{array}{l}\text { O aluno que faz as duas } \\
\text { opções será sem dúvida um } \\
\text { profissional mais completo e } \\
\text { competente. }\end{array}$ & $\begin{array}{l}\text { Sim, já trabalho com jovens e } \\
\text { adoro poder lhes ensinar } \\
\text { algo. }\end{array}$ & $\begin{array}{l}\text { Sim, mesmo no contexto de } \\
\text { hoje do Brasil o mercado de } \\
\text { trabalho ainda exige nível } \\
\text { superior. }\end{array}$ & $\begin{array}{l}\text { Pessoalmente } \quad \text { espero } \\
\text { amadurecer e que o curso me } \\
\text { mostre outras perspectivas e } \\
\text { vidar Profissionalmente } \\
\text { ganhar \$ fazendo o que gosto. }\end{array}$ & Sim, é instigante. \\
\hline N48 & Tenho facilidade e afinidade & Não. Mas a Licenciatura tem & Talvez. Se gostar de didática & Não. O que realmente conta é & Espero ter uma nova visão do & Um pouco. Os livros são \\
\hline
\end{tabular}




\begin{tabular}{|c|c|c|c|c|c|c|}
\hline & $\begin{array}{l}\text { com a matéria em si e o } \\
\text { mercado de trabalho e } \\
\text { principalmente pesquisas } \\
\text { foram decisivas na escolha. }\end{array}$ & $\begin{array}{l}\text { maior mercado de trabalho } \\
\text { (este não é o meu primeiro } \\
\text { critério em optar por } \\
\text { Licenciatura). }\end{array}$ & $\begin{array}{l}\text { pretendo dar aula, não quero } \\
\text { ser um mau professor. }\end{array}$ & $\begin{array}{l}\text { as habilidades naturais de } \\
\text { cada um. }\end{array}$ & $\begin{array}{l}\text { mundo. Uma visão ampla, } \\
\text { questionadora e encontrar } \\
\text { respostas e propor soluções } \\
\text { para o mundo. }\end{array}$ & $\begin{array}{l}\text { muito chatos. Os autores são } \\
\text { muito superficiais e pouco } \\
\text { objetivo. Mas a matéria é } \\
\text { importante. }\end{array}$ \\
\hline N49 & Ascensão profissional. & Sim. & Sim, remuneração extra. & $\begin{array}{l}\text { Sim, porque o mercado de } \\
\text { trabalho dá mais } \\
\text { oportunidades para quem } \\
\text { tem diploma de curso } \\
\text { superior. }\end{array}$ & $\begin{array}{l}\text { Ascensão de cargo no } \\
\text { trabalho e maiores } \\
\text { oportunidades em conseguir } \\
\text { trabalho em outras empresas. }\end{array}$ & $\begin{array}{l}\text { Sim, tenho maior facilidade } \\
\text { nas ciências exatas. }\end{array}$ \\
\hline N50 & $\begin{array}{l}\text { Por gostar de Física e querer } \\
\text { ser professor. }\end{array}$ & Não. & Sim. Gosto de dar aula. & $\begin{array}{l}\text { Sim. Porque o mercado de } \\
\text { trabalho está cada vez mais } \\
\text { competitivo. }\end{array}$ & $\begin{array}{lrr}\begin{array}{l}\text { Espero que } \\
\text { proporcione }\end{array} \text { curso } & \text { me } \\
\text { perspectivas necessárias para } & \text { as } \\
\text { ingressar na } & \text { carreira } & \text { como } \\
\text { professor } & \text { e } & \text { como } \\
\text { pesquisador. } & & \\
\end{array}$ & $\begin{array}{l}\text { Sim. Sempre gostei de } \\
\text { cálculos e simpatizei com a } \\
\text { Física. }\end{array}$ \\
\hline N51 & $\begin{array}{l}\text { Por achar que tenho vocação } \\
\text { e afinidade com a carreira. }\end{array}$ & $\begin{array}{l}\text { Não. Apesar do Bacharelado } \\
\text { ter um aprofundamento } \\
\text { maior em Física, não habilita } \\
\text { o profissional na área de } \\
\text { educação que quero. }\end{array}$ & Sim. Adoro lecionar. & $\begin{array}{l}\text { Sim. Qualquer tipo de } \\
\text { ampliação de conhecimento é } \\
\text { importante para a formação } \\
\text { individual e contribui para o } \\
\text { crescimento social. }\end{array}$ & $\begin{array}{l}\text { Boa formação em Física; } \\
\text { técnicas em educação e nova } \\
\text { forma de passar o conteúdo } \\
\text { de Física, menos tradicional, } \\
\text { que motivem mais os alunos. }\end{array}$ & $\begin{array}{l}\text { Sim. Pelo fascínio de } \\
\text { relacionar os fenômenos } \\
\text { físicos da natureza. }\end{array}$ \\
\hline N52 & $\begin{array}{l}\text { Já trabalho como professor de } \\
\text { física em colégios. }\end{array}$ & $\begin{array}{l}\text { Não, pois pretendo continuar } \\
\text { lecionando. }\end{array}$ & $\begin{array}{l}\text { Sim. Já trabalho na área } \mathrm{e} \\
\text { gosto. }\end{array}$ & $\begin{array}{l}\text { Sim. Para progredir } \\
\text { profissionalmente. }\end{array}$ & $\begin{array}{l}\text { Abrir mais oportunidades de } \\
\text { emprego em outros colégios } \\
\text { que exigem licenciatura. }\end{array}$ & $\begin{array}{l}\text { Sim, gosto de entender o } \\
\text { funcionamento de máquinas } \\
\text { e o porquê dos fenômenos } \\
\text { físicos. }\end{array}$ \\
\hline N53 & $\begin{array}{l}\text { Imagino que há um } \\
\text { interessante campo de } \\
\text { trabalho e principalmente } \\
\text { pela afinidade da matéria. }\end{array}$ & Não. & $\begin{array}{l}\text { Sim. Identifico-me com a } \\
\text { profissão. }\end{array}$ & $\begin{array}{l}\text { Acho bastante necessário, } \\
\text { mas não ao ponto de } \\
\text { indispensável nem tão pouco } \\
\text { independente do conteúdo. }\end{array}$ & $\begin{array}{l}\text { Acredito estar entrando num } \\
\text { campo bastante carente e } \\
\text { com várias opç̃os e } \\
\text { pessoalmente que traga-me } \\
\text { realização e satisfação de ser } \\
\text { um profissional da área. }\end{array}$ & $\begin{array}{l}\text { Sim. Afinidade e interesse } \\
\text { pelos fenômenos. }\end{array}$ \\
\hline N54 & Dar aula em colégios. & Não. & $\begin{array}{l}\text { Sim, para melhorar o nível } \\
\text { dos alunos do } 2^{\circ} \text { grau. }\end{array}$ & Sim, obtenção emprego. & $\begin{array}{l}\text { Dar condições para exercer a } \\
\text { função do professor com } \\
\text { adequada didática. }\end{array}$ & Sim. O mundo é físico!! \\
\hline N55 & $\begin{array}{l}\text { Terminar } \circ \quad \text { curso de } \\
\text { licenciatura, } \quad \text { tive alguns } \\
\text { problemas para concluir. }\end{array}$ & Não! & $\begin{array}{ll}\text { Sim! Compartilhar } \\
\text { conhecimento é importante. }\end{array}$ & $\begin{array}{l}\text { Acredito que sim! Mercado } \\
\text { competitivo. }\end{array}$ & $\begin{array}{l}\text { Trabalhar como professor e } \\
\text { se possível fazer um mestrado } \\
\text { na área de ensino. }\end{array}$ & Sim! Gosto dos cálculos... \\
\hline N56 & $\begin{array}{l}\text { Porque gosto de física e } \\
\text { pretendo dar aula de física, }\end{array}$ & & $\begin{array}{l}\text { Sim, porque tenho facilidade } \\
\text { em transmitir meu }\end{array}$ & $\begin{array}{l}\text { Sim porque o mercado de } \\
\text { trabalho esta cada vez mais }\end{array}$ & $\begin{array}{l}\text { Espero que me proporcione } \\
\text { um alto grau de instrução e }\end{array}$ & $\begin{array}{l}\text { Sim porque tudo em nossas } \\
\text { vidas envolve física. }\end{array}$ \\
\hline
\end{tabular}




\begin{tabular}{|c|c|c|c|c|c|c|}
\hline & tenho facilidade em ensinar & & conhecimento. & competitivo. & $\begin{array}{l}\text { aumento minha vontade de } \\
\text { pesquisar e que consiga } \\
\text { transmitir os meus } \\
\text { conhecimentos aqueles que } \\
\text { precisam. }\end{array}$ & \\
\hline N57 & $\begin{array}{l}\text { Porque me interessei pela } \\
\text { matéria que me dará um forte } \\
\text { preparo na área de exatas, e } \\
\text { me interessa também ser } \\
\text { professor futuramente. }\end{array}$ & $\begin{array}{l}\text { Creio que me adaptaria bem } \\
\text { em qualquer uma das duas, } \\
\text { porém a licenciatura me } \\
\text { preparará para a área de } \\
\text { docência, que no momento é } \\
\text { o que me interessa. }\end{array}$ & $\begin{array}{l}\text { Sim, é uma área muito } \\
\text { interessante e o mercado de } \\
\text { trabalho, ao que me consta, } \\
\text { está necessitando de } \\
\text { profissionais na área. }\end{array}$ & $\begin{array}{l}\text { Hoje em dia um diploma de } \\
\text { nível superior faz a diferença, } \\
\text { porém não basta para ter um } \\
\text { sucesso profissional. }\end{array}$ & $\begin{array}{l}\text { Principalmente a área de } \\
\text { docência, porém é uma área } \\
\text { indispensável para quem } \\
\text { pretende cursar engenharia. }\end{array}$ & $\begin{array}{l}\text { Sim, nela consigo ver a } \\
\text { aplicação matemática com } \\
\text { muito mais clareza sem } \\
\text { contar que estudar física é } \\
\text { conhecer os fenômenos } \\
\text { naturais que envolvem o dia a } \\
\text { dia de todos. }\end{array}$ \\
\hline N58 & $\begin{array}{l}\text { Por que interesso pelos } \\
\text { assuntos abordados no curso } \\
\text { de Física, e pretendo } \\
\text { trabalhar nessa área, seja } \\
\text { como professor ou como } \\
\text { pesquisador (no caso de uma } \\
\text { eventual transferência para o } \\
\text { Bacharelado em Física). }\end{array}$ & $\begin{array}{l}\text { Não, entendo que o curso de } \\
\text { Licenciatura dá ênfase "como } \\
\text { ensinar física" e o curso de } \\
\text { bacharel } \\
\text { pesquisadores. }\end{array}$ & $\begin{array}{l}\text { Não, pretendo trabalhar na } \\
\text { área de pesquisa. }\end{array}$ & $\begin{array}{l}\text { Sim, acredito que o mercado } \\
\text { de trabalho valoriza diplomas, } \\
\text { pois, o número de pessoas } \\
\text { nas universidades ainda é } \\
\text { muito pequeno de forma que } \\
\text { as pessoas "formadas" têm } \\
\text { maior credibilidade dos que } \\
\text { outras sem curso superior. }\end{array}$ & $\begin{array}{l}\text { Espero que o curso de Física } \\
\text { me proporcione um bom } \\
\text { conhecimento na área das } \\
\text { ciências exatas e } \\
\text { possibilidades de trabalhar } \\
\text { em centros de pesquisa. }\end{array}$ & $\begin{array}{l}\text { Sim, pois quando estudo } \\
\text { física, aprendo como } \\
\text { funcionam algumas leis na } \\
\text { natureza, descubro como } \\
\text { funciona o ambiente ao meu } \\
\text { redor. }\end{array}$ \\
\hline N59 & $\begin{array}{l}\text { Porque tenho muito gosto } \\
\text { pela física e por ensiná-la. } \\
\text { Além de gosto, facilidade. }\end{array}$ & $\begin{array}{l}\text { Não, Licenciatura é o que } \\
\text { quero, é necessário para } \\
\text { meus planos futuros, ser } \\
\text { professor. }\end{array}$ & $\begin{array}{l}\text { Sim, pois tenho facilidade e } \\
\text { gosto em ensinar. }\end{array}$ & $\begin{array}{l}\text { Sim. Devido à grande } \\
\text { concorrência, um diploma } \\
\text { mostra a sua capacidade, isso } \\
\text { pode fazer a diferença. }\end{array}$ & $\begin{array}{l}\text { Penso em ser professor, } \\
\text { começando em colégios e } \\
\text { cursinhos, mas um dia em } \\
\text { uma universidade como a } \\
\text { USP. }\end{array}$ & $\begin{array}{l}\text { Sim. Tudo que estudo em } \\
\text { física me ajuda e explica as } \\
\text { coisas do dia a dia no mundo. }\end{array}$ \\
\hline
\end{tabular}


ANEXO C - Questionário do Licenciando IFUSP em (Per)curso 
O que mudou, para mim, ao ingressar no curso de Licenciatura em Física?

Essa pesquisa faz parte de um projeto que pretende compreender qual a contribuição do curso de licenciatura para a formação de seus alunos, tanto em temos de conhecimentos de Física como de saberes docentes. Pretende-se que essa análise possa contribuir para um aprimoramento do curso e gostaríamos de solicitar sua colaboração. Obrigada.

\section{Período: ( ) Diurno ( ) Noturno}

Forma de ingresso: ( ) Vestibular ( ) Transf. Bacharelado
Ano de ingresso:
( ) Aluno graduado
( ) Outro
Curso ( ) Técnico
( ) Regular

Qual a escolaridade de seu pai: ( ) Ensino Fundamental Incompleto ( ) Ensino Fundamental Completo

\section{Se estiver ministrando aulas atualmente, indique:}

( ) № de aulas/semana:

\section{( ) Ensino Médio Completo ( ) Ensino Superior}

( ) Escola Pública ( ) Outras: Há quanto tempo leciona:

Trabalha ou exerce alguma outra atividade regular (exceto lecionar): （） Não （） Sim. Em que:

\section{Ao ingressar no Curso de Licenciatura em Física, sua PRINCIPAL motivação era:}
( ) Ser professor
( ) Obter uma formação científica geral
( ) Fazer pesquisa em Física
( ) Facilitar a entrada no mercado de trabalho
( ) Ingressar em uma universidade pública
( ) Outra:

2. Sua visão do que é a ciência FíSICA mudou (ou não), a partir das disciplinas que já cursou? Em que sentido?

3. Sua visão do que é SER PROFESSOR mudou (ou não), depois que você entrou no curso? Em que sentido?

4. Um bom professor, do seu ponto de vista, é aquele que, por exemplo, ....

5. Indique alguns aspectos positivos (e negativos) relacionados ao curso que correspondam (ou não) a suas expectativas.

\section{O que você pretende fazer quando acabar o curso?}
( ) Ministrar aulas como atividade principal
( ) Não ministrar aulas imediatamente
( ) Ministrar aulas, eventualmente
( ) Outro:

Comentários e/ou observações: (Use o verso, se necessário) 
ANEXO D - Dados referentes ao Questionário do Licenciando em (Per)curso 


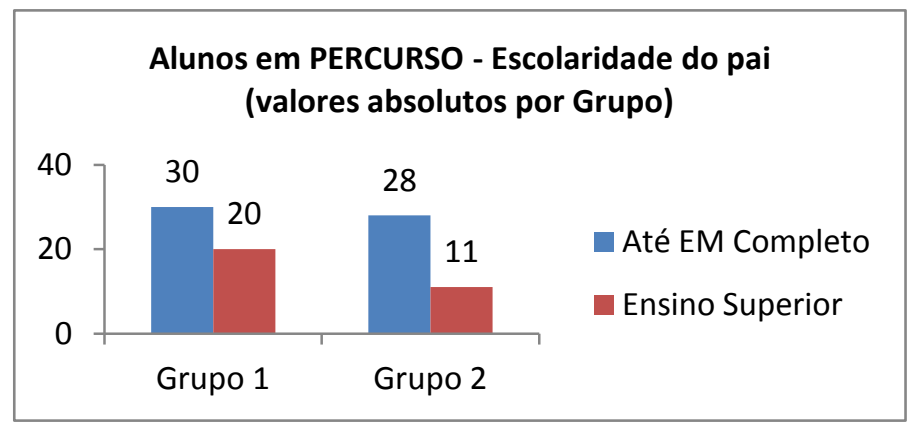

Escolaridade do pai, segundo os Grupos 1 e 2 de alunos em percurso (absoluto).

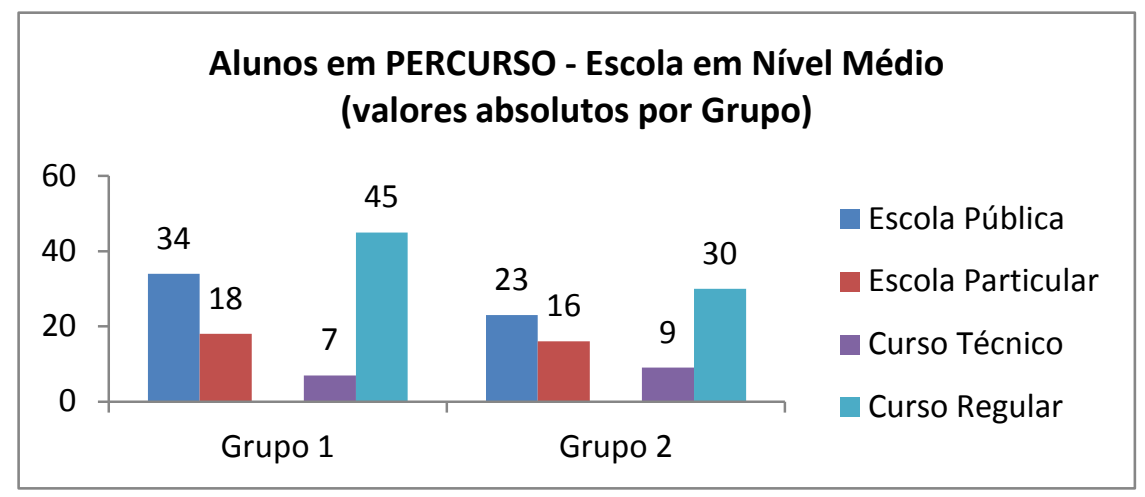

Tipo de Escola em Nível Médio dos alunos em Percurso, segundo os Grupos 1 e 2 (absoluto).

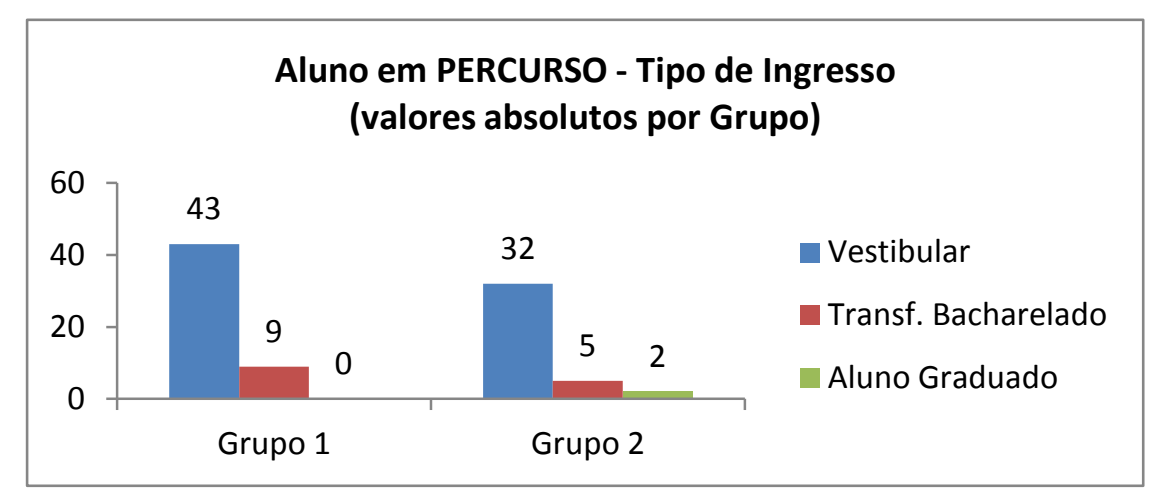

Tipo de ingresso dos alunos em Percurso, segundo os Grupos 1 e 2 (absoluto). 


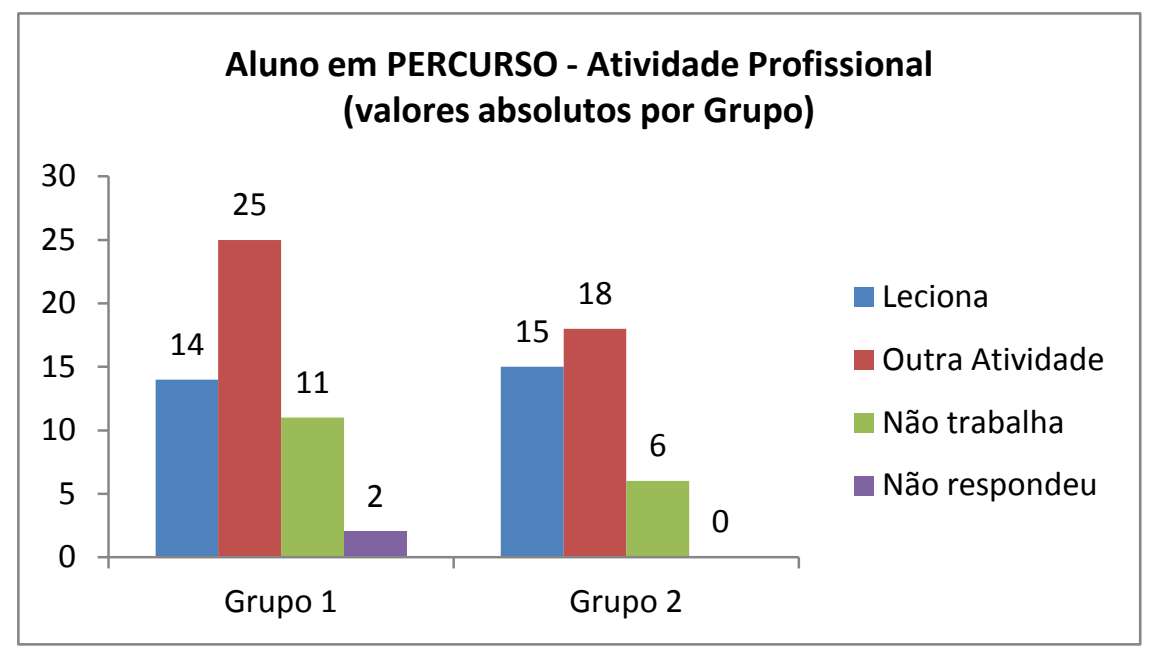

Atividade Profissional dos alunos em Percurso, segundo os Grupos 1 e 2 (percentual).

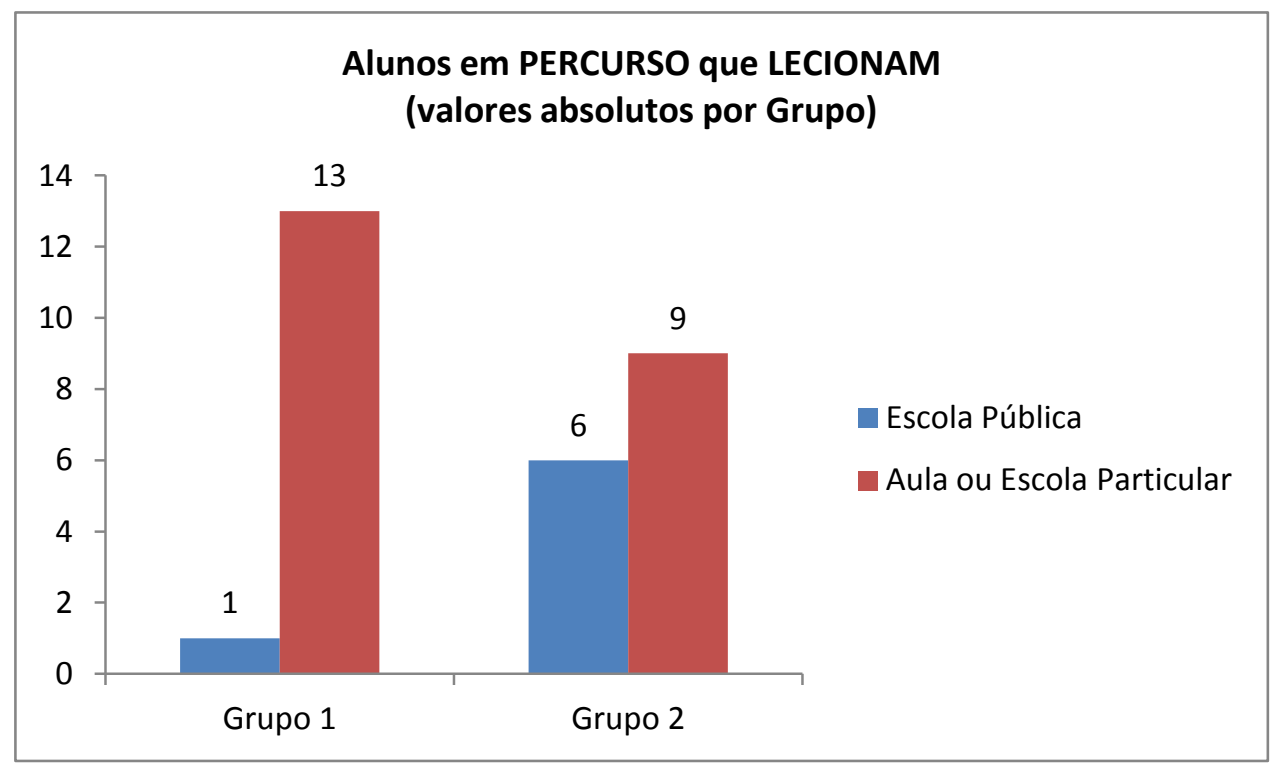

Alunos em Percurso que Lecionam, segundo os Grupos 1 e 2 (absoluto).

Mudança na Visão de Professor - Alunos em Percurso

\begin{tabular}{|r|c|c|}
\hline \multicolumn{3}{|c|}{ Visão do Ser Professor - absoluto } \\
\hline & Grupo 1 & Grupo 2 \\
\hline mudou & 34 & 24 \\
\hline não mudou & 18 & 13 \\
\hline não respondeu & 0 & 2 \\
\hline total & 52 & 39 \\
\hline
\end{tabular}

\begin{tabular}{|c|c|c|}
\hline \multicolumn{3}{|c|}{ Visão do Ser Professor - percentual } \\
\hline & Grupo 1 & Grupo 2 \\
\hline mudou & $65 \%$ & $62 \%$ \\
\hline não mudou & $35 \%$ & $33 \%$ \\
\hline não respondeu & $0 \%$ & $5 \%$ \\
\hline total & $100 \%$ & $100 \%$ \\
\hline
\end{tabular}




\section{Questionário - Licenciandos em PERCURSO - VISÃO DE FíSICA}

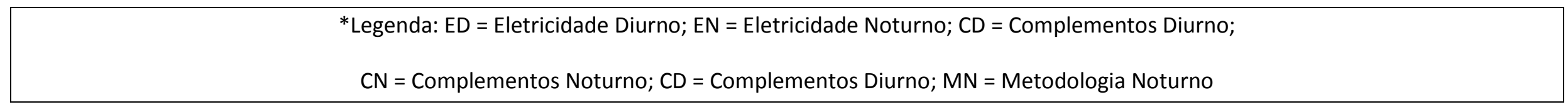

\begin{tabular}{|c|c|c|c|}
\hline Aluno* & Sua visão do que é a FísıCA mudou (ou não), a partir das disciplinas que já cursou? Em que sentido? & & $\begin{array}{c}\text { NC - Natureza da Ciência } \\
\text { ABR - Abrangência } \\
\text { APL - Aplicações } \\
\text { IND - Indefinido }\end{array}$ \\
\hline ED1 & Não, nada mudou para mim em relação do que é Física. & Não & 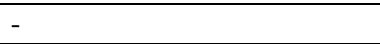 \\
\hline ED2 & $\begin{array}{l}\text { Não sei responder ao certo. Acredito que a visão esteja em constante transformação. Espero, daqui algum tempo, poder } \\
\text { responder mais objetivamente à essa pergunta. }\end{array}$ & Não sei & IND \\
\hline ED3 & Não. & Não & - \\
\hline ED4 & Sim. Em muitas disciplinas no IFUSP os professores ensinaram a observar a natureza, e tentar entender as leis que nos faz existir. & Sim & NC \\
\hline ED5 & $\begin{array}{l}\text { Mudou. Aqui nos foi apresentado por alguns professores (os bons) que a física estuda fenômenos e cria modelos para estudá-los } \\
\text { e prevê-los. }\end{array}$ & Sim & NC \\
\hline ED6 & Sim, pois é algo muito mais complexo do que já imaginava ser. & Sim & $\mathrm{ABR}$ \\
\hline ED7 & Sim, hoje eu acho a física muito mais interessante e difícil. & Sim & $\mathrm{ABR}$ \\
\hline ED8 & $\begin{array}{l}\text { Não sei ao certo se mudou, eu diria que ela foi amadurescendo (sic) e se transformando. Então sim, ela mudou! No sentido de } \\
\text { conteúdos, dificuldades. }\end{array}$ & N sei & ABR \\
\hline ED9 & $\begin{array}{l}\text { Minha visão do que é física não mudou, mas minha motivação em estudá-la foi muito comprometida pelo curso no IFUSP, que } \\
\text { não contribuiu nesse sentido. }\end{array}$ & Não & - \\
\hline ED10 & Sim. Mudou no sentido de ver a física mais como uma descrição da natureza. & Sim & NC \\
\hline ED11 & Sim. Aumentou minha visão aonde física pode ser aplicada. & Sim & $\mathrm{ABR}$ \\
\hline ED12 & Não & Não & - \\
\hline ED13 & Sim, a importância prática e teórica passou a ser mais clara. & Sim & $A B R$ \\
\hline ED14 & Claro que mudou, pois entramos na universidade com a noção básica do que é a física. & Sim & ABR \\
\hline ED15 & Sim, mostrou-me ser mais abrangente e aplicável do que imaginava inicialmente. & Sim & APL \\
\hline ED16 & Mudou, ela agora me parece muito mais complexa e interessante. & Sim & ABR \\
\hline ED17 & Não. Mudou a minha visão do que é ser físico. & Não & - \\
\hline ED18 & Sim, a Física é muito mais abrangente do que eu imaginei. & Sim & $A B R$ \\
\hline EN1 & A visão do que é física não mudou. & Não & - \\
\hline EN2 & Mudou em alguns aspectos, onde eu não tinha uma visão tão ampla do que é a física e o quanto ela é importante. & Sim & $A B R$ \\
\hline EN3 & Sim. No sentido de enchergar (tic) o que existe por trás das coisas. & Sim & APL \\
\hline
\end{tabular}




\begin{tabular}{|c|c|c|c|}
\hline EN4 & Sim. A medida que os conteúdos são apresentados os conhecimentos adquiridos por meio de senso comum tem caido por terra. & Sim & ABR \\
\hline EN5 & $\begin{array}{l}\text { Sim. Através de um estudo mais formal, pode-se adquirir uma visão mais profunda e também maior ligação entre diversas partes } \\
\text { da Física que antes pareciam isoladas. }\end{array}$ & Sim & ABR \\
\hline EN6 & Infelizmente um curso que é formador de professores, não possue (tic) em geral professores preparados para formar professores & Não & - \\
\hline EN7 & $\begin{array}{l}\text { Sim principalmente por ver as disciplinas "profundamente" ou melhor por ver as disciplinas que cursei no colegial de outra } \\
\text { maneira. }\end{array}$ & Sim & ABR \\
\hline EN8 & Minha visão mudou, pois para saber Física não basta saber resolver exercícios. & Sim & ABR \\
\hline EN9 & Sim, Física é muito mais do que se pensava no ensino médio. & Sim & ABR \\
\hline EN10 & Mudou no sentido de ampliar cada vez mais meu conhecimento. & Sim & ABR \\
\hline EN11 & Não mudou muito. & Não & - \\
\hline EN12 & Sim, pois agora sei que tenho que estudar e me preparar mais em termos de conteúdos e práticas. Dependerá de mim. & Sim & IND \\
\hline EN13 & Não. & Não & - \\
\hline EN14 & $\begin{array}{l}\text { Sim, hoje tenho uma noção maior do tamanho da física (abrangência) e entendo melhor que ela não é tão simples, mas apesar } \\
\text { disto muito bela. }\end{array}$ & Sim & ABR \\
\hline EN15 & Não mudou. & Não & - \\
\hline EN16 & Não. & Não & - \\
\hline EN17 & Sim, pois tive melhor entendimento dos fenômenos ensinados no E.M. & Sim & $\mathrm{ABR}$ \\
\hline EN18 & Sim mudou, depois que eu comecei a ver assuntos mais específicos, gostei muito das matérias que tive com exceção de cálculo. & Sim & ABR \\
\hline EN19 & Sim, em parte. Uso menos a intuição e mais o cálculo agora. & Sim & IND \\
\hline EN20 & Sim. Ela abrange muito mais do que eu imaginava. & Sim & ABR \\
\hline EN21 & Não. & Não & - \\
\hline EN22 & Sim, ficou mais clara, conheci um pouco mais sobre ciência. & Sim & $\mathrm{ABR}$ \\
\hline EN23 & Sim, ficou mais apaixonante. & Sim & ABR \\
\hline EN24 & Ajudou eu analisar melhor os problemas que encontramos no dia a dia. & Sim & APL \\
\hline EN25 & $\begin{array}{l}\text { Obtive maiores conhecimentos sobre quais fatores físicos influenciam em nosso cotidiano, fazendo assim com que eu tenha } \\
\text { maior possibilidade de entender o mundo ao meu redor. }\end{array}$ & Sim & APL \\
\hline EN26 & Sim, mudou no sentido de conseguir enxergar a física no dia-a-dia. & Sim & APL \\
\hline EN27 & $\begin{array}{l}\text { Sim, entrei na faculdade imaginando que teria aulas referentes aos assuntos vistos no cursinho, mais de maneira + aprofundada } \\
\text { e discutida, e na maior parte das matérias que fiz tive que memorizar resolução de exercícios p/ ser aprovado. }\end{array}$ & Sim & IND \\
\hline EN28 & Não. & Não & - \\
\hline EN29 & Mudou, no sentido de aprofundar e conhecer a origem de assuntos vistos superficialmente na escola. & Sim & ABR \\
\hline EN30 & Não. & Não & - \\
\hline EN31 & Sim. No sentido de usar a matemática como ferramenta. & Sim & APL \\
\hline EN32 & $\begin{array}{l}\text { Sim, mudou bastante. A Física possui um campo extremamente vasto e multidisciplinar, em muitos momentos me surpreendi e } \\
\text { gostei ainda mais de aprofundar assuntos que eram vistos superficialmente durante o E.M. }\end{array}$ & Sim & ABR \\
\hline EN33 & & Ebranco & BRANCO \\
\hline EN34 & Mudou. No sentido da importância das atividades experimentais para chegarmos a uma conclusão a respeito de um fenômeno & Sim & NC \\
\hline
\end{tabular}




\begin{tabular}{|c|c|c|c|}
\hline & físico. & & \\
\hline CN1 & $\begin{array}{l}\text { Não mudou. A diferença maior que eu senti foi no conteúdo de Física Moderna e cálculos avançados o que não imaginamos } \\
\text { quando estamos fora da USP. }\end{array}$ & Não & - \\
\hline CN2 & A física de modo geral não mudou para mim, pois a idéia de que é uma disciplina ampla e em constante mudança permanece. & Não & - \\
\hline CN3 & $\begin{array}{l}\text { Sim. Por mais que temos professores focado nos conteúdos, outros fizeram perceber a dimensão deste curso não somente no } \\
\text { âmbito acadêmico como no social. }\end{array}$ & Sim & NC \\
\hline CN4 & Minha visão pouco mudou. Exceto quanto aos cursos (disciplinas) de Moderna, Relatividade e algumas optativas. & $\begin{array}{l}\text { (sim) } \\
\text { Pouco }\end{array}$ & ABR \\
\hline CN5 & Sim! No sentido de ver as coisas que estão ao meu redor. & Sim & APL \\
\hline CN6 & $\begin{array}{l}\text { A minha visão mudou com relação as concepções teóricas e práticas que tinha antes, de uma maneira simplória, hoje admito ter } \\
\text { mais dúvidas do que certezas, mas mesmo parecendo estranho me sinto mais apta para tal questionamento. }\end{array}$ & Sim & NC \\
\hline CN7 & Sem dúvida mudou, a visão de física do ensino médio que tinha era totalmente clássica nunca tive contato com física moderna. & Sim & $\mathrm{ABR}$ \\
\hline CN8 & $\begin{array}{l}\text { Sim. O conceito de ciência e, em particular a física, foi aprimorado, dando condições de compreender, mesmo que de forma } \\
\text { básica, a maioria dos fenômenos. }\end{array}$ & Sim & NC \\
\hline CN9 & $\begin{array}{l}\text { Sim. Antes de entrar no curso de licenciatura eu pensava que descobriria muitos dos "porquês", e depois me parece que há } \\
\text { apenas uma necessidade de querer passar nas matérias, mesmo sem entender nada. }\end{array}$ & Sim & IND \\
\hline CN10 & Sim, os cálculos eram sempre presentes, hoje a teoria tem mais importância. & Sim & $\mathrm{NC}$ \\
\hline CN11 & Creio que melhorei meu entendimento sobre as coisas em geral, em especial nos ramos da física. & Sim & ABR \\
\hline CN12 & & Ebranco & BRANCO \\
\hline CN13 & $\begin{array}{l}\text { Sim, mudou a partir do momento que soube que muito do que aprendi (que foi o que me fez cursar física) não era válido e tinha } \\
\text { outra visão de mundo. }\end{array}$ & Sim & NC \\
\hline CN14 & Não. & Não & - \\
\hline CN15 & Sim, vejo que vai muito além do que se aprende na escola, é algo muito mais amplo e não necessariamente "matemático". & Sim & NC \\
\hline CD1 & $\begin{array}{l}\text { Sim. Obtive um entendimento mais profundo de conhecimentos específicos e gerais da Física, que me proporciona maior prazer } \\
\text { ao estudar. }\end{array}$ & Sim & ABR \\
\hline CD2 & $\begin{array}{l}\text { Sim mudou. A Física para mim era como uma verdade incontestável (quase uma religião) essa era a minha visão na época } \\
\text { colegial, agora é só uma construção humana. }\end{array}$ & Sim & NC \\
\hline CD3 & Sim, mudou no sentido de me trazer maior fundamentação para explicação dos fenômenos. & Sim & ABR \\
\hline CD4 & Minha visão continuou a mesma, é claro de maneira amplificada. & Não & - \\
\hline CD5 & $\begin{array}{l}\text { Sim. As atividades de estágio mostraram uma realidade bastante distante do discurso que se tem por parte dos docentes da área } \\
\text { de ensino, a ponto de me fazer desistir de ser professora. }\end{array}$ & Sim & IND \\
\hline CD6 & Mudou apenas a visão das aulas de física, não mudando a visão do que é física. & Não & - \\
\hline CD7 & Sim, completamente. Ganhei gosto pela física nuclear para trabalhar com o acelerador de partículas. & Sim & ABR \\
\hline CD8 & Sim mudou; hoje encaro a Física não como amoltoado (tic) de fórmulas; mas sim valorizo mais o conceito e a parte experimental. & Sim & NC \\
\hline CD9 & Sim. Em suma, algumas disciplinas me ajudaram a erigir uma concepção de Ciência bem fundamentada. & Sim & NC \\
\hline CD10 & Sim, hoje tenho mais consciência das suas limitações. & Sim & NC \\
\hline
\end{tabular}




\begin{tabular}{|c|c|c|c|}
\hline CD11 & $\begin{array}{l}\text { Sim, deu uma compreensão muito maior do que é a física, mostrando-me por outro lado que a física tem um sem fim de } \\
\text { caminhos a ser seguido. }\end{array}$ & Sim & ABR \\
\hline CD12 & Sim, mudou no sentido que hoje compreendo a estrutura das ciências e como seus discursos repercutem no dia a dia. & Sim & NC \\
\hline CD13 & Mudou, percebi o quanto a física é uma criação do homem e necessariamente ñ representa realmente a natureza. & Sim & NC \\
\hline CD14 & Mudou. Minha visão sobre o mundo mudou com os conhecimentos adquiridos aqui. & Sim & ABR \\
\hline CD15 & Sim. Minha visão mudou muito, pois, vejo que a física não é o que aprendi no colégio é algo mais complexo, dinâmico e bonito. & Sim & ABR \\
\hline CD16 & A minha visão mudou: as disciplinas ampliaram o meu conhecimento. & Sim & ABR \\
\hline MN1 & $\begin{array}{l}\text { Percebi que a física é um assunto muito mais em aberto do que achava. O desenvolvimento não se dá da maneira que aparenta } \\
\text { no colégio, de maneira linear, "encaixada". }\end{array}$ & Sim & NC \\
\hline MN2 & $\begin{array}{l}\text { Sim, eu tinha quase nenhuma idéia sobre o que é física, eu só achava legal alguns tópicos que lia em um livro sobre explicações } \\
\text { de objetos e fenômenos. Mas a física é muito além disso. }\end{array}$ & Sim & ABR \\
\hline MN3 & Sim. Muitas disciplinas ainda ensinam através do rigor matemático, porém algumas me fez enxergar o mundo de outra maneira. & Sim & NC \\
\hline MN4 & Sim, a física deixou de ser algo neutro e racional, para ser uma empreitada humana, em busca da compreensão do Universo. & Sim & NC \\
\hline MN5 & Não muito. Sempre tive a visão da Física como um processo contínuo e filosófico. Idéia que reforcei no curso. & Não muito & NC \\
\hline MN6 & Mudou muito no sentido de que eu realmente não sabia nada de física, e ainda não sei. & Sim & ABR \\
\hline MN7 & $\begin{array}{l}\text { Sim, muito quanto a complexidade e quanto a necessidade que se faz necessária de cada conteúdo, estando a física em } \\
\text { constante aprimoramento. }\end{array}$ & Sim & ABR \\
\hline MN8 & Sim, achava que só tinha fórmulas. & Sim & IND \\
\hline
\end{tabular}




\section{Questionário - Licenciandos em PERCURSO - VISÃO DO SER PROFESSOR}

\begin{tabular}{|c|c|c|c|c|}
\hline \multicolumn{5}{|c|}{$\begin{array}{l}\text { *Legenda: ED = Eletricidade Diurno; EN = Eletricidade Noturno; CD = Complementos Diurno; } \\
\qquad \mathrm{CN}=\text { Complementos Noturno; CD = Complementos Diurno; MN = Metodologia Noturno }\end{array}$} \\
\hline Aluno* & $\begin{array}{l}\text { Sua visão do que é SER PROFESSOR mudou (ou } \\
\text { não), depois que você entrou no curso? Em que } \\
\text { sentido? }\end{array}$ & $\begin{array}{l}\text { Um bom professor, do seu ponto de vista, é } \\
\text { aquele que, por exemplo, ... }\end{array}$ & $\begin{array}{l}\text { Indique alguns aspectos positivos (e negativos) do } \\
\text { curso que correspondam (ou não) as suas expectativas. }\end{array}$ & $\begin{array}{c}\text { A - Foco no } \\
\text { ensino } \\
\text { B - Foco na } \\
\text { aprendizagem } \\
\text { C- Perspectiva } \\
\text { Educacional } \\
\text { mais ampla }\end{array}$ \\
\hline ED1 & $\begin{array}{l}\text { Mudou um pouco porque há uma grande } \\
\text { diversidade de se apresentar uma aula. Pode ser } \\
\text { excelente, bom, ruim ou péssimo. }\end{array}$ & $\begin{array}{l}\text { Apresenta a matéria de forma coerente e clara } \\
\text { para melhores entendimentos. Também tem } \\
\text { que ser interativo com os seus alunos para } \\
\text { tornar a aula mais divertida e não cansativa. }\end{array}$ & $\begin{array}{l}\text { Pontos positivos posso dizer que são poucos: como a } \\
\text { boa apresentação das aulas e a interação boa entre o } \\
\text { aluno e o professor. Tenho somente um único ponto } \\
\text { negativo do curso porque é a que teve maior } \\
\text { abrangência (ou ocorrência) durante o mesmo: é o } \\
\text { conflito entre as explicações do monitor e do professor. }\end{array}$ & $\mathrm{A} 2$ \\
\hline ED2 & $\begin{array}{l}\text { Mudou, pois não havia a menor ideia do que era } \\
\text { ser professor, a não ser, aquele a qual construí } \\
\text { como aluno no ensino básico. }\end{array}$ & ... dá tempo para o aluno pensar. & $\begin{array}{l}\text { Positivo: oportunidade de consultar bons materiais, } \\
\text { alguns professores. } \\
\text { Negativo: Diferença entre a física que se vê na } \\
\text { licenciatura e a física que se vê no bacharelado. Deveria } \\
\text { ser uma só. }\end{array}$ & B1 \\
\hline ED3 & Não. & $\begin{array}{l}\text { Prepara aula, conhece profundamente a } \\
\text { matéria, tem paciência para explicar a matéria } \\
\text { de várias maneiras. }\end{array}$ & $\begin{array}{l}\text { Ponto positivo - matérias separadas para cada assunto, } \\
\text { como óptica, mecânica, ... }\end{array}$ & $\mathrm{A} 1$ \\
\hline
\end{tabular}




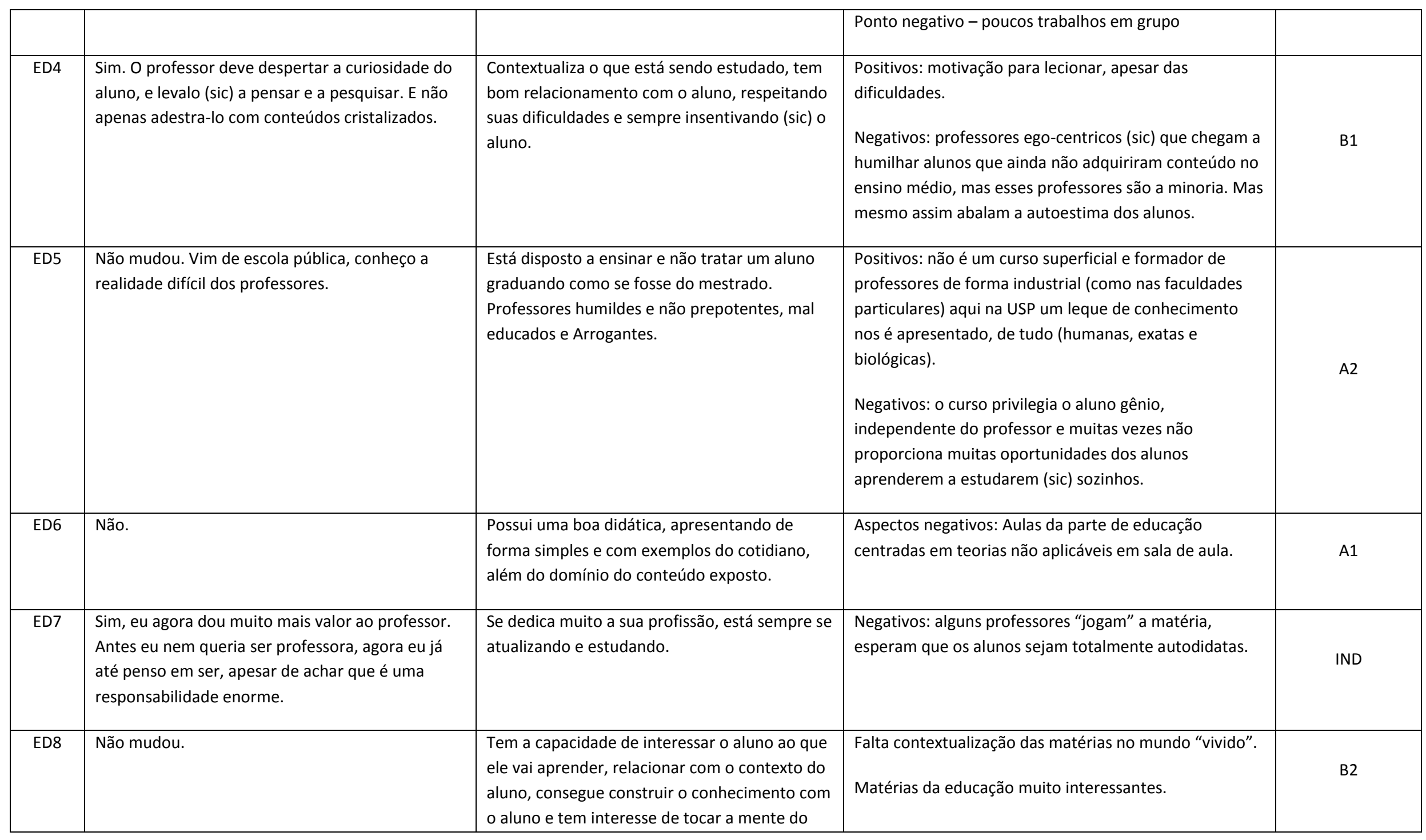




\begin{tabular}{|c|c|c|c|c|}
\hline & & $\begin{array}{l}\text { aluno em vários aspectos, não só ligados à } \\
\text { física. }\end{array}$ & & \\
\hline ED9 & $\begin{array}{l}\text { As disciplinas específicas de educação da FE } \\
\text { contribuíram muito para agregar práticas e } \\
\text { conceitos sobre o que é lecionar e a importância } \\
\text { social da profissão. }\end{array}$ & $\begin{array}{l}\text { Motiva o aluno a buscar mais informações } \\
\text { acerca do tema e a interagir mais com o } \\
\text { professor pela vontade de aprender. }\end{array}$ & $\begin{array}{l}\text { Positiva: habilitação profissional com vantagem } \\
\text { competitiva no mercado de trabalho. } \\
\text { Negativa: não desenvolveu o prazer pela ciência da } \\
\text { Física. }\end{array}$ & B2 \\
\hline ED10 & Não. & $\begin{array}{l}\text { Consegue passar transmitir o seu } \\
\text { conhecimento de maneira simples e clara, e faz } \\
\text { com que o aluno fique interessado pelo } \\
\text { conteúdo. }\end{array}$ & $\begin{array}{l}\text { Há uma cobrança muito baixa dos alunos, e além disso, } \\
\text { alguns acabam sendo resumidos (não é dado todo o } \\
\text { conteúdo que talvez deveria ser passado*) ou } \\
\text { facilitadas. } \\
\text { * digo isso em relação aos livros. }\end{array}$ & A2 \\
\hline ED11 & $\begin{array}{l}\text { Sim, comecei a ver mais o lado do professor; o que } \\
\text { a profissão exige e não é tão visível assim. }\end{array}$ & $\begin{array}{l}\text { Possui uma relação horizontal com o aluno, } \\
\text { gosta de dar aula e não desiste de aluno algum. }\end{array}$ & $\begin{array}{l}\text { * Há matérias que exigem muito, sendo de poucos } \\
\text { créditos. } \\
\text { *Professores que não possuem uma boa didática e } \\
\text { forma de ensino. }\end{array}$ & B1 \\
\hline ED12 & Sim & $\begin{array}{l}\text { Um bom professor é aquele se preocupa com a } \\
\text { aprendizagem do aluno, não apenas cumpri o } \\
\text { conteúdo programado, mas verifica se alguns } \\
\text { estão compreendendo. }\end{array}$ & & B1 \\
\hline ED13 & $\begin{array}{l}\text { Sim, não vejo o professor como um mero } \\
\text { "profeta", que cospe informação, mas alguém } \\
\text { formador de opinião, que constroe (sic) } \\
\text { perspectivas de vida. }\end{array}$ & $\begin{array}{l}\text { Mostra as opç̃es, sugere a "melhor", mas não } \\
\text { força, não impõe nada. }\end{array}$ & $\begin{array}{l}\text { Esperava que não houvesse tanta diferença em relação } \\
\text { ao bacharel, que houvesse um ciclo comum. }\end{array}$ & B2 \\
\hline
\end{tabular}




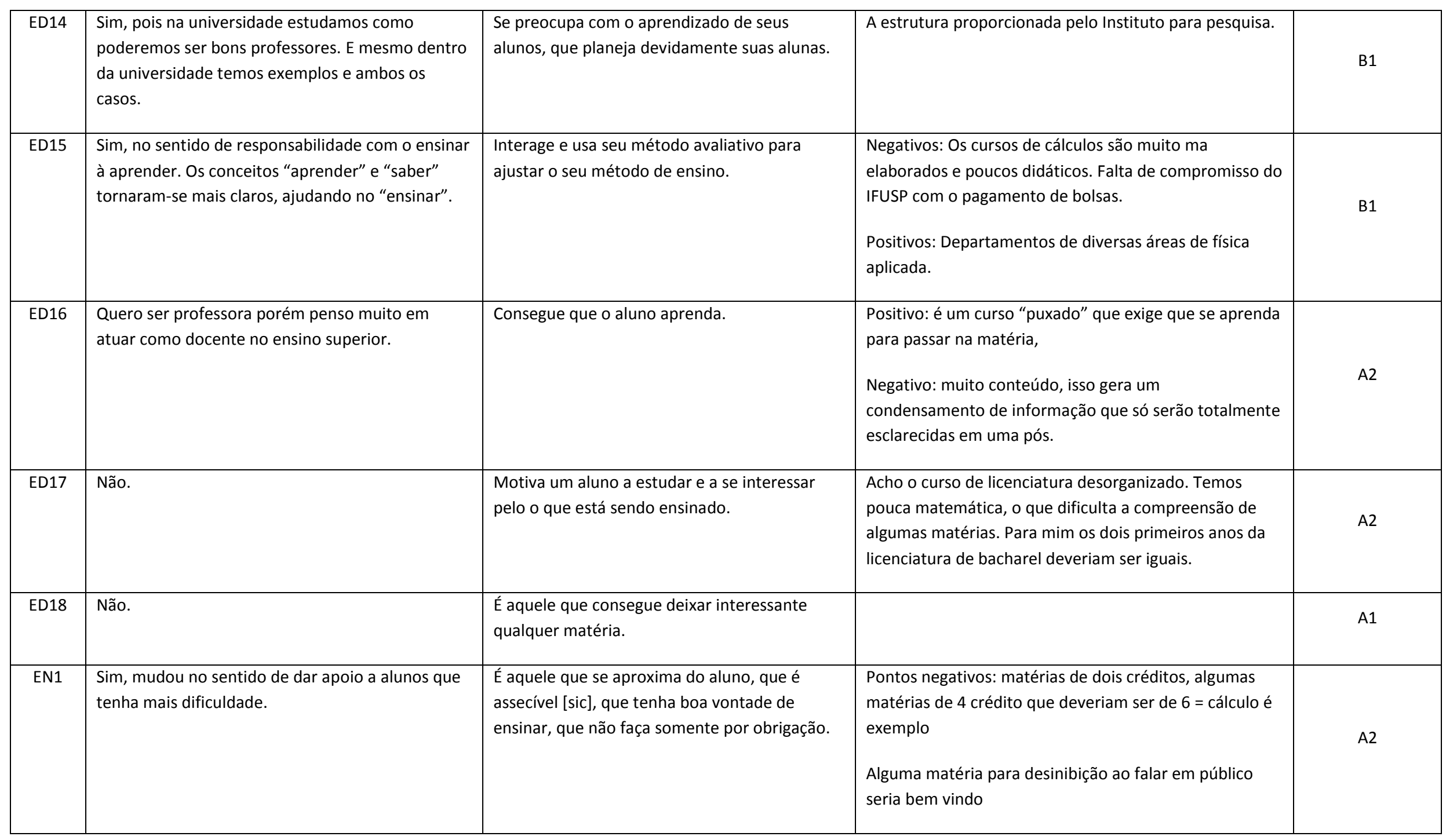




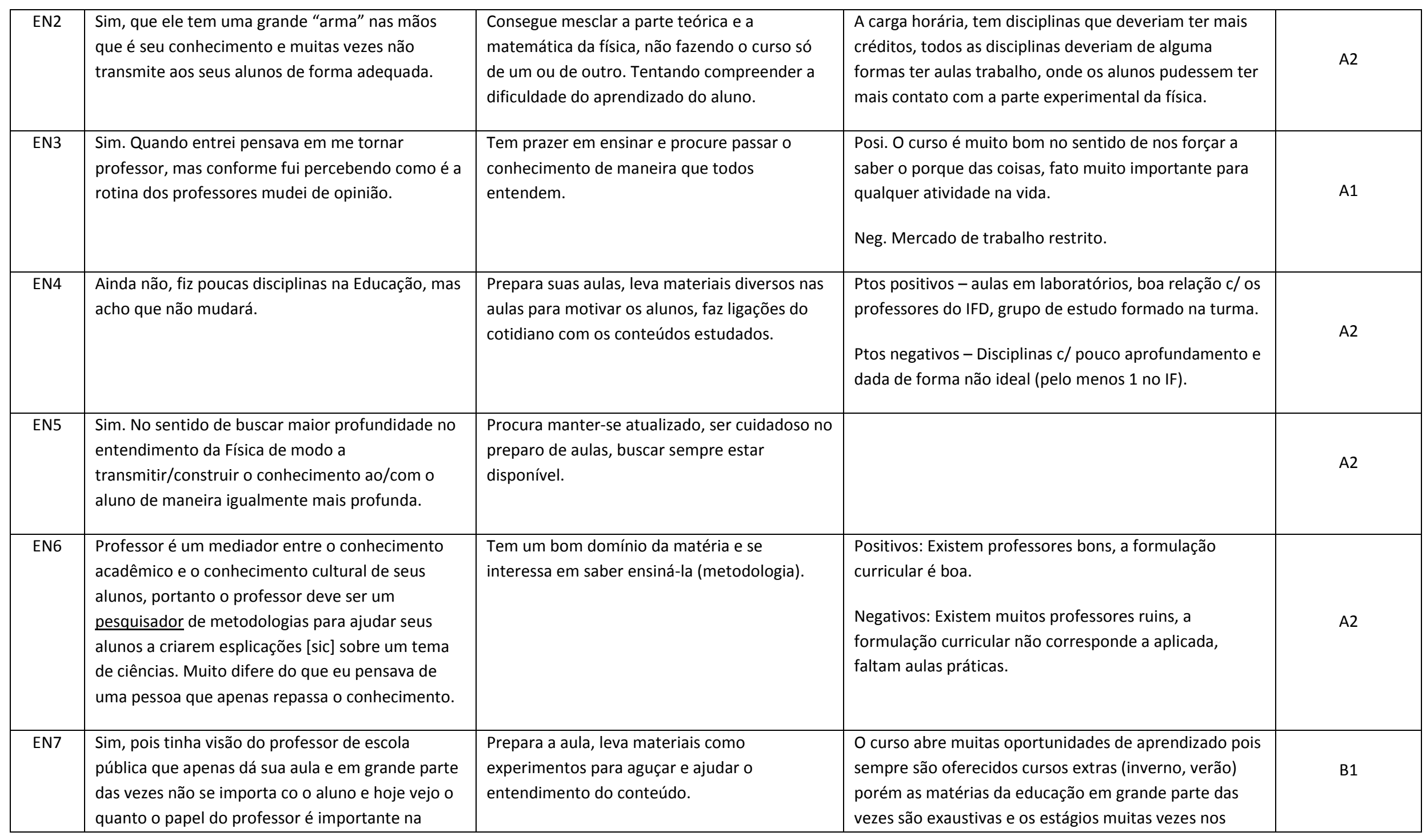




\begin{tabular}{|c|c|c|c|c|}
\hline & formação do aluno. & & $\begin{array}{l}\text { mostram a realidade do colégio nos desmotivando a } \\
\text { exercer o cargo de professor. }\end{array}$ & \\
\hline EN8 & $\begin{array}{l}\text { Minha visão mudou, pois o professor não } \\
\text { transmitirá apenas conhecimento sobre Física; o } \\
\text { educador também é responsável pela formação de } \\
\text { caracter do aluno. }\end{array}$ & $\begin{array}{l}\text { Mostra exemplos de como aplicar a "Física” no } \\
\text { dia-dia do aluno. }\end{array}$ & $\begin{array}{l}\text { Negativos: falta de divulgação de iniciação para alunos } \\
\text { da licenciatura. }\end{array}$ & c \\
\hline EN9 & $\begin{array}{l}\text { Sim, vi que o professor é muito mais desvalorizado } \\
\text { do que pesquisador, não só fora como dentro da } \\
\text { USP. }\end{array}$ & $\begin{array}{l}\text { Sabe a matéria e permite o aprendizado dos } \\
\text { alunos. }\end{array}$ & $\begin{array}{l}\text { Problemas com alguns professores que são péssimos } \\
\text { (especialmente os do IME). Parte positiva é a ótima } \\
\text { qualidade do curso oferecido por alguns prof do IF. }\end{array}$ & A2 \\
\hline EN10 & Sim, que dar aula não é só passar o conteúdo. & $\begin{array}{l}\text { Que vê a dificuldade do aluno e trabalha para } \\
\text { minimizala [sic]. }\end{array}$ & $\begin{array}{l}\text { Positivos são os laboratórios e os professores } \\
\text { experientes em pesquisa. } \\
\text { Negativo é que tem professores que parecem saber } \\
\text { bem o conteúdo mas não consegue transmitilo [sic]. }\end{array}$ & B1 \\
\hline EN11 & $\begin{array}{l}\text { Mudou. Pois achava, ou melhor, tinha como } \\
\text { referencial os professores que tive. Percebi que é } \\
\text { bastante engessado em relação o que imaginava. }\end{array}$ & $\begin{array}{l}\text { Consegue motivar o aluno e ter amizade } \\
\text { também. Não só amizade c/ o aluno mas com } \\
\text { as pessoas que trabalham de alguma forma c/ } \\
\text { o professor (Direção, secretários, etc). }\end{array}$ & $\begin{array}{l}\text { Os aspectos positivos são alguns professores dão ideias } \\
\text { de como apresentar o conteúdo p/ os alunos. } \\
\text { O negativo é que outros não demonstram nenhum tipo } \\
\text { de interesse e só se preocupam com suas respectivas } \\
\text { pesquisas. }\end{array}$ & A2 \\
\hline EN12 & $\begin{array}{l}\text { A referência professor na Universidade de São } \\
\text { Paulo, IFUSP, é completamente diferente do } \\
\text { professor da rede pública. }\end{array}$ & $\begin{array}{l}\text { Prepara bem as aulas, associa os conteúdos } \\
\text { com as outras disciplinas, bom em } \\
\text { relacionamento. }\end{array}$ & $\begin{array}{l}\text { Negativos: poucos laboratórios, associação das } \\
\text { disciplinas que são dependentes, monitoria ainda fraca. }\end{array}$ & A2 \\
\hline EN13 & Não. & $\begin{array}{l}\text { Se esforça para que seu aluno aprenda os } \\
\text { conhecimentos da maneira mais proveitosa } \\
\text { possivel. }\end{array}$ & $\begin{array}{l}\text { Penso que o curso deveria ser unificado, ou seja, } \\
\text { deveria ser Licenciatura e Bacharelado em Física e não } \\
\text { dividido como é atualmente é. }\end{array}$ & A2 \\
\hline EN14 & Sim, pois ministrei algumas aulas algum tempo, $\mathrm{e}$ & Explique uma coisa muito bem, ao invéz [sic] & Prova! Péssimo método de avalição, ainda mais na & A1 \\
\hline
\end{tabular}




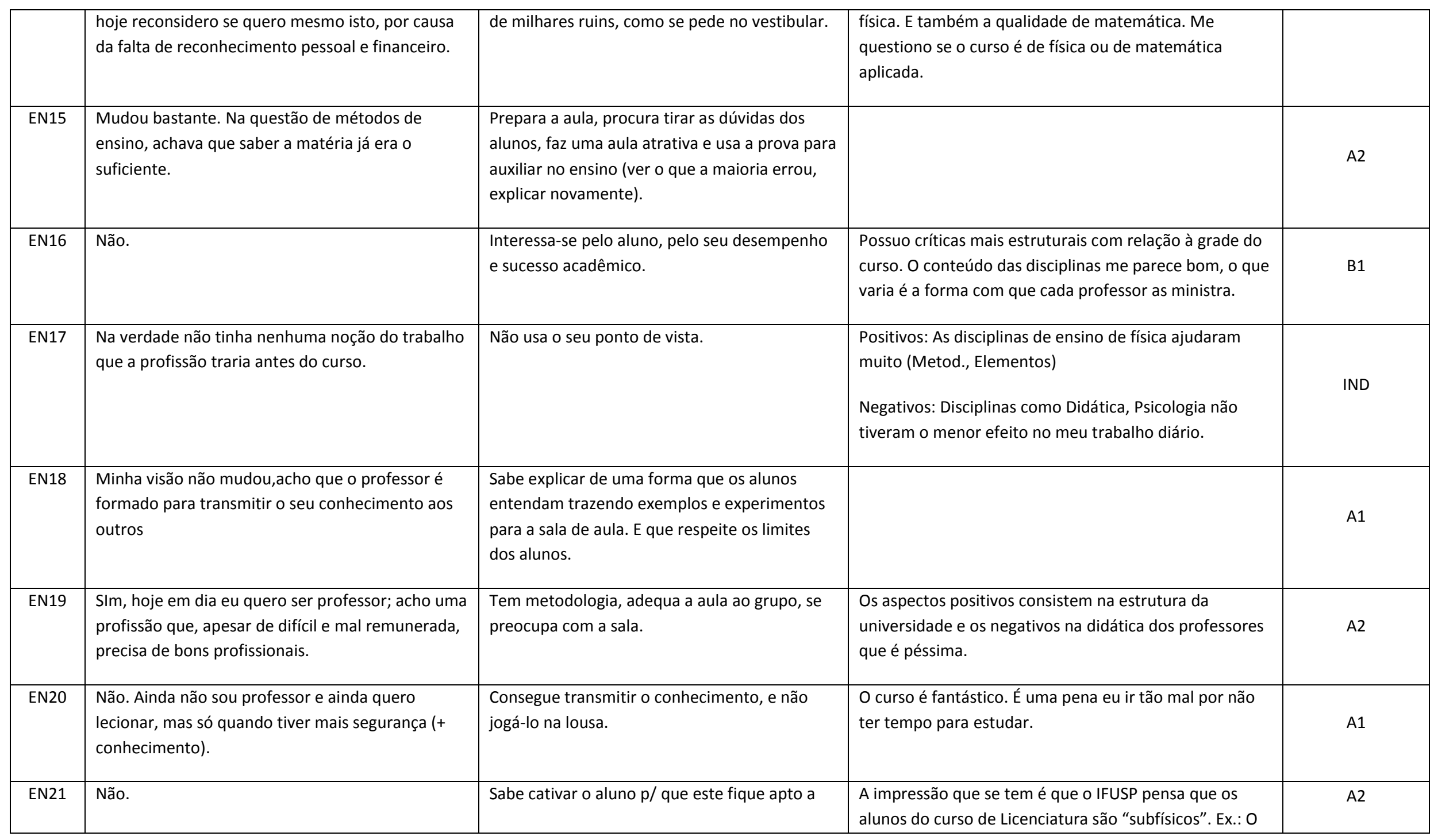




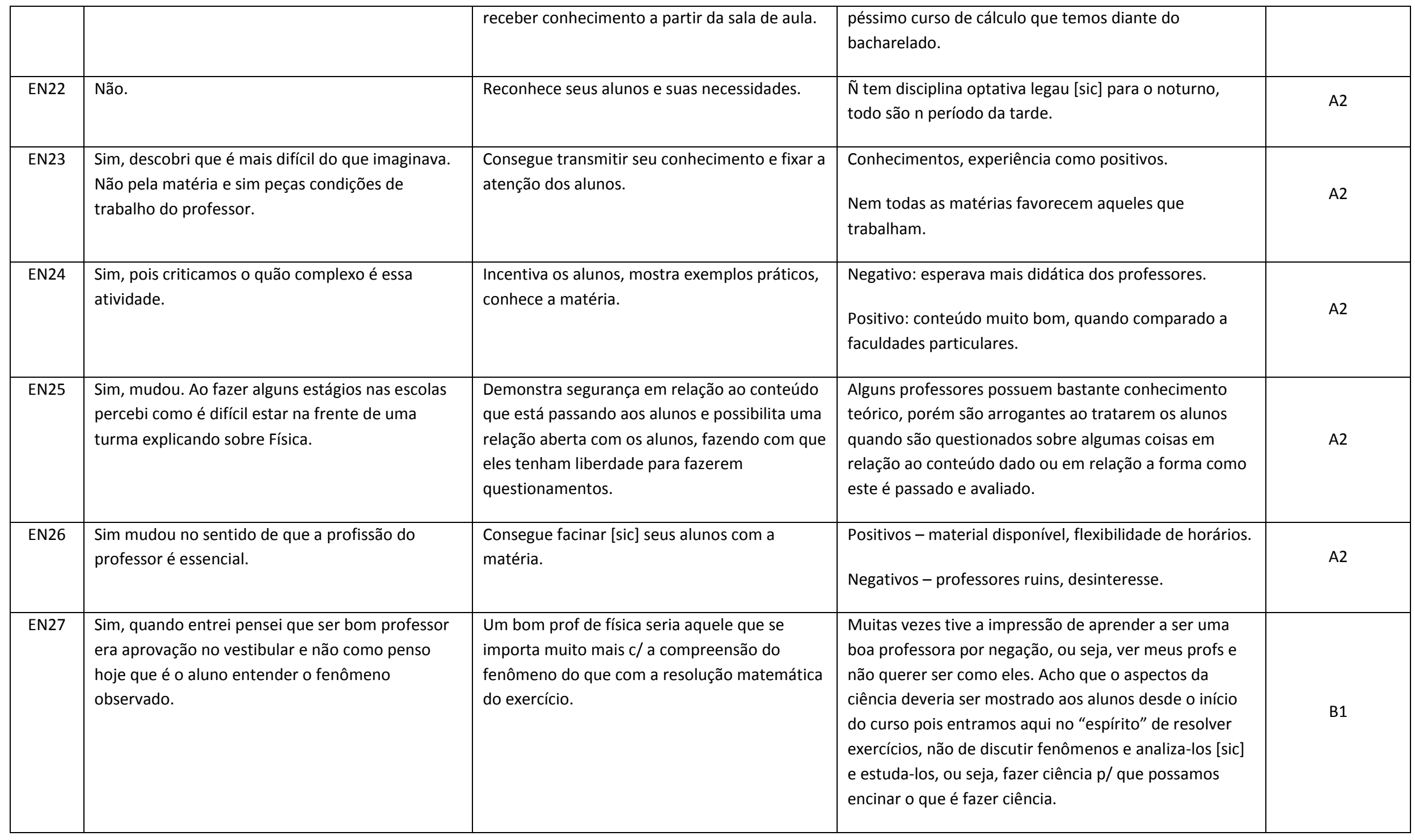




\begin{tabular}{|c|c|c|c|c|}
\hline EN28 & Não. & Gosta de lecionar. & Negativo: & IND \\
\hline EN29 & $\begin{array}{l}\text { Sim, no sentido em aprender na prática como o } \\
\text { professor tem que fazer e o que fazer, } \\
\text { principalmente sendo um curso "polêmico", no } \\
\text { sentido da física ser uma matéria temida pelos } \\
\text { alunos. }\end{array}$ & $\begin{array}{l}\text { Sabe ensinar o aluno sem "decoreba" e quando } \\
\text { possível efetua experimentos para sair da } \\
\text { teoria de sala; o que consegue compartilhar } \\
\text { conhecimento e que não sabe para si próprio. }\end{array}$ & $\begin{array}{l}\text { No geral é um bom curso com excelentes laboratórios e } \\
\text { biblioteca enorme, mas que em determinados } \\
\text { conteúdos há professores que acham que o aluno já } \\
\text { domina o conteúdo, o que muitas vezes não ocorre, e } \\
\text { acaba não dando tempo de correr por fora, porque } \\
\text { muitos trabalham e não somente estudam, e precisam } \\
\text { de explicações claras e coesas, e não "jogadas" como } \\
\text { alguns professores fazem. }\end{array}$ & A2 \\
\hline EN31 & Não. & Leciona e deixa o aluno ser participativo. & $\begin{array}{l}\text { Negativos: formas de avaliação. } \\
\text { Positivo: mercado de trabalho. }\end{array}$ & B1 \\
\hline EN33 & $\begin{array}{l}\text { Sim, antes achava que deveria ensinar aos alunos } \\
\text { cálculos, acho que os alunos devem aprender a } \\
\text { pensar. }\end{array}$ & $\begin{array}{l}\text { Independe [sic] do assunto ensinar o aluno a } \\
\text { pensar. }\end{array}$ & & B1 \\
\hline EN34 & Não. & $\begin{array}{l}\text { Tenha o respeito e a admiração dos seus } \\
\text { alunos. E o reconhecimento dos alunos de que } \\
\text { o professor foi importante em algum aspecto }\end{array}$ & $\begin{array}{l}\text { Positivos: aulas aprofundadas. } \\
\text { Negativos: exceço [sic] de aulas desnecessárias e pré- }\end{array}$ & B1 \\
\hline
\end{tabular}




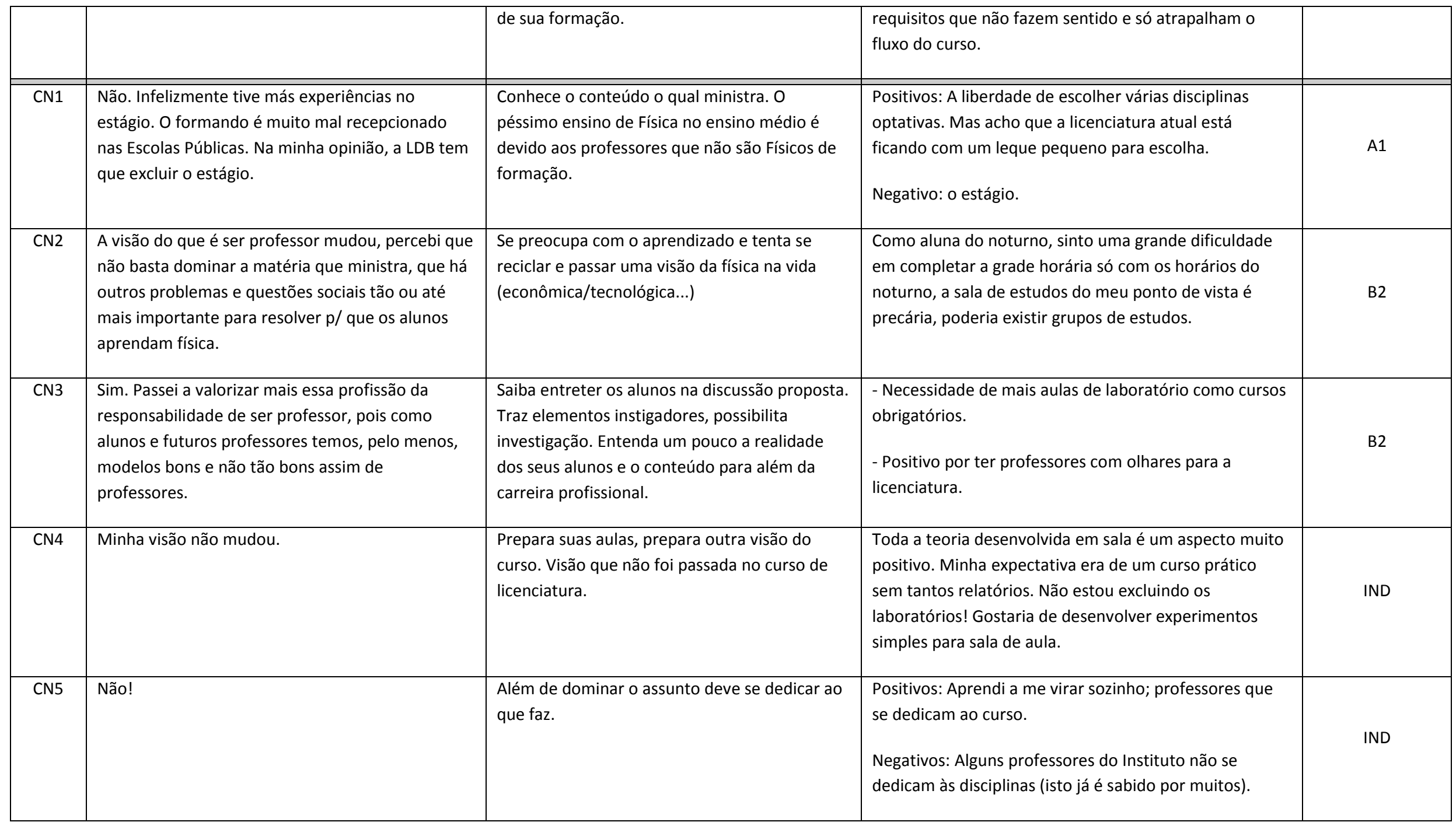




\begin{tabular}{|c|c|c|c|c|}
\hline CN6 & $\begin{array}{l}\text { Mudou e muito, antes achava que era uma } \\
\text { profissão difíil, hoje tenho certeza e sei que a } \\
\text { profissão carrega uma responsabilidade formativa } \\
\text { de um peso que eu não tinha consciência quando } \\
\text { entrei. }\end{array}$ & $\begin{array}{l}\text { Consegue transmitir o conteúdo a ser } \\
\text { ensinado, tem domínio de conteúdo, é } \\
\text { responsável nos seus atos, e se importa com o } \\
\text { ato de ensinar. }\end{array}$ & $\begin{array}{l}\text { Positivo: Contato com os professores, acesso a diversas } \\
\text { literaturas, grade curricular, convivência universitária, } \\
\text { formação de um modo geral. } \\
\text { Negativos: grade curricular (sempre alterando), falta de } \\
\text { oferecimento de disciplinas, desorganização por parte } \\
\text { do corpo discente e docente. }\end{array}$ & A1 \\
\hline CN7 & $\begin{array}{l}\text { Mudou, como trabalho em outro área pensava em } \\
\text { exercer a profissão para renda complementar, } \\
\text { hoje não acho que isso seja certo. }\end{array}$ & $\begin{array}{l}\text { - incentiva, questiona, e respeita os limites dos } \\
\text { alunos. }\end{array}$ & $\begin{array}{l}\text { - falta preparar o aluno mais para exercer profissão, o } \\
\text { aluno deveria ser como futuro professor e não como } \\
\text { futuro cientista ou físico. }\end{array}$ & A2 \\
\hline CN8 & $\begin{array}{l}\text { Sim. Hoje compreendo que um professor precisa } \\
\text { de muito mais que conhecimento científico. } \\
\text { Também compreendi que boa vontade e amor não } \\
\text { basta para ser um bom professor atualmente. }\end{array}$ & $\begin{array}{l}\text { Possui preparo psicológico para lidar com } \\
\text { pessoas. E, juntamente, deve ter vontade de } \\
\text { aprender e ensinar. }\end{array}$ & & IND \\
\hline CN9 & Não. & Motiva os alunos em todos os aspectos. & $\begin{array}{l}\text { A "reta final" do curso foi muito positiva. Consegui, } \\
\text { mesmo sem muito tempo, me dedicar um pouco mais e, } \\
\text { por exemplo, em Física Moderna I e II, entendi um } \\
\text { pouco mais. }\end{array}$ & IND \\
\hline CN11 & $\begin{array}{l}\text { Não mudou, pois eu não tinha uma visão. Construí } \\
\text { uma perspectiva dessa profissão ao longo do } \\
\text { curso. }\end{array}$ & $\begin{array}{l}\text { Tem uma boa didática, conversa bem, postura } \\
\text { elegante a falar, demonstra com simplicidade } \\
\text { conhecimento. }\end{array}$ & $\begin{array}{l}\text { Negativo - ñ consigo entender a cobrança de } \\
\text { conhecimento muitos degraus acima do necessário p/ } \\
\text { lecionar p/ ensino médio, principalmente em relação à } \\
\text { matemática }\end{array}$ & A1 \\
\hline CN12 & & & & Ñ RESPONDEU \\
\hline
\end{tabular}




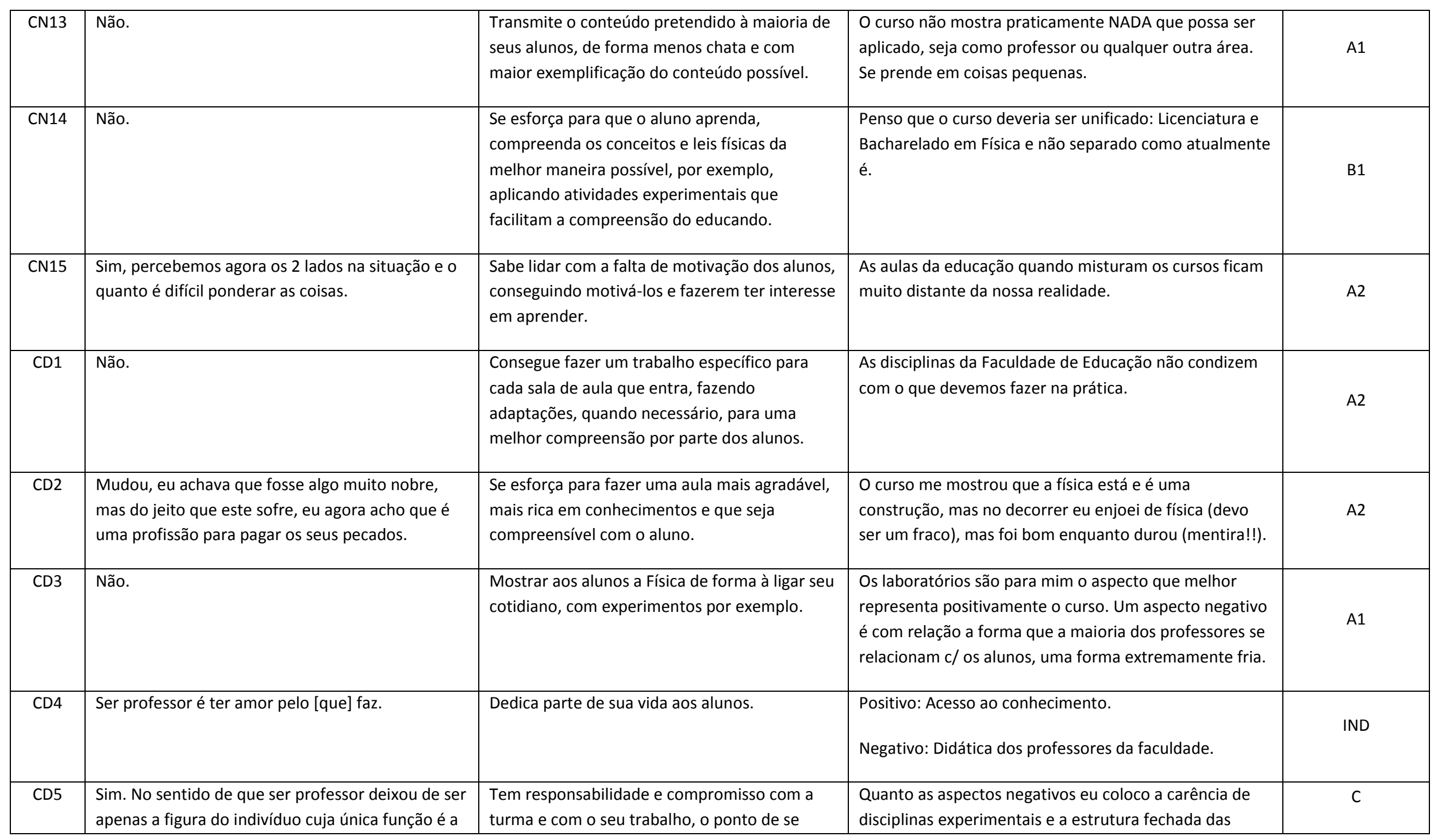




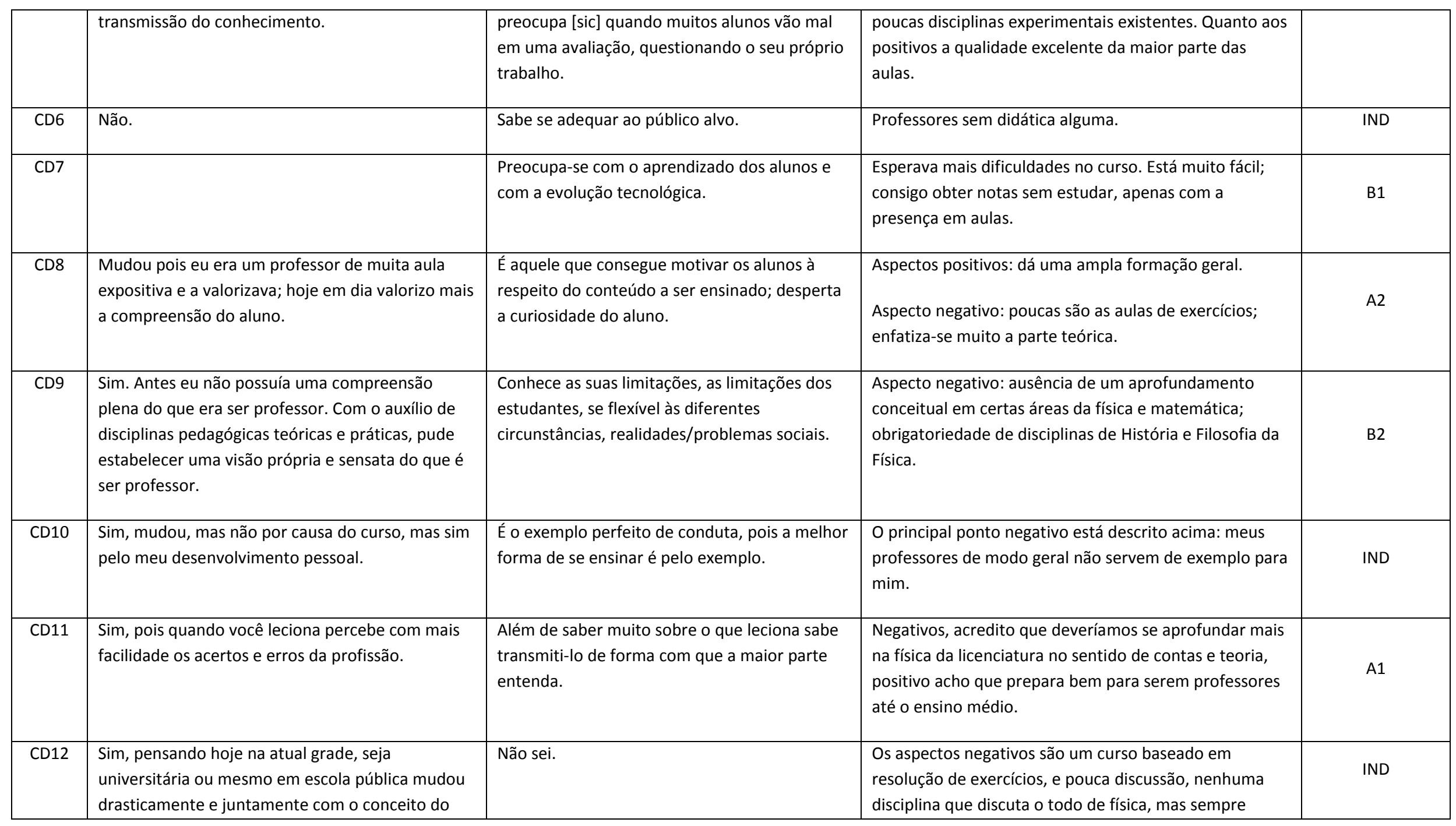




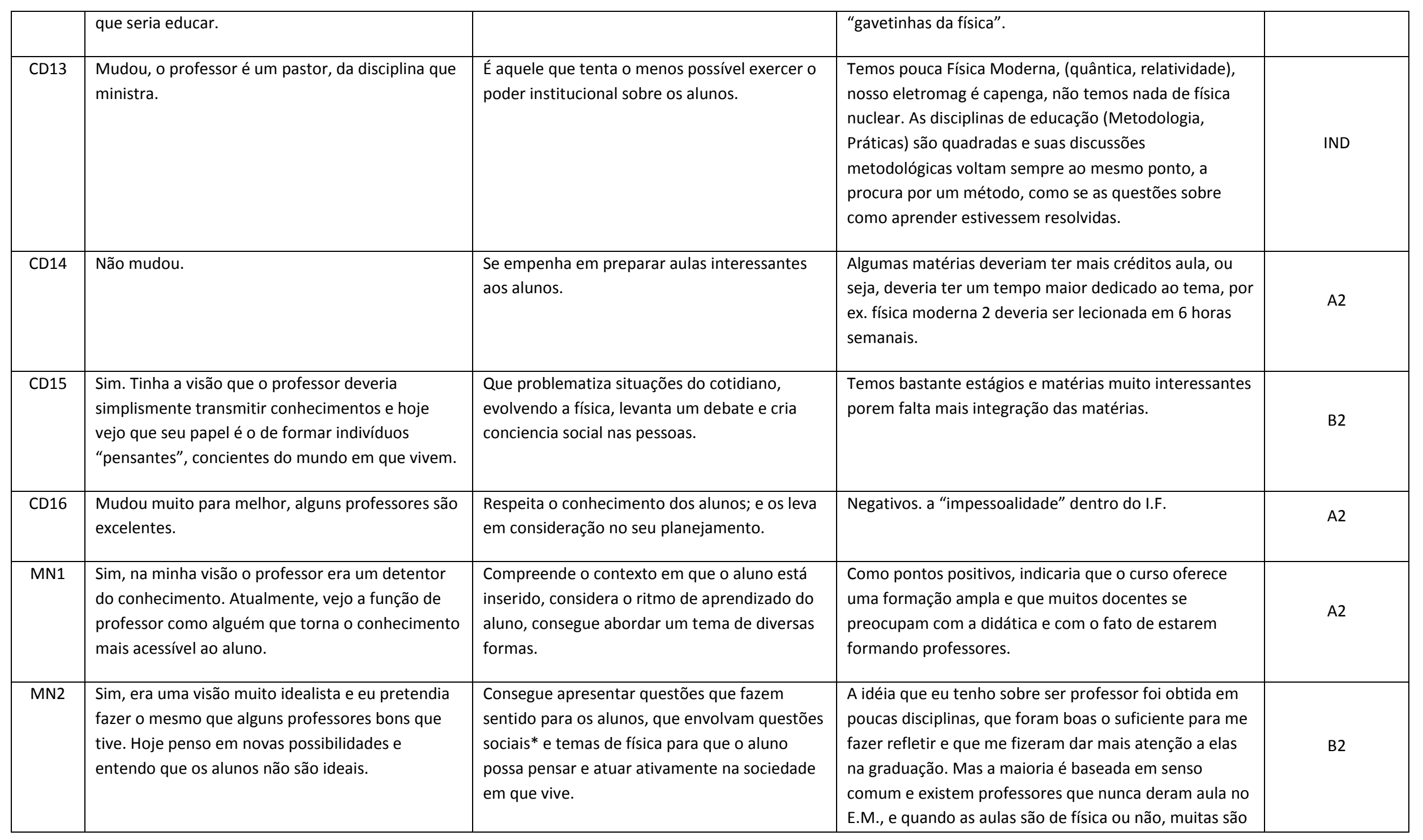




\begin{tabular}{|c|c|c|c|c|}
\hline & & & desconectadas d ensino. & \\
\hline MN3 & Não. & $\begin{array}{l}\text { Que busca ensinar os alunos não apenas no } \\
\text { conteúdo que é exigido nas escolas, mas que } \\
\text { deseja ensinar visando o dia-a-dia e através de } \\
\text { suas pesquisas. }\end{array}$ & Positivos, exige sempre mais dos alunos. & B1 \\
\hline MN4 & $\begin{array}{l}\text { Mudou muito, a ideia que tinha de ser professor } \\
\text { era de reprodutor de conteúdo e preparador para } \\
\text { o vestibular. Hoje eu acredito numa formação } \\
\text { científica para as pessoas leigas. }\end{array}$ & $\begin{array}{l}\text { Se foca num ensino por competências ao invés } \\
\text { de conteudista, conhece e ensina ciência } \\
\text { através de todos os seus aspectos (humano, } \\
\text { histórico, etc). }\end{array}$ & $\begin{array}{l}\text { A maior parte do ciclo básico da Física tem os mesmos } \\
\text { problemas citados acima, que ocorre no ensino médio. } \\
\text { Minha visão mudou nas disciplinas realmente voltadas à } \\
\text { licenciatura. }\end{array}$ & B2 \\
\hline MN5 & $\begin{array}{l}\text { Reforcei e embasei a ideia do professor como } \\
\text { educador, no processo de alfabetização científica, } \\
\text { incentivo à crítica e não decorar e/ou aplicar } \\
\text { conceitos. }\end{array}$ & $\begin{array}{l}\text { Mostra a educação como ferramenta } \\
\text { libertadora. }\end{array}$ & $\begin{array}{l}\text { Algumas disciplinas que reafirmaram e incentivaram as } \\
\text { ideias acima em contra ponto com algumas que } \\
\text { reforçam os problemas do professor "catequisador" que } \\
\text { não abre para discussão e questionamentos tendo a } \\
\text { física como questão absoluta e fechada. }\end{array}$ & C \\
\hline MN6 & $\begin{array}{l}\text { Não mudou, pois a escola continua o mesmo } \\
\text { sistema, apenas melhorei mais minha cultura. }\end{array}$ & Se dedica no que faz. & $\begin{array}{l}\text { Um aspecto positivo é carga de conteúdo que } \\
\text { recebemos, aspecto negativo é a falta de ferramentas } \\
\text { didáticas, ou matérias específicas sobre o tema. }\end{array}$ & IND \\
\hline MN8 & $\begin{array}{l}\text { Sim, acho que em tudo, aprendi a ter um olhar } \\
\text { diferente quando falamos da educação (do } \\
\text { ensino). }\end{array}$ & $\begin{array}{l}\text { Que tem conhecimento e preparação para } \\
\text { ensinar. }\end{array}$ & $\begin{array}{l}\text { Quase todos os pontos são positivos, o negativo é ter } \\
\text { que estudar laboratório de Física, já que sou aluna da } \\
\text { matemática. }\end{array}$ & A1 \\
\hline
\end{tabular}


ANEXO E - Considerações sobre o número de concluintes em função da forma e ano de ingresso 


\section{Considerações sobre o número de concluintes em função da forma e ano de ingresso}

Se considerarmos as estimativas para um regime de fluxo contínuo, assim como todos os demais aspectos já mencionados (que por um lado facilitam as análises e por outro limitam as conclusões) teríamos, de modo geral, uma taxa de $40 \%$ de conclusões e $60 \%$ de evasão. Mas podemos, a partir dos dados fornecidos pelo Sistema de Graduação, olhar as taxas de conclusão tal que sejam levados em conta o ano e o tipo de ingresso além da possibilidade efetiva, de que o curso possa ter sido integralizado. Com isso queremos dizer, por exemplo, que dos 1969 alunos encerrados de 1997 a 2010, embora haja conclusões em todos os anos, as taxas calculadas sobre o total de encerramentos ano a ano, podem revelar números que, isoladamente, não sejam muito significativos.

Da totalidade de casos, temos catorze anos de encerramentos que estão associados a ingressos que ocorreram desde 1978. A tabela 26 apresenta os 1969 encerramentos segundo o ano de ingresso do aluno:

\begin{tabular}{|c|c|c|c|}
\hline $\begin{array}{c}\text { ano de } \\
\text { ingresso }\end{array}$ & $\begin{array}{l}\text { no de } \\
\text { alunos }\end{array}$ & $\begin{array}{c}\text { ano de } \\
\text { ingresso }\end{array}$ & $\begin{array}{l}\mathrm{n} \text { o de } \\
\text { alunos }\end{array}$ \\
\hline 1978 & 1 & 1998 & 214 \\
\hline 1985 & 2 & 1999 & 175 \\
\hline 1986 & 2 & 2000 & 140 \\
\hline 1988 & 1 & 2001 & 145 \\
\hline 1989 & 7 & 2002 & 138 \\
\hline 1990 & 1 & 2003 & 149 \\
\hline 1991 & 3 & 2004 & 122 \\
\hline 1992 & 11 & 2005 & 112 \\
\hline 1993 & 47 & 2006 & 89 \\
\hline 1994 & 62 & 2007 & 87 \\
\hline 1995 & 82 & 2008 & 68 \\
\hline 1996 & 115 & 2009 & 36 \\
\hline 1997 & 152 & 2010 & 8 \\
\hline
\end{tabular}

Uma vez que a tabela acima nos fornece o número de alunos que encerraram o curso segundo o ano de ingresso, faz sentido termos poucos associados aos anos anteriores a 1995-96 (que provavelmente devem aparecer em listas de encerramento geradas antes de 1997) e também poucos associados aos anos posteriores a 2002-03, já que muitos dos 
ingressantes destes anos ainda encontram-se ativos no curso (haja vista a estatística que temos para o tempo de conclusão média).

Sabendo que há quatro tipos possíveis para o ingresso ${ }^{37}$ - vestibular, graduado, transferência externa ou transferência usp (interna) - podemos utilizar como referência os cerca de 100-110 ingressantes por ano para, dentre a totalidade dos 1969 casos da amostra, verificar as taxas de integralização do curso. $E$, verificamos que os dados são tais que entre os anos de 1997 e 2002, praticamente 100\% dos ingressantes via vestibular aparecem encerrados. Isto é, as listas de encerramentos geradas de 1997 a 2010, nos permitem computar em torno de 100-110 alunos ingressantes por vestibular entre os anos de 1997 a 2002 que tiveram seus cursos encerrados (seja por terem concluído ou não). De toda forma, esta faixa de anos (1997-2002) parece contemplar a totalidade daqueles que passaram pelo curso.

Número de encerramentos por Tipo e Ano de ingresso.

\begin{tabular}{|c|c|c|c|c|}
\hline \multicolumn{5}{|c|}{ ENCERRADOS - TIPO E ANO DE INGRESSO } \\
\hline & vestibular & graduado & $\begin{array}{c}\text { transf } \\
\text { ext }\end{array}$ & $\begin{array}{c}\text { transf } \\
\text { usp }\end{array}$ \\
\hline 1997 & 99 & 40 & 6 & 7 \\
\hline 1998 & 108 & 60 & 5 & 41 \\
\hline 1999 & 109 & 32 & 2 & 32 \\
\hline 2000 & 102 & 24 & 1 & 13 \\
\hline 2001 & 104 & 18 & 2 & 21 \\
\hline 2002 & 100 & 5 & 0 & 33 \\
\hline
\end{tabular}

Se agora, calcularmos as taxas de conclusão considerando o ano e o tipo de ingresso, obtemos o que nos mostra o Gráfico 25 , a seguir:

\footnotetext{
${ }^{37}$ Além do caso raro de ingresso por Liminar.
} 


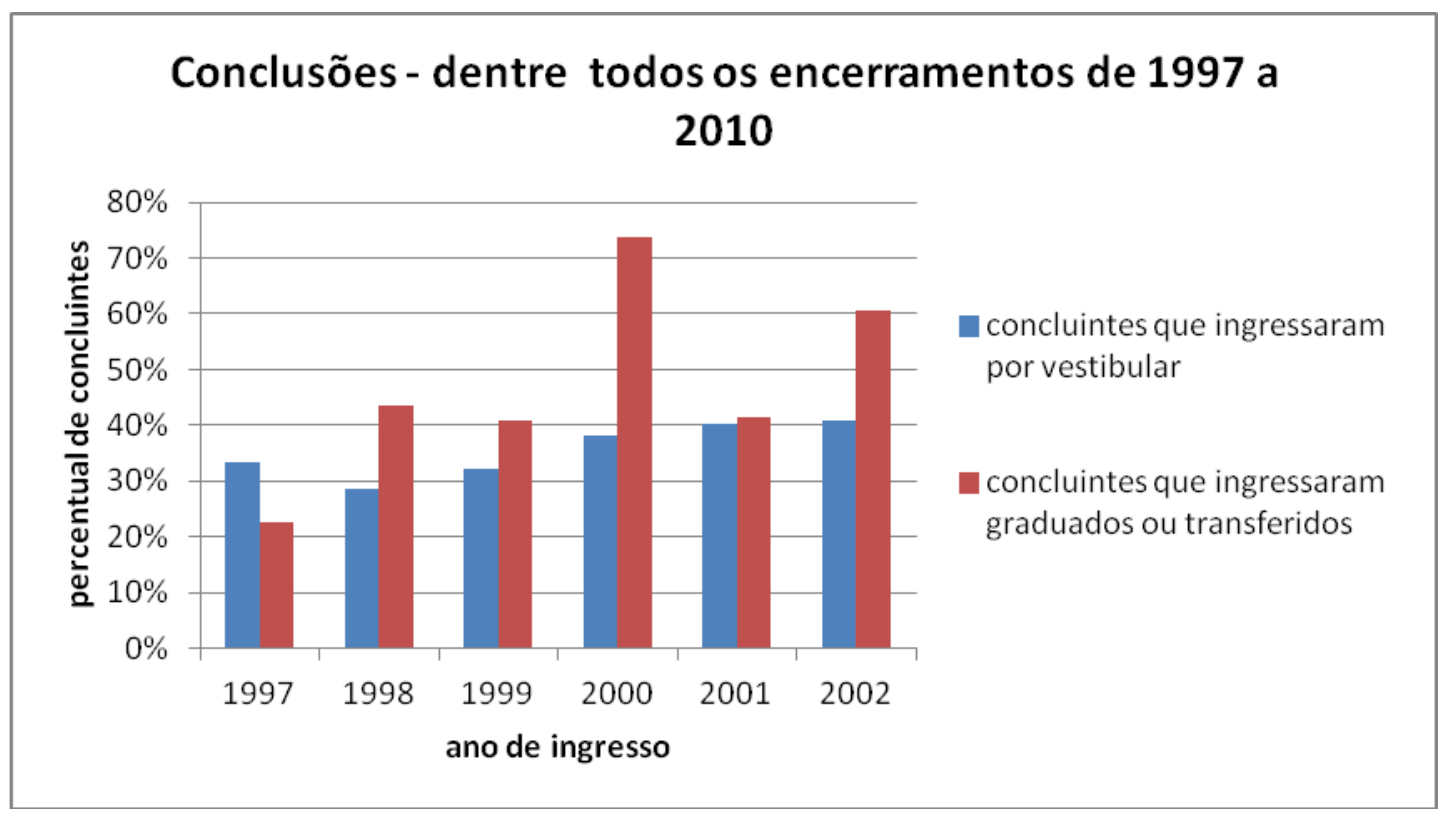

Percentual de conclusões computadas até 2010 de alunos que ingressaram entre os anos de 1997 e 2002.

O gráfico acima nos revela, por exemplo, que - em média - 36\% dos ingressantes via vestibular (dos anos de 1997 a 2002) concluíram seu curso e, que - em média - 47\% dos que ingressaram graduados ou por transferência, concluíram a licenciatura. Ou seja, a taxa de conclusão é maior nos casos em que o aluno ingressa já com uma graduação ou vem transferido de outros cursos.

Se, de novo, considerarmos a não-conclusão do curso como indicativo de abandono e/ou desistência, teremos então uma taxa de $64 \%$ de evasão daqueles ingressantes por vestibular e, uma taxa de pouco mais de $50 \%$ de evasão dos ingressantes graduados e transferidos. Ou seja, em média teremos pouco mais de $40 \%$ de conclusões e pouco menos de $60 \%$ de desistências/abandonos; resultado que concorda com os anteriormente vistos e discutidos. 